Ewa Kobyłecka-Piwońska

SPOJRZENIA Z ZEWNĄTRZ Witold Gombrowicz

w literaturze argentyńskiej (1970-2017)

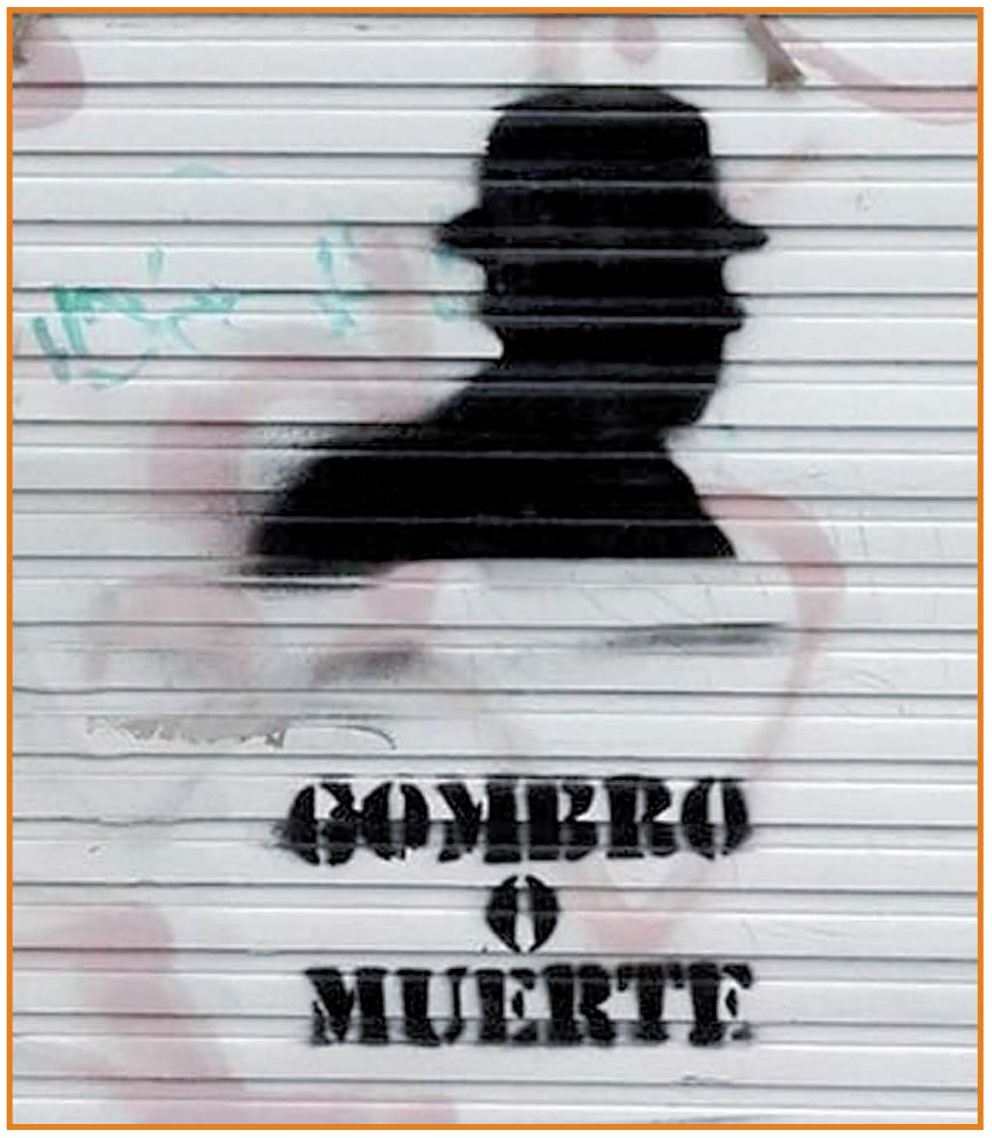


SPOJRZENIA Z ZEWNĄTRZ 



\title{
Ewa Kobyłecka-Piwońska
}

\section{SPOJRZENIA Z ZEWNĄTRZ}

\author{
Witold Gombrowicz \\ w literaturze argentyńskiej (1970-2017)
}


Ewa Kobyłecka-Piwońska - Uniwersyłet Łódzki, Wydział Filologiczny, Katedra Filologii Hiszpańskiej, ul. Pomorska 171/173, 90-236 Łódź

Publikacja została sfinansowana ze środków Narodowego Centrum Nauki przyznanych na podstawie decyzii numer DEC-2013/09/D/HS2/00563.

(C) Copyright by Ewa Kobyłecka-Piwońska, Łódź-Kraków 2017

(C) Copyright for this edition by Uniwersytet Łódzki, Łódź-Kraków 2017

(C) Copyright for this edition by Towarzystwo Autorów i Wydawców Prac Naukowych UNIVERSITAS, Łódź-Kraków 2017

ISBN WUt: 978-83-8088-812-8

e-ISBN WUt: 978-83-8088-813-5

ISBN Universitas: 97883-242-3153-9

e-ISBN Universitas: 97883-242-3249-9

Redaktorzy inicjujący

Urszula Dzieciątkowska

Jan Sadkiewicz

Recenzja

prof. dr hab. Włodzimierz Bolecki

Opracowanie redakcyine

Joanna Nazimek

Projekt okładki i stron tyłułowych

Sepielak

Na okładce

zdięcie własne Autorki

https://www.doi.org/10.18778/8088-812-8

www.universitas.com.pl 


\section{O niewdzięcznej praktyce porównywania}

Choć badania komparatystyczne przeżywają w ostatnich dekadach prawdziwy rozkwit - oswobodzone z ograniczeń literaturoznawstwa narodowego, otwarte na wytwory kultury powstałe nie tylko na gruncie innego języka, ale zgoła innego niż język tworzywa i gotowe zaakceptować swój „słaby profesjonalizm”" by dzięki temu lepiej odpowiedzieć na wyzwania „nowej humanistyki” - to doświadczenie badacza lub badaczki „porównujących” pozostaje zainfekowane pewnym gorzkim przeczuciem. Gest ustanowienia pokrewieństwa i analogii, wykazania podobieństw, mozolne uzasadnianie związków skutkuje mianowicie utraceniem jednostkowości dzieła literackiego, które - porównane i zestawione - może co najwyżej rezonować w odniesieniu do lub w zestawieniu z innym. „A mnie po diabła co Sartoriusz powiedział, gdy Ja Mówię?!", chciałoby się zakrzyknąć wraz z autorem, który pojedynek na porównywanie sromotnie przegrywa i w pośpiechu „uchodzi”2. Przedsięwzięcie komparatystyczne, w założeniu nastawione na otwarcie perspektywy badawczej, może rykoszetem skutkować takim właśnie „pośpiesznym uchodzeniem” pisarza z krytycznych

1 V. Ryszard Nycz, Kulturowa natura, staby profesjonalizm. Kilka uwag o przedmiocie poznania literackiego i statusie dyskursu literaturoznawczego, w: Michał Paweł Markowski, Ryszard Nycz (red.), Kulturowa teoria literatury. Główne pojęcia i problemy, Universitas, Kraków 2010, s. 5-38.

2 V. Witold Gombrowicz, Trans-Atlantyk, Wydawnictwo Literackie, Kraków 1986, s. 38 . 
analiz, których celem nie jest bezstronne zaangażowanie w oryginalny świat (koncepcje, dociekania, idee), jaki pisarz ten proponuje. Innymi słowy, komparatystycznemu nastawieniu towarzyszy nieuchronnie rodzaj mauvaise foi, którą krytyk akceptuje, zyskując w zamian prawo do poszerzenia interpretacyjnej wolności o konteksty nierzadko samemu autorowi odległe. Wiadomo oczywiście, że intertekstualność jest immanentną cechą literatury i - trudno to ukryć - główną racją bytu krytyki, powołanej do (skądinąd niekoniecznie wiernej samemu pisarzowi) egzegezy jego twórczości. Wiadomo także, że „lęk przed wpływem”, czyli w gruncie rzeczy lęk przed „zdemaskowaniem" tego wpływu, który ze swej istoty jest dla twórcy koniecznym doświadczeniem formującym, towarzyszy pisarzom (i niektórym krytykom, jak Harold Bloom) od zawsze, z wyłączeniem być może Homera. Równie immanentne twórczemu doświadczeniu „kłamstwo romantyczne” - „retoryczne oszustwo skrywające prawdę o kondycji opóźnienia, wtórności i ogromnej podatności na wpływ, która wówczas ujawniła się ostrzej niż kiedykolwiek przedtem w dziejach ludzkości" ${ }^{3}$ - jest rodzajem analogicznej mauvaise foi, tym razem autora, albo - gwoli ścisłości - rodzajem jego bonne foi, bo przekonaniem nabytym nieświadomie, po wyparciu niechcianej prawdy o wpływie. Praca komparatysty polega więc na demaskowaniu poprzedników i prekursorów, a także na poszukiwaniu ewentualnych „spadkobierców”, co jest w gruncie rzeczy tą samą praktyką porównania, tyle że $\mathrm{z}$ innymi nazwiskami wyjściowymi.

Badaniom nad argentyńskimi interpretacjami Witolda Gombrowicza przyświeca bez wątpienia podobny postulat demaskatorski: Kto i jak go czytał? Co filtruje z jego tekstów? Gdzie odnaleźć można gombrowiczowskie tropy? Założenia, które towarzyszą proponowanym przeze mnie studiom nad recepcją autora w innej kulturze narodowej, potęgują jeszcze wyjściowy dyskomfort komparatysty, biorący się z przekonania, że badany autor wymyka się w swojej wyjątkowości,

3 Agata Bielik-Robson, Sześć dni stworzenia. Harolda Blooma mitologia twórczości, w: Harold Bloom, Lęk przed wpływem. Teoria poezji, przeł. Agata Bielik-Robson, Marcin Szuster, Universitas, Kraków 2002, s. 206. 
a to dlatego, że uprzywilejowują zdecydowanie kontekst odbioru, nadając mu prawo do (nad)interpretacji przyjmowanego „z zewnątrz" tekstu. Innymi słowy, przedstawiony przeze mnie „argentyński Gombrowicz" powie znacznie więcej o literaturze argentyńskiej aniżeli o samym Gombrowiczu. Jedynie takie podejście badawcze, nastawione na kulturę przyjmującą, pozwala uniknąć wytykania Argentyńczykom błędów i nieścisłości interpretacyjnych w stosunku do ustaleń krytyki polskiej, ich doxa w świetle naszej episteme. Tak pragmatycznie nakierowana metoda badawcza - mająca wskazać, jak Gombrowicz „działa” w uniwersum literackim swej przybranej ojczyzny - wymaga, rzecz jasna, kilku świadomych ustępstw na rzecz kultury docelowej. Najważniejszym z nich jest zgoda na czytanie autora Dziennika jako pisarza argentyńskiego, co wydaje się zadaniem karkołomnym nie tyle ze względu na narodowe sentymenty, ile z konieczności całkowitego zawieszenia polskiego kontekstu genezy i odbioru jego dzieła. Rodzime okoliczności powstawania utworów (niewątpliwie obecne pomimo stopniowego „wchodzenia w Argentynę"4) oraz wyrosła wokół nich gombrowiczologia pozostaną tutaj bez większego znaczenia. Z drugiej strony „argentynizacja” Gombrowicza oznacza także rezygnację z chętnie ostatnio przyjmowanej przez komparatystów perspektywy transkulturowej, która zakłada badanie literackich tworów nie tyle w oderwaniu od kultury, w której powstały, co w oderwaniu, w uwolnieniu od wszelkich kulturowych ograniczeń, postrzeganych jako więzienie dla indywidualnego doświadczenia. Argentyńska lektura Gombrowicza jest od takiej interpretacji bardzo odległa, niechętnie rezygnuje z rodzimych punktów odniesienia, nawet współcześnie, kiedy - jak się wydaje - literatura latynoska wkroczyła na tory globalizacji, gloryfikując przeróżne postnarodowe tożsamości. Argentyńczycy czytają bowiem autora Ferdydurke jako pisarza swojego, godnego przywołania w wielu stricte narodowych kontekstach, choć jednocześnie postrzegają jego twórczość jako graniczny przypadek własnego kanonu

4 Witold Gombrowicz, Kronos, wstęp Rita Gombrowicz, posł. Jerzy Jarzębski, przypisy Rita Gombrowicz, Jerzy Jarzębski, Klementyna Suchanow, Wydawnictwo Literackie, Kraków 2013, s. 83. 
literackiego, skądinąd dość otwartego na obcość (pisał jednak po polsku). Dlatego niewątpliwie narodowa lektura, jaką proponuje Juan José Saer, nie przeszkadza mu zatytułować swój tekst o Gombrowiczu Spojrzenie z zewnatrz $z^{5}$, który to tytuł parafrazuję na własny użytek.

Poza szczegółowym określeniem metody badawczej, którą wykładam w pierwszym rozdziale, badanie „efektu Gombrowicza” w literaturze regionu La Platy wymaga pochylenia się nad hiszpańskojęzycznymi przekładami jego dzieł, niejednokrotnie znacznie odbiegającymi od polskiego oryginału. W wersji argentyńskiej Ferdydurke, Ślub i Dziennik zostały bowiem przepisane lub uaktualnione przez autora, przez co zmienia się także dopuszczalne pole ich interpretacji. Kolejnym poruszanym przeze mnie zagadnieniem są loci communes, które argentyńska krytyka ustala dla dzieła Gombrowicza - takie jak cielesność i młodość, język, podróż i wygnanie, konfiguracja literackiego „ja” - wyznaczane zawsze w zgodzie z wewnętrzną dynamiką tamtejszej literatury. Wstępem do tych rozważań jest krótka rekonstrukcja procesu historyczno-krytycznego, który pozwolił na „argentynizjację” autora Dziennika. Ostatni, najdłuższy rozdział niniejszej monografii jest poświęcony „używaniu” Gombrowicza przez współczesnych pisarzy argentyńskich, niejednokrotnie reprezentujących bardzo odległe estetyki, które z kolei skłaniają ich do tworzenia różnych prekursorów, odmiennych Gombrowiczów, akcentując poszczególne składowe jego dzieła. Przyjęłam rok 1970 za symboliczną cezurę początkową moich badań, by skupić się na interpretacjach niezapośredniczonych autokomentarzem samego pisarza - w 1963 roku na zawsze opuszcza on Argentynę, a jego twórczość stopniowo „uwalnia się” od ciężaru legendy Gombrowicza-prowokatora i enfant terrible sceny literackiej oraz zaczyna być komentowana w gronie szerszym niż krąg bliskich przyjaciół pisarza.

5 Juan José Saer, Spojrzenie z zewnątrz, przeł. Klementyna Suchanow, Krystian Radny, „Literatura na Świecie” 2001, nr 4, s. 72-82; wyróżnienie moje - E.K.P. 
1.

\section{Komparatystyka, literatura światowa i „inna” historia literatury}

\section{Metoda badawcza}

Badania nad recepcją dzieła Witolda Gombrowicza w Argentynie sytuują się niewątpliwie w polu zainteresowania studiów komparatystycznych, które w ostatnich dziesięcioleciach doczekały się mnogości określających je przymiotników: obok tradycyjnej komparatystyki literackiej (niekiedy zwanej typologiczną ${ }^{1}$ ), mówi się o interdyscyplinarnej, kulturowej czy komparatystyce mediów ${ }^{2}$. Na dodatek dziedzina ta dzieli swój przedmiot badań z refleksją postkolonialną (i właściwym jej spektrum ujęć politycznych), teorią i praktyką tzw. literatury światowej, translatologią oraz postulowaną "możliwą historią literatury”"3 (zwaną także ponowoczesną, słabą, porównawczą lub kulturową $\left.{ }^{4}\right)$. W zależności od przyjętej perspektywy komparatystyka te obszary badawcze wchłania, krzyżuje się z nimi lub staje się ich częścią, akceptując swoją

$1 \quad$ V. Andrzej Zawadzki, Między komparatystykq literacka a kulturowa, w: Teresa Walas, Ryszard Nycz (red.), Kulturowa teoria literatury 2. Poetyki, problematyki, interpretacje, Universitas, Kraków 2012, s. 325-368.

2 V. Mieczysław Dąbrowski (red.), Komparatystyka dla humanistów. Podręcznik akademicki, Wyd. UW, Warszawa 2011. Oprócz tego istnieje cała gama indywidualnych projektów komparatystycznych, takich jak komparatystyka wewnętrzna, dekonstrukcjonistyczna, pozasłowna, integralna etc.; v. Andrzej Hejmej, Komparatystyka. Studia literackie - studia kulturowe, Universitas, Kraków 2013, s. 79.

3 V. Ryszard Nycz, Możliwa historia literatury, „Teksty Drugie” 2010, nr 5, s. 167-184.

4 „Konstelacje komparatystyczne” omawia szczegółowo: Andrzej Hejmej, op. cit., S. $284-290$. 
niestabilność i „niezdyscyplinowanie” jako cenę tak szerokiego horyzontu badawczego. Z drugiej strony przeciwnicy komparatystyki zarzucają jej brak właściwego przedmiotu badań oraz pasożytowanie na pokrewnych dyscyplinach, w szczególności filologiach narodowych ${ }^{5}$. Ta wielopłaszczyznowość, a także kłopotliwe bogactwo terminologiczne sprawiają, że badacz zajmujący się z tej perspektywy tekstem literackim (a często także tekstem kultury), czuje się w obowiązku określić, obficie powołując się na prace teoretyczne, jaki właściwie rodzaj komparatystyki uprawia (co stało się udziałem piszącej te słowa i tłumaczy natłok przypisów na tej oraz kolejnych stronach).

Szeroko rozumiana komparatystyka stała się więc w ostatnich dziesięcioleciach dyscypliną modną, sytuującą się w awangardzie zmian, którym podlega wiedza o literaturze oraz kulturze, sprawnie uzasadniającą swoją nowoczesność, co zdejmuje ze współczesnego komparatysty obowiązek odżegnywania się od uprawiania tzw. wpływologii, popularnej jeszcze w pierwszej połowie xx wieku i inspirowanej pozytywistycznym faktualizmem ${ }^{6}$. Chociaż we współczesnych pracach poświęconych badaniom porównawczym nadal padają nieustanne podejrzenia o ich kryzys lub nawet śmierć ${ }^{7}$, którym z kolei towarzyszą postulaty likwidatorskie, nie ulega wątpliwości, że badania te przeżywają raczej okres triumfu, szczególnie w Polsce, gdzie

$5 \quad$ Klasyczny jest zarzut René Welleka (Kryzys literatury porównawczej, przeł. Zdzisław Łapiński, „Pamiętnik Literacki” 1968, t. 59, z. 3, s. 269-279) o braku wyraźnego przedmiotu badań i własnej metodologii oraz ostrzeżenia René Etiemble’a (Porównanie to jeszcze nie dowód, przeł. Wanda Błońska, „Pamiętnik Literacki” 1968, t. 59, z. 3, s. 311-332) przed ustanawianiem zbyt łatwych analogii. Te i inne problemy metodologiczne badań porównawczych omawia: Edward Kasperski, Komparatystyka współczesna. Zadania i zakres, w: Ewa Szczęsna, Edward Kasperski (red.), Komparatystyka dzisiaj, t. 1: Problemy teoretyczne, Universitas, Kraków 2010, s. 15-16.

6 Za swoisty manifest tego rodzaju badań komparatystycznych uchodzi praca: Paul Van Tieghema, La littérature comparée, Colin, Paris 1931. Fakt, iż ośrodkiem tradycyjnych badań porównawczych była wówczas Francja, antycypuje moje rozważania na temat literatury światowej w ujęciu Pascale Casanovy.

7 V. Gayatri Chakravorty Spivak, Death of a Discipline, Columbia University Press, New York 2003. 
nadrabiamy zaległości z ostatnich dziesięcioleci ${ }^{8}$. Co więcej, wspomniane wyżej „niezdyscyplinowanie” - wynikające tak ze stosowanych w komparatystyce nieostrych kategorii badawczych, jak z wielości języków, kultur i środków przekazu - bywa często interpretowane jako zaleta, w tym „rozmyciu teoretycznym” upatruje się bowiem w gruncie rzeczy odpowiedzi na płynność ponowoczesnej epoki, której tylko badania $z$ natury swej interdyscyplinarne potrafią jeszcze narzucić poznawczą siatkę pojęć, nawiązać dialog, porównać zjawiska na pozór odległe, innymi słowy: odnaleźć sens, który wymyka się tradycyjnym dyscyplinom literaturoznawstwa. $\mathrm{Z}$ drugiej strony formułowane $\mathrm{z}$ takim rozmachem perspektywy badawcze komparatystyki sprawiają, że rozbudza ona niezwykle szeroki horyzont oczekiwań, jak się wydaje, trudnych do spełnienia. I tak ma być odpowiedzią na wyżej wspomniane przemiany cywilizacyjne, w szczególności globalizację i rozwój zaawansowanych systemów przekazu informacji, uwrażliwiać na różnicę kulturową, skupiać jak w soczewce problemy świata epoki postkolonialnej, różnorakich mniejszości oraz kwestie genderowe, nie uciekając przy tym od posługiwania się różnymi kodami przekazu:

8 Dowodem na to niech będzie urodzaj polskich publikacji poświęconych studiom komparatystycznym w ostatnich latach, pośród których można wymienić (w żadnym razie nie pretendując do wyczerpania tej listy): numer „Tekstów Drugich" dedykowany literaturze światowej (2014, nr 4); wydawany od 2010 „Rocznik Komparatystyczny”; antologię Niewspółmierność. Perspektywy nowoczesnej komparatystyki pod redakcją Tomasza Bilczewskiego (Universitas, Kraków 2010); zbiór studiów na temat badań porównawczych w poszczególnych krajach europejskich zatytułowany Drogi i rozdroża współczesnej komparatystyki europejskiej zredagowany przez Alinę Nowickią-Jeżową, Krystynę Wierzbicką-Trwogę i Tomasza Wójcika (Elipsa, Warszawa 2012); pracę zbiorową Kultura $w$ stanie przekładu. Translatologia - komparatystyka - transkulturowość, której redaktorami są Włodzimierz Bolecki i Ewa Kraskowska (Fundacja Akademia Humanistyczna, Warszawa 2012); monografię Edwarda Kasperskiego Kategorie komparatystyki (Wydział Polonistyki UW, Warszawa 2010) oraz wspominane już publikacje: dwutomową Komparatystykę dzisiaj i Komparatystykę dla humanistów. O statusie komparatystyki w Polsce xx i początku xxı wieku, sytuującej się raczej na marginesie dyscyplin pokrewnych i pogrążonej w instytucjonalnym niebycie, przenikliwie pisze Tomasz Bilczewski we wstępie do antologii Niewspótmierność (s. XIX-XX). 
słowem, obrazem, muzyką ${ }^{9}$. Ponadto ma być lekarstwem na bolączki literatur narodowych, grzeszących w szczególności podejściem stricte nacjonalistycznym i rozpatrującym poszczególne literatury w oderwaniu od szerszego kontekstu kulturowego, w którym te niewątpliwie są zanurzone. Stosunek łączący te dyscypliny nie musi być zresztą antagonistyczny, ponieważ podejście komparatystyczne - a więc w jakiejś mierze zewnętrzne - pozwala odkryć w analizowanych dziełach nowe, niedostrzegalne w kontekście narodowym pokłady sensu. Co więcej, kulturom odległym od centrum (a więc także polskiej) nowoczesna komparatystyka oferuje możliwość wprowadzenia ich tworów w obieg międzynarodowy, ukazując ich związki z dziełami autorów stanowiących tzw. hiperkanon, czyli stosunkowo nielicznej grupy „wielkich” pisarzy globalnie rozpoznawalnych. Autor pojęcia hiperkanonu, David Damrosch, z dezaprobatą konstatuje istnienie niewzruszonej od lat elity literackiej, której wieloletnie już studia postkolonialne wcale nie nadwerężyły, przeciwnie - twórcy ci zyskali dzięki nim jedynie nowe pola odczytań: „Powinniśmy przeciwstawić się hegemonii hiperkanonu, ponieważ jednak jego istnienie jest faktem, trzeba zarazem obrócić go na naszą korzyśćc” ${ }^{0}$. To „obracanie” ma być właśnie szansą dla pomniejszych literatur: ich autorzy, analizowani w związku i w połączeniu z „ekstraklasą” literatury zyskują na popularności i mają szansę przebić się do czytelników nienarodowych ${ }^{11}$.

9 V.Mieczysław Dąbrowski, Wstęp, w: idem (red.), op. cit., s. 7-11. O komparatystyce jako modelu nowoczesności pisze także Andrzej Hejmej (op. cit., s. 78-83). Mój sceptyczny ogląd oczekiwań stawianych współczesnej komparatystyce zainspirowany został lekturą książki Stanleya Fisha Profesjonalna poprawność. Badania literackie a polityczna zmiana (przeł. Stanisław Wójtowicz, Wyd. Poznańskiego Towarzystwa Przyjaciół Nauk, Poznań 2012), w której - nie kwestionując osiągnięć badawczych humanistyki w ostatnich dziesięcioleciach - amerykański badacz wypowiada się krytycznie na temat celowości i faktycznej realności projektu zaangażowania badań literackich w tworzenie nowego społeczeństwa.

David Damrosch, Literatura światowa w dobie postkanonicznej i hiperkanonicznej, przeł. Anna Tenczyńska, w: Tomasz Bilczewski (red.), op. cit., s. 376.

11 Niejako na marginesie artykułu Damroscha pragnę poruszyć kwestię , akademickiego kolonializmu", którego komparatystyka nierzadko pada ofiarą. Dobrym na 
Ostatecznie - by kontynuować listę oczekiwań i nadziei, jakie rozbudza komparatystyka - ma być ona także odzwierciedleniem sposobu życia, który przypada w udziale coraz większej liczbie ludzi i w którym pytanie: „skąd pochodzisz?”, zastąpić wypada pytaniem: „pomiędzy czym się znajdujesz?"12. Doświadczenie migracji - już nie wygnania ani podróży - sprzyja bowiem komparatystycznemu spojrzeniu w życiu codziennym, w którym to, co swojskie, jest nieustannie konfrontowane z tym, co (coraz mniej) obce. Badania porównawcze byłyby więc także językiem opisu dla doświadczenia przynależności do wielu miejsc lub raczej braku przynależności, swoistego zawieszenia pomiędzy wieloma kulturami i językami.

Ten, jak się zdaje, nadmierny optymizm poznawczy został zresztą już wykryty i skrytykowany na gruncie - co znamienne - samej komparatystyki, dobrze pojętej „mistrzyni podejrzeń” względem samej siebie. Gayatri Spivak prognozuje nie tyle śmierć całej komparatystyki jako dziedziny poznania, lecz schyłek pewnego sposobu jej uprawiania, nastawionego na porównywanie dokonywane z perspektywy literatur centralnych oraz opartego na poczuciu nieufności i lęku wobec kultur i języków Innych: „Trzeba zacząć traktować języki półkuli południowej jako aktywne media kulturowe, a nie jako przedmiot badań

to przykładem jest właśnie wielokrotnie już cytowana antologia pod redakcją Tomasza Bilczewskiego Niewspółmierność. Książka ta - niewątpliwie paląco potrzebna i uzupełniająca lukę w polskich badaniach porównawczych - zawiera wyłącznie prace uczonych związanych z anglojęzyczną, głównie północnoamerykańską akademią, ugruntowując tym (fałszywe) przekonanie, że w komparatystyce uprawianej w innych językach nic ciekawego się nie zdarzyło. Tymczasem komparatystyka hiszpańskojęzyczna rozwija się prężnie, głównie dzięki badaniom Claudia Guilléna, Daría Villanuevy i Césara Domíngueza. V. numer 787/788 czasopisma „Ínsula” z 2012 roku, poświęcony literaturze porównawczej, w szczególności zawarty w nim artykuł Maria J. Valdésa Literatura comparada o literatura mundial en inglés: diálogo internacional o imperialismo cultural (s. 9-12). O obecności hiszpańskich badaczy w ścisłej czołówce światowej komparatystyki niechaj świadczy praca: César Domíngez, Haun Saussy, Darío Villanueva, Introducing Comparative Literature. New Trends and Applications, Routledge, New York 2015.

12 V. Charles Bernheimer, Wstęp. Lęk przed porównaniem, przeł. Piotr Sobolczyk, w: Tomasz Bilczewski (red.), op. cit., s. 130. 
kulturowych prowadzonych przez migranta z metropolii, którego ignorancja jest czymś usankcjonowanym" ${ }^{13}$. W podobnym tonie wypowiada się Emily Apter w książce pod znamiennym tytułem Against World Literature. On the Politics of Untranslatability, w której punktuje szereg naiwnych założeń, na których opiera się współczesna komparatystyka, określanych wspólnym mianem: „założenia przekładalności” ${ }^{14}$. Zamiast niego badaczka wysuwa założenie nieprzekładalności, które podminować ma dobre samopoczucie komparatystyki, przesuwając punkt ciężkości z wiary w możliwość międzykulturowej komunikacji (porównywalność, asymilację, waloryzację „mniejszych” literatur, uwrażliwienie na ich odmienność etc.) na to, co tę komunikację potencjalnie utrudnia lub nawet uniemożliwia.

Mając na uwadze płynność teoretyczną dyscypliny, a także przedmiot badań - czyli teksty Gombrowicza, o którym Jerzy Jarzębski przenikliwie pisał, że skwapliwie zachęca do zgłaszania votum separatum $^{15}$ - przystępuję do analizy głównych narzędzi metodologicznych podsuwanych przez współczesną komparatystykę, a więc mechanizmu recepcji twórcy obcego w kulturze narodowej oraz idei literatury

13 Gayatri Chakravorty Spivak, Przekraczanie granic, przeł. Ewa Kraskowska, w: Tomasz Bilczewski (red.), op. cit., s. 170.

14 Przemysław Czapliński tłumaczy je w następujący sposób: „Presumpcja ta mówi, że każde dzieło literackie można przełożyć na inne języki (zwłaszcza na angielski) bez utraty kluczowych sensów i wartości, że przełożone dzieło można osadzić w europejskim systemie kategorii literackich (takich jak epika, liryka, dramat, esej, reportaż...) i ulokować w tradycjach obcych dziełu oryginalnemu, że taksonomicznie oswojone dzieło można odnieść do uniwersalnego słownika (prawda, Bóg, istnienie, seksualność) i wreszcie, że zawsze można przypisać komuś posiadanie owego dzieła (narodowi, autorowi, wydawcy)"; Przemysław Czapliński, Literatura światowa i jej figury, „Teksty Drugie” 2014, nr 4, s. 32.

15 V. Jerzy Jarzębski, Z Gombrowiczem do Europy, w: idem, Natura i teatr. 16 tekstów o Gombrowiczu, Wydawnictwo Literackie, Kraków 2007, s. 15. W tym samym eseju pisze: „W czym przydać tu się może Gombrowicz? Przede wszystkim ustawia nam głos. Zamiast mamrotać coś nieśmiało w obliczu skumulowanej wiedzy wszystkich wieków ludzkości, odzyskujemy dzięki niemu niezbędną bezceremonialność, bez której nie ośmielilibyśmy się w tej sytuacji mówić głośno i we własnym imieniu"; ibid., s. 12. 
światowej, nowej historii literatury i związanej z nią kategorii literatury pogranicza. Chodzi przede wszystkim o to, by narzędzia te skontekstualizować, przyłożyć je do konkretnego przypadku, jakim jest istnienie twórczości Gombrowicza w kulturze argentyńskiej, i sprawdzić ich funkcjonalność.

\section{Oko Innego}

Jak pisze Teresa Walas, oko Innego - cudzoziemca - dostarcza nowej perspektywy dla badacza (albo wykładowcy) literatury rodzimej, ponieważ stawia go w sytuacji komunikacji zaburzonej brakiem wspólnej encyklopedii, odmiennością kultur i doświadczeń historycznych, w której wartość i dobrze rozumiana atrakcyjność literatury narodowej nie jest z góry dana, lecz dopiero wymaga udowodnienia, przynajmniej w przypadku kultur „słabszych”16. Zmusza to specjalistę do swoistego nastawienia się na odbiorcę, dostrojenia przekazu do jego wiedzy i przede wszystkim rozbudzenia nieoczywistej chęci poznania, która zwykła więdnąć w kontakcie ze zwyczajową dla literatury polskiej opowieścią o „cnocie nienagrodzonej” ${ }^{17}$. Zamiast niej Walas proponuje inne drogi transferu kultury polskiej, akcentujące jej egzotyzm (fabuła o „szaleńcach wyobraźni”, opowieść niesamowita i niepokojąca) lub, przeciwnie, eksponujące to, co łączy ją z kulturą wolnej Europy (czyli m.in. modernizm w wersji Witkacego, Schulza i Gombrowicza). Jeszcze inny rodzaj „uatrakcyjnionej” opowieści

16 Teresa Walas, Oko innego/cudzoziemca jako możliwa perspektywa poznawcza literatury polskiej, w: Ryszard Nycz, Władysław Miodunka, Tomasz Kunz (red.), Polonistyka bez granic. IV Kongres Polonistyki Zagranicznej, Uniwersytet Jagielloński, 9-11 października 2008, t. 1: Wiedza o literaturze i kulturze, Universitas, Kraków 2011, s. 214-215.

17 „Opowieść ta może mieć charakter martyrologiczno-hagiograficzny lub być pozytywistycznym z ducha case study, w obu przypadkach domaga się od Innego hermeneutycznej translokacji w często nieznane mu doświadczenie historyczne oraz zaakceptowania osobliwego systemu wartości (np. poglądu, że obowiązek patriotyczny pisarza więcej jest wart niż artystyczny cel literatury lub szukanie właściwego sposobu ekspresji własnej osobowości)"; ibid., s. 216. 
o polskiej literaturze mógłby ukazywać „różne polskie wynalazki literackie mniej lub bardziej artystycznie udane, którym drogę do światowego rejestru utrudnił lub wręcz odciął ograniczony zasięg języka, czasem zaś też dodatkowo lokalność problematyki"18. W propozycji Walas - doświadczonej profesjonalistki w dziedzinie „przekładalności” polskiej kultury na obce języki - interesują mnie szczególnie dwie kwestie: po pierwsze, stwierdzenie, że kontakt z obcym czytelnikiem zakładać musi dystans do własnego stanu wiedzy, gotowość zawieszenia jej i wzięcia w nawias, po drugie natomiast fakt, że w każdej z trzech proponowanych narracji - egzotycznej, integrującej i rewindykacyjnej - znajduje się miejsce dla Gombrowicza. Do konieczności „zdystansowania” za chwilę powrócę, zaś wszechobecność autora Ferdydurke w opowieściach dla cudzoziemskiego oka dowodzi, że mowa o naszym głównym „eksportowym” pisarzu, stosunkowo łatwo przekładalnym (choć tylko w sensie metaforycznym) na obce kody kulturowe ${ }^{19}$. I zważywszy na fakt, że poruszamy się w obrębie literatury „słabej”, niedysponującej szeroką gamą pisarzy, których recepcje w obcych kulturach można by omawiać w monografiach, zagadnienie „Gombrowicz w literaturze argentyńskiej” prowokuje zapewne pytania natury ogólniejszej: Jak nas postrzegają? Co z polskiego doświadczenia może wydać się atrakcyjne? Pytania te muszą jednak pozostać bez odpowiedzi z tego mianowicie powodu, że badania recepcyjne dostarczyć mogą jedynie wiedzy o kulturze przyjmującej konkretne dzieło, w nikłym zaś stopniu o kulturze, która to dzieło „wydała”. Przedmiotem analizy jest tutaj oko Innego: Co dostrzega, a co pomija? Jak kalibruje? Jakim złudzeniom chętnie ulega?

\footnotetext{
18 Ibid., s. 220.

19 W tym sensie uległa dezaktualizacji opinia Czesława Miłosza, zgodnie z którą Gombrowicz jest „zanadto polski” dla Amerykanów; v. Benjamin Paloff, Czy fraza „Polish literature” oznacza ,literature polska"? (Problem teorii recepcji i nie tylko...), w: Ryszard Nycz, Władysław Miodunka, Tomasz Kunz (red.), op. cit., s. 82. Paloff precyzuje, że w Stanach Zjednoczonych czyta się Gombrowicza za pomocą rodzimych wzorów interpretacyjnych, które w tym przypadku odwołują się do ikon popkultury; ibid., s. 86.
} 


\section{O funkcjonowaniu w obcej kulturze: problem recepcji}

Klasycznej metody badań recepcyjnych dostarcza popularna w latach 70. szkoła konstancka, której główny przedstawiciel Hans Robert Jauss sformułował swoją teorię w odpowiedzi na wyczerpanie psychologicznego paradygmatu badawczego, ujmującego proces recepcji jedynie w kategoriach jednostkowych i subiektywnych. Dodatkowo estetyka recepcji wpisuje się w tendencję waloryzującą rolę odbiorcy i interpretacji w spotkaniu lub dialogu z dziełem literackim, dystansując się tym samym wobec teorii z kręgu New Criticism, które czytelnika postrzegały w kategoriach szkodliwego nośnika affective fallacy. Kluczowa w koncepcji niemieckiego badacza jest próba zdefiniowania horyzontu oczekiwań, „który to system w przypadku każdego dzieła w historycznym momencie jego pojawienia się określony jest przez uprzednie rozumienie gatunku, przez formę i tematykę uprzednio znanych dzieł oraz przez opozycję języka poetyckiego i praktycznego" $^{20}$. Horyzont oczekiwań daje się zobiektywizować za pomocą reakcji publiczności i wyroków krytyki (spontaniczny lub opóźniony sukces, odrzucenie etc.). Proces odbioru podlega ponadto systematycznej modyfikacji, szczególnie dzięki dziełom, które nie mieszcząc się w dotychczasowym horyzoncie oczekiwań, obalają go i wprowadzają tzw. dystans estetyczny, który na nowo określa spektrum oczekiwań wobec literatury. Rola publiczności ma więc być dwojaka: z jednej strony aktualizuje tkwiący w dziele potencjał, z drugiej natomiast stoi na straży raz ustalonej interpretacji. Formułowane pod adresem teorii Jaussa zarzuty kwestionowały przede wszystkim jej pretensje do obiektywizacji horyzontu oczekiwań: możliwości jego rekonstrukcji dla dawnych epok oraz przede wszystkim zasadności traktowania publiczności jako monolitu o jednolitych oczekiwaniach wobec tekstu literackiego ${ }^{21}$.

20 Hans Robert Jauss, Historia literatury jako prowokacja dla nauki o literaturze, w: idem, Historia literatury jako prowokacja, przeł. Małgorzata Łukasiewicz, posł. Kazimierz Bartoszyński, Wyd. IBL, Warszawa 1999, s. 145.

21 V. Henryk Markiewicz, Odbiór i odbiorca w badaniach literackich, „Ruch Literacki” 1979, z. 1, s. 13. Podobną wymowę ma krytyka przeprowadzona przez Stanleya Fisha, który zamiast jednolitego „horyzontu” wprowadza pojęcie „wspólnoty 
Nie sposób wprawdzie odrzucić twierdzenia Jaussa, że proces odbioru dzieła sterowany jest przez oczekiwania czytelników, lecz współczesne badania recepcyjne wymagają - jak dowodzi Marta Skwara $^{22}$ - uwzględnienia rozpoznań wypracowanych w ramach innych obszarów badawczych komparatystyki, takich jak studia nad literaturą światową oraz przekładem. „Jedną z cech recepcji twórcy »obcego « $[. .$.$] jest próba wpisania jego głosu i postaci w to, co znamy;$ tak jednak, by owo znane i »nasze« inaczej oświetlić, wzmocnić, zuniwersalizować” ${ }^{23}$. Dlatego też Skwara pisze w swojej książce o „polskim Whitmanie”, a nie po prostu o „Whitmanie w Polsce”. Umiejscowienie interpretacji w stosunkowo odległym kręgu kulturowym, wyposażanym w swoisty horyzont oczekiwań, zmienia - jak sugeruje tytuł tego studium - samą istotę poezji Amerykanina. Praca Skwary łączy

interpretacyjnej”, będącej zbiorem obowiązujących w danej grupie przekonań na temat literatury i dostarczającej kontekstu dla interpretacji: „podzielana bazowa zgoda, zarazem kierująca interpretacją, jak i dostarczająca pewnego mechanizmu rozstrzygania pomiędzy interpretacjami”; Stanley Fish, Czy na tych ćwiczeniach jest tekst?, przeł. Andrzej Szahaj, w: idem, Interpretacja, retoryka, polityka. Eseje wybrane, red. i przedm. Andrzej Szahaj, wstęp do pol. wyd. Richard Rorty, Universitas, Kraków 2002, s. 76.

Marta Skwara, „Polski Whitman”. O funkcjonowaniu poety obcego w kulturze narodowej, Universitas, Kraków 2010. Inną polską badaczką zajmująca się problemem odbioru jest Małgorzata Gaszyńska-Magiera, autorka studium Recepcja przekładów literatury iberoamerykańskiej w Polsce w latach 1945-2005 z perspektywy komunikacji międzykulturowej (Wyd. UJ, Kraków 2011). Przyjęta przez nią metodologia - łącząca problematykę właściwą dla estetyki recepcji Jaussa z teorią komunikacji międzykulturowej oraz najnowszymi teoriami z zakresu translacji - służy do zbudowania rozległej panoramy historii polskiego czytelnictwa na przykładzie odbioru prozy iberoamerykańskiej. Przedstawione przez nią ilościowe i jakościowe metody analityczne nie znajdują jednak zastosowania w moim projekcie, ponieważ nie składałyby się na obraz „argentyńskiego Gombrowicza”, tworzony w ostatecznym rozrachunku nie tyle przez liczebność wzmianek, co przez nośność wybranych interpretacji. Inną bliską tematycznie polską monografią jest studium Eweliny Poniedziałek Literatura krajów Ameryki Łacińskiej w polskiej recepcji w latach 1945-1989 (Wyd. UAM, Poznań-Kalisz-Konin 2009), przy czym jest to praca wyłącznie gromadząca dane materiałowe, w znikomym stopniu podejmująca metodologiczne kwestie zaplecza badań recepcyjnych. 
tradycyjne założenia estetyki recepcji Jaussa ze współczesnymi studiami na temat przekładu (Susan Bassnett i André Lefevere’a): główny zrąb jej książki stanowi z jednej strony analiza historycznych warunków odbioru Whitmanowskich tekstów, tak w pracach krytycznych i popularnonaukowych, jak w wykonaniu czołowych twórców kultury polskiej, z drugiej natomiast skrupulatna analiza serii przekładowych. Nieobce jest jej także podejście neopragmatyczne, widoczne w odwołaniach do koncepcji „wspólnoty interpretacyjnej” Stanleya Fisha oraz przede wszystkim w nastawieniu badawczym - interesuje ją pytanie: „jak to działa?”, jak w praktyce funkcjonują wspólnoty wytwarzające znaczenie. Do tego Skwara powołuje się jeszcze na badaczy z kręgów neomarksistowskich, w szczególności Tony’ego Bennetta i jego koncepcję formacji czytelniczych, utożsamianych z konkretną grupą społeczną, dla której tworzy się teksty ${ }^{24}$. Jak argumentuje autorka, tylko tak szeroko nakreślona perspektywa badawcza pozwala objąć całość zjawisk składających się na „funkcjonowanie poety obcego w kulturze narodowej”, a więc: teksty krytyczne, przekłady, związki intertekstualne z twórczością rodzimą, obieg wydawniczy i kulturowy oraz jednostkowe odczytania ${ }^{25}$.

24 Prace Bennetta nie kryją swojej politycznej intencji. Bazując na teorii Pierre’a Bourdieu, której zasługi (refleksje nad pojęciem kapitału kulturowego, rozważania o formowaniu się i różnicowaniu klas społecznych) docenia, Bennett krytykuje ją jednocześnie za nadinterpretowanie wyników badań prowadzące m.in. do nieuzasadnionego akcentowania różnić pomiędzy gustem mieszczaństwa i robotników. V. Tony Bennett, Habitus Clivé: Aesthetics and Politics in the Work of Pierre Bourdieu, w: Philip Goldstein, James L. Machor (red.), New Directions in American Reception Study, Oxford University Press, Oxford 2008, s. 57-98.

25 V. Marta Skawara, „Polski Whitman”, s. 14. W kolejnej książce poświęconej recepcji Whitmana Skwara posługuje się pojęciem „seria recepcyjna”, która „obejmować powinna [...] wszelkie teksty i fakty interpretujące oryginał, jego przekład(y) i inne teksty z nim związane dla odbiorcy kultury narodowej”. Badaczka nadal porusza się na pograniczu translatologii i komparatystyki, wzbogacając studia nad „serią przekładową” o jej „tekstualizacje” w kulturze przyjmującej (obejmujące utwory intertekstualnie związane z oryginałem i przekładem) oraz, szerzej, recepcję, na którą składają się dodatkowo komentarze, recenzje, analizy, zabiegi edytorskie, etc. Eadem, Polskie serie recepcyjne wierszy Walta Whitmana. Monografia wraz z antologia przekładów, Universitas, Kraków 2014, s. 13. 
Ten tygiel metodologiczny - wykorzystujący teorię recepcji i komunikacji literackiej, translatologię i intertekstualność, dodatkowo stosowany na bogatym materiale badawczym - posłużył Skwarze do stworzenia niezwykle ciekawej opowieści o Polsce: o jej kontakcie z tym, co obce, o zaściankowości, komunistycznych trybach dezinterpretacji, indywidualnych i zbiorowych wyobrażeniach ${ }^{26}$. Co znamienne, nie zajmuje się ona w ogóle problemem trafności tych interpretacji (pomijając może wulgarnie zideologizowane lektury Whitmana w krajach demokracji ludowej), nie zestawia ich z amerykańskim lub światowym stanem wiedzy na temat twórczości tego autora, a w każdym razie nie czyni tego z zamiarem waloryzowania lub dewaloryzowania jednych na korzyść innych. Taka normatywna powściągliwość nie zawsze charakteryzowała badaczy argentyńskiej recepcji autora Ferdydurke.

Metodologia wypracowana przez Martę Skwarę będzie niewątpliwie pomocna przy próbie rozpoznania, w jaki sposób funkcjonuje dzieło Gombrowicza w Argentynie, przy czym już na wstępie pragnę zaznaczyć trzy zasadnicze różnice narzucone w moim projekcie lekturowym przez sam przedmiot badań. Po pierwsze, odwrócenie perspektywy narodowej: w przypadku niniejszego studium chodzić będzie o istnienie polskiego autora - choć polskość tę przyjdzie mi jeszcze kwestionować - w przestrzeni obcej. To z kolei wymagać będzie od czytelnika, nieuchronnie przecież wprzęgniętego w tradycję narodową, wspomnianego zawieszenia całej dostępnej (choćby ze szkoły) wiedzy z zakresu tzw. gombrowiczologii i zaakceptowania utrudnionej komunikacji, „swoistej odmiany szumu”27, która zakłóci nasz rodzimy przekaz. To nie my (Polacy) będziemy bowiem wykładać Gombrowicza w jednej z wybranych narracji, ale to nam będą go wykładać i, co więcej, z pominięciem polskiego kontekstu. Po drugie, o ile transfer Walta Whitmana do Polski odbywał się

26 Sama autorka następująco określa swoje cele badawcze: „W ten sposób zyskujemy nie tylko inną wiedzę o kulturze narodowej (czasem po prostu przypominając zbyt łatwo zapomnianą tradycję przekładową), ale $\mathrm{i}$ »naszą « literaturę widzimy $\mathrm{w}$ innej perspektywie, $\mathrm{w}$ perspektywie tego, jak i na ile jest zdolna prowadzić dialog z literaturą światową”; eadem, „Polski Whitman”, s. 34.

27 Teresa Walas, Oko innego/cudzoziemca..., s. 214. 
na typowej drodze wiodącej z centrum literatury ku jej peryferiom, o tyle umiejscowienie Gombrowicza w kulturze argentyńskiej zakłada raczej przemieszczenie pomiędzy dwoma obszarami peryferyjnymi. Fakt ten, co postaram się wykazać, będzie miał zasadnicze znaczenie dla procesu recepcji, zmieniając - by posłużyć się już terminem Pierre’a Bourdieu - stawkę w grze. Po trzecie (i jest to kwestia najważniejsza), Argentyńczycy nie czytają Gombrowicza jako autora całkowicie „obcego”: przestrzeń ich interpretacji rozpięta jest pomiędzy traktowaniem go jako pisarza po prostu argentyńskiego a dostrzeganiem w nim cudzoziemca wprawdzie, ale zanurzonego w kulturze regionu La Platy. Perspektywa ta utrudnia swobodne stosowanie terminu „recepcja” (zarezerwowanego dla pisarzy obcych), a także wymyka się mechanizmowi cyrkulacji literatury światowej (przynajmniej w wersji Pascale Casanovy).

\section{Literatura światowa}

Literatura światowa, szybko zwyżkująca w ostatnich latach na rynku idei i narzędzi metodologicznych literaturoznawstwa, jest kolejną odsłoną badań komparatystycznych, którą wypada rozpatrzyć, pochylając się nad mechanizmem interpretacji dokonywanej na styku różnych kultur. Będąca transpozycją starej Weltliteratur Johanna Wolfganga von Goethego, literatura światowa doczekała się wielu współczesnych definicji, z których dwie - Pascale Casanovy i Davida Damroscha - są dla mnie szczególnie godne uwagi.

W opublikowanej w 1999 roku monografii La République mondiale des Lettres francuska badaczka zastosowała zaczerpnięty od Pierre’a Bourdieu socjologiczny model pola do badania literatury światowej, pojmowanej jako „struktura odporna na jednostkowe ataki, stabilna i skazująca czytelnika na rozpoznawanie przygnębiających prawidłowości”28. Projekt Casanovy mało ma wspólnego z ideą swobodnego przepływu wartości pomiędzy kulturami - zwanego wpływem lub inspiracją - bazuje natomiast na rynkowym modelu wartości

28 Przemysław Czapliński, op. cit., s. 27. 
intelektualnych, w którym monopolista (stolica światowej republiki literatury, umiejscowiona, przynajmniej do lat 6o. ubiegłego wieku, w Paryżu) bezceremonialnie narzuca swoje wartości narodom i pisarzom do niej aspirującym. Paryż wyznacza w tej szczególnej państwowości „literacki południk zero”, który jest miarą nie tyle przestrzeni, ile czasu:

[...] estetyczny dystans mierzy się w kategoriach czasowych: południk zero wyznacza teraźniejszość, czyli w porządku twórczości literackiej, nowoczesność. Odległość dzielącą od centrum dane dzieło lub korpus dzieł ustala się zgodnie z odległością, która dzieli je w czasie od kanonów określających, w tym konkretnym momencie, teraźniejszość literatury ${ }^{29}$.

Narody, które z powodów historycznych lub ekonomicznych (a najczęściej obu) nie zdołały wypracować zawczasu silnej pozycji w tej republice skazane są na „podwójną geografię": miejsce, jakie zajmują w literaturze światowej ich pisarze określa się przede wszystkim poprzez odległość, która dzieli daną literaturę narodową od południka zero. Przyjęcie do elity zależy od różnorakich strategii „narzucenia się” centrum, możliwych do sklasyfikowania według klucza „asymilacji” lub „buntu”30, przy czym „narzucenie” to wiąże się niechybnie z wynarodowieniem: twórczość pisarza uznanego za członka republiki światowej traci swój rodzimy kontekst, jest czytana w oderwaniu od momentu historycznego i uwarunkowania kulturowego, w którym powstała $^{31}$. Literatura światowa to diaboliczna idea, w imię której stosunkowo niewielka grupa utrzymująca monopol na „wartości powszechne" nie dostrzega, a nawet neguje hierarchiczny i konfliktowy porządek rządzący prawami tej wspólnoty, aspirująca większość zaś fikcji tej chętnie się poddaje, stając się obiektem świetnie działającej

29 Pascale Casanova, La República mundial de las Letras, przeł. Jaime Zulaika, Anagrama, Barcelona 2001, s. 123.

30 Ibid., s. 269-330.

31 Doskonałym przykładem tego „wynarodowienia” jest Jorge Luis Borges, którego twórczość czyta się poza Ameryką Łacińską jako antycypującą różnorakie idee postmodernistyczne, pomijając całkowicie jej osadzenie w literaturze argentyńskiej; v. Beatriz Sarlo, Borges, un escritor de las orillas, Siglo XXI, Madrid 2007, s. 1-9. 
przemocy symbolicznej. W modelu Casanovy mechanizmu funkcjonowania obcego twórcy w kulturze narodowej nie sposób wyjaśnić jedynie poprzez analizę krytycznego przyjęcia, artykułów, recenzji, tłumaczeń i nakładów - to bowiem zakładałoby istnienie dwóch światów literackich równych i synchronicznych.

Jedynie jeśli rozpatruje się ten fenomen w oparciu o specyficzną geografię literacką oraz estetyczną miarę czasu, czyli w oparciu o opis rywalizacji, walk, stosunków siłowych, które organizują to pole literackie $[\ldots]$, zrozumieć można jak naprawdę „przyjmuje się”, „asymiluje” i „włącza" dzieło obce ${ }^{32}$.

Zaproponowany przez francuską badaczkę opis literatury światowej zbiega się z intuicjami wielu pisarzy, w szczególności tych sytuujących się z daleka od centrum (ci zamieszkujący bliskie okolice południka zero raczej ten opis negują). Specyficznych sił działających w polu literatury, a niemających wiele wspólnego z nią samą, świadom był z pewnością Gombrowicz, który pisze Dzienniku:

Przypominam sobie herbatkę w pewnym argentyńskim domu, gdzie mój znajomy, Polak, zaczął mówić o Polsce - i znów, naturalnie, wyjechał na stół Mickiewicz, Kościuszko wraz z królem Sobieskim i bitwą pod Wiedniem. Cudzoziemcy grzecznie przysłuchiwali się gorącym wywodom i przyjmowali do wiadomości, iż „Nietzsche i Dostojewski byli polskiego pochodzenia” i że „mamy dwie Nagrody Nobla w literaturze”. Pomyślałem,

32 Pascale Casanova, op. cit., s. 142. Dodajmy na marginesie, że koncepcja Casanovy - której książka ukazała się po hiszpańsku zaledwie dwa lata po swoim francuskim debiucie - była w Ameryce Łacińskiej szeroko, także krytycznie, komentowana. Graciela Montaldo zarzuca jej np. zbyt normatywny punkt widzenia, który rozpatruje kultury peryferyjne jedynie w ich relacji do europejskiego kanonu, pomijając całkowicie inne punkty odniesienia (inne kultury, inne niż literackie praktyki kulturowe) oraz posługiwanie się jedynie kategoriami centrum-peryferie i literatura narodowa, ignorując fakt, że skutkiem tak definiowanej literatury światowej jest także wzniesienie „barier gustu i tradycji”, służących podziałowi na elitę i masy, „legalne i nielegalne użycia kultury"; v. Graciela Montaldo, La expulsión de la república, la deserción del mundo, w: eadem, Zonas ciegas. Populismos y experimentos culturales en Argentina, FCE, Buenos Aires 2010, s. 114. 
że gdyby ktoś wychwalał w ten sposób siebie lub swoją rodzinę, byłby to gruby nietakt. Pomyślałem, iż ta licytacja z innymi narodami na geniuszów i bohaterów, na zasługi i zdobycze kulturalne, jest właśnie wysoce niezręczna pod względem taktyki propagandowej - gdyż z naszym półfrancuskim Szopenem i niezupełnie rdzennym Kopernikiem nie możemy wytrzymać konkurencji włoskiej, francuskiej, niemieckiej, angielskiej, rosyjskiej; więc ten punkt widzenia skazuje nas właśnie na podrzędność. Cudzoziemcy jednak nie przestawali słuchać cierpliwie, jak słucha się tych, co to, mając pretensję do arystokracji, co chwila przypominają, iż prapradziadek był kasztelanem liwskim. A wysłuchiwali z tym większym znudzeniem, że nic ich to nie obchodziło, ponieważ sami, jako naród młody i pozbawiony na szczęście geniuszów, byli poza konkursem. Ale słuchali z pobłażaniem i nawet z sympatią, gdyż ostatecznie wczuwali się w sytuację psychologiczną del pobre polaco; ten zaś, przejęty swoją rolą, nie ustawał ${ }^{33}$.

Gombrowicz nie miał większych złudzeń ani co do samego istnienia „konkursu” i reguł nim rządzących (konsekrująca rola Nagrody Nobla), ani co do miejsca, jakie w tej literackiej geografii przypadło tak narodowi polskiemu, jak argentyńskiemu. Sama Argentyna byłaby zresztą doskonałym przykładem narodu o tzw. małej literaturze, której cechą konstytutywną był bliski mariaż z polityką - pisarze zobowiązani byli do poruszania tematyki narodowej, definiowania odrębnej tożsamości (często dopiero co uzyskanej), ilustrowania historii i problemów własnego kraju etc. Gdy w xix wieku Argentyna uzyskała niepodległość, faktycznie wszystkie jej praktyki literackie zostały podporządkowane celom politycznym - fundowanie literatury nieodwracalnie zbiegło się z fundowaniem narodu - i palące stało się pytanie o tożsamość. Co charakterystyczne dla krajów dotkniętych piętnem kolonializmu, odpowiedź dodatkowo skomplikowała kwestia języka, bo hiszpański postrzegany był jako pozostałość kolonialna, a kulturowo słabe języki autochtoniczne (na terenie Argentyny nie rozwinęła się żadna znacząca cywilizacja prekolumbijska) zostały zepchnięte do roli kodów barbarzyństwa. W 1837 roku Juan María Gutiérrez domagał się wprost zerwania zależności kulturowych z Hiszpanią: „pozostajemy

33 Witold Gombrowicz, Dziennik 1953-1969, Wydawnictwo Literackie, Kraków 2013, e-wydanie. 
jeszcze związani silnym pętem języka, ale ulegnie ono powolnemu osłabieniu w miarę, jak podążać będziemy za intelektualnymi tendencjami rozwiniętych krajów Europy" ${ }^{34}$. Niezależność kulturowa, ugruntowująca polityczną, została w końcu uzyskana poprzez Francję, której dominacja w argentyńskim polu literackim będzie przytłaczająca jeszcze w pierwszej połowie xx wieku.

Koncepcja literatury światowej Pascale Casanovy tylko częściowo przystaje do opisu sposobu, w jaki funkcjonuje dzieło Gombrowicza w Argentynie. Francuska badaczka skupia się bowiem na procesie kanonizacji, który doprowadził wybranych pisarzy „mniejszych literatur" do elitarnego grona, w którym członkostwo reglamentował Paryż. Stawką w tej grze, w której Gombrowicz uczestniczył z pełną świadomością jej mechanizmów, jest uniwersalizacja (przynajmniej w obrębie kultury Zachodu), dokonująca się przy jednoczesnym „wynarodowieniu”. W przypadku literatur peryferyjnych (jak polska), będących przez wieki „dłużniczkami” idei narodu, „wynarodowienie” to bywa oczywiście zbawienne: uwolnienie od rodzimego kontekstu pozwala ujawnić wówczas nowe sensy dzieła, chociaż za ich ujawnieniem („odkryciem”) stoją nieodmiennie krytyczne instancje centrum. Kwestią skądinąd problematyczną pozostaje, na ile ten proces kanonizacji powiódł się w przypadku Gombrowicza. Jest on wprawdzie jednym z najbardziej rozpoznawalnych zagranicą pisarzy polskich, jednak jego teksty - zauważa Jarzębski - nie weszły do kluczowego dla dwudziestowiecznej humanistyki kręgu, tworzonego przez Francuzów: Gilles'a Deleuze'a, Michela Foucaulta, Pierre'a Bourdieu czy Rolanda Barthes'a ${ }^{35}$. Dopiero u progu xx I wieku, za sprawą interpretacji zaproponowanych przez Amerykanów (nie sposób nie zauważyć, że stolica „światowej republiki literatury” przeniosła się w ostatnich

34 Fisonomía del saber español: cuál deba ser entre nosotros; cyt. za: Beatriz Sarlo, Oralidad y lenguas extranjeras. El conflicto en la literatura argentina durante el primer tercio del siglo $\mathrm{xx}$, w: eadem, Carlos Altamirano, Ensayos argentinos: de Sarmiento a la Vanguardia, Siglo xxI, Buenos Aires 1997, s. 270.

35 Jerzy Jarzębski, Gombrowicz - pisarz prowincji?, w: Dominika Świtkowska, Tomasz Tyczyński (red.), Gombrowicz i okolice, Muzeum Literatury im. A. Mickiewicza, Warszawa 2013, s. 15. 
dziesięcioleciach do Nowego Jorku) i akcentujących rozmaite formy peryferyjności pisarza - geograficzną, kulturową, społeczną, genderową - Gombrowiczowi udało się wkroczyć do grona myślicieli kojarzonych $\mathrm{z}$ nowymi formacjami intelektualnymi: postmodernizmem, postkolonializmem, queer i Lacanowską psychoanalizą. Powracając do problemu adekwatności języka Casanovy do opisu casusu argentyńskiej recepcji Gombrowicza, zauważyć należy, że nie mamy tu do czynienia z transferem pomiędzy prowincją literatury a jej stolicą, lecz raczej przemieszczeniem pomiędzy peryferiami (Polska-Argentyna), ułatwionym wprawdzie dzięki uznaniu przez Paryż i niejako za jego przyzwoleniem (twórczość Gombrowicza zaczyna się bowiem przebijać na rynku argentyńskim dopiero po jego wyjeździe do Europy). Buenos Aires z oczywistych względów nie posiada mocy „kanonizującej”, a więc stawką w grze argentyńskiej jest, przeciwnie, ponowne „unarodowienie” autora Ferdydurke, wpisanie ex post $\mathrm{w}$ tradycję literacką tamtego regionu. Ten rodzaj „uzurpacji” Gombrowicza czyni zeń pisarza, któremu albo udało się nawiązać „jakąś tajemną więź z głównymi liniami rozwojowymi argentyńskiej powieści współczesnej”36, albo umiał trafnie, choć z pozycji peryferyjnych, rozpoznać trawiące ją bolączki i kompleksy. Argentyńczycy będą więc szukać w twórczości Gombrowicza nie tyle zapożyczonych idei uniwersalnych - rozumianych jako idee właściwe wiodącym w drugiej połowie xx wieku formacjom intelektualnym, takim jak strukturalizm, poststrukturalizm, dekonstrukcja etc. - co cech stricte argentyńskich, możliwych do odkrycia i wyjaśnienia jedynie w zetknięciu z kulturą regionu La Platy.

O ile pasywny model literatury światowej wypracowany przez Casanovę rozpoznaje siły rządzące $\mathrm{w}$ tym polu $\mathrm{z}$ perspektywy jego twórców, o tyle zasadniczo odmienny model Davida Damroscha, oparty na praktyce lektury, trafniej zdaje sprawę z doświadczenia czytelnika: „w jego ujęciu literatura światowa nie jest tym, co tworzy się poza naszym udziałem, lecz cyrkulacją dzieł, którą sami możemy

36 Ricardo Piglia, Czy istnieje powieść argentyńska? Borges a Gombrowicz, przeł. Klementyna Suchanow, Krystian Radny, „Literatura na Świecie” 2001, nr 4, s. 70. 
uruchamiać”37. Każdy, pojedynczy nawet akt konfrontacji dzieła z obcą mu kulturą jest tworzeniem literatury światowej, przy czym konsekwencje tej konfrontacji są obustronne:

literatura światowa odnosi się zawsze do wartości i potrzeb zarówno kultury goszczącej, jak i kultury źródłowej dzieła; w związku z tym jest to podwójna refrakcja, która wszakże może zostać opisana prze figurę elipsy, z kulturami źródłową i goszczącą dostarczającymi dwóch punktów odniesienia, tworzącymi eliptyczną przestrzeń, w której dzieło funkcjonuje jako literatura światowa, połączone z dwiema kulturami, przez żadną $\mathrm{z}$ osobna niedające się opisać ${ }^{38}$.

Damrosch z jednej strony łagodzi zwyczajową niechęć komparatystyki do filologii narodowych, akcentując fakt, że wszystkie dzieła literackie powstały w obrębie tego, co obecnie nazywamy literaturą narodową, a więc siłą rzeczy są przez nią w dużym stopniu determinowane; $z$ drugiej natomiast przyznaje kulturze przyjmującej prawo do wykorzystania obcych tekstów zgodnie z własną tradycją lub bieżącą potrzebą: jako pozytywnego modelu, negatywnego przykładu lub „obrazu radykalnej inności”, wobec którego buduje swoją tożsamość ${ }^{39}$. W tym sensie koncepcja Damroscha, ogniskująca swoje zainteresowanie na „miejscu negocjacji pomiędzy kulturami”, zdecydowanie różni się od wszelkich badań stricte recepcyjnych, które koncentrują się w zasadzie na kulturze przyjmującej i sposobach, w jakie dzieło obce w nią ingeruje.

W przeciwieństwie do Casanovy, która proces tłumaczenia postrzegała nie tyle jako przestrzeń dla możliwej wymiany kulturowej, ile kolejny chwyt na utrzymanie dominacji centrum, amerykański badacz upatruje w przekładzie istotnej cechy literatury światowej. „Literatura zazwyczaj wtedy pozostaje wewnątrz własnej tradycji narodowej lub regionalnej, kiedy traci w tłumaczeniu, natomiast zyskując w przekładzie

\footnotetext{
37 Przemysław Czapliński, op. cit., s. 29.

38 David Damrosch, Dość czasu i świata, przeł. Adam F. Kola, „Teksty Drugie” 2014, nr 4, s. 104.

39 Ibid.
} 
na równowadze, dzieła stają się częścią literatury światowej”40. Ewentualne straty stylistyczne zostają wynagrodzone zwiększeniem zasięgu oddziaływania i w ten sposób zróżnicowaniem kreatywnych interakcji pomiędzy czytelnikiem i tekstem.

Ostatnią cechą, a ściślej aktywnością konstytuującą literaturę światową w ujęciu Damroscha jest specyficzny „tryb lektury”, „bezstronne zaangażowanie w świat poza naszym własnym” ${ }^{41}$. Literatura światowa nie istnieje więc jako kanon dzieł, ale wy darza si ę, tak jak rozmowa lub spotkanie. Te spotkania dwóch tekstów, do których dochodzi w umyśle czytelnika zaangażowanego z kolei w określoną tradycję narodową, są z gruntu przypadkowe - dzieła nie muszą być bliskie historycznie ani kulturowo, ważne, żeby współbrzmiały. Czytanie w „trybie narodowym” wymaga biegłości w kulturze źródłowej, której kontekst „chroni”42 dzieło, przestawienie na tryb „światowy” zwalnia z obowiązku zaangażowania w jedną tradycję, otwiera natomiast pole pogranicza, w którym teksty rezonują w oderwaniu od tradycji narodowych.

Casus Gombrowicza w Argentynie byłby niewątpliwie aktem tak pojętej literatury światowej (kultura obca w serii jednostkowych konfrontacji z dziełem inkorporuje je na własny użytek), gdyby nie poruszany już wyżej problem ponownego „unarodowienia”. Innymi słowy, Argentyńczycy czytają autora Ferdydurke bez gotowości bezstronnego zaangażowania w świat poza ich własnym ${ }^{43}$, lecz przeciwnie, w jakimś odwróconym trybie lektury narodowej, który, wprawdzie całkowicie obojętny na kontekst polski, pragnie jednak eksponować punkty styczności między twórczością Gombrowicza a tym, co postrzegane jest jako własna tradycja literacka. Oczywiste pozostaje, że każdy czytelnik, jak ujmuje to Damrosch, jest nieuchronnie „wprzęgnięty w tradycję narodową"44, więc postulowana „bezstronność" nigdy nie jest idealna i realizować się może jedynie w sferze

\footnotetext{
40 Ibid., s. 111.

41 Ibid., s. 123.

42 „Nie zobaczymy dzieł literatury światowej w pełni chronionych wewnątrz ich kontekstu kulturowego"; ibid., s. 125.

43 Ibid., s. 122.

44 Ibid., s. 123.
} 
potencjalnej: czytając w trybie „światowym” deklarujemy gotowość otwarcia na to, co z gruntu obce, $\mathrm{z}$ trudem dające się uzgodnić $\mathrm{z}$ obeznanymi procedurami interpretacji. Ta właśnie gotowość wydaje się w argentyńskiej lekturze Gombrowicza problematyczna i to pomimo stosowanej tam często kategorii pogranicza, postrzeganej jako paradygmatyczna dla pola literaty światowej.

Konsekwencją mówienia o literaturze w perspektywie jej „światowości” (nie „powszechności”, nadto kojarzonej jedynie z kanonem Zachodu lub w najlepszym wypadku z prostą sumą literatur poszczególnych narodów) jest postulowana przez badaczy potrzeba wypracowania nowej historii literatury, uwzględniającej najnowsze zdobycze komparatystyki, przede wszystkim różnie definiowaną kategorię miejsc granicznych na styku literatur narodowych ${ }^{45}$. Ryszard Nycz dostrzega w kategorii pogranicza potencjał analityczny, alternatywny dla badań posługujących się relacją centrum-peryferie. O ile ta druga skupia się na eksponowaniu zależności pozornie autonomicznych kultur od ekspansyjnego centrum, o tyle analizy „pograniczne” mają akcentować lub wydobywać właśnie tę „stłumioną hybrydyczność” na pozór jednorodnej kultury ${ }^{46}$. Przymierzona do polskiej tradycji literackiej kategoria pogranicza ujawnia swoje możliwości operacyjne: obejmuje np. problematykę pogranicza politycznego, wewnętrznego (zróżnicowania etniczne i kulturowe), metaforycznych określeń Polski jako przedmurza, tożsamości jednostkowej lub wspólnotowej w perspektywie antropologiczno-kulturowej ${ }^{47}$. Jednak w odróżnieniu od Argentyny Polska reprezentuje typ kultury, który Nycz nazywa „rdzennym”:

45 Mam tu na myśli przede wszystkim artykuł Ryszarda Nycza Możliwa historia literatury. O kategorii pogranicza (i jej zastosowaniu do polskiej literatury kresowej) pisze także Edward Kasperski (Kategorie komparatystyki, s. 313-322). O nowej historii literatury pisała w Polsce m.in. Teresa Walas w dwóch pracach: Czy jest możliwa inna historia literatury? (Universitas, Kraków 1993) oraz Historia literatury w perspektywie kulturowej - dawniej i dziś (w: Michał Paweł Markowski, Ryszard Nycz [red.], Kulturowa teoria literatury. Główne pojęcia i problemy, Universitas, Kraków 2010, s. 93-135). Ryszard Nycz, Możliwa historia literatury, s. 181.

47 Ibid., s. $179-180$. 
o dośrodkowej, monocentrycznej strukturze; ekskludująca poza swe granice wszystko, co inne bądź hybrydyczne; zamknięta (mentalnie) na obce wpływy i odwrócona od swych ściśle wyznaczonych granic, w pobliżu których rośnie niebezpieczeństwo, że do głosu i istnienia dojść może to wszystko, co skażone, gorsze i nieczyste ${ }^{48}$.

Tymczasem kultura Ameryki Łacińskiej, jak każda dotknięta ekspansją kolonialną, zbudowała własną tożsamość właśnie na jej braku, a mianowicie wokół pojęć metysażu i hybrydyczności, lokalizując się tym samym po stronie inkluzywnych kultur pogranicza. Argentyna, choć w latynoskiej przestrzeni wielokulturowych interakcji zajmuje miejsce szczególne, nie jest wyjątkiem, a pojęcie pogranicza ze wszystkimi swoimi odcieniami (politycznym, etnicznym, kulturowym, antropologicznym, wyobrażeniowym) jest konstytutywne dla latynoskiej tożsamości w ogóle, stąd stosowanie go nie przynosi, jak w przypadku polskiego kontekstu, zasadniczego przewartościowania czy reinterpretacji istniejącego stanu wiedzy. Moje rozważania nie służą w żadnym razie kwestionowaniu operatywności tej kategorii badawczej (która została aż nadto dobrze uzasadniona), a jedynie wyjaśnieniu, dlaczego argentyńskie interpretacje Gombrowicza, często odwołujące się do pojęć semantycznie bliskich granicy („spojrzenie z zewnątrz”, margines, obcośćc ${ }^{49}$ ), będę traktować jako przykład „argentynizacji" autora Trans-Atlantyku, a nie próbę otwarcia na to, co fundamentalnie inne, lub dowód na bezstronne zaangażowanie w świat poza własnym. We współczesnej argentyńskiej praktyce krytycznoliterackiej kategoria pogranicza jest od lat głównym

\footnotetext{
48 Ibid., s. 178.

49 Mam na myśli artykuł Juana José Saera pt. Spojrzenie z zewnątrz (przeł. Klementyna Suchanow, Krystian Radny, „Literatura na Świecie” 2001, nr 4, s. 72-82) oraz serię prac Silvany Mandolessi, np. Una literatura abyecta. Gombrowicz en la tradición argentina (Rodopi, Amsterdam-New York 2012), „Heterotopia” i literatura narodowa w „Dzienniku argentyńskim” Witolda Gombrowicza (przeł. Natalia Gendaj, „Rocznik Komparatystyczny” 2010, t. 2, s. 245-260), Sobre exiliados, migrantes y extranjeros: hacia una definición terminológica ("Cahiers du CRICCAL" 2010, t. 39, nr 1, s. 71-78).
} 
budulcem pojęcia tożsamości, a poszukiwania „czystości pochodzenia”, której symulakry tworzono ze szczególnym natężeniem w XIX wieku, zostały dawno zarzucone.

\section{Badania intertekstualne. Anything goes?}

Przekonanie o intertekstualnej naturze znaczenia, czyli o tym, „iż znaczenie spoczywa w różnicach między jednym tekstem czy dyskursem a innymi" ${ }^{50}$, towarzyszy badaniom literackim przynajmniej od lat 6o., w oczywisty sposób waloryzując rolę procesu interpretacji: czytelnik nie tyle wydobywa sens z tekstu, co go weń wpisuje ${ }^{51}$. Uznanie „unikatowości relacyjnej lub sytuacyjnej, uzyskiwanej za sprawą niepowtarzalnej pozycji określanej siecią relacji intertekstualnych"52 za fundamentalną cechę dzieła literackiego pociąga za sobą wypracowanie metody badawczej, która tę unikatowość wydobywa i sankcjonuje. Na gruncie komparatystyki badania intertekstualne zastąpiły więc analizy prowadzone w oparciu o kategorię wpływu: pytanie o genezę (skąd dany motyw pochodzi?) zastąpiono pytaniem o jego funkcjonalność (czemu służy? co oznacza?). Nie zagłębiając się w historię pojęcia intertekstualności, rozpoczętej przez Julię Kristevę w 1969 roku, ani problem jego ewentualnych prekursorów (w szczególności Ferdinanda de Saussure’a i Michaiła Bachtina), nie wdając się także w rozważania natury strukturalnej, które najpłodniej rozwinął Gérard Genette w Palimpsestach ${ }^{53}$, zasygnalizuję

50 Jonathan Culler, Porównywalność, przeł. Tomasz Bilczewski, w: Tomasz Bilczewski (red.), op. cit., s. 110.

51 Jest to skrajne stanowisko, reprezentowane np. przez neopragmatystę Stanleya Fisha w eseju Jak rozpoznać wiersz, gdy się go widzi (przeł. Adam Grzeliński, w: idem, Interpretacja, retoryka, polityka, s. 81-98). Inni badacze skłonni są ostrożniej dawkować władzę czytelnika, którą zresztą sprawuje on - jak u Fisha - w dużej mierze nieświadomie. Możliwe ograniczenia i obwarowania dowolnej interpretacji omawiam poniżej.

52 Ryszard Nycz, Poetyka intertekstualna: tradycje i perspektywy, w: Michał Paweł Markowski, Ryszard Nycz (red.), op. cit., s. 154.

53 Gérard Genette, Palimpsesty. Literatura drugiego stopnia, przeł. Tomasz Stróżyński, Aleksander Milecki, słowo/obraz terytoria, Gdańsk 2014, s. 7-16. Genette wyróżnia pięć typów transtekstualności: bardzo wąsko rozumianą 
jedynie kilka kwestii pragmatycznych, których dookreślenie pozwoli na efektywne stosowanie tej metody badawczej w moich analizach.

Najbardziej palącą dla mnie kwestią jest problem intencjonalności odniesień międzytekstowych: czy w badaniach należy uwzględniać tylko świadomie wpisane w dzieło nawiązania, czy też - zważywszy na praktyczne trudności z określeniem tej intencji, niebezpiecznie zbliżającej się do kategorii wpływu - otworzyć je na wielość interpretacji, ograniczoną jedynie potencjałem analitycznym (lub fantazją) krytyka? ${ }^{54} \mathrm{~W}$ kwestii tej wypowiadam się po stronie „uchwytnej gry znaczen”" ${ }^{5}$ - niekoniecznie zamierzonej, ale możliwej do intersubiektywnego sprawdzenia i zaakceptowania. Znaczenie - w tym przypadku: propozycja sieci intertekstualnych związków - jest w dużej mierze konstruowane, jednak konstrukcja ta jest wypadkową tzw. interpretantu zawartego w tekście przyjmującym (i określającego jego stosunek do tekstu przejętego: instrukcję, jak ma być czytany ${ }^{56}$ ) oraz sytuacji czytelnika (jego kompetencji, momentu

intertekstualność (relację współobecności dwóch tekstów, np. w cytacie, aluzji), paratekstuaność (relację z własnym paratekstem, tworzonym przez tytuły, przedmowy, wstępy, uwagi od wydawcy etc.), metatekstualność (relację potocznie zwaną „komentarzem”), architekstualność (nie zawsze jawnie oznaczone odesłanie do reguł kompozycyjnych, najczęściej gatunkowych, np. powieść, esej etc.) oraz hipertekstualność, czyli „każdą relację łączącą tekst B (który będę nazywał hipertekstem) z wcześniejszym tekstem A (który będę oczywiście nazywał hipotekstem), na który tekst B zostaje przeszczepiony w sposób niemający nic wspólnego z komentarzem”; ibid., s. 11. Typologia Genetta była krytykowana za przeciążenie i nierozłączność (v. Michał Głowiński, O intertekstualności, w: idem, Prace wybrane, t. 5: Intertekstualność, groteska, parabola. Szkice ogólne i interpretacje, Universitas, Kraków 200o, s. 11-12), niemniej jej terminologia przyjęła się w krytyce francuskojęzycznej.

54 V. Ryszard Nycz, Poetyka intertekstualna: tradycje i perspektywy, s. 160-161. Marta Skwara pisze o biegunie „rozpoznawalności”, uzasadnionej wskazaniem konkretnych zabiegów na tekstach wcześniejszych, takich jak cytaty, aluzje czy parafrazy, oraz biegunie „interpretatywności”, „warunkowanej głównie przez zdolności perswazyjne interpretatora"; Marta Skawara, Stara i nowa komparatystyka literacka, w: Mieczysław Dąbrowski (red.), op. cit., s. 204.

55 Marta Skwara, Stara i nowa komparatystyka literacka, s. 204.

56 V. Michał Głowiński, O intertekstualności, s. 18-19; Ryszard Nycz, Intertekstualność i jej zakresy: teksty, gatunki, światy, w: idem, Tekstowy świat. Poststrukturalizm a wiedza o literaturze, Universitas, Kraków 2000, s. 83. 
historycznego, przestrzeni kulturowej). Relacja ta jest obustronna: to, co odbiorca „wyczytuje” z interpretantu, jest niewątpliwie pochodną jego zaangażowania (krytycznego, literackiego, kulturowego), które jednak powinno znaleźć swoje umocowanie w samym tekście. Innymi słowy, subiektywna perspektywa badacza - tak na poziomie ogólnym, rozumianym jako przynależność do konkretnej wspólnoty interpretacyjnej, jak szczegółowym, uwzględniającym cel analiz oraz przyjętą metodologię - nie jest $\mathrm{z}$ pewnością pomijalna, nie powinna jednak stanowić jedynego uzasadnienia ustanawianych relacji między dwoma (lub więcej) dyskursami.

W tej trzystopniowej strukturze - tekst przejmowany, tekst przejmujący, badacz-odbiorca - pierwszy człon jest najmniej autonomiczny i najbardziej chwiejny, podlega bowiem podwójnej kontekstualizaji. „Sam tekst przejęty - pisze Głowiński - nie jest jeszcze w nowym kontekście wyraźnie znaczeniowo wyposażony" ${ }^{57}$; o wyposażeniu tym decyduje po pierwsze interpretant, a po drugie ten, kto dokonuje jego rekonstrukcji. W niniejszym projekcie Gombrowicz będzie podlegał tej właśnie dwustopniowej lekturze: w tekstach przyjmujących (trudno nie zauważyć, że także zanurzonych w konkretnym polu literackim) oraz, pośrednio, w moich badaniach recepcyjnych. Piszę „pośrednio”, gdyż - przypomnę - podstawowym ich celem jest analiza tekstów przyjmujących, pragmatyczne ujęcie sposobów, w jakie Argentyńczycy przejmują twórczośći legendę polskiego pisarza, przetwarzają i używają zgodnie z własną mapą literacką.

Gombrowicz - co postaram się wykazać w niniejszym studium - funkcjonuje w Argentynie w sferze tzw. intertekstualności pożądanej, o której Głowiński pisze następująco:

Każda epoka ma swoją sferę intertekstualności aprobowanej i pożądanej oraz intertekstualności odrzucanej i negowanej; obok tych sfer oznaczonych pozytywnie bądź negatywnie istnieją w każdym czasie ogromne dziedziny literackie, będące - by tak powiedzieć - intertekstualnie neutralne, takie, których się nie odrzuca, bo nie ma powodu [...] ale też się ich nie przywołuje ${ }^{58}$.

\footnotetext{
57 Michał Głowiński, O intertekstualności, s. 19.

58 Ibid., s. 31. Głowiński sytuuje wprawdzie pojęcie „intertekstualność aprobowana” historycznie, pisząc o epokach, jednak równie uzasadnione wydaje się także
} 
Po okresie pozostawania w sferze neutralnej, w latach 70., Gombrowicz staje się najpierw rozpoznawalnym punktem odniesienia, a następnie - i jest to zmiana z ostatnich dziesięcioleci - pożądanym ogniwem związków międzytekstowych. W tej stosunkowo krótkiej (bo datowanej zaledwie od xIx wieku) tradycji literackiej Gombrowicz nie jest z pewnością pisarzem centralnym, funkcjonuje jednak, ogólnie rzecz ujmując, w obrębie antykanonu jako jeden z jego historycznych, uprawomocniających filarów. Ponadto fakt, że istnieje grupa tekstów, w których rozpoznanie odniesień do autora Dziennika nie tylko ich lekturę uwieloznacznia i uatrakcyjnia, ale jest po prostu koniecznym warunkiem zrozumienia, wskazuje jednoznacznie, że Gombrowicz oddziałuje na aprobowane współcześnie kody lekturowe.

\section{Co wiadomo o „argentyńskim Gombrowiczu”?}

O „argentyńskim Gombrowiczu” wiadomo w Polsce zarazem wiele i prawie nic. W sposób szczegółowy i nieomal kompletny (przynajmniej na tyle, na ile to w ogóle możliwe w odniesieniu do przeszłości) udało się zrekonstruować dane historycznoliterackie, zebrać wspomnienia o nim, odnaleźć nieliczne artykuły, jakie zdołał opublikować w prasie argentyńskiej. Nieocenionym źródłem wiedzy o argentyńskim etapie życia Gombrowicza są monografie Rity Gombrowicz oraz Klementyny Suchanow, które rekonstruują wydarzenia z lat 1939-1963 $\mathrm{w}$ formie zbioru wspomnień dyktowanych przez przyjaciół i znajomych lub wartkiej narracji, z prawdziwą pasją odtwarzającej szczegóły faktograficzne ${ }^{59}$. Polem badawczym obu autorek jest biografia

użycie „przestrzenne” lub kulturowe, szczególnie w odniesieniu do kultur sobie odległych (jak polska i argentyńska).

59 Rita Gombrowicz, Gombrowicz w Argentynie. Świadectwa i dokumenty 1939-1963, przeł. Zofia Chądzyńska, Anna Husarska, Wydawnictwo Literackie, Kraków 2004 (pierwodruk francuski ukazał się w 1984 roku); Klementyna Suchanow, Argentyńskie przygody Gombrowicza, Wydawnictwo Literackie, Kraków 2005. Na temat związków Gombrowicza z argentyńskimi pisarzami v. Dieter Reichardt, Gombrowicz a literatura argentyńska, przeł. Ryszard Wojnakowski, w: Marek 
Gombrowicza i historia jego twórczości, natomiast interesujący mnie problem historii interpretacji zdecydowanie się w nim nie mieści ${ }^{60}$. Polska krytyka w zasadzie nie zajmowała się kwestią recepcji argentyńskiej, choć ta budziła niewątpliwie jej zainteresowanie z powodów natury afektywnej - kraj ten stał się przecież dla Gombrowicza drugą ojczyzną. Zainteresowaniu temu towarzyszyło oczekiwanie należytego skomentowania i docenienia, co skądinąd zrozumiałe - wszak chodzi o naszego klasyka, którego dzieło zdaje się posiadać ogromny potencjał interpretacyjny $^{61}$.

Studium poświęcone sensu stricto recepcji Gombrowicza w Argentynie powstało w 2008 roku na gruncie krytyki hiszpańskiej, choć - co będzie miało doniosłe znaczenie - z polonistycznej perspektywy badawczej: jego autor, Pau Freixa Terradas, wykłada w Katedrze Slawistyki Uniwersytetu w Barcelonie ${ }^{62}$. Jego zasługi

Zybura (oprac.), „Patagończyk w Berlinie”. Witold Gombrowicz w oczach krytyki niemieckiej, Universitas, Kraków 2004, s. 269-294.

60 W ostatnim rozdziale Argentyńskich przygód Gombrowicza zatytułowanym Gombrowicz w oczach Argentyńczyków (s. 225-252), Klementyna Suchanow zamieszcza wprawdzie krótki szkic poświęcony współczesnym związkom literatury argentyńskiej z polskim pisarzem, w którym wymienia wiele kluczowych nazwisk, nie jest to jednak w żadnej mierze wyczerpujące studium recepcji.

61 Rita Gombrowicz pisze we wprowadzeniu do swojej książki (op. cit., s. 5) o obawie przed zapomnieniem, jaka towarzyszyła jej w podróży do Argentyny („Upływało dziesięć lat od chwili, kiedy Gombrowicz ją opuścił. Cóż mogłam tam znaleźć?”), by zaraz potem skonstatować z ulgą: „Od pierwszej chwili po przyjeździe zrozumiałam, że moje żale i obawy były nieuzasadnione”. Klementyna Suchanow (op. cit., s. 251) wprost deklaruje swoją ciekawość o lekturę Polaka w jego przybranej ojczyźnie: „Intrygowało mnie zawsze, jak mogą go odbierać ONI”. Jerzy Jarzębski (W Buenos Aires - po trzydziestu pięciu latach, w: idem, Podglądanie Gombrowicza, Wydawnictwo Literackie, Kraków 2001, s. 234) z zadowoleniem odkrywa w Buenos Aires „nowe, młodsze pokolenie czcicieli Mistrza”.

62 Jego praca doktorska, obroniona w 2008 roku na Uniwersytecie w Barcelonie, powstała w języku katalońskim: Recepció de l'obra de Witold Gombrowicz a Argentina i configuració de la seva imatge a l'imaginari cultural argentí; dostępna jest on-line: http://goo.gl/YZFfsL, dostęp: 10 x 2016. Korzystam z wersji hiszpańskojęzycznej: 
w zakresie gombrowiczologii obejmują, oprócz szeregu prac na temat argentyńskiej recepcji, także tłumaczenia (przełożył kilka opowiadań z tomu Bakakaj i jest współautorem nowego przekładu Pornografii) oraz studia krytyczne z zakresu translacji, do których sięgnę w kolejnym rozdziale. W swoich badaniach recepcyjnych Freixa Terradas przyjmuje klasyczną metodologię badawczą, wywiedzioną z estetyki recepcji Jaussa, według której odbiór dzieła następuje na dwóch poziomach: pasywnym (najtrudniejszym do uchwycenia ze względu na brak konkretnych śladów tekstowych, obejmuje on bowiem odczytania dokonane przez ogół czytelników; narzędziem badawczym są w tym przypadku modele statystyczne używane w historii, socjologii lub językoznawstwie oraz, za czym optuje Freixa Terradas, zbieranie świadectw ustnych) i aktywnym, dokonywanym przez krytykę literacką, a także innych twórców kultury (w tym ostatnim przypadku hiszpański badacz posługuje się zarówno kategorią związków intertekstualnych, jak i wpływu ${ }^{63}$ ). Zważywszy na fakt albo przekonanie o tym, że aktywna recepcja Gombrowicza jest w Argentynie nader skromna ${ }^{64}$, autor studium proponuje skupić uwagę na sferze wyobrażeniowej, zaczerpniętej z antropologii i historii mówionej. Niezależnie od trafności stwierdzenia o braku

Recepción de la obra de Witold Gombrowicz en la Argentina y configuración de su imagen en el imaginario cultural argentino, dostępnej on-line: http://goo.gl/ A3avU1, dostęp: 10 x 2016.

63 Pau Freixa Terradas, Recepción de la obra de Witold Gombrowicz..., m.in. s. 12, 32, 206, 211.

64 Trudno stwierdzić, w jakiej mierze konstatacja ta jest wynikiem badań, a w jakim je determinuje. W innym miejscu Freixa Terradas stwierdza bowiem: „W przeciągu ostatnich czterech lat zajmowaliśmy się badaniem odbioru dzieła Witolda Gombrowicza w jego adopcyjnym kraju - Argentynie. Od samego początku było jasne, że odbiór ten będzie słaby i trudny do zanalizowania ze względu na małą ilość badań, opracowań krytycznych, artykułów prasowych, odniesień itd. Żeby nie wspominać już o wpływie polskiego pisarza na twórczość argentyńskich artystów - nieistniejącym lub tak nikłym, że z całą pewnością poszukiwania przekształciłyby się w bezowocną chimerę"; idem, Argentyński portret wyobrażeniowy Gombrowicza, w: Ryszard Nycz, Władysław Miodunka, Tomasz Kunz (red.), op. cit., s. 537 . 
klasycznej recepcji (Freixa Terradas pisze nawet o „nie-recepcji”65), z którym będę polemizować, propozycja badawcza operująca pojęciami „wyobrażeniowości kulturowej” w odniesieniu do różnorakich wizerunków samego Gombrowicza (już nie jego tekstów) wydaje mi się bardzo cenna, szczególnie, gdy dotyczy epoki następującej bezpośrednio po powrocie pisarza do Europy. Wizerunek wówczas wypracowany - „wyobrażeniowy embrion” - będzie podstawą dla konstruowanego później portretu Polaka, stanowiącego najbardziej płodny wymiar jego argentyńskiej recepcji ${ }^{66}$. W pierwszej części pracy Freixa Terradas śledzi „wcielenia” Gombrowicza w kolejnych dekadach, począwszy od lat 40., a skończywszy na roku 2004, ujawniając przy tym sukcesywne strategie interpretacyjne, narzucane najpierw przez samego Gombrowicza, a potem wypracowywane przez krytykę ${ }^{67}$. I tak autor Ferdydurke jawi się najpierw jako anonimowy pisarz walczący bezskutecznie o uznanie w kręgach literackich Buenos Aires, by w kolejnej dekadzie przyjąć perspektywę transatlantycką i otrzymać pierwsze dowody sławy międzynarodowej. W latach 60., w których Gombrowicz będzie mógł jeszcze z oddali sterować swoim wizerunkiem w Argentynie, tworzy się jego argentyńska legenda, dostępna wówczas jedynie wąskiemu kręgowi bezpośrednich znajomych i „uczniów”. Zatryumfuje ona dopiero w kolejnym dziesięcioleciu za sprawą serii sukcesów teatralnych. Lata 8o. to m.in. interpretacje Ricarda Piglii i Juana José Saera, które ustanowią paradygmat lektury narodowej, przekroczony w kolejnej dekadzie, głównie dzięki pracom pisanym z pozycji psychoanalitycznych. Taka dystrybucja czasowa pozwala więc wydobyć zmieniające

65 V. idem, Recepción de la obra de Witold Gombrowicz..., s. 15. Teza o braku rzeczywistej lektury Gombrowiczowskiego dzieła w Argentynie zostaje powtórzona w artykule Pau Freixy Terradesa i Bożeny Zaboklickiej pt. Gombrowicz jako postać fikcyjna w literaturze argentyńskiej („Teksty Drugie” 2016, nr 1, s. 303-316).

66 V. Pau Freixa Terradas, Argentyński portret wyobrażeniowy Gombrowicza, s. 539 .

67 O kolejnych „autoprezentacjach” Gombrowicza, choć sytuując je bardziej według tekstów niż lat, pisze przenikliwie Jerzy Jarzębski w tekście Gombrowicz - problemy autoprezentacji (w: idem, Natura i teatr, s. 23-39). 
się dominanty w „portrecie wyobrażeniowym” Gombrowicza: punkty zwrotne, sploty wydarzeń, momenty kulminacyjne, które zginęłyby w zwykłym repertorium wyjętych z prasy argentyńskiej wzmianek o Polaku. Freixa Terradas zapowiada wprawdzie „systematyczne poszukiwania każdego słowa napisanego i opublikowanego w Argentynie o Gombrowiczu" ${ }^{68}$, na szczęście obietnicy tej nie spełnia i konstruuje - zamiast katalogu danych bibliograficznych - czytelną historię strategii interpretacyjnych.

W drugiej części pracy hiszpański badacz dokonuje przeglądu najważniejszych jego zdaniem literackich i filmowych reprezentacji Witolda Gombrowicza, skupiając się bardziej na budowie i roli tej postaci w danym tekście, niż na pozycji jego autora w argentyńskim polu literackim, co skutkuje jednakowoż pomieszaniem nazwisk kluczowych (np. Ricarda Piglii) z nazwiskami mało znaczącymi ${ }^{69}$. Freixa Terradas jest bez wątpienia świadom faktu, że pisarze wykorzystujący postać Gombrowicza grają w zupełnie innych „ligach literackich" i nośność ich interpretacji jest odmienna, ale czytelnikowi nieobeznanemu z tamtejszą sceną literacką raczej to umyka.

Najpoważniejszy zarzut pod adresem omawianego studium dotyczy niezwykle wąsko nakreślonych ram dla związków intertekstualnych, co powoduje, że autor ogranicza się w dużej mierze do poszukiwania epigonów (termin ten nader często pojawia się w pracy), których, na szczęście, nie znajduje zbyt wielu ${ }^{70}$. Odniesienie do ogólnie pojętego „systemu filozoficznego" Gombrowicza, którego glosy to Dziennik i Testament, Freixa Terradas traktuje jako konieczną składową godnej do zaakceptowania relacji międzytekstowej. Nieumiejętności przyswojenia Gombrowiczowskich treści i ich płodnego wykorzystania w relacji

68 Pau Freixa Terradas, Recepción de la obra de Witold Gombrowicz..., s. 31.

69 Na przykład Néstor Tirri może być dla badaczy argentyńskiego okresu życia Gombrowicza postacią pierwszoplanową, jednak jego twórczość literacka ma nikły wpływ na kształtowanie się odbioru dzieł polskiego pisarza w Argentynie. Słusznie zauważa przy tym, że na gruncie literatury polskiej twórczość Gombrowicza - choć bez wątpienia znana i czytana - także nie pozostawiła tworów epigonicznych; v. Pau Freixa Terradas, Recepción de la obra de Witold Gombrowicz..., s. 209-210. 
intertekstualnej towarzyszy, zdaniem hiszpańskiego badacza, miałkość krytyki. Odrzuca on jako nieprawomocne lub nieznaczące wszelkie interpretacje nieusankcjonowane $z$ jednej strony przez samego pisarza (choćby znaczeniotwórczą rolę homoseksualizmu) $^{71}$, z drugiej zaś przez polską lub światową (czyli w dużej mierze francuską) krytykę. To ostatnie następuje np. wtedy, gdy zarzuca Argentyńczykom gloryfikowanie „dobrowolnej anonimowości” i „fascynacji porażką” u Gombrowicza oraz ignorowanie faktu, że celem jego „marginalnego dyskursu" było w rzeczywistości zajęcie centralnego miejsca na mapie literatury światowej. $W$ tym przypadku autor - poza tym, że sam zaczyna kierować się kryterium biograficznym ${ }^{72}$ - nie dostrzega, że to dążenie do centrum literatury jest bez wątpienia widoczne i produktywne dla krytyki polskiej lub francuskiej, ale jednocześnie może pozostać całkowicie nieistotne z perspektywy argentyńskiej, która Gombrowicza przeczyta pragmatycznie, kierując się własną specyfiką i uwzględniając „bieżące potrzeby”.

Drugą moją wątpliwość budzi teza o nieznajomości tekstów Gombrowicza w Argentynie i próbie ich zastąpienia nośną narracją o życiu pisarza, która odbiór jego dzieła w zasadniczy sposób zubaża: recepcja aktywna wyczerpuje się, jak utrzymuje Freixa Terradas, w konstrukcji "portretu wyobrażeniowego" twórcy. Tymczasem zabieg „ufikcyjnienia” postaci jako formy interpretacji wydaje się narzucać w przypadku pisarza, który sam do praktyk autofikcyjnych uciekał się nader często.

71 Skłonny jest docenić recenzje pióra Carlosa Coldaroli, Rogera Pla oraz Virgilia Piñery, jednak ich jakość przypisuje m.in. wskazówkom samego pisarza, który znał osobiście wszystkich trzech krytyków; ibid., s. 6o. Kwestię homoseksualizmu pisarza jako danej zasadniczo bez znaczenia dla interpretacji dzieła porusza na s. 213 .

72 Miarą strategii interpretacyjnej (zawartej dodatkowo w fikcji literackiej) czyni jej zgodność z faktami biograficznymi: „[...] te wyobrażenia o anonimowym życiu pisarza sprawiły, że Ricardo Piglia widział los Gombrowicza jako konsekwencję »fascynacji porażką«. Tym niemniej korespondencja, Dziennik i dowody biograficzne pokazały, jak dalekie od prawdy były te stwierdzenia”; idem, Argentyński portret wyobrażeniowy Gombrowicza, s. 543; v. idem, Recepción de la obra de Witold Gombrowicz..., s. 273-274. 
Zresztą także w Polsce traktuje się trajektorie życiowe autora Dziennika jako ważną składową interpretacyjną, co w sposób żartobliwy, lecz celny ujmuje Andrzej Stanisław Kowalczyk: „Spośród dzieł Witolda Gombrowicza największą popularność zyskało w Polsce jego życie, natomiast opowiadania, powieści i dramaty pozostały lekturą entuzjastów, czytelników smakoszy. [...] Spod uroku sugestywnej wizji własnego życia, którą nam narzucił, trudno się uwolnić"73. Ponadto hiszpański badacz wydaje się nie brać pod uwagę faktu, że powieściowe reprezentacje postaci Gombrowicza mogą być w dużej mierze wypadkową tekstów właśnie, a w szczególności Dziennika argentyńskiego, który - jak sam przyznaje - był zawsze najpoczytniejszym (bo dostępnym na rynku) dziełem pisarza ${ }^{74}$.

Pomimo tych zastrzeżeń książka Freixy Terradesa pozostaje najważniejszym i najbardziej całościowym studium argentyńskiej recepcji Gombrowicza, gromadzącym i porządkującym różnorakie (literackie, filmowe, prasowe) dane materiałowe. Jego surowe sądy o braku odzewu ze strony krytyki argentyńskiej były w dużej mierze uwarunkowane historycznie: w 2008 roku nie istniała jeszcze część argentyńskich opracowań o autorze Trans-Atlantyku, a zainteresowanie jego dziełem - co zresztą Freixa Terradas przewiduje ${ }^{75}$ - miało wzrosnąć w kolejnych latach. Ponadto moje obiekcje pod adresem jego pracy wynikają w dużej

73 Andrzej Stanisław Kowalczyk, „Za niedyskrecję matka biła mnie po łapach”, w: Jerzy Giedroyc, Witold Gombrowicz, Listy 1950-1969, wyb., wstęp i przypisy Andrzej Stanisław Kowalczyk, Czytelnik, Warszawa 2006, s. 5. Dzieło pisarza przez pryzmat jego życia czyta np. Janusz Margański w Geografii pragnień. Opowieści o Gombrowiczu (Wydawnictwo Literackie, Kraków 2005). Na założeniu przenikania się dzieła i życia zbudowana jest także zredagowana przez Włodzimierza Boleckiego Autobiografia pośmiertna Gombrowicza (Wydawnictwo Literackie, Kraków 2002).

74 Pau Freixa Terradas, Recepción de la obra de Witold Gombrowicz..., s. 99. Freixa Terradas przyznaje wprawdzie, że argentyńskie portrety pisarza bazują na jego dziele, ale określa je wspólnie jako „bardzo powierzchowną lekturę biograficzną”. Tymczasem w wielu przypadkach - co postaram się wykazać w kolejnych rozdziałach - jest to być może lektura pobieżna, jeśli chodzi o zgodność z danymi faktograficznymi, usytuowana jednak w argentyńskim polu literackim, odsłania swoją złożoność.

75 Ibid., S. 282. 
mierze $\mathrm{z}$ różnic $\mathrm{w}$ przyjętych założeniach metodologicznych (które chociażby inaczej ustalają granice intertekstualności aprobowanej) oraz w perspektywach badawczych. Jako doskonały znawca literatury polskiej, a w szczególności Gombrowicza, hiszpański badacz stawia w centrum swoich zainteresowań dzieło tego pisarza i jego autorytet interpretacyjny, podług którego ocenia dokonania krytyki argentyńskiej. A ta rzeczywiście nie zwykła była podejmować tych problemów, które on sam wskazywał jako kluczowe, co z kolei było wynikiem zarówno naturalnej dla każdej literatury narodowej tendencji do wchłaniania twórcy obcego na własnych warunkach, jak i faktycznej niedostępności rozlicznych paratekstów, w których Gombrowicz własne dzieło wyłożył.

\section{Argentyńska stawka w grze o Gombrowicza}

W moim ujęciu (zakorzenionym bardziej w tradycji hispanistycznej niż polonistycznej) punktem wyjścia będzie dzieło Witolda Gombrowicza, jednak dojścia - literatura i krytyka argentyńska, które będą to dzieło przetwarzać zgodnie z własnym zapotrzebowaniem na „antagonistów Borgesa”, „rewolucjonistów języka” czy „pisarzy-wygnańców”. Tak zresztą pojmuje mechanizm przyswajania obcych poetyk najważniejszy chyba argentyński interpretator Gombrowicza, Ricardo Piglia:

To literatura narodowa organizuje, porządkuje i moduluje wkraczanie obcych tekstów oraz określa sytuację lektury. Nic nie znaczy stwierdzenie, że interesuje mnie, dajmy na to, Brecht lub William Gaddis; należałoby raczej zobaczyć, z jakiego miejsca ich czytam, do jakiego nurtu włączam ich książki, w jaki sposób ten kontekst może je skazić, a język narodowy - „wchłonąć”. Zawłaszczenia niektórych elementów dzieł zagranicznych dokonuje się w gruncie rzeczy po to, by ustanawiać związki i przymierza, które są zawsze sposobem na akceptowanie lub zanegowanie tradycji narodowych ${ }^{76}$.

76 Ricardo Piglia, El laboratorio de la escritura, w: idem, Crítica y ficción, Anagrama, Barcelona 2006, s. 56. Wszędzie tam, gdzie nie podaję nazwiska tłumacza, przekład jest mój - E.K.P. 
Nadając pierwszeństwo „miejscu czytania”, traktuję moje analizy bardziej jako możliwą wersję nieortodoksyjnej, pobocznej historii literatury argentyńskiej niźli pracę z zakresu gombrowiczologii. Dlatego też ważniejsze modele recepcyjne - jak te grupy „Literal”, Ricarda Piglii i Césara Airy - będę sytuować w konkretnym momencie rozwoju pola literackiego, na które, jak zakładam, modele te starały się oddziaływać. Badaniom poświęconym twórczości polskiego pisarza moje studium przysłużyć się może jedynie pośrednio, przedstawiając determinanty stricte literackie, ale także kulturowe, historyczne oraz polityczne, które przez ponad czterdzieści lat określały to, co z Gombrowicza w Argentynie „wyczytano”. W Polsce interpretacje zza oceanu wzbudzają ambiwalentne przyjęcie: z jednej strony z satysfakcją przyjmuje się dowody na zainteresowanie polskim twórcą na peryferiach zachodniego świata, $\mathrm{z}$ drugiej odczytania te bywają traktowane w najlepszym razie jako interpretacyjne osobliwości. Oczywistym jest skądinąd, że argentyńskie zainteresowanie Gombrowiczem jest w jakimś sensie wyrywkowe, bo zamiast całościowych studiów nad jego twórczością proponuje fragmentaryczne, nawet migawkowe tropy interpretacyjne, w których zwykle przedkłada się narodową tradycję nad jednostkowość i oryginalność dzieła. Gombrowicz - miast narzucać swoją artystyczną niepowtarzalność, trudną do „udomowienia” w określonej tendencji lub grupie estetycznej - bywa rozpatrywany w seriach: jako prekursor, antagonista, innowator, nawet jeśli towarzyszy temu narracja o jego „marginalności”. Równie oczywiste jest to, że argentyńskie lektury autora Ślubu bywają niepoparte całościową wiedzą w zakresie korpusu tekstów pisarza - głównie ze względu na ich niedostępność - oraz że towarzyszy im zupełna nieznajomość polskiego kontekstu historyczno-literackiego. Te braki skutkują jednak próbkami recepcji, które mogą aktywować nowe doświadczenie literatury narodowej, uwolnione od bagażu polskiej historii i niezapośredniczone przez uczuciową identyfikację z tym, co własne.

Jeśli mowa o tego rodzaju uwarunkowaniach pozaliterackich: Gombrowicz bywa czytany albo jako pisarz uniwersalny (jego pochodzenie jest wówczas nieznaczące), albo polski, co z kolei aktywizuje sieć związków intertekstualnych z rodzimą klasyką. Kontekst 
argentyński - literacki, historyczny, geograficzny, kulturowy - jest za to traktowany jako pomijalny, pomimo faktu, że w Buenos Aires powstała zasadnicza część Gombrowiczowskiego dzieła. Wprawdzie w Koranie „nie ma wielbłądów”77, jak pisał Jorge Luis Borges, rozgoryczony rodzimą literaturą przesyconą do cna lokalnym kolorytem, a zdanie to stało się kwintesencją krytyki, która kwestionuje popularne w dziewiętnastowiecznej Ameryce pojmowanie literatury jako prostej emanacji otoczenia. Historyczne i geograficzne tło praktyki pisarskiej (bez względu na to, czy wprost obecne w treści) nie wyczerpuje, co oczywiste, znaczenia tekstu, bywa jednak pomocne w jego uchwyceniu. Śledzenie stricte argentyńskich uwarunkowań dzieła Gombrowicza nie jest wprawdzie przedmiotem moich badań (należałoby raczej do zadań historyka literatury), jednakowoż przyznanie im racji interpretacyjnego bytu jako elementowi znaczeniotwórczemu jest pomocne $\mathrm{w}$ zrozumieniu tamtejszych propozycji lektury.

Zważywszy na fakt, iż celem mojej pracy jest prześledzenie sposobów, w jakie twórczość oraz legenda Gombrowicza przenikają do literatury argentyńskiej niezapośredniczone instrukcjami samego autora, ustalam początkową cezurę moich badań na rok 1970. W tym bowiem momencie - około siedmiu lat po powrocie Polaka do Europy - formują się pierwsze strategie interpretacyjne, których autorzy nie byli bezpośrednimi „uczniami” pisarza i używają jego tekstów (a także osoby) do realizacji własnych pomysłów estetycznych. Jest to oczywiście data umowna i nie wyklucza nielicznych odstępstw, wynikłych z wewnętrznej dynamiki argentyńskiego pola literackiego. Nie mieszczą się w moim obszarze badawczym projekty lekturowe, którym patronował bezpośrednio lub pośrednio (czyli z Europy) sam Gombrowicz, niemniej założenie to dotyczy jedynie samych projektów, nie ich autorów. Innymi słowy, uwzględniam w moich analizach datowaną na lata 80. i 9o. twórczość literacką i krytyczną Jorgego Di Paoli oraz Carlosa Gómeza. Ich teksty - bardzo zresztą od siebie odmienne - interesują mnie właśnie o tyle, o ile próbują

77 Jorge Luis Borges, Pisarz argentyński i tradycja, w: idem, Polemiki, przeł. Joanna Partyka, Prószyński i S-ka, Warszawa 20o8, s. 181. 
przekroczyć wytyczne autora, dystansują się od wskazówek z pierwszej ręki, wchodzą w polemikę.

$\mathrm{Z}$ drugiej strony granice mojego pola badawczego zakreśla sama literatura i teksty jej poświęcone - krytyczne, prasowe, historyczne. Recepcję Gombrowicza badam zatem przede wszystkim w obszarze słowa pisanego, a więc np. teatralne realizacje jego sztuk w Argentynie - które z oczywistych względów są mi bezpośrednio niedostępne, a jednocześnie ich doniosłość dla interesującego mnie tematu jest niepodważalna - będę rozpatrywać w obszarze późniejszych tekstowych „reakcji” literackich i krytycznych, które zostały jakoś przez nie sprowokowane. Wyjątkiem będzie tu film Alberta Fischermana Gombrowicz o la seducción, który z równie oczywistych powodów może stać się bezpośrednim obiektem moich analiz i który w latach 8o. zasłynął nie tylko wśród wąskiej publiczności zainteresowanej postacią i twórczością Polaka, ale też wśród sympatyków kina w ogóle.

Wyniki moich dotychczasowych badań jednoznacznie wskazują, że rozpowszechniona teza o nieznajomości tekstów Gombrowicza w Argentynie ${ }^{78}$ (którą dyskutowałam powyżej przy okazji polemiki z Freixą Terradesem) wymaga reinterpretacji z dwóch zasadniczych powodów. Pierwszy ma charakter zwykłej aktualizacji: w 2010 roku wydawnictwo El Cuenco de Plata z siedzibą w Buenos Aires przejęło od barcelońskiego Seix Barral prawa do hiszpańskich tłumaczeń Gombrowicza i sukcesywnie wznawia kolejne dzieła, co zasadniczo poprawia ich dostępność na rynku ${ }^{79}$. Drugi powód jest bardziej zasadniczy:

78 Powtarza ją Silvana Mandolessi w Una literatura abyecta (s. 16-17).

79 Cykl „Biblioteca Gombrowicz” w El Cuenco de Plata rozpoczęły wspomnienia autorstwa Rity Gombrowicz Gombrowicz en la Argentina. 1939-1963. W 2010 roku ukazało się El casamiento (Ślub), cztery lata później Ferdydurke, następnie w 2015 Trans-Atlántico, Bacacay i Curso de filosofía en seis horas y cuarto (Kurs filozofii w sześć godzin i kwadrans) oraz w 2016 Cosmos, Diario argentino (Dziennik argentyński) i Peregrinaciones argentinas (Wędrówki po Argentynie). El Cuenco de Plata planuje publikację nowego przekładu Pornografii. Jednocześnie w 2010 roku wydawnictwo Página/12 wydało Autobiografía sucinta. Correspondencia, czyli zbiór artykułów i wywiadów Gombrowicza oraz jego listy z Jeanem Dubuffetem. 
opinia o Gombrowiczu w Argentynie jako pisarzu „bez dzieła”, za to z niezwykle interpretacyjnie produktywną legendą życia bazuje z jednej strony na niepodważalnym fakcie długotrwałego braku tekstów (który ogranicza zresztą tylko szeroko pojętą publikę, nie zaś wąskie grono entuzjastów), z drugiej natomiast na przekonaniu o tym, że proponowane przez Argentyńczyków portrety wyobrażeniowe pisarza są w jakiś sposób niezgodne z obrazem, jaki posiadamy w Polsce. Tymczasem moje dotychczasowe badania nad hiszpańskimi przekładami autora Ferdydurke, w szczególności nad konstrukcją Dziennika argentyńskiego, dowodzą, że odbiorcy w przybranej ojczyźnie pisarza czytają (w jakiejś mierze oczywiście) innego Gombrowicza i ich interpretacje pozostają w zgodzie z tymi, które implikuje lub narzuca sam tekst.

Drugi rozdział monografii poświęcam więc hiszpańskojęzycznym przekładom tekstów Gombrowicza, ze szczególnym uwzględnieniem Dziennika argentyńskiego ze względu na jego „siłę rażenia”: jest ważnym punktem odniesienia u niemal wszystkich interpretatorów. Analizy tłumaczeń poprzedzam krótkim wstępem na temat pozycji badań nad przekładem we współczesnej komparatystyce - powracam tu do koncepcji już pokrótce referowanych, by przyjrzeć się statusowi, jaki przyznają tak tekstom tłumaczonym, jak w ogóle praktyce tłumaczenia jako podstawowej realizacji literatury porównawczej, jej warunku, a nawet aktu przemocy symbolicznej w relacji centrum-peryferie. W kolejnym rozdziale przyjrzę się sposobom, w jakie krytyka argentyńska czyta autora Pornografii, przy czym jej projekty interpretacyjne uszereguję nie chronologicznie, lecz tematycznie, wokół newralgicznych dla literatury argentyńskiej pól znaczeniowych, ku którym dzieło Polaka ciąży: problematycznej kwestii tożsamości narodowej (w tym tożsamości samego Gombrowicza), doświadczeniu wygnania i wykluczenia (zarówno ze społeczeństwa, jak i z kanonu literatury), kwestii języka i funkcjonowania poza językiem rodzimym, konstrukcji ,ja” literackiego i statusu autofikcji. W ostatnim rozdziale omówię strategie interpretacyjne stworzone przez ważniejszych twórców argentyńskiej kultury, każdorazowo starając się nakreślić miejsce - w tradycji literackiej i na scenie politycznej - z którego są formułowane. 

2.

\section{Jakiego Gombrowicza czytają Argentyńczycy? Kwestia przekładu}

Badania nad przekładem awansowały w ostatnich latach z pozycji właściwej dla nauk typowo pomocniczych na centralne miejsce w rozległym spektrum zainteresowań komparatystyki, którą to zmianę przy-

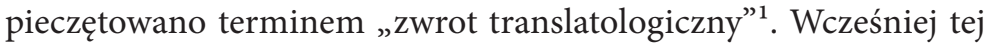
praktyce badawczej przyświecało przekonanie o dominacji oryginału nad przekładem, a w konsekwencji skupienie na tekście wyjściowym i tropieniu potknięć tłumacza, którego działalność była traktowana jako wtórna, naśladowcza i z konieczności uproszczająca pierwotne bogactwo znaczeń. Na fali nowego, płynnego społeczeństwa, która wyniosła komparatystykę, wypłynęły też studia przekładoznawcze: doświadczenie wygnania, ekspansja wielokulturowości i konieczność funkcjonowania pomiędzy różnymi językami złożyły się na zmianę paradygmatu i dowartościowanie tekstu docelowego, który stał się równy rangą tekstowi wyjściowemu. „W skrócie można komparatystykę literacką określić jako sztukę rozumienia skupioną wokół możliwości i porażek przekładu”, pisze George Steiner, rozciągając zresztą termin „tłumaczenie” ogólnie na „ontologicznie niejasny” proces pojmowania cudzego dyskursu we własnym języku²: każdy akt percepcji jest w swej

1 V. Andrzej Hejmej, Komparatystyka. Studia literackie - studia kulturowe, Universitas, Kraków 2013, s. 211.

2 George Steiner, Czym jest komparatystyka literacka?, przeł. Agnieszka Matkowska, w: Tomasz Bilczewski (red.), Niewspótmierność. Perspektywy nowoczesnej komparatystyki, Universitas, Kraków 2010, s. 520. 
istocie porównawczy. Najnowsze studia przekładoznawcze zrezygnowały więc z podejścia normatywnego (jaki przekład jest dobry?) na rzecz podejścia deskryptywnego („co robią przekłady, w jaki sposób krążą po świecie i jakie wywołują reakcje?”)

Refleksja na temat translatologii przybiera we współczesnych badaniach komparatystycznych dwie zasadnicze formy: pierwsza rozpatruje „tłumaczenie” tradycyjnie w odniesieniu do literatury, ogniskując się wokół kwestii języka i jego przekładalności; druga, operuje przede wszystkim kategorią „,interpretacji” jako zasadniczym wymiarem procesu tłumaczenia i w jej ramach buduje różne teorie translacji ${ }^{4}$. Przykładem podejścia pierwszego typu są rozważania Steinera, który tak definiuje zakres obowiązków komparatysty: „kluczowe znaczenie mają oczywiście wszystkie aspekty przekładu: jego historia, środki leksykalne czy gramatyczne, metody, począwszy od interlinearnych tłumaczeń »słowo w słowo«, po najswobodniejsze imitacje czy metamorficzne adaptacje"5. Steiner optuje za praktyką close reading najlepszych nawet przekładów, w poszukiwaniu nieuniknionych porażek i niepełności, zasadnicza nieprzekładalność języków jest bowiem najbardziej namacalnym przejawem kulturowej różnicy.

W obrębie drugiego typu teorii mieszczą się natomiast koncepcje ujmujące przekład w kategoriach politycznych, etycznych, postkolonialnych etc. Na przykład Pascale Casanova bada translację jako mechanizm przeniesienia kapitału kulturowego do kultur o niższym potencjale literackim (jej celem jest wówczas przyswojenie kapitału)

3 Steven Ungar, „Pisanie językami”. Rozważania o dziele tłumaczonym, przeł. Agnieszka Pokojska, w: Tomasz Bilczewski (red.), op. cit., s. 538.

4 Andrzej Hejmej, op. cit., s. 214. Marta Skwara, powołując się na Edwarda Saida, łączy oba podejścia, składające się na pożądaną postawę współczesnego filologa: „[...] dociekliwość filologiczna ukierunkowana na badanie znaczenia tekstów i składających się na nie słów (w tym słów przekładanych czy przyjmowanych $\mathrm{z}$ innych kultur) z jednej strony, z drugiej zaś uwrażliwienie na funkcjonowanie tekstu w obiegu kulturowym i politycznym"; Marta Skwara, Stara i nowa komparatystyka literacka, w: Mieczysław Dąbrowski (red.), Komparatystyka dla humanistów. Podręcznik akademicki, Wyd. UW, Warszawa 2011, s. 179.

5 George Steiner, op. cit., s. 520-521. 
lub, odwrotnie, do języka dominującego (która nie służy bynajmniej demokratyzacji kapitału literackiego, a jedynie wzmocnieniu pozycji centrum). Szczególnym przypadkiem tej ostatniej jest przekład-konsekracja (traduction-consécration), który skutkuje przyswojeniem lub zagarnięciem pisarza języka peryferyjnego przez literaturę światową, co w latach 50. staje się udziałem Gombrowicza, wspomaganego przez Kota Jeleńskiego ${ }^{6}$. Hiszpańskie przekłady tekstów Polaka, przynajmniej te, które wyprzedziły wersje francuskie, jak Ferdydurke, Ślub i w pewnej mierze także Dziennik argentyński, omijają „południk zerowy" i tym samym nie podlegają dialektyce centrum-peryferie z jej logiką wymiany dóbr kulturowych, która w ostatecznym rachunku zawsze wzmacnia kapitał centrum, rozpowszechniając go albo anektując na jego rzecz nowe wartości. Casanova rozpatruje mechanizm translacji zawsze w sprzężeniu z pozycją obu języków - wyjściowego i docelowego - w hierarchii ustanowionej według posagu „literackości”, jakim dysponują: od języków całkowicie go pozbawionych (jak niektóre języki afrykańskie) do języków reprezentujących kultury w tym względzie „prestiżowe”. W tym kontekście zauważyć wypada, że hiszpański, postrzegany do połowy xx wieku jako język drugo- lub trzeciorzędny, w drugiej połowie ubiegłego stulecia ulega dowartościowaniu, tak z powodów literackich (wywołanych przez tzw. boom literatury latynoskiej), jak politycznych (Ameryka Łacińska staje się najpierw obiektem zainteresowania międzynarodowego z powodu rewolucji kubańskiej, a kilka dekad później masowa imigracja Latynosów do Stanów Zjednoczonych i ich udział w tamtejszym życiu politycznym ułatwia promocję hiszpańskiego jako ważnego języka kultury).

O przekładzie pisze także Damrosch, oczywiście w zupełnie innych, jaśniejszych, chciałoby się rzec, barwach: „literatura światowa jest

6 Casanova wspomina obszerniej o Gombrowiczu właśnie przy okazji tłumaczeń (w szczególności odautorskich) i „gier językowych” pomiędzy kulturami o różnym kapitale literackim; v. Pascale Casanova, La República mundial de las Letras, przeł. Jaime Zulaika, Anagrama, Barcelona 2001, s. 193-195. Na temat przekładu konsekrującego v. eadem, Consécration et accumulation de capitale littéraire. Traduction comme échange inégal, „Actes de la Recherche en Sciences Sociales” 2002, t. 44, nr 1, s. 7-20, https://goo.gl/emHmfi, dostęp: 20 x 2016. 
pisarstwem, które zyskuje w tłumaczeniu"7. Przekład nie jest narzędziem manipulacji ani źródłem tragicznych wyborów ${ }^{8}$, przeciwnie:

literatura zazwyczaj wtedy pozostaje wewnątrz własnej tradycji narodowej lub regionalnej, kiedy traci w tłumaczeniu, natomiast zyskując w przekładzie na równowadze, dzieła stają się częścią literatury światowej; stylistyczne straty, wynagradzane przez wejście w głąb, są zastępowane przez zwiększenie zasięgu'.

W translacji chodzi więc nie o to, by zachować niezapośredniczoną wersję oryginalną, ale o to, by poszerzyć realne możliwości twórczego kontaktu czytelnika z dziełem. Parafrazując słynne powiedzenie Roberta Frosta o poezji, która gubi się w tłumaczeniu, Damrosch dystansuje się do tych teorii przekładu, które zakładają istnienie przepaści między językami (skutkującej widmem nieprzekładalności), możliwej do połowicznego pokonania dzięki perfekcyjnej znajomości języka i kultury wyjściowej. To pragmatyczne podejście amerykańskiego badacza („znaczna część poezji, wliczając w to Frosta, [...] została przetłumaczona $\mathrm{z}$ dobrym skutkiem na wiele języków”10) wydaje się bardzo przydatne w przypadku Gombrowicza, którego język uchodzi za trudno lub w ogóle nieprzekładalny, przynajmniej w swojej silnej komponencie stylistycznej, a brak natywnej i specjalistycznej znajomości kontekstu polskiego (baroku i sarmatyzmu, romantyzmu i mesjanizmu, literatury międzywojnia etc.) w zasadzie przedsięwzięcie tłumacza unicestwia. Większość studiów poświęconych przekładom autora Pornografii skupia się na wskazywaniu

7 David Damrosch, Dość czasu i świata, przeł. Adam F. Kola, „Teksty Drugie” 2014, nr 4, s. 109.

8 „Pisarze "przetłumaczeni« stają przed dramatyczną, strukturalną antynomią, która zmusza ich do wyboru pomiędzy przekładem na język literacki, który oddziela ich od publiczności narodowej, oraz zamknięciem w »małym« języku, co z kolei skazuje ich na niewidzialność lub egzystencję literacką całkowicie ograniczoną do narodowego życia literackiego"; Pascale Casanova, La República mundial de las Letras, s. 335.

9 David Damrosch, op. cit., s. 111.

10 Ibid., s. 110. 
w tekście docelowym niekonsekwencji, niedbałości, wpadek, uproszczeń, nadmiernych ułagodzeń etc. (zadanie to zresztą Gombrowiczowski styl niezwykle ułatwia), eksponując w tym rachunku straty, ignorując zaś zyski ${ }^{11}$. Część badaczy przyznaje jednocześnie - co byłoby argumentem na rzecz tezy Damroscha - że „w niektórych przypadkach wybitnej prozy ten system [tekstu - E.K.P.] jest w oryginale na tyle skonsolidowany (i dodatkowo - dysponuje pewną redundancją wyznaczników), że nawet pominięcie w przekładzie ich części nie unicestwia systemu jako całości”12. Wewnętrzna siła emanująca z dzieła Gombrowicza skutecznie opierałaby się więc zniszczeniu w przekładzie, co stanowi wystarczające uzasadnienie istnienia nieuchronnie ułomnych tłumaczeń. Stosunkowo niewielu badaczy zwraca uwagę na fakt, że samo przyjęcie w obrębie obcej kultury jest już wartością dodaną dla tekstu literackiego, który ze

11 V. Maryla Laurent, Język Gombrowicza, czyli całkowanie wieloznaczności, Monika Grabowska, „Kujmy się, kujmy, bo cwaje dostaniemy” - szkoła w „Ferdydurke” $i$ w jej przekładzie na francuski oraz Monika Surma-Gawłowska, ,Ferdydurke” po włosku, czyli Gombrowicz okiełznany, w: Elżbieta Skibińska (red.), Gombrowicz itłumacze, Leksem, Łask 2004, s. 21-36, 37-52 i 61-68. Wyjątek stanowi pod tym względem studium Magdy Heydel na temat angielskiego przekładu Ferdydurke autorstwa Danuty Borchardt: „Analiza nie może zatrzymywać się na stwierdzeniu, że w przekładzie utracone zostały pewne wartości, ale trzeba pytać, jakie wartości zostały w przekładzie wytworzone”; Magda Heydel, Angielskie wersje „Ferdydurke” - strategie przekładania nieprzekładalnego, w: Elżbieta Skibińska (red.), op. cit., s. 114. Równie przychylnie o drugim przekładzie Ferdydurke na hiszpański, autorstwa Jerzego Sławomirskiego i Anny Rubió (,jest godnym rywalem tłumaczenia autorskiego"), wypowiada się Bożena Zaboklicka (Gombrowicz po hiszpańsku, czyli rywalizacja z przekładem autorskim, w: Dominika Świtkowska, Tomasz Tyczyński [red.], Gombrowicz i okolice, Muzeum Literatury im. A. Mickiewicza, Warszawa 2013, s. 92).

12 Jerzy Brzozowski powołuje się tutaj na pracę Antoine’a Bermana z 1985 roku La traduction et la lettre ou l'auberge du lointain; v. Jerzy Brzozowski, Fabuła czy poezja? Bakakaj po portugalsku, w: Elżbieta Skibińska (red.), op. cit., s. 216. W podobnym tonie wypowiada się Marcin Cieński, który na pytanie postawione w tytule swojego artykułu O sarmackiej swojskości - czy Gombrowicza można tłumaczyć nie znając literatury i kultury staropolskiej? (w: Elżbieta Skibińska [red.], op. cit., s. 175) odpowiada twierdząco. 
swej istoty zakłada otwarcie na różne, nie tylko macierzyste, style odbioru. O tej podstawowej ekspozycji dzieła na obce kody lektury pisze, właśnie kontekście tłumaczeń, Elżbieta Skibińska, upatrując w niej uzasadnienia dla dokonywania przekładów, nawet jeśli z założenia są one niedoskonałe ${ }^{13}$.

O krok dalej idzie André Lefevere, który spór o przekładalność i ekwiwalencję w zasadzie unieważnia, rozpatrując przekład jako wypadkową zjawiska „refrakcji”, definiowanego jako „adaptowanie dzieł literackich na potrzeby obcej publiczności, dokonywane z zamysłem wywarcia wpływu na sposób, w jaki będą czytane"14. Zjawisko refrakcji istnieje od zawsze i - jak to ujmuje belgijski teoretyk translacji - zamiast nad nim „lamentować”, należy je raczej zaakceptować i zastanowić się nad sposobem jego działania, bowiem dzieło zyskuje czytelników w innej kulturze właśnie dzięki „nieporozumieniom i błędnym przekonaniom”, które kierują procesem jego recepcji ${ }^{15}$. Przekład, który Lefevere określa terminem rewriting, jest najgrubszym pryzmatem, w którym „załamuje się” tekst obcy, ale nie jedynym: stopień refrakcji zależy także od struktur władzy (osób i instytucji) oraz obowiązujących w przestrzeni przyjmującej ideologii (politycznych i literackich).

13 Powołuje się ona przy tym na tekst Michała Głowińskiego: „Czy [...] tłumaczenie - jako takie - skazane jest na niepowodzenie? Zdecydowanie nie. Jak twierdzi Michał Głowiński, »Dzieło literackie [...] przez samą sytuację komunikacyjną, jaką projektuje i w jakiej uczestniczy, predestynowane jest do wchodzenia w kontakt $\mathrm{z}$ różnymi kontekstami i różnymi stylami odbioru nie pokrywającymi się z jego kontekstem i jego kodem macierzystym«. Ta właściwość dzieła literackiego - według Głowińskiego mająca charakter uniwersalny i pierwszoplanowy - »ratuje« przekład czy uzasadnia jego istnienie, pomimo wpisanej w powstawanie tłumaczenia i w jego ostateczny kształt niemożności osiągnięcia pełnej ekwiwalencji między oryginałem a przekładem”; Elżbieta Skibińska, Czy „Pornografia” jest przekładalna? Rekonesans: młodość w przekładzie francuskim, w: eadem (red.), op. cit., s. 163.

14 André Lefevere, Ogórki Matki Courage. Tekst, system i refrakcja w teorii literatury, przeł. Agata Sadza, w: Piotr Bukowski, Magda Heydel (red.), Współczesne teorie przekładu. Antologia, Znak, Kraków 2009, s. 227.

15 Ibid., s. 226. 
Refrakcja - pisze Lefevere - (niezależnie od tego, czy występuje w formie przekładu, krytyki czy historiografii), która ma na celu przeniesienie dzieła literackiego z jednego systemu do drugiego, stanowi kompromis między tymi systemami i jest w tym sensie idealnym wyznacznikiem ograniczeń dominujących w tych systemach. Różnica między dwiema hierarchiami ograniczeń pozwala wyjaśnić, dlaczego pewne dzieła „nie przyjmują się”, bądź też, w najlepszym wypadku, zajmują niejednoznaczną pozycję w systemie, do którego się je importuje ${ }^{16}$.

Przyglądając się hiszpańskojęzycznym przekładom Gombrowicza, uwzględniać będę rozpoznania wypracowane na gruncie obu typów teorii translatologicznych: wychodzę od porównań języka wyjściowego i docelowego (tropię więc momenty niepełności i rozchwiania między oryginałem a przekładem, nie czyniąc z nich jednak zasadniczej treści analizy), by dojść do rozważań o pozajęzykowych determinantach refrakcji: przede wszystkim określić, co było każdorazowo stawką w grze przekładowej, czyli co w danych okolicznościach historycznych i kulturowych pragnęli osiągnąć tłumacze. $Z$ tej perspektywy najciekawsze wydają się te przekłady, za którymi stał sam Gombrowicz (Ferdydurke, Ślub oraz Dziennik argentyński), i to im poświęcę zasadniczą część moich rozważań, pokrótce jedynie omawiając te dzieła, w których mamy do czynienia z klasyczną relacją tłumacz-tekst. Korespondencja pisarza $z$ hiszpańskim i argentyńskimi wydawcami oraz jego własne próby translatorskie zaświadczają, że niezwykle zależało mu na zaistnieniu w tym obszarze kulturowym.

Argentyńska Ferdydurke jest przypadkiem o bardzo bogatej bibliografii, obejmującej analizy językowe i historyczne, przy czym punkty widzenia kultury wyjściowej i przyjmującej są, co zresztą zrozumiałe, bardzo odmienne, inne bowiem warstwy lub wymiary tekstu uznawane są za kluczowe. W argentyńskiej tradycji literackiej powieść ta, uwolniona instancją autora-tłumacza od swej pierwotnej zależności od oryginału, zyskała status dzieła całkowicie odrębnego, którego przekład zaczęto z czasem postrzegać w kategoriach ważnego wydarzenia literackiego. Przypadek Ślubu, który Gombrowicz przetłumaczył wspólnie

\footnotetext{
16 Ibid., s. 230.
} 
z Alejandrem Rússovichem i opublikował w Argentynie w 1948 roku (polski oryginał ukazał się dopiero pięć lat później!), nie był tak „płodny" krytycznie i to pomimo znaczących różnic na poziomie tekstu (wersja hiszpańska jest „adaptacją” polskiej) oraz doniosłej roli tego dramatu we wprowadzeniu Polaka na argentyńską scenę literacką w latach 7o. Tekst Dziennika argentyńskiego nie doczekał się zgoła żadnych opracowań, mimo że chodzi o najlepiej znane dzieło Gombrowicza w jego przybranej ojczyźnie i stały punkt odniesienia dla jego argentyńskich komentatorów. Nie mamy tu wprawdzie do czynienia z przekładem odautorskim, niemniej pisarz ingerował w tekst przede wszystkim na poziomie kompozycyjnym, zmieniając przy tym jego wymowę.

\section{Argentyńska Ferdydurke}

Historyczne okoliczności tego przekładu stanowią najlepiej znany argentyński epizod życia Gombrowicza: rzekomo dla podreperowania niewesołej sytuacji materialnej pisarz decyduje się przełożyć na hiszpański swoją pierwszą powieść w 1947 roku w kawiarni Rex, wspomożony licznym acz zmiennym w czasie „komitetem tłumaczy” ${ }^{17}$. Przewidzianego efektu materialnego przekład wprawdzie nie przyniósł, ale przysłużył się autorowi dwojako - okazał się symbolicznym początkiem nowej, stabilnej epoki w jego życiu („gdy wydano Ferdydurke zaniosłem ją tam "gdzie stoi wieża przez Anglików zbudowana« i pokazałem ją Retiro - na pożegnanie, na znak chyba ostatecznego zerwania" ${ }^{18}$ ) oraz, na dłuższą metę, przyniósł mu rozgłos: ten ekscentryczny i jedyny w swoim rodzaju

17 Jego trzon stanowiły cztery osoby (Virgilio Piñera, Luis Centurión, Adolfo de Obieta i Humberto Rodríguez Tomeu), ponadto wśród współpracowników Gombrowicz wymienia jeszcze kilkanaście osób; v. Witold Gombrowicz, Prólogo para la primera edición castellana (1947), w: idem, Ferdydurke, przeł. autor i komitet tłumaczy, Seix Barral, Barcelona 2011. Fragment tej przedmowy w przekładzie Ireneusza Kani ukazał się w: idem, Varia 1. Czytelnicy i krytycy, Wydawnictwo Literackie, Kraków 2004, s. 409-414.

18 Idem, Dziennik 1953-1969, Wydawnictwo Literackie, Kraków 2013, e-wydanie. 
tryb tłumaczeniowy był w najgorszym razie interpretowany jako translacyjne kuriozum, a w najlepszym jako moment fundacyjny nowego stylu literackiego. Gombrowicz nie znał bowiem dobrze hiszpańskiego, szkicował pierwszą wersję, którą potem wspólnie z komitetem przerabiał, „szukając słów właściwych, walcząc ze składnią, z nowotworami, z duchem języka"19. Zanim język tego przekładu został usankcjonowany przez Piglię jako „język przyszłości”20 - niezrozumiany w swoim czasie, bo anonsował literaturę, która dopiero miała się wydarzyć - budził sporo zastrzeżeń, którym autor i tłumacze próbowali zaradzić w przedmowach. W Nocie o przekładzie wyjaśnia się najpierw, że oryginalny język tej powieści „odbiega od używanego na co dzień, od jego praw powszechnych, jego normalnego i powszechnego rytmu"21, która to właściwość została odtworzona w hiszpańskim, a więc wszelkie odstępstwa od normy - tak neologizmy, jak „pewna surowość zdania, pewien staroświecki smak"22 - są efektem przez tłumaczy zamierzonym. Argumenty te nie rozwiały jednak wątpliwości argentyńskiego filologa i eseisty Raimunda Lidy, który domagał się korekty przekładu w całości, ani Ernesta Sábato, który wnosił o poprawki tylko niektórych fragmentów, a zastrzeżenia zachowali właściwie wszyscy poproszeni o opinię pisarze ${ }^{23}$.

19 Ibid.

20 „W argentyńskiej wersji Ferdydurke hiszpański brzmi tak, jakby miał za chwilę się rozpaść, jest spazmatyczny, sztuczny, sprawia wrażenie języka przyszłości”; Ricardo Piglia, Czy istnieje powieść argentyńska? Borges a Gombrowicz, przeł. Klementyna Suchanow, Krystian Radny, „Literatura na Świecie” 2001, nr 4, s. 69-70.

21 Nota sobre la traducción [podpisana przez „Tłumaczy”], w: Witold Gombrowicz, Ferdydurke, s. 24. Polski przekład za: Rajmund Kalicki (oprac.), Tango Gombrowicz, Wydawnictwo Literackie, Kraków 1984, s. 45.

22 Nota sobre la traducción, s. 24. Polski przekład za: Rajmund Kalicki (oprac.), op. cit., s. 45 .

23 Także Roger Pla i Arturo Capdevila. V. Rita Gombrowicz, Gombrowicz w Argentynie. Świadectwa i dokumenty 1939-1963, przeł. Zofia Chądzyńska, Anna Husarska, Wydawnictwo Literackie, Kraków 2004, s. 74; Rajmund Kalicki (oprac.), op. cit., s. 58; Laura Ísola, "Ferdydurke" de Witold Gombrowicz. Diario de una traducción, w: Jorge Monteleone, Sylvia Iparraguirre (red.), Nuevos territorios de la literatura latinoamericana, Instituto de Literatura Hispanoamericana, Buenos Aires 1997, s. 394. O przyjęciu Ferdydurke przez argentyńską krytykę 
Z polskiej perspektywy język argentyńskiej Ferdydurke domaga się z kolei analiz porównawczych z oryginałem tym pilniej, że posłużył za podstawę do tłumaczenia na francuski, a z niego na angielski, włoski, kataloński, szwedzki i norweski. Wyczerpującą analizę autoryzowanych przekładów na hiszpański i francuski przedstawia Magdalena Miecznicka, która klasyfikuje odnotowane w nich zmiany w kategoriach skrótów (stanowiących w sumie prawie jedną dziesiątą tekstu), zastąpień i uproszczeń (dotyczących m.in. aluzji do polskiej rzeczywistości) oraz wyjaśnień, a także porównuje tłumaczenia neologizmów, imion własnych i cytatów ${ }^{24}$. To szczegółowe repertorium znacznych różnic pomiędzy oryginałem a przekładem uzupełnić można o zastrzeżenia dotyczące konkretnych wyborów translatorskich, przede wszystkim przekładu „pupy” jako culo (słowo to po hiszpańsku posiada nieistniejące w polskim konotacje seksualne) oraz "gęby” jako facha (którego znaczenie w języku docelowym jest znacznie szersze, odnosi się bowiem ogólnie do wyglądu, powierzchowności, jest także potocznym określeniem na faszystę) $)^{25}$.

Z konstatacji istnienia niebagatelnych rozbieżności między obiema wersjami (kwalifikowanych zwykle jako uproszczenia) badacze tego przekładu wyciągają całkiem odmienne wnioski. Magdalena Miecznicka stwierdza, że oba autoryzowane przekłady są tekstami o „odmiennej [od oryginału - E.K.P.] dynamice językowej”, jednak odmienność ta oznacza w tym przypadku ewidentne „zubożenie”, a nawet „okaleczenie” ${ }^{26}$ pierwowzoru: „różnice w przekładach dotyczą nie tylko - jak powiedział sam Gombrowicz - „rozwydrzenia słownego«,

pisze Klementyna Suchanow (Czernicka-Suchanow) w artykułach: Proces "ferdydurkizacji” Argentyny („Teksty Drugie” 2008, nr 3, s. 206-229) oraz El caso Gombrowicz: La traducción de “Ferdydurke” de 1947 („Hispamérica” 2007, nr 107, s. 3-13).

24 V. Magdalena Miecznicka, Aneks I. Autoryzowane przekłady „Ferdydurke”, w: Witold Gombrowicz, Ferdydurke, oprac. Włodzimierz Bolecki, Wydawnictwo Literackie, Kraków 2004, s. 782-803.

25 V. Marcin Kurek, „Ferdydurke” po hiszpańsku (kilka uwag o autorskim przekładzie Gombrowicza), w: Elżbieta Skibińska (red.), op. cit., s. 16.

26 V. Magdalena Miecznicka, op. cit., s. 782. 
a zatem zasadniczej dla poetyki powieści struktury językowej, lecz także jej głębszych sensów i kontekstów lektury" ${ }^{27}$. Z tej perspektywy argentyńskie pretensje do „własnej” Ferdydurke zostają wprawdzie uwzględnione (tekst faktycznie jest „nieco inny" ${ }^{28}$ ), ale jednocześnie zdyskredytowane, bo mowa o tekście przede wszystkim mocno pogruchotanym w warstwie językowej i dyskursywnej, pozbawionym subtelności oryginału, co z góry czyni każdą hiszpańskojęzyczną lekturę fragmentaryczną i pobieżną.

Marcin Kurek, inny badacz tego przekładu, również rozpoznaje znaczne uproszczenia na poziomie języka docelowego, nie uważa jednak, by skutkowały one zubożeniem sensu, przeciwnie nawet: skróty w wymiarze językowym są właśnie ceną za utrzymanie i wyrażenie zasadniczej problematyki powieści. Strategią Gombrowicza jest dla Kurka „skrócenie i uproszczenie tekstu w jego warstwie narracyjnej i skoncentrowanie wysiłku na fragmentach eseistycznych i metaliterackich" ${ }^{29}$. Przeszczepienie Ferdydurke w nową tkankę kulturową i językową - Damroschowskie „zwiększenie zasięgu” - byłoby więc dostatecznym uzasadnieniem stylistycznych deficytów przekładu. Sukcesu tej strategii dowodzi cytowany przez Kurka tekst Piglii, w którym argentyńska Ferdydurke ujawnia swoje znaczenie dla tamtejszej tradycji literackiej, a więc eksponuje się bardziej zyski (nowe odczytania) niż straty ${ }^{30}$.

W moim przekonaniu najtrafniejszy i najbardziej całościowy pogląd na temat argentyńskiego przekładu powieści prezentuje Bożena Zaboklicka, której stanowisko jest owocem wieloletniej praktyki translatorskiej, rozwijanej także w kontakcie z dziełem Gombrowi$\mathrm{cza}^{31}$. Tłumaczka skłonna jest przede wszystkim uwzględniać w swoich analizach konsekwencje „refrakcyjnego kompromisu” Lefevere’a.

\footnotetext{
27 Ibid., s. 804.

28 Ibid., s. 805 .

29 Marcin Kurek, op. cit., s. 19.

30 Mowa o cytowanym wyżej artykule Czy istnieje powieść argentyńska?.

31 Bożena Zaboklicka wspólnie z Franceskiem Miravitllesem przełożyła na hiszpański m.in. pełną wersję Dziennika; Witold Gombrowicz, Diario 1956-1969, Seix Barral, Barcelona 2005.
} 
Porównując np. dwa hiszpańskojęzyczne tłumaczenia Ferdydurke $e^{32}$, bierze pod uwagę ich kontekst historyczny (prawie sześćdziesiąt lat różnicy), kulturowy (Buenos Aires i Barcelona) oraz ideologiczny:

w przeciwieństwie do mody na udomowienie obcego tekstu w przekładzie, która panowała, kiedy Gombrowicz pracował nad hiszpańską wersją swojej powieści, w chwili obecnej przeważa pogląd, że przekład nie powinien być niewidoczny, lecz wprost przeciwnie, powinien brzmieć jak przekład ${ }^{33}$.

Tłumaczenie dokonane w Buenos Aires jest wprawdzie także „tłumaczeniem widocznym”, czyli naginającym język przyjmujący do specyfiki oryginału, ale konsekwencją obecnej w nim „mody na udomowienie" są chociażby zastąpienia i uproszczenia w wypadku aluzji do polskiej kultury i historii. Zaboklicka zwraca ponadto uwagę na determinantę narodową - oba hiszpańskie tłumaczenia tej powieści zostały dokonane wspólnie przez Polaków oraz osoby hiszpańskojęzyczne: „w przypadku takich tandemów przekładowych obserwuje się zazwyczaj silniejszą tendencję do obrony specyfiki oryginału niż w przekładach dokonywanych przez cudzoziemców, których strategia przekładowa częściej skupia się na specyfice kultury docelowej”34. Zaboklicka jako jedyna wspomina więc o „obronie specyfiki oryginału” kosztem płynnego brzmienia przekładu, czego dostatecznym potwierdzeniem są zastrzeżenia zgłaszane przez argentyńskich profesjonalistów języka (Raimunda Lidę, Ernesta Sábato $\mathrm{i}$ innych). Innymi słowy, z perspektywy polskiej tłumaczki ewentualne obiekcje pod adresem przekładu - odnotowane przez innych badaczy w charakterze zarzutów formułowanych na gruncie kultu-

32 Drugie tłumaczenie hiszpańskojęzyczne tej powieści ukazało się w Barcelonie w 2005 roku. Jego autorami byli Jerzy Sławomirski i Anna Rubió, którzy wcześniej dokonali ponownego przekładu Ferdydurke na kataloński, także bezpośrednio z polskiego. Pierwsze tłumaczenie na kataloński ukazało się już w roku 1968, jego autorem był Ramón Folch i Camarasa, który - za zgodą Gombrowicza - przekładał z wersji argentyńskiej.

33 Bożena Zaboklicka, Gombrowicz po hiszpańsku..., s. 90.

34 Ibid.; wyróżnienie w oryginale. 
ry przyjmującej i dopełniających jeszcze niedostatków widocznych z perspektywy polskiego oryginału ${ }^{35}$ - mogą być właśnie dowodem na sukces przedsięwzięcia translatorskiego Gombrowicza i komitetu tłumaczy.

Co więcej, tłumaczka Dziennika ostrożniej podchodzi do konstatacji dotyczącej uproszczenia i zubożenia języka przekładu, zwracając uwagę na to, że wiele z ulubionych chwytów stylistycznych autora Ferdydurke jest po prostu niemożliwych do oddania po hiszpańsku, jednak nieprzekładalności tej komitet tłumaczy stawia czoła, kompensując utracony w jednej partii tekstu sens wprowadzeniem $\mathrm{w}$ innej dodatkowych (nieistniejących w oryginale) gier stylistycznych ${ }^{36}$. Wytykane przekładowi niepełności mogą być, jak ponadto zauważa Zaboklicka, także zabiegiem zamierzonym, jeśli mianowicie potraktować argentyńskie tłumaczenie jako okazję do poprawienia napisanego dziesięć lat wcześniej utworu ${ }^{37}$. Oprócz niewątpliwych

35 V. Magdalena Miecznicka, op. cit., s. 773-775.

36 Jako przykład tej kompensacji tłumaczka podaje zastąpienie słowa „pupa” ośmioma różnymi neologizmami stworzonymi na bazie słowa culo oraz brzmiące po hiszpańsku nienaturalnie (a więc „udziwnione”) związki frazeologiczne zaproponowane dla słowa facha; v. Bożena Zaboklicka, Gombrowicz po hiszpańsku..., s. 87.

37 V. eadem, Witold Gombrowicz, ¿escritor argentino?, w: Karolina Kumor, Edyta Waluch de la Torre (red.), Realidades heterogéneas. Reflexiones en torno a la literatura, lengua, historia y cultura ibéricas e iberoamericanas, Instituto de Estudios Ibéricos e Iberoamericanos, Warszawa 2012, s. 210. Gombrowicz sam zresztą wspomina o tym, że korzystając z posiadania praw autorskich do tej powieści, wprowadził wiele zmian w jej argentyńskiej wersji. W liście do swojego hiszpańskiego tłumacza, Gabriela Ferratera, pisze: „Hiszpański przekład Ferdydurke został wykonany W 1947 przeze mnie i dwudziestu współpracowników; była to dość trudna praca i wielokrotnie zmieniałem tekst, wykorzystując prawo, które przysługuje mi jako autorowi" (La traduction espagnole de Ferdydurke a été faite en 1947, par moi avec l'aide d'une vingtaine de collaborateurs; cétait une travaille difficile et bien de fois je changeais le texte profitant de mes droits d'auteur, list bez daty, prawdopodobnie $\mathrm{z}$ roku 1965). Moje studia nad Dziennikiem argentyńskim dowodzą, że podobny zabieg korekcji własnych tekstów przy okazji kolejnych wydań i tłumaczeń nie był jednorazowy. Zresztą w tym samym liście do Ferratera Gombrowicz wspomina także o zmianach wprowadzonych do książkowej edycji Dziennika: „Giedroyć 
cięć partii tekstu Gombrowicz wprowadził do argentyńskiej wersji także nowe fragmenty (najdłuższy z nich to Przedmowa do Filidora dzieckiem podszytego), zachowane następnie w polskim wydaniu $\mathrm{Z} 1956$ roku $^{38}$. Do takiego zabiegu rewriting, który obejmował znaczne skróty, krótkie dopiski i rozliczne zmiany kompozycyjne, uciekł się Gombrowicz także w przypadku wydanego w roku 1968 Dziennika argentyńskiego.

Reasumując, w interpretacji Bożeny Zaboklickiej argentyńska Ferdydurke odstępuje od dogmatu wierności wobec tekstu źródłowego, a język docelowy wymusza na niej w wielu fragmentach uproszczenia i skróty, które tłumacze próbują „nadrobić” w innych. Powstała w ten sposób nowa wersja nie jest usprawiedliwiona jedynie jako narzędzie w Gombrowicza walce o sławę międzynarodową, lecz jej racją bytu jest możliwość zaistnienia powieści w nowej sieci intertekstualnej, dostarczanej przez kulturę argentyńską. Miarą powodzenia tego projektu przekładowego jest sukces (choć nie natychmiastowy) Ferdydurke w jej środowisku docelowym.

może przesłać Panu egzemplarze »Kultury«, ale publikując go [Dziennik - E.K.P.] w książce, wprowadziłem poprawki, czasem znaczące” (Giedroyć peut vous envoyer les ex[amplaires] de Kultura, mais en le publiant en livre, j'ai fait des corrections, parfois importantes). Korespondencja Gombrowicza z Ferraterem została opracowana przez Zofię Stasiakiewicz w pracy Entre Catalunya i Polònia: Witold Gombrowicz i Gabriel Ferrater. Correspondència inèdita (1965-1967) dostępnej on-line: http://goo.gl/is2eik, dostęp: 12 XI 2016.

38 Dopisana przez Gombrowicza nota do wydania z 1956 roku głosi: „W niniejszym wydaniu autor wprowadził pewne zmiany - najdłuższą nową wersję mamy w rozdziale IV, s. 8o-93, oraz drobniejsze poprawki na s. 28-29, 39, 47-49, 49-50 i kilka innych. Zmiany te zostały już wprowadzone w wydanie hiszpańskie Ferdydurke (nakł. Argos, Buenos Aires 1947 r. - przekład dokonany przez kilkanaście osób, m.in. Virgilio Piniera, Humberto Rodriguez Tomeu, Adolfo de Obieta, Luis Centurion)"; Włodzimierz Bolecki, Dodatek krytyczny, w: Witold Gombrowicz, Ferdydurke, s. 354. Co ciekawie, w krytyce hiszpańskojęzycznej uważa się, że Gombrowicz z czasem wymazuje zasługi komitetu tłumaczy dla światowego sukcesu powieści; v. Alessandra Riccio, Gombrowicz o de la ingratitud, „Inti. Revista de Literatura Hispánica” 1998, nr 48, s. 19-32. 
Piszący o tym przekładzie Argentyńczycy nie poruszają, ze zrozumiałych względów, kwestii wierności wobec oryginału i koncentrują się raczej na samym procesie translacyjnym oraz specyfice stylu, jaki na tradycyjnej hiszpańszczyźnie wymusili tłumacze. Najsłynniejszym tekstem poświęconym tym kwestiom jest wielokrotnie już cytowany artykuł Czy istnieje powieść argentyńska? Ricarda Piglii, o którym będę pisać szerzej przy okazji omawiania problematyki języka i chwiejnego statusu hiszpańskiego w Argentynie pierwszej połowy xx wieku. W skrócie napomknę tylko, że Piglia wspomina to ekstrawaganckie przedsięwzięcie translatorskie, nadając mu aurę tajemniczości i unikalności:

Zamiarem Gombrowicza, jak opowiadano, było wymyślić nowy język - nie chodziło o tworzenie neologizmów [...], lecz o wymuszenie na słowach nowych znaczeń, o przeniesienie ich z jednego kontekstu w drugi. Nad tym pierwotnym materiałem rozpoczęła się praca heterogenicznej i nawiedzonej ekipy [pod wodzą Virgilia Piñery - E.K.P.] ${ }^{39}$.

Piglia oddala nie wprost wszelkie zarzuty pod adresem jakości przekładu: ten nowy, umyślnie pokrętny język miał stanowić przeciwwagę dla eleganckiej i precyzyjnej linii stylistycznej, którą wyznaczają Paul Groussac, Leopoldo Lugones i Jorge Luis Borges, a jego chropowatości, niezręczne związki frazeologiczne i udziwnienia inicjować mają inną, heretyczną tradycję literacką ${ }^{40}$.

Myśl Piglii rozwija Laura Ísola, która do wydarzenia, jakim było tłumaczenie Ferdydurke, przykłada kategorie tożsamości i wygnania: przekład (w szczególności, dodajmy, przekład siebie samego) jest jedną ze strategii autoprezentacji w nowej kulturze, w której podmiot piszący został zanurzony jako wygnaniec - gwałtownie i totalnie. Jest to doświadczenie z gruntu odmienne od przekładu dokonywanego $\mathrm{w}$ trybie tradycyjnego tłumaczenia, odbywającego się niejako $\mathrm{z}$ dala

\footnotetext{
39 Ricardo Piglia, op. cit., s. 69.

40 Pierwszy kwalifikuje Gombrowicza jako „pisarza języka hiszpańskiego” Gabriel Ferrater w tekście Witold Gombrowicz („Presencia” 1966, nr 9, s. 15), sam należący do dwóch wspólnot językowych (hiszpańskiej i katalońskiej).
} 
od miejsca, do którego ten podmiot przynależy, i nie określającego tak dramatycznie jego kondycji życiowej. W przypadku Gombrowicza, jak zauważa Ísola, mamy do czynienia dodatkowo z inną zmienną - bardzo ograniczoną znajomością języka docelowego, zmuszającą go do powołania komitetu tłumaczy. Ten niedostatek języka nie unieważnia jednak całego przedsięwzięcia, przeciwnie - umożliwia je: „cieszę się, że Ferdydurke narodziła się po hiszpańsku w ten właśnie sposób, a nie w smutnych pracowniach producentów książek"41. Niemożność i brak zostają przekute na zasadę twórczą ${ }^{42}$. Refleksje argentyńskiej badaczki zyskują jeszcze na wyrazistości, jeśli zestawić Gombrowiczowskie doświadczenie autoprzekładu - powtórzone w Ślubie - z tym, które przypadło w udziale innym pisarzom wygnanym poza własny język. Casanova następująco pisze o Vladimirze Nabokovie:

Tak jak Cioran, Panait Istrati, Strindberg i wielu innych, postrzega prze-pisywanie (reécriture) w obcym języku jako straszną próbę: „Tłumaczenie samego siebie jest przerażające, jak oglądanie własnych wnętrzności i przymierzanie ich niczym rękawiczek, odkrycie, że najlepszy słownik nie jest przyjacielem, lecz polem wroga" ${ }^{43}$.

Wydaje się, że ten wstępny niedostatek języka, który w konsekwencji czyni z tłumaczenia Ferdydurke wielomiesięczny spektakl w kawiarni Rex (błędy i niedopatrzenia są weń wpisane z powodu „nadmiaru rozpraszających dyskusji”44, słownik polsko-hiszpański nie istnieje), pozwala Gombrowiczowi uniknąć bolesnego doświadczenia przekładu jako autopsji własnego „ja”.

41 Witold Gombrowicz, Prólogo para la primera edición castellana (1947), s. 22. Polski przekład za: Rita Gombrowicz, op. cit., s. 98.

42 V. Laura Ísola, Escrituras del exilio: Gombrowicz en Buenos Aires, w: Alvaro Fernández Bravo, Florencia Garramuño, Saúl Sosnowski (red.), Sujetos en tránsito: (in)migración, exilio y diáspora en la cultura latinoamericana, Alianza, MadridBuenos Aires 2003, s. 180.

43 Pascale Casanova, La República mundial de las Letras, s. 188. Cytat z Nabokova pochodzi z jego listu do Zinaidy Szachowskiej z października 1935 roku.

44 Witold Gombrowicz, Prólogo para la primera edición castellana (1947), s. 22. Polski przekład za: Rita Gombrowicz, op. cit., s. 98. 


\section{Ślub - przekład na dwie ręce}

O tym, jak odbywał się drugi odautorski przekład Gombrowicza, wiadomo niewiele - sam pisarz nie komentował go tak szeroko jak tłumaczenia Ferdydurke, w literaturze argentyńskiej nie obrosło ono legendą niezwykłego wydarzenia literackiego, przez co krytyka, tak polska, jak argentyńska, nie poświęcała mu większej uwagi. Zrażony obojętnością, z jaką przyjęto Ferdydurke, Gombrowicz stracił zapał do wdrażania równie konsekwentnej „akcji promocyjnej” i sam proces przekładu pominął nieomal całkowitym milczeniem; większość informacji na ten temat pochodzi od drugiego tłumacza, Alejandra Rússovicha. Pisarz ochoczo i obficie analizował samą sztukę - liczne jej metakomentarze rozsiane są po Dzienniku, Testamencie i przedmowach, co każe sądzić, że Gombrowicza nade wszystko interesowało właściwe wyłożenie problematyki tego trudnego tekstu, a w znacznie mniejszym stopniu kwestia przekładu. O ile milczenie autora na temat okoliczności powstania wersji hiszpańskojęzycznej może być zrozumiałe, o tyle to désintéressement krytyki - przy jednoczesnym fermencie twórczym, wzbudzonym przez przekład Ferdydurke - może dziwić, zważywszy na szereg paraleli między tymi tekstami, począwszy od ich czasowej bliskości ${ }^{45}$. Oba tłumaczenia w znacznym stopniu odbiegają od polskiego oryginału, przy czym w przypadku Ślubu to pierwszeństwo oryginału jest problematyczne, bo argentyński tekst ukazał się w 1948 roku, a polski został wydany przez paryski Instytut Literacki dopiero pięć lat później. Co więcej, choć tryb przekładowy Ferdydurke był z pewnością bardziej ekscentryczny, to i procedura przekładu sztuki nie była całkiem konwencjonalna: Gombrowicz nadal nie władał biegle hiszpańskim, drugi tłumacz po polsku nie mówił w ogóle, a poszczególne sceny bywały „wytańcowywane” przez autora, by zachować właściwy im rytm, lub wykrzykiwane na nadmorskiej

45 „Pomysł tej sztuki [Ślubu - E.K.P.] miał odległe korzenie - wspomina Rússovich. - Ale dopiero po przetłumaczeniu Ferdydurke na hiszpański projekt okrzepł”; Rita Gombrowicz, op. cit., s. 139. 
alei Costanera, by sprawdzić ich brzmienie ${ }^{46}$. Argentyński przekład Ślubu - w przeciwieństwie do przekładu pierwszej powieści - nie posłużył wprawdzie jako podstawa do tłumaczeń na języki bardziej centralne (francuski), co ewentualnie mogłoby wyjaśniać skromną liczbę studiów translatorskich tego przypadku, ale był z kolei tekstem, który utorował Gombrowiczowi drogę do sławy w Argentynie i Europie. Jorge Lavelli, który w 1963 roku wyreżyserował Ślub w Paryżu, przeczytał go najpierw w wersji argentyńskiej, a następnie wystawił we Francji w przekładzie przygotowanym przez Gombrowicza na podstawie tekstu hiszpańskojęzycznego ${ }^{47}$.

Kulturalna „siła rażenia” obu argentyńskich przekładów była więc, koniec końców, podobna i to praktyczne kryterium - zwiększenie zasięgu, udaną refrakcję - należy uznać za najlepszą dla nich rekomendację. Podobnego zdania jest autorka jedynego studium krytycznego na temat odautorskiego przekładu Ślubu, Bożena Zaboklicka, która ponownie broni prawa autora do wprowadzania niejednokrotnie znaczących zmian w stosunku do polskiego oryginału i dodatkowo przekonująco tłumaczy ich nową wymowę, wymuszoną, jak ująłby to Lefevere, ograniczeniami systemu przyjmującego. Zanim do tych zmian przejdę, kilka słów o paratekstach argentyńskiego wydania z 2010 roku: do trzech autorstwa Gombrowicza - Prefacio (Przedmowy), Comentario (Komentarza) i Indicaciones para los actores y el regisseur (Wskazówek dla aktorów i reżysera) - przedrukowanych z 1948, dodano jeszcze współczesną notę Alejandra Rússovicha na temat tłumaczenia, w której podkreśla on odmienność obu wersji językowych: „Przekład ten w pewien sposób unieważnił tekst oryginalny, przenosząc go w język, który nie ma nic wspólnego z polskim. Jednocześnie zależało nam na zachowaniu sensu, rytmu, brzmienia, a nawet deformacji języka słowiańskiego" ${ }^{38}$. Do tego

46 Ibid., s. 140-141; Alejandro Rússovich, El otro idioma de Witoldo, „Clarín. Revista N” 1999, 25 VII, https://goo.gl/KTTqB7, dostęp: 10 XI 2015.

47 V. José Tcherkaski, Las cartas de Gombrowicz (Jorge Lavelli lo recuerda en una conversacin entrañable), Siglo xxi, Buenos Aires 2004, s. 63; Rita Gombrowicz, op. cit., s. 143-144.

48 Alejandro Rússovich, Sobre esta traducción, w: Witold Gombrowicz, El casamiento, przeł. Alejandro Rússovich, Witold Gombrowicz, El Cuenco de Plata, Buenos Aires 2010, s. 5. 
nowego tekstu Gombrowicz dodaje trzy wyżej wspomniane noty wyjaśniające, które w dużej mierze powtarzają treści zawarte w komentarzach do polskiego wydania, choć - jeśli przyjąć, że te redagował dopiero na potrzeby publikacji - to akurat kolejność ich powstawania byłaby odwrotna. Tak czy inaczej w paratekstach hiszpańskojęzycznych pojawiają się znane polskiemu czytelnikowi idee „kościoła międzyludzkiego”, opozycji „świata wewnętrznego” i „świata zewnętrznego”, wzajemnej deformacji etc. Znaczącą różnicą jest akcentowana w Prefacio potrzeba wytłumaczenia się z samej konieczności prologowania własnego dzieła:

Pozbawienie aktualnej literatury prawa do komentarza stawia ją w niekorzystnym położeniu w stosunku do literatury dawniejszej i pozbawia ją wielu inteligentnych czytelników, którzy tylko z braku pewnych informacji nie są w stanie rozwiązać zagadki „jak należy to czytać”. Ponadto, wystawia bezbronnego (autora) na krytyki „znawców”, którzy w większości nie mają czasu, ochoty ani umiejętności, by poznać coś, czego by wcześniej nie znali ${ }^{49}$.

W wydaniu argentyńskim Gombrowicz wyprzedza więc ewentualne zarzuty o to, że dzieło powinno tłumaczyć się samo, a wszelkie parateksty są z natury zbędne jako twory pomocnicze i drugorzędne w stosunku do tekstu głównego. Ta potrzeba eksplikacji dziwi o tyle, że w literaturze argentyńskiej prolog jest gatunkiem uprawianym systematycznie m.in. przez Borgesa, który z prawdziwą pasją prologował dzieła własne i cudze, oraz Macedonia Fernándeza - jego Museo de la Novela de la Eterna składa się w dużej mierze z samych prologów, w tym jednego do „czytelników, którzy cierpieliby, gdyby nie wiedzieli o czym mówi ta powieść", a innego do krytyków (skądinąd rozwijającego wiele myśli zawartych w Prefacio do argentyńskiego Ślubu $)^{50}$. Z drugiej strony parateksty Argentyńczyków mają

\footnotetext{
49 Witold Gombrowicz, Prefacio, w: idem, El casamiento, s. 7.

50 W prologu A los críticos (Do krytyków) Macedonio zarzuca im przede wszystkim, że formułują wobec dzieła wymóg doskonałości (perfección); Macedonio Fernández, Museo de la Novela de la Eterna, oprac. Ana Camblong, Adolfo de Obieta, ALLCA xx, Madrid 1997, s. 16-19. Gombrowicz pisze w Prefacio do El casamiento (s. 8): „Za każdym grymasem, intelektualnym chwytem lub wyszukanym,
} 
dość specyficzny charakter - są przestrzenią dla formułowania idei natury ogólnej, nierzadko odległych od treści zawartych w tekście głównym, natomiast Gombrowicz traktuje je czysto utylitarnie, jako platformę do wyłuszczenia właściwej wykładni dzieła. Innym lejtmotywem argentyńskiego Prefacio (ale już nie polskiej Idei dramatu) jest obawa przed zaszufladkowaniem w którejś z popularnych w owym czasie teorii: „Czyżby ten dramat był freudowski? albo egzystencjalistyczny? Jeśli już nie możecie obyć się bez izmów, zobaczcie przynajmniej, że nie jest egzystencjalistyczny, a ferdydurkistyczny"51. W Ameryce Południowej, gdzie wszystko wydarza się „ukradkiem, po cichu” (a la sordina) ${ }^{52}$, imperatyw sprowadzania nowych idei do wspólnego mianownika gotowych, otrzymanych z zewnątrz koncepcji wydaje się Gombrowiczowi działać skuteczniej niż w Polsce - stąd potrzeba zaznaczenia własnej wyjątkowości. Możliwe też, że w 1953 roku, kiedy przygotowuje wydanie dla Instytutu Literackiego wie już, że od popularnych „izmów” epoki będzie mógł odciąć się w Dzienniku.

Największe zmiany w stosunku do polskojęzycznego oryginału zostały wprowadzone pod koniec aktów II i III. W obu wersjach akt II kończy się zdradą - Henryk obala Ojca i ogłasza się Królem - ale proces, który do tej zdrady prowadzi, jest odmienny. W polskim Ślubie Henryk zdaje się najpierw opierać podszeptom Pijaka (choć nie do końca, bo w długim monologu rozpatruje jednak korzyści takiego

uczonym, erudycyjnym i mądrym zarzutem, na którym musi potknąć się każda wolna myśl, kryje się postulat tak prosty, co pretensjonalny: postulat doskonałości. Wymaga się, by dzieło sztuki było doskonałe, i jako takie nie wymagało komentarzy”. Trudno powiedzieć, czy Gombrowicz miał szansę znać dzieło Macedonia, opublikowane pośmiertnie w 1967 roku, choć jego redakcja zaczęła się jeszcze w 1925. Wiadomo skądinąd, że miał okazję poznać samego pisarza zgodnie z ustaleniami Klementyny Suchanow, został mu przedstawiony w jego mieszkaniu w Buenos Aires i przypadli sobie do gustu. W Dzienniku brak jednak wzmianek o Macedoniu; v. Klementyna Suchanow, Argentyńskie przygody Gombrowicza, s. 75-76.

51 Witold Gombrowicz, Prefacio, s. 11.

52 Ibid., s. 9. 
obrotu sprawy), by potem, ostatecznie sprowokowany strachem Ojca ${ }^{53}$, dokonać jednak zamachu. W wersji argentyńskiej scena „kuszenia” i zdrady jest o kilkanaście stron dłuższa: Pijak okazuje się ambasadorem Hitlera, którego wojska gromadzą się przy polskiej granicy, co z kolei „osłabia Króla” - okazuje on strach nie tyle przed synem (jak w wersji polskiej), co przed zagrożeniem zewnętrznym. Na Henryka znacznie silniej naciska Pijak, każąc mu rzucić się na Ojca, ten jednak odmawia, a nawet wyjawia władcy knowania „ambasadora Hitlera”. W El casamiento Gombrowicz usuwa ponadto długi monolog Henryka, w którym ten „nastraja się” do zdrady: „Ja stwarzam królów! Ja powinienem być królem! Jestem najwyższy! Nic wyższego ode mnie! Ja jestem Bogiem!" ${ }^{4}$. Zamiast tego dodaje krótką wymianę zdań z Władziem: Henryk prosi go, by rzucił się na Pijaka-ambasadora (sam nie może, sparaliżowany własnym poczuciem godności), jeśli ten rzuci się na Ojca:

Jeśli będziesz mi posłuszny, mogę wszystko.

Cóż prostszego! Ja rozkazuję,

ty spełniasz. We dwójkę

możemy zrobić wszystko ${ }^{55}$.

Po czym Henryk napuszcza Pijaka na Ojca, a następnie Władzia na Pijaka, który zostaje aresztowany. Z kolei w końcu aktu III Gombrowicz rozwija w El casamiento kwestię zazdrości o Władzia - nieobecne w polskiej wersji „głosy” podszeptują mu jego własną zazdrość, nazywają go „zabójcą i tyranem, ojczyzno-rzeźnikiem [patricarnicero] i ojco-zamachowcem [parriderrumbado]", którego panowanie trwa, dopóki prawdziwy król jest uwięziony. Podszepty te narastają

53 „[Ojciec] zaczyna bać się własnego syna i ten strach przetwarza Henryka w prawdziwego zdrajcę"; idem, Ślub, w: idem, Dramaty, Wydawnictwo Literackie, Kraków 1986, s. 96.

54 Ibid., s. 165.

55 Si me obedeces, yo puedo todo. / ¿Qué más fácil! To ordeno, / Tú cumples. Entre los dos / se puede hacer todo; idem, El casamiento, s. 112. 
w Henryku („Nie wierzę mojemu głosowi, bo on odpowiada tym głosom” ${ }^{56}$ ) i każe on uwolnić rodziców, którzy „przechadzają się to tu, to tam, a ludzie ustępują im miejsca, jak gdyby znowu królowali” ${ }^{57}$, nastając tym samym na władzę Henryka. Drugą modyfikacją w akcie III jest rozmycie winy za śmierć Władzia: znika fragment, w którym „polski” Henryk bierze za nią odpowiedzialność (na pytanie Pijaka: „Zabił sam siebie? Po co zabił?”, odpowiada: „Z mojego rozkazu!...”58). Pozostają za to tylko jego słowa: „Ja tu za nic nie jestem odpowiedzialny! [...] My tylko łącząc się pomiędzy sobą, wciąż w nowe układamy się kształty"59.

Wprowadzone zmiany sugerują - jak obserwuje Bożena Zaboklicka - inne rozłożenie akcentów: o ile w akcie II Ślubu impuls do zdrady pochodzi przede wszystkim ze „świata wewnętrznego” Henryka, jest konsekwencją "natężonej pracy jego ducha”60, o tyle w El casamiento, zdrada następuje pod naporem „świata zewnętrznego" (Pijaka - ambasadora Hitlera) oraz „kościoła międzyludzkiego”61. Potwierdzają to modyfikacje wprowadzone w akcie III wersji argentyńskiej, w którym okazuje się, że śmierć Władza jest wynikiem wzajemnego kształtowania się ludzi, działania Formy, a nie rozkazu Henryka.

Bezpośrednie nawiązanie do Hitlera w akcie II El casamiento wydaje się wymuszone ograniczeniami kultury przyjmującej: argentyńskiemu czytelnikowi kontekst II wojny światowej i europejskich totalitaryzmów nie narzucał się samoistnie. Wersja polska wolna jest wprawdzie od bezpośrednich nawiązań do konkretnego momentu historycznego, ale już w komentarzach skierowanych do europejskiego czytelnika Gombrowicz konsekwentnie odwołuje się

\footnotetext{
56 Yo no creo a mi propia voz, porque ella / responde a esas voces; ibid., s. 179.

57 Se pasean por aquí y por allí y la gente les da paso como si reinasen otra vez...; ibid., s. 181.

58 Idem, Ślub, s. 220.

59 Ibid., S. 222-223.

60 Ibid., s. 92.

61 Bożena Zaboklicka, Una nueva interpretación de "El casamiento" de Witold Gombrowicz a la luz de la traducción de la obra al castellano realizada pro el proopio autor, „Eslavística Complutense” 2007, nr 7, s. 37-40.
} 
do przykładu Hitlera i wywyższającej pracy „sfery międzyludzkiej”: „»Boskość« Henryka dokonuje się poprzez opanowanie innych ludzi, jak boskość Hitlera" "62. Wydaje się więc, że wyeksponowany w wersji argentyńskiej wątek niemieckiego totalitaryzmu (jako spektakularny przykład wzajemnego stwarzania się ludzi) zaciążył nad sposobem, w jaki sam pisarz analizował własne dzieło - jako „kronikę historii, która oszalała" ${ }^{63}$. Zaboklicka dodaje jeszcze do tych szaleństw historii, w których Ślub bierze swój początek, jedno szaleństwo argentyńskie: w latach 40. u władzy umacnia się flirtujący z faszyzmem Juan Domingo Perón, okrzyknięty przez masy mężem opatrznościowym ${ }^{64}$. Podobnie jak w przypadku Ferdydurke, w języku hiszpańskim istnieją obecnie dwa przekłady Ślubu - odautorskiemu towarzyszy przekład dokonany przez Javiera Fernándeza de Castro w 1973 roku ${ }^{65}$. Tłumacz ten korzystał z francuskiej wersji dramatu (Le mariage), przez co zdecydował się na dość niefortunny tytuł El matrimonio, który po hiszpańsku oznacza związek lub parę małżeńską, a nie ceremonię zaślubin.

62 Witold Gombrowicz, Testament. Rozmowy z Dominique de Roux, przeł. Ireneusz Kania, Wydawnictwo Literackie, Kraków 2012, e-wydanie. W Dzienniku pisze z kolei o Hilterze jak o Henryku: „[...] najdziwniejszą cechą tego spotężnienia jest, że ono tworzy się od zewnątrz - Hitlerowi wszystko urasta w rękach, ale on sam jest taki, jaki był, zwykły, ze wszystkimi swymi słabościami; to karzeł, który objawia się, jak Goliat; to pospolity człowiek, który od zewnątrz jest Bogiem; to miękka dłoń ludzka, uderzająca jak maczugą. I Hitler jest teraz w szponach tego Wielkiego Hitlera - nie dlatego, aby nie zachował zwykłych, prywatnych, uczuć czy myśli, prywatnego rozsądku, ale ponieważ one są zbyt drobne, i za słabe, i nic nie mogą przeciw Olbrzymowi, który od zewnątrz go przenika”; idem, Dziennik 1953-1969; wyróżnienie w oryginale.

63 Gombrowicz cytuje w Dzienniku te słowa Luciena Goldmanna o Ślubie (z jego tekstu Krytyka nic nie zrozumiała, w: Witold Gombrowicz, Varia 2. Polemiki i dyskusje, Wydawnictwo Literackie, Kraków 2004, s. 123-139), by zgodzić się z pierwotną intuicją francuskiego krytyka o historycznych uwarunkowaniach dramatu, a następnie zdystansować wobec uproszczeń jego interpretacji.

64 Bożena Zaboklicka, Una nueva interpretación de "El casamiento"..., s. 35.

65 Witold Gombrowicz, El Matrimonio/Opereta, przeł. Javier Fernández de Castro, Barral Editores, Barcelona 1973. 


\section{Dziennik argentyński. Rekonstrukcja przeszłości66}

Dziennik argentyński (Diario argentino), czyli dokonany przez samego autora wybór fragmentów z Dziennika nie był dotąd przedmiotem żadnych analiz porównawczych ze swoim pierwowzorem. Z polskiej perspektywy tekst ten wydaje się bowiem drugorzędny, więcej: wydaje się w jakimś sensie współgrać, a nawet ugruntowywać drugorzędność argentyńskich studiów nad Gombrowiczem, które opierają się na tej znacznie okrojonej wersji opus magnum Polaka. Faktem jest, że Dziennik argentyński był przez lata jego najpoczytniejszym tekstem w Argentynie, głównie dlatego, że jedynym dostępnym na rynku w sposób ciągły (przy jednoczesnej ciągłej rzeczywistej niedostępności hiszpańskojęzycznego pełnego wydania Dziennika ${ }^{67}$. Doniosłość tej książki dla argentyńskich interpretacji autora Trans-Atlantyku, a także brak jakichkolwiek studiów na temat jej przekładu oraz dokonanych skrótów uzasadnia objętość niniejszego podrozdziału, znacznie przewyższającą te poświęcone pozostałym tłumaczeniom Gombrowicza na hiszpański. Celem moich analiz nie jest roztrząsanie ewentualnej wartości Dziennika argentyńskiego ani jego racji bytu (w szczególności poza Argentyną), a jedynie analiza historii wydania, architektury fragmentów oraz tłumaczenia.

Tak jak hiszpańskojęzyczne tłumaczenie Ferdydurke stało się argentyńską Ferdydurke, na tyle odległą od oryginału, że traktowaną często jako zgoła inna powieść, tak o Dzienniku argentyńskim mówi się w Buenos Aires, używając zaimka dzierżawczego „nasz” - wszak

\footnotetext{
66 Rozdział ten ukazał się w „Tekstach Drugich” 2016, nr 1, s. 264-280.

67 Diario argentino miał w Buenos Aires szereg wydań: w 1968, 2001 i 2006 roku. Pełne wydanie Dziennika ukazało się natomiast nakładem wydawnictw hiszpańskich: Alianza Editorial wydała kolejno w 1988 i 1989 pierwsze dwa tomy w tłumaczeniu Bożeny Zaboklickiej i Francesca Miravitllesa; Seix Barral, w ramach prestiżowej serii „Biblioteca Gombrowicz”, wydał w 2005 i wznowił w 2011 już całość Dziennika (Diario 1953-1969), w przekładzie tych samych tłumaczy. Jedynie to ostatnie wydanie jest obecnie dostępne na rynku hiszpańskojęzycznym, jednak - jak w przypadku wszystkich książek wydanych poza Ameryką Łacińską - w cenie dla przeciętnego czytelnika nieprzystępnej.
} 
istnieje on jedynie na tamtejszym rynku wydawniczym. Luis Gusmán pisze na przykład, że tekst ten inicjuje w Argentynie długą tradycję pisania dzienników - formy literackiej faktycznie niezwykle tam rozpowszechnionej - legitymizując ich twórczy, a nie jedynie autobiograficzny charakter ${ }^{68}$. Dziennik argentyński będzie punktem odniesienia dla szeregu studiów nad Gombrowiczem, w szczególności nad jego ewentualnym zakorzenieniem w tradycji regionu La Platy ${ }^{69}$. Z drugiej strony Juan José Saer - pisarz argentyński mieszkający wiele lat we Francji - krytykuje ten wybór w następujących słowach:

[...] jak wiadomo, większa część dziennika została napisana w Argentynie. Z niewytłumaczalnych powodów istnieje wybór zwany Dziennikiem argentyńskim, wydany kilka lat temu w Buenos Aires. To rozbicie jest niedorzeczne choćby dlatego, że cały dziennik jest argentyński; aczkolwiek znaczna jego część została napisana po powrocie do Europy, a całe dziesiątki stron nie mają najmniejszego związku z Argentyną, to zasadniczą racją bytu Dziennika jest argentyńskie doświadczenie ${ }^{70}$.

W części dotyczącej „niedorzeczności” wydawania fragmentów Dziennika-Saer najwyraźniej nie wie, że za tym przedsięwzięciem stoi sam autor - jego opinia jest w Argentynie raczej odosobniona, natomiast w części, która akcentuje „argentyńskość” całego tekstu, Saer wyraża poglądy wspólne wielu tamtejszym interpretatorom Gombrowicza.

68 Luis Gusmán, Ideales y rodeos del esclavo de sus diarios, „Clarín. Revista Ñ” 2014, $30 \mathrm{x}$, http://goo.gl/mSrjGu, dostęp: 5 III 2015.

69 V. Silvana Mandolessi, Una literatura abyecta. Gombrowicz en la tradición argentina, Rodopi, Amsterdam-New York 2012; José Amícola, El diario trans-atlántico de Witold Gombrowicz, „Zama” 2012, nr 4, s. 137-146; Alan Pauls, Cómo se escribe el diario íntimo, El Ateneo, Buenos Aires 1996.

70 Juan José Saer, Spojrzenie z zewnątrz, przeł. Klementyna Suchanow, Krystian Radny, „Literatura na Świecie” 2001, nr 4, s. 72-82. W cytowanym fragmencie polski przekład zniekształca znacząco oryginał i w konsekwencji przeczy sam sobie. Saer nie pisze bowiem, że „znaczna” część Dziennika została napisana po powrocie do Europy (co zresztą byłoby nieprawdą), a jedynie że „część”; v. idem, La perspectiva exterior: Gombrowicz en la Argentina, w: idem, El concepto de ficción, Seix Barral, Barcelona 2004, s. 29. 


\section{„Zasugeruję Panu inne rozwiązanie, zapewne najlepsze"71}

Historia Dziennika argentyńskiego zaczyna się w 1965 roku. Rok wcześniej wydawnictwo Sudamericana wznawia Ferdydurke z prologiem Ernesta Sábato. Chociaż sprzedaż osiągnęła wyniki „bardziej niż skromne", Sudamericana wyraża zainteresowanie wydaniem Pornografii lub Dziennika 1953-1956. Pisarz sugeruje wówczas lepsze rozwiązanie - wybranie fragmentów „blisko związanych z krajem” i złożenie ich w jednym tomie: „W ten sposób czytelnik argentyński zobaczy, że nie jestem tak całkowicie obcy, co z kolei ułatwi przenikanie innym moim książkom" (1o lutego 1965) ${ }^{72}$. Propozycja Gombrowicza trafia na podatny grunt, ponieważ zbiega się w czasie ze zmianą polityki wydawniczej w Buenos Aires. W latach 40. i 50. argentyński rynek książki przeżywa okres prosperity m.in. dzięki ekspansji na terenie Hiszpanii, pogrążonej przez frankizm w głębokiej stagnacji kulturalnej: w owym czasie argentyńskie wydawnictwa eksportują ponad 40\% tytułów, co z kolei zmusza je do układania katalogów bardziej powszechnych, z nader skromną reprezentacją autorów argentyńskich $^{73}$. Sytuacja ta zmienia się właśnie w latach 6o. - hossa trwa jeszcze, ale powolne odradzanie się hiszpańskich domów wydawniczych powoduje obniżenie eksportu i skłania Argentyńczyków do koncentrowania się na autorach lokalnych. Dziennik argentyński doskonale łączy te tendencje: pisarz formatu światowego, dopiero

71 Witold Gombrowicz w liście do Antonia López Llausása, wieloletniego dyrektora generalnego w wydawnictwie Sudamericana i twórcy jego sukcesu (10 lutego 1965). Korespondencję Gombrowicza z wydawcami w Argentynie i tłumaczami na hiszpański - Pitolem i Ferraterem - cytuję dzięki uprzejmości Wydawnictwa Literackiego.

72 Pomysł opublikowania „argentyńskich” fragmentów Dziennika narodził się wcześniej - już w 1960 roku Gombrowicz proponował ich wydanie Jacobo Muchnikowi. Korespondencja między nimi urywa się jednak, gdy Muchnik domaga się całości tekstu, nie chcąc podejmować decyzji na podstawie przedstawionego przez Gombrowicza fragmentu.

73 V. Ana Gallego Cuiñas, Literatura argentina y mercado editorial (una mirada estrábica), „Ínsula” 2013, nr 793/794, s. 32-33. 
co odkryty w Paryżu, proponuje książkę o tematyce rodzimej, poczętą z i dla ducha argentyńskiego ${ }^{74}$. Gombrowicz od razu wysyła schemat książki, a wydawca z zadowoleniem komentuje jej objętość, nieprzekraczającą dwustu stron, co pozwoli obniżyć cenę, czyniąc ją „bardziej dostępną niż Ferdydurke”. „Sądzę - pisze López Llausás w marcu 1965 roku - że nowa książka poprawi sprzedaż poprzedniej”. Od samego początku skrócona wersja Dziennika przeznaczona była wyłącznie na rynek argentyński, Gombrowicz domaga się nawet wyłączenia książki ze sprzedaży na rynku hiszpańskim (gdzie ma zamiar wydać w przyszłości tekst nieokrojony), na co Sudamericana jednak się nie zgadza. Każe to sądzić, że o ile czytelnicy hiszpańscy mogli, w zamyśle Gombrowicza, jeszcze poczekać, o tyle w Argentynie pragnął zapewnić sobie sukces natychmiastowy, nawet za cenę znacznego skrócenia tekstu Dziennika ${ }^{75}$.

Tytuł książki narzuca się Gombrowiczowi od razu i już w pierwszym liście (z 10 lutego 1965) pisze: „moglibyśmy z łatwością opublikować mój Dziennik argentyński". Sęk w tym, że w kolejnych jego listach słówko „mój” przenika do tytułu i w ciągu całej, wieloletniej korespondencji Gombrowicz będzie pisał o Moim dzienniku argentyńskim. Wydawca przeciwnie - z równą konsekwencją omija zaimek dzierżawczy. Różnica

74 Gombrowicz doskonale wyczuwa charakterystyczną dla argentyńskiej kultury (przynajmniej do pierwszej połowy $\mathrm{xx}$ wieku) potrzebę przeglądania się w cudzym spojrzeniu. Sergio Chejfec dostrzega w argentyńskiej recepcji Dziennika echa owego upodobania do odkrywania siebie poprzez perspektywę cudzoziemca: „poznania, kim jesteśmy dla innych, jak nas wymawiają i opisują w obcych językach”, która skutkuje czytaniem ich tekstów jako „metafor miejsca”, czyli lekturą uprzywilejowującą tę „opowieść o nas, Argentyńczykach” względem innych możliwych sensów dzieła; Sergio Chejfec, La música de las anomalías, w: Gisela Heffes (red.), Poéticas de los (dis)locamientos, Literal Publishing, Texas 2012, s. 51-52.

75 W tym kontekście warto przypomnieć strategię, którą Gombrowicz przyjmuje na polskim rynku: nie zgadza się na publikację żadnej książki, dopóki nie ukaże się drukiem całość Dziennika. Jeśli chodzi o rynek hiszpańskojęzyczny, pisarz uparcie rozgranicza Hiszpanię i Amerykę Łacińską, domagając się dla wszystkich książek oddzielnego wydawcy na Półwyspie Iberyjskim. Być może pokłada więcej zaufania w barcelońskim Seix Barral, którego gwiazda faktycznie wschodzi w latach 6o. wraz z rodzącym się boomem na powieść latynoską. 
perspektyw jest oczywista: podczas gdy autor akcentuje pośrednio swoje „ja”, perspektywę osobistą, Sudamericana woli podkreślać „argentyńskość” tekstu, który w ten sposób wpisuje się w istniejącą już tradycję pisarzy cudzoziemców komentujących Argentynę. Ostatecznie książka ukazuje się pod tytułem Dziennik argentyński, a Gombrowicz, zirytowany innymi aspektami współpracy, nie komentuje nawet zniknięcia zaimka.

Po ostatecznym ustaleniu kwestii dotyczących honorarium („znacznie zaniżonego w stosunku do tego, co oferują mi wydawcy europejscy"; list z 1965 roku, bez daty dziennej), dystrybucji na terenie Hiszpanii oraz tłumaczenia (o czym za chwilę) w styczniu 1966 roku musiało wydawać się, że Dziennik argentyński wkrótce pojawi się na rynku. Mijały jednak miesiące i nic: korespondencja krążyła przez ocean, a Gombrowicz był coraz bardziej zirytowany. Ponaglał, groził, wprowadzał klauzule ustalające ostateczną datę publikacji. Świadomość zbliżającego się końca wyziera z jego listów: „nie mam już czasu”, „to trwa już całą wieczność” (14 listopada 1966), „nie mogę pracować w tym rytmie [...] proszę mi łaskawie napisać bez ogródek, czy są Państwo gotowi przyspieszyć nieco moje wydania” (23 września 1967), „mimo całej mojej dobrej woli, nie mogę już dłużej czekać” (16 lutego 1968). Wymiana listów staje się coraz bardziej napięta, a gdy książka ukazuje się wreszcie w połowie 1968 roku, Gombrowicz jest niezadowolony: okładka wydaje mu się nietrafiona - widnieje na niej figura dziewczynki karmiącej gołębie, co zresztą wydaje się nawiązaniem do równie zaskakującego zabawkowego konika, zdobiącego wydanie Ferydurke („nie rozumem, dlaczego uporczywie prezentują mnie Państwo jako autora dla dzieci”; 27 września 1968), tytuł jest źle widoczny, a na okładce brak informacji o autorze (w szczególności o tym, że jest kandydatem do Nobla). Sprzedaż jest znowu „nader skromna”, o co strony obwiniają się wzajemnie. Gombrowicz próbuje jeszcze zainteresować Sudamericanę Bakakajem, ale - otrzymawszy chłodną odpowiedź - nawiązuje współpracę z wydawnictwem Jorgego Álvareza ${ }^{76}$. W ostatnim liście, datowanym na dziesięć dni

76 Jorge Álvarez (1932-2015) był jednym z głównych animatorów kultury argentyńskiej lat 6o. i 7o., niezależnym wydawcą i producentem muzycznym. Publikował 
przed śmiercią, Gombrowicz z nadzieją pisze o kolejnych wydaniach w Buenos Aires („Jestem bardzo zadowolony, że będziemy razem pracować, tym bardziej że moje wydania w Argentynie są nieco przyblokowane"). Co zastanawiające, konsekwentnie proponuje swoim argentyńskim wydawcom Bakakaj („zbiór dość zabawnych opowiadań”), Rozmowy z Dominique de Roux („rozbudzają zainteresowanie moją literaturą”; 13 lipca 1969), w dalszej kolejności Kosmos („który przyniósł mi 20 tysięcy dolarów międzynarodowej nagrody"; list bez daty) i dzieła teatralne. Zawodzi go intuicja co do Trans-Atlantyku, którego najwyraźniej nie uważa za tekst przeznaczony na tamtejszy rynek (zostanie w końcu wydany w Hiszpanii w 1971 roku), a który, przeciwnie, będzie po latach uznany za najbardziej argentyńską powieść Gombrowicza.

\section{„Zastanawiał się Pan nad tym, kto mógłby napisać przedmowę do Dziennika?"ᄁ}

Wydanie Ferdydurke z 1967 roku opatrzył przedmową Ernesta Sábato - Gombrowiczowi zależało na poparciu znanego pisarza. Wydawca Dziennika argentyńskiego szuka podobnego kandydata - kogoś, kto wsparłby tekst swoją sławą - i proponuje Carlosa Mastronardiego. Gombrowicz odmawia: „Moje osobiste relacje z Mastronardim nie są najlepsze, więc proszę nie prosić go o współpracę przy przedmowie. Ponadto nie wydaje mi się, żeby była potrzebna - wystarczy moja” (25 października 1967).

Przedmowa Gombrowicza do Dziennika argentyńskiego ma zaledwie trzy strony, o połowę mniej od tej, którą opatruje Ferdydurke. Jej głównym celem jest wytłumaczenie się z przymiotnika - w jakim sensie dziennik jest a r g e nt y ń ski? Doskonale zdaje sobie sprawę, że jako pisarz cudzoziemiec podejmujący tematykę argentyńskości wpisuje się w długą tradycję: hrabia Keyserling, Waldo Frank, Rabindranath

najważniejszych autorów tamtego okresu, m.in. Luisa Gusmána i Germána Garcię, promotorów dzieła Gombrowicza w Argentynie.

77 Z listu Antonia Lópeza Llausása do Witolda Gombrowicza z 17 października 1967 roku. 
Tagore, a przede wszystkim José Ortega y Gasset byli zapraszani, by wyrokować o narodowym duchu Argentyńczyków. Gombrowicz odcina się od tej tradycji - cytuje kilka popularnych sądów, zapożyczonych od autora Buntu mas, i konkluduje: „wolę trzymać się z dala od tej nadmiernie patetycznej retoryki"78. Odżegnuje się zdecydowanie od wszechobecnej w Argentynie literatury zaangażowanej - dziennik ma być literaturą wyłącznie prywatną - co zresztą zaskarbi mu w połowie lat 70. pierwszych czytelników, którzy będą stawiać jego teksty ponad legendą jego argentyńskiego życia ${ }^{79}$. Argentyna jest w Dzienniku wyłącznie pretekstem: nie chodzi o opis, ale o przeżycie - jak zauważa Sergio Chejfec, dla Gombrowicza Argentyna nie jest miejscem, lecz sytuacją. Powtarzające się na jego kartach nazwy własne - Venezuela, Tandil, Retiro, Santiago - nie odnoszą się w gruncie rzeczy do punktów w przestrzeni fizycznej, lecz kondensują doznania i doświadczenia ${ }^{80}$.

Druga kwestia, dla mnie bardziej interesująca, to deklarowane w pierwszych zdaniach „zniekształcenie perspektywy”: „być może trudno będzie właściwie odczytywać te stronice, nie znając ich uzupełnienia - wszystkiego tego, co w Dzienniku napisałem o człowieku, sztuce, Polsce, Europie, o sobie samym i o rozmaitych moich sprawach” ${ }^{81}$. To „zniekształcenie perspektywy” - nawet jeśli wymuszone potrzebą rynku, jest także w wysokim stopniu przemyślane - składa się na pierwszy rys nowej autoprezentacji, zaprojektowanej dla tej kategorii czytelnika, którą określić można jako „Argentyńczyka

78 Witold Gombrowicz, Przedmowa [do Diario Argentino], przeł. Ireneusz Kania, w: idem, Varia 1, s. 430. Ortega y Gasset poświęcił Argentynie i Argentyńczykom szereg esejów, wydanych w zbiorze Meditación del pueblo joven y otros ensayos sobre América (Alianza Editorial, Madrid 1995). Pisze w nich o Argentyńczykach jako narodzie in statu nascendi. Gombrowicz nawiązuje do tego określenia, pisząc w przedmowie do Diario argentino (s. 429): „Zwykle o Argentynie mówi się, że nie istnieje, albo że istnieje, ale nie jako rzeczywistość, albo że istnieje, owszem, lecz jako coś jeszcze zalążkowego, bolesnego, rozpaczliwego... i że Argentyńczyk jeszcze się nie narodził - stąd jego cierpienie i wstyd, et cetera”. Mam na myśli pisarzy tworzących grupę „Literal”: Germána Garcíę, Luisa Gusmána oraz Osvalda Lamborghiniego. Sergio Chejfec, Gombrowicz, mito nativo, „El Ciudadano” wiosna 1999, s. nlb. Witold Gombrowicz, Przedmowa [do Diario argentino], s. 429. 
czytającego Gombrowicza po jego powrocie do Europy”. Częścią tej nowej autoprezentacji jest poczynione w przedmowie wyznanie dotyczące skomplikowanych relacji pisarza z elitą literacką Buenos Aires:

[...] po moim wyjeździe z Argentyny powstało coś w rodzaju melodramatycznej legendy; okazuje się oto, że pisarz, uznany dziś w Europie, żył w Argentynie upokorzony, otoczony wzgardą i odrzucany przez miejscowy Parnas. Ale to nieprawda. Sam, z własnej woli, nie utrzymywałem ścisłych stosunków z Parnasem, gdyż środowiska literackie pod wszystkimi szerokościami geograficznymi składają się z ludzi ambitnych, przeczulonych, pochłoniętych własną wielkością, gotowych obrażać się o byle $\mathrm{co}^{82}$.

Gombrowicz przedstawia więc swoje niepowodzenie jako pisarza w kategoriach własnego wyboru i wpisuje się (świadomie lub nie) w mocno zakorzeniony w literaturze argentyńskiej topos pisarza niedocenionego (escritor fracasado). Kompozycja i wybór fragmentów Dziennika argentyńskiego - o czym później - ugruntują tylko tę przynależność.

„Język polski, a w szczególności pański styl, odtwarza się lepiej w hiszpańskim" ${ }_{3}$

Ostatecznie tłumaczem Dziennika argentyńskiego został Sergio Pitol, który później przełożył także Bakakaj, Kosmos i Trans-Atlantyk (ten ostatni z Kazimierzem Piekarcem). Początkowo wydawca sugeruje tłumaczenie z wersji francuskiej, na co Gombrowicz zdecydowanie się nie zgadza (w 1969 roku czas nagli go już tak bardzo, że sam proponuje Jorgemu Álvarezowi przekład z francuskiego: „[...] prosi mnie Pan o oryginały, ale ponieważ oryginały są po polsku, przesyłam tłumaczenia. Są dosyć dobre. Wolę dobrego tłumacza z francuskiego niż złego z polskiego"; list bez daty dziennej). Pitola polecił Gombrowiczowi inny jego tłumacz na hiszpański, Gabriel Ferrater, który początkowo sam podjął się przekładu fragmentów Dziennika z wersji francuskiej i niemieckiej, ale potem ceduje to przedsięwzięcie na Meksykanina,

\footnotetext{
82 Ibid., s. 230-431.

83 Z listu Sergia Pitola do Witolda Gombrowicza z 20 czerwca 1966 roku.
} 
który może przekładać bezpośrednio z polskiego. Ferrater posyła pisarzowi dokonany przez Pitola przekład Bram raju Jerzego Andrzejewskiego, który musiał świadczyć o translatorskim talencie, bo Gombrowicz zaraz pyta: „Czy może mi pan bezzwłocznie przysłać adres Sergia Pitola?” (21 kwietnia 1966), a później będzie go hołubił i wspierał w przepychankach z wydawcą. Lejtmotywem ich korespondencji (pisanej zresztą po hiszpańsku do końca, czyli do października 1968) są utyskiwania na Sudmericanę - zgubione fragmenty, niezapłacone faktury, brak odpowiedzi. Pitol wysyła Gombrowiczowi pierwszą próbkę tłumaczenia w połowie 1966 roku i pisze w liście:

język polski, a szczególnie pański styl, odtwarza się lepiej w hiszpańskim, języku, który podobnie jak polski jest w stanie oddać przemoc za pomocą składni i wyrazić podobne odcienie dzięki obfitości zdrobnień, zgrubień, wyrażeń pejoratywnych itd. Odniosłem wrażenie, że tekst francuski „przylizuje” styl i czyni go zbyt „rozsądnym” (2o czerwca 1966) ${ }^{84}$.

Odpowiedzi Gombrowicza nie znamy, ale musiała być przychylna, bo korespondencja przebiega bez tarć, z czasem przybierając nawet ton przyjacielski. Pisarz najwyraźniej zaakceptował zmiany językowe, które Pitol anonsował mu w listach: zastąpienie myślnika innymi znakami oraz pocięcie długich zdań. O ile pierwsza $z$ nich była faktycznie narzucona przez zasady interpunkcji hiszpańskiej, o tyle druga była subiektywną decyzją Pitola i hiszpańscy tłumacze Dziennika - Bożena Zaboklicka oraz Francesc Miravitlles - nie przychylili się do niej.

W porównaniu z wersją hiszpańską (z Półwyspu Iberyjskiego) tekst Dziennika argentyńskiego jest, ogólnie rzecz ujmując, odleglejszy od oryginału (pomijam tutaj kwestie kompozycyjne - wybranie i układ fragmentów - które poruszę w kolejnym punkcie). Przekład Pitola doczekał się wielu pochwał, w tym m.in. samego pisarza oraz Bożeny Zaboklickiej, cenionej i wielokrotnie nagradzanej tłumaczki Gombrowicza na hiszpański. Meksykanin celnie odczytuje intencje autora oraz

84 Cytuję ten fragment w przekładzie Bożeny Zaboklickiej, zamieszczonym w niepublikowanym artykule Gombrowicz po hiszpańsku w przekładach Sergio Pitola, udostępnionym dzięki uprzejmości autorki. 
potrafi doskonale oddać niełatwy skądinąd literacki styl Dziennika („ustawił tak wysoko poprzeczkę jakości przekładów Gombrowicza, że niełatwo mu dorównać" ${ }^{85}$. Moją intencją nie jest więc podważanie sławy świetnego tłumacza z polskiego, którą Pitol cieszy w świecie hiszpańskojęzycznym, a jedynie zwrócenie uwagi na te (nieliczne zresztą) miejsca, w których jego przekład wydaje się nietrafiony i - jak zobaczymy - fałszuje oryginał.

W najprostszych przypadkach potknięcia tłumacza (albo redaktora) to zwykłe literówki, które czasem zasadniczo zmieniają sens zdania (kiedy sudando zastępuje słowem dudando ${ }^{86}$ i zamiast oryginalnego „i zresztą pocę się" wychodzi „, zresztą wątpię”; podobnie zastępuje reclamaba czasownikiem declamaba ${ }^{87}$, a w miejscu oryginalnego „domagała się literatury politycznej” pojawia się „deklamowała” etc.). W innych przypadkach z argentyńskiej mecenaski Gombrowicza Cecylii Benedit de Debenedetti robi Alicję ${ }^{88}$, a z nazwy jej wiejskiej posiadłości (Mercedes) osobę, z którą można mieć jakieś przygody ${ }^{89}$. Płynąc po Paranie, w argentyńskim przekładzie Gombrowicz w zaskakujący sposób spotyka na dziobie zamiast Paragwajczyka papugę ${ }^{90}$, która na domiar złego odpowiada na jego „dzień dobry” słowami „ładna pogoda”. W kilku innych przypadkach, Pitol gubi lub, przeciwnie, dodaje słówko „nie”, zmieniając zdanie twierdzące w przeczące i na odwrót ${ }^{91}$.

85 Ibid.

86 Witold Gombrowicz, Diario argentino, przeł. Sergio Pitol, Adriana Hidalgo, Buenos Aires 2006, s. 30.

87 Ibid., s. 59.

88 Ibid., s. 40.

89 W oryginalnym zdaniu „opowiadała o swoich przygodach w Mercedes” Pitol zastępuje przyimek „w” przyimkiem „Z”, zapewne dlatego, że Mercedes to także żeńskie imię własne; v. ibid., s. 13.

90 Hiszpańskie słowo paraguayo (Paragwajczyk), myli mu się prawdopodobnie z papagayo (papuga), kto wie czy nie pod wpływem miejsca (znajdują się na dziobie statku).

91 Oryginalne „ja, któremu bicz klęski wybił z głowy fochy i fumy” pojawia się $\mathrm{w}$ formie zaprzeczonej, natomiast w innym zdaniu - „nie w tym rzecz, by artysta nie miał kompleksów” - druga część przybiera formę twierdzącą („nie w tym rzecz, by artysta miał kompleksy”); v. ibid., s. 16 i 61. 
Jednym z poważniejszych defektów Dziennika argentyńskiego jest zagubienie lub zignorowanie $\mathrm{w}$ tłumaczeniu intertekstualnych odniesień do innych tekstów literackich ( $w$ tym przede wszystkim dzieł samego Gombrowicza). Pitol nie zna np. hiszpańskiego przekładu Ferdydurke, co powoduje, że „parobka” przekłada jako gañán ${ }^{92}$ (a nie peón), „gębę” jako jeta ${ }^{93}$ (a nie facha), a „dni [...] podszyte są nocą Retiro" jako dias recubiertos (a nie forrados) por la noche de Retiro ${ }^{94}$. W Dzienniku argentyńskim brak ponadto jakichkolwiek przypisów, co szczególnie kłopotliwe w tych miejscach, w których Gombrowicz nie usunął bezpośrednich nawiązań do kultury polskiej. I tak bez wyjaśnienia obywają się np. „żeromszczyzna tandilowska”, Radziwiłłowie oraz fraszka Kochanowskiego $\mathrm{Na} z$ drowie ${ }^{95}$. W hiszpańskim wydaniu Seix Barral dość starannie opatrzono przypisami odniesienia do kultury polskiej (nazwiska pisarzy, tytuły dzieł, gazet, cytaty, skróty etc.).

\section{„Nie zabraknie na tych stronach treści, które się nie spodobają, wzbudzą sprzeciw etc. Tym lepiej"96}

O ile przekład Dziennika argentyńskiego gubi czasami niuanse oryginału, o tyle jego konstrukcja - wybór i układ fragmentów - przebiega ściśle według wskazówek autora i tym samym należy ją traktować jako podstawową składową Gombrowiczowskiej autoprezentacji.

Fundamentalną różnicą między Dziennikiem a Dziennikiem argentyńskim jest perspektywa czasowa. W pierwszym przypadku mamy

\footnotetext{
92 Ibid., s. 42.

93 Ibid., S. 182.

94 Ibid., s. 42. Podobnie dwuwiersz Witkacego, który Gombrowicz umieszcza na ścianie ustępu przy ulicy Callao („Panowie i panie, miejcie tę naturę...”), Pitol przekłada dosłownie (Señoras y señores tengan la bondad de...; ibid., s. 21), gubiąc tym samym jego komizm i sens, podczas gdy tłumacze hiszpańscy - słusznie spodziewając się, że powiedzenie Witkacego jest czytelnikowi hiszpańskojęzycznemu nieznane - przekładają całość i to zachowując rym: Señoras y señores, para nuestro beneficio / No la hagan en la tapa, sino en el orificio; idem, Diario 1953-1969, s. 220. Idem, Diario argentino, s. 158, 137 i 163. 
do czynienia z typową dla tej formy literackiej narracją przeplatającą (narration intercalé): narrator opisuje, co wydarzyło się danego dnia, a więc w niedalekiej przeszłości, często opatrując te wydarzenia komentarzem z perspektywy teraźniejszej ${ }^{97}$. Oczywiście Dziennik Gombrowicza nie jest typowym dziennikiem i - czego dowodzą liczne poprawki i przeróbki nanoszone na rękopisie - autor traktuje go bardziej jako powieść, która wymaga drobiazgowego retuszu ${ }^{98}$. W Dzienniku argentyńskim perspektywa czasowa uwalnia się, stając się dosłownie perspektywą powieści - czas wydarzeń i moment pisania dzieli dystans co najmniej kilkuletni, bo ostatni fragment włączony do tego zbioru pochodzi z 1963 roku. Praca nad redakcją jest co prawda w dużej mierze zakończona, ale nie zupełnie - Gombrowicz może teraz uszeregować wybrane fragmenty według uznania, żonglować nimi tak, by nadać im ostatecznie właściwą wymowę (możliwości tej nie miał oczywiście, gdy musiał na bieżąco wysyłać teksty Jerzemu Giedroyciowi). Ponadto może ex post dopisać brakujące passusy lub usunąć te, które wydają mu się zbędne.

Zważywszy na nową kolejność chronologiczną, Dziennik argentyński obywa się bez dat rocznych (pozostają dni tygodnia). Zasadniczy jego zrąb - blisko połowę - stanowią fragmenty wybrane z pierwszego tomu Dziennika (lata 1953-1956). Na pozostałą część składają się przede wszystkim wyjątki z drugiego (1957-1961) oraz, w dużo mniejszym stopniu, bo to zaledwie około trzydzieści stron, z tomu trzeciego (1961-1966). Proporcje te odpowiadają tematyce argentyńskiej, która z oczywistych powodów jest najsilniej obecna w dwóch pierwszych tomach, a z czasem jej znaczenie zanika. Co znamienne jednak, ostatni wybrany fragment mówi o Paryżu (o „paryżofobii” Gombrowicza)

\footnotetext{
97 V. Gérard Genette, Figures III, Seuil, Paris 1972, s. 156.

98 Paweł Rodak pisze o „literaryzacji” Dziennika, którego rękopis, a potem maszynopis był przez Gombrowicza starannie poprawiany i redagowany, w książce Między zapisem a literatura. Dziennik polskiego pisarza wx wieku (Żeromski, Nałkowska, Dąbrowska, Gombrowicz, Herling-Grudziński) (Wyd. UW, Warszawa 2011, s. 428). Wydaje się, że w przypadku Dziennika argentyńskiego mamy do czynienia z „literaryzacją” drugiego stopnia, dotyczącą w mniejszym zakresie treści fragmentów (już poprawionych), a w większym ich kompozycji i kolejności.
} 
i wcale nie jest chronologicznie ostatnim, który poruszałby problematykę argentyńską. Przeciwnie, w kolejnych latach - choć większość zapisków koncentruje się na sprawach mniej lub bardziej doraźnych, takich jak wywiady, nagrody, nowe znajomości - Gombrowicz poświęca jeszcze Argentynie długie passusy. W 1964 roku pisze, że tamten okres jego życia „nabierał mitologicznego blasku”:

Dwadzieścia cztery lata wyzwolenia $\mathrm{z}$ historii. Buenos Aires - sześciomilionowy obóz, koczowisko, imigracja z całej kuli ziemskiej, Włosi, Hiszpanie, Polacy, Niemcy, Japończycy, Węgrzy, przemieszane, tymczasowe, $\mathrm{z}$ dnia na dzień... A rdzenni Argentyńczycy mówili swobodnie que porqueria de pais („świński kraj”) i ich swoboda brzmiała zachwycająco po duszącej furii nacjonalizmów ${ }^{99}$.

Dziennik argentyński kończy się przezornie wcześniej - na nowym, paryskim rozdaniu; autor woli pominąć te nostalgiczne wspomnienia, głównie dlatego, że zbyt blisko sąsiadują z teraźniejszością (Gombrowicz rozpoczyna prace nad tym tekstem na początku 1965 roku). Choć tematycznie niedalekie, zostają pominięte z uwagi na fakt, że czas, którego dotyczą, nie zamknął się za pisarzem ostatecznie - brak im właśnie klasycznej perspektywy powieściowej.

Znaczenie tej perspektywy widać wyraźnie w pierwszej połowie tekstu - odpowiadającej, jak pisałam, fragmentom wybranym z pierwszego tomu Dziennika - w której zmiany w stosunku do pierwowzoru są największe, w zasadzie zostaje ona rozłożona na części i „zmontowana” od nowa. Chronologicznie pierwszy fragment, dotyczący koncertu w Teatrze Colón, zostaje np. umieszczony jako czwarty z kolei, za fragmentami o rozpaczy na ulicy Corrientes (o czym za chwilę), o żółtych, ciasnych butach ze sklepu Ostende oraz za spisem trywialnych wydarzeń, „które ogłaszam, abyście wiedzieli, jaki jestem w mojej codzienności" (wszystkie te passusy także są wybrane z różnych miejsc Dziennika i ułożone w nowej kolejności). Co oczywiste, a przy tym, jak zobaczmy, bardzo znaczące, Gombrowicz pomija wszystkie fragmenty skierowane do polskiego czytelnika: przeglądy

99 Witold Gombrowicz, Dziennik 1953-1969. 
prasy, polemiki z czytelnikami, wspomnienia z kraju i komentarze do jego aktualnej sytuacji, układając na początku te urywki (w większości nieprzekraczające jednej strony), które uważa za najważniejsze lub najbardziej atrakcyjne. Początek Dziennika argentyńskiego brzmi następująco:

Ryk syren, świstawki, race, strzelające korki od butelek i szum rozległy wielkiego miasta w wielkim poruszeniu. W tej minucie Nowy Rok 1955 wkracza. Idę ulicą Corrientes, sam i zrozpaczony.

Nie widzę przed sobą nic... żadnej nadziei. Wszystko mi się wykańcza, nic nie chce się zacząć. Bilans? Po tylu latach jednak wytężonych, jednak pracowitych, kim jestem? Urzędniczkiem zarżniętym siedmioma godzinami urzędolenia, zdławionym we wszystkich przedsięwzięciach pisarskich. Nie mogę nic pisać poza tym dziennikiem ${ }^{100}$.

Wymowa tego fragmentu zasadniczo różni się od tej, którą posiada słynny (także zresztą dodany, „wmontowany” po fakcie) początek Dziennika. Zostaje jeszcze wzmocniona na kolejnych stronach - ukazujących zresztą wydarzenia niezwiązane wcale z Argentyną - na których Gombrowicz pisze: „chciałbym w tym dzienniczku jawnie przystąpić do konstruowania sobie talentu", i dodaje:

To wszystko - gdyby udało mi się przywołać ducha. Ale nie czuję się na siłach [...]. Przystąiłem do pisania tego mojego dziennika po prostu, aby się ratować, ze strachu przed degradacją i ostatecznym pogrążeniem $\mathrm{w}$ falach życia trywialnego, które już mi sięga do ust ${ }^{101}$.

Takie rozłożenie akcentów powoduje, że szereg argentyńskich interpretacji autora Ferdydurke będzie się koncentrować na tematyce porażki: tak Gombrowicza czyta m.in. Piglia w Sztucznym oddychaniu ${ }^{102}$,

\footnotetext{
100 Ibid.

101 Ibid.

102 Rodrigo Blanco Calderón poświęca tym pisarzom artykuł pod znamiennym tytułem Piglia y Gombrowicz: sobre el fracaso y otras estrategias de escritura (Piglia i Gombrowicz: o porażce i innych strategiach pisania), który ukazał się w: Jorge Carrión (red.), El lugar de Piglia. Crítica sin ficción, Candaya, Barcelona 2008, s. 27-43.
} 
a Alan Pauls pisze w jego kontekście o „szlachetnej tradycji loserów”"103. Jeśli dodać do tego fakt, że z Dziennika argentyńskiego zostają usunięte zażarte polemiki z czytelnikami prasy polonijnej i pisarzami - główne pole bitwy o sławę i uznanie - trudno dziwić się, że Gombrowicz postrzegany jest w kategoriach pisarza, który w y bi e r a porażkę (akcentując jeszcze ten rzekomy wybór w przedmowie), a ewentualny rozgłos jego dzieła jest mu w zasadzie obojętny. W Dzienniku argentyńskim porażka wydaje się podstawowym warunkiem tworzenia i akcentując ją, Gombrowicz trafnie wyczuwa, że literatura argentyńska drugiej połowy xx wieku, czytając na nowo Roberta Arlta i Macedonia Fernándeza, znajdzie w niej jedną z najbardziej płodnych inspiracji.

Konstrukcja Dziennika argentyńskiego w podobny sposób wspiera interpretację zaproponowaną przez Miguela Grinberga w „Eco Contemporáneo" w 1963 roku, który czyta Gombrowicza jako pisarza kontrkulturowego, patrona ruchów undergroundowych ${ }^{104}$. We fragmencie, w którym pisarz charakteryzuje pokrótce w ośmiu punktach „swojego człowieka”: „1) Człowiek stwarzany przez formę, w najgłębszym, najogólniejszym znaczeniu. 2) Człowiek jako wytwórca formy, jej niezmordowany producent" ${ }^{105}$ etc., w wersji argentyńskiej usuwa zdanie wprowadzające to wyliczenie: „Ujmują mnie na ogół jako jedną więcej walkę ze społeczeństwem, krytykę społeczeństwa. Zobaczmyż, czy mój człowiek nie rozsadzi tego ujęcia"106, oraz zdanie je podsumowujące: „Chcecie to wszystko sprowadzić do jednego jedynego buntu przeciw społecznym formom bytowania?” ${ }^{107}$. Skróty te w oczywisty sposób

\footnotetext{
103 V. Alan Pauls, Reyes en el exilio, „Suplemento Radar”, http://goo.gl/W4VeMH, dostęp: 10 XI 2016.

104 Taką interpretację zaproponowanej przez Grinberga lektury Gombrowicza zawdzięczam pracy: Pau Freixa Terrades, Recepción de la obra de Witold Gombrowicz en la Argentina y configuración de su imagen en el imaginario cultural argentino, niepublikowana rozprawa doktorska, Universidad de Barcelona, 2008, s. 87-90, http://goo.gl/A3avU1, dostęp: 10 XI 2016.

105 Witold Gombrowicz, Dziennik 1953-1969; cf. idem, Diario argentino, s. 121.

106 Idem, Dziennik 1953-1969.

107 Ibid.
} 
zmieniają wymowę fragmentu na korzyść interpretacji Grinberga, którą - o czym mówi w innym fragmencie Dziennika ${ }^{108}$ - Gombrowicz przyjmował z nieukrywanym zadowoleniem i którą w 1965 roku musiał postrzegać jako umożliwiającą penetrację jego tekstów w Buenos Aires.

W pierwszej połowie Dziennika argentyńskiego - najstaranniej zmontowanej z różnorodnych fragmentów pierwszego tomu oryginału - koncentruje się także większość dopisanych, zmodyfikowanych lub w ogóle usuniętych akapitów. Co ciekawe, Gombrowicz, który w liście do wydawcy butnie zapowiada, że rozliczne fragmenty „się nie spodobają, wzbudzą sprzeciw" (1o lutego 1965), zadaje sobie trud tych poprawek właśnie w trosce o dobro konkretnych osób. O Cecili Benedit de Debenedetti pisze w polskim Dzienniku, że:

żyła w jakimś zamroczeniu, zdumiona, przerażona, odurzona życiem, osaczona ze wszystkich stron, budząca się ze snu, aby przetoczyć się w inny sen i bardziej fantastyczny, walcząca po chaplinowsku z materią istnienia... ona niezdolna była wytrzymać tego, że istnieje... zresztą kobieta świetnych przymiotów, cnót wybitnych, o szlachetnej i arystokratycznej duszy ${ }^{109}$.

W wersji argentyńskiej dodaje do tego: „to rozkojarzenie nie przeszkadzało jej postępować właściwie i z głębokim poczuciem odpowiedzialności" ${ }^{110}$. Następnie dopisuje długi passus, by należycie uwypuklić

108 „[O]to ci blousons noirs sztuki, ci iracundos (jedna ich grupa zwała się »Mufados«, druga »Elefantes«) doskoczyli do mnie, pełni wojennego zapału, zaczęto na chybcika opracowywać sposoby przeniknięcia do najważniejszych gazet, Miguel Grinberg, przywódca Mufados, przygotowywał gorączkowo numer swojej bojowej »rewisty«, mnie poświęcony - mobilizacja, ruch, elektryczność! Czemu ja przyglądałem się ze zdziwieniem... bo to doprawdy wyglądało, jakby już wiedzieli o moim zbliżającym się końcu... a przecież jeszcze nie wiedzieli... Ze zdziwieniem, ale i nie bez przyjemności, na to spoglądałem - albowiem cieszy wrodzoną mi przekorę, iż wbrew całemu Grand Guignolowi, odbierającemu mi wszelką powagę w oczach szanujących się literatów, jestem jednak - a kuku! - kimś poważnym i jestem wartością"; ibid. Fragment ten został także włączony do Diario argentino (s. 235). Idem, Dziennik 1953-1969.

110 Idem, Diario argentino, s. 40. 
rolę Virgilia Piñery oraz Humberta Rodrígueza Tomeu w tłumaczeniu Ferdydurke (zresztą usuwając przy tym krótką wzmiankę o Adolfie de Obieta, który także współtworzył komitet tłumaczy). Dba przy tym o wychwalenie powieści La carne de René Piñery ${ }^{11}$. Specjalne traktowanie otrzymuje na kartach Dziennika argentyńskiego Borges, który w latach 6o. cieszył się już renomą międzynarodową. Jego osoba najwyraźniej nie dawała Gombrowiczowi spokoju, bo właśnie fragmenty dotyczące autora Fikcji - zwykle utrzymane w tonie polemicznym - często przerabia lub w ogóle usuwa ${ }^{112}$. Jeśli np. w Dzienniku charakteryzuje go jako pisarza oderwanego „zupełnie od podłoża”, to w Dzienniku argentyńskim skłonny jest dodać - co skądinąd bliższe prawdzie - że Borges „od czasu do czasu przyprawiał swoją metafizykę [...] regionalizmem i powieścią o gauczach"113. W wersji argentyńskiej zdanie, które w oryginale dotyczyło Borgesa: „Ocierałoby się o nonsens żądanie aby on, będąc starszy, mógł wypowiedzieć bezpośrednio młodość"114 ${ }^{11}$, odnosi się ogólnie do pisarzy tamtego regionu ${ }^{115}$. Większość dopisanych passusów (w sumie kilka stron) dotyczy refleksji nad kulturą argentyńską. Gombrowicz niuansuje w nich swoje opinie, wspomina o podziale na literaturę skrojoną na wzór francuski oraz tę, która zachwycała się folklorem, by ostatecznie obie uznać za sztuczne, pisane według programu.

Dziennik argentyński postrzega się często jako swego rodzaju streszczenie Gombrowiczowskiego Dziennika, przygotowane na użytek czytelnika hiszpańskojęzycznego i niewiele wnoszące do studiów z zakresu

111 Ibid., s. 56-57.

112 Z krytycznego pod adresem literatury argentyńskiej fragmentu Gombrowicz usuwa akapit, w którym pisze m.in.: „Literatura ich to pięknosłowie. Żeby być artystą, wystarczy pięknie się wyrażać. Najbardziej oryginalny i samodzielny pisarz Argentyny, Borges, pisze doskonałą i elegancką hiszpańszczyzną, jest stylistą w sensie literackim (nie w sensie rozwiązania duchowego), najchętniej uprawia literaturę o literaturze, pisanie o książkach - a jeśli odda się czasem czystej wyobraźni, to ona uwiedzie go jak najdalej od życia, w sferę pokrętnej metafizyki, układania pięknych rebusów, scholastyki złożonej z metafor"; idem, Dziennik 1953-1969.

113 Idem, Diario argentino, s. 47.

114 Idem, Dziennik 1953-1969.

115 Idem, Diario argentino, s. 48. 
gombrowiczologii. Pisarz faktycznie widział w nim wprowadzenie do własnej twórczości, które jednocześnie udowadniało jego „argentyńskość” i bliską relację z drugą ojczyzną. Lektura korespondencji Gombrowicza z Sudamericaną oraz Sergiem Pitolem jasno pokazuje, że pisarzowi niezwykle zależało na szybkim zaistnieniu na argentyńskim rynku literackim (chociaż z punktu widzenia „walki o sławę” było to terytorium drugorzędne): w 1965 roku, kiedy klaruje się pomysł opublikowania argentyńskich fragmentów całości, w językach „centralnych” - francuskim i niemieckim - ukazał się zaledwie przekład pierwszego tomu. Ten pośpiech wyjaśnia wyżej wspomniane nieścisłości przekładowe. Elementem dodanym Dziennika argentyńskiego jest nowy (w stosunku do całości tekstu) układ fragmentów, które w ten sposób uzyskują inną wymowę. Z punktu widzenia studiów nad argentyńską recepcją autora Ferdydurke jest to tekst kluczowy, determinuje bowiem intuicję i kierunek interpretacji Gombrowicza w tamtym obszarze kulturowym. Analiza Dziennika argentyńskiego - w szczególności jego kompozycji - wskazuje, że to, co traktuje się często jako uproszczenia argentyńskiego odczytania, jest w dużej mierze konsekwencją celowej autoprezentacji pisarza.

\section{Pozostałe przekłady}

Na hiszpański przełożono właściwie wszystkie teksty Gombrowicza (w roku 2017 nie istnieje jeszcze przekład Kronosu, choć wydawnictwo El Cuenco de Plata zapowiada jego hiszpańskie wydanie), ich genealogie są jednak odmienne: większość przełożono bezpośrednio z polskiego, ale część - przede wszystkim dzieła teatralne - tłumaczono poprzez francuski (co było kiedyś powszechnie przyjętą praktyką w odniesieniu do języków „egzotycznych”116) i do dzisiaj nie istnieją ich przekłady

116 Gombrowicz, o czym wspominałam przy okazji Dziennika argentyńskiego, początkowo nalegał na przekłady bezpośrednio z polskiego, z czasem jednak - być może ponaglany świadomością zbliżającej się śmierci - zaczął nie tylko akceptować tłumaczenia zapośredniczone przez francuski, ale nawet je preferować, przedkładając kunszt tłumacza nad znajomość oryginalnego kodu językowego. 
niezapośredniczone przez trzeci język. Wszystkie hiszpańskojęzyczne tłumaczenia autora Dziennika wykonane bezpośrednio z polskiego - z wyjątkiem Ferdydurke i Ślubu - powstały poza Argentyną, głównie dzięki tłumaczom z meksykańskiej wspólnoty językowej (Sergio Pitol), z Półwyspu Iberyjskiego (Gabriel Ferrater, Anna Rubió, Pau Freixa Terradas) oraz Polakom (Bożena Zaboklicka, Kazimierz Piekarec, Jerzy Sławomirski). Jedyny argentyński tłumacz Gombrowicza - pomijając członków komitetu tłumaczy Ferdydurke, któremu zresztą przewodzili Piñera i Tomeu, władający kubańską odmianą kastylijskiego - czyli José Bianco, przekładał jego teksty z francuskiego.

Najsłynniejszym tłumaczem Gombrowicza na hiszpański jest bez wątpienia Sergio Pitol, autor omawianego już przekładu Dziennika argentyńskiego (1968), a także Kosmosu (1969), Trans-Atlantyku (we współpracy z Kazimierzem Piekarcem, 1971) oraz Bakakaju (w roku 1970 ukazały się pod tytułem La Virginidad [Dziewictwo] trzy opowiadania: Zbrodnia z premedytacja, Biesiada u hrabiny Kotłubaj oraz Dziewictwo właśnie, cztery lata później Pitol uzupełnił ten przekład o siedem kolejnych tekstów). Urodzony w 1933 roku w Meksyku, Pitol spędził wiele lat poza krajem, m.in. w Polsce, gdzie przebywał w sumie sześć lat pomiędzy 1963 a 1975 rokiem. W swojej ojczyźnie znany jest głównie jako pisarz, laureat prestiżowej Premio Cervantes, a poza krajem również jako tłumacz, przede wszystkim $\mathrm{z}$ angielskiego, a także polskiego, rosyjskiego i włoskiego. Gombrowicza poznaje około roku 1966, kiedy pisarz - za namową innego tłumacza, Gabriela Ferratera - proponuje mu najpierw przekład wybranych rozdziałów z Dziennika, a potem już całość Dziennika argentyńskiego. W 1967 roku Pitol redaguje i wydaje w Meksyku Antología del cuento polaco contemporáneo (Antologię współczesnych polskich opowiadań), w której zamieszcza dwa teksty Gombrowicza: Zbrodnię z premedytacja oraz Filidora dzieckiem podszytego.

Tłumaczenia Pitola nie spotkały się z dużym zainteresowaniem krytyki - jej uwagę, co zrozumiałe, przykuwały bardziej autorskie przekłady Gombrowicza, przede wszystkim Ferdydurke. Najwięcej analiz doczekał się przekład Trans-Atlantyku, zapewne dlatego, że uchodzi za dzieło trudno lub zgoła nieprzekładalne (sam autor kwalifikuje jego 
tłumaczenie jako un peu épineuse ${ }^{117}$ ), a ponadto cieszy się współcześnie sławą najbardziej inspirującej i aktualnej powieści Gombrowicza ${ }^{118}$. Tak jak Ferdydurke, przekład Trans-Atlantyku wzbudził bardzo spolaryzowane reakcje badaczy. Dla Pau Freixy Terradesa hiszpańskie tłumaczenie tak dalece odbiega od oryginału, że zasługuje bardziej na miano adaptacji: przede wszystkim tandem Pitol-Piekarec ${ }^{119}$ nie znajduje sposobu na oddanie w języku docelowym archaicznej tonacji tekstu, przez co powieść traci swój (sparodiowany) sarmacki rodowód, znika rytm gawędy szlacheckiej oraz patetyczny ton polskich romantyków. Tłumacze przekładają na hiszpański „mniej lub bardziej standardowy”, który zdradza chęć „oczyszczenia” wersji docelowej z jej silnego osadzenia w polskiej kulturze na rzecz przeniesienia do kontekstu bardziej uniwersalnego (o czym zaświadcza drobna acz znacząca zmiana w tytule) ${ }^{120}$. Faktycznie, analiza porównawcza obu wersji językowych dowodzi, że wyrażenia archaizujące, w które powieść niewątpliwie obfituje, w hiszpańskim zanikają nieomal całkowicie ${ }^{121}$, co, jeśli dorzucić brak przypisów, w zasadzie

117 V. list Witolda Gombrowicza do Gabriela Ferratera z 8 maja 1967 roku.

118 Tak mówi o niej Jean-Pierre Salgas w rozmowie na temat nowych kontekstów interpretacyjnych Gombrowicza; v. Kazimiera Szczuka et al., Debata „Używanie Gombrowicza, czyli co robimy z klasykami”, w: Dominika Świtkowska, Tomasz Tyczyński (red.), op. cit., s. 42-43.

119 Współautor przekładu, Kazimierz Piekarec, był tłumaczem i dyrektorem Sekcji Polskiej Radia France Internationale.

120 V.Pau Freixa Terradas, "Trans-Atlantyk" de Witold Gombrowicz, guia de lectura per a no-polonesos, „Anuari de Filologia. Llengües i Literatures Modernes” 2012, nr 2, s. 21. W pierwszej wersji przekład hiszpański ukazał się pod tytułem Transatlántico. 121 Cf. następujące fragmenty: „Płyńcież do Ślamazary waszy św. żeby was ona dali Ślimaczyła!” (Witold Gombrowicz, Trans-Atlantyk, Wydawnictwo Literackie, Kraków 1986, s. 12), w przekładzie: ¡Marchad a esta Santa Babosa para que os vuelva más moluscos! (idem, Trans-Atlántico, przeł. Sergio Pitol, Kazimierz Piekarec, Seix Barral, Barcelona 2003, s. 18); „Oczywiste było, że Gonzala siła ludzka nie zmusi, aby przed pistoletem nabitym stanął; a gdy zaprzysiągł Tomasz, że jego jak psa zabije jeśli mu nie stanie, rzecz cała kryminałem zakończyć się mogła” (s. 62), w przekładzie: Era evidente que ninguna fuerza en el mundo iba a obligar a Gonzalo a colocarse frente a una Pistola cargada; por otra parte, Tomasz había jurado matarlo como a un perro si no aceptaba el duelo; toda aquella aventura poodía tener su coroloario en la Cárcel (s. 95); „Rada w radę. Powiadam: - Wyjść 
uniemożliwia czytelnikowi dotarcie do treści utworu, którą dla hiszpańskiego badacza stanowi, oprócz samego Gombrowicza, Polska. Obrońcy przekładu w wykonaniu Pitola i Piekarca zwracają jednak uwagę na to, że nawet wierne oddanie tej archaizacji w języku docelowym nie byłoby zabiegiem skutecznym, zważywszy na dzielące obie kultury różnice:

Sądzę, że archaizacja, która u Gombrowicza odsyła czytelnika do konkretnej mentalności patriotyczno-sklerotycznej, gdyż kojarzy się z gawędą paskowską, czy jej parodią sienkiewiczowską, po hiszpańsku nie spełniałaby tej roli, gdyż archaizacja dla celów parodystycznych nie należy do tradycji literackiej języka hiszpańskiego i zabieg ten raczej przeszkadzałby w odbiorze utworu, koniec końców, współczesnego ${ }^{122}$.

Na rzecz rezygnacji z oddania w przekładzie intensywnej stylizacji językowej przemawia również fakt, że w odautorskim tłumaczeniu Ślubu Gombrowicz sam nie decyduje się na przełożenie idiolektu Ojca i Matki, dla którego wzorcem stylizacyjnym - z łatwością rozpoznawalnym przez polskiego czytelnika - była wiejska gwara. W tłumaczeniu Trans-Atlantyku Zaboklicka odnotowuje ponadto stosowany

nam trzeba, bo tu już i niczego straszniejszego nie dokonamy; a tyż nie ta piwnica nas więzi, a tylko Ostroga. Jeżeli więc kupą wyjdziemy, a z Ostrogami przy butach, to jeden drugiemu się nie wymknie" (s. 107), w przekładzie: Comenzaron las discusiones. Volví a intervenir: - Tenemos que salir, porque aquí ya no podemos hacer nada terrible. No es el sótano quien nos aprisiona, sino la Espuela. Si salimos todos juntos, y con las Espuelas ajustadas en las Botas, nadie podrá escapar (s. 168). Bożena Zaboklicka, Gombrowicz po hiszpańsku w przekładach Sergio Pitola, s. 10. O podobnym problemie pisze Jerzy Jarniewicz: „Dla czytelnika angielskiego sarmacki rodowód powyższych fraz [»gość w dom, Bóg w dom «, »Polak do tańca jak do różańca", "zastaw się, a postaw się" - E.K.P.], ich zakorzenienie w przekonaniach, jakie Polacy mają o sobie samych, bez odpowiednich przypisów jest nieczytelny. Przykładowo: fraza "gość w dom, Bóg w dom « wywodzi się z jednego z najsilniejszych polskich stereotypów mówiących o przysłowiowej polskiej gościnności; polska gościnność jest jednak przysłowiowa tylko dla Polaków, dla obcojęzycznych czytelników "gość w dom, Bóg w dom « jest niewinną, okazjonalną, opartą o składniowy paralelizm frazą”; Jerzy Jarniewicz, Frazes i frazeologia $w$ angielskim przekładzie „Trans-Atlantyku”, czyli „tu właśnie cisna mnie buty”, w: Elżbieta Skibińska (red.), op. cit., s. 199. 
„Z wielkim wyczuciem stylu gombrowiczowskiego” chwyt - użycie wielkiej litery tam, gdzie brak jej w oryginale po to, by język powieści „udziwnić, rekompensując utracony archaizm języka.

Kluczem do oceny tego tłumaczenia są, jak sądzę, nie tyle analizy przekładoznawcze, ile interpretacyjne. Jeśli bowiem zakładać, jak czyni to Pau Freixa Terradas, że Trans-Atlantyk jest przede wszystkim opowieścią o przezwyciężeniu polskości - którą co prawda można próbować uniwersalizować jako postulat wyswobodzenia się z formy narodowej w ogóle, lecz nawet wówczas jej osadzenie w Polsce jest nieusuwalne ${ }^{123}$ - to faktycznie, tłumaczenie na hiszpański jest chybione, prawdopodobnie tak samo jak tłumaczenie na każdy inny język ${ }^{124}$. Jeśli jednak zgodzić się na przesunięcie interpretacyjnego punktu ciężkości ku innym obszarom, takim jak kwestie tożsamości seksualnej, obcości, a nawet funkcjonowania w zglobalizowanym świecie, to okazuje się, że przekłady Trans-Atlantyku (w tym hiszpański) nic z tej problematyki nie tracą. Więcej nawet - wydaje się, że właśnie „uśpienie” specyficznie polskiego kontekstu w tłumaczeniu pozwoliło tę powieść na nowo „wymyślić”, a o tych świeżych treściach jako pierwsi pisali, co znamienne, ci czytelnicy, którzy do Trans-Atlantyku mieli jedynie dostęp zapośredniczony przez przekład ${ }^{125}$.

123 „Podporą tej uniwersalności musi być z konieczności Polska, tak jak ludzkość wspiera się na konkretnej jednostce”; Pau Freixa Terradas, "Trans-Atlantyk” de Witold Gombrowicz..., s. 21.

124 Freixa Terradas chwali wprawdzie tłumaczenie angielskie autorstwa Carolyn French i Niny Krasov za wierność oryginałowi i próbę (nie w pełni udaną) zastąpienia polskiego języka archaicznego siedemnastowiecznym angielskim (ibid., s. 21). Co znamienne, za to samo - czyli nazbyt płynny i nowatorski angielski tam, gdzie polszczyzna Gombrowicza jest celowo skostniała i konwencjonalna - krytykuje ten przekład Jerzy Jarniewicz (Frazes i frazeologia w angielskim przekładzie „Trans-Atlantyku”..., s. 199). Tak samo przekład francuski gubi, zdaniem badaczy, „soczystość sarmackiej mowy”: „[...] ujawnia się okrutnie brak stosownych odpowiedników, zarówno na płaszczyźnie językowej, jak i socjo-kulturowej. Idiom szlachecki i ziemiański nigdy nie był specjalnością francuskąa”; Marek Tomaszewski, „Trans-Atlantyk” Witolda Gombrowicza po francusku, w: Elżbieta Skibińska (red.), op. cit., s. 182.

125 Latynoska badaczka Marta Sierra (Las “Tierras de la memoria”: las estéticas sin territorio de Witold Gombrowicz y Felisberto Hernández, „Hispanic Review” 
W tym wypadku tłumaczenie skutkowało nie tylko ilościowym zwiększeniem zasięgu, ale i uniwersalizacją znaczenia, a odzew wśród krytyków hiszpańskojęzycznych jest - jak w przypadku Ferdydurke - najlepszą miarą wprawdzie nie wierności, lecz skuteczności tego przekładu. Inne przekłady Pitola - Kosmos i Bakakaj - były jeszcze mniej komentowane, zapewne dlatego, że język tych utworów (przynajmniej $\mathrm{w}$ zestawieniu $\mathrm{z}$ lingwistycznym kodem wymyślonym w Trans-Atlantyku) nie tamuje tak szczelnie prób wiernego przekładu. W ostatniej powieści Gombrowicza problematyczne staje się oddanie w języku docelowym neologizmów ${ }^{126}$, ale rytm i muzyczność tekstu - w opinii Bożeny Zaboklickiej - udaje się tłumaczowi zachować ${ }^{127}$.

2006, t. 74, $\mathrm{nr}$ 1, s. 59-82) dostrzega w Trans-Atlantyku realizację avant la lettre typowo latynoskiej estetyki neobaroku. Inne „niepolskie” lektury tej powieści proponują m.in. Jean-Pierre Salgas, Witold Gombrowicz lub ateizm integralny, przeł. Jan Maria Kłoczowski, Czytelnik, Warszawa 2004, s. 140-142; Hanjo Berressem, Reguły dewiacji. Fizyczne i psychiczne aberracje w powieściach Witolda Gombrowicza, w: Ewa Płonowska-Ziarek (red.), Grymasy Gombrowicza. W kręu problemów modernizmu, społeczno-kulturowej roli płci i tożsamości narodowej, przeł. Janusz Margański, Universitas, Kraków 2001, s. 135-141; Silvana Mandolessi, op. cit. Do tej grupy można także włączyć badaczy, którzy wprawdzie mogli przeczytać Trans-Atlantyk w oryginale, ale ich lektura wykształciła się zagranicą, a więc w kontekście niwelującym ciężar polskości nad tym dziełem; v. Ewa Płonowska-Ziarek, Blizna cudzoziemca i barokowa fałda. Przynależność narodowa a homoseksualizm w „Trans-Atlantyku” Witolda Gombrowicza, w: eadem (red.), op. cit., s. $243-278$.

126 Zaboklicka podaje przykład „nie zawsze dziwolążył się słowotwórstwem” (Witold Gombrowicz, Kosmos, Wydawnictwo Literackie, Kraków 1986, s. 21), które Pitol oddaje po prostu jako pero no siempre empleaba aquel lenguaje (idem, Cosmos, przeł. Sergio Pitol, Seix Barral, Barcelona 2010, s. 34). Gdzie indziej słowo „rozkosznisium” (s. 112) upraszcza jako placer (s. 168), ale już niełatwy fragment: „Kocium? Detal, kto by się przejmował kociotrupem kociokwika? Spójrz, brateńku, co za bąk i jak trąbi, szelma! Kociościerw jeszcze wczoraj łaskotał mnie system unerwienia drżącą łaskotką - ale dziś?” (s. 104) brzmi po hiszpańsku wspaniale: ¿El gatuperio? ¡Frusilerías! ¿Quién va a preocuparse de cadáveres gatúnicos, de gatometrajes! Mire, señoritingo, qué ruido hace ese miserable abejorro. Todavía ayer el gatuperio me irritaba el sistema nervioso con un cosquilleo penetrante... ¿Pero hoy? (s. 156-157).

127 „[Z]arówno obłędny język Leona, skonstruowany z nagromadzenia zdrobnień, czy galopujące monologi Kulki są prawdziwymi majstersztykami stylistycznymi”; 
Wykładająca na Uniwersytecie w Barcelonie polska tłumaczka i specjalistka z zakresu translatologii, na której prace wielokrotnie się tutaj powoływałam, sama stworzyła wspólnie z Franceskiem Miravitllesem tandem, który podjął się przekładu pełnej wersji Dziennika. Pierwsze dwa tomy ukazały się kolejno w 1988 i 1989 roku nakładem wydawnictwa Alianza Editorial, a następnie w 2005 Seix Barral opublikował całość (Diario 1953-1969) ${ }^{128}$, za którą tłumacze zostali uhonorowani katalońską nagrodą imienia Ángela Crespo. O tym przekładzie pisałam już przy okazji Dziennika argentyńskiego, wskazując m.in. na jego wierność wobec oryginału - tłumacze hiszpańscy nie decydują się np. na stosowany często przez Pitola zabieg cięcia zdań, wiernie i precyzyjnie oddając Gombrowiczowski styl. Do wydania hiszpańskiego opracowali przypisy - co prawda dość skromne - wyjaśniające najważniejsze nazwiska, tytuły i pojęcia właściwe tylko dla polskiej kultury, co zresztą wywołało obiekcje po drugiej stronie Atlantyku. Blas Matamoro zauważa bowiem - i trudno odmówić mu racji - brak podobnych wyjaśnień w odniesieniu do zjawisk kultury argentyńskiej, widząc w ich przemilczeniu ciche założenie całkowitej pomijalności kontekstu przybranej ojczyzny dla zrozumienia treści Dziennika: „istnieje w tych tekstach rodzaj obojętności na realia południowoamerykańskie, która może przeszkadzać czytelnikom w ogóle, a w szczególności tym zza oceanu"129. Zaboklicka i Miravitlles zdecydowali się także na oznaczenie w przekładzie słów występujących w oryginale po hiszpańsku, co wydaje się zabiegiem jak najsłuszniejszym, zważywszy na fakt, że Gombrowicz bardzo często uciekał się do hiszpańskiego we fragmentach bezpośrednio związanych $\mathrm{z}$ jego

Bożena Zaboklicka, Gombrowicz po hiszpańsku w przekładach Sergio Pitola, s. 8. Na przykład dla prośby Leona: „Czemużbyś papusiu swojmsusiu nie podpapciła papupapu rzodkiewskagowego? Rzuć!” (Witold Gombrowicz, Kosmos, s. 21), Pitol znajduje doskonałe: ¿por qué no le das a tutulu papacítulu un rábanulu? Tíramulu (idem, Cosmos, s. 34).

Oddzielnie ukazywał się jeszcze tekst wystąpienia Przeciw poetom; idem, Contra los poetas, przeł. Francisco Ochoa de Michelena, Sequitur, Madrid 2009.

129 Blas Matamoro, La Argentina de Gombrowicz, „Cuadernos Hispanoamericanos” 1989, $\mathrm{nr} 469 / 470$, s. 276. 
doświadczaniem Argentyny. I tak, dla przykładu, peón, amigo de Choromański, refresco, estanciero, conde, aficionado, fino, poetiza, ale i puto defilują na kartach Dziennika, pośrednio uzasadniając pretensje Blasa Matamoro do argentyńskiego zakorzenienia tego tekstu. Szczytny zamysł tłumaczy - i jest to w zasadzie jedyny zarzut, jaki można im postawić - zostaje zrealizowany jedynie po części, niektóre bowiem hiszpańskojęzyczne wyrażenia Gombrowicza pozostają, nie wiedzieć czemu, bez odpowiedniego oznaczenia.

Ten sam tandem translatorski przełożył jeszcze Wędrówki po Argentynie (Peregrinaciones argentinas, 1987), a polska tłumaczka jest ponadto (wraz z Juanem Carlosem Vidalem) autorką przekładu Wspomnień polskich (Recuerdos de Polonia, 1985) oraz, we współpracy z Pau Freixą Terradesem, trzech opowiadań z tomu Bakakaj, których brakowało w tłumaczeniu $\mathrm{z} 1974$ roku $^{130}$. Obecnie ten ostatni tandem przekładowy pracuje nad nową hiszpańską wersją Pornografii.

Przekład tej powieści ukazał się w Hiszpanii po raz pierwszy w 1968 roku pod tytułem La seducción (dosłownie: „uwiedzenie”), który to tytuł miał, zdaniem tłumacza Gabriela Ferratera, uchronić ją przed interwencją cenzorską ${ }^{131}$. Ferrater tłumaczył pierwszą wersję Pornografii z francuskiego, wspomagając się także wersją niemiecką oraz - jak sam pisał w liście do Gombrowicza - polskimi słownikami ${ }^{132}$.

130 Hiszpańskojęzyczne wydanie Bakakaju z 1974 roku pokrywa się z edycją Wydawnictwa Literackiego z 1957. Brakuje w nim opowiadań Dramat baronostwa, $Z$ diariusza prywatnego Hieronima Ponizalskiego, Studnia oraz Pampelan $w$ tubie, włączonych do wydania krytycznego: Witold Gombrowicz, Bakakaj i inne opowiadania, oprac. Zdzisław Łapiński, Wydawnictwo Literackie, Kraków 2002. Ich przekład na hiszpański (za wyjątkiem $Z$ diariusza prywatnego Hieronima Poniżalskiego) ukazał się w Argentynie w 2015 roku nakładem wydawnictwa El Cuenco de Plata.

131 V. jego list do Gombrowicza z 14 marca 1967 roku, w: Zofia Stasiakiewicz, op. cit., s. 59-6o. Przed frankistowską cenzurą uratowała Pornografię nie tylko zmiana tytułu, ale przede wszystkim przekonanie cenzora o tym, że ta „powieść o trudnym do uchwycenia znaczeniu" i tak nie znajdzie wielu czytelników; v. raport T. Álvareza Turienzo z 26 lipca 1965 roku, cyt. za: Zofia Stasiakiewicz, op. cit., s. 34 .

132 List z 20 lipca 1965 roku, cyt. za: Zofia Stasiakiewicz, op. cit., s. 45. 
Językoznawcza analiza tego przekładu, przeprowadzona przez Bożenę Zaboklicką oraz Pau Freixę Terradesa (autorów nowego hiszpańskiego tłumaczenia), potwierdza, że Ferrater przygotowywał go w oparciu o kilka wersji językowych tej powieści, włączając w to polski oryginał, co z kolei wyjaśnia fakt, iż w 2002 roku to samo tłumaczenie ukazało się nakładem Seix Barral pod tytułem Pornografía jako przekład bezpośrednio z języka polskiego.

Pornografia otwiera osobną, stosunkowo liczną grupę przekładów dokonanych na hiszpański poprzez język trzeci, w tym wypadku francuski. Zalicza się do nich m.in. powieść Opętani, którą przełożył W 1982 roku José Bianco, argentyński pisarz i tłumacz z angielskiego i francuskiego (autor przekładów Henry’ego Jamesa, Samuela Becketta, Stendhala, Gustave’a Flauberta i innych). Bianco był przyjacielem Borgesa, który pisywał przedmowy do jego książek i przez wiele lat sekretarzował w czasopiśmie „Sur”. Jego współpraca z Victorią Ocampo skończyła się w roku 1961, kiedy Bianco odwiedził castrowską Kubę i nawiązał współpracę z bliską rewolucyjnemu reżimowi instytucją kulturalną Casa de las Américas, za co został usunięty ze swojej funkcji w „Sur”. Zainteresowanie Gombrowiczem - podobnie jak wizyty na Kubie - Bianco zawdzięcza swojej długoletniej przyjaźni z Virgiliem Piñerą.

Ponadto, z francuskiego przełożono na hiszpański wszystkie dzieła teatralne: Iwonę, księżniczkę Burgunda nawet dwukrotnie (w 1968 przez Álvara del Amo oraz w 1972 przez Jorgego Lavellego i Roberta Daniela Scheuego), także wspominany wyżej Ślub doczekał się ponownego tłumaczenia z francuskiego autorstwa Javiera Fernándeza de Castro, który przełożył również Operetkę (obie sztuki zostały opublikowane w Barcelonie w 1973 roku). Francuski mediował oczywiście także w hiszpańskich wersjach Testamentu. Rozmów z Dominique de Roux (w 1970 ukazał się w Meksyku przekład Aurelia Garzóna del Camino, w 1991 w Barcelonie Rosy Alapont) oraz Kursu filozofii w sześć godzin i kwadrans (w tłumaczeniu José Maríi Ventosa z roku 1997). 

3.

\section{Krytyka argentyńska o Gombrowiczu}

Celem niniejszego rozdziału będzie ukazanie, jak funkcjonuje dzieło Gombrowicza w argentyńskiej krytyce literackiej, a więc przyjrzenie się dyskursom, które umożliwiły jego włączenie, miejscom, z których się je interpretuje (a także przeciwko komu), wyczytanym tak z tekstów, jak z legendy pisarza „plamom tematycznym” użytecznym w dyskusjach konstytutywnych dla tego pola w ostatnich pięćdziesięciu latach. Ograniczam się tutaj do argentyńskiej produkcji krytycznej, pomijając na razie kwestie rezonowania Gombrowiczowskiego dzieła w fikcji literackiej, pomimo faktu, że jasne rozróżnienie pomiędzy tymi gatunkami pisarstwa - fikcją i krytyką - bywa w Argentynie bardzo trudne do utrzymania. Charakterystycznym bowiem dla tamtejszych pisarzy gestem - odziedziczonym bez wątpienia po Borgesie, choć nieobcym także Gombrowiczowi - jest dbałość o kontekst odbioru, o stworzenie całej machiny interpretacyjnej (prekursorów, centralnych tematów, trybów lektury etc.), która niejednokrotnie - jak w przypadku grupy Césara Airy oraz Ricarda Piglii - osiąga status dzieła samego w sobie. Interpretacje autora Ferdydurke proponowane przez samych twórców kultury, wyłożone zarówno w tekstach literackich, jak i metaliterackich, używają bowiem jego dzieła według własnych wytycznych, nierzadko świadomie forsując jego spójność i wymowę. Natomiast akademicka narracja krytyczna jest zasadniczo wolna od podobnych „nadużyć”, co oczywiście nie oznacza, że nie usiłuje czytać Gombrowicza w zgodzie z własną wewnętrzną dynamiką, szczególnie 
jeśli pojmować jej dyskurs nie tyle jako zbiór specjalistycznych teorii, ale szerzej - jako opowieść o kolejnych wersjach tego, co stanowić ma esencję argentyńskości (lo argentino). Chodzić więc będzie, ogólnie rzecz ujmując, o to, by prześledzić, w jaki sposób aspekty dla tej tradycji znaczące mogą zostać na nowo określone i przedefiniowane w świetle tekstów Gombrowicza, które z kolei w nowym kontekście same ulegają reinterpretacji.

Na korpus tekstów wykorzystanych w tym rozdziale składają się propozycje krytyczne, które oceniam jako opiniotwórcze i znaczące dla argentyńskiej recepcji autora Trans-Atlantyku. Znajdują się wśród nich trzy monografie, poświęcone w całości lub w znacznej części jego twórczości: Pabla Gaspariniego El exilio procaz. Gombrowicz por la Argentina (Bezczelne wygnanie: Gombrowicz w Argentynie) z 2007 roku, Silvany Mandolessi Una literatura abyecta. Gombrowicz en la tradición argentina (Literatura odrazy. Gombrowicz w tradycji argentyńskiej) z 2012 oraz José Amícoli Estéticas bastardas (Estetyki nieprawe) także z roku 2012. Oprócz tych trzech studiów monograficznych Gombrowicz jest także bohaterem bardzo wielu tekstów naukowych i popularnonaukowych o różnym ciężarze gatunkowym. Ambicją moich analiz nie jest jednak skatalogowanie jak największej liczby wzmianek o pisarzu, lecz odnalezienie w gąszczu tekstów kilku ścieżek lektury, którymi argentyńska krytyka będzie dzieło Gombrowicza „przemierzała”. W tym celu spojrzenie synchroniczne wydaje mi się bardziej produktywne niż perspektywa historyczna i zamiast szeregować teksty według upływających dekad, zgrupuję je wokół kilku powracających w nich stałych o charakterze tematycznym, estetycznym, formalnym i kulturowym. Te krytyczne inwarianty obejmują, po pierwsze, pole tematyczne wokół problematyki wygnania i deterioryzacji z jego wymiarem politycznym i kulturowym; po drugie, kwestie seksualności, płci, cielesności i fascynacji młodością (ze szczególnym uwzględnieniem historycznego kontekstu Argentyny); po trzecie, problem języka w perspektywie historycznej (tworzenia się narodu) oraz przestrzennej (literatury powstającej na marginesie języka ojczystego); po czwarte, zagadnienia wykorzystania protokołu autofikcjonalnego w Gombrowiczowskich tekstach oraz, na koniec, estetyczne 
i kulturowe dyskusje wokół kanonu i tzw. kontrkanonu. Nie traktuję oddzielnie kwestii związanej z definicją i granicami narodu argentyńskiego, głównie dlatego że rozkłada się ona pomiędzy wszystkie wyżej wymienione stałe interpretacyjne - wygnanie, cielesność, język, kanon i autofikcję - które to pojęcie lo argentino definiują, kwestionują lub znoszą. Zaproponowane tu dla Gombrowicza drogi lektury pokrywają się z tymi, które krytyka argentyńska uznawała w ogóle za atrakcyjne, przynajmniej w pewnym momencie historycznym (np. problematyka wygnania była paląca w latach 8o., po zakończeniu dyktatury wojskowej, o kanonie dyskutowano głównie w kolejnej dekadzie, a problemy seksualności i autofikcji należą do zagadnień istotnych w ostatnich latach), co dowodzi przynajmniej „przystawalności” dzieł Polaka do literackiej mapy Argentyny.

We wszystkich określonych powyżej kategoriach lub inwariantach interpretacyjnych Gombrowicz zajmuje pozycję na marginesie (co dyskurs krytyczny próbuje oddać w sformułowaniach takich jak „spojrzenie z zewnątrz” ", „bycie pomiędzy”, „estetyka nieprawa”2 hybrydyczność), która umożliwia mu kontestację pozycji uznawanych za centralne. Zbyt pochopne byłyby jednak próby usytuowania autora Ślubu w literaturze argentyńskiej jedynie przy pomocy opozycji centrum-peryferie i automatyczne umieszczanie go pod drugim jej członem, a to mianowicie dlatego, że samo centrum jest w Argentynie zawsze w jakiś sposób peryferyjne, nieczyste i hybrydyczne. Argentyńska tożsamość zbudowana jest bowiem na serii nieusuwalnych opozycji (cywilizacja-barbarzyństwo, Indianie-Kreole, Argentyńczycy-imigranci), jest sama w sobie konstruktem świeżym, w którym linie łączenia, zszywania elementów kulturowo sobie obcych widać gołym okiem. Dość powiedzieć, że bezsprzeczne centrum dwudziestowiecznej literatury argentyńskiej - dzieło Jorgego Luisa Borgesa - jest postrzegane jako ironiczne i parodystyczne skrzyżowanie tradycji argentyńskiej i obcej, tego, co cywilizowane, i tego, barbarzyńskie. Twórczość Gombrowicza

1 Juan José Saer, Spojrzenie z zewnątrz, przeł. Klementyna Suchanow, Krystian Radny, „Literatura na Świecie” 2001, nr 4, s. 72-82.

2 José Amícola, Estéticas bastardas, Editorial Biblos, Buenos Aires 2012. 
jest oczywiście pisarstwem, które kwestionuje kategorie czystości i jednoznaczności (narodowej, płciowej, estetycznej), ale - przynajmniej rozpatrywane w kontekście argentyńskim - jedynie radykalizuje skądinąd silnie już tam obecny dyskurs o inności. W przeciwieństwie do kultury polskiej, która stanowi dla czytelnika niniejszej książki „naturalne” tło odbioru Gombrowicza, kultura latynoska - o czym już pisałam - jest typowym przykładem inkluzywnej kultury pogranicza, heterogenicznej i skwapliwie wchłaniającej elementy zasadniczo sobie obce. Zanim więc przejdę do pozycjonowania autora Ferdydurke w krytyce ostatnich pięćdziesięciu lat, omówię pokrótce dwie kwestie wstępne: po pierwsze, proces kształtowania się Argentyny jako narodu (bez znajomości którego trudno byłoby zrozumieć, na jakich zasadach przenika tam narracja Gombrowicza o uwikłaniu w formę narodową), po drugie, na jakich prawach dyskurs normujący i porządkujący, czyli podręczniki i historie literatury, włącza jego dzieło do tradycji argentyńskiej.

\section{O argentyńskiej tożsamości narodowej}

Nie lubię ja gdy Masło zbyt maślane, Kluski zbyt kluskowe. Trans-Atlantyk

Argentyna uzyskuje niepodległość w początkach XIx wieku, w epoce fascynacji teorią Johanna Gottfrieda Herdera, która waloryzuje języki narodowe oraz tworzone w nich literatury ludowe: „ustanawiając konieczny związek pomiędzy narodem a językiem, [Herder - E.K.P.] nadaje wszystkim ludom nieuznanym jeszcze kulturowo ani politycznie prawo do domagania się równorzędnej (literackiej i politycznej) egzystencji”3. Koncepcje niemieckiego filozofa były w dziewiętnastowiecznej Argentynie bardzo popularne, mimo że oba człony tej

3 Pascale Casanova, La República mundial de las Letras, przeł. Jaime Zulaika, Anagrama, Barcelona 2001, s. 106. 
tożsamościowej relacji - naród i język - okazywały się raz po raz wysoce problematyczne.

Retrospektywna opowieść o narodzie argentyńskim - będąca bardziej narracją wyobrażeniową niż faktograficzną - zaczyna się kilka dekad po uzyskaniu niepodległości, w 1845 roku, kiedy Domingo Faustino Sarmiento publikuje ważną dla całej Ameryki Łacińskiej książkę zatytułowaną Facundo lub Cywilizacja i barbarzyństwo na argentyńskiej pampie. Definiuje ona kulturę latynoską w terminach starcia sił cywilizacji - reprezentowanych przez wykształconych na francuską i północnoamerykańską modłę intelektualistów - z siłami barbarzyństwa, dzikusami z pochodzenia (Indianami) lub z wyboru (zacofanymi gauczami, nieokrzesanymi sektorami społeczeństwa, ślepo ufającymi uzurpowanej władzy caudillos). Procesem definiowania kultury narodowej - zarówno tego, co się na nią składa, jak i przede wszystkim tego, co pozostaje na zewnątrz - zawiadują intelektualiści, którzy w ten sposób wkraczają w pole władzy: Sarmiento w roku 1868 zostaje wybrany na prezydenta Republiki i realizuje projekt nowoczesnego narodu, którego filarami są imigracja i kultura miejska ${ }^{4}$. Nowo skrojona ojczyzna wkracza wówczas w coraz szybszy rytm przemian, których kulminacja przypadnie na lata 20. i 30. xx wieku, chociaż ich kierunek daleki będzie od tego, o jakim marzył Sarmiento. Tak czy inaczej, siła symboliczna wyartykułowanej przez niego dychotomii jest nie do przecenienia: „Facundo jest jak wirus - pisze Ricardo Piglia - kto raz go przeczytał, wszędzie widzi ucywilizowanych i barbarzyńców"5.

Konstrukcja nowej kultury wymagała wyrzeczeń i - o czym łatwo zapomnieć, wyliczając sukcesy Sarmienta na polu modernizacji kraju - zasadzała się bardziej na praktykach bezpośredniej przemocy niż praktykach dyskursywnych. W 1869 roku rozpoczyna się

4 O związkach między nowoczesnością a przestrzenią miejską w Argentynie v. Graciela Montaldo, De pronto, el campo, „Punto de Vista” 1992, nr 42, s. 21-25. O roli intelektualistów w procesie definiowania narodu argentyńskiego v. eadem, Nación: una historia de la incultura, w: eadem, Zonas ciegas. Populismos y experimentos culturales en Argentina, FCE, Buenos Aires 2010, s. 25-38.

5 Ricardo Piglia, Una trama de relatos, w: idem, Crítica y ficción, Anagrama, Barcelona 2006, s. 38 . 
znamienna dla tego procesu operacja zwana eufemistycznie „Podbojem pustyni” (Conquista del Desierto), której celem było odebranie Indianom rozległych połaci ziemi na Pampie i w Patagonii. Rzekoma „pustynia” była bowiem w rzeczywistości zamieszkana, jednak jej gospodarze „nie posiadali kultury”, a więc nie istnieli. Przekonanie to pozwala z jednej strony pozbyć się „barbarzyńców” stojących u progu zabarykadowanej w Buenos Aires cywilizacji, ale z drugiej skutkuje świadomością pierwotnego braku fundamentu, pustki, na której wznosi się argentyńska kultura narodowa, pozbawiona prehistorii w postaci wielkich cywilizacji prekolumbijskich ${ }^{6}$. Zgodnie z projektem Sarmienta próżnię powstałą w wyniku unicestwienia Innych zapełnić mieli europejscy imigranci, których Argentyńczycy gościnnie zapraszają w preambule do swojej konstytucji z 1853 roku. Europejczycy entuzjastycznie odpowiadają na to zaproszenie: między rokiem 1870 a 1914 przybywają do Argentyny setki tysięcy osób, w początkach xx wieku połowa mieszkańców stolicy to cudzoziemcy, ukazują się gazety po włosku, niemiecku i w jidysz. Elity intelektualne początkowo kultywują egzaltację mitem wielokulturowego miasta, ponieważ niewyobrażalnie rozległe tereny równinnej pampy i Patagonii wydają się scenerią sprzyjającą despotycznej władzy caudillos, ale z czasem go porzucają. Przytłaczająca większość nowo przybyłych nie odpowiada bowiem ideałowi imigranta: zamiast chłopów i rzemieślników z Północy (którzy udali się do Stanów Zjednoczonych), Argentynę zalewa biedota z Południa i Wschodu: przede wszystkim Włosi i Hiszpanie, w dalszej kolejności Niemcy, Rosjanie, Polacy (głównie żydowskiego pochodzenia) oraz Azjaci. Pochodzący ze wsi lub małych miasteczek, zostają upchnięci w zubożałych conventillos, gdzie biedują w niewyobrażalnym ścisku - nie są kosmopolityczni, są po prostu obcy ${ }^{7}$. Ponadto populacja nowo przybyłych jest młodsza,

6 V. Beatriz Sarlo, En el origen de la cultura argentina: Europa y desierto, w: eadem, Escritos sobre literatura argentina, Siglo XxI, Buenos Aires 2007, s. 28.

7 Eadem, Buenos Aires: el exilio de Europa, w: eadem, Escritos sobre literatura argentina, s. 37-39. O doświadczeniu fizycznego braku przestrzeni Gombrowicz wspomina kilkakrotnie jeszcze w latach 50., np.: „Morón, które dawniej było przestronne, teraz jest spiętrzone, duszne, miejskie. Ilość! Idę na stację omnibusową, 
szybciej się rozrasta i wkrótce przewyższa liczebnie Argentyńczyków pochodzenia kreolskiego, którzy uznają imigrantów za synonim nowego barbarzyństwa. Do tego intensywny rytm przemian technologicznych - Buenos Aires w pierwszych dekadach xx wieku ma już metro, elektryczność, kanalizację, telefony, starannie zaprojektowane parki - potęguje jeszcze poczucie zagubienia w zbyt szybko zmieniającej się rzeczywistości.

Wobec tej nowej „pustki kulturowej”, która tym razem wdarła się aż do samej stolicy, elity intelektualne zmuszone są na nowo przemyśleć swój projekt - nie tyle projekt przyszłości, bo ta należy do imigrantów, co przeszłości: w niej ma znaleźć swój fundament „prawdziwa Argentyna”, prawowici użytkownicy jej języka i tradycji. W dyskusjach lat 20. i 3o. pobrzmiewa obawa o zagrożoną lub wręcz zdmuchniętą przez kolejne fale imigrantów tożsamość narodową, którą należy od nowa zdefiniować w oparciu o stałe takie jak tradycja i relacje z kulturą Europy (a nie z jej zacofanymi mieszkańcami). Historia zostaje na nowo odczytana w oparciu o la gauchesca, literaturę sławiącą poczynania gauczów, dawnych „barbarzyńców”, którzy teraz - kiedy faktycznie należą właśnie do przeszłości - mogą stać się esencją narodowego ducha. Z drugiej strony próbuje się odzyskać kontakt z kulturą Starego Świata - począwszy od końca lat 20. na zaproszenie tutejszych elit (głównie z kręgu czasopisma „Sur”) przybywają do Argentyny europejscy intelektualiści: w 1929 roku hrabia Keyserling i Waldo Frank, w 1932 Pierre Drieu la Rochelle, a w 1939 Ortega y Gasset i Roger Caillois. W końcu

umieszczam siebie w kolejce, z narożnego baru - słodkawy smród, za mną i przede mną osoby, kuper i nochal, anemia i liszaj, jeden kupczyk drugiemu, że na trzy procent sto siedemdziesiąt pięć, baba babie że pięć trzydzieści, podrożało, a radio kieszonkowe: »kupujcie szparko mydło w proszku Tarko«. Chłopaczek daje sobie prztyczka. Słońce. Mdło. Tutaj stoimy w kolejce, a tam, na przeciwległym chodniku, idą i idą, mijają i mijają, bez przerwy lizą i lizą, skąd tyle tego, przecież już jestem o dwadzieścia kilometrów od centrum Buenos Aires! A jednak mijają i mijają, wciąż wyłażą zza rogu i przechodzą i wyłażą i przechodzą i wyłażą i przechodzą i wyłażą aż zwymiotowałem. Zwymiotowałem, a ten co przede mną stał spojrzał i nic, bo i cóż! Tłok"; Witold Gombrowicz, Dziennik 1953-1969, Wydawnictwo Literackie, Kraków 2013, e-wydanie. 
w roku 1953 Borges próbuje rozstrzygnąć spór o argentyńskość, definiując ją w kategoriach nieskrępowanego używania kultury Zachodu i wypracowanych przez nią wizji Orientu ${ }^{8}$. Jednak niekonkluzywne wysiłki w uchwyceniu esencji argentyńskiej tożsamości zdają się dowodzić czegoś wręcz przeciwnego: że kraj ten pozostaje mieszanką ras, języków, kultur, stylów architektonicznych i estetycznych, połączonych w niejednorodną całość metodą bricolage’u. Członkom tej wspólnoty towarzyszy wspominana wyżej melancholijna świadomość braku korzeni, który Héctor A. Murena nazwał „pierworodnym grzechem Ameryki”: o ile w Europie ludzie doświadczają historii na każdym kroku (przedmioty, ziemie, budowle - wszystko posiada przeszłość), o tyle w Nowym Świecie są wyrzuceni poza historię, żyją w pustce, której zapełnić nie sposób?

Na dyskusje o tożsamości nakładają się spory dotyczące języka. Uzyskaniu niepodległości towarzyszy gest podwójnego odrzucenia: po pierwsze, języków i kultur autochtonicznych, nigdy niebranych pod uwagę jako pożądany komponent narodowej tożsamości, po drugie - języka i kultury hiszpańskiej, które symbolizowały zacofanie i opresyjność. Polityczna emancypacja miała swój wymiar językowy: niepodległość zakładała wykształcenie gramatyki i słownika stricte argentyńskich, niezależnych od hiszpańskiego modelu, poprzez promocję innych języków europejskich ${ }^{10}$. W latach 20. i 30., wraz z naporem kolejnych fal imigrantów, kończy się definitywnie okres lingwistycznego optymizmu i intelektualiści odkrywają, że „ten sam język obcy posiada dwie zupełnie różne realizacje społeczno-kulturowe: z jednej strony istnieją języki obce pisane i mówione

$8 \quad$ Jorge Luis Borges, Pisarz argentyński i tradycja, w: idem, Polemiki, przeł. Joanna Partyka, Prószyński i S-ka, Warszawa 2008.

9 Héctor A. Murena, El pecado original de América, FCE, Buenos Aires 2006 (pierwsze wyd. w 1948 roku).

10 Jego kwintesencją jest polemika pomiędzy Andrésem Bello i Domingiem Faustinem Sarmientem. Wenezuelski filozof i językoznawca opowiadał się za jednym, skodyfikowanym modelem hiszpańskiego (i prymatem jego wersji wykształconej), natomiast Sarmiento bronił pluralizmu wariantów kastylijskiego, tak geograficznych (Hiszpania, Ameryka Łacińska), jak społecznych (języki mówione i pisane). 
przez ludzi wykształconych, z drugiej - te pisane i mówione przez imigracyjne masy (języki plakatów, ulotek handlowych i politycznych, gazet dla imigrantów)"11. Tym samym na scenie literackiej i, szerzej, społecznej wykształca się „kosmopolityzm uprawniony” (którym poszczycić się może dwujęzyczna elita) oraz „kosmopolityzm chaotyczny" (charakterystyczny dla mas nowo przybyłych, mówiących wykoślawionym, niedbałym hiszpańskim z obcym akcentem). O „właściwej” i „niewłaściwej” relacji z językiem macierzystym i obcym decyduje paradoksalnie pozycja społeczna: Victoria Ocampo jest pod tym względem przypadkiem skrajnym - wychowana w rodzinie arystokratycznej, kultywującej bliskie związki z kulturą europejską, pisze swoje teksty po francusku, a następnie zleca ich tłumaczenie na hiszpański ${ }^{12}$. Może sobie na to pozwolić, bo jej prawomocny związek z hiszpańskim gwarantuje dobre pochodzenie, a ewentualne trudności wynikają właśnie z nadmiaru kapitału językowego ${ }^{13}$. Na drugim końcu językowej skali, której rozpiętość w Argentynie pierwszej połowy xx wieku była bardzo szeroka, sytuuje się Gombrowicz ze swoim chwiejnym hiszpańskim, nikomu niedostępnym polskim i dobrym, ale wtórnym francuskim (nie był dwujęzyczny).

Dyskusje o języku koncentrują się - jak pisze Beatriz Sarlo - na kwestii dopuszczalnej polifonii: Ile i czyich głosów jest w stanie wytworzyć tekst kultury, który nie ulegnie rozkładowi pod naporem

11 Beatriz Sarlo, Oralidad y lenguas extranjeras. El conflicto en la literatura argentina durante el primer tercio del siglo $\mathrm{xx}$, w: eadem, Carlos Altamirano, Ensayos argentinos: de Sarmiento a la Vanguardia, Siglo xxI, Buenos Aires 1997, s. 274; wyróżnienie w oryginale.

12 Dla obu sióstr Ocampo angielski i francuski były pierwszymi językami, hiszpańskiego nauczyły się później, zresztą bez większego entuzjazmu. „Gdy próbowałam pisać po hiszpańsku - wspomina Victoria- czułam się jak leworęczna, którą zmusza się do używania prawej ręki”. Jej siostra Silvina także nie postrzegała go jako swojego języka macierzystego: „Przyzwyczajam się powoli do hiszpańskiego, bo na początku wychodziły mi zdania gramatycznie nie hiszpańskie, lecz francuskie, a nawet angielskie"; cyt. za: Judith Podlubne, Alberto Giordano, Exilio y extraterritorialidad: Wilcock y Bianciotti, w: Elsa Drucaroff (red.), Historia crítica de la literatura argentina, t. 11, Emecé, Buenos Aires 2000, s. 385.

13 Beatriz Sarlo, Oralidad y lenguas extranjeras, s. 28o. 
konfliktów ideologicznych i społecznych? Na jaką różnorodność pozwolić sobie może naród, którego przeszłość nie jest ani tak długa, ani tak bogata, by zapewnić jedność tylu różnic? Jakie miejsce przyznać głosowi Innego w kulturze, która jeszcze nie zdążyła skonstruować mitu własnego głosu? ${ }^{14} \mathrm{Na}$ dyskusje o dozwolonej wielojęzyczności i o hiszpańskim modelowym, nakłada się kwestia tłumaczeń: Kto może ich dokonywać? Czy język docelowy (hiszpański) powinien być językiem ojczystym tłumacza? Które teksty warte są przekładu? Począwszy od lat 30. kierowane przez Victorię Ocampo wydawnictwo „Sur” rozpoczęło prężną akcję tłumaczenia najnowszych autorów europejskich i północnoamerykańskich (Williama Faulknera, Virginii Woolf, Jamesa Joyce’a, Vladimira Nabokova, André Gide’a, Jeana Geneta, by wymienić tylko kilka nazwisk). Spory dotyczące praw translatorskich dzielą pole literackie według nowego kryterium: na tych, którzy mogą czytać w językach oryginalnych (a także z nich tłumaczyć), oraz na tych, którzy są skazani na mediację przekładu ${ }^{15}$.

Konsekwencją tych zażartych dyskusji o różnorodności języka (o granicach i poprawności) jest przekonanie, które w argentyńskiej świadomości zadomowiło się na kolejne dekady: że hiszpański jest językiem ubogim, który trzeba wzbogacić poprzez praktykę tłumaczenia, przeszczepiania doń obcych elementów, „infekowania” innymi kodami językowymi, często dopuszczając się przy tym zamierzonej manipulacji źródła ${ }^{16}$. O ile konieczność tej językowej dyfuzji była akceptowana,

\footnotetext{
14 Ibid., s. 275.

15 Ibid., s. 279.

16 Ibid., s. 281. O tym samym zjawisku (praktyce niewiernego „tłumaczenia” obcych kultur w celu wzbogacenia własnej) pisze Néstor García Canclini w kontekście specyficznej kondycji kultury latynoskiej, czyli nowoczesności (kulturowej) pozbawionej zmodernizowania gospodarczego (modernismo sin modernización): „adaptowanie obcych idei w mylny sposób leży u podstaw naszej literatury i sztuki”. I dalej: „nawet w krajach takich jak Argentyna, w których historia etniczna oraz większość tradycji została zniszczona, artyści »uzależnieni« od europejskich wzorów nie byli jedynie imitatorami importowanych estetyk, nie można ich też oskarżać o wynarodawianie własnej kultury"; Néstor García Canclini, Culturas híbridas. Estrategias para entrar y salir de la modernidad, Paidós, Buenos Aires 2013, s. 89 i 91.
} 
o tyle problematyczna stawała się decyzja, kto i na jakich zasadach miałby jej dokonywać. Losy argentyńskiej Ferdydurke, napisanej takim właśnie językiem eksperymentalnym, pokazują, że do lat 50. prawo do reformowania hiszpańskiego zarezerwowane było tych, którzy mogli poszczycić się jego natywną, perfekcyjną znajomością, potem natomiast uległo demokratyzacji.

W latach 40. Xx wieku cykl przemian związanych z imigracją zostaje zakończony i rozpoczyna się konsolidacja społeczeństwa na bazie peronizmu - eksperymentu społecznego, którego Gombrowicz był już naocznym świadkiem. Jego deklarowana obojętność dla polityki, połączona ze szczególną niechęcią do rządów Peróna, nie zmienia jednak faktu, że estetyczne poglądy pisarza - fascynacja młodością i niższością, o których więcej będę pisać niżej - w jakiś pokrętny sposób zbiegły się z interesami i ideologią tej populistycznej władzy, bazującej na poparciu rzesz młodych pariasów. Niedostatek kapitału materialnego i symbolicznego będzie bowiem zasadą, która posłuży peronizmowi do skonsolidowania narodu, tak drastycznie pozbawionego wspólnej przeszłości - peronistowskie społeczeństwo to wspólnota braku, którą scala nie jakaś specyficzna wartość lub cecha, ale właśnie to, czego jest pozbawiona, co zasadniczo należy do Innego $^{17}$. Ponadto populizm mocno nadweręża zapoczątkowaną jeszcze przez romantyków tradycję udziału intelektualistów w projektowaniu państwa - jeśli naród ma być homogeniczną całością, zarezerwowana dla ludzi intelektu rola mediatora staje się zbędna. Zamiast tego peronizm operuje jasnym rozróżnieniem na wrogów i przyjaciół ludu, według którego dzieli pole literackie: pisarze „reakcyjni” pozostają wierni ideałowi autonomii sztuki, natomiast ci, którzy „bratają się” z masami, zdradzają go. Źródeł porażki Gombrowicza w świecie literackim Buenos Aires szukać należy prawdopodobnie w całkowitej niemożliwości lub niechęci opowiedzenia się po którejś ze stron. Zarówno deklarowany konserwatyzm polityczny, jak i ideały estetyczne zbliżały go do pisarzy awangardowych, zgrupowanych od lat 30. wokół „Sur” (wyjątkiem była jego przyjaźń z Mastronardim, luźno

17 V. Graciela Montaldo, La escena populista, w: eadem, Zonas ciegas, s. 73. 
związanym z grupą Victorii Ocampo), ale dystansowało go od nich Retiro - elita literacka lat 40. była w kwestiach obyczajowych raczej staroświecka. Dodatkowo postulaty rewaloryzacji młodości - nawet jeśli wykraczały znacznie poza kult młodzieńczej prowokacji - musiały wydać się pisarzom z kręgu „Sur” chybione lub, w najlepszym razie, spóźnione: w latach 40. i 50. Borges odżegnuje się właśnie od tekstów z młodości, zamykając ostatecznie etap twórczy lat 20., którego kwintesencją był obrazoburczy, buńczuczny ton awangardowego czasopisma „Martín Fierro”, skupiającego właśnie artystów „młodych" ${ }^{\prime 8}$. Ostatecznie więc Gombrowicz - faktycznie niezrozumiany przez "Sur” - wiąże się z pisarzami takimi jak Arturo Capdevila i Manuel Gálvez, których poglądy literackie były raczej anachroniczne, a ideały polityczne - bliskie populizmowi nowej władzy. Mimo tego pozostaje krytycznym obserwatorem ponad dziesięcioletniej epoki tzw. pierwszego peronizmu, przychylnie wspomina w Kronosie o tzw. wyzwolicielskiej rewolucji, która obaliła Peróna w 1955 i rozpoczęła rządy antyperonistów, które - w wersji na przemian wojskowej i cywilnej - trwały do roku $1973^{19}$.

Moja opowieść o Gombrowiczu w Argentynie rozpoczyna się w końcu lat 6o., w czasie dyktatury generała Juana Carlosa Onganía, słynącej m.in. z szeroko stosowanej cenzury, której ofiarą padły - obok baletu Święto wiosny Igora Strawińskiego i filmu Blow-up Michelangela Antonioniego - powieści Nanina Germána Garcíi oraz El frasquito (Buteleczka) Luisa Gusmána, zagorzałych miłośników Gombrowiczowskiej prozy. Polityczne rozgorączkowanie

18 Na temat egzaltacji ideału młodości przez pisarzy związanych z pismem „Martín Fierro" v. Carlos Walker, Jorge Luis Borges: de "Martín Fierro" a "Sur" (1924-1935), „Iberoamericana” 2011, t. 11, nr 42, s. 25-42.

19 Juan Carlos Gómez wspomina wprawdzie o tekście napisanym przez Gombrowicza przed wybuchem Rewolucji Wyzwolicielskiej w 1955 roku, nigdy nieogłoszonym drukiem, w którym pisarz podobno wychwala rządy peronistów. Tekst ten - prawdopodobnie fragment Dziennika - nie zachował się; v. Juan Carlos Gómez, Nowy przewodnik po Gombrowiczu, przeł. Rajmund Kalicki, „Twórczość" 2004, nr 5, s. 49; idem, Zapiski gombrowiczowskie, przeł. Ewa Zaleska, „Twórczość” 2008, nr 11, s. 8 o. 
argentyńskiego społeczeństwa osiąga swoje apogeum w 1973 roku, kiedy Perón powraca z wygnania i rozpoczyna drugi okres rządów, będący epoką otwarcie praktykowanego terroru państwowego oraz nasilającej się działalności zbrojnych bojówek, która pogrąży społeczeństwo argentyńskie w powolnym chaosie. Klimat kulturalny tamtej epoki, w której do ekstremum dochodzą tendencje widoczne już w latach 6o., doskonale oddaje słynne zdanie Julia Cortázara: „Literatura to mój karabin maszynowy"20. W tej jakże nieprzychylnej sobie atmosferze Gombrowicz zaczyna zdobywać popularność. Z jednej strony w 1972 roku odnosi ogromny triumf w teatrze dzięki realizacji Iwony Jorgego Lavellego (poprzedzonej, co nie bez znaczenia, wielkim paryskim sukcesem Ślubu) - o sztuce rozpisują się popularne gazety. $\mathrm{Z}$ drugiej - w tym samym okresie zaczyna być czytany i komentowany przez młodych pisarzy związanych z grupą „Literal”, która - choć wówczas nikomu jeszcze nie znana - zostanie po latach uznana za zalążek tzw. antykanonu, z którego wywodzić się będą pisarze o ustalonej dziś renomie: Osvaldo Lamborghini, Héctor Libertella i César Aira. Kilka lat później - w 1976 roku - rozpoczyna się najtragiczniejszy okres w dziejach współczesnej Argentyny, dyktatura junty wojskowej, która własne rządy ochrzciła eufemistyczną nazwą „Proces Narodowej Reorganizacji”. „Proces”, który kosztował życie około trzydziestu tysięcy „znikniętych”, rozpoczął w kulturze argentyńskiej rozłam na jej część emigracyjną i krajową. O ile dla pisarzy emigracyjnych (w większości zaangażowanych w rewolucyjną walkę) Gombrowiczowska twórczość pozostaje ideologicznie po prostu niestrawna, o tyle dla niektórych przedstawicieli literatury krajowej, zmuszonej szyfrować swoje przesłanie w pozornie niewinnych historiach, opowieść o pisarzu, który kontestuje kulturową czystość i odżegnuje się od własnej ojczyzny, okazuje się bardzo interesująca. Doświadczenie dyktatury wojskowej zdyskredytowało głoszoną przez jej ideologów doktrynę jednorodnej „kultury narodowej”, ale z drugiej strony przyniosło także krytyczną rewizję postulatów i mechanizmów

20 V. wywiad Alberta Carbone z Juliem Cortázarem pt. Julio Cortázar: mi ametralladora es la literatura, „Crisis” 1973, nr 2, s. 10. 
działania radykalnej lewicy, które poniosły, jak sądzono, nieodwracalną klęskę. Zgromadzone na Wydziale Filozofii i Literatury (Filosofía y Letras) Uniwersytetu w Buenos Aires środowisko krytyków akademickich (niewątpliwie najbardziej opiniotwórcze) intensywnie nadrabiało braki w metodologii badawczej, spowodowane marazmem lat dyktatury. Marazm dotyczył zresztą tylko kultury oficjalnej - istniejące od 1978 roku wpływowe czasopismo „Punto de Vista” zdołało stopniowo zastąpić obowiązujące w poprzed nich dekadach teorie (przede wszystkim strukturalizm i lacanowską psychoanalizę) socjologią kultury Raymonda Williamsa, Richarda Hoggarta, a następnie Pierre'a Bourdieu, które pozostając po lewej stronie sceny politycznej, pozwalały uniknąć upraszczających antagonizmów i myślowych kolein, w jakie wpadły ich ideologiczne poprzedniczki w latach 60. i 70. „Punto de Vista” zdołało zgromadzić wokół siebie najważniejsze głosy argentyńskiej krytyki (choć przeżyło także kilka głośnych rozłamów) i wypromować dwóch pisarzy, których estetyki będą stanowiły w kolejnych dekadach wzór do naśladowania - Ricarda Piglię i Juana José Saera. Uosabiając esencję nowoczesnej argentyńskości, przynajmniej w odniesieniu do literatury, ci dwaj autorzy narzucili także narodowy model odczytania Gombrowiczowskiej prozy, w którym autora Ferdydurke czyta się z perspektywy jej wpływu na kulturę regionu La Platy. W latach 9o. krytyka argentyńska stopniowo adaptuje całe spektrum teorii postmodernistycznych, których triumf symbolicznie zbiega się w czasie ze spektakularnym rozwojem społeczeństwa konsumpcyjnego, powstałego za rządów Carlosa Menema (19891999), wzorcowo realizującego założenia dyktowane przez logikę kulturową późnego kapitalizmu. Menemizm ostatecznie zakończył się równie spektakularnie - kryzysem ekonomicznym w 2001 roku, który, choć bez wątpienia ciężki, był tylko jednym z wielu kolejnych, na stałe wpisanych w gospodarczy system Argentyny. W ciągu dwóch ostatnich dekad refleksja teoretycznoliteracka wyniosła problematykę globalną, skoncentrowaną wokół przekraczania granic i kontaminacji tożsamości płciowych (queer), narodowych (wielokulturowość, życie mię d zy językami, kanoniczności) i gatunkowych (autofikcjonalna 
opowieści o literackim „ja”), na którą stopniowo wypływa także Gombrowicz, bo jego twórczość okazuje się interpretacyjnie płodna w tym nowym paradygmacie krytycznym.

\section{Gombrowicz jako pisarz argentyński}

Głos swój nieustannie ściszał, ale, im cichszy, tym właśnie donośniej, bo inni, ściszając się, jeszcze bardziej go nasłuchiwali (choć i nie słuchają).

Trans-Atlantyk

Pisząc o „argentyńskim Gombrowiczu” - pisarzu „przywłaszczonym” przez tamtejszy kanon literatury - z konieczności odwołuję się często do koncepcji narodu i tego, co narodowe, a to z kolei zdaje się implikować taki sposób myślenia o literaturze, który wbrew współczesnym tendencjom traktuje ją jako twórczość ściśle związaną z wyrażaniem ponadhistorycznej, twardej tożsamości, scalonej „więzami primordialnymi" ${ }^{21}$. Jednak casus argentyński, jak starałam się wyżej pokazać, unieważnia myślenie o narodzie w terminach twardo zdefiniowanej przynależności, zbliżając go - paradoksalnie, bo mamy do czynienia z populacją właśnie wielokulturową - do kategorii etniczności, która identyfikację z grupą postrzega znacznie bardziej elastycznie, podkreślając jej historyczną zmienność oraz rolę wyobraźni w definiowaniu wspólnoty. Współczesne studia nad związkami pomiędzy literaturą a wspólnotą (etniczną, narodową) bazują na trzech nowych paradygmatach wiedzy o kulturze: po pierwsze, na idei jej deterioryzacji, odejścia „od wyobrażenia o ścisłym odwzorowaniu kultury i przestrzeni i od uznania przestrzennego zakorzenienia kultur"; po drugie, na odrzuceniu „modelu monadycznych, odgraniczonych »czystych»

21 V. Eugenia Prokop-Janiec, Etniczność, w: Michał Paweł Markowski, Ryszard Nycz (red.), Kulturowa teoria literatury. Główne pojęcia i problemy, Universitas, Kraków 2010, s. 409. 
obszarów kulturowych" na rzecz tezy o ich immanentnej hybrydyczności; po trzecie zaś, na potrzebie opisania kultur zglobalizowanych ${ }^{22}$. W badaniach nad „argentyńskim Gombrowiczem” dwa pierwsze założenia - o rozerwaniu związku pomiędzy kulturą a terytorium oraz o wewnętrznym zróżnicowaniu tej pierwszej - stosują się bez wątpienia w całej rozciągłości. Stosunkowo gładkie włączenie autora Dziennika do argentyńskiego kanonu jest bowiem możliwe przede wszystkim dzięki specyficznym własnościom tej kultury - rozmytej tożsamości narodowej oraz dyskusyjnej naturze języka, który w Argentynie pierwszych dekad xx wieku działał raczej jako czynnik różnicujący niż scalający wspólnotę. Sprawę językowej odrębności dodatkowo komplikuje fakt, że w całej Ameryce hiszpańskiej wspólny język nie jest z oczywistych względów wyznacznikiem narodowości, a tym samym pisanie w języku innym niż hiszpański nie jest także podstawowym kryterium obcości. W historii literatury argentyńskiej nie brakuje pisarzy, których twórczość powstawała w innych językach, przy czym wybór tego pierwotnego tworzywa podyktowany bywał najróżniejszymi względami, od najbardziej podstawowych, jak przywiązanie do macierzystej mowy, po te wymuszone okolicznościami zewnętrznymi, takimi jak chęć zaistnienia w literaturze światowej, często w połączeniu z doświadczeniem wygnania. Naturalistyczny pisarz argentyński Guillermo Enrique Hudson (znany także jako William Henry Hudson), Anglik z pochodzenia, pisał w języku ojczystym ${ }^{23}$, Héctor Biancotti i Copi, choć Argentyńczycy, wybrali francuski, a znaczna część dzieła Juana Rodolfa Wilcocka napisana została po włosku (po tym zresztą, jak porzucił wyuczony hiszpański, w którym zadebiutował w latach 40. w Buenos Aires, nie spróbowawszy nawet - ku zgorszeniu sióstr Ocampo - pisać w którymś ze swoich dwóch macierzystych języków

22 Ibid., s. 414-415. O procesie hybrydyzacji kultur latynoskich i relatywizowaniu pojęcia tożsamości pisze także Néstor García Canclini (op. cit., s. 14-18).

23 W odniesieniu do Hudsona i Cunninghame’a Grahama Martinez Estrada pisał, że „najlepsza literatura argentyńska została napisana po angielsku”; Ezequiel Martinez Estrada, La literatura y la formación de la conciencia nacional, w: Saúl Sosnowski (red.), Lectura crítica de la literatura americana. La formación de las culturas nacionales, Buenos Aires Biblioteca Ayacucho, Carcacas 1996, s. 52. 
cywilizowanych, angielskim lub francuskim). Osiadła w Paryżu Silvia Baron Supervielle - by zamknąć tę niepełną listę argentyńskich pisarzy „zadomowionych” w obcych językach - od lat 6o. pisze po francusku, określając się jednak jako autorka z Río de la Plata.

Przypadek Gombrowicza jest więc jednym z wielu przypadków utrudnionej lokalizacji literackiej: pisarz nigdy wprawdzie nie porzucił polskiego na rzecz hiszpańskiego, ale zasadnicza część jego dzieła powstała w Ameryce i mimo że ten kontekst historyczno-geograficzny jej nie determinuje, to jednak - jak argumentują Argentyńczycy - nie pozostaje on bez znaczenia ${ }^{24}$. „Przemiany w twórczości Gombrowicza są nierozerwalnie związane z doświadczeniem argentyńskim; doświadczenie to przenika i kształtuje znaczną część jego dzieła, które w oderwaniu od niego stałoby się niezrozumiałe", pisze Juan José Saer ${ }^{25}$. Za najbardziej „argentyńskie” teksty uważa się Trans-Atlantyk, tłumaczenie Ferdydurke z 1947 roku oraz Dziennik argentyński. Wszystko to powoduje, że Gombrowicz zostaje włączony, i to dwukrotnie, do monumentalnej Historia crítica de la literatura argentina (Historii krytycznej literatury argentyńskiej) pod redakcją Noé Jitrika, co instytucjonalizuje jego przynależność do tej tradycji.

W tomie jedenastym, poświęconym literaturze współczesnej, autorowi Dziennika poświęca się cały obszerny rozdział, natomiast w tomie siódmym, który traktuje o tendencjach właściwych dla pierwszej połowy xx wieku, Gombrowicz dzieli z Rogerem Caillois rozdział poświęcony wygnańcom. Jeśli wziąć pod uwagę kryterium chronologiczne (które autorzy tego imponującego dzieła niewątpliwie stosują), obecność Polaka w części dotyczącej współczesności - a ściślej: drugiej połowy minionego wieku - wydaje się nieuzasadniona. Ale Historia crítica nie chce być klasycznym podręcznikiem literatury i ucieka od jej konwencjonalnej periodyzacji po to, by w sposób selektywny skupić się na autorach, którzy dokonują zasadniczych przekształceń i reorganizacji argentyńskiej tradycji literackiej, znacząc miejsca zerwania

\footnotetext{
24 W Argentynie Gombrowicz napisał Trans-Atlantyk, Ślub, Pornografię, większość Dziennika, a także w dużej mierze Kosmos.

25 Juan José Saer, Spojrzenie z zewnątrz, s. 77.
} 
bardziej niż kontynuacji. Włączenie Gombrowicza do epoki, do której historycznie nie przynależy, świadczy o przekonaniu, że jego dzieło stało się dla literatury argentyńskiej znaczące z kilkudziesięcioletnim opóźnieniem: okresy jego fizycznej i literackiej obecności rozmijają się całkowicie. We wstępie do jedenastego tomu Elsa Drucaroff sytuuje autora Ferdydurke pod szyldem „narracyjnych doświadczeń wygnania”, obok wspominanych już Wilcocka ${ }^{26}$ i Bianciottiego, których teksty zyskują nowe ramy interpretacyjne w kontekście wydarzeń z lat 1975-1983, kiedy junta wojskowa zmusiła do emigracji znaczną część intelektualistów. Kwestia polskości Gombrowicza jest przez badaczkę traktowana tylko jako jeden $\mathrm{z}$ wielu przypadków granicznych (na poziomie narodowym, językowym, gatunkowym), jedno z licznych odstępstw od klasycznej i porządkującej narracji podręcznikowej, które zdecydowała się zaakceptować w swojej wielowątkowej opowieści o literaturze argentyńskiej ${ }^{27}$.

Alejandro Rússovich, autor rozdziału o Gombrowiczu, powraca do zagadnienia jego problematycznej przynależności, które rozstrzyga dwustopniowo - na poziomie zawartości dzieła i jego późniejszego rezonowania. Po pierwsze, argumentuje Rússovich, znaczna część Gombrowiczowskich tekstów została napisana lub prze-pisana (Ferdydurke, Ślub) w przybranej ojczyźnie: „atmosfera argentyńska, a nawet problematyka argentyńska w okresie szczególnie napiętym dla narodowej kultury, musiały zaciążyć na niespokojnym trybie jego pisania"28.

26 Związki między Gombrowiczem i Wilcockiem dostrzega także Luis Chitarroni: „Szkoda, że Witoldo nie »skontaktował się« tutaj z J.R. Wilcockiem, zanim ekskluzywizm Victorii Ocampo i »Sur « prowokacyjnie ich nie rozdzielił. Autor El caos stanąłby do pojedynku w »symetrii odwrotnej « - w określeniu Levi-Straussa - wyjeżdżając z Argentyny do Włoch. (Zbiór opowiadań Wilcocka zdradza ponadto pewne podobieństwa do Bakakaju)"; Luis Chitarroni, Un maestro indiscutible de la forma, „Clarín. Revista N" 2015, 3 xII, http://goo.gl/cxiKQ5, dostęp: 10 x 2016.

27 Elsa Drucaroff, La narración gana la partida, w: eadem (red.), op. cit., s. 11-13.

28 Alejandro Rússovich, Gombrowicz en el relato argentino, w: Elsa Drucaroff (red.), op. cit., s. 361. W innym miejscu Rússovich następująco opisuje to osadzenie Gombrowicza w Argentynie: „Doświadczenie życia głęboko związanego z pewnym narodem, z młodością spędzoną na ulicach, wśród niższych warstw, musiały 
W Dzienniku Gombrowicz sytuuje się wyraźnie na mapie literackiej Buenos Aires, polemizując z obiema dominującymi wówczas poetykami: kosmopolitycznym „Sur” i „Nación” oraz tradycyjnym realizmem. $\mathrm{Z}$ drugiej strony, pisze Rússovich, przynależność autora Ferdydurke do literatury argentyńskiej rozstrzygnęła się niejako post factum - we wpływie (scharakteryzowanym zresztą bardzo ogólnie), jaki wywarł na autorów młodszego pokolenia: Jorgego Di Paolę, Osvalda Lamborghiniego, Mariana Betelú.

Rússovich stara się akcentować punkty styczne twórczości Gombrowicza z literaturą argentyńską, kilkakrotnie odnotowuje paralele z twórczością Macedonia Fernándeza (autoreferencyjność tekstu, wyostrzona świadomość krytyczna, ironia), Oliveria Gironda (gry językowe), a nawet Sarmienta i Ezequiela Martíneza Estrady (wielopłaszczyznowy charakter dzieła, obejmujący całe spektrum zagadnień, od dygresji filologicznych i analiz kulturowych po polemiki i relacje z podróży) - wszystko to, by zadośćuczynić „,argentyńskości” Gombrowicza, ale siatka jego odniesień jest przede wszystkim uniwersalna: św. Augustyn, Jean-Jacques Rousseau, Miguel de Cervantes, Pedro Calderón, Charles Dickens, Baruch Spinoza, Arthur Schopenhauer etc. Wbrew dominującej w Argentynie tendencji do „repatriacji” Gombrowicza Rússovich, w zgodzie z własnym, filozoficznym wykształceniem, widzi w nim przede wszystkim autora uniwersalnego, którego (jak Borgesa) nie sposób zamknąć w przyciasnej kategorii

spowodować w jego duszy jakiś oddźwięk, który pojawi się w literaturze. Pornografia, a zwłaszcza Dziennik pełne są wpływów argentyńskich, by nie wspomnieć o Kosmosie, który opowiada te same, co jego własne konflikty w Banku Polskim, kłótnie z sekretarką prezesa, a zwłaszcza problem, który uosabia postać Fuksa. Można by przytoczyć wiele innych przykładów, ale najwyraźniejsze znajdziemy w wersji hiszpańskiej Ferdydurke przygotowanej przez »komitet redakcyjny«, a także w Ślubie, którego wersję autor zredagował po hiszpańsku z moją pomocą"; idem, Gombrowiczowska wizja świata wedle dzieł napisanych $w$ Argentynie, z fr. przeł. Elżbieta Jogałła, w: Jerzy Jarzębski (red.), Witold Gombrowicz nasz współczesny. Materiały międzynarodowej konferencji naukowej w stulecie urodzin pisarza. Uniwersytet Jagielloński-Kraków, 22-27 marca 2004, Universitas, Kraków 2010, s. 17. 
narodu. W podobnym tonie pisze Jorge Di Paola w apendyksie do artykułu Rússovicha, Witoldo, el escritor tábano, grając kartą nonkonformizmu i odmowy gładkiego dopasowania: „artysta zmarły z głodu - topos, który stał się już mitem i rodzajem dietetycznej legendy, która bezskutecznie przestrzega tego, kto nie negocjuje z marnymi osobistościami życia narodowego swojego miejsca na świecie"29.

Drugi z artykułów poświęconych Gombrowiczowi w Historia crítica de la literatura argentina eksploruje już tereny bardziej narodowe niż uniwersalne: Joaquín Mazzi zestawia autora Kosmosu z innym wygnańcem, Rogerem Caillois, nazywając obu „naszymi bliskimi obcymi” i kreśląc łączące ich paralele (przymusowe zerwanie z własnym literackim i kulturowym milieu, doznana w Argentynie transformacja wewnętrzna, polemiczny stosunek do kategorii

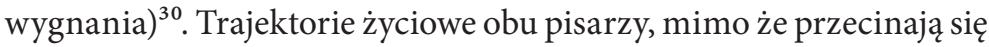

29 Jorge Di Paola, Apéndice: Witold, el escritor tábano, w: Elsa Drucaroff (red.), op. cit., s. 375 .

30 Joaquín Mazzi, 1939 y después: el largo invierno austral de Gombrowicz y Caillois, w: Celina Manzoni (red.), Historia crítica de la literatura argentina, t. 7: Rupturas, Emecé, Buenos Aires 2009, s. 413. Podobnie jak Polaka, wybuch wojny zaskoczył Francuza w Buenos Aires - dokąd przybył na zaproszenie Victorii Ocampo - i zmusił do pozostania przez sześć kolejnych lat. Doskonale zaaklimatyzowany w tamtejszych kręgach literackich, Caillois rozpoczął w 1941 roku wydawanie czasopisma „Lettres Françaises”, hojnie sponsorowanego przez Ocampo (i wyśmianego przez Gombrowicza w Dzienniku: „Opowiadano o niej [Ocampo - E.K.P.], że jeden pisarz francuski o znanym nazwisku upadł przed nią na kolana, krzycząc, że nie wstanie póki nie otrzyma kilkudziesięciu tysięcy na założenie literackiej revue"; Witold Gombrowicz, Dziennik 1953-1969). Na jego łamach pisali czołowi francuscy intelektualiści - Marlaux, Maritain, Aron i Michaux, by wymienić tylko niektórych - wzmacniając osłabione w latach 30. wpływy Paryża w Buenos Aires. W Argentynie Caillois reprezentuje, jak zauważa Pablo Gasparini, całą kulturę francuską, której naczelne wartości, zagrożone przez nazizm, wymagają obrony, a w znacznie mniejszym stopniu swój osobisty, radykalny program awangardowy, nie tak skądinąd daleki od programu Gombrowicza. Natomiast autor Trans-Atlantyku przebywa w Buenos Aires we własnym imieniu i zdecydowanie odmawia pośredniczenia pomiędzy kulturą polską a argentyńską, które przecież mogłyby porozumieć się w płodnym dialogu. Innymi słowy, Gombrowicza koncepcja 
dwukrotnie - w Buenos Aires lat 40. i w Paryżu 6o. - biegły jednak zupełnie innymi torami: pobyt Caillois w Argentynie jest w wielu aspektach (miłosnym, estetycznym i finansowym) warunkowany przyjaźnią z Victorią Ocampo, Gombrowicza determinuje równie wieloaspektowy brak (materialny, kulturowy, symboliczny), choć z czasem systematycznie wypełniany skromnym kapitałem poparcia finansowego i literackiego. Dla Francuza doświadczeniem formującym była współpraca z „Sur”, dla Polaka - spacery po Retiro i praca w banku. Różniły ich także strategie wydawnicze: opiniotwórczej i elitarnej „Lettres Françaises” odpowiada efemeryczna boutade, jakim była „Aurora”, natomiast realizowanej na łamach francuskiego czasopisma akcji przekładowej nieortodoksyjne i „złe” tłumaczenie Ferdydurke. Opowieść Mazziego jest przede wszystkim historycznoliteracka, co tłumaczy ilościową przewagę Caillois, którego rozlicznym przyjaźniom, flirtom i projektom estetycznym, poświadczonym w listach i wspomnieniach, przeciwstawia się jeśli nie anonimowość, to marginalność Gombrowicza. Zestawienie obu pisarzy dokonane z historycznej perspektywy ich argentyńskiego wygnania (Mazzi pomija inne aspekty ich życiorysów, a kwestie twórczości traktuje bardzo pobieżnie) służy w ostatecznym rozrachunku pokazaniu, że „obcość" miewa zupełnie odmienne realizacje praktyczne.

Nieco inne podejście do casusu Gombrowicza proponuje Martín Prieto, który w Breve historia de la literatura argentina, poświęciwszy mu dłuższy ustęp, konkluduje, że jedynie przekład Ferdydurke może znaleźć „osobliwe i poboczne miejsce w historii literatury argentyńskiej”31. Kryterium włączania lub wyłączania z chwiejnego kanonu argentyńskiego, na którego obrzeżach krąży całe spektrum

„ojczyzny” nie nadawała się do tego, by patronować szeroko zakrojonemu projektowi obrony wartości kultury polskiej; v. Pablo Gasparini, El exilio procaz. Gombrowicz por la Argentina, Beatriz Viterbo, Rosario 2006, s. 53-56.

31 Martín Prieto, Breve historia de la literatura argentina, Taurus, Buenos Aires 2006, s. 185. Prieto zdecydowanie neguje możliwość włączenia Trans-Atlantyku do kanonu literatury argentyńskiej: powołując się na opinie Freixy Terradesa o zupełnej zatracie w przekładzie specyficznego języka sarmackiego baroku, który to brak czyni tę powieść niedostępną dla cudzoziemców, konkluduje, że 
autorów spornych (bo np. piszących w innym języku), jest dla Prieto "produktywność” (productividad) dzieła, wyrażająca się w „zmianie w sposobie pisania i czytania w danej epoce”, która „nie tylko determinuje literaturę pisaną i czytaną po jego publikacji, lecz zmusza do przemyślenia tradycji i przeszłości" ${ }^{\prime 2}$. To kryterium pozwala mu włączyć do kanonu literatury argentyńskiej piszącego po francusku Copiego (o którym mowa będzie poniżej), a także całą włoskojęzyczną twórczość Rodolfo Wilcocka, ale Gombrowicz mieści się w nim tylko warunkowo i tylko jako autor jednego dzieła - Ferdydurke. Jednak ta stosunkowo obszerna wzmianka, jaką Prieto poświęca autorowi Dziennika - szczególnie jeśli jego spuściznę chce się zredukować do jednej powieści - świadczy o tym, że mechanizmy unarodowienia Gombrowicza, z którymi polemizuje Prieto, pracują już pełną parą. Redagowana przez Jitrika Historia crítica odegrała bowiem rolę sankcjonującą argentyńską „,aneksję” pisarza i umożliwiła kolejnym badaczom pomijanie tej tradycyjnie wstępnej kwestii narodowej lokalizacji, wieńcząc tym samym proces, który rozpoczęli wiele lat wcześniej pisarze takiego formatu jak Ricardo Piglia i Juan José Saer. W studiach krytycznych, które będę omawiać poniżej, problem ten zostaje potraktowany bardzo skrótowo, nawet jeśli ich autorom towarzyszy często niewypowiedziana wprost świadomość, że pracują - jak to ujmuje José Amícola - na „rozszerzonym” kanonie literatury rodzimej ${ }^{33}$.

jej „argentyńskość” jest jedynie pozorna i ogranicza się do usytuowania fabuły w tym kraju; ibid.

32 Ibid., s. 10.

33 José Amícola, Estéticas bastardas, s. 15. Krytyk ten skłonny jest nawet pisać o Gombrowiczu „kompletnie zargentynizowanym” w początkach lat 6o. (a więc w czasie, gdy redaguje Pornografie); ibid., s. 66. Silvana Mandolessi woli pisać o „argentyńskim dziele” Gombrowicza, definiując je jako teksty o Argentynie, w których przybrana ojczyzna jest bezpośrednio przedstawiona (Dziennik, Testament, Wędrówki po Argentynie oraz Trans-Atlantyk); v. Silvana Mandolessi, Una literatura abyecta. Gombrowicz en la tradición argentina, Rodopi, Amsterdam-New York 2012, s. 21. Dla porównania warto odnotować, że w zbiorze artykułów na temat kanonu literackiego - Susana Cella (red.), Dominios de la literatura. Acerca del canon, Losada, Buenos Aires 1998 - nazwisko 


\section{O przestrzeni: podróż, wygnanie, migracja}

Płyńcież do Szaleńca, Wariata waszego św. ach chyba Przeklętego, żeby on was skokami, szałami swoimi Męczył, Dręczył, was krwią zalewał [...]. Z takim więc Przekleństwem od okrętu się odwróciwszy, do miasta wstąpiłem.

Trans-Atlantyk

Podróż i wygnanie to dwie stałe literatury argentyńskiej - tym oczywistym stwierdzeniem wypada mi zacząć niniejszy podrozdział, a czytać w nim będę Gombrowicza jako „obcego", któremu przypadł w udziale los typowo argentyński. W historii tej literatury na próżno szukać życiorysów niedotkniętych trudami ucieczki, wieloletniego pobytu na obczyźnie lub choćby dalekiej podróży jako doświadczenia formującego. Sarmiento napisał swoje epokowe dzieło o cywilizacji i barbarzyństwie na wygnaniu w Chile, narodowy epos Martín Fierro José Hernándeza opowiada historię gaucza-uciekiniera, nielubiący podróżować Borges zapragnął jednak umrzeć i zostać pochowany w Genewie, Cortázar i Saer wybrali na swoją drugą ojczyznę Francję. Ostatnia dyktatura wojskowa zmusiła do wyjazdu prawie wszystkich rozpoznawalnych pisarzy, a obecnie pobyt na którymś z uniwersytetów północnoamerykańskich stał się rodzajem akademickiego must have. Literatura argentyńska jest więc $\mathrm{w}$ dużej mierze konsolidowana z zewnątrz, a jej granice przestrzenne nie pokrywają się z państwowym terytorium. W tym natłoku politycznych, ekonomicznych i kulturowych wychodźców nie dziwi, że twórczość Gombrowicza czyta się jako wiwisekcję tej kondycji życiowej, a kwestia tożsamości narodowej rozpatrywana jest nieodmiennie w sprężeniu z tym, co zewnętrzne i obce:

[...] znaczna część naszej literatury - od swoich początków, ale zwłaszcza w XIX i na początku Xx wieku - była tworzona przez cudzoziemców,

Gombrowicza także pada kilkakrotnie, ale jeszcze jako przykład aneksji problematycznej lub zaskakującej. 
piszących w obcych językach: niemieckim, angielskim, francuskim, włoskim. Jeszcze nie mieliśmy własnej literatury, a już europejscy marynarze, badacze, handlarze, poszukiwacze przygód, a nawet szpiedzy, opisywali w listach, relacjach, wspomnieniach naszą ziemię, nasz krajobraz, naszą ludność, nasze odmienności w stosunku do reszty świata [...]. Gombrowicz wpisuje się w tę tradycję w szczególny sposób. Dzięki delikatnym płucom, które szczęśliwie zmuszały go do częstych wyjazdów z wilgotnego Buenos Aires, dostarczył nam niezwykle cennych świadectw o Córdobie, Tandilu, Mar del Plata, Santiago del Estero ${ }^{34}$.

Problem - nazwijmy to ogólnie - przestrzennego przemieszczenia pojawia się w argentyńskiej kulturze w trzech różnych odsłonach: po pierwsze, zmaterializowany w osobach zagranicznych podróżników i pisarzy, którzy od początku xıx do pierwszych dekad xx wieku studiowali tamtejszego ducha i przyrodę; po drugie, w klasycznym doświadczeniu wygnania, zakładającego przymusowe opuszczenie domu i w różnym natężeniu odczuwaną utratę korzeni, historycznie obejmującego okres od ukształtowania się argentyńskiej państwowości do czasów współczesnych; oraz, po trzecie, właściwy ostatnim dekadom fenomen literatury migracyjnej (literatura migrante), zdystansowanej wobec terytorialnego przypisania i świadomie lokującej się na międzykulturowej granicy. Twórczość Gombrowicza okazuje się dla argentyńskiej krytyki przyczynkiem do refleksji nad oddaleniem i dystansem do tego, co swojskie w każdym z tych wymiarów.

Z historycznego punktu widzenia pobyt autora Ferdydurke w Ameryce Łacińskiej zbiega się z powolnym schyłkiem epoki podróży europejskich intelektualistów (wspomnianych już hrabiego Keyserlinga, Drieu la Rochelle’a, Ortegi y Gasseta, także Le Corbusiera), którzy

34 Juan José Saer, Spojrzenie z zewnątrz, s. 74-75. O relacji Gombrowicza ze współczesnymi mu europejskimi i amerykańskimi intelektualistami odwiedzającymi Argentynę pisze, w kontekście polemicznym, Pablo Gasparini w El exilio procaz (s. 44-84). W polskiej krytyce także dostrzegano analogie łączące Gombrowicza $\mathrm{z}$ europejskimi intelektualistami podróżującymi po Argentynie; v. Aleksander Fiut, Zwiedzanie „Kontynentu z Trzeciego Dnia Stworzenia”: Gombrowicz i Keyserling, w: Jerzy Jarzębski (red.), op. cit., s. 567-578. 
między pierwszą a trzecią dekadą xx stulecia odwiedzili Argentynę, kontynuując pozostawioną po dziewiętnastowiecznych naturalistach narrację opartą na konwencji egzotyzmu, w której kraj ten jawi się jako pozbawiony esencji i domagający się dookreślenia z zewnątrz. Gombrowicz jest emigrantem w tradycji polskiej, a w argentyńskiej podróżnikiem, i to podróżnikiem tak w sensie praktycznym, jako autor Dziennika argentyńskiego oraz Wędrówek po Argentynie, jak ontologicznym, „jako ktoś, kogo określa się stworzonym przez doświadczenie przemieszczania się" ${ }^{35}$. O tym, że przestrzeń staje się często kryterium porządkującym materię narracyjną w tekstach Polaka pisze Sergio Chejfec:

Dziennik [argentyński - E.K.P.] to opis mapy, a jego epizody zostają poukładane według ich wagi terytorialnej; dlatego niemal w całym tekście - w przeciwieństwie do większości dzienników - porządek czasowy zostaje usunięty na rzecz rozmytej serii (poniedziałek, wtorek etc.). Nawet w Trans-Atlantyku upływ czasu spręża się maksymalnie, by wysunąć na pierwszy plan zestawienie dwóch przestrzeni ${ }^{36}$.

Travel writings Gombrowicza dystansują się jednak od podstawowej wytycznej tego gatunku - niefikcyjności - subiektywizując przestrzeń

35 Silvana Mandolessi, Heterotopía y literatura nacional en "Diario Argentino" de Witold Gombrowicz, „Ciberletras: Revista de Crítica Literaria y de Cultura” 2007, nr 18, https://goo.gl/JKgzgB, dostęp: 12 III 2016 (polska wersja opublikowana pod tytułem Heterotopia i literatura narodowa $w$ „Dzienniku argentyńskim” Witolda Gombrowicza, przeł. Natalia Gendaj, „Rocznik Komparatystyczny” 2011, t. 2, s. 245-264). O tym, jak odmienna jest perspektywa polskiej krytyki, niechaj świadczy następujący, sarkastyczny fragment z artykułu Małgorzaty Czermińskiej Do kawiarni i za ocean. Paradoksy Gombrowiczowskiej filozofii podróży (w: Bernadetta Żynis [red.], Gombrowicze, Wyd. Pomorskiej Akademii Pedagogicznej, Słupsk 2006, s. 131): „Nie mogę oprzeć się wrażeniu, że starając się wyłowić z tekstów Gombrowicza to, co napisał o podróżach, skazuję się nieuchronnie na los owej samotnej kury, dziobiącej coś na trawniku. Niewątpliwie są w jego pisarstwie problemy donioślejsze, które przede wszystkim zasługują na interpretację, jako Gombrowiczowskie specialité de la maison".

36 Sergio Chejfec, La tradición de la angustia, „El Ojo Mocho” (Buenos Aires) wiosna/ lato 2004, s. 62. 
w taki sposób, że konkretne i szczegółowe z pozoru opisy miejsc zmącone zostają chwilowym, lecz przytłaczającym odczuciem piszącego „ja”: pustką (październik w Mar del Plata), ciemnością (podróż po Río Paraná), i stają się w konsekwencji iluzoryczne i nierzeczywiste. Ich narrator okazuje się typowym unreliable narrator Wayne’a Bootha, celowo podważającym własny autorytet wiarygodnej, upoważnionej do postrzegania i komunikowania instancji narracyjnej ${ }^{37}$. Jako podróżnik Gombrowicz bywa często zestawiany z Ortegą y Gassetem ze względu na czasową bliskość ich relacji z argentyńskich wędrówek (Otrega odbył do Río de la Plata trzy podróże między 1916 a 1942 rokiem) i wyrażony expressis verbis polemiczny stosunek Polaka do Hiszpana ${ }^{38}$. Porównania obu pisarzy są w dużej mierze rejestrem różnic: począwszy od pozycji, z której formułują swoje sądy (Ortega jest zaproszony do wystąpienia z prestiżowymi wykładami, polskie teksty autora Ferdydurke pozostają niedostępne nawet dla garstki młodych zapaleńców), skończywszy na głoszonych tezach. Autor Buntu mas próbuje przede wszystkim zgłębić narodowego ducha i zdefiniować argentyńskość, skwapliwie wykorzystując swoją pozycję intelektualnego autorytetu,

37 Silvana Mandolessi, Heterotopia i literatura narodowa..., s. 252-255. W tym zabiegu ułudnego opisu Mandolessi widzi spełnienie jednej z funkcji, którą Foucault przypisuje przedstawieniom heterotopii, czyli miejsca niezmyślonego (w odróżnieniu od utopii), lecz zdecydowanie odmiennego od innych, bo łączącego przestrzenie niekompatybilne (jak scena teatralna) lub zakładające załamanie czasowe (jak muzea i biblioteki). Przestawienia heterotopiczne działają dwojako: z jednej strony podkreślają swoją iluzoryczność (jak w Gombrowiczowskich tekstach podróżniczych), z drugiej - prezentują miejsca tak dopracowane i dobrze zorganizowane, że te swojskie wydają się chaotyczne i zepsute. W tym drugim wymiarze Argentyna także jest heterotopią: stwarza miejsce, w którym mechanizmy narodowego przywiązania nie są tak opresyjne jak w Polsce: „wyrównuje utratę ojczyzny, nie zastępując jej nową”; ibid., S. 257.

38 V. podrozdział „Dziennik argentyński”. Rekonstrukacja przeszłości, s. 70-87. W Dzienniku Gombrowicz pisze także o „argentyńskiej defensywie”, nawiązując polemicznie do tytułu eseju Ortegi y Gasseta El hombre a la defensiva (Człowiek w defensywie). Porównanie poglądów Gombrowicza i Ortegi y Gasseta okazuje się inspirujące dla wielu badaczy; cf. Silvana Mandolessi, Una literatura abyecta, s. 145-156; Pablo Gasparini, El exilio procaz, s. 44-51. 
z której Polak równie chętnie rezygnuje, anulując jednocześnie pytania o tożsamość kulturową: co dla Ortegi jest źródłem argentyńskich kłopotów z autodefinicją - nieokreśloność, niedojrzałość, nieuformowanie - dla Gombrowicza stanowi o atrakcyjności rozluźnionej formy narodowej. W ten sposób, konkluduje Mandolessi, autor Trans-Atlantyku dostarcza pisarzom takim jak Piglia, Saer i Aira instrumentu do kwestionowania homogenicznego i opresyjnego obrazu czystego „my”, którego totalitarny ideał miał niejednokrotnie „nawiedzać” argentyńską historię.

Umiejscowienie Gombrowicza w tradycji podróżniczej - na jej obrzeżach lub w konfrontacji z jej głównym nurtem - ma doniosłe znaczenie interpretacyjne, sytuuje bowiem autora Dziennika w kontekście pytań o postkolonialny charakter zewnętrznych (przede wszystkim europejskich) narracji o Argentynie i, szerzej, całej Ameryce Łacińskiej. Jak widzieliśmy, w drugiej połowie XIX i początkach $\mathrm{xx}$ stulecia ten niepodległy już politycznie kontynent zostaje ponownie wymyślony i opowiedziany przez naturalistów - obserwatorów przyrody, zwyczajów, polityki - a potem przez intelektualistów, zainteresowanych $\mathrm{z}$ kolei poszukiwaniem kulturowej istoty latynoamerykańskości. Obie te opowieści zostały jeszcze w XIX wieku skwapliwie zaadaptowane przez autochtonicznych pisarzy, którzy narodowe terytorium opisywali w konwencji egzotycznej podróży, postrzegając je oczami reprezentantów kultur „wyższych”. W Argentynie, pisze Graciela Montaldo, rodzima elita polityczna i intelektualna skłonna była po wielokroć porządkować historię - dostosowywać paradygmat czasowy do potrzeb aktualnych wizji narodu, reinterpretować przeszłość w zgodzie z potrzebami teraźniejszości - ale mapy miast i kraju kreśliło się zawsze z perspektywy obcych, którzy przemierzali te tereny, „znacząc na ciele ojczyzny inne szlaki i drogi”39. Czasem zawiadowali tubylcy, przestrzenią - cudzoziemcy. Ten prymat historii nad geografią kończy się w latach 80. xx wieku, kiedy pisarze i intelektualiści stopniowo porzucają imperatyw eksplorowania

39 Graciela Montaldo, Diez años en democracia: los cambios en el Canon, „Hispamérica" 1995 , t. 24 , $\mathrm{nr} 7$, s. 47. 
przeszłości na rzecz „upolitycznienia refleksji o przestrzeni”, rozumianej jako „nadanie jej problematycznego wymiaru” ${ }^{40}$, dostrzeżenia w niej tego, co wcześniej przemilczane, jako nieprzystające do miejsc uznanych za reprezentatywne dla narodowego ducha (Buenos Aires i gauczowska pampa). Wśród tych obcych, których relacje $z$ argentyńskich podróży (stanowiące „wersje naszego problematycznego kulturowego terytorium"41) warto na nowo rozpatrzyć, Montaldo wymienia obok Hudsona, Supervielle'a, Copiego i Lamborghiniego także Gombrowicza. Polak, powodowany bardziej przyziemnymi potrzebami schorowanego ciała aniżeli żądzą poznania, przemierza i opisuje właśnie te miejsca kulturowo drugorzędne - w Dzienniku niewiele jest wzmianek o stolicy, a jeśli się pojawiają, to w kontekście jednoznacznie negatywnym ${ }^{42}$; pampa jest wprawdzie scenerią w Trans-Atlantyku, ale - skondensowana w estancji Gonzala - zostaje przedstawiona jako dziwaczna, odpychająca mieszanina elementów do siebie nieprzystających. Współcześni komentatorzy Dziennika argentyńskiego i Wędrówek po Argentynie dostrzegają w nich tę skonstatowaną przez Montaldo „refleksję upolitycznioną”, niekanoniczną, która u Gombrowicza przejawia się zarówno w osobie nierzetelnego i niewiarygodnego narratora, odżegnującego się od roli autorytetu, jak i w samych opisach iluzorycznej, zsubiektyzowanej, heterogenicznej przestrzeni: pampa jest „odrażająco”" ${ }^{43}$ egzotyczna, a przestrzeń Santiago del Estero lub Goya nie jest synekdochą Argentyny (jak pampa u Ortegi y Gasseta), lecz obrazem piszącego „ja”.

\footnotetext{
$40 \quad$ Ibid., s. 46.

41 Ibid.

42 V. Ewa Kobyłecka-Piwońska, "Este eczema de cinco millones". La Buenos Aires de Witold Gombrowicz, w: Nicolás Hochman (red.), El fantasma de Gombrowicz recorre la Argentina, Heteronimos, Buenos Aires 2015, s. 284-295.

43 Wywiedziona z pism Julii Kristevy kategoria lo abyecto (ohydy) służy Mandolessi do wielopoziomowego opisu twórczości Gombrowicza, począwszy od „dyskursu obrzydzenia” w Bakakaju, poprzez opis własnego „ja” w tekstach o charakterze autobiograficznym, a skończywszy na krytyce koncepcji narodu (argentyńskiego) w Trans-Atlantyku; Silvana Mandolessi, Una literatura abyecta, s. 65-108 i 171-220.
} 
Drugim sposobem, na jaki Gombrowicz jest obecny w argentyńskiej przestrzeni, jest kondycja wygnańca, także realizowana w sposób prowokacyjny i przekorny w stosunku do jej topicznych wyobrażeń. Tradycyjnie wygnanie zakłada traumatyczne uczucie zerwania związku z ojczyzną, postrzegane negatywnie poczucie braku przynależności, połączone zwykle z intensywną pracą pamięci, która wspomnienie o ojczyźnie ma odzyskiwać i pielęgnować, często na zasadzie kontrapunktu wobec teraźniejszych doświadczeń nowego, przyjmującego kraju ${ }^{44}$. Ten romantyczny paradygmat wygnania był konstytutywny tak dla polskiej, jak - w jeszcze większym stopniu - argentyńskiej rzeczywistości, w której w sposób drastyczny zrealizował się po raz ostatni w latach dyktatury wojskowej (1976-1983). Scena kulturalna została wówczas skonfigurowana według jasnej linii podziału przestrzennego na tych, którzy zostali, oraz tych, którzy lata Procesu Narodowej Reorganizacji spędzili na obczyźnie ${ }^{45}$. Dyskusje literackie drugiej połowy lat 80 . zostały w dużej mierze zdominowane przez rozliczenia tamtego okresu, a ich ciężar skupiał się na rekonstrukcji wspólnego pola literackiego i kwestionowaniu manichejskich podziałów lub, przeciwnie, na ich podtrzymywaniu. Kwestią palącą stał się wtedy stosunek do statusu wygnańca (jego akceptacja bywała bowiem postrzegana jako milczące przyzwolenie na działania totalitarnego państwa, które to wygnanie wymusiło), z czasem ciężar dyskusji przeniósł się na decyzję o powrocie lub pozostaniu na obczyźnie.

44 Eadem, Sobre exiliados, migrantes y extranjeros: hacia una definición terminológica, „Cahiers du CRICCAL” 2010, t. 39, nr 1, s. 71-78.

45 Linię ostrego podziału nakreślił wyraźnie Luis Gregorich w artykule La literatura dividida („Clarín” 1981, 29 I, tekst dostępny w: Saúl Sosnowski (red.), Represión y reconstrucción de una cultura: el caso argentino, Eudeba, Buenos Aires 1988, s. 121-124), pojmując wygnanie w tych właśnie tradycyjnych kategoriach (nostalgii, melancholii, wyobcowania, powolnej degeneracji), deprecjonując przy tym produkcję literacką wygnańców jako oderwaną od narodowej rzeczywistości i czytelników. Tekst Gregoricha wzbudził wiele polemicznych komentarzy, kwestionujących bardziej zasadność tak jaskrawej parcelacji aniżeli dramatyczną i beznadziejną kondycję uchodźców; v. Beatriz Sarlo, El campo intelectual: un espacio doblemente fracturado oraz Noé Jitrik, Miradas desde el borde: el exilio y la literatura, w: Saúl Sosnowski (red.), Represión y reconstrucción de una cultura..., s. $95-107$ i $133-147$. 
Wszystkim tym polemikom wspólna była jednoznacznie negatywna wizja wygnania, oparta na poczuciu braku: ojczyzny, języka, kultury, czytelników etc. Nieliczne głosy afirmowały wprawdzie uchodźstwo jako możliwość zdystansowania się do własnej kultury, ale nieodmiennie w kategoriach politycznych: jako lekcję demokracji, doświadczenie wolności słowa etc. W tak ideologicznie skonfigurowanych dyskusjach, właściwych dla naelektryzowanej polityką i przemocą epoce lat 70. i 80., aktywowane w Gombrowiczowskich tekstach tropy pozostały nieznaczące i jałowe ${ }^{46}$. Atak na formę narodową poprzez afirmację „,bycia poza” (ojczyzną, narodem, kulturą), ale tylko we własnym imieniu, w liczbie pojedynczej, chybia wówczas celu i musi czekać na przygaśnięcie tego rozgorączkowania, by ukazać swój potencjał jako operująca oszczerstwem i drwiną krytyka wszelkiego (także narodowego) przyporządkowania ${ }^{47}$. Z tej perspektywy pisze o autorze Ferdydurke Juan José Saer w słynnym eseju Spojrzenie z zewnątrz z 1990 roku, w którym Gombrowiczowska lekcja wykładana jest w kategoriach czysto negatywnych jako odmowa wszelkiego samookreślenia: ,jeśli dla innych sens życia polega na wypełnianiu egzystencjalnej pustki różnymi społecznymi rolami, to dla pisarza rzecz sprowadza się do tego, by ją w sobie uchować" ${ }^{38}$. Ta programowa niepewność, stanowiąca o atrakcyjności jego stanowiska znacznie bardziej niż „odgrzewany indywidualizm”, zostaje ostatecznie

46 Wyjątkiem zaprzeczającym regule jest wydana w 1980 roku powieść Ricarda Piglii Sztuczne oddychanie, w której postać Tardewskiego (wzorowana na Gombrowiczu) staje się przyczynkiem do refleksji nad dyktaturą (v. rozdział Miejsca lektury. Gombrowicz czytany przez argentyńskich pisarzy, s. 159-318). O Gombrowiczu jako wygnańcu z wyboru, który swojego wieloletniego pobytu w Argentynie nie postrzega w terminach bieżącej polityki czy wydarzeń historycznych, kwestionując tym samym dominujące w tym kraju spojrzenie na problematykę wygnania, pisze Nicolás Hochman w artykule Exilio y paralaje („Letras Históricas” 2011, nr 4, s. 121-138).

47 Ten punkt widzenia jest dominujący w studium Pabla Gaspariniego El exilio procaz. Wymowny tytuł tej monografii (określający Gombrowiczowskie wygnanie przymiotnik procaz przełożyć można jak „,bezczelny”, „bezwstydny” czy „zuchwały") uwypukla lekceważące stanowisko Polaka w kwestii własnego wychodźstwa w Argentynie, postrzeganego bardziej jako okazja do realizacji stanowiska estetycznego aniżeli tragiczny przymus historyczny.

48 Juan José Saer, Spojrzenie z zewnątrz, s. 72. 
ukształtowana dzięki argentyńskiemu wygnaniu, które Gombrowicz konceptualizuje inaczej niż większość emigrantów: podkreślając swoją odmienność od Zachodu i odrębność własnej perspektywy, stając się w ten sposób - pisze Saer - „Znakiem, paradygmatem i symbolem” nowej kondycji wygnańca ${ }^{49}$. Sławione $w$ tytule eseju zewnętrzne spojrzenie jest totalne, bo zewnętrzne wobec wszelkich nazwań, ról społecznych, „izmów”: Gombrowicz jest obcy w najbardziej radykalnym sensie tego słowa, gdyż reprezentując tylko siebie, staje się inny od i dla wszystkich.

Ta bezwzględna odmowa przynależności do grupy (narodowej, społecznej, estetycznej etc.) pozwala z kolei innym badaczom czytać twórczość Polaka przez pryzmat psychoanalitycznej kategorii obcego nie tylko w rozumieniu przedstawiciela innej narodowości, ale przede wszystkim jako kogoś zasadniczo innego, reprezentującego negację tego, co znane, kogoś, kto swoją odmiennością zagraża integralności grupy. Krytyczna narracja o obcym toczy się w tym dyskursie nie z perspektywy jednostki wygnanej, lecz wspólnoty, która musi jej obecność tolerować. Romantyczna wizja wygania (trauma utraty korzeni) i jej modernistyczne rozwinięcie (opiewające wyostrzający zmysły dystans oraz artystyczne spojrzenie flâneura) ustępuje opowieści o zasadniczej niemożności zaakceptowania tego innego przez członków tzw. nowej ojczyzny. Cudzoziemiec, twierdzi Julia Kristeva, jest zagrożeniem dla narodowej tożsamości, będąc jednocześnie jej integralnym składnikiem, w opozycji do którego tożsamość ta się konstytuuje ${ }^{50}$. Problem w tym, że Gombrowicz nie respektuje podziału na swoich i obcych, sytuuje się poza nim. W Trans-Atlantyku, zauważa Silvana Mandolessi, w zdominowanej przez Polaków scenerii obcym jest teoretycznie Gonzalo, ale szybko okazuje się, że niepokojąco bliski postaci „Gombrowicza” w rzeczywistości jest jego alter ego. W tej postaci antagonistyczna para swój-obcy zostaje zdekonstruowana lub zignorowana, bo Gonzalo-Gombrowicz, zamiast wyraźnie sytuować się na pozycji innego, wobec którego naród definiuje swoją tożsamość,

\footnotetext{
49 Ibid., s. 78.

50 Julia Kristeva, Extranjeros para nosotros mismos, przeł. Xavier Gispert, Plaza \& Janés, Barcelona 1991, s. 103-104.
} 
okazje się niebezpiecznym, zdradliwym tworem, który przez swoje radykalne nierespektowanie dozwolonych granic seksualności, narodowości i estetyki rozsadza od środka narodową wspólnotę ${ }^{51}$.

Prezentowane w tekstach Polaka doświadczenie wygnania, odżegnujące się od retoryki utraty i nostalgii oraz opozycji narodowośćobcość, okazuje się doskonale przystawać do opisu współczesnego fenomenu migracji, który w ostatnich dekadach zdominował charakter masowych przemieszczeń, zastępując paradygmat bazujący na binarnej opozycji ojczyzna-obczyzna. Już w 1981 roku Michel de Certeau pisał o życiu jako „przekraczaniu granic” w świecie, w którym żadne uwarunkowanie - miejsce urodzenia, rodzina, własność, sieć relacji przyjacielskich i miłosnych, status zawodowy - nie determinuje jednostek tak jak wcześniej ${ }^{52}$. Trauma wygnania zostaje zastąpiona ambiwalentnym poczuciem braku identyfikacji z jakąkolwiek przestrzenią (a często także z językiem), akceptowalnym doświadczeniem bycia „pomiędzy”, które pytania o tożsamość czy przynależność narodową właściwie usuwa. Zjawisko masowych migracji pozwala mówić z kolei o deterytoralizacji (desterritorialización), czyli utracie „naturalnego" związku pomiędzy kulturą a przestrzenią społeczną i geograficzną ${ }^{53}$. Twórczość Gombrowicza - w szczególności Trans-Atlantyk - okazuje się przykładem takiej właśnie „literatury pozbawionej terytorium”

51 Silvana Mandolessi, Una literatura abyecta, s. 191-193. Kreśląc analogie pomiędzy problematycznymi granicami narodowymi w Trans-Atlantyku a pomysłem Kristevej na rozpatrywanie narracji narodowych z perspektywy cudzoziemca, Mandolessi rozwija interpretację zaproponowaną wcześniej przez Ewę Płonowską-Ziarek w szkicu Blizna cudzoziemca i barokowa fałda. Przynależność narodowa a homoseksualizm w „Trans-Atlantyku” Witolda Gombrowicza, w: eadem (red.), Grymasy Gombrowicza. W kręgu problemów modernizmu, społeczno-kulturowej roli płci i tożsamości narodowej, przeł. Janusz Margański, Universitas, Kraków 2001, s. 261-264.

52 Michel de Certeau, Californie, un théâtre des passants, „Autrement” 1981, 31 IV, s. 10-18. O współczesnej migracji pisze się oczywiście także w bardziej negatywnym tonie, dopatrując się w niej najbardziej jaskrawego przejawu nierówności społecznych wynikłych z postępującej globalizacji; v. Zygmunt Bauman, Globalizacja: i co z tego dla ludzi wynika, przeł. Ewa Klekot, PIW, Warszawa 2004. O zjawisku deterioryzacji pisze m.in. Néstor García Canclini, op. cit., s. 281-297. 
(literatura sin territorio) avant la lettre, a zerwanie z konkretnym miejscem przejawia się w niej dwupoziomowo: w konstrukcji przestrzeni oraz podmiotu opowiadającego. Trans-Atlantyk - zauważa Marta Sierra - rozgrywa się w „pomiędzy”, czyli w polskiej diasporze w Argentynie, na granicy dwóch kultur. Z jednej strony dystansuje się do kraju pochodzenia: zamiast lokować $\mathrm{w}$ nim idylliczne wspomnienia gwarantujące tożsamość, ojczyzna jest miejscem godnym raczej pożałowania niż bolesnych rozpamiętywań. Z drugiej strony Gombrowicz sytuuje akcję powieści na pampie - przestrzeni w wysokim stopniu symbolicznej (konotującej zarówno kolebkę argentyńskiej narodowości, jak i trwałą w Ameryce Łacińskiej tradycję oddalonych od cywilizacji miejsc utopijnych) - tylko po to, by jej symbolikę skompromitować chaotyczną, zgrzytliwą estetyką podważającą wszelkie stałe tożsamościowe: kulturę, płeć, naród. Brak umocowania przestrzennego przejawia się także w konstrukcji podmiotu opowiadającego - w szczególności we wspomnianej już podwójnej postaci Gombrowicza-Gonzala - podważającej całą serię dualizmów, na których wznosi się dyskurs narodowej wspólnoty argentyńskiej: swójobcy, miasto-wieś, cywilizacja-barbarzyństwo, kobiece-męskie etc. Z polskiej perspektywy krytycznej, która skłonna jest postrzegać Trans-Atlantyk jako nieprzekładalną na inne języki parodystyczną realizację sarmackiej gawędy, wydaje się interesujący fakt, że w obu deformacjach - miejsca i subiektywnego „ja” - argentyńska badaczka dostrzega tropy antycypujące latynoski neobarok, współczesną estetykę literacką, eksplorującą w sposób radykalny elementy właściwe dla swojej osiemnastowiecznej poprzedniczki: nadmiar, bezładną mieszankę, sztuczność, parodię, kpinę z czysto komunikatywnej funkcji języka, ostentacyjny, ale i dwuznaczny erotyzm ${ }^{54}$.

54 Marta Sierra, Las "Tierras de la memoria”: las estéticas sin territorio de Witold Gombrowicz y Felisberto Hernández, „Hispanic Review” 2006, t. 74, nr 1, s. 59-82. O transnarodowości (transnacionalidad) w Trans-Atlantyku pisze także Pablo Gasparini w artykule Patria y "filiatrías" (exilio y transnacionalidad en Gombrowicz, Copi y Perlongher) („Hispamérica” 2006, t. 30, nr 105, s. 45-58). Właśnie pragnienie przekraczania granic narodowych i potrzeba wypowiadania się z ,innego miejsca” są dla Gaspariniego podstawą do ustanowienia związku 
Problematyka przemieszczenia (dislocación), diaspory i podróży pozostaje znacząca dla literatury argentyńskiej w XxI wieku, straciwszy swój wymiar polityczny na rzecz estetycznego. O różnych narracjach tego „bycia poza” (estar afuera) piszą Sylvia Molloy i Mariano Siskind we wstępie do książki Poéticas de la distancia: adentro y afuera de la literatura argentina (Poetyki dystansu: ze środka i z zewnątrz literatury argentyńskiej), zbierającej świadectwa kulturowego i przestrzennego „oddalenia” kilkunastu współczesnych pisarzy ${ }^{55}$. Punktem wspólnym tych opowieści jest specyficzny protokół narracyjny, „skonstruowany w trudnej do wypowiedzenia przestrzeni pomiędzy dyskursem krytycznym i autobiografią"56, w której głównym bohaterem jest autor i jego twórczość. O Gombrowiczu wprost się nie wspomina, ale charakterystyka tego trybu narracyjnego - „pisanie zwraca się ku samemu sobie, by odtworzyć narrację własnego powstawania oraz figurę pisarza, który ją tworzy"57 - stosuje się świetnie do Dziennika.

\section{Młodość i cielesność}

Zaczynam na Retiro, sam.

Kronos

Problem ciała i cielesności otwiera z jednej strony pole badawcze zajmujące się erotyką i seksualnością, szczególnie jeśli są one ujmowane jako w jakiś sposób problematyczne, graniczne lub wstydliwe, z drugiej - kwestię przemocy, której ciało staje się ofiarą, a wymierzonej tak

między autorem Dziennika a dwoma pisarzami argentyńskimi: Copim i Néstorem Perlongherem.

55 Silvia Molloy, Mariano Siskind (red.), Poéticas de la distancia: adentro y afuera de la literatura argentina, Norma, Buenos Aires 2006, s. 9-13.

56 Ibid., s. 12.

57 Ibid. 
przez inną jednostkę, jak przez opresyjne państwo lub jego instytu$c_{j e}{ }^{58}$. Krytyka argentyńska angażuje Gombrowicza w obu tych wymiarach, uwypuklając przy tym znaczenie historycznych i przestrzennych uwarunkowań (Buenos Aires lat 40. i 50., fenomen imigracji, sukces peronizmu) i wskazując na ich obustronną zależność: z jednej strony Gombrowicza dyskurs o cielesności formuje się ostatecznie dzięki argentyńskim doświadczeniom, z drugiej - jego intuicje w tej materii okazują się doskonale opisywać rzeczywistość i późniejszą historię tego kraju.

Nie sposób roztrząsać tutaj problematycznej kwestii seksualności pisarza i jej konsekwencji dla Gombrowiczowskiego postrzegania świata - zagadnienie to zresztą zostało dogłębnie zbadane przez europejską krytykę, która skłonna albo je marginalizować, albo, przeciwnie, przydawać mu centralne znaczenie. Z argentyńskiego punktu widzenia istotna jest przede wszystkim kwestia ambiwalentnego stosunku do (homo)seksualnej tożsamości, wyrażonego nie tyle w różnorakich „zasłaniających" chwytach literackich ${ }^{59}$, co w postaci puto z Trans-Atlantyku. W swoim znakomitym studium na temat literatury argentyńskiej Carlos Gamerro - ceniony przez krytykę i wielokrotnie nagradzany pisarz - zauważa, że „pierwszą powieścią, która uległa zarazem semantycznej i fonicznej fascynacji słowem puto jest - nic zresztą dziwnego - napisany po polsku Trans-Atlantyk"60 . O ile w polskiej wersji powieść ta opowiada przede wszystkim o ciśnieniu narodowej formy, o tyle w argentyńskiej jest „powieścią o Puto”, przy czym stricte argentyńskim wkładem ma być nie tyle sama postać Gonzala, co przesadzone, skrajne reakcje, jakie wzbudza w pozostałych bohaterach. Witold raz to z lubością odtwarza wobec niego stereotypy kultury macho, innymi razy skłonny jest mu sprzyjać, zawsze jednak konformistycznie dostosowuje się do bieżącej koniunktury. Zachowując w polskim oryginale

\footnotetext{
58 Na temat przemocy jako endemicznej cechy literatury argentyńskiej v. Juan José Saer, El escritor argentino en su tradición, „La Nación” 2002, 21 vII, http://goo.gl/ tofulW, dostęp: 14 XI 2016.

59 V. Olaf Kühl, Gęba Erosa. Tajemnice stylu Gombrowicza, przeł. Krzysztof Niewrzęda, Maria Tarnogórska, wstęp Włodzimierz Bolecki, Universitas, Kraków 2005.

60 Carlos Gamerro, El puto en la literatura argentina, w: idem, Facundo o Martín Fierro. Los libros que inventaron la Argentina, Sudamericana, Buenos Aires 2015, e-wydanie.
} 
z gruntu pogardliwy termin puto, Gombrowicz zapoczątkował daleką od politycznej poprawności linię narracyjną o postaci homoseksualnej (kontynuowaną później m.in. przez Osvalda Lamorghiniego w $\mathrm{La}$ causa justa). Gonzalo, rozpatrywany jako postać niezależna od „Gombrowicza”, jako „puto w stanie wrzenia" ${ }^{61}$, ponownie spełnia funkcje „narodowotwórcze" - zajmuje to samo miejsce, jakie w XIX wieku przypadało Indianom: obcego, względem którego prawowita i czysta kultura argentyńska (istniejąca bardziej w sferze wyobrażonej niż realnej) definiuje i pielęgnuje swoją tożsamośćc2 .

Intuicje Gamerro potwierdza argentyńska krytyka akademicka, która do interpretacji trudno uchwytnej i klasyfikowanej Gombrowiczowskiej seksualności adaptuje teorię queer, kwestionującą istnienie wszelkiej znormatywizowanej tożsamości (tak homo-, jak heteroseksualnej). Najczęściej cytowaną w tym kontekście powieścią jest ponownie Trans-Atlantyk, w postaci Gonzala krzyżują się bowiem dwie linie wykluczenia: (homo)seksualna i narodowa (jest cudzoziemcem), a jego prywatne, „odrażające” (abyecto) pożądanie okazuje się nieustannie zagrażać porządkowi publicznemu i jedności wspólnoty. Eksplicytna w teoriach spod znaku queer konstatacja związków pomiędzy heteroseksualnym reżimem a kształtowaniem się narodowej tożsamości powoduje, że Gonzalo - jako jedyny pierwszoplanowy Argentyńczyk w powieści - zyskuje specyficzny potencjał polityczny: $z$ jednej strony jest typowym reprezentantem tamtejszej arystokracji, a opis pampy, na której znajduje się jego estancja, wpisuje się w tradycyjne wyobrażenia tego miejsca (pustka, przestrzeń, samotność), z drugiej posiada cechy (a raczej mieszankę cech), które tę argentyńskość ośmieszają i niweczą: ten „Metys chyba, Portugalczyk, z perskiej tureckiej matki w Libii urodzony" ${ }^{63}$ hołduje wszelkiej maści odstręczającym odstępstwom od normy (ponownie - estetycznej, seksualnej, narodowej) ${ }^{64}$.

61 Witold Gombrowicz, Dziennik 1953-1969.

62 Linię obowiązującą do roku 1983, kiedy upada dyktatura, a w społeczeństwie argentyńskim następuje „przesyt tradycyjnymi formami represji [...] i puto zaczyna, najpierw powoli, potem w zawrotnym tempie, zmieniać się w geja”; ibid.

63 Idem, Trans-Atlantyk, Wydawnictwo Literackie, Kraków 1986, s. 42.

64 Silvana Mandolessi, Una literatura abycta, s. 191-205; José Amícola, Estéticas bastardas, s. 115-116. Od queerowych interpretacji autora Dziennika dystansuje 
Interpretacja Gombrowiczowskiej erotyki zmienia się wraz ze zmianą korpusu tekstów, które mają ją reprezentować: jeśli bowiem porzucić Trans-Atlantyk i barwną postać Gonzala (której wzorem mógł być tak Gombrowicz znany z Kronosu, jak Vigilio Piñera) na rzecz Dziennika, centralnym tematem staje się już nie ciało męskie, ale ciało młode, niedojrzałe i plebejskie. Ta fascynacja nizinami społecznymi zbiega się w paradoksalny sposób ze znienawidzonym przez Polaka peronizmem, który masom biedoty, zwanym pogardliwie cabecitas negras, zaoferował w latach 40. niespotykany wcześniej awans społeczny. Rozpatrywanie twórczości tego pisarza w kategoriach polityczno-społecznych jest nader ryzykowne, ale trudno nie zauważyć, że dokonana w Dzienniku pod hasłem „Retiro” estetyzacja młodego plebsu posiada swój wymiar polityczny stricte argentyński. Álvaro Abós następująco ujmuje ten - przez samego Gombrowicza niezamierzony - związek pomiędzy jego koncepcją kultury a społeczną sytuacją Argentyny lat 40. i 50.:

Gombrowicz szczycił się swym estetyzmem, pogardą dla praw postępu i problemów społecznych. Jednak przez swój pociąg do młodych, zapomnianych proletariuszy - erotyczny nie społeczny - znalazł się, paradoksalnie, w samym centrum wydarzeń mających doprowadzić do głębokich socjalnych przemian. Czyż „owa niewyznana, milcząca młodość kraju", z jaką Gombrowicz obcował, nie była tą samą, która od 1945 roku oklaskiwała Peróna na placach i ulicach miasta? Czyż tematyka, którą Gombrowicz wyłożył w Dzienniku i którą wykorzystał w swoich powieściach: brak dojrzałości, wyzbycie się korzeni, niedoskonałość - nie urosła do rangi symbolu w chwili, gdy wypowiadały się polityczne masy, choć ich życie było tylko epizodem, ograbione ze swej ziemi, wyobcowane w samym środku miejskiej kultury? ${ }^{65}$

się Pablo Gasparini, przy czym granice tej teorii wyznacza on dość wąsko, identyfikując ją właściwie z gay studies. Jego własne rozważania, w których akcentuje się próby destabilizacji wszelkich norm i standardów postępowania, zdają się zresztą wpisywać w krąg zainteresowań krytyki queerowej; v. Pablo Gasparini, El exilio procaz, s. 242-243.

65 Álvaro Abós, Kwartet z Buenos Aires, przeł. Justyna Ziarkowska, „Odra” 1995, nr 2, s. 41. 
Z polskiej perspektywy nader symboliczną postacią jest parobek z Ferdydurke, tyle że już w 1939 roku na stałe ustępuje on miejsca marynarzowi, żołnierzowi lub kolejarzowi, a relacja niższość-wyższość w przedwojennej rzeczywistości uprzywilejowująca Gombrowicza zostaje zniesiona (wszyscy są równie „nisko”) lub zgoła odwrócona. Literacki projekt Gombrowicza jest oczywiście pozbawiony politycznych intencji, czy to w wersji criollistowskiej (egzaltacja ludu jako wartości kulturowej), czy peronistowskiej (młodość jako siła polityczna), i pozostaje skoncentrowany na ciele jako podstawowej opozycji wobec ducha, a więc na pożądaniu i zmysłowości. Jeśli jednak „wmontować” ten zachwyt nad młodym, plebejskim ciałem w historię Argentyny - jak czyni to tamtejsza krytyka - okaże się, że staje się on interpretacyjnie płodny w dwóch kierunkach: w polityczno-kulturowej konfrontacji pomiędzy „młodymi” a „starymi” oraz w relacji do miasta.

Gombrowiczowski postulat rewaloryzacji młodości p r z e ciw ko dojrzałości musiał być w Argentynie połowy xx wieku postrzegany jako polityczny głównie dlatego, że domagał się odwrócenia społecznej hierarchii dokładnie wtedy, gdy peronizm społeczny ład starej epoki faktycznie zdemontował. Zapoczątkowane w tym okresie polityczno-społeczne tarcia, nierzadko przyjmujące formę przemocy bezpośredniej, w późniejszych dekadach kształtują się jako konflikt pokoleniowy, w którym „młodzi” to peronistowska guerrilla (zwana zresztą Juventud Peronista, czyli młodzieżówką), a „starzy” - establishment polityczno-kulturalny. Dwunasta z dwudziestu „peronistowskich prawd” głosiła, że „w Nowej Argentynie dzieci są jedynymi uprzywilejowanymi" ${ }^{66}$. Dlatego teorie spod znaku psychoanalizy upatrują w kategorii „dzieciobójstwa” antropologicznego klucza do zrozumienia struktury społecznej, a Gombrowicz zostaje prekursorem także i na tym polu, zważywszy na fakt, że metaforyczne lub dosłowne dzieciobójstwo występuje na kartach jego tekstów.

66 Juan Domingo Perón ogłasza je publicznie 17 października 1950 roku. Ujęte w dwadzieścia jedno- i dwuzdaniowych punktów, miały prostym językiem wykładać ideologiczne podstawy peronistowskiej doktryny. 
Trans-Atlantyk lub Biesiada u hrabiny Kottubaj są czytane w opozycji do opublikowanej w 1969 roku powieści Adolfa Bioya Casaresa Diario de la guerra del cerdo (Dziennik świńskiej wojny), która konflikty społeczne lat 6o. opisuje właśnie jako dziką przemoc wymierzaną „starym” przez „młodych”67. Z kolei kategoria „synczyzny”, oparta na demaskatorskim przekonaniu, że naród jest wymyśloną przez „starych” konstrukcją wzniesioną na krwi przelanej przez „młodych”, okazuje się także przydatna w interpretacjach wojny o Falklandy-Malviny z 1982 roku $^{68}$.

Rozwinięciem problematyki cielesności w jej wymiarze polityczno-społecznym jest nowe zobrazowanie przestrzeni miejskiej, którą młode, plebejskie ciało obejmuje w posiadanie. „Argentyńska” twórczość Gombrowicza - Dziennik, Trans-Atlantyk, także Kronos - osadzona jest w Buenos Aires, lecz nie w eleganckich dzielnicach klasy średniej, jak Palermo czy Recoleta, ale w podejrzanej strefie zwanej skądinąd el Bajo (czyli „niską”, ze względu na opadające ku Río de la Plata ukształtowanie terenu). Dla romantyków miejska, wielokulturowa polis była korelatem nowoczesności i opozycją dla wiejskiego barbarzyństwa: w XIX wieku „miasto samo w sobie było konstrukcją o charakterze pedagogicznym. Przestrzeń udzielała lekcji zachowania i funkcjonowała niczym mechanizm edukujący. Mieszkanie w mieście było etymologicznie i symbolicznie aktem ucywilizowania" ${ }^{69}$. Przeciwnie w obu Gombrowiczowskich dziennikach - oficjalnym i nieoficjalnym - stolica jest scenerią pokątnych transakcji kulturowych, nielegalnych spotkań i wstydliwych kontaktów. W Kronosie mamy do czynienia z miejskim homo errans, człowiekiem, który określa

67 V. Germán García, Arnaldo Rascovsky, una controversia silenciada, w: idem, El psicoanálisis y los debates culturales. Ejemplos argentinos, Paidós, Buenos Aires 2005, s. $183-185$.

68 Rodolfo Fogwill, autor pierwszej fikcji inspirowanej tymi wydarzeniami, Los pichy-cyegos, był admiratorem Trans-Atlantyku i występuje w poświęconym tej powieści odcinku z serii El libro perdido, cyklu krótkometrażowych filmów wyprodukowanych przez argentyńską Bibliotekę Narodową i Telewizję Publiczną (http://goo.gl/PpF5zw, dostęp: 4 I 2016).

69 Beatriz Sarlo, Buenos Aires: el exilio de Europa, s. 38. 
się w bezpośrednim odniesieniu do przestrzeni, znaczonej trasami jego erotycznych wędrówek: „[...] idę na Retiro, spotykam Alda. W środę Raúla na przystanku Retiro. W czwartek na Esmeralda: Juana Antonia. Lepiej się miewam nieco. W sobotę Plaza Italia Jaime. W niedzielę deszcz. Poniedziałek, Jorge na Corrientes [...]. Wtorek Antonia Santa Fe. Czwartek Domingo na Corrientes"70 etc. Podobnie zresztą w Dzienniku potrzeby ciała wymagają przemieszczenia, ruchu, poszukiwań, co widać w zwrotach opisujących doświadczenia Retiro: „udałem się na Retiro”, „włóczyć się” po Retiro, w które „mnie popchnął splot tendencji" ". Gombrowicz sytuuje się tym samym w tej linii argentyńskich pisarzy (jak Roberto Arlt, a później Carlos Correas), dla których narracja autobiograficzna, często skandalizująca, krzyżuje się z opisem miasta - ulic, placów, skwerów, parków, portowych spelunek - wszystkich tych szemranych miejsc, które są scenerią poniżenia i spotkania z młodym (męskim) ciałem ${ }^{72}$. „Przywołuje pamięć o biedzie między Corrientes 1258 i Tacuarí 242, gdzie schronienie znalazło najróżniejszej maści pospólstwo, ze zdrowym dystansem kogoś, kto - znajdując się blisko, stopiony z tym, co nasze - umiał patrzeć z daleka”73. „Gombrowiczem” opowiada się więc Buenos Aires młode, imigranckie i witalne, a ponadto opowiada

70 Witold Gombrowicz, Kronos, wstęp Rita Gombrowicz, posł. Jerzy Jarzębski, przypisy Rita Gombrowicz, Jerzy Jarzębski, Klementyna Suchanow, Wydawnictwo Literackie, Kraków 2013, s. 163.

71 Idem, Dziennik 1953-1969.

72 Dlatego np. Javier Fernández wskazuje na Gombrowicza jako poprzednika narracji o mieście Carlosa Correasa; Javier Fernández, Carlos Correas: un autorretrato en la ciudad, w: Miguel Vitagliano (red.), Boedo. Políticas del realismo, Título, Buenos Aires 2012, s. 238-239. V. Pablo Gasparini, Gombrowicz y la ciudad: las oscuridades de Retiro, w: Daniel Balderston et al., Literatura y otras artes en America latina. Actas del XXXIV Congreso del Instituto Internacional de Literatura Iberoamericana, Iowa City, 2 al 6 de julio de 2002, t. 1, University of Iowa, Iowa 2004, s. 177-180.

73 Adrián Cangi, Estampas de la decepción, „Revista La Biblioteca” 2008, nr 7, s. 83. Autor omawia literackie obrazy Buenos Aires u pięciu pisarzy: Roberta Arlta, Ezequiela Martíneza Estrady, Witolda Gombrowicza, Néstora Perlonghera i Carlosa Astrady. 
się specyficznym trybem narracyjnym, w którym percepcja miasta jest w gruncie rzeczy opisem kondycji samego „ja”, „konturem jego charakteru, skonkretyzowaniem ducha"74.

\section{O języku i przekładzie}

Dość mi było na jeden moment związać się duchowo z Retiro, a język kultury zaczynał brzmieć w uszach fałszywie i pusto.

Dziennik 1953-1969

O tym, że język nie jest transparentnym instrumentem komunikacji, wiadomo przynajmniej od 1906 roku, kiedy Ferdinand de Saussure rozpoczął swoje słynne wykłady na uniwersytecie genewskim. W tym samym okresie przekonanie o „nieprzezroczystej” naturze tego medium stało się konstytutywne dla ruchów awangardowych - dla Gombrowicza (choć już nie dla Borgesa) język i językowa przemoc jest zarówno fundamentem formy, jak i narzędziem jej podważania ${ }^{75}$. Z czasem przekonanie o performatywnej funkcji języka okazuje się punktem wspólnym różnych gałęzi humanistyki, niezależnie od tego, czy pragną one akcentować psychologiczny, społeczny czy filozoficzny aspekt ludzkiego istnienia. "Język i językowy obraz świata kulturowo reprezentują rzeczywistość, wartościują ją społecznie, wyznaczają człowiekowi miejsce i sposoby zachowania w niej, a występujące w nich kategoryzacje i stereotypy [...] mają funkcje kognitywne, afektywne i społeczne"76.

\footnotetext{
$74 \quad$ Ibid., s. 84.

75 „Uwrażliwienie” na kwestię języka jest - jak zauważa José Amícola - jednym z punktów, w których estetyki Gombrowicza i Borgesa oddalają się od siebie. Argentyńczyk pozostaje bowiem obojętny na odkrycie roli słowa w procesie konstruowania tożsamości (tak zbiorowej, jak indywidualnej): „dla niego gry językowe pozostaną tym właśnie: grami, które wyrzucił jako zbędny balast wraz ze swoją młodością i fascynacją surrealizmem”; José Amícola, Estéticas bastardas, s. $89-90$.

76 Eugenia Prokop-Janiec, op. cit., s. 418.
} 
Krytyka argentyńska w nikłym stopniu odnotowuje sprawczą rolę języka w Gombrowiczowskim dziele, nie poświęca wiele miejsca „językowym fabułom", w których dramat zarysowuje się właśnie wokół mówienia, słowa zaś, a nawet tylko ich brzmienia, narzucają interpretację faktów ${ }^{77}$. Przekonanie o nieprzezroczystej naturze komunikacji językowej oraz o tym, że langue i parole są podstawowym nośnikiem tożsamości jest dla niej jednak znaczące na poziomie bardziej systemowym - języków narodowych. Ich opresyjny, determinujący charakter ujawnia się przede wszystkim w momentach językowej transgresji, doświadczanej przez pisarzy „wyrzuconych” poza język ojczysty i określonych przez George'a Steinera mianem ekstraterytorialnych ${ }^{78}$, których twórczość, językowo bezdomna, niezakorzeniona w konkretnym lingwistycznym obszarze, jest - zdaniem amerykańskiego krytyka - siłą napędową współczesnej literatury. Gombrowicz nie jest oczywiście typowym przykładem językowego wygnańca, jak Nabokov lub Beckett; przeciwnie - dla Steinera pozostałby tylko jednym z twórców „rozpaczliwie przywiązanych do języka ojczystego"79. Sam Gombrowicz w Dzienniku kilkakrotnie odnosi się do własnej (nie)znajomości hiszpańskiego, hołubi ją i podkreśla: w 1940 roku wygłasza w tym języku odczyt Doświadczenia i problemy Europy najmniej znanej, choć, jak sam deklaruje, właściwie nim nie włada i całkowicie nie rozumie oburzonej reakcji publiczności. W roku 1947 tłumaczy Ferdydurke we współpracy ze słynnym komitetem, bagatelizując swój

77 V. Jerzy Jarzębski, Między chaosem a formą, w: Bolesław Faron (red.), Prozaicy dwudziestolecia międzywojennego, Wiedza Powszechna, Warszawa 1974, s. 198-200. Termin „fabuła językowa” zaczerpnęłam od Michała Głowińskiego (Straszny piatek $w$ domu u hrabiny. O „Biesiadzie u hrabiny Kotłubaj”, w: idem, Gombrowicz i nadliteratura, Wydawnictwo Literackie, Kraków 2002, s. 16-43). Można podejrzewać, że intuicje dotyczące sprawczej roli języka są jednym z tych elementów Gombrowiczowskiej prozy, które zostają bezpowrotnie utracone w tłumaczeniu, przynajmniej w tej mierze, w jakiej ujawniają się w brzmieniu słów i specyficznej konstrukcji gramatycznej (takiej jak rzeczowniki odsłowne); v. Jerzy Jarzębski, op. cit.

78 V. George Steiner, Extraterritorial. Ensayos sobre literatura y revolución del lenguaje, przeł. Edgardo Russo, Adriana Hidalgo, Buenos Aires 2000.

79 Ibid., s. 21. 
wkład w to przedsięwzięcie: „naprzód ja tłumaczyłem, jak mogłem, z polskiego, a potem zanosiłem maszynopis do kawiarni Rex, gdzie moi przyjaciele argentyńscy przerabiali wraz ze mną zdanie po zdaniu, szukając słów właściwych, walcząc ze składnią, z nowotworami, $\mathrm{z}$ duchem języka" ${ }^{80}$. Na krótko przed jej wydaniem wygłasza Przeciw poetom, zaczynając ponownie od zaznaczenia językowego niedostatku:

Byłoby rozsądniej z mojej strony nie zagłębiać się w tematy drastyczne, gdyż moja sytuacja nie jest specjalnie korzystna. Jestem całkiem nieznanym cudzoziemcem, brak mi prestiżu, a mój hiszpański jest paroletnim dzieckiem, które ledwo umie mówić. Nie potrafię układać zdań mocnych ani zręcznych, ani wytwornych czy wyrafinowanych, ale kto wie, czy ta przymusowa dieta nie okaże się dobra dla zdrowia? Czasem chciałbym wysłać wszystkich pisarzy świata za granicę, poza ich własny język, poza wszelkie ozdoby i filigrany słowne, aby przekonać się, co by $\mathrm{z}$ nich wtedy zostało ${ }^{81}$.

W ostatnim zdaniu Gombrowicz zdaje się przyklaskiwać Steinerowi - wyobcowanie z własnego kodu językowego stwarza nową, rewolucyjną literaturę, nawet jeśli (dodaje autor Dziennika) nie towarzyszy mu idealne wyczucie języka „przyjmującego”. Z tej perspektywy znamienny wydaje się postulat, który formułuje Pablo Gasparini w artykule poświęconym twórczości argentyńskiego pisarza włoskiego pochodzenia Antonia Porchii oraz Gombrowicza właśnie, a mianowicie konieczności przedefiniowania lub rozszerzenia Steinerowskiej eksterytorialności. O ile w zamyśle amerykańskiego krytyka pojęcie to stosowało się wyłącznie do figury cudzoziemca-poligloty, któremu przyznaje się prawo do kultywowania własnej różnicy kulturowej, o tyle w nowym ujęciu powinna uwzględniać kondycję imigranta, od którego oczekuje się właśnie asymilacji i rozmyślnego wyzbycia się poprzedniej kultury, języka etc. Paradygmatyczna (Borgesowska) definicja kultury argentyńskiej

\footnotetext{
80 Witold Gombrowicz, Dziennik 1953-1969.

81 Polski przekład podaję za: Rita Gombrowicz, Gombrowicz w Argentynie. Świadectwa i dokumenty 1939-1963, przeł. Zofia Chądzyńska, Anna Husarska, Wydawnictwo Literackie, Kraków 2005, s. 107.
} 
jako heterogenicznej i kosmopolitycznej, uprawnionej do dowolnego korzystania z tradycji europejskiej, powinna - zdaniem Gaspariniego - uwzględnić fakt, że „ta eksterytorialność została zbudowana ta kże na utracie, przemilczeniu oraz konsekwentnym nawrocie tego, co pozornie porzucone lub zniszczone"82. To, co z argentyńskiej kultury wyparte - jak cocoliche $e^{83}$, którym w pierwszych dekadach xx wieku mówiła prawie połowa mieszkańców Buenos Aires - odzyskuje sztuka niższa, przede wszystkim teatr z rodzaju grotesco rioplatense, którego centralnym tematem jest właśnie niedostatek języka, utrudniająca komunikację mieszanka kodów, językowe barbarzyństwo, podważające normy i niemożliwe do zasymilowania. Przedstawione w nich perypetie bohaterów mają swoje źródło w ubóstwie językowym, które umacnia tylko ubóstwo materialne i kulturowe. W cytowanym wyżej fragmencie, datowanym na rok 1947, kiedy czasy świetności grotesco rioplatense już minęły, Gombrowicz broni podobnej niedoskonałości formy, pielęgnuje ją w sobie na przekór stopniowej językowej asymilacji w hiszpańskim. Deklarowany przezeń po wielokroć i na wyrost brak językowy z czasem staje się bardziej strategią niż faktem, bo rzekoma słabość pozwala wyrazić niedojrzałość, świadomą rezygnację z elegancji, obycia i gładkości ${ }^{84}$. Ten aspekt lingwistycznego uwikłania

82 V. Pablo Gasparini, La extraterritorialidad del pobre, w: Nicolás Hochman (red.), Pensar el afuera, Kazak Ediciones, Mar del Plata 2010, s. 119; wyróżnienie w oryginale.

83 Język typu pidgin, mieszanka hiszpańskiego z różnym dialektami włoskimi.

84 Z czterech strategii językowych, które Claudio Guillén wyróżnia u autorów żyjących poza rodzimym krajem - obojętność dla języka B i „rezydowanie” wyłącznie w A; pozostawienie języka A jako języka literatury przy jednoczesnym przyswojeniu języka B; porzucenie języka A na rzecz języka B; wybranie języka C jako „języka kultury” niezależnie od miejsca zamieszkania - Gombrowicz wybiera opcję drugą, rodzaj „dwujęzyczności utajonej”. Guillén odnotowuje także potencjał twórczy tej niedoskonałej dwujęzyczności: „Jeśli z jednej strony dwujęzyczność wygnańca skutkować może potknięciami i cierpieniami, to z drugiej często rozbudza świadomość języka i jednocześnie, albo w konsekwencji, rodzi zobowiązanie wobec prawdy i literatury"; Claudio Guillén, Múltiples moradas. Ensayo de Literatura Comparada, Tusquets, Barcelona 1998, s. 76. O Gombrowiczu Guillén wspomina kilkakrotnie, chętnie cytując Dziennik, jednak nie pisze 
Gombrowicza będzie frapować Argentyńczyków (m.in. Ricarda Piglię), szczególnie w kontekście komitetowego przekładu Ferdydurke, łamiącego uzus językowy i przekładowy na różne sposoby.

Gdy w 1947 Gombrowicz publikuje argentyńską wersję tej powieści, w Buenos Aires trwa przekładowy boom, napędzany działalnością założonego w 1933 roku przez Victorię Ocampo wydawnictwa "Sur” (wzorowanego na podobnych przedsięwzięciach europejskich). Konsekwencją zapoczątkowanej wówczas na szeroką skalę praktyki przekładów na hiszpański europejskich i północnoamerykańskich klasyków był powolny wzrost prestiżu tłumacza. Jego nazwisko zaczęło pojawiać się pod nazwiskiem autora i tytułem dzieła, co stanowiło zasadnicze novum w porównaniu z wcześniejszymi zwyczajami przemilczania wszelkich odniesień do autora przekładu oraz pozwalało mu na stopniowe wypracowanie swojej „marki”. W kolejnych dekadach jego prestiż i autorytet w argentyńskim polu literackim znacząco wzrastają. W działalności przekładowej, ściśle podległej polityce wydawniczej, najlepiej widać bowiem bieżące priorytety pola: co warto tłumaczyć, co skłonni są docenić czytelnicy, którzy autorzy postrzegani są jako centralni $^{85}$. W latach 30. i 40. przekładem intensywnie zajmują się np. Borges (tłumaczy m.in. Woolf, Faulknera i Gide’a), José Bianco (Becketta i Nathaniela Hawthorne’a), a także sama Ocampo (przekłada Alberta Camusa i Geneta, i to pomimo przekonania, że przekład nieuchronnie zubaża oryginał), co w oczywisty sposób nobilituje pracę tłumacza, który zaczyna cieszyć się statusem „drugiego autora”. Środowisko „Sur” determinuje wówczas, które teksty obce mają prawo stać się, poprzez przekład, częścią literatury argentyńskiej, a także jak wygląda uprawniona strategia tłumaczeniowa. Nietrudno dostrzec, że proces powstawania argentyńskiej wersji Ferdydurke, w którym, bywało, interweniowali nawet przypadkowi klienci Rexa, dalece odbiegał od

o nim w kontekście wygnania (sporo miejsca poświęca za to Mickiewiczowi i Norwidowi).

85 Patricia Wilson, Página impar: el lugar del traductor en el auge de la industria editorial, w: Sylvia Saítta (red.), Historia critica de la literatura argentina, t. 9, Emecé, Buenos Aires 2004, s. 125. 
tego wzoru, łamiąc po kolei przyjęte procedury postępowania (kryteria selekcji, profesjonalizację i autorytet tłumacza, doskonałą znajomość języka wyjściowego i docelowego). Dlatego też wzmianka o tym tłumaczeniu - będącym skądinąd radykalną realizacją Borgesowskiej idei niewiernego przekładu - pojawia się w każdej nieomal pracy na temat polityki tłumaczeniowej w Argentynie, jako przykład translatorskiej transgresji, początek nowej, antykanonicznej tradycji literackiej.

Z zupełnie innej perspektywy, właściwej dla humanistyki przełomu tysiącleci, geneza argentyńskiej Ferdydurke bywa także czytana jako casus mieszczący się w zakresie studiów postzależnościowych, traktujących o możliwych dyskursach na temat Innego. W tej interpretacji, której autorką jest Nora Catelli, powieść Gombrowicza zachowuje wprawdzie swoją „estetyczną ekscentryczność” - udziwnioną składnię, neologizmy, potknięcia stylistyczne, które złożyły się na jej „antykanoniczny” walor - ale staje się jednocześnie przykładem na „ideologiczną” lub „kulturową” asymilację ${ }^{86}$. Argentyńska badaczka zestawia Ferdydurke z drugim wydaniem Manual de la lengua pampa (Podręcznikiem języka pampa), zbiorem kilkunastu krótkich narracji i dialogów z życia społeczności tubylczej. Wydanie Z 1941 roku jest dwujęzyczne - język Indian jest bowiem postrzegany jako tak różny od hiszpańskiego, że przekład bez transkrypcji oryginału wydaje się niemożliwy: „wizualizacja języka innego jest konsekwencją jego totalnej obcości (język indiański jest całkowicie obcy), dwujęzyczna scenografia staje się natomiast zbędna tam, gdzie kulturowe doświadczenie tradycji, świata i bogów jest wspólne"87. Takim przykładem jest Ferdydurke - polski, choć lingwistycznie odległy od hiszpańskiego, nie wymaga unaocznienia, transkrypcji, jesteśmy bowiem „braćmi w semantycznym doświadczeniu” (camaradas de la experiencia semántica $)^{88}$. Ewentualne napięcia pomiędzy językiem wyjściowym a docelowym, zgrzyty wersji hiszpańskiej,

\footnotetext{
86 Nora Catelli, Rastros de la lucha: traducciones, versiones y menciones en la cultura argentina, „Punto de Vista” 1999, nr 64, s. 1-5.

87 Ibid., s. 3.

88 Ibid.
} 
„Ślady walki” (rastros de la lucha), o których pisze Ferrater ${ }^{89}$, są dla Catelli we w n ęt r z ny m epizodem literatury argentyńskiej: polski i hiszpański pokojowo współżyją „w literackim doświadczeniu, ponieważ gra nie toczy się o przeżycie. A ściślej, gra o przeżycie już się skończyła. Została wygrana"90. Gombrowicz konotuje bowiem obcość względną, asymilowaną, obcość imigrantów; Indianie - obcość totalną. Z tej perspektywy język Ferdydurke - o którym Piglia pisze, że jest „spazmatyczny, sztuczny”, „brzmi jakby za chwilę miał się rozpaść" ${ }^{\prime 1}$ - traci swój transgresyjny charakter, służąc w gruncie rzeczy wykazaniu giętkości języka przyjmującego, czyli hiszpańskiego.

\section{Opowieść o „ja”}

Uciążliwa i dręcząca praca... bo, żeby zbliżyć się do prostoty i naturalności musiałem nakładać maski i to była chytrość, przebiegłość, zgrzyty, fałsze, przecież mówię, że nie zdołałem niczego osiągnąć, a tylko zdobyłem pewne przybliżenie...

Testament. Rozmowy z Dominique de Roux

Ferdydurke funkcjonuje w argentyńskiej przestrzeni literackiej nie tylko jako gotowy do interpretacji tekst, ale także jako specyficzna praktyka tłumaczenia, jako wydarzenie, które abstrahując od „wierzchniej” aury sensacji, doraźnej boutade literackiej, ujawnia a posteriori swoje znaczenia dla sposobu, w jaki tamtejsza literatura postrzega samą siebie, definiuje własne granice i wartości. W tym sensie Ferdydurke jest częścią większego projektu, szerzej zakrojonego programu, który skrótowo nazwać wypada „Witold Gombrowicz” i który zwyczajowo kataloguje

\footnotetext{
89 Chodzi m.in. o alternację form voseo i tuteo. Catelli (ibid.) cytuje artykuł Ferratera pt. Witold Gombrowicz, opublikowany w czasopiśmie „Presència” 1966, nr 39.

90 Nora Catelli, op. cit., s. 4.

91 Ricardo Piglia, Czy istnieje powieść argentyńska? Borges a Gombrowicz, przeł. Klementyna Suchanow, Krystian Radny, „Literatura na Świecie” 2001, nr 4, s. 70.
} 
się pod szyldem autofikcji. Opowieść o sobie samym (konstrukcja samego siebie) ujawnia się w twórczości Gombrowicza na dwa sposoby: w Dzienniku oraz innych tekstach (pseudo)autobiograficznych (takich jak Testament. Rozmowy z Dominique de Roux, Wspomnienia polskie, także niedostępny po hiszpańsku Kronos) oraz w powieściach, $\mathrm{w}$ figurze utożsamienia autora $\mathrm{z}$ narratorem, będącym jednocześnie jedną z pierwszoplanowych postaci.

Zainteresowanie tym aspektem Gombrowiczowskiego dzieła jest niewątpliwie wynikiem mody na autofikcję, której pierwsze teoretyczne ujęcia, powstałe w latach 7o. na gruncie francuskim ${ }^{92}$, w ostatniej dekadzie tryumfalnie - jeśli przyjrzeć się liczbie publikacji i kongresów - przeniknęły do krytyki hiszpańskojęzycznej ${ }^{93}$. Ogólnie rzecz ujmując, w tym rozmytym i trudno definiowalnym trybie narracyjnym ujawnia

92 Mam na myśli analizy teoretycznoliterackie powstałe wokół powieści Serge’a Doubrovsky'ego Fils, w tym tekst samego Doubrovsky’ego Autobiographie/vérité/ psychanalyse napisany w 1980 roku, opublikowany w: idem, Autobiographiques: de Corneille à Sartre, PUF, Paris 1988, s. 61-79.

93 V. kompilację teoretycznoliterackich tekstów o autofikcji Any Casas La autoficción. Reflexiones teóricas (Arco/Libros, Madrid 2012), zawierającą przede wszystkim tłumaczenia krytyków francuskich, lub tom pod redakcją Very Toro, Sabine Schlickers i Any Luengo La obsesión del yo. La auto(r)ficción en la literatura española y latinoamericana (Iberoamericana, Madrid 2010). Krytyka hiszpańska - wzorem francuskiej - charakteryzuje się ambicją definiowania tego wieloaspektowego fenomenu, szeroko zakrojoną próbą katalogowania i typologii autofikcjonalnych paktów, argentyńska jest mniej systematyczna; v. przede wszystkim studia Alberta Giordano, m.in. La contraseña de los solitarios. Diarios de escritores, Beatriz Viterbo, Rosario 2012.

O sukcesie autofikcjonalnej narracji poza środowiskiem specjalistów i akademii świadczy artykuł Winstona Manrique Sabogala El yo asalta la literatura („Ja” naciera na literaturę), opublikowany w literackim dodatku dziennika „El País”, „Babelia” (2008, 13 IX), https://goo.gl/GFFVBC, dostęp: 24 XI 2016. Innym dowodem na to, że zwrot autobiograficzny dotarł do literatury obszaru języka hiszpańskiego jest znaczne powiększenie się korpusu tekstów diarystycznych, także o dzienniki opublikowane pośmiertnie, co do których nie wiadomo, czy w zamyśle autora były przeznaczone do wydania, czy też ich upublicznienie jest wynikiem panującej na ten gatunek literacki mody (m.in. dzienniki Bioya Casaresa, Alejandry Pizarnik, Juana Ramóna Ribeyro, Alfonsa Reyesa). V. Daniel Mesa Gancedo, Diarios personales hispanoamericanos en el siglo XXI, „Cuadernos Hispanoamericanos" 2013, nr 751, s. 7-23. 
się odwrót od narzuconej przez strukturalizm metody badawczej, która ograniczała się do badania ,ja” tekstowego, ucinając jako jałowe wszelkie spekulacje czy odniesienia do uwarunkowań wobec tekstu zewnętrznych. W autofikcji podmiot literacki powraca - po ogłoszonej przez Barthes’a „śmierci autora”, zainspirowanej o wiele wcześniejszą krytyką kartezjańskiego cogito - ale inaczej: nie jako wytwórca fikcyjnego świata, ale ktoś, kto p o p r z e z tekst buduje swoją tożsamość. „Miejscem narodzin podmiotu jest tu akt narracji, któremu podmiot »zawdzięcza siebie«, przy czym [...] nie ma on nigdy charakteru w pełni samodzielnego, lecz jest także współtworzony przez narracje innych" ${ }^{\text {94 }}$. Porządek tekstowy (literatury) i pozatekstowy (życia) mieszają się ze sobą, ponieważ bycie sobą to pisanie o sobie, doświadczanie siebie jest równoległe z budowaniem własnego ,ja” w procesie opowiadania. Odrodzeniu podmiotu jako narracyjnej konstrukcji sprzyja także kultura masowa, która - jak pisał Walter Benjamin - w pierwszych dekadach xx wieku spowodowała stopniowe przenoszenie aury $\mathrm{z}$ dzieła sztuki na sam proces tworzenia i w konsekwencji na artystę. „Przejście od estetyki dzieła do estetyki działania", zacierające rozróżnienie pomiędzy dziełem a życiem, następuje już w epoce pierwszej awangardy i skutkuje demokratyzacją sztuki: dowolna rzecz może dostąpić rangi dzieła, a każdy może być artystą ${ }^{95}$. Następnie w kulturze masowej epoki postindustrialnej opowieść o artyście

94 Andrzej Zawadzki, Autor. Podmiot literacki, w: Michał Paweł Markowski, Ryszard Nycz (red.), op. cit., s. 243. Tzw. narracyjna koncepcja podmiotu jest tylko jedną z kilku wyróżnionych w tym artykule form „powrotu autora”, charakterystyczną właśnie dla twórczości Gombrowicza. Na gruncie literatury argentyńskiej także rejestruje się tzw. zwrot autobiograficzny w narracji powieściowej: „Także powieść argentyńska zniosła zakaz autobiograficzny. Przegląd prozy najnowszej - powieści z drugiej połowy 2007 [...] - skłania do postawienia pytania, które krytyka wyrzuciła ze swego zwyczajowego spisu: gdzie jest autor? Życie rzeczywiste miesza się tam z wymyślonym, nadając osobie autora mniejszą lub większą spójność oraz skłaniając do wyciągania sprzecznych wniosków”; Graciela Speranza, ¿Dónde está el autor? Sobre el fantasmático regreso del autor a la ficción, „Quimera” 2008, nr 301, s. 25.

95 Magdalena Popiel, Poetyka autokreacji. Narracje doświadczenia artystycznego, w: Teresa Walas, Ryszard Nycz (red.), Kulturowa teoria literatury 2. Poetyki, problematyki, interpretacje, Universitas, Kraków 2012, s. 85. 
demokratyzuje się z kolei w opowieści narcystycznej: „artysta awangardowy stał się w tym ujęciu prefiguracją człowieka ponowoczesnego"96, który z własnego życia ma tworzyć dzieło sztuki, a k o n st r u o w a n i e tożsamości, autokreacja okazuje się procesem koniecznym i wymagającym $^{97}$. Ten wektor kulturowego zainteresowania należy, jak sądzę, uwzględnić choćby jako tło dla badań nad tymi formami literackimi, które - jak dzienniki, wspomnienia, wywiady, relacje z podróży - oferują warunki idealne dla konstruowania opowieści o sobie.

W literaturze argentyńskiej narracje zorganizowane wokół podmiotu-autora, pojmowanego jeszcze w sposób esencjalistyczny (jako jednostka autonomiczna, istniejąca niezależnie od tekstu, w którym tylko opisuje siebie innym), mają status mitów założycielskich: twórczości Dominga Faustina Sarmienta i Lucia Victoria Mansilli są stricte autobiograficzne, nawet jeśli opowieść o sobie traktuje się w nich jako przyczynek do opowieści o własnym kraju. O ile autorom tym można jeszcze zarzucić naiwne przekonanie o niezapośredniczonym (przez język, struktury nieświadomości, społeczne uwarunkowania) dostępie do własnego ,ja”, o tyle w xx wieku programową i intencjonalną narrację autokreacyjną uprawiał już Jorge Luis Borges, którego teksty wspomnieniowe (jak Autobiografia lub wywiad-rzeka udzielony

\footnotetext{
96 Ibid., s. 65.

97 Ocena tego zjawiska bywa pozytywna - jak w przypadku cytowanego przez Popiel neopragmatysty Richarda Rorty’ego - lub bardziej zdystansowana. Anthony Giddens konstatuje: „Refleksyjność nowoczesności obejmuje sam rdzeń jaźni, w kontekście porządku posttradycyjnego »ja « staje się refleksyjnym projektem. Przemiany w życiu jednostek zawsze wiązały się z koniecznością psychicznej reorganizacji, która w kulturach tradycyjnych często przyjmowała zrytualizowaną postać rytuałów przejścia. Jednak w tych kulturach, w których na poziomie zbiorowości zasadniczo wszystko pozostawało bez zmian z pokolenia na pokolenie, zmiana tożsamości - jak wówczas, gdy jednostka z wieku dorastania wkraczała w dorosłość - była wyraźnie zaznaczona. W układach ponowoczesnych, przeciwnie, zmiany tożsamościowe wymagają od jednostek dociekania i pracy w ramach refleksyjnego procesu, w którym przemiana osobista przeplata się ze społeczną”; Anthony Giddens, Nowoczesność i tożsamość. „Ja” i społeczeństwo w epoce późnej nowoczesności, przeł. Anna Szulżycka, Wyd. Naukowe PWN, Warszawa 2010, s. 52; wyróżnienie w oryginale.
} 
Osvaldowi Ferrariemu), a przede wszystkim opowiadania, są stałym punktem odniesienia w studiach nad autofikcją, niezależnie od ich kulturowej proweniencji. Ten format literacki nie był więc novum w latach 50., kiedy Gombrowicz pisze Trans-Atlantyk i rozpoczyna redakcję Dziennika, a krytycy zajmujący się problemem „stwarzania siebie" w jego twórczości nieodmiennie poruszają się w kontekście narzuconym już przez autora Alefa, którego literackie autokreacje można po prostu dalej rozwijać: punktem wyjścia dla rozważań o Witoldzie Gombrowiczu będzie nieodmiennie Jorge Luis Borges. Słynna scena z Trans-Atlantyku, w której narrator mierzy się z Wielkim Pisarzem, dostarcza skądinąd pretekstu do takiej kontekstualizacji lektury:

W tej nowej formie autofikcji, powstałej w konfrontacji z Borgesem, antagoniści Gombrowicz i Copi kradną mistrzowi jego własny literacki chwyt, by w ten sposób skuteczniej wyśmiać miejsce, które zajmuje, posługując się przy tym ironią, którą nazwać można postmodernistyczną, bo pogardliwą w stosunku do najbliższej i najczystszej tradycji ${ }^{98}$.

O ile u Borgesa - pisze Amícola - narracyjne portrety własne będą służyły subtelnej kompromitacji estetyki realistycznej, w szczególności tej o ambicjach psychologizujących, o tyle chwiejne, dwuznaczne zachowanie „Witolda” (w szczególności jeśli przyjąć, że jego alter ego jest Gonzalo) ma być wyrazem fundamentalnej niemożności samookreślenia. Autofikcja burzy tu logikę opowiadania w imię „zasady niesprzeczności” (principio de la no contradicción): „rzeczy dzieją się w pewien sposób, ale równie dobrze mogłyby wydarzać się w przeciwny"99. Ta eksponowana ambiwalencja w ocenie zdarzeń (postaci z łatwością poruszają się między ekstremami), a nawet wewnętrz-

98 José Amícola, Estéticas bastardas, s. 125. Z podobnej porównawczej perspektywy badacz ten czyta Dziennik argentyński, który zestawia ze swoistym „dziennikiem” Adolfa Bioya Casaresa, zatytułowanym Borges; v. idem, El diario trans-atlántico de Witold Gombrowicz, „Zama” 2012, nr 4, s. 137-146.

99 Idem, El diario trans-atlántico de Witold Gombrowicz, s. 161. O różnych realizacjach formatu autofikcyjnego v. idem, Autoficción, una polémica literaria vista desde los márgenes (Borges, Gombrowicz, Copi, Aira), „Olivar” 2009, nr 12, s. $181-196$. 
na sprzeczność przedmiotów (patrz opis estancji Gonzala) skutkuje przekonaniem o radykalnym nieistnieniu jakiejkolwiek esencji osób i natury rzeczy. U Gombrowicza i Copiego - Amícola odnajduje serię punktów stycznych między ich estetykami - autofikcja spełnia także inną funkcję u Borgesa nieobecną: dekonstruuje narodowe mity, dezawuując oficjalną narrację patriotyczną, w oczywisty sposób wznoszącą się na dyskursie operującym przekonaniem o niezbywalnej istocie (człowieka, rzeczy, zdarzeń).

Także Silvana Mandolessi podsumowuje refleksje na temat konstrukcji „ja” w tekstach autobiograficznych (Dziennik, Testament, Wędrówki po Argentynie) analizą porównawczą dwóch opowiadań: Gombrowicza Yo y mi doble (Ja i mój sobowtór) ${ }^{100}$ oraz Borgesa Tamten ${ }^{101}$, w których narrator opowiada spotkanie z samym sobą. Różnice w sposobach konceptualizacji własnego alter ego - w pierwszym relacja między „ja” a „tym drugim” wyraża walkę o władzę i jest perwersyjna $\mathrm{w}$ tej mierze, $\mathrm{w}$ jakiej spojrzenie podmiotu rejestruje fizyczne skazy swojego młodszego odpowiednika, próbując go (bezskutecznie) poniżyć, w drugim natomiast jest bardziej pojednawcza w stosunku do drugiego „ja”, z którym podmiot nawiązuje szczery, intymny dialog - badaczka postrzega jako znaczące dla interpretacji Gombrowiczowskiej subiektywności: jej oryginalność docenić można w pełni dopiero na „neutralnym” tle, którego dostarcza proza Borgesa, czyli traktując ją jako specyficzne odstępstwo od literackiej normy.

Gombrowiczowska wersja „sobąpisania” funkcjonuje w argentyńskiej przestrzeni literackiej jeszcze w inny sposób: nie tylko jako strategia opowiadania, chwyt utożsamienia autora z narratorem, którego lejtmotywem jest nieusuwalna, konfliktowa dwoistość, ale także jako świadoma konstrukcja siebie, praktyka tworzenia równolegle tekstu i własnego „ja” lub własnego „ja” w tekście. W tym drugim

100 Witold Gombrowicz, Yo y mi doble, przeł. z fr. Mónica Mansour, „Pagina/12” 1996, 11 VIII, s. 4-5. Opowiadanie to jest jedną z pierwszych wersji początkowego rozdziału Ferdydurke; v. idem, Ferdydurke. Wstęp, w: idem, Varia 1. Czytelnicy i krytycy, Wydawnictwo Literackie, Kraków 2004, s. 47-53.

101 Jorge Luis Borges, Tamten, w: idem, Księga piasku, przeł. Zofia Chądzyńska, Prószyński i S-ka, Warszawa 1998, s. 5-16. 
znaczeniu - które ujawni się, gdy porzucimy powieści na rzecz diarystyki - polski pisarz uwalnia się także od cienia Borgesa, którego tak konsekwentne i nieustępliwe pisanie o sobie nigdy nie interesowało. Ten aspekt Gombrowiczowskiej autofikcji ujmuje najtrafniej Julio Premat w studium poświęconym konstrukcji figury autora w literaturze argentyńskiej, które otwiera właśnie odwołaniem do Dziennika:

Witold Gombrowicz - jak niewielu dwudziestowiecznych pisarzy - potrafił stworzyć własne, autonomiczne miejsce, na przekór przytłaczającym imperatywom estetycznym, ideologicznym, a przede wszystkim historycznym, które ciążyły nad kruchym grzbietem kogoś takiego jak on, polskiego pisarza zesłanego na przedmieścia świata ${ }^{102}$.

Tym „własnym miejscem” jest Dziennik, w którym Gombrowicz realizuje "gest silnego pisarstwa” (gesto de escritura fuerte) - wymyśla własną figurę autora w miejscu pustki indywidualnej (jest nieznanym pisarzem) oraz kulturowej, jaką jest dla świata Zachodu Argentyna lat 50. Dopiero ten podwójny brak - prestiżu i kultury - gwarantuje wolność pisania i pozwala osiągnąć właściwy ton dla wyrażenia, a raczej dla skonstruowania, własnej tożsamości:

[...] sam muszę stać się własnym komentatorem, więcej, reżyserem. Muszę wykuć Gombrowicza-myśliciela i Gombrowicza-geniusza, i Gombrowicza-demonologa kultury oraz wielu innych nieodzownych Gombrowiczów ${ }^{103}$.

Ja jestem najważniejszym i bodaj jedynym moim problemem: jedynym ze wszystkich moich bohaterów, na którym mi naprawdę zależy. Przystąpić do stwarzania siebie i uczynić z Gombrowicza postać - jak Hamlet, albo don Kiszot - ? - ! - ${ }^{104}$

102 Julio Premat, Héroes sin atributos. Figuras de autor en la literatura argentina, FCE, Buenos Aires 2009, s. 9.

103 Jerzy Giedroyc, Witold Gombrowicz, Listy 1950-1969, wyb., wstęp i przypisy Andrzej Stanisław Kowalczyk, Czytelnik, Warszawa 2006, s. 59 (list z 6 sierpnia 1952 roku).

104 Witold Gombrowicz, Dziennik 1953-1969. Oba fragmenty cytuje także Julio Premat. 
Podstawowym celem przedsięwzięcia zwanego Dziennikiem jest więc zupełnie jaw ny proces stwarzania siebie jako pisarza, który nieodzownie współistnieje z procesem twórczym. Odkrycie i pełne wykorzystanie autokreacyjnej funkcji tego gatunku czyni z jego autora punkt odniesienia dla szeregu pisarzy argentyńskich, których autorskie figury analizuje dalej Premat. To, co w Dzienniku jest czystą możliwością - testuje się szereg różnych „Gombrowiczów”, pojemność twórczą genre’u - kolejni twórcy zapełnią już konkretną treścią, spróbują stworzyć jakiś obraz własny, choć niekoniecznie jedyny i koherentny (Borges jest pisarzem tradycji prze-pisującym swoje dzieło, Saer jest „nikim”, wymazuje własną biografię, Piglia przedstawia siebie jako czytelnika i detektywa, Aira gra z motywem enfant terrible etc.).

Rozwinięcie tezy Premata o Gombrowiczu jako poprzedniku figury autora w literaturze argentyńskiej pozwala w moim przekonaniu mówić o wpływie czy konsekwencji w podwójnym sensie. Po pierwsze, jego konstrukcja jest ostentacyjna i zuchwała, jest procesem wystawionym na widok publiczny, który drażni swym egocentryzmem nawet gusta czytelnicze wykształcone już na umowności paktu autofikcjonalnego. Gombrowicz - pisze Jan Błoński - otwarcie żąda uznania od czytelnika, zarazem postępując tak, by mu to uznanie uprzykrzyćc ${ }^{105}$. Jest to konstrukcja cyniczna w nowoczesnym sensie tego słowa - świadoma fałszywości wszelkich ideologii, rozczarowana, zdegustowana współczesnym światem, pragmatycznie go jednak akceptuje, odmawiając wszelkich form realnego zaangażowania ${ }^{106}$. Po drugie, w projekcie twórczym Dziennika liczy się przede wszystkim sam proces, praktyka autokreacji, a nie jej efekt - nazbyt rozproszony (przez wielość „nieodzownych Gombrowiczów”), by tworzyć jakikolwiek obraz ostateczny. W tym sensie jego autor jest poprzednikiem diagnozowanej przez Reinalda Laddagę tendencji charakteryzującej argentyńską twórczość literacką pierwszych

105 V. Jan Błoński, „Dziennik”, czyli Gombrowicz dobrze utemperowany, w: idem, Forma, śmiech i rzeczy ostateczne. Studia o Gombrowiczu, Universitas, Kraków 2003, s. $139-178$.

106 V. Peter Sloterdijk, Krytyka cynicznego rozumu, przeł. i wstęp Piotr Dehnel, Dolnośląska Szkoła Wyższa, Wrocław 2008, s. 19-25. 
dekad xxı wieku i wyrażającej się w tworzeniu nowego rodzaju autorskiej figury, która nie jest już wynikiem „dbałej stylizacji” (producción densa del estilo) ani bohaterem niezwykłych historii, lecz wytwórcą „spektakli rzeczywistości” (espectáculos de realidad), rodzaju sceny, na której - wzorem współczesnych artystów - wystawia samego siebie ${ }^{107}$. Ta najnowsza literatura nie interesuje się gotowym „ja” tylko dostarcza perspektywy do obserwowania jego nigdy nieukończonej konstrukcji, co do której nie wiadomo nawet, w jakiej mierze jest prawdziwa, a w jakiej zmyślona ${ }^{108}$.

Oba te rozwiązania - procesualność i drażniącą autoprezentację - wykorzysta np. César Aira, którego autorska figura, bazująca na „ucieczce do przodu” i odmowie wszelkiej poprawki tekstu raz napisanego, oraz twórcza aktywność, w której deprecjonuje się efekt (w postaci świetnie napisanej książki), wywołały sporo zamieszania w literaturze argentyńskiej ostatnich dekad xx wieku. Cynizm będzie podstawowym budulcem literackiego „ja” Osvalda Lamborghiniego, a Rodoflo Fogwill z powodzeniem wykorzysta znaną z Dziennika strategię autokreacji poprzez uszczypliwe i prowokacyjne polemiki literackie, ostentacyjne „bycie przeciw” wszystkim, nawet jeśli skutkuje wewnętrzną sprzecznością.

\section{Gombrowicz w argentyńskim kanonie literackim}

Borges i ja, to przeciwieństwa.

Testament. Rozmowy z Dominique de Roux

Przegląd krytycznych interpretacji Gombrowicza dokonywanych na gruncie krytyki argentyńskiej chciałabym zamknąć krótkim komentarzem na temat miejsca, jakie przypisuje się temu pisarzowi na mapie literackiej Buenos Aires. Kwestia ta ma dla mnie wymiar nie tyle

\footnotetext{
107 Reinaldo Laddaga, Espectáculos de realidad. Ensayos sobre la narrativa latinoamericana de las últimas dos décadas, Beatriz Viterbo, Rosario 2007, s. 14. 108 Ibid.
} 
historyczno-faktograficzny (w którym celem byłaby rekonstrukcja relacji łączącej go z literackim „parnasem” Buenos Aires w latach 40. i $50 .{ }^{109}$ ), ile interpretacyjny. Chciałabym mianowicie ustalić, czy w autorze Dziennika można ex post upatrywać prekursora jakiejś późniejszej formacji estetycznej i tym samym przypisać mu znaczące miejsce w argentyńskiej tradycji literackiej, miejsce, którego znaczenie można dostrzec dopiero z perspektywy czasu.

Rozważania nad pozycją Gombrowicza w argentyńskim kanonie ponownie zakładają konieczność konfrontacji jego twórczości z twórczością Borgesa, przy czym potrzeba tego porównania wynika nie tyle z ewentualnych zbieżności pomiędzy ich estetycznymi stanowiskami, co z wewnętrznej dynamiki tej literatury, dla której Borges pozostaje swoistym modelem z Sèvres. Najważniejsze typologie literackie ustala się bowiem, zestawiając autora Alefa z jego antagonistami (Roberto Arlt, Rodolfo Walsh) lub epigonami w zależności od tego, którą linię rozwojową tamtejszej kultury pragnie się wydobyć. Gdyby nie istniał Borges - pisze Beatriz Sarlo - rozpadłaby się najprostsza forma porządkowania literatury argentyńskiej pierwszej połowy xx wieku ${ }^{110}$. Dlatego

109 Próby wybicia się Gombrowicza na kulturalnej scenie Buenos Aires w latach 1939-1963, a także przyczyny porażki, analizują z socjologicznego punktu widzenia, zakorzenionego w koncepcji Pierra Bourdieu: Danuta Teresa Mozejko, Condiciones de aceptabilidad del discurso de un migrante. El caso Gombrowicz en la Argentina, „Amerika. Mémoires, Identités, Territoires” 2011, nr 5, http:// amerika.revues.org/2537, dostęp: 1 x 2016; Cristian Cardozo, Agente social y estrategias discursivas: La seducción de Witold Gombrowicz como caso, V Jornadas de Sociología de la Universidad Nacional de La Plata, 2008, http://goo.gl/B32iuQ, dostęp: 1 X 2016; idem, Sobre la construcción del yo en Diario (1953-1969) y Diario Argentino de Witold Gombrwoicz, Actas del II Coloquio Internacional "Escrituras del Yo", Universidad de Rosario, 2010, http://goo.gl/2btcqP, dostęp: 1 x 2016; idem, Gombrowicz y la irreverencia de la forma: estrategias discursivas para ingresar al campo literario argentino del periodo 1939-1963, viII Congreso Internacional de Teoría y Crítica Literaria Orbis Tertius, Universidad Nacional de La Plata, 2012, http://goo.gl/B32iuQ, dostęp: 1 x 2016.

110 Beatriz Sarlo, Si no hubiera existido Borges, „La Nación” 2011, 10 vi, http://goo.gl/ RZNrJ, dostęp: 3 X 2016. Opinię Sarlo potwierdzają liczne studia na temat kanonu literackiego w Argentynie, w których Borges pozostaje pisarzem centralnym; v. Verónica Tobeña, La cuestión del canon en la literatura argentina. Un campo 
też wszyscy badacze argentyńskich brzmień w prozie Gombrowicza zmuszeni są taką konceptualizację jego relacji z Borgesem przeprowadzić, przy czym wachlarz możliwych ujęć porównawczych jest dość szeroki.

Część krytyków, jak Piglia i Saer, skłonna jest akcentować podobieństwa łączące obu pisarzy: „to samo upodobanie do prowokacji, ta sama teoretyczna nieufność do awangardy i, przede wszystkim, ten sam zamysł niszczenia starych form"111, a także bezceremonialny stosunek do kultur i tradycji centralnych ${ }^{112}$. José Amícola dorzuca jeszcze do tego repertorium cech wspólnych niechęć do realizmu i polityczny konserwatyzm $^{113}$. Silvana Mandolessi skupia się z kolei na rozważeniu tych kilku zbieżności w poetykach Borgesa i Gombrowicza, które - po głębszej analizie - okazują się jedynie pozorne. Obaj na przykład zwracają się ku „niższości” (Borges, w swojej fascynacji literaturą popularną, powieścią o gauczach, przemocą przedmieść i tangiem), ale czynią to z zasadniczo odmiennych pozycji:

[...] pozbawiając formy „barbarzyństwa” [niższości - E.K.P.] wszelkiej konotacji ideologicznej, Borges przekształca je w czystą fikcję, w fikcję specyficznie argentyńską, ale wpisującą się $[\ldots]$ w literacki projekt na samym szczycie kultury wysokiej. W rezultacie dychotomia cywilizacjabarbarzyństwo zostaje usunięta ${ }^{114}$.

Tymczasem u Gombrowicza fascynacja niższością prowadzi do krytyki kultury wysokiej i tym samym do dewaluacji członu „cywilizacja”. W innym miejscu Mandolessi zajmuje się pojęciem tradycji w kulturach peryferyjnych, która - zdefiniowana przez Borgesa jako

cultural abierto en dos, „A Contracorriente” 2002, t. 9, nr 2, s. 282-318. Dodać wypada na marginesie, że (wbrew temu, co zdawał się sądzić sam Gombrowicz) Borgesa nie należy identyfikować ze środowiskiem literackim „Sur”, któremu przewodziła Victoria Ocampo i które w latach pobytu Gombrowicza w Argentynie było synonimem establishmentu literackiego. Borges ściśle współpracował $\mathrm{z}$ „Sur”, ale jego estetyczne koncepcje wykraczały poza ortodoksję pisma.

111 Juan José Saer, Spojrzenie z zewnątrz, s. 8o.

112 Ricardo Piglia, Czy istnieje powieść argentyńska?, s. 66.

113 José Amícola, Estéticas bastardas, s. 88 i 94.

114 Silvana Mandolessi, Una literatura abyecta, s. 213. 
możliwość dowolnego czerpania z kultur „pierwszorzędnych”115 - powinna być Gombrowiczowi bliska. Jeśli jednak przyjrzeć się temu, co konkretnie obaj rozumieją pod słowem „tradycja”, bliskość ta przestaje być oczywista: u autora Alefa chodzi bowiem o dynamiczny stan ciągłej reinterpretacji, ponieważ literatura jest procesem twórczego prze-pisywania wielkich symboli kultury Zachodu; w ujęciu Gombrowicza tradycja należy natomiast do zamkniętej przeszłości, jest czymś, co manifestuje się w teraźniejszości tylko jako opresyjna forma ${ }^{116}$.

$\mathrm{Na}$ drugim biegunie argentyńskich krytyków zajmujących się dziełem Polaka znajdują się ci, którzy - jak Pablo Gasprini - wolą upatrywać w nim antagonisty Borgesa, a próby zbliżenia obu koncepcji literackich traktują jako wypaczenie Gombrowiczowskiego przesłania, które w ten sposób staje się spekulatywne, nadmiernie teoretyzujące i wyszukane. Innymi słowy, ustanawianie analogii rzekomo łączących autora Dziennika z Borgesem i, szerzej, argentyńską elitą literacką lat 40. i 50. powoduje, że on sam dołącza do grona pisarzy „tantalicznych”, którzy - Gasparini cytuje Piñerę - wolą o literaturze w nieskończoność dyskutować, niż ją uprawiać. Paradygmatycznym przykładem takiego podejścia jest dla tego badacza koncepcja Piglii, którego lektura Gombrowicza ignoruje istotę jego twórczości: potrzebę zuchwałego i aroganckiego (procaz) wyrażania własnego „ja”, „tego bezczelnego braku szacunku w pisaniu, przez który rozumieć trzeba przede wszystkim odrzucenie literatury profesjonalnej i spekulatywnej, a szerzej, pragnienie uczynienia z literatury błazenady"117.

Tak znaczące różnice w porównawczych lekturach Gombrowicza i Borgesa biorą się w dużej mierze z interpretacyjnej pojemności dzieła Argentyńczyka, któremu przypisuje się zarówno literacki konserwatyzm, wyrażający się przede wszystkim w dbałości o styl i elegancję

\footnotetext{
115 Jorge Luis Borges, Pisarz argentyński i tradycja.

116 Silvana Mandolessi, Cultural Hierarchies, Secondary Nations. The Tension between Europe and "Minor" Cultures in Witold Gombrowicz and Jorge Luis Borges, w: Nele Bemong, Mirijam Truwant, Pieter Vermeulen (red.), Re-thinking Europe. Literature and (Trans)national Identity, Rodopi, Amsterdam-New York 2008, s. 160.

117 Pablo Gasparini, El exilio procaz, s. 131.
} 
języka oraz unikaniu wszelkich form opartych na figurze nadmiaru lub przesady, czyli estetyczną ortodoksję, p r z e ci i której pisać będą autorzy tacy jak Manuel Puig lub Osvaldo Lamborghini, z zasady ekscentryczni i „nieumiarkowani” w formie i treści, oraz paradoksalnie także prekursorstwo w dziedzinie tejże estetyki tzw. złego pisania, świadomie rezygnującej z perfekcji na rzecz otwartej manifestacji braku (brzydoty, niewiedzy, niezręczności stylu etc.). „We współczesnej literaturze hiszpańskojęzycznej - pisze Julio Prieto - Borges jest najbardziej elokwentnym krytykiem »złego pisania« i jego najskrytszym poprzednikiem”118. Rzeczona „niepoprawność” miałaby się u niego przejawiać w sposób nader subtelny, nie tyle na poziomie stylu i języka, ile w treści lub w specyficznych literackich konceptach, takich jak apokryficzne atrybucje cytatów, pochwały niewiernych tłumaczeń, przekonanie o wyższości kopii nad oryginałem, eksponowanie drugorzędnych postaci (tłumacz, komentator) i form (prolog, antologia). Nawet jeśli przypisanie Borgesowi ideału „złej literatury” wydaje się pomysłem dosyć przewrotnym, dającym się obronić jedynie dzięki ironicznemu wymiarowi jego dzieła, to samo pojęcie jest niewątpliwie znaczące dla późniejszej literatury argentyńskiej i warto się nad nim pochylić, zważywszy także na fakt, że Gombrowiczowska „niedojrzałość” bywa czytana jako jeden z jego przejawów, m.in. przez Césara Airę, najsłynniejszego współczesnego orędownika tradycji „złego pisania"119. Prieto definiuje tę kategorię stosunkowo szeroko, jako podstawową cechę literatury nowoczesnej, która nie tyle „wyklucza sąd estetyczny, ile go komplikuje, bo stawia pytanie już nie o to, co w sztuce jest dobrego lub złego, ale o to, jak wytropić mutacje dobrego wywołane »złymi« jakościami” ${ }^{20}$. Choć definicja Prieto wydaje się nazbyt

118 Julio Prieto, Sobre ilegibilidad y malas escrituras en Hispanoamérica, „Ínsula” 2011, nr 777 , s. 4.

119 „Kiedy Macedonio Fernández broni »biednego i złego pisania«, albo Beckett i Gombrowicz proponują myślenie o fikcji z perspektywy jej »niedostatku« lub "niedojrzałości«, nie ignorują formy, lecz walczą z nią: bardzo się starając, by nie pisać dobrze, przywiązują zarazem sporo uwagi do tego, by z dbałością pisać "źle«"; ibid., s. 2. Ibid. 
pojemna i w efekcie konotuje zbyt wiele zjawisk (od Paula Valéry'ego i Borgesa do Gombrowicza i Néstora Perlonghera), to jeśli ograniczyć ją do postulatów świadomego infekowania tradycyjnej wartości kulturowej tym, co z gruntu jej przeciwne (błędem, odstępstwem od klasycznej normy, niewiedzą, estetycznymi antywartościami), to „złe pisanie” okazuje się kategorią nader przydatną dla określenia miejsca, z którego Gombrowicz przemawia w literaturze argentyńskiej i z którego zjednuje sobie zwolenników. Wszystkie próby jego usytuowania odwołują się bowiem do tej kategorii: „odraza” (lo abyecto) Mandolessi, „nieprawa estetyka” (estética bastarda) Amícoli, „estetyka śmietnika” Marzeny Grzegorczyk, „bezwstyd” i „bezczelnośc” (procacidad) Gaspariniego, nawet ,język wykluczenia” (lengua desposeída) Piglii.

Reasumując, decyzja o tym, jaki e go Gombrowicza się czyta, które aspekty jego twórczości uważa za kluczowe - innymi słowy, rozstrzygnięcie, jak jego dzieło rezonuje z dziełem Borgesa - będzie miała oczywiście zasadnicze znaczenie dla identyfikacji jego ewentualnych literackich „spadkobierców”. Jeśli podążać tropem Piglii i Saera, autor Dziennika pozostaje wprawdzie pisarzem-outsiderem, który komponuje Ferdydurke rwącym się „językiem przyszłości”, niejako na przekór Borgesowi-styliście, ale jednocześnie roztrząsa w swoich tekstach wszystkie paradygmatyczne kwestie kultury argentyńskiej: tradycję, oryginalność, nacjonalizm, styl literacki etc., nawiązując „tajemną więź z głównymi liniami rozwojowymi argentyńskiej powieści współczesnej"121. Z tej perspektywy Trans-Atlantyk jest powieścią o narodowej przynależności, a jego autor - wywrotowym może, ale kontynuatorem klasycznej debaty. Tego Gombrowicza przyswoją sobie np. Guillermo David, Hernán Ronsino i Lucas Cosci. Na drugim biegunie znajduje się Gombrowicz, który fundamentalne problemy współczesnej sobie literatury argentyńskiej - kim jesteśmy? co znaczy być Argentyńczykiem? - anuluje jako bezsensowne, w geście podobnym do tego, którym Koło Wiedeńskie unieważniło pytania metafizyczne, czyli jako z gruntu źle postawione. Literatura jest bowiem głosem z konieczności indywidualnym, mówiącym z in ne go (własnego)

121 Ricardo Piglia, Czy istnieje powieść argentyńska?, s. 70. 
miejsca, głosem obdarzonego konkretnym (często homoseksualnym) ciałem ,ja” i głosem pr ze ciw ko wszelkim dyskursom „,normalizującym" w imię powrotu do autonomicznej sztuki. Tego Gombrowicza odnajdziemy m.in. w tekstach Césara Airy, Osvalda Lamborghiniego i Jorgego Di Paoli. 



\section{Miejsca lektury. Gombrowicz czytany przez argentyńskich pisarzy}

W argentyńskim polu literackim ustalenie własnego „rodowodu” (linaje), czyli źródła inspiracji, określonej tradycji estetycznej poprzedzającej dzieło, jest kwestią fundamentalną i to także dla pisarzy, którzy - jak César Aira - chętnie posługują się krytycznym językiem awangardy, zorientowanym wokół estetycznego imperatywu inwencji, „ucieczki do przodu” i literatury jako ready-made. Kluczowym punktem omawianej w poprzednim rozdziale konstrukcji figury autora jest drobiazgowa konfiguracja linii własnych poprzedników, co w zasadzie nie powinno dziwić w kraju, w którym już w połowie ubiegłego stulecia Borges przenikliwie odwrócił tradycyjny wektor relacji pomiędzy twórcą a jego prekursorem, nadając temu pierwszemu prawo do modyfikowania przeszłości na własny użytek ${ }^{1}$. Niemniej zasługuje na uwagę, po pierwsze, intensywność i zasięg tej „praktyki konstruktorskiej”: co u Borgesa było trzeźwą konstatacją faktu - pisarze rzeczywiście narzucają własne lektury tradycji - u jego następców przybrało formę systematycznej i skutecznej akcji, która skłania krytyków do mówienia właśnie o „systemie Piglii” lub „systemie Airy”2.

1 V. Jorge Luis Borges, Kafka i jego prekursorzy, w: idem, Dalsze dociekania, przeł. Andrzej Sobol-Jurczykowski, Prószyński i S-ka, Warszawa 1999, s. 156-16o.

2 Jorge Fornet, El escritor y la tradición. Ricardo Piglia y la literatura argentina, FCE, Buenos Aires 2007, s. 7; José García Tomeu, Una polémica actual: la reconstrucción del sistema literario argentino, „Anales de Literatura Hispanoamericana” 2007, t. 36, s. 199-219. 
Ta dbałość o własną historię jest w gruncie rzeczy przejawem dbałości o interpretację własnego dzieła, o przygotowanie miejsca, z którego się je czyta i tym samym spełnia specyficzną funkcję „egzegetyczną”, ponieważ teksty poświęcone poprzednikom okazują się nader często komentarzem do własnej twórczości, jak choćby w przypadku monografii Copi Césara Airy. Po drugie, osobliwością argentyńskich „konstrukcji rodowodu” jest zaskakująca powtarzalność nazwisk, co Ricardo Piglia tłumaczy w następujący sposób: „Gdy kanon jest zamknięty i krótki - jak nasz - bardzo trudno go odnowić, można tylko czytać od nowa [releer] i zmieniać miejsce ciągle tym samym pisarzom [...], nie sposób odnaleźć nowych, sekretnych tekstów, bo

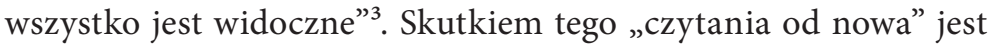
specyficzny, relacyjny charakter argentyńskiego kanonu, w którym nazwiska twórców często funkcjonują sparowane: istnieje Roberto Arlt w lekturze Piglii, obok i niezależnie od Arlta takiego, jakim czyta go Aira; Macedonio Fernández w lekturze Bogresa nie jest tym samym Macedoniem, do którego odwołuje się „Literal”. Podobna rozbieżność interpretacji spotyka także Gombrowicza. Sukces pisarza - Gombrowiczowskie "narzucenie się” - oznacza więc nie tylko wypromowanie „własnych” poprzedników jako istotnych dla kanonu w ogóle, ale także konkretnej ich lektury jako jedynej właściwej. César Aira „lansuje” w ten sposób pisarza wcześniej mało znaczącego, Osvalda Lamborghiniego, pozostając ponadto - jako wydawca jego spuścizny - jego oficjalnym interpretatorem.

Mając na uwadze powyższe refleksje, wypada mi odnotować pewien paradoks, który w tej swoistej „walce o prekursorów” jest szczególnie dotkliwy dla Gombrowicza: pisarz, który domagał się prawa do mówienia wyłącznie we własnym imieniu, zostaje zmuszony do funkcjonowania w obcym środowisku, służy niejako cudzym interesom i im jego relacja $\mathrm{z}$ „następcą” bardziej eksplicytna (jak w przypadku Piglii, który o autorze Ferdydurke pisze sporo), tym dalej posunięta deformacja jego „przesłania”. To zniekształcenie

3 Ricardo Piglia, Borges como crítico, w: idem, Crítica y ficción, Anagrama, Barcelona 2006, s. 157 . 
dzieła - przyprawienie mu kolejnych „gąb” - wydaje mi się w gruncie rzeczy ceną za ucieczkę przed monotonią epigonizmu: moim celem nie jest bowiem odnalezienie biernych naśladowców, lecz pisarzy, którym Gombrowiczowska twórczość posłużyła do konstrukcji własnego przekazu. Nie zawsze zresztą będzie to przekaz erudycyjny i błyskotliwy w warstwie interpretacyjnej i językowej - zdarzą się (choć nieliczne) propozycje bardziej siermiężne, w których przyprawiona Gombrowiczowi „gęba” musi szczególnie uwierać. W tak zdefiniowanym polu badawczym, w którym wierność poprzednikowi literackiemu nie jest ani możliwa, ani nawet pożądana, należy jasno określić zasady, na których opierają się ustanowione związki międzytekstowe, by uniknąć - jak pisałam w pierwszym rozdziale - dowolności interpretacyjnej ograniczonej jedynie umiejętnościami retorycznymi krytyka. W tym celu proponowane przeze mnie afiliacje intertekstualne będą każdorazowo uzasadniane na co najmniej jeden z możliwych sposobów: 1. czytelne aluzje do legendy samego Gombrowicza lub jego dzieł znajdują się w samym tekście analizowanym lub w jego paratekstach; 2. inna twórczość (literacka, krytyczna, teatralna, filmowa) danego pisarza zawiera sformułowane wprost odniesienia do autora Dziennika, co pozwala ekstrapolować związki intertekstualne na inne jego teksty.

Zastosowany w poprzednim rozdziale porządek tematyczny - tutaj niemożliwy do utrzymania ze względu na jednostkowość literackich propozycji - zostaje zastąpiony czasowym, który obejmuje przedział od lat 70. zeszłego stulecia do momentu aktualnego, czyli połowy drugiej dekady xxı wieku. Zastosowana tu chronologia będzie jednak chronologią lektu ry tekstów, nie ich publikacji - w niektórych przypadkach (jak Copiego) dzieło dotarło do czytelników z dużym opóźnieniem i jego wpływ na horyzont literackich oczekiwań był niejako odroczony. Ponadto przyjęty w tym rozdziale układ chronologiczny bywa czasami trudny do utrzymania także dlatego, że kilkakrotnie mamy do czynienia z dziełem, które - jak u Piglii - wykracza poza jedno dziesięciolecie, a które ze względu na swój jednorodny, spójny wewnętrznie charakter korzystniej rozpatrywać całościowo, bez rozbijania na kolejne dekady. 


\section{„Literal”. Germán García 4}

Politycznie „rozpalone” lata 70. to pozornie czas Gombrowiczowi nieprzychylny: dzieło obojętne na doraźne spory ideologiczne, wzgardliwe wobec imperatywu społecznego zaangażowania, dzieło, którego autor na dodatek $\mathrm{z}$ upodobaniem mieni się hrabią, nie mogło wówczas zaistnieć w głównym nurcie literackim. Paradoksalnie jednak w tej właśnie epoce Gombrowicz znajduje w Argentynie pierwszych czytelników, którzy - nieprzytłoczeni legendą pisarza i narzuconymi przez niego dyrektywami interpretacyjnymi - przystępują do lektury tekstów. Ich znaczenie w latach 70. będzie marginalne: wydadzą zaledwie kilka numerów pisma „Literal”, które utonie najpierw w morzu wezwań do rewolucji, a później w kulturalnej pustce epoki dyktatury. Jednak kilka dekad później sam periodyk oraz pisarze z nim związani - jak Osvaldo Lamborghini lub Ricardo Zelarayán - zostaną na nowo "odkryci”, zgodnie z wyżej opisaną dynamiką p o n o w n e g o czytania. Obecnie „Literal” ma status czasopisma mitycznego (tym bardziej że do czasu wydania faksymilowego w 2011 roku jego numery były bardzo trudno osiągalne) dzięki takim twórcom jak Héctor Libertella, Alan Pauls, César Aira czy Damián Tabarovsky, dla których reprezentuje ono zalążek kontrkanonu ${ }^{5}$, tryumfującego ostatecznie w początkach Xxi wieku. Zamyka ono długą listę czasopism - takich jak „Martín Fierro”, „Sur”, „Contorno” lub „Poesía Buenos Aires” - które, każde w innym momencie historycznym, doprowadziły do przewartościowania argentyńskiej sceny literackiej. Trzon redakcji „Literal” stanowili Germán García (spiritus movens całego przedsięwzięcia), Luis Gusmán i Osvaldo Lamborghini, a współpracował z nimi m.in. Edgaro Russo, przyszły dyrektor wydawnictwa El Cuenco de Plata i inicjator serii wydawniczej „Biblioteca Gombrowicz”. W sumie w latach 1973-1977

4 Rozdział ten ukazał się w „Tekstach Drugich” 2016, nr 1, s. 280-302.

5 V. Damián Tabarovsky, Literatura de Izquierda, Beatriz Viterbo, Rosario 2004, s. 26; Héctor Libertella, Prólogo, w: idem, Literal 1973-1977, Santiago Arcos, Buenos Aires 2002, s. 4; Juan Mendoza, El proyecto "Literal", w: "Literal" (19731977), Biblioteca Nacional, Buenos Aires 2011, s. 7-19. 
ukazało się tylko pięć numerów czasopisma, w tym dwa łączone: numer 1 w 1973, numer 2/3 w 1975 i 4/5 trzy lata później. Bezpośrednią przyczyną powołania do życia „Literal” było skrajne upolitycznienie wydawanych wówczas periodyków kulturalnych, a konkretnie konsekwentne dryfowanie współredagowanego przez Garcíę czasopisma „Los Libros" ${ }^{\text {w }}$ stronę ideologii maoistowskiej. W numerze z maja 1972 roku jedyny artykuł niezwiązany z bieżącą polityką jest autorstwa Garcíi właśnie i będzie ostatnim, który pisarz opublikuje na łamach tego pisma, rozczarowany kursem, jaki ostatecznie obrało.

Wspomniany artykuł nosi tytuł Gombrowicz textual ${ }^{7}$ (który oznacza zarówno „Gombrowicz dosłownie”, jak i „Gombrowicz w tekście”) i wraz z artykułem opublikowanym przez Garcíę w 1969 roku pt. Leer a Gombrowicz ${ }^{8}$ (Czytanie Gombrowicza), uważany jest za kluczowy dla późniejszego projektu „Literal”, ponieważ zapowiada stosowane w piśmie główne linie interpretacji literackiej. W obu tekstach akcentuje się konieczność l e kt u r y Gombrowicza - rzecz bynajmniej nieoczywistą w Argentynie końca lat 6o. i początku 70., kiedy legenda pisarza była jeszcze na tyle żywa, że zdawała się przyćmiewać jego twórczość. W artykule z 1969 roku, opublikowanym z powodu śmierci pisarza, czytamy:

Mówimy o tekstach. A Witold? Sam dokonał ucieczki w słowa i pozostawił nam przestrzeń naładowaną znakami, proponując jedyną sensowną rzecz: pisanie o pismach Gombrowicza. Czyli czytanie go w tych znakach, które były jego projektem. Dzięki temu, że Gombrowicz jest dla nas tekstualny, możemy się od niego uwolnić, pozwalając mu zaistnieć w pełni.

Tym symbolicznym gestem, jakim jest waloryzacja tekstów Gombrowicza (a nie legendy, którą po sobie pozostawił), García odbiera prawo do ich „wykładni” jego bezpośrednim uczniom, osobom, które - jak

6 Czasopismo wzorowane początkowo na francuskiej „Quinzaine Littéraire”, redagowane m.in. przez Ricarda Piglię i Beatriz Sarlo, wydawane w latach 1969-1976.

7 Germán García, Gombrowicz textual, „Los Libros” 1972, nr 26, s. 26-28.

8 Idem, Leer a Gombrowicz, „Los Libros” 1969, nr 2, s. 12.

$9 \quad$ Ibid.; wyróżnienie w oryginale. 
Juan Carlos Gómez - uważały się za namaszczonych przez „mistrza” jego literackich „spadkobierców”. Prawo do interpretacji - sugeruje García - niezależnej zresztą od dyrektyw samego autora, przysługuje każdemu, bez względu na jego osobistą więź z pisarzem. Więcej nawet: Gombrowicz „tekstualny” pozwala uwolnić się od osoby Gombrowicza, której cień ciąży nad dziełem, uniemożliwiając mu „zaistnienie w pełni”" "Literal” dokona podobnego gestu - podważenia znaczenia, jakie mógł mieć bezpośredni kontakt $\mathrm{z}$ autorem, przy jednoczesnej wnikliwej lekturze dzieła - w stosunku do Macedonia Fernándeza.

Drugi artykuł jest już propozycją konkretnej lektury Gombrowicza: García cytuje obszerne fragmenty tekstów - od Bakakaju po Kosmos - które następnie scala w interpretacji przeprowadzonej w duchu psychoanalizy lacanowskiej. Terminy typowo Gombrowiczowskie, takie jak „forma” i „niedojrzałość”, mieszają się z zestawem pojęć psychoanalitycznych: libido, trójkąt edypalny, imię ojca, metafora analna, sublimacja etc. Bardziej niż zawiłości lacanowskiej lektury Gombrowicza (która skądinąd później okazała się bardzo płodna, a García rozwijał ją potem $\mathrm{w}$ kolejnych szkicach ${ }^{11}$ ) interesuje mnie jednak doraźny wymiar tego tekstu, a mianowicie to, przeciwko komu zostaje napisany. Po pierwsze, uderza w literaturę pojętą jako instytucja, a ściślej jako zespół kodów lektury narzuconych przez mniej lub bardziej zorganizowaną instytucję, której podstawą jest szkoła: „hierarchiczny (i nieświadomy) podział organizuje naszą lekturę zgodnie z mieszczańskim mitem głębi oraz zgodnie z religijnym mitem wysokości, usuwając powierzchnię tekstu”12. Żaden z członków „Literal” nie był związany z uniwersytetem - miejscem godnym bardziej pożałowania niż uznania - a spotkania i debaty intelektualne, które później skrystalizują się na łamach czasopisma, odbywały się kawiarniach Buenos Aires. Po drugie, przedmiotem ataku są te właśnie, narzucone przez instytucję kody lektury:

10 Kilka lat później García poświęci Gombrowiczowi kolejny artykuł, pod równie znamiennym tytułem Gombrowicz, cytowany; idem, Gombrowicz, citado, „Pluma y Pincel" 1976, nr 15, s. 3.

11 V. idem, Gombrowicz. El estilo y la heráldica, Atuel, Buenos Aires 1992.

12 Idem, Gombrowicz textual, s. 28. 
[...] teksty Gombrowicza, jak wiele innych, musimy jeszcze przeczytać. Stanie się to możliwe, gdy w aktualnym modelu lektury (oraz w instytucjach, które go umożliwiają) zostanie przezwyciężone to, co wyobrażeniowe i ideologiczne, co jest w rzeczywistości wypartą negacją przedmiotu, który chce się rozszyfrować ${ }^{13}$.

Ten „aktualny model lektury” - wyznaczony przez realizm i populizm - nie tyle narzuca jakieś modelowe odczytanie tekstów Gombrowicza, ile w ogóle je uniemożliwia - ich język jest bowiem w tym przypadku nieadekwatny.

„Literal” - wzorowany na francuskim „Tel Quel” - zachowa tych samych wrogów. Artykuł No matar la palabra y no dejarse matar por ella (Nie zabijać słów i nie dać się za nie zabić) ${ }^{14}$, otwierający pierwszy numer i uważany za manifest grupy, przypuszcza atak na realizm, szczególnie w jego (triumfującej wówczas) wersji literatury świadectwa: „w odróżnieniu od informacji, prawda tekstu nie podlega sprawdzeniu przez rzeczywistość" ${ }^{15}$. Estetyce realistycznej zarzuca się m.in., że - choć deklaruje się jako rewolucyjna - stosuje wobec języka taką samą przemoc, jaką stara się obnażyć w świecie realnym ${ }^{16}$. Prawdziwie rewolucyjna literatura powinna tymczasem dokonać przewrotu w dziedzinie języka: ,jeśli słowo odmawia spełniania swojej instrumentalnej funkcji, to znaczy, że spadło z taśmy montażowej dominującej ideologii”" ${ }^{17}$. Odrzuca się także populistyczne przekonanie o tym, że literatura powinna „działać”: „język i potrzeba wykluczają się, ponieważ słowo »chleb« nie nakarmiłoby, nawet wtedy, gdyby

13 Ibid

14 No matar la palabra y no dejarse matar por ella, „Literal” 1973, nr 1, s. 5-13. Większość artykułów opublikowanych w „Literal” (ten także) nie była podpisana traktowano je jako dzieło wspólne.

15 Ibid., s. 5.

16 Ibid., s. 7. Podobną obserwację znajduję w książce Michała Pawła Markowskiego Czarny nurt. Gombrowicz, świat, literatura (Wydawnictwo Literackie, Kraków 2004, s. 85): „fascynacja prozą realistyczną, która jest świadectwem mocnego zakorzenienia w świecie i absolutnej submisywności wobec Ojca, czyli Prawa, może być odczytywana jedynie jako wyparcie pierwotnego pożądania”.

17 No matar la palabra y no dejarse matar por ella, s. 13. 
manifestanci z okrzykami »chleba!« zasiedli przy stole negocjacji płacowych"18. Z tekstu literackiego zdejmuje się z jednej strony obowiązek zmagania się z niesprawiedliwością społeczną, z drugiej natomiast nie postrzega się literatury w kategoriach „sztuki czystej”. Kwiecisty dyskurs o jej domniemanych powinnościach zostaje zastąpiony językiem, który mówi przede wszystkim o subiektywnym odbiorze tekstu, akcentując m.in. przypadkowość sytuacji czytelnika: „Czytelnikom przytrafiają się różne rzeczy. W kluczowym momencie powieści (jak mówi nam Gombrowicz) przeszkadza braciszek, mucha zaczyna bzyczeć właśnie wtedy, gdy czytelnik dociera do punktu kulminacyjnego: i efekt stracony” ${ }^{19}$. Broniona przez „literalistów” „urywana” lektura jest zresztą typowym dla awangardy trybem odbioru, w którym akcentuje się konieczność wyjścia „ku życiu”, zastąpienia kontemplacyjnego modelu relacji z dziełem modelem, w którym dopuszcza się - i pożąda - bodźców wobec sztuki zewnętrznych.

W całym manifeście nazwisko Gombrowicza pada tylko raz, ale echa gombrowiczowskie słychać znacznie częściej, np. kiedy mowa o ironii jako podstawowym środku, który demontuje jednoznaczność słowa i pozbawia je tym samym pewnego odniesienia do rzeczywistości. W ogóle styl oparty na polisemii - „gdyby słowa były jak muchy, trudno byłoby je wytresować tak, by latały w określonym kierunku [en un sentido prefijado]"20 - często pojawia się na kartach „Literal”. Wpływ Gombrowicza (także Borgesa, choć traktowanego tu z dużym dystansem) widać także, gdy mowa o uporczywym i bezproduktywnym poszukiwaniu argentyńskości. Kwestia tożsamości narodowej pojawiła się wraz z odzyskaniem niepodległości i z czasem, pod wpływem kolejnych fal imigrantów, staje się coraz bardziej paląca. Mniej więcej do połowy xx wieku kultura argentyńska oscyluje między romantyczną apologią tego, co swojskie (stąd gloryfikacja gauczów), i dogmatyczną reprodukcją wzorów europejskich (głównie francuskich). Borges i Gombrowicz, jak wiadomo, znoszą ten dylemat,

\footnotetext{
18 Ibid., s. 8.

19 Ibid.

20 Ibid., s. 9. Hiszpańskie sentido oznacza zarówno „kierunek”, jak i „sens”.
} 
włączając kulturę argentyńską do „kultur drugorzędnych”, mających prawo do nonszalanckiego i synkretycznego korzystania z tradycji krajów „pierwszorzędnych”. W latach 7o. kwestia argentyńskości powraca $\mathrm{w}$ populistycznym wydaniu, towarzysząc frenetycznym dyskusjom politycznym między zwolennikami i przeciwnikami peronizmu, jak też między różnymi frakcjami tego ruchu.

O Gombrowiczu wspomina się w pierwszym numerze „Literal” jeszcze raz, w artykule końcowym zatytułowanym La intriga (Intryga $)^{21}$. Tytuł nawiązuje do akcji promocyjnej samego czasopisma: w geście typowym dla grup awangardowych lat 20. członkowie redakcji „Literal” wywieszają w centrum Buenos Aires plakaty, na których w ośmiu punktach poprzedzonych tytułem Intryga wykładają swoje credo. „Zmowa”, „spisek” będą lejtmotywami grupy - po pierwsze, ze względu na polityczny klimat epoki ${ }^{22}$, po drugie, z uwagi na „wyznawaną” koncepcję literatury: „To prawda, że brakuje nam wiedzy o pisaniu, równie prawdziwe jest podejrzenie, że nigdy jej nie posiądziemy. Ale jesteśmy wystarczająco bezczelni, by udawać jej rezultaty”23. „Literal” otwarcie deklaruje, że uprawia literaturę z pozycji niższości i braku, w opozycji zarówno do akademii, jak i do masowego czytelnika. Prześmiewczy ton, parodia, czerpanie z miejsc kulturowo podrzędnych - wszystko to składa się na gombrowiczowską "estetykę śmietnika”, do której zresztą nawiązuje się wprost w komentowanym artykule:

Dwóch mistrzów głupoty - Gombrowicza i Flauberta - da się prawdopodobnie [...] usłyszeć na tych stronach: pierwszemu zawdzięczamy

21 La intriga, „Literal” 1973, nr 1, s. 119-122. Pomijam jeszcze jedną wzmiankę o Gombrowiczu, w recenzji książki Ricarda Zelarayána La obsesion del espacio. Wzmianka ta jest raczej powierzchowna - tekst recenzji nie rozwija ewentualnego związku obu pisarzy - choć oczywiście znacząca o tyle, o ile przywołuje twórczość Gombrowicza jako ewentualny kontekst dla czytania Zelarayána.

22 V. Ariel Idez, "Literal". La vanguardia intrigante, Prometeo, Buenos Aires 2010, s. 112. Motyw spisku jest zresztą kluczowy dla literatury argentyńskiej, przynajmniej od czasów Roberta Arlta. O jego doniosłości wiele pisał - także powołując się na Gombrowicza - Ricardo Piglia w Teoría del complot (w: idem, Antología personal, Anagrama, Barcelona 2015, s. 99-118).

23 La intriga, s. 119. 
odkrycie subkultur, zdegradowanych mitologii i brzydoty; drugiemu sposób odtwarzania treściowo pustych dyskursów społecznych, które chcą uchodzić za doskonałe ${ }^{24}$.

W kolejnych numerach czasopisma bezpośrednich wzmianek o Gombrowiczu brak, ale pozostanie on jednym z punktów odniesienia grupy, która odrzuciwszy w typowo awangardowym geście modele literackie wówczas en vogue, zmuszona była fundować własną tradycję. Najważniejszym jej komponentem będzie Macedonio Fernández, czytany na nowo, inaczej niż wcześniej - a mianowicie przez Gombrowicza $^{25}$. Z perspektywy czasu w wywiadzie udzielonym w 2009 roku Luis Gusmán następująco komentował „długi” „Literal” wobec swoich poprzedników:

[...] każde czasopismo potrzebuje autora, który kondensowałby jego pozycję estetyczną i politykę językową. Funkcję tę spełniali Macedonio Fernández oraz Gombrowicz. Gombrowicz umożliwił nam - dzięki swojej poetyce stworzonej z odpadków wyższego świata kultury, z nieopierzonych mitów i z niewyznanych namiętności - stworzenie sekretnej maski, dzięki której mogliśmy funkcjonować w oficjalnym obiegu kulturowym tamtych czasów ${ }^{26}$.

24 Ibid., s. 122.

25 Mendoza pisze z kolei o „macedonizacji” Gombrowicza (macedonización de Gombrowicz), co może świadczyć po prostu o tym, że obu tych autorów postrzegano jako sobie bliskich; v. Juan Mendoza, El proyecto "Literal", s. 18.

26 Idem, "Una manera de leer provocada por una manera de escribir". Entrevista a Luis Gusmán, Dossier Literal de la Biblioteca Nacional Argentina, http://goo.gl/1jUqLG, dostęp: 5 V 2016. Gusmán parafrazuje fragment wstępu do hiszpańskiej Pornografii (przedrukowany z wersji francuskiej): „Człowiek, udręczony przez swoją maskę, potajemnie i na własny użytek sfabrykuje sobie swego rodzaju podkulturę - świat skonstruowany z odpadków wyższego świata kultury, krainę tandety, nieopierzonych mitów, nie wyznanych namiętności... Świat pośledniego autoramentu, kompensacji. Tam właśnie rodzi się jakaś wstydliwa poezja, jakaś kompromitująca uroda...”; Witold Gombrowicz, Przedmowa do francuskiego wydania Pornografii, przeł. Ireneusz Kania, w: idem, Varia 1. Czytelnicy i krytycy, Wydawnictwo Literackie, Kraków 2004, s. 418. W serii wywiadów z członkami grupy „Literal” Gombrowicza wspomina ponadto Jorge Quiroga: „»Literal« reprezentował w literaturze argentyńskiej pewien sposób czytania. Bez środków, bez wielkich aparatów teoretycznych i nie wiadomo czego, zaproponował lekturę Gombrowicza. [...] wybrano [go] intuicyjnie, z przyjemności 
Ta „sekretna maska” - przywdziewana wówczas wobec „cortazaryzmu, populizmu i realizmu” - to wspomniana już wyżej maska głupoty, arogancji (irreverencia), nieuprawomocnionej wiedzy (saber ilegítimo), doskonale określająca miejsce, z którego „literaliści” - i wszyscy czerpiący $\mathrm{z}$ nich inspirację - atakują kulturę oficjalnąą ${ }^{27}$.

Wracając do kwestii prekursorów: zaproponowana przez „Literal” lektura Macedonia będzie ponownie lekturą „przeciwko” - antagonistyczną, jak przenikliwie odnotowuje Ariel Idez, w stosunku do tej, jaką ponad czterdzieści lat wcześniej narzuciła grupa związana z awangardowym czasopismem „Martín Fierro”, w której skład wchodzili m.in. Jorge Luis Borges, Oliverio Girondo i Leopoldo Marechal ${ }^{28}$. Dla „martinfierrystów”, którzy pierwsi odkryli Macedonia i ocalili go od zapomnienia, był on przede wszystkim mistrzem i nauczycielem, podobnym Sokratesowi, który naucza w kawiarniach Buenos Aires, lecz którego tekstów się nie czyta. Borges był głównym inicjatorem tradycji (bo nie sposób tu mówić o lekturze) „Macedonia ustnego”, która dominowała aż do epoki „Literal”, także, trzeba przyznać, z powodów nie do końca literackich: Macedonio miał w zwyczaju pisać na luźnych kartkach, które, o ile w ogóle docierały do jego domu, ginęły tam w legendarnym wprost bałaganie. Ich losem pisarz się nie przejmował - jego obra maestra, Museo de la Novela de la Eterna (Muzeum Powieści Eterny), zostanie wydana dopiero w 1967 roku dzięki staraniom jego syna, Adolfa de Obiety (skądinąd przyjaciela Gombrowicza), a publikacja Dzieł zebranych, obejmujących dziewięć tomów, rozpocznie się dopiero w roku 1974. To z kolei wyjaśnia, dlaczego pokolenie „Literal” mogło jako pierwsze p r z e c z y t a ć Macedonia i rewindykować - jak

czytania”; Jorge Quiroga, Literal, una irrupción en la literatura argentina, Dossier Literal de la Biblioteca Nacional Argentina, http://goo.gl/1jUqLG, dostęp: 5 V 2016.

27 V. Luis Gusmán, Qué significó Gombrowicz en los 60, „Clarín. Revista N” 2006, 11 II, http://goo.gl/5A8Z9r, dostęp: 5 V 2016. Ten właśnie ton - arogancki, hardy, wyzbyty należnego szacunku - pozostał, zdaniem Prieto, najtrwalszym dziedzictwem „Literal”, którego modele teoretyczne (językoznawstwo i psychoanaliza) $\mathrm{z}$ czasem straciły na znaczeniu; v. Martin Prieto, Breve historia de la literatura argentina, Taurus, Buenos Aires 2011, e-wydanie. 
w przypadku Gombrowicza - tradycję dosłowną (textual), przeciwko interpretacji opartej na bezpośredniej znajomości i legendzie autora.

Punktów styczności między Gombrowiczem i Macedoniem jest co najmniej kilka - nie sposób ich tu szczegółowo omawiać, zasygnalizuję tylko te, które pozwoliły włączyć obu pisarzy do projektu „Literal”. Żaden nie należał do głównego nurtu literatury argentyńskiej: Gombrowicz znany był wąskiemu gronu entuzjastów (dopiero wyreżyserowana przez Lavellego inscenizacja Iwony w 1972 roku uczyni go bardziej rozpoznawalnym), status literacki Macedonia także był niepewny. Borges wprawdzie uznawał go za swojego mistrza, wielokrotnie twierdząc przy tym, że istnieje dwóch Macedoniów - zły pisarz i świetny rozmówca ${ }^{29}$. W obu przypadkach to odosobnienie było dobrowolne: Gombrowicz wybiera wygnanie, a Macedonio uparcie zaniedbuje własne dzieło w przekonaniu, że literatura nie musi konieczne być n a pis a n a (jak w przypadku Polaka, wśród przyjaciół Fernándeza krążyły więc, częściej niż teksty, jego rozliczne dowcipy i bons mots). Obaj związani z awangardą jednocześnie poza nią wykraczają - nieprzypadkowo zostali w pełni docenieni dopiero w latach 6o.: Macedonia uważa się za prekursora m.in. dzieła otwartego, powieści radykalnie autoreferencyjnej, tekstu jako gry, estetyki recepcji Wolfganga Isera. Obaj też polemizują z tradycyjną metafizyką - wizja Macedonia była skrajnie idealistyczna, w jej centrum znajdowały się Nicość (Nada) lub nie-byt (no-ser), które objawiały się w ulotności wszelkich stanów i doświadczeń, a więc podważały realność rzeczy. A jeśli rzeczywistości nie sposób odróżnić od marzeń sennych, to sztuka realistyczna traci rację bytu: zastępuje ją Belarte, koncepcja estetyczna odrzucająca mimesis („niniejsza propozycja estetyczna to prowokacja pod adresem szkoły realistycznej, próba zdyskredytowania prawdy lub realności tego, o czym

29 Stosunek „Literal” do Borgesa był równie złożony. Z jednej strony w latach 7o. jego kanonizacja w pełni się już dokonała, co z kolei powinno skutkować odrzuceniem ze strony ruchu mającego się za awangardowy. „Literal” nie decyduje się jednak na to „ojcobójstwo", ponieważ Borges okazuje się doskonałym sprzymierzeńcem $\mathrm{w}$ innej sprawie - w walce przeciwko realizmowi i populizmowi. W latach 70. jego krytyczne wypowiedzi o peronizmie uczyniły zeń persona non grata w coraz rozleglejszych kręgach literatury zaangażowanej. 
opowiada powieść”30), psychologię postaci w każdej formie („nie chcę przede wszystkim - i po wielokroć tego unikałem - by moja postać zdawała się naprawdę żyć"31) oraz tradycyjnie pojętą fabułę (Museo de la Novela de la Eterna składa się w dużej mierze z prologów). Głównymi narzędziami Belarte są absurd i ironia: Macedonio - jak Gombrowicz - przybiera maskę ironisty, bo groteska i kpina są potężną bronią przeciwko sprawdzonym schematom postrzegania świata i literatury. Na pokrewność poetyk obu pisarzy zwraca uwagę także Ricardo Piglia, niezwiązany bezpośrednio z „Literal”, ale bliski wykładanej tam estetyce:

Przed przybyciem Gombrowicza do Argentyny Macedonio nie ma partnera do rozmowy o sztuce pisania powieści. Trans-Atlantyk, powieść argentyńska, jest już powieścią w stylu Macedonia (nie wspominając o Ferdydurke). Wychodząc od Gombrowicza, można czytać Macedonia. A dokładniej: Gombrowicz pozwala czytać Macedonia ${ }^{32}$.

Macedonio-pisarz zostaje późno odkryty i późno wydany, przy czym to odkrycie ciągle się dokonuje: najlepszym dowodem jego dobrej

30 Macedonio Fernández, Museo de la Novela de la Eterna, oprac. Ana Camblong, Alfonso de Obieta, ALLCA xx, Madrid 1997, s. 38.

31 Ibid., s. 40.

32 Ricardo Piglia, Notas sobre Macedonio en un diario, w: idem, Formas breves, Anagrama, Barcelona 2000, s. 23. W innym miejscu Piglia w następujący sposób pisze o pokrewieństwie między tymi pisarzami: „Czy Gombrowicz i Macedonio kiedykolwiek się spotkali? W owych latach [40. - E.K.P.], zarówno jeden, jak i drugi żyli na marginesie, w swoich ubogich pokoikach pensjonatów, pewni swojej wartości, lecz niepewni przyszłości swoich dzieł. Zapewne z wielu względów byli dla siebie wzajemnie jedynymi potencjalnymi czytelnikami. Można mieć prawie pewność, że Macedonio przeczytał Ferdydurke, ponieważ odniesienia do tej książki pojawiają się w jednym z jego ineditów. Jeśli natomiast chodzi o Gombrowicza, był on bez wątpienia jedynym, który mógł odczytać Museo de la Novela de la Eterna w pełni, jedynym czytelnikiem na poziomie wizji twórczej Macedonia”; Ricardo Piglia, Czy istnieje powieść argentyńska? Borges a Gombrowicz, przeł. Klementyna Suchanow, Krystian Radny, „Literatura na Świecie" 2001, nr 4, s. 70. Na podobieństwo poetyki Gombrowicza i Macedonia zwraca także uwagę: Alejandro Rússovich, Gombrowicz en el relato argentino, w: Elsa Drucaroff (red.), Historia crítica de la literatura argentina, t. 11, Emecé, Buenos Aires 2000, s. 365. 
passy jest fakt, że we wspomnianej Historia crítica de la literatura argentina jeden cały wolumin poświęcony jest wyłącznie literackiemu projektowi Macedonia ${ }^{33}$. Obaj pisarze - by zamknąć długą listę podobieństw - byli ponadto znani z upodobania do prologowania własnych tekstów: liczne prologi Museo de la Novela de la Eterna są kpiną z realistycznych pretensji gatunku powieściowego; przedmowy Gombrowicza strzegą natomiast interpretacyjnej ortodoksji, naprowadzając czytelnika na przesłanie, które autor wprzódy zdeponował w tekście. „Literalistów” oskarżano o tworzenie „literatury prologowanej" (literatura prologada), niezrozumiałej bez wyjaśnień najeżonych odniesieniami do najnowszych, importowanych teorii literackich - oni sami uważali zaś sztukę prologu za równą samej literaturze, za jej integralną część ${ }^{34}$.

Zaproponowana przez „literalistów” lektura Gombrowicza nie wyczerpuje się w aluzjach i tekstach zamieszczonych w czasopiśmie. Pod koniec lat 6o. i na początku 70. główni członkowie grupy wydali powieści - w większości natychmiast zakazane przez ówczesną cenzurę - w których wyraźnie pobrzmiewają echa gombrowiczowskiej estetyki. Mowa o Nanina (1968) i Cancha Rayada (1969) Germána Garcíi, w mniejszym stopniu o El fiord (1969, Fiord) i Sebregondi retrocede (1973, Sebregondi ustępuje) Osvalda Lamborghiniego. Punktem

33 V. Roberto Ferro (red.), Historia crítica de la literatura argentina, t. 8: Macedonio, Emecé, Buenos Aires 2007. Tylko Domingo Faustino Sarmiento posiada swój „własny” tom w ramach tej publikacji, reszta zebrana jest tematycznie i poświęcona wielu pisarzom.

34 Najsłynniejsze ich powieści były opatrzone wstępami: García pisze (pod pseudonimem Leopoldo Fernández) prolog do powieści El fiord Lamborghiniego (v. Germán García, Los nombres de la negación, w: Osvaldo Lamborghini, El fiord, Chinatown, Buenos Aires 1969; przedruk w: idem, Fuego amigo. Cuando escribí sobre Osvaldo Lamborghini, Grama Ediciones, Buenos Aires 2003, s. 13-29), Piglia do El frasquito Gusmána (v. Ricardo Piglia, El relato fuera de la ley, w: Luis Gusmán, El frasquito, Ediciones Noé, Buenos Aires 1973, s. 7-23). W pierwotnym zamyśle Lamborghiniego El fiord miał być poprzedzony ponad dwudziestoma prologami; v. Julio Premat, Héroes sin atributos. Figuras de autor en la literatura argentina, FCE, Buenos Aires 2009, s. 136. 
stycznym tych powieści jest „narracja o ciele” ${ }^{35}$ spod znaku erotyki (nierzadko obscenicznej i bliskiej pornografii), a także przemocy, praktykowanej w wymiarze pokoleniowym (starsi na młodych), seksualnej oraz państwowej (władza przeciwko obywatelowi). U schyłku lat 60. i w początkach 7o. - jak słusznie zauważa López Casanova - cielesność, a przede wszystkim seksualność staje się przestrzenią konfliktu: wolna miłość to część nowego porządku, o który się walczy ${ }^{36}$. Ferment ten, wspólny całemu światu zachodniemu, zyskuje w Argentynie epoki tzw. drugiego peronizmu i następującej po niej dyktatury wojskowej nowy wymiar: władza praktykuje przemoc polityczną razem z seksualną, oba porządki - jak w El fiord, ale także w El frasquito Luisa Gusmána (1973) - mieszają się ze sobą. W niniejszym rozdziale zajmę się tylko powieściami Germána Garcíi; w literackiej twórczość Luisa Gusmána Gombrowiczowskich śladów jest bowiem najmniej ${ }^{37}$, a w tekstach Osvalda Lamborghiniego pojawiają się najpełniej dopiero w kolejnej dekadzie, kiedy jego estetyka uwalnia się od bezpośrednich związków z projektem „Literal” (dlatego poświęcę jej kolejny, osobny podrozdział).

Główny inspirator i ideolog „Literal”, Germán García (ur. 1944), sam chętnie wspomina o ferdydurkistowskiej genezie powieści Nanina

35 V. Martina López Casanova, La narración de los cuerpos, w: Elsa Drucaroff (red.), op. cit., s. 183-215. Nazwisko Gombrowicza jako prekursora tej estetyki pada także $\mathrm{w}$ innym artykule zawartym w tymże tomie - Luisa Chitarroniego Continuidad de las partes, relato de los límites, s. 174. Wypada dodać, że jednym z sympatyków „Literal” był Jorge Di Paola, który dla poczytnego w latach 7o. tygodnika „Panorama” przeprowadził wywiady z Gusmánem i Lamborghinim. Nazwisko Gombrowicza jako inspiratora poetyki El frasquito przywołuje w krótkim artykule poprzedzającym wywiad z Gusmánem; v. Jorge Di Paola, Gusmán: el dominio de los mitos informes, „Panorama” 1973, 18 I, s. 30.

36 Martina López Casanova, op. cit., s. 183.

37 Zresztą pomimo tego, co sugerują niektórzy argentyńscy krytycy. Damián Tabarovsky pisał o Gusmánie jako o „następcy Gombrowicza”, powołując się przy tym na zdanie Luisa Chitarroniego, autora prologu do niedawno wznowionego El frasquito. Chitarroni widzi w gombrowiczowskiej „niedojrzałości” jeden z kluczy do interpretacji powieści Gusmána. V. Damián Tabarovsky, El heredero de Gombrowicz, „Clarín. Revista N” 2013, 13 III, https://goo.gl/S1guFj, dostęp: 15 XII 2014. 
(jedna z jej scen, w której bohater odwiedza dom pewnego muzyka i poznaje jego wnuczkę, miałaby być hołdem dla rodziny Młodziaków ${ }^{38}$ ), wydaje się jednak, że najwięcej odwołań do Gombrowicza zawiera jego kolejna książka, Cancha Rayada. Opublikowana rok po sukcesie Naniny powieść jest groteskową wariacją na temat popularnej w owym czasie konwencji literatury świadectwa (literatura testimonial), nie stroni przy tym od długich partii pisanych techniką monologu wewnętrznego oraz scen typowo dramatycznych. Tytuł powieści nawiązuje do bitwy pod Cancha Rayada (1818), spektakularnej klęski poniesionej przez generała San Martína, narodowego bohatera argentyńskiego, w walkach o niepodległość Chile. „Dobrzy” wówczas przegrali - bohaterowi powieści, chłopcu o imieniu Leo, z trudem przyjdzie to zrozumieć. Dorasta w burzliwych latach 6o.: jego ojciec, zaangażowany w ruch robotniczy, zginie w trakcie jednej z ,akcji”, a Leo przeprowadzi się do swojego wuja, nieszkodliwego dziwaka, który siostrzeńca nauczy koniecznej wiedzy o kobietach: „wyszukuje te, które uważa za najłatwiejsze, swata mnie z tymi, którymi najbardziej pogardza”39. Ostatnia część książki, opisująca „dorastanie” Leo pod opieką wuja, nieprzypadkowo opatrzona jest mottem z Ferdydurke:

[...] czas już, abyście przestali mieć się za wyższe istoty, które mogą kogokolwiek pouczać, oświecać, prowadzić, uwznioślać oraz umoralniać [...]. O, nie, ten pisarz, o którym mówię, nie będzie oddawał się pisaniu dlatego, że uważa się za dojrzałego, lecz właśnie ponieważ zna swą niedojrzałość i wie, że nie posiadł formy [...] starajcie się przezwyciężyć formę, uwolnić się od formy ${ }^{40}$.

38 V. Juan Mendoza, "Permanecer en la vanguardia". Entrevista a Germán García, Dossier Literal de la Biblioteca Nacional Argentina, http://goo.gl/1jUqLG, dostęp: 5 V 2016.

39 Germán García, Cancha Rayada, Otium Narrativa, Buenos Aires 2014, s. 181.

40 Witold Gombrowicz, Ferdydurke, oprac. Włodzimierz Bolecki, Wydawnictwo Literackie, Kraków 2004, s. 79-82. Cytat w języku hiszpańskim różni się znacząco od oryginału: Y tampoco escribirá para pretenciosamente educar, elevar, guiar, moralizar y edificar a los otros [...]. Y no escribirá porque ya es maduro y consiguió la forma, sino que justamente porque todavía es inmaduro y solo en la humillación, ridiculez y sudor se esfuerza por atraparla [...]. Tratad de oponeros 
Postać wuja wzorowana jest na Gombrowiczu - to ekscentryczny poeta, który w barach deklamuje swoją twórczość („przed staruszkami z kwiatami w dekoltach i eunuchami o słodkim głosie"41) i wygłasza siostrzeńcowi „tyrady o różnej intensywności na temat znaczenia poezji i życia poetyckiego" ${ }^{42}$, utrzymane skądinąd w prześmiewczym tonie Przeciw poetom:

Wielcy - powiedział - to ludzie Światowi, inni są tylko lokalni lub wręcz dzielnicowi. Jeśli zauważysz, że jakiś argentyński poeta naśladuje Eluarda, Bretona lub Apollinaire’a, nie myśl o nim źle. Argentyńczykowi - zważywszy, że nie przebywa w Paryżu - z łatwością przychodzi naśladownictwo, ale to go nie umniejsza, lecz zbliża go do wielkich. Poeci, jak kury, nie muszą wiedzieć do kogo należy jajo, żeby je wysiadywać ${ }^{43}$.

Czasem znika nocami, być może włóczy się po Retiro, nękany osobliwą parafilią - upodobaniem do damskich majtek, które kradnie i których kolekcję gromadzi na strychu. Z tego upodobania przyjdzie mu - jak Gombrowiczowi - tłumaczyć się na komisariacie. Próbuje edukować siostrzeńca, ale patetyczny ton nieubłaganie przepoczwarza się w bełkotliwy dyskurs pana Cieciszowskiego z Trans-Atlantyku:

Nasza argentyńskość potrzebuje tych, którzy w przyszłości staną na jej czele, pragnie młodzieży żywotnej (ale nie hardej) z pomysłami (ale nie własnymi), wyrazistej i z pasją (ale nie na tyle pewnej siebie, by spełniło się karm kruki, a te wydziobią ci oczy).

Pamiętaj: upór i konsekwencja. Albo lepiej: witalność i posłuszeństwo. A może: autorytet i rozwaga ${ }^{44}$.

Ze wszystkich dzieł Gombrowicza Ferdydurke najwyraźniej pobrzmiewa w Cancha Rayada: kiedy wuj Leo wspomina, jak w dzieciństwie

a la forma, liberaos de la forma; idem, Ferdydurke, przeł. autor i komitet tłumaczy, Seix Barral, Barcelona 2011, s. 105-108.

41 Germán García, Cancha Rayada, s. 190.

42 Ibid., s. 188.

43 Ibid.

44 Ibid., s. 193. 
pewien zboczeniec gwałci go przez uszy, śpiewając mu sprośną piosenkę $^{45}$, albo kiedy pewnego razu, w wieku 36 lat, budzi się w krótkich spodenkach, dokładnie takich, w jakich „tamtego dnia wrócił ze szkoły" ${ }^{\prime 6}$. Peany na cześć Wielkich Patriotów wygłaszane przez nauczycielkę Leo niepokojąco przypominają słynne „Słowacki wielkim poetą był" Bladaczki. Wspominane wyżej długie passusy, w których postaci wygłaszają swoje kwestie niczym w utworze dramatycznym („ćwiczenia w dyskusji”, jak nazywa je narrator) także mają swój odpowiednik w Ferdydurke.

Przy innej okazji wuj mówi do Leo: „Ja, drogi siostrzeńcu, szukałem samego siebie. Biegłem jak gdyby nigdy nic i nagle odwracałem się na pięcie, by się przyłapać, ale moje prawdziwe ja już umykało" ${ }^{47}$. Zdanie to jest jedną z możliwych definicji Gombrowiczowskiego Dziennika, tym bardziej że zaraz następuje odniesienie do tej formy literackiej: krótka notka opatrzona konkretną datą („12/6/67”). Kilka linijek niżej wuj wdaje się w rozmowę z pewnym staruszkiem, zachowując się przy tym jak „postać z powieści z czasów jego dzieciństwa, ma nawet słabość do dialogów z myślnikiem [...], co sprawia, że inni z uprzejmości też czują się w obowiązku dodawać myślnik do odpowiedzi" ${ }^{48}$. Jego dystyngowany ton i staroświecka maniera (literacka) narzucają się natychmiast rozmówcy - oto kolejny lejtmotyw gombrowiczowskich stosunków międzyludzkich. W postaci Gombrowicza-wuja García uaktywnia także popularny w literaturze argentyńskiej motyw pisarza przegranego (escritor fracasado), dominujący skądinąd także w tekstach Ricarda Piglii poświęconych autorowi Ferdydurke. Gombrowicz nie jawi się tutaj jako wytrawny gracz w „światowej republice literatury”, lecz jako ekscentryczna, dziwaczna i marginalna postać, której przyjdzie

\footnotetext{
45 „Przerażony (kochałem już wtedy kastylijski), próbowałem egzorcyzmować sens tych niegodziwych słów [...]. Cały mój świat chwiał się [...]. Rozchorowałem się, zdeformowałem, urosłem i wyrosłem"; ibid., s. 198. „I ja, w wieku 36 lat, obudziłem się w krótkich spodenkach, dokładnie takich, w jakich tamtego dnia wróciłem ze szkoły"; ibid.

47 Ibid., S. 202.

48 Ibid., s. 202-203.
} 
zginąć w absurdalnym wypadku komunikacyjnym. Ta specyfika argentyńskiego postrzegania Gombrowicza bierze się - jak wyżej wykazywałam - m.in. z kompozycji Dziennika argentyńskiego, w którego pierwszych zdaniach akcentuje się motyw osobistej porażki pisarskiej i rozczarowania życiem.

W Cancha Rayada - podobnie jak kilka lat później w „Literal” - oręż gombrowiczowskiej groteski wymierzony jest przeciwko panującej wówczas niepodzielnie estetyce realistycznej oraz w obronie kategorii (literackich, kulturowych, społecznych), które kryją się pod pojęciem niedojrzałości. Obie te intuicje, trzeba przyznać, nie wykraczają poza klasyczne (odautorskie) interpretacje Gombrowicza. W jakim sensie „literaliści” przełamują tę konwencjonalną lekturę? W kontekście argentyńskim narzucają nowy model „obcowania” z Gombrowiczem - za pośrednictwem tekstu. W latach, w których w prasie argentyńskiej dominowała o nim raczej narracja „wspominkowa”, „Literal” eksponuje nie człowieka, lecz teksty. W kontekście szerszym (gombrowiczologii) zasługą pisma jest lektura Gombrowicza kodem psychoanalizy lacanowskiej - eksplorującym tłumioną, wymagającą odkrycia seksualność - na wiele lat przed podobnymi próbami w polskiej (Michał Paweł Markowski) lub europejskiej (Olaf Kühl) krytyce. Niezależnie od zastrzeżeń, jakie można sformułować wobec „psychoanalitycznej” interpretacji Gombrowicza, nie sposób zaprzeczyć jej wielkiej produktywności w ostatnich latach (Włodzimierz Bolecki nazywa ją nawet „monokulturą interpretacyjną" ${ }^{49}$ ). „Literaliści” jako pierwsi czytają Gombrowiczowską cielesność dla niej samej, nie jako wyraz czegoś głębszego, duchowego, jako zaszyfrowaną koncepcję filozoficzną. $Z$ tą różnicą, trzeba przyznać, że o ile Markowski i Kühl traktują Lacana $\mathrm{z}$ dystansem jako narzędzie do interpretacji tekstu, o tyle dla „literalistów” (aktualnie praktykujących analityków) jest on punktem wyjścia i dojścia, a Gombrowicz pozostaje raczej swoistą egzemplifikacją jego psychoanalitycznych tez.

49 Włodzimierz Bolecki, Czego wyparł się Witold Gombrowicz?, w: Olaf Kühl, Gęba Erosa. Tajemnice stylu Witolda Gombrowicza, przeł. Krzysztof Niewrzęda, Maria Tarnogórska, wstęp Włodzimierz Bolecki, Universitas, Kraków 2005, s. XI. 


\section{Osvaldo Lamborghini}

Osvaldo Lamborghini (1940-1985) to, obok Ricarda Zalarayána, najlepiej znany pisarz wywodzący się z kręgu „Literal” - twórca specyficznego, transgresywnego języka, operującego groteską i szyderczą karykaturą w sferach silnie ztabuizowanych, okrzyknięty po śmierci „przeklętym”, zdaje się na literackiej mapie Buenos Aires figurą niepowtarzalną, zjawiskiem zgoła odosobnionym. Nic dziwnego, że podejmowane przez krytykę próby odnalezienia mu prekursorów - literatury z ducha gauczowskiej, Macedonia, nieodzownego Borgesa - pozostają umowne, intuicyjne, zawsze fragmentaryczne. Nie inaczej ma się rzecz ze związkiem Lamborghini-Gombrowicz: choć interpretacyjnie kuszący, wyczerpuje się zwykle na zasygnalizowaniu kryptocytatu, napomknięciach o niedojrzałości i formie, ewentualnie mglistych powołaniach na wspólnotę pisarzy marginalnych. Nazwisko Gombrowicza krąży wprawdzie w tle krytyk poświęconych autorowi El Fiord - wspominają o nim Jorge Di Paola ${ }^{50}$, César Aira ${ }^{51}$, Reinaldo Laddaga $^{52}$, Julio Premat ${ }^{53}$, Alan Pauls ${ }^{54}$, Luis Chitarroni ${ }^{55}$, a także polska badaczka Agnieszka Flisek ${ }^{56}$ - pozostają to jednak zaledwie próby sondowania możliwej płaszczyzny wspólnej. Najpełniejsze studium na temat ewentualnego długu Lamborghiniego wobec autora Ferdydurke zawiera jeden z rozdziałów monografii Pabla Gaspariniego El exilio

50 Jorge Di Paola, Osvaldo Lamborghini: un museo literal, „Panorama” 1973, 2 II, s. 63; idem, Las jornadas de Sebregondi, „Panorama” 1973, 14 VI, s. 66.

51 César Aira, Prólogo, w: Osvaldo Lamborghini, Novelas y cuentos, Ediciones del Serbal, Barcelona 1988, s. 7.

52 Reinaldo Laddaga, Espectáculos de realidad. Ensayo sobre la narrativa latinoamericana de las últimas dos décadas, Beatriz Viterbo, Rosario 2007, s. 105.

53 Julio Premat, op. cit., s. 163.

54 Alan Pauls, ¡Lengua, sonaste!, „Babel” 1989, nr 9, s. 5.

55 Luis Chitarroni, op. cit., s. 161-182.

56 Agnieszka Flisek, Algunas consideraciones sobre el carácter cínico de la escritura de Osvaldo Lamborghini, „Sociocriticism” 2011, t. 26, nr 1/2, s. 316; eadem, Osvaldo Lamborghini y Copi: caminos de la escritura los por que el yo abandona a sí mismo para salir al encuentro de otro, „Sociocriticism” 2009, t. 24, $\mathrm{nr} 1 / 2$, s. $360-361$. 
proca $z^{57}$, którego celem - jak zaznacza sam autor - nie było udowodnienie „wpływu” czy „dziedzictwa” (mowa bowiem o „bastardach” Gombrowicza), a jedynie dostrzeżenie:

jak rzeczywistość argentyńska końca lat 70. i początku 80. sprawia, że problematyka gombrowiczowska staje się zaskakująco odkrywcza w analizach związków pomiędzy literaturą, ideologią i polityką wobec tożsamości narodowej „wykręconej” w stronę terroru, oskarżeń i mrzonek o wielkości ${ }^{58}$.

Możliwe paralele pomiędzy Gombrowiczem a trzema autorami argentyńskimi - Lamborghinim, Copim i Perlongherem - budowane są tutaj nie tyle na wspólnocie praktyk pisarskich, stylu i tematów, co na podobieństwie artystycznego credo, wspomnianej wyżej figury autora, w której akcentuje się bezczelny, arogancki (irreverente, procaz) ton kogoś, kto konsekwentnie unika w swojej twórczości wszelkich imperatywów narodowościowych oraz odmawia przynależności do grupy, w tym także do rozpoznanych przez krytykę konkretnych formacji estetycznych. I chociaż zgadzam się z Gasparinim co do faktu, że konsekwencją politycznej gorączki lat 7o. było odkrycie Gombrowiczowskiej problematyki, w tym przede wszystkim prawa do mówienia z „podrzędnego” miejsca („Literal” jest tego najlepszym dowodem), to jednak zaproponowana przez argentyńskiego badacza lektura Lamborghiniego poprzez autora Ferdydurke wydaje mi się nie trafiać w sedno tej relacji. Gasparini konstruuje ją bowiem, wychodząc od najsłynniejszego opowiadania Argentyńczyka, El fiord ${ }^{59}$ Z 1967 roku, „mitycznego” tekstu o wyjątkowo silnym ładunku obsceniczności, ekshibicjonizmu i przemocy, w którym władza polityczna artykułuje się przede wszystkim na poziomie perwersyjnej seksualności. Związek międzytekstowy zostaje ustanowiony na podstawie

57 Pablo Gasparini, Osvaldo Lamborghini. Del muro al baño: obscenidad política y políticas de lo obsceno, w: idem, El exilio procaz. Gombrowicz por la Argentina, Beatriz Viterbo, Rosario 2006, s. 277-313. Ibid., s. 265-266.

59 Osvaldo Lamborghini, El fiord, w: idem, Novelas y cuentos, s. 19-34. Przynależność gatunkowa tego tekstu (opowiadanie? krótka powieść?) pozostaje nieokreślona. 
obecnej u obu autorów praktyki graffiti, którą postrzega się jako rodzaj ordynarnego, obcesowego aforyzmu, słownej realizacji pragnienia w pomylonym, nieodpowiednim miejscu: autor Dziennika umieszcza swoje „Panowie i panie...” na ścianie publicznego ustępu na Callao, u Lamborghiniego - eksponującego „to, co Gombrowicz wolałby przemilczeć" 60 - graffiti przybiera formę haseł politycznych, które, wykrzykiwane w scenerii zdominowanej przez serię seksualnych gwałtów, nabierają groteskowego, kompromitującego wydźwięku - są słowami „nie na miejscu”, przykładem ekstremalnego, hiperbolicznego pomieszania sfery publicznej z prywatną. Nie podważając znaczenia tego anonimowego trybu wypowiadania się, w którym rozkosz wypływa ze „strasznej jawności napisu [...] $\mathrm{w}$ połączeniu $\mathrm{z}$ absolutnym zatajeniem sprawcy" ${ }^{61}$ (o graffiti pisze także Olaf Kühl w kontekście Gombrowiczowskiej poetyki maski ${ }^{62}$ ), trudno dostrzegać w nim rozległą płaszczyznę dla dialogu obu tych estetyk, skądinąd w wielu punktach od siebie odmiennych. Wychodząc od debiutanckiego El fiord, trudno taką płaszczyznę z n a c z ą co poszerzyć - choć Pau Freixa Terradas przenikliwie wskazuje na „tworzenie alegorycznych przestrzeni literackich, w których postaci lub elementy tekstowe odsyłają zawsze [...] do idei i elementów symbolicznych, lub - co ważniejsze i bardziej charakterystyczne - zmianę znaczenia bądź oceny moralnej różnych elementów alegorycznych w czasie trwania akcji”, a ponadto wykorzystanie sceny pojedynku oraz upodobanie do groteski i prowokacji, cechy, które zresztą sam badacz - w moim przekonaniu nazbyt krytycznie - dyskwalifikuje jako niewystarczające do ustanowienia „relacji wpływu” ${ }^{63}$. W kwestii uprawomocnienia relacji Gombrowicz-Lamborghini nie wnosi za

\footnotetext{
60 Pablo Gasparini, El exilio procaz, s. 282.

61 Witold Gombrowicz, Dziennik 1953-1969, Wydawnictwo Literackie, Kraków 2013, e-wydanie; wyróżnienie w oryginale.

62 Olaf Kühl, op. cit., s. 157-16o.

63 Pau Freixa Terradas, Recepción de la obra de Witold Gombrowicz en la Argentina y configuración de su imagen en el imaginario cultural argentino, niepublikowana rozprawa doktorska, Universidad de Barcelona, 2008, s. 216, http://goo.gl/A3avU1, dostęp: 10 V 2016.
} 
to nic specjalnie odkrywczego wielokrotnie przywoływana przez Freixę Terradasa w tym kontekście postać markiza de Sebregondi, wzorowana m.in. na autorze Trans-Atlantyku ${ }^{64}$. Jeśli jednak zmienić korpus analizowanych tekstów i skupić się na La causa justa (W sprawiedliwej sprawie) z 1983 roku, inspiracje Gombrowiczowskie stają się znacznie bardziej uchwytne.

Tekst o którym mowa - gatunkowa niejednoznaczność jest znakiem rozpoznawczym prozy Lamborghiniego - jest jednym z nielicznych, które faktycznie pragnął opublikować, a nawet, „rzecz niezwykła, sam przygotował maszynopis" ${ }^{35}$. Zasadnicza większość jego produkcji literackiej zachowała się w formie mniej lub bardziej fragmentarycznych prób, wydanych po śmierci autora przez Césara Airę - głównego egzegetę Lamborghiniego - pod raczej woluntarystycznym tytułem Novelas y cuentos (Powieści i opowiadania) ${ }^{66}$. Edytorska praca Airy zasługuje zresztą na krótki komentarz, jest bowiem dziełem samym w sobie, staranną „konstrukcją prekursora” obejmującą zarówno fizyczne przygotowanie tekstów, jak i komentarz krytyczny, który wyznacza im miejsce w obrębie écriture automatique i po wielokroć podkreśla ich formalną doskonałość, a także budowę postaci-autora, „mężczyzny przystojnego, eleganckiego, o arystokratycznych manierach, dosyć wyniosłego, ale także bardzo serdecznego" ${ }^{67}$. „Operacja Lamborghini” spotkała się z krytyką tych, którzy widzieli w niej przede wszystkim

64 „Homoseksualista aktywny, kokainista (jak mówi, »nigdy nie brakowało mi cierpliwość, tyłka i strachu«), markiz de Sebregondi, uciekając ze swoich ruin, dobił do tych ziem: zakotwiczył w Buenos Aires. Oto nadchodzi. Pojawia się, jego kroki są krótkie, opanowane. Zawraca, cofa się, nadchodzi. Ma markiz zniszczone ubranie i sztuczny kwiat w butonierce"; Osvaldo Lamborghini, Sebregondi retrocede, w: idem, Novelas y cuentos, s. 53. Tekst rozpoczyna się ponadto aluzją do Ferdydurke: „Części są czymś więcej niż częściami”; ibid., s. 37.

65 César Aira, Prólogo, w: Osvaldo Lamborghini, Novelas y cuentos, s. 14. Za życia Lamborghiniego ukazały się tylko El fiord, Sebregondi retrocede (Noé, Buenos Aires 1973) i Poemas (Tierra Baldía, Buenos Aires 1980).

66 Pierwsze wydanie $\mathrm{z} 1988$ zostało wznowione i rozszerzone - już w dwóch tomach - w roku 2003, ponadto Aira wydał także powieść-sagę Tadeys (1994) i Poemas (1969-1985).

67 César Aira, Prólogo, w: Osvaldo Lamborghini, Novelas y cuentos, s. 16. 
opowieść próbującą ucywilizować tego niewygodnego, subwersywnego pisarza i stępić ekstremizm jego tekstów ${ }^{68}$. Bez względu na intencje Airy (Julio Premat zwraca uwagę na ostentacyjnie fikcyjny charakter opisanej $\mathrm{w}$ prologu osoby pisarza oraz jawnie ironiczne przedstawienie konstelacji fragmentów jako serii niedościgłych chefs-d’euvre ${ }^{69}$ ) jego edytorskie przedsięwzięcie doprowadziło, po pierwsze, do kanonizacji całej twórczości Lamborghiniego, także licznych ineditów, nadając temu szczególnemu work in progress ostateczny charakter „zamkniętego” dzieła, oraz, po drugie, do uprawomocnienia nowego literackiego rodowodu, który prowadzi od autora El fiord przez Copiego do samego Airy. „CHŁOPCY, musicie dalej pisać, bo ja nie jestem ojcem: jestem przeznaczeniem” - pisze w Las hijas de Hegel (Córkach Hegla) ${ }^{70}$, co zresztą wygląda na parafrazę słynnego: „Chłopcy, zabijcie Borgesa”, które podobno rzucił swoim „uczniom” Gombrowicz, wsiadając na statek do Europy ${ }^{71}$.

Na tym tle napisana na wygnaniu w Barcelonie na dwa lata przed śmiercią La causa justa zachowuje więc pozycję dosyć wyjątkową jako tekst zakończony. Pierwszą jej część - rodzaj wprowadzenia - stanowi długi fragment poświęcony niejakiemu Luisowi Antonio Sullo, „erudycyjnemu linotypiście”, który „nigdy nie czytał, ale jego podkreślenia były doskonałe” i którego czytelnik widzi na łożu śmierci, „na skraju swojej ostatniej herezji: umierającego na raka w wieku 56 lat"72. Opis tej sceny „rozłazi” się natychmiast pomiędzy przeszłością i teraźniejszością, rozdarty głosami, które wracają wciąż w te same miejsca, choć nie wiadomo nawet, do kogo należą ani do kogo są skierowane: Luisa Antonia, samego narratora, Osvalda Lamborghiniego lub - co

68 V. Elsa Drucaroff, Los hijos de Osvaldo Lamborghini, w: Noé Jitrik (red.), Atípicos en la literatura latinoamericana, Universidad de Buenos Aires, Buenos Aires 1997, s. 145-154; Luis Gusmán, Sebregondo no retrocede, w: Juan Pablo Dabove, Natalia Brizuela (red.), Y todo el resto el resto es literatura. Ensayos sobre Osvaldo Lamborghini, Interzona, Buenos Aires 2008, s. 49-54.

69 Julio Premat, op. cit., s. 161-162.

70 Osvaldo Lamborghini, Las hijas de Hegel, w: idem, Novelas y cuentos I, Sudamericana, Buenos Aires 2013, s. 225; wyróżnienie w oryginale.

71 V. Julio Premat, op. cit., s. 163.

72 Osvaldo Lamborghini, La causa justa, w: idem, Novelas y cuentos, s. 193. 
najbardziej prawdopodobne - do wszystkich naraz? Usytuowana w tej niepewnej, nieistniejącej przestrzeni narracja rozpływa się w końcu w refleksjach piszącego ,ja”:

Jedynie postacie z książek - tych, których już się nie pisze - nadają ,formę” swojemu losowi. Ale nie ma rady, czasami sprawy trochę się komplikują. Niektórzy z nas nie znajdują żadnej formy dla - było nie było - losu. Gdybyśmy tylko potrafili ją znaleźli, nawet chcielibyśmy mieć los. Ale obwinianie samego siebie w powieści (naprawdę dobrej) o śmieszne pretensje do napisania powieści, nie zwalnia mnie...

Chciałem zrobić miejsce słowu „zwalnia”, które może odegrać całkiem ważną rolę. Czytelnik zapewne stracił czas. Ale to ja jestem czytelnikiem. Ale to także mnie nie zwalnia ${ }^{73}$.

Forma (dialektyka pomiędzy nieuchronnym uformowaniem i chęcią uwolnienia się od formy, oba stany postrzegane równocześnie jako pożądane i krępujące) oraz przygody języka (słowa, ich brzmienia i polisemie są wydarzeniami, impulsem akcji) - oto dwa najważniejsze elementy gombrowiczowskiej problematyki w La causa justa.

Kolejny etap opowieści to historia postaci o imieniu Nal - choć poboczna wobec centralnych wydarzeń, wprowadza bohatera, który powracać będzie w kolejnych tekstach Lamborghiniego. Nal jest człowiekiem dobrym i szlachetnym, ale jego ciało szpeci deformacja, która czyni go przedmiotem okrutnych żartów - posiada ogromnych wprost rozmiarów pupę - i która jest pretekstem do następujących rozważań narratora:

Człowiek, który rodzi się pupiasty [culón], człowiek, który rodzi się dupiasty [nalgudo], całe życie taszczy za sobą te dwa przezwiska: pupiasty, dupiasty. Ludzie silą się na pozornie subtelne rozróżnienia. My, literaci, także, ale to nasz zawód: sami chcieliśmy zajmować się słowami, a teraz zewsząd narzekania - $\mathrm{i}$ tak rozróżnianie sensu pupiastego od dupiastego nagle staje się naszym najpilniejszym i obligatoryjnym zadaniem (podczas gdy chcielibyśmy także wypowiedzieć się o człowieku w ogóle $)^{74}$.

73 Ibid., s. 196.
74 Ibid. 
Nawiązanie do argentyńskiej Ferdydurke, w której „pupa” tłumaczona jest szeregiem neologizmów zbudowanych na rdzeniu słowa culo (cuculito, cuculazo, cucucú, cuculí, cuculucho, cuculeíto, cuculandrito etc.), jest w tym fragmencie oczywiste. Tym bardziej że ta szczególna właściwość - pupiastość - przenika do imienia bohatera ${ }^{75}$ i staje się kwintesencją jego uformowania, jak w przypadku rodziny Młodziaków. Co w Ferdydurke było zespołem idei lub wartości (związanych z kultem nowoczesności), tutaj jest czystym defektem fizycznym, „deformacją” rozczłonkowującą ciało, przyłączoną „,(groteskową) częścią, która nie pasuje do reszty" ". Pupiastość jest formą zdegradowaną, pomyloną, formą, od której nie ma ucieczki, bo Nal jest „upupiony” bez reszty, jako przykładny ojciec rodziny, wzorowy obywatel i odpowiedzialny pracownik. U Gombrowicza konflikt form determinuje strefę międzyludzką, nasycając ją przemocą (symboliczną lub bezpośrednią, fizyczną), bo spotkanie dwóch jednostek nigdy nie jest niewinną wymianą, tylko konfliktem, starciem form, próbą narzucenia się. Innymi słowy, spotkanie rozgrywa się jedynie poprzez spektrum (często wysublimowanych) działań idących od gwałtu do przyzwolenia na gwałt, nie ma wymiany po prostu, bez wyrządzenia lub przyjęcia krzywd. U Lamborghiniego przestrzeń relacji międzyludzkich się radykalizuje - przestaje być manipulacją i grą, by stać się czystym gwałtem, dlatego że organizuje się według modelu sado-maso, w którym przemoc nie jest metaforyczna, nie odgranicza się do języka (choć często w nim generuje), jest za to tak ekstremalna i hiperboliczna, że staje się własną karykaturą ${ }^{77}$. Nala prześladuje "kompulsywny poklepywacz” (nalgueador compulsivo), który dopada go w miejscach publicznych, czyniąc zeń „zgoda, terminu się nie używa, ale kim był w takiej chwili Nal jak nie bezsilnym poklepańcem [nalgudo]"78. Tak jak mecenasa Kraykowskiego i jego prześladowcę, łączą ich jakieś tajemne siły, zdeterminowane układem referencji, tajemniczym „odnoszeniem się”,

\footnotetext{
75 Imię Nal pochodzi od hiszpańskiego naglas (pośladki).

76 Osvaldo Lamborghini, La causa justa, s. 197.

77 V. opowiadania El fiord i El niño proletario, w: idem, Novelas y cuentos.

78 Idem, La causa justa, s. 199.
} 
przy czym w La causa justa to „odnoszenie się” jest bardziej konkretne - znamy zasadę, rację albo raczej nonsens, na którym związek się opiera (pupa i chęć poklepywania), ale akcja wywołana jest w równym stopniu pragnieniem poklepania co posiadaniem pupy: bierna cecha domaga się dopełnienia, cudzej reakcji. „Ja” nie jest moją wewnętrzną istotą, tworem wyłącznie własnych lęków i pragnień, ale produktem granicznym, wytworem cudzych reakcji ${ }^{79}$. „Cierpienie staje się nieznośne, kiedy odkrywasz, że żyjesz tylko po to, by ten odrażający typ cię poklepywał i ślinił się poklepując"80.

Historia Nala łączy się następnie z centralnymi wydarzeniami tej nouvelle: pracownicy Firmy (pisanej wielką literą dla wyrażenia szacunku i kultu dla przestrzeni pracy) organizują mecz piłki nożnej pomiędzy drużynami Żonatych i Kawalerów, po którym ma nastąpić wspólna biesiada wokół typowo argentyńskiego asado. Obie drużyny reprezentują oczywiście zestaw cech skondensowanych w swoich nazwach: Żonaci (starzy) są poważni, odpowiedzialni i zwarci, siła Kawalerów (młodych) bierze się z umiejętności udawania, sprawiania wrażenia. Po meczu, którego wynik jest przewidywalny - młodzi ogrywają starych - „wydarzenia zaczynają niestety się wydarzać" ${ }^{\prime 1}$. Obie drużyny spotykają się w szatni, gdzie w atmosferze rozprężenia jeden z zawodników kieruje do drugiego te oto żartobliwe słowa: „Wiesz stary, tak cię kocham, że na własną matkę przysięgam, że wyssałbym ci fiuta, gdybym był ciotą, ale wiesz, że nie jestem"82. Ta rubaszna propozycja poszłaby wśród śmiechów w niepamięć, gdyby nie obecny w szatni Japończyk Tokuro, mistrz karate, świetny bokser, ochotnik w wojnie o Malviny, a także nieustępliwy wielbiciel cesarza i samurajskiego kodeksu. Tokuro włada językiem tylko na poziomie znaczeń dosłownych i domaga się spełnienia

79 V. Andrzej Zieniewicz, Osoba między kokieteria, manipulacja i opowieścią, czyli Gombrowicz jako prekursor teorii autoprezentacji, w: Jerzy Jarzębski (red.), Witold Gombrowicz nasz współczesny. Materiały międzynarodowej konferencji naukowej w stulecie urodzin pisarza. Uniwersytet Jagielloński - Kraków, 22-27 marca 2004, Universitas, Kraków 2010, s. 233-246.

80 Osvaldo Lamborghini, La causa justa, s. 199.

81 Ibid., s. 200.

82 Ibid., s. 203. 
obietnicy, bo „kto nie dotrzymuje słowa, traci honor. A kto dziś traci honor i zdradza przyjaciela, jutro zdradzi Ojczyznę i Cesarza" ${ }^{33}$. Narracja płynnie ustępuje miejsca teatralnemu podziałowi na role (chwyt stosowany w Ferdydurke), oddającemu dramatyzm sytuacji, w której żaden dyskurs konkurencyjny wobec patriotycznego dyskursu Japończyka (przede wszystkim ten oparty na wspólnocie Firmy: „wszyscy jesteśmy przyjaciółmi i pracujemy razem”" ${ }^{84}$ nie może się „narzucić”. W sprawiedliwej sprawie Tokuro nie waha się uciec do przemocy i zabija Janskiego, inżyniera polskiego pochodzenia, po tym jak koledzy wystawili go do obrony przed szalonym Japończykiem. Ten osiąga swój cel - obietnica zostaje spełniona - pogrąża się jednak w smutku z powodu śmierci Janskiego, z którym, jak się okazuje, łączyła go zażyła przyjaźń. Prawdziwa jej natura zostaje jedynie zasugerowana, rzecz w tekstach Lamborghiniego - zwykle obfitujących w drastyczne opisy aktów miłości homoseksualnej - rzadko spotykana. Polak i Japończyk spotykali się kilka razy w tygodniu, by studiować, każdy w swoim języku, materiały z zakresu elektroniki, wymieniać się informacjami i rozwijać dla dobra Firmy. Raz na jakiś czas dopuszczali się bufonady, którą zwali „robieniem teatru” i którą Janski praktykował jeszcze „na najbardziej ruchliwych skrzyżowaniach w Warszawie" z pewnym Czechem $^{85}$.

Udawali, ze spotykają się na pełnym ludzi rogu ulicy, na przykład Perú i Avenida de Mayo, Corrientes i Montevideo itp. Zaczynali strasznie się kłócić, ale każdy w swoim języku, jeden po polsku, drugi po japońsku. Ludzie gromadzili się wokoło i im było ich więcej, tym bardziej na siebie wrzeszczeli. I wówczas działo się coś niezwykłego [...] - ludzie zaczynali brać jedną ze stron. I to zapamiętale. Bili się między sobą, jedni gotowi dać się zabić za Japończyka, inni chętni go zlinczować, bo przyznawali polską rację Polakowi. Po Tokuro było oczywiście widać że Japończyk, ale języka Janskiego nawet nie rozpoznawali. Nie szkodzi, czasem [dochodziło - E.K.P.] nawet do przepychanek i aktów przemocy ${ }^{86}$.

\footnotetext{
83 Ibid., s. 204.

84 Ibid., s. 207.

85 Ibid., S. 220-221.

86 Ibid., s. 221.
} 
Scenę tę - inspirowaną zapewne działalnością nowojorskiego The Living Theatre - czytać można także jako wariację na temat opowiadania Bankiet ${ }^{87}$, którego fabuła także rozgrywa się wokół gremialnego powtórzenia, z tym że u Gombrowicza repryza gestów króla ze strony dworskich dostojników pozbawia je natychmiast ich mocy subwersyjnej: Gnul pragnie „być nie na miejscu”, ale nie może. Tutaj przeciwnie, wic polega na skłonieniu publiczności do powtórzenia, stadnego powtórzenia dyskursu, do zarażenia się kłótnią i odegrania jej bez najmniejszego powodu - bo to właśnie problem własnego i cudzego mówienia oraz subtelności języka jest centralną problematyką La causa justa.

Opowiadanie Lamborghiniego jest realizacją "fabuły językowej” tak, jak zdefiniował ją Michał Głowiński w odniesieniu do Biesiady u hrabiny Kotłubaj: „Ciąg wypadków dzieje się nie tylko z tej racji, że jest za pomocą słów przekazywany, same fakty językowe stają się wydarzeniami"88. Sposoby wypowiadania i fakty językowe (takie jak wieloznaczności, gry słów i komizm) stają się w obu tekstach samymi wydarzeniami. Tokuro jest w męskiej szatni bytem tak samo nieprzystającym, jak mieszczanin w arystokratycznym salonie: język argentyńskiego macho jest mu tak obcy, że nawet nie próbuje go naśladować, nie przebiera się weń, w odróżnieniu od narratora Biesiady. Zdarzenia przebiegają dość przewidywalnie (stereotypowe samce przerzucają się przechwałkami i groźbami zgodnie z przyjętym rytuałem, używając języka na pokaz, ostentacyjnie) do momentu, gdy interweniuje Japończyk, któremu do języka kompletnie brak dystansu, rozumie go bowiem jedynie na poziomie przekazu informacji. Humor słowny, mówienie z „przymrużeniem oka”, gra z konwencją i pewna umowność komunikacji pozostają mu obce, co doprowadza - tak samo jak w Biesiadzie - do krwawego finału, poprzedzonego typową

\footnotetext{
87 Witold Gombrowicz, Bakakaj i inne opowiadania, oprac. Zdzisław Łapiński, Wydawnictwo Literackie, Kraków 2002, s. 196-203.

88 Michał Głowiński, Straszny piątek $w$ domu u hrabiny (O „Biesiadzie u hrabiny Kotłubaj”), w: idem, Gombrowicz i nadliteratura, Wydawnictwo Literackie, Kraków 2002, s. 25.
} 
dla Gombrowicza sceną pojedynku. Tokuro pozwala sobie za to na żarty „poza” językiem, gdy znaczenie słów jest niezrozumiałe i do żadnej komunikacji nie dochodzi. Podczas „robienia teatru” nie ma mowy o „niedotrzymaniu słowa”, bo liczy się tylko jego brzmienie, jego fizyczność - bohaterowie obrzucają się bowiem słowami tak, jakby rzucali przedmiotami. Gra z materialnym wymiarem słów oraz sprawczą mocą gestów - właściwa Gombrowiczowskiej estetyce - jest zresztą chwytem często stosowanym przez Lamborghiniego: w opowiadaniu Matinales gest włożenia palca do ucha (podobny przecież do "popukania się w czoło") wywołuje szaleństwo bohatera ${ }^{89}$.

La causa justa jest więc - w odróżnieniu od innych tekstów Lamborghiniego, w których język służy przede wszystkim do prowokacji ciałem, do wyrażenia gwałtu i do samego gwałcenia, atakowania czytelnika „przez uszy” - opowiadaniem o nieautentyczności mówienia. Bohaterowie posługują się językiem sztucznym, innego bowiem nie ma, mówią zlepkami słownymi (jeśli w El fiord z lat 6o. były to jeszcze hasła polityczne, to w o kilka dekad późniejszej La causa justa są to już językowe zbitki kodów machismo i management ${ }^{90}$ ), dają się łatwo u for mow ác. Tylko narrator świadom jest sztuczności mówienia, tego „powiedziało mi się” zamiast „mówię”, dlatego raz po raz manifestuje swój dystans wobec języka - jak wtedy, gdy zwrot „choroba rozkwita" każe mu pomyśleć o przyniesieniu doniczki ${ }^{91}$.

Punktów styczności pomiędzy Gombrowiczem i Lamborghinim - mniej ewidentnych i nie „na wyłączność” - jest więcej; sygnalizuję kilka: groteskowa narracja, użycie wyobrażeń stereotypowych w funkcji dosłownej (jeśli Japończyk, to samuraj, jeśli proletariackie dziecko, to biedne i masakrowane przez bogatych ${ }^{92}$, etc.), ambiwalentny stosunek do tradycji literackiej, która jest rodzajem wyzwania, kwestią

89 Osvaldo Lamborghini, Matinales (aguas del alba), w: idem, Novelas y cuentos, S. 113.

90 „Grał z przyzwyczajenia, zacieśnienie więzów służyło »wzrostowi poziomu komunikacji«, jak zwykł mawiać wicedyrektor wewnętrznego public relations”; ibid., s. 201.

91 Ibid., s. 195.

92 V. idem, Sebregondi retrocede, w: idem, Novelas y cuentos, s. 63-70. 
wymagającą rozwiązania ${ }^{93}$, najczęściej w trybie parodii (sarmatyzmu i romantyzmu u Gombrowicza, la gauschesca u Lamborghiniego), częste połączenie pomiędzy językiem, seksualnością oraz władzą lub nacjonalizmem (z tej perspektywy Tokuro jawi się jako ktoś, kto okrutnie przerywa głupią zabawę - w tle opowiadania czai się widmo argentyńskiej dyktatury wojskowej). Bliskie są także ich autorskie figury - ostentacyjność gestu pisania, demonstracyjność „ja”, rykoszetem kreujące jeszcze inne dziedzictwo, zbiór legendarnych anegdot, z których wyłania się osobowość kontrowersyjna, wewnętrznie sprzeczna i charyzmatyczna. W argentyńskich narracjach krytycznych o tych twórcach - tak samo zresztą jak o kolejnym pisarzu z gombrowiczowskiej „rodziny”, Copim - dzieło literackie nie funkcjonuje „obok” życia, ale w nim: „ja” literackie i ,ja” znane ze wspomnień przyjaciół i znajomych nieustannie się ze sobą przeplatają, bo w obu przypadkach (życia i literatury) mamy do czynienia z relacją autofikcyjną.

\section{Copi}

Życie Raula Damonte (1938-1987), lepiej znanego w literaturze pod pseudonimem Copi, ułożyło się zresztą w dużej mierze na wzór tego, które przypadło w udziale Gombrowiczowi: urodzony w tzw. dobrej rodzinie (nawet lepszej, a na pewno bogatszej niż małoszyckie ziemiaństwo), uciekł od domowych wygód i dystynkcji do Paryża, gdzie ostatecznie osiadł w 1962 roku, a do Argentyny powrócił zaledwie dwa razy na krótko przed śmiercią w 1987. Jak Gombrowicz, Copi miał do swego pochodzenia stosunek ambiwalentny, jednocześnie krytyczny i admirujący, a świat wielkiej argentyńskiej burżuazji mieszał się w jego tekstach ze światem travestis, oba jednako kiczowate i obłudne. Podobnie jak autor Trans-Atlantyku, swojego ponad dwudziestoletniego pobytu w obcym kraju nie traktował w romantycznych kategoriach wygnania, lecz jak zbawienną okazję do nabrania dystansu

93 Michał Głowiński, Gombrowiczowska nadliteratura, w: idem, Gombrowicz i nadliteratura, s. 5-15. 
do ojczyzny. We Francji imał się różnych zawodów niegodnych swego pochodzenia, współpracował z teatrem Pánico Fernanda Arrabala, publikował słynne komiksy w największych dziennikach i tygodnikach, a także zaczął pisać - wszystkie teksty, z wyjątkiem La vida es un tango (Życie to tango), po francusku. Jego pierwsze dzieło teatralne, La journée d’une rêveuse, wyreżyserował Jorge Lavelli, z którym Copi pozostał artystycznie związany przez kolejne lata. Wybór ob ce go języka, zapewne podyktowany wyborem o b c e j estetyki, skomplikował oczywiście jego przynależność do argentyńskiej tradycji literackiej. Do lat 9o. jego twórczość pozostawała w narodowej próżni, w jałowej przestrzeni „pomiędzy”: obojętnie przyjęty przez francuską krytykę (w języku Prousta pisał do końca jak cudzoziemiec, nie udawało mu się uniknąć niezręczności językowych), nie był także „odzyskiwany” przez Argentyńczyków, którym jego groteskowe, campowe i politycznie frywolne teksty brzmiały wówczas wyraźnie nieswojo ${ }^{94}$. Sytuacja zmieniła się w drugiej połowie lat 8o., kiedy po upadku dyktatury i porażce ideologii lewicowych w Argentynie nastały czasy literackich przewartościowań, ostatecznie uwalniających literaturę od polityczno-społecznych zobowiązań. „Argentynizację" Copiego przypieczętowuje wydana w 1991 roku monografia autorstwa Césara Airy, która zbiera cykl wykładów wygłoszonych trzy lata wcześniej na Uniwersytecie w Buenos Aires ${ }^{95}$. Od tamtej pory zainteresowanie Copim rośnie wraz z popularnością, jaką zdobywa jego komentator. Wspomniana monografia jest - jak większość tekstów krytycznych Airy - wykładem jego własnej ars narrativa, stąd będę się do niej odwoływać częściej $\mathrm{w}$ kolejnym rozdziale, ale posiada niewątpliwie zaletę, której brak innym, późniejszym studiom o Copim, a mianowicie koncentruje

94 Patricio Pron kwestionuje próby przypisania Copiego do estetyki tzw. latynoskiego neobaroku, choć odnajduje w jego twórczości elementy groteski rioplatense (el grotesco rioplatense); v. Patricio Pron, Aquí me río de las modas. Procedimientos transgresivos en la narratica de Copi y su importancia para la constitución de una nueva poética en la literatura argentina, niepublikowana rozprawa doktorska, Georg-August-Universität de Göttingen, Alemania, 2007, s. 41-48, https://goo. gl/o5OPia, dostęp: 19 vi 2016.

95 César Aira, Copi, Beatriz Viterbo, Rosario 1991. 
się na aspekcie czysto formalnym, na konstrukcyjnych walorach jego tekstów i zastosowanych metodach (procedimientos).

Większość krytyków skupia się bowiem na kwestiach treści, na estetyce camp, groteskowym przyswojeniu kiczu i przeróbce argentyńskich mitów narodowych. I z tej perspektywy także ustanawia powiązania pomiędzy Copim i Gombrowiczem: obaj postrzegają tożsamość narodową przez pryzmat tożsamości seksualnej, dekonstruują „czystość” narodowych narracji, wszczepiając weń elementy kiczu i estetyki wstrętu (asco), zastępują kult esencji upodobaniem do tego, co niedokończone i niepełne ${ }^{96}$. Obaj pragną uwolnić się od tradycji narodowych, zmieniając jednocześnie swoje dzieło w nieustanną z nimi polemikę. Ten „narodowy” aspekt wspólny nie wydaje mi się pomijalny, przeciwnie - będę o nim wspominać w dalszej części rozdziału, jednak najważniejszy punkt styczności leży gdzie indziej, a mianowicie w analizowanej przez Airę nowej poetyce spod znaku surrealistycznej inwencji, zawrotnego tempa opowiadania i nagłych zwrotów akcji, nieskrępowanych relacjami przyczynowo-skutkowymi. Ta nowa jakość w literaturze argentyńskiej, którą Patricio Pron wywodzi od Copiego, ma - co staram się tutaj udowodnić - w rzeczywistości dłuższą genealogią, czerpiącą garściami z Bakakaju i Trans-Atlantyku. Nie twierdzę bynajmniej, że c a ło ść twórczości tego autora ma Gombrowiczowski rodowód: wspomniane wyżej elementy stylistyki camp z jej ironiczną waloryzacją kiczu oraz otwarcie przejawiające się w tekstach zaangażowanie w kulturę LGBT (Copi był skądinąd utalentowanym aktorem-transwestytą), u autora Dziennika nie występują na tyle jawnie, by można było między nimi ustanowić jakieś międzytekstowe związki. Ale poszczególne składniki tej „nowej estetyki” - którą od Copiego i Airy przejmie cały szereg argentyńskich autorów - obecne są wyraźnie w kilku opowiadaniach z tomu Bakakaj, co postaram się wykazać poprzez analizę porównawczą opowiadania Copiego L'Uruguayen (Urugwajczyk) oraz Przygód i Zdarzeń na brygu Banbury.

\footnotetext{
96 V. José Amícola, Estéticas bastardas, Editorial Biblos, Buenos Aires 2012, s. 123-158; Pablo Gasparini, El exilio procaz, s. 266-277; Agnieszka Flisek, Osvaldo Lamborghini y Copi..., s. 360-361.
} 
Opublikowany w 1972 roku L'Uruguayen - pierwszy tekst narracyjny Copiego, który wcześniej wydał sześć sztuk teatralnych, a także cieszył się już famą uznanego rysownika - został przełożony na hiszpański dopiero w $1997^{97}$. Napisany jest w formie listu do bliżej nieznanego Mistrza (Maestro), któremu narrator opowiada swoje przygody z odległego miasta Montevideo, dokąd przybywa prawdopodobnie z Francji. „Powód mojego tutaj pobytu - wyznajmy to od razu - wymyka mi się"98. Narrator, którego wiarygodność zostaje szybko poddana w wątpliwość poprzez rażące nielogiczności wywodu, początkowo opowiada o tubylcach, przyjmując ton dziewiętnastowiecznego naturalisty, opisującego osobliwe zwyczaje plemion autochtonicznych, ale potem dystans do „nich” skraca, a jego w opowieści pobrzmiewa czasami czułość i wyrozumiałość. Urugwajczycy mają więc osobliwą formę komunikowania się, „bez przerwy wymyślają nowe słowa"99 , które pozwalają im natychmiast posiąść, symbolicznie lub fizycznie, nazwane rzeczy - niczym w Ameryce czasów konkwisty, kiedy sam akt nadania nazwy fundował powstanie (nieistniejącego realnie) miasta i ustanawiał relację własności. To tłu maczy rozliczne dyskusje i pojedynki słowne, których stawką jest posiadanie coraz to atrakcyjniejszych miejsc. Performatywność języka na tym się nie kończy:

Urugwajczycy wymawiają średnio trzy słowa dziennie, niektórzy wymawiają zawsze to samo słowo, inni zaś uparcie milczą. Kiedy dwóch spośród nich wymawia zwyczajowo to samo słowo (nieważnie jakie), automatycznie stają się „braćmi krwi”, czyli należą do tej samej formacji politycznej, i natychmiast zostają rozstrzelani ${ }^{100}$.

97 Ukazał się w przekładzie Enrique Vila-Matasa w antologii pod redakcją Héctora Libertelli pt. Copi, Lamborghini, Wilcock y otros: 11 Relatos Argentinos del siglo XX (Antología Alternativa) (Perfil, Buenos Aires 1997), w której oprócz Copiego znaleźli się m.in. „literaliści” Osvaldo Lamborghini i Luis Gusmán, a także César Aira. Copi, El uruguayo, przeł. Enrique Vila-Matas, http://goo.gl/krmEHK, dostęp: 16 VI 2016.

99 Ibid.

100 Ibid. 
Pewnego dnia miasto zostaje całkowicie pokryte piaskiem, a narrator - jedyny ocalały z tego tajemniczego kataklizmu - rysuje na nim pogrzebane pod spodem budynki i osoby, a następnie, by zaradzić niszczącej rysunki sile wiatru, przyczepia do nich karteczki z nazwami: „samochód” w miejscu piaskowego samochodu etc. Ze świata „realnego” pozostaje początkowo tylko piaskowa reprezentacja, a potem same słowa. Z wykopanego na plaży przez psa narratora dołu wychodzą kurczaki, które pieką się same, gdy tylko dotkną gruntu. Morze zalewa miasto, by potem zaraz cofnąć się, zostawiając dziesiątki ofiar - jedynie narratorowi udaje się uciec. Pewnego razu budzi się otoczony liczną grupą wojskowych, których następnie spotyka na plaży, zajętych mierzeniem dołu z kurczakami, ale zaraz spada na nich bomba zrzucona $z$ tajemniczego samolotu. Chwilę później podobna bomba zabija kąpiącego się prezydenta. Narrator żyje samotnie w opustoszałym mieście, przechadzając się po nim, sypiając w hotelach, uprawiając jogging i shopping, a nawet dopuszczając się aktów nekrofilii. Orientuje się, że posiada dar czynienia (niedorzecznych oczywiście) cudów. Po kilku latach ofiary powodzi zmartwychwstają i prześladują narratora, którego z zagadkowych względów kojarzą z ostatnim wypowiedzianym przed śmiercią słowem. Odnajduje się także zmartwychwstały prezydent, który kanonizuje narratora, obcinając mu wargi i powieki, by zachować je na relikwie. Od tej pory święty - wybrawszy sobie imię rata (szczur) - żyje w wykopanym w piasku dole, czyniąc dalej mniejsze lub większe cuda. Pewnego dnia Urugwaj przyjmuje wizytę Papieża Argentyny, który przybywa udekorować narratora medalem argentyńskiego komika. Któregoś poranka, „po wypiciu kawy z mlekiem, papież poprosił nas, byśmy mu pokazali przed odjazdem kilku Urugwajczyków. Objechaliśmy więc konno Urugwaj, co nie było trudne, bo kraj cały czas się kurczy"101. Papież uwodzi prezydenta, który jedzie z nim do Argentyny, skąd po pewnym czasie powraca z informacją, że rzekomy zwierzchnik kościoła jest w rzeczywistości sutenerem i zmuszał go do pracy w domach publicznych. Tymczasem narrator uczy Urugwajczyków prowadzenia krótkich konwersacji

101 Ibid. 
oraz sprawiających im wiele radości gier słownych, polegających na zbiorowym powtarzaniu tego samego zdania.

To krótkie streszczenie nie wyczerpuje wszystkich niuansów historii, która obfituje w nagłe zmiany akcji, kataklizmy, jednym cięciem zmieniające układ sił, lub fantastyczne wydarzenia, nagle uwalniające bohatera $\mathrm{z}$ opresji. Jedyną zasadą rządzącą budową narracji jest sławiona (i stosowana) przez Airę zasada czystej inwencji, która stanowi przeciwwagę dla „królestwa wyjaśnienia” ( reino de la explicación), jego zdaniem głównej przyczyny upadku współczesnej prozy:

L'Uruguayen ma coś z opowieści prymitywnej, pierwotnej. Jego ekscentryczność może wydawać się bardzo nowoczesna, bardzo avant-garde, ale to tylko złudzenie spowodowane dekadencją sztuki opowiadania w naszych czasach [...]. Opowieść sama w sobie, od której się odzwyczailiśmy, jest chemicznie wolna od wyjaśnienia ${ }^{102}$.

Gdy Gombrowicz odczytuje po latach opowiadania z tomu Bakakaj, przychodzą mi do głowy podobne określenia: „iskrzące świecidełko fantazji, pomysłowości, humoru, ironii”; „jakie to wibrujące od spięć niesamowitych, wizji zaskakujących, jak tryska zabawą, humorem, igraszką"103.

Tak fantastycznie, ekscentrycznie, dziwacznie zacząłem - dlaczego? - zapytuje się jeszcze - Dlaczego to zostało od razu oderwane od normalnej rzeczywistości, pchnięte w manię, w szaleństwo, w absurd nie pozbawiony wszakże uroczystej logiki, w jakąś celebrację nonsensu? ${ }^{104}$

Gombrowicz odpowiada samym sobą („wciąż byłem pomiędzy, w niczym nie osadzony"105), ale Aira wskazałby mu raczej imperatyw literacki: zerwanie z prawdopodobieństwem, drwina $z$ relacji przyczynowo-skutkowej, a także zawrotne tempo wydarzeń

\footnotetext{
102 César Aira, Copi, s. 16-17.

103 Witold Gombrowicz, Testament. Rozmowy z Dominique de Roux, przeł. Ireneusz Kania, Wydawnictwo Literackie, Kraków 2012, e-wydanie.

104 Ibid., s. 14.

105 Ibid.
} 
następujących po sobie w nielogicznym ciągu - oto klucz do ucieczki przed wyjaśnieniem, czyli przed interpretacją ${ }^{106}$, która jest rodzajem „uformowania"107.

L'Uruguayen jest, jak wspominałam, długim listem, którego redakcję autor wielokrotnie przerywa (zwykle z braku ochoty na pisanie), by powrócić do niej po dłuższym lub krótszym czasie. Otrzymanie odpowiedzi nie jest nawet zakładane, wydaje się bowiem wątpliwe, by list kiedykolwiek miał zostać wysłany - dlatego jego narracja bardziej przypomina dziennik, urywany zapis bieżących wydarzeń, aniżeli krótką powieść epistolarną. List jest rodzajem tekstu autodestrukcyjnego, ponieważ narrator na wstępie formułuje do adresata prośbę o skreślanie kolejnych linijek w miarę czytania: „dzięki tej sztuczce, na końcu lektury pozostanie panu z tej książki tak mało, jak mnie, bo - jak zapewne się Pan zorientował - praktycznie nie mam już pamięci"108. Podobny zabieg symultanicznego pisania/czytania oraz niszczenia własnego tekstu stosuje narrator Zdarzeń na brygu Banbury: zapisuje na kawałkach papieru swoje rozmyślania dotyczące rejsu (fauny, marynarzy, dowódców etc.), które sukcesywnie pali zaraz po skończeniu tej swoistej redakcji, bez słowa wyjaśnienia. Zapisy w tym szczególnym, efemerycznym dzienniku nie są wymuszone konwencją narracyjną - opowiadanie utrzymane jest w pierwszej osobie, więc czytelnik i tak ma bezpośredni wgląd w „aurę umysłu F. Zantmana”" ${ }^{109}$, co z kolei każe przypuszczać, że notatki narratora przeznaczone dla niego samego służą poukładaniu wrażeń, podjęciu karkołomnych decyzji o tym, jak się zachować („I ten papier spaliłem - jednakże nie znaczy to, abym nie wprowadził w czyn postanowień odnośnie

\footnotetext{
106 Skutkiem dekadencji opowiadania jest, zdaniem Airy, powstanie krytyki literackiej jako osobnego gatunku; v. César Aira, Copi, s. 17.

107 O zapożyczonej od Gombrowicza kategorii formy wspomina María Negroni w artykule Un tratado sobre la extranjería de lo propio. "El uruguayo" de Copi („Orbis Tertius: Revista de Teoría y Crítica Literaria” 2006, nr 12, http://goo. gl/4jQfu9, dostęp: 17 vi 2016).

108 Copi, El uruguayo.

109 W pierwszym wydaniu z 1933 roku pełen tytuł opowiadania brzmiał: Zdarzenia na brygu Banbury. Aura umysłu F. Zantmana.
} 
do Clarkego i Smitha"110). Oba te chwyty polegające na domaganiu się destrukcji tekstu przez czytelnika (L'Uruguayen) lub bezpośrednim dokonywaniu jej przez autora (Zdarzenia na brygu Banbury) mają sens podobny: oprócz tego, że są drwiną z aspiracji literatury do wiekopomności i do przetrwania, są także negacją logiki wyrażającej się poprzez związki przyczynowo-skutkowe. W obu opowiadaniach wydarzenia nie wynikają z siebie, nie są ułożone w porządku logicznego następstwa, w pewnym sensie więc nie sposób odtworzyć ich w pamięci - jeśli rozumieć pamięć jako umiejętność nadania informacji jakiegoś, najczęściej przyczynowo-skutkowego, uformowania. Zniszczenie zapisu usuwa historię wydarzeń, pozostawiając czystą teraźniejszość, której nijak nie daje się wyjaśnić lub zinterpretować, bo znika „skreślona”, zanim ukaże jakiekolwiek znaczące, sensowne związki z przeszłością. Bohaterowie rejestrują tylko kolejne, absurdalne wypadki, nonsensowne serie przygód, z tą zasadniczą różnicą, że narratorowi Copiego brak zdolności do autorefleksji, nie ubolewa nad niemożliwością „powiązania” wydarzeń w ciągi wynikowe, raczej brnie do przodu od jednego do drugiego kataklizmu, natomiast Zantman - jak typowy narrator Gombrowiczowski, który pełnię swoich umiejętności rozwinie w Kosmosie - nieustannie rozpatruje tajemnicze związki „odnoszenia się”, gorączkowo pragnie rzeczy sprzecznych: należeć do marynarzy i pozostać outsiderem na statku, uformować swoją męskość w czasie próby, jaką jest rejs morski, i jednocześnie pozostać niedojrzałym, ulec miłości homoerotycznej i potępić ją jako krańcowy objaw perwersyjnej rozwiązłości. „Copi” z L’Uruguayen jest czystym rejestratorem zdarzeń, które następują tak szybko, że nie ma czasu na ich skomentowanie, podczas gdy komentarz Zantmana (nic wprawdzie nierozjaśniający), owo niemożliwe „ustosunkowanie się” do chaosu świata, jest podstawową treścią opowiadania.

Mimo tej różnicy w poziomie „refleksyjności” narracji, która konsekwentnie przenosi się na inne teksty obu autorów („znakiem towarowym” prozy Copiego będzie właśnie bezpośredni, prostolinijny

110 Witold Gombrowicz, Zdarzenia na brygu Banbury, w: idem, Bakakaj i inne opowiadania, s. 131. 
stosunek narratora do absurdów świata przedstawionego, Gombrowicza natomiast - nerwowa problematyzacja znaków, gestów i słów), L'Uruguayen wykazuje szereg podobieństw z opowiadaniami z tomu Bakakaj na poziomie konstrukcji relacji pomiędzy „ja” i Innym: po pierwsze z tym, kogo postrzega jako swojego zwierzchnika lub pana, oraz, po drugie, „innymi” w szerokim sensie, z grupą. Wyżej wspomniany tajemniczy adresat listu, ów Mistrz, mający skrupulatnie skreślać kolejne linijki tekstu, traktowany jest zrazu z uniżeniem i atencją, wyraźnie zaznaczonymi w wyszukanej elegancji pierwszych zdań:

Drogi Mistrzu! Bez wątpienia zaskoczą Pana wieści ode mnie z miasta tak odległego jak Montevideo [...]. Jeśli ośmielam się kierować doń ten list, z pewnością irytujący, to bardziej z pragnienia bycia przez Pana przeczytanym, aniżeli przez walory tego, co mam do powiedzenia: nie ośmieliłbym się znieważyć Pana myślą, że moja historia może obchodzić go bardziej niż mnie ${ }^{111}$.

„Gra” w szacunek bardzo szybko się urywa, narrator ewidentnie nie może jej długo znieść i inwokacje do „drogiego Mistrza” przeplata ze sformułowaniami: „płacz, stary frajerze, nigdy więcej do ciebie nie wrócę", jakby respekt domagał się uzupełnienia inwektywami („Mistrzu. Dupku”, „Do jutra, stary durniu. Dzień dobry, dupku”) ${ }^{112}$, by ponownie zakończyć list uprzejmym „Do jutra, Mistrzu”. Ta specyficzna, oparta na dialektyce miłości i nienawiści relacja bohatera z kimś, komu czuje się podległy, jest charakterystyczna dla kilku postaci z Bakakaju, których los często bywa sparowany - decyzją własną lub cudzą - z losem Innego. Ten inny jest dla narratora jednocześnie źródłem rozkoszy i cierpienia, bo albo delektuje się okazywanym przezeń lekceważeniem lub zgoła pogardą (jak tancerz mecenasa Kraykowskiego), albo ze spokojem poddaje się najwymyślniejszym torturom, jakie „pan” dla niego rezerwuje, jak bohater Przygód, który zaskarbił sobie „bezgraniczną nienawiść” pewnego kapitana przypadkowym

\footnotetext{
111 Copi, El uruguayo.

112 Ibid.
} 
odkryciem jego „tajemnicy fizjologicznej”, tego, że był Białym Murzynem $^{113}$. „Nie tyle dla mego [narratora - E.K.P.] cierpienia, ile dla własnej rozkoszy”, ów kapitan szykuje dlań szereg prób - polegających zwykle na zamknięciu w ciasnej przestrzeni w kształcie jaja lub kuli, a następnie wrzuceniu do oceanu - z których cudem udaje mu się wyjść cało. W odróżnieniu od Tancerza, narrator Przygód sam jest obiektem perwersyjnych starań Murzyna, który uwozi go na swoim statku niczym zbiegłą niewolnicę, bo „kto raz zakosztował kogoś w ten sposób, jak on mnie"114, wiąże się ze swoją ofiarą na zawsze. Natura powiązania pomiędzy „panem” i „niewolnikiem” jest w każdym przypadku taka sama i opiera się na sadomasochistycznej przyjemności z odrzucenia lub znoszenia wysublimowanych męczarni. U Copiego ten związek jest mniej eksplicytny w tym sensie, że nie stanowi podstawowego celu opowieści, o jego relacji z Mistrzem wiemy tylko tyle, że był to związek „młodego” ze „starym”, od którego ten pierwszy „ucieka jak złodziej"115. W L'Uruguayen narracja nie krąży wokół dręczącej narratora „więzi” dlatego, że bohaterowie posługują się w sferze erotyki językiem dosłownym, sucho konstatują najbardziej perwersyjne fakty, w przeciwieństwie do postaci Bakakaju, które uciekają się nieustannie do metafor, abstrakcji i niedopowiedzeń, czyniąc z erotyki element w tekście wszechobecny, rodzaj metajęzyka, w którym wypowiedzieć (zasugerować, zaszyfrować) można wszystko - siebie, innych, sztukę ${ }^{116}$.

Oprócz tej ambiwalentnej relacji z Innym-Panem (Mistrzem, mecenasem, Murzynem) bohaterowie wykreowani przez obu autorów w podobny sposób „nawiązują” - by posłużyć się Gombrowiczowskim szyfrem - do innych, czyli do grupy. Warunki wyjściowe są w obu narracyjnych systemach bardzo zbliżone: owi „oni” są jednolici, co podkreśla unifikująca nazwa - Urugwajczycy (L'Uruguayen), marynarze (Zdarzenia na brygu Banbury), trędowaci (Przygody), a samotny

113 Witold Gombrowicz, Przygody, w: idem, Bakakaj i inne opowiadania, s. 98-99.

114 Ibid., s. 101.

115 Copi, El uruguayo.

116 Janusz Pawłowski, Erotyka Gombrowicza, w: Zdzisław Łapiński (red.), Gombrowicz i krytycy, Wydawnictwo Literackie, Kraków 1984, s. 558. 
bohater odnajduje się w ich otoczeniu w sposób nagły, wrzucony w ich świat bez możliwości odwrotu: „Copi” i narrator Przygód przybywają na wyspę, Zantman okrętuje się na statku płynącym do Ameryki Południowej. W izolowanej przestrzeni wyspy albo brygu obowiązują inne niż w „normalnym” życiu zasady: obcy mówią inaczej (język Urugwajczyków i marynarzy oparty jest na figurze powtórzenia), zachowują się inaczej i często padają ofiarą bezsensownej przemocy (Urugwajczyków prześladują kataklizmy, a na brygu Banbury gwałt służyć ma powstrzymaniu buntu załogi, trędowatych terroryzuje choroba). Narrator obserwuje ich z zewnątrz, nie wnika w ich świat, bo albo odczuwa nad nimi moralną i cywilizacyjną przewagę, jak biały człowiek nad dzikim plemieniem („Copi”), albo nieustannie waha się pomiędzy uczuciem odrazy i pożądania, potępieniem homoerotycznych praktyk marynarskich i ulegnięciem im (Zantman), albo po prostu ucieka ze wstrętem przed prześladowaniem trędowatych (powracamy tym samym do toposu „dzikusów”). Uczucie wstrętu jest zresztą miejscem wspólnym wszystkich trzech tekstów, przy czym u Gombrowicza jest odwrotną stroną erotycznego pożądania, a „Copiego" chwile obrzydzenia skłaniają do kilkudniowej apatii, która owocuje nagłą umiejętnością dokonywania cudów.

We wszystkich trzech analizowanych tekstach mamy także do czynienia $\mathrm{z}$ podobną konwencją w opisach przyrody, ironicznie operującą narracją właściwą dla dziewiętnastowiecznych europejskich naturalistów. Zantman skrupulatnie odnotowuje egzotyczne „igraszki pelikanów z rybami głębinowymi" ${ }^{117}$, stadko delfinów nieodstępujące od rufy, żarłoczne rekiny ${ }^{118}$ etc., ale ekscesy przyrody zaczynają niepokoić go w miarę jak rośnie erotyczne napięcie z marynarzami - dzika, irracjonalna natura zdaje się odsłaniać albo zdradzać jego perwersyjne skłonności: oto nagle pojawia się „ryba obojnak"119, a skorpion popełnia samobójstwo, wstrzykując sobie truciznę do odwłoka („Dlaczego wybrał się z tym do mnie? Czy nie mógł

\footnotetext{
117 Witold Gombrowicz, Zdarzenia na brygu Banbury, s. 122.

118 Ibid., s. 127 i 129.

119 Ibid., s. 147.
} 
załatwić się w szparze?" $\left.{ }^{20}\right)$. Copi także parodiuje opowieści podróżnicze przełomu XVIII i xıx wieku, w szczególności ich odmianę zwaną literaturą przeżycia (literatura de supervivencia), obfitującą w opisy kataklizmów i nieśmiałe próby zrozumienia dzikiej przyrody, która nie stosuje się do praw znanych w Europie ${ }^{121}$. Parodia ta służy, jak sugeruje Amícola ${ }^{122}$, dekonstrukcji europocentrycznego spojrzenia na Amerykę, owego spojrzenia naukowego, które egzotyzuje i obłaskawia jednocześnie, ale przede wszystkim pozwala na swobodną dialektykę katastrofa-cud, która rządzi rytmem opowiadania wspólnym Copiemu i Gombrowiczowi. Bohaterowie L'Uruguayen i Przygód co rusz popadają w kolejne tarapaty - morskie nawałnice, więzienia, tsunami, burze piaskowe, spadające bomby, katastrofy lotnicze - z których wydobywają się czystym przypadkiem, a autor nie zadaje sobie nawet trudu, by „uprawdopodobnić” ten nieoczekiwany zbieg okoliczności. Dla przykładu: po dwóch miesiącach niebezpiecznej egzystencji na wyspie trędowatych bohater szczęśliwym trafem odkrywa kilka butelek nafty pochodzących z rozbitego okrętu, łata balon i odlatuje, a Urugwajczycy, kiedy trzeba (kiedy wymagają tego kolejne przygody bohatera), zmartwychwstają. Te nagłe zmiany akcji, rozgrywające się w egzotycznej przestrzeni, która ironicznie je „uzasadnia”, pozwalając na „cud”, będą podstawowym elementem mechanizmu, który César Aira przyswoi sobie pod nazwą "ucieczka do przodu” (fuga hacia adelante) - niczym w surrealistycznej écriture automatique narracyjne potknięcia nie są nigdy poprawiane, tylko „zostawiane w tyle” w niekończącym się procesie pisania, zwanym literaturą.

Z drugiej strony kwestia opisów przyrody doprowadza ponownie do kwestii języka i arbitralności jego użycia - skądinąd wątku także obecnego w dziewiętnastowiecznych relacjach z podróży do „dzikich”, których niezrozumiałe formy komunikacji przypieczętowywały

\footnotetext{
120 Ibid., s. 130.

121 José Amícola, "L’Uruguayen" de Copi como espejo del triple estereotipo, w: Florent Kohler (red.), Stéréotypes culturels et constructions identitaires, Presses universitaires François-Rabelais, Tours 2007, s. 145-151. Korzystam z wersji internetowej https://goo.gl/P8aLkg, dostęp: 22 X 2016.

122 Ibid.
} 
tylko ich fundamentalną i n n o ść. Pierwsza część perypetii opisanych w Przygodach - ta, którą napędza pragnienie zemsty Murzyna - kończy się nagle następującym passusem:

W tym samym czasie olbrzymi bolid wpadł w Morze Kaspijskie, które w jednej chwili - całe wyparowało. Pękate, nabrzmiałe zwały chmur opasały ziemię i unosiły się tuż nad nią, grożąc drugim potopem [...]. Zapanowało wielkie przygnębienie. Nikt nie wiedział, jak ściągnąć ospałe cielska na powrót, bez szkody, w łożysko, z którego powstały. Wreszcie jeden tam zaczął łechtać jedną - akurat nadciągającą nad opustoszałe morze, w najczarniej fioletową, obwisłą i ociężałą część jej kadłuba. Otworzyła swoje upusty ${ }^{123}$.

W L'Uruguayen kraj kurczy się tak bardzo, że „niebo zaczyna się zaraz tam, gdzie kończy plaża, dzięki czemu można ręką dotknąć słońca w momencie, w którym przechodzi nad głową"124. „Cielsko chmury”, jak każde inne ciało, można połechtać, a słońce złapać jak piłkę - jak w językach pierwotnych, co do których wierzono, że ich gramatyka jest odwzorowaniem praw natury, a znaczące i znaczone wiążą się ze sobą w naturalny, konieczny sposób, znosząc przepaść między rzeczami i słowami. Oba opowiadania doprowadzają do absurdu tę własność języka pierwotnego, dosłownie traktując metaforyczne asocjacje: jednoaspektowe podobieństwo lub analogia obejmuje całość znaczenia (jeśli słońce podobne jest do piłki, to można je jak piłkę złapać etc.). Logika narracji pozwala na ustanawianie wszelkich analogii - przede wszystkim tych nieuprawnionych, które z podobieństwa słów wnioskują o podobieństwie rzeczy (Bolek Kalafior) lub traktują dosłownie analogie czysto metaforyczne („cielsko chmury”). Pierwszy cud, którego dokonuje „Copi”, polega na pomieszaniu porządku dyskursu (słów) i rzeczy: myśli z takim natężeniem o krowie, że materializuje słowo „krowa” na fasadzie hotelu po drugiej stronie ulicy $^{125}$. Natomiast w języku Urugwajczyków, którego niuanse „Copi”

\footnotetext{
123 Wiold Gombrowicz, Przygody, s. 106.

124 Copi, El uruguayo.

125 Ibid.
} 
wykłada zaraz na wstępie swojego opowiadania, mamy do czynienia z dynamiką o kierunku na pozór przeciwnym: po pierwsze, brakuje w nim czasowników, a więc elementów mowy, które pozwalają łączyć słowa w logiczne ciągi, po drugie - porządek języka nie odwzorowuje w żaden ustalony sposób rzeczywistości, słowo i jego desygnat łączą się czysto przypadkowo (ten sam signifiant odnosi się za każdym razem do innego signifié). Język Urugwajczyków jest właściwie mechanizmem wymyślania kolejnych wyrazów, które najpierw arbitralnie nabywają znaczenia, a potem pozwalają wejść w posiadanie nazwanego przedmiotu:

Nie przestają wymyślać słów, które wpadają im do głowy. Gdyby któryś z nich zobaczył mnie, jak piszę (na czas pisania ukrywam się), mógłby wymyślić słowo na określenie mojego zeszytu, mojego stylu i mnie samego (mówię mógłby, ale jestem pewien, że by to zrobił), a słowo to automatycznie zmieniłoby się w miejsce, które natychmiast by zajął, pozostawiając mnie w pewnym sensie poza ${ }^{126}$.

O ile narrator obu opowiadań dowolnie posługuje się relacją podobieństwa, „rozplenia” związki i łączy „wszystko ze wszystkim”, o tyle Urugwajczycy zdają się żyć w świecie relacji prowizorycznych i całkowicie arbitralnych, wolnych, niezależnych „stanów rzeczy” (nawet powiązanie słów w zdaniu nie następuje). Skutek tych operacji na języku i rzeczywistości jest w obu przypadkach taki sam: dyskredytacja związków przyczynowo-skutkowych następuje zarówno wtedy, gdy wszystko się łączy za wszystkim, jak i wtedy, kiedy nic nie łączy się z niczym. Ta podwójna refleksja nad wytwarzaniem sensu w języku ma w ostatecznym rozrachunku skutek podobny do hume'owskiej krytyki: dekonstruuje nasze przyzwyczajenia postrzegania, zwyczaj narzucania na fakty „obiektywnej” siatki związków przyczynowych i optuje za światem, którego wyja śn ie nie staje się - o ile nie niemożliwe - problematyczne.

Nieco innej płaszczyzny porozumienia na linii GombrowiczCopi, innej natury związków międzytekstowych opartych nie tyle na 
wspólnocie stylu lub konwencji opowiadania, ile na krytycznym stosunku do narracji wspólnotowych, dostarcza porównanie Trans-Atlantyku z L’Internationale argentine (Argentyńską Międzynarodówką). Ta ostatnia, wydana pośmiertnie w 1988 roku książka Argentyńczyka uważana jest przez krytykę za zgoła niepasującą do stylu wypracowanego w jego poprzednich powieściach, które - jak L'Uruguayen - charakteryzowały się bardzo szybkim tempem akcji, bezrefleksyjnym działaniem postaci, nagromadzeniem absurdalnych wydarzeń o komicznym efekcie etc. César Aira nazywa ją wprost „niezbyt dobrą” i dodaje, że choć „z wielu względów może uchodzić za poruszającą, jest rezygnacją z własnego stylu na rzecz "stylu narodowego «"127. Ó „styl narodowy” jest właśnie innym punktem przecięcia się estetyk Gombrowicza i Copiego - choć traktowany polemicznie, jest (i trudno odmówić tu Airze racji) w ostatecznym rozrachunku refleksją nad naturą narodowego przyporządkowania.

Akcja powieści rozgrywa się w połowie lat 8o. w Paryżu, gdzie na (dobrowolnym) wygnaniu przebywa argentyński pisarz Darío Copi. Pewnego razu spotyka Nicanora Sigampę ${ }^{128}$, „kolosalnego Murzyna” i gwiazdę narodowego sportu, polo, który wręcza mu czek na pięćset tysięcy franków w imieniu instytucji zwanej właśnie Argentyńską Międzynarodówką, jako stypendium fundowane „nowym przyjaciołom”. "Copi” - choć nie ufa swojemu darczyńcy - akceptuje najpierw czek, a po pewnym czasie także zaproszenie na kolację w domu Sigampy, podczas której dyskutują nad finansowaną przezeń tajemniczą instytucją zrzeszającą Argentyńczyków w kraju i poza nim. Narrator udaje się następnie do restauracji La Coupole, gdzie spotyka m.in. swoich rodziców i innych członków latynoskiej diaspory w Paryżu. Wszyscy obecni tam Argentyńczycy okazują się należeć już do międzynarodówki i korzystać z pieniędzy tajemniczego magnata. Jakiś czas później „Copi”

\footnotetext{
127 César Aira, Copi, s. 89.

128 Pierwowzorem tej postaci był dziadek autora, Natalio Botana, człowiek bardzo majętny i z dużymi ambicjami politycznymi. Botana (z pochodzenia Urugwajczyk) był założycielem bulwarówki „Crítica”, cieszącej się ogromną popularnością w Buenos Aires w pierwszej połowie xx wieku.
} 
spotyka Sigampę ponownie i ten proponuje mu, by został prezydentem Argentyny. Narrator początkowo odmawia, ale później - na prośbę ambasadora, który potrzebuje pożyczyć od Sigampy równowartość całego długu zagranicznego Argentyny, by móc pozostać na stanowisku - zmienia decyzję i godzi się na kandydowanie, a także na wypracowanie doktryny politycznej w oparciu o własne wiersze. Po wielu perypetiach dobra passa narratora odwraca się: matka wyznaje mu, że naprawdę nazywa się Kopisky i jest dzieckiem nieślubnym, Żydem urodzonym w Auschwitz. To przekreśla jego szanse na prezydenturę (wyborcy nie zagłosują na kogoś o semickich korzeniach), a Sigampa, naciskany przez rodzinę, postanawia poprzeć innego kandydata-poetę, którego narzeczoną jest Raoula Borges, nieślubna córka Jorgego Luisa. „Copi” postanawia zabić swojego kontrkandydata, strzelając doń podczas pierwszego wiecu wyborczego, ale sam zostaje zastrzelony przez ochroniarza Sigampy.

To zwięzłe streszczenie nie oddaje wszystkich meandrów opowiadanej historii, w szczególności komicznych refleksji nad argentyńską diasporą w Paryżu, ale wystarczy dla uchwycenia ogólnej tematyki tej krótkiej powieści. Porównanie z Trans-Atlantykiem narzuca się samo, zważywszy na punkt wyjścia obu tekstów, jakim jest chęć „rozliczenia się" z ojczyzną poprzez humorystyczne przedstawienie narodowej wspólnoty na obczyźnie w momencie, w którym znajduje się w zwrotnym, bolesnym punkcie swojej historii: Polska u progu II wojny światowej, której tragiczne implikacje były w 1953 roku jeszcze odczuwane, a Argentyna kilka lat po zakończeniu krwawej dyktatury. Oba narody posiadają wówczas jasno wytyczoną sferę tabu, rodzaj niedotykalnej mitologii wspólnotowej, którą oba teksty bezpardonowo atakują: Gombrowicz wykpiwa bogoojczyźniany etos polskiego patrioty, Copi zaś bolesny mit zmiażdżonej przez wojsko lewicy. Los tysięcy „znikniętych” (desaparecidos) bluźnierczo odbija się echem w historii rodziców narratora, którzy „torturowani przez wojskowych, zdołali uciec na grzbiecie muła przez kordylierę i objąć [...] stanowisko konsuli Urugwaju w Paryżu"129. Powody zatrzymania i tortury, czyli

129 Copi, La Internacional Argentina, przeł. Alberto Cardín, Anagrama, Barcelona 1989, s. 20. 
cały okres walki w szeregach bojówek rewolucyjnych (tzw. militancia), zostaje sprowadzony do krótkiej wzmianki o tym, że ich spokojny, drobnomieszczański żywot zakończył się w latach 6o. wraz z odkryciem haszyszu i LSD. W samym Paryżu byli rewolucjoniści wiodą życie dostatnie, handlując kokainą i starając się wszelkimi sposobami utrzymać swoją finansową i towarzyską pozycję - podobnych wycieczek pod adresem autorytetów i męczenników z obu stron sceny politycznej oraz nieprzystojnych kpin z narodowych świętości jest $\mathrm{w}$ tekście wiele. $\mathrm{W}$ obu powieściach obraz emigrantów jest zresztą komiczny i jednoznacznie negatywny: $\mathrm{z}$ dala od kraju narodowe wady przybierają na sile, obłuda przykrywa bezwstyd, hipokryzję i głupotę.

W L'Internationale argentine i Trans-Atlantyku mamy dodatkowo do czynienia $\mathrm{z}$ relacją narratora $\mathrm{z}$ bogatym, lecz kontrowersyjnym protektorem, rozwijającą się wedle znanego już schematu miłości i odrzucenia. Protektor ten jest człowiekiem o skomplikowanym pochodzeniu, zaprzeczającym idei narodowej czystości - Gonzalo to „Metys chyba, Portugalczyk, z perskiej tureckiej matki w Libii urodzony”" a w Sigampie narrator widzi „osobowość samotniczą pod przykrywką tej światowej, powściągliwej i bardzo argentyńskiej dezynwoltury, skopiowanej na początku wieku od angielskich podróżników. Typowy wytwór buenosariańskiej dzielnicy San Isidro [...], jak bardzo nie byłby czarny"131. Przy pierwszym spotkaniu z Sigampą narrator wspomina swój najsłynniejszy wiersz Oda a la Cordillera (Oda do Kordyliery) „o wielkiej sile, ale, och!, n i e d o j r z a ły”132. Początkowo narrator ma do swego protektora stosunek wysoce ambiwalentny: „Gombrowicz” niechętnie „chodzi” z Gonzalem, „Copi” z dystansem odnosi się do dziwacznych propozycji Sigampy. Z czasem więzy się zacieśniają, a narrator przyjmuje wystosowane przezeń zaproszenie do domu lub posiadłości, które okazują się przestrzenią wysoce symboliczną. Estancja

130 Witold Gombrowicz, Trans-Atlantyk, Wydawnictwo Literackie, Kraków 1986, S. 42.

131 Copi, La Internacional Argentina, s. 8. Dzielnica San Isidro jest uważana za siedzibę arystokracji.

132 Ibid., s. 10; wyróżnienie moje - E.K.P. 
Gonzala jest na wskroś hybrydyczna, tłoczą się na niej przedmioty z różnych kultur i historii, tracąc tym sposobem swoją niepowtarzalność, wynikającą z „czystości” rodowodu. Sigampa wprawdzie nie miesza bezładnie swoich skarbów, ale efekt kulturowego metysażu osiąga w inny sposób: w swoim wystawnym domu w bogatej podparyskiej dzielnicy Neuilly urządza jedno pomieszczenie w wiejskim stylu argentyńskim (dużo drewna, kominek, wyprawione krowie skóry, wieszak z rogów byka, na ścianie obrazy argentyńskich „mistrzów”), kolejne umeblowane jest ultranowocześnie, następne znowu kopiuje dekoracje tradycyjnej estancji na pampie ${ }^{133}$. Wewnętrznie każde jest spójne, jest wręcz uosobieniem ortodoksji (nacjonalistycznej lub kosmopolitycznej), ale zestawione w jednej przestrzeni wspólnej ujawnia swoją sztuczność. Jeśli dodać do tego formułowane raz po raz podejrzenia o homoseksualizm Nicanora Sigampy, eksplicytny staje się związek tożsamości narodowej z seksualną i waloryzacja tego, co „nieczyste” lub hybrydyczne, kosztem esencjalistycznego pojmowania natury ludzkiej.

Oba teksty łączy ponadto silna intertekstualna relacja, jaką nawiązują z mitami literackimi epok wcześniejszych, uznanych za fundacyjne dla mitów narodowych. Trans-Atlantyk, ogólnie rzecz ujmując, jest parodią polskiego sarmatyzmu i jego romantycznego "przedłużenia” w Panu Tadeuszu, opisany w L'Internationale argentine projekt wypracowania doktryny politycznej opartej na (zaściankowej skądinąd) poezji nawiązuje natomiast do tradycyjnego w Argentynie związku literatury z polityką, wywodzącego się także z epoki romantyzmu ${ }^{134}$. Powieść Copiego jest ponadto wariacją na temat politycznej boutade Macedonia Fernandéza, który w 1920 roku wystawił swoją kandydaturę na urząd prezydenta Argentyny, a także współczesną aranżacją lejtmotywu twórczości Roberta Arlta, czyli spisku tajemniczej sekty, która pragnie przejąć władzę w państwie.

W znakomitym i dotychczas najpełniejszym studium o twórczości Copiego Patricio Pron argumentuje, że źródeł „nowej poetyki”, która

\footnotetext{
133 Ibid., s. 12-13.

134 Związek ten był zresztą charakterystyczny dla całej Ameryki Łacińskiej; v. Ángel Rama, La ciudad letrada, Ediciones del Norte, Hanover 1984.
} 
tryumfuje w literaturze argentyńskiej w latach 8o., należy szukać u autora L'Uruguayen ${ }^{135}$. Jej znaki rozpoznawcze - odmowa politycznego zaangażowania, wykorzystanie poetyki absurdu, imperatyw inwencji twórczej, upodobanie do przestrzeni egzotycznych, humor, parodia tematów, stylów i konwencji literackich, eksperymentowanie z językiem i klasyczną estetyką realistyczną - pozwolą w połowie tej dekady wyróżnić grupę pisarzy ( $\mathrm{z}$ centralną figurą Césara Airy), którzy „narzucą" swoją jakość literacką, tworząc z jednej strony własny rodowód literacki, a z drugiej styl pisania "obowiązujący” w kolejnych dekadach. Gombrowicz okazuje się naturalnym poprzednikiem tej strategii twórczej, do której dodałabym jeszcze jeden wyróżnik: wielokrotnie wyżej wspominaną specyficzną kreację figury autora, który korzystając z serii inspiracji opatrzonych w Dzienniku mianem estetyki śmietnika $^{136}, \mathrm{z}$ upodobaniem reżyseruje siebie jako błazna-prowokatora, wymykającego się wszelkim tradycyjnym określeniom (narodowym, seksualnym etc.), i nie stara się zaistnieć jako trwający w tekście, wewnętrznie spójny podmiot.

\section{César Aira}

Literacki projekt Césara Airy (ur. 1949), zapoczątkowany jeszcze w latach 70., ale w pełni realizowany od kolejnej dekady, stanowi rzeczywisty przełom $\mathrm{w}$ argentyńskim myśleniu o tym, czym jest lub powinna być literatura, jakie są jej ewentualne zadania i jak wyglądać ma proces twórczy. Swoim czytelnikom, wśród których nie brakuje pisarzy tzw. młodszego pokolenia oraz akademików - Aira jest obecnie jednym z autorów hołubionych przez krytykę uniwersytecką, co zresztą w znacznej mierze pozbawia jego dzieło aury antymainstreamowego buntu, którą początkowo miało - zrewolucjonizował biblioteki,

135 Patricio Pron, Aquí me río de la modas, w szczególności rozdział Tercer excurso: la tradición "alternativa" y el "lugar" de Copi en la literatura argentina, s. $178-202$.

136 Witold Gombrowicz, Dziennik 1953-1969. 
wprowadzając doń nowych pisarzy (Lamborghiniego, Copiego, Pizarnik) i to od razu na miejsce zarezerwowane dla geniuszy, spod których piór nieodmiennie wychodzą arcydzieła. Swoim naśladowcom wskazał nowy - a raczej odzyskany z dwudziestowiecznej sztuki - sposób obcowania z tekstem literackim, który odsyłał do lamusa tradycyjne wartości, takie jak doskonałość stylu, artyzm, ideał intelektualnego lub duchowego przywództwa artysty i związanych z tym zobowiązań wobec pozaliterackiej rzeczywistości. Z drugiej strony nie brakuje także głosów Airze nieprzychylnych, upatrujących w jego w karierze analogii do bajki o nagim królu i wytykających mu m.in. niespójność głoszonych tez ${ }^{137}$. Niezależnie od ewentualnej słuszności tych zarzutów program literacki tego autora jest na tyle wyrazisty, że nim przejdę do tropienia międzytekstowych związków z twórczością Gombrowicza, wypada mu poświęcić kilka słów wstępu.

„W moim przypadku chodzi nie tyle o sztukę narracji, co o sztukę po prostu. Nigdy nie interesowało mnie opowiadanie ani w ogóle spełnianie oczekiwań czytelnika"138. Z braku lepszego słowa Aira nazywa swoje teksty powieściami (novelas), zresztą ze względu na ich skromną objętość zwykle w zdrobnionej wersji novelitas, i powraca $\mathrm{w}$ nich do awangardowych projektów artystycznych początku xx wieku oraz ich późniejszych przeformułowań w latach 50. i 60. Jego mentorami są Marcel Duchamp (dzieło sztuki pojęte jako ready-made), John Cage (przypadek jako metoda twórcza), Jean-Luc Godard (improwizacja), a także literacki poprzednik tych awangardowych tropów Raymond Roussel. Zdaniem Airy dokonana w XIx wieku profesjonalizacja pisarza, uosabiana przez Honoré de Balzaca i Gustave’a Flauberta, doprowadziła do osłabienia imperatywu inwencji twórczej i skazała pisarzy na mozolne udoskonalanie istniejących

\footnotetext{
137 Jednym z jego krytyków jest Ricardo Piglia: określa on Airę ironicznym mianem „małego kujona” (niño olfa), który zarzuca innym zbytnie przywiązanie do teorii i tradycji literackiej, samemu będąc autorem erudycyjnych esejów krytycznoliterackich i gorącym orędownikiem „własnych” klasyków; v. Ana Porrúa, César Aira: imposión y juventud, „Punto de Vista” 2005, nr 81, s. 28.

138 César Aira, Ars narrativa, „Criterion” 1994, nr 8. Korzystam z wersji dostępnej on-line: http://goo.gl/Gokfn6, dostęp: 31 VIII 2016.
} 
już schematów twórczych ${ }^{139}$. Sztuka awangardowa była odpowiedzią na ten zastój, który - według Airy - powtarza się w literaturze argentyńskiej lat 70. i 80., co pisarz dobitnie i prowokacyjnie konstatuje w krótkim artykule opublikowanym w czasopiśmie „Vigencia”, w którym krytykuje większość liczących się wówczas autorów, na czele z Ricardem Piglią, będącym - jego zdaniem - uosobieniem literackiego przeintelektualizowania ${ }^{140}$. W iście awangardowym geście zerwania $z$ tradycją (Aira docenia wprawdzie Borgesa, ale własnych poprzedników „stwarza” wśród pisarzy całkowicie wówczas marginalnych), postuluje taki program literacki, w którym sztuka pojęta jest jako akcja, a nie na przykład proces poznawczy lub, gorzej, platforma społecznego zaangażowania: „Największym osiągnięciem awangardy jest [...] przywrócenie na pierwszy plan akcji, niezależnie od tego, jaka by nie była frenetyczna, ludyczna, nieukierunkowana i obojętna na efekt. Musi być obojętna na efekt, jeśli ma pozostać

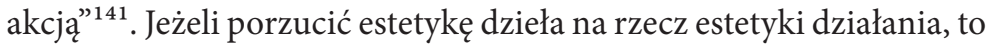
jedynym obowiązkiem sztuki staje się akt istnienia lub prze-trwania po tym, jak profesjonalna maestria dotknęła ściany - stąd frenetyczny właśnie rytm twórczy Airy, który publikuje nawet po kilka powieści rocznie, mając ich na koncie w sumie około osiemdziesięciu (ich liczba zmienia się tak szybko, że zwykło się podawać datę dzienną wydania). To literackie continuum jest więc trwającym procesem,

139 „Po tym, jak uformowała się figura pisarza-profesjonalisty, pozostają dwie możliwości, obie równie melancholijne: pisać dalej stare powieści w unowocześnionych sceneriach lub heroicznie spróbować zrobić krok naprzód. Ta ostatnia ewentualność szybko okazuje się drogą bez wyjścia: podczas gdy Balzac napisał pięćdziesiąt powieści i pozostało mu jeszcze wystarczająco czasu na życie, Flaubert w pocie czoła napisał pięć, Joyce dwie, a Proust tylko jedną. I była to praca, która pożarła życie, wchłonęła je w procesie nieludzkiego hiperprofesjonalizmu. Zawodowstwo w literaturze było tylko etapem przejściowym, ograniczonym do określonego momentu historycznego, ideałem, który mógł działać jedynie jako obietnica, dopóki się nie dokonał; kiedy się skrystalizował, nadszedł czas szukania czegoś nowego"; idem, La nueva escritura, „Boletín del Centro de Estudios de Teoría y Crítica Literaria” (Rosario) 200o, nr 8, s. 166.

140 Idem, Literatura argentina: nada más que una idea, „Vigencia” 1981, nr 51, s. 1. Idem, La nueva escritura, s. 170. 
obojętnym na własny efekt lub rezultat, a zbudowanym na procedurze (procedimiento) „ucieczki do przodu” (huida hacia adelante). „Procedura” jest centralnym narzędziem literackiego programu Airy, zapożyczonym od awangardy: „[...] konstruktywizm, écriture automatique, ready-made, dodekafonia, cut-up, przypadek, nieokreśloność. Wielcy artyści xx wieku to nie ci, którzy wytworzyli dzieła, lecz ci, którzy wymyślili procedury po to, by dzieła robiły się same albo nie robiły wcale"142. Talent, inspiracja, uczucia, wspomnienia, opinie - „cały ten koszmar »ja «, z którego staram się obudzić” ${ }^{143}$ - są całkowicie zbędne, konieczne jest za to wymyślenie i wdrożenie odpowiedniego „algorytmu”. W tym sensie procedura idealna pozwoliłaby na automatyczne tworzenie sztuki, ignorując całkowicie ograniczenia wynikające z jej profesjonalizacji - tak zresztą Aira rozumie słynne zdanie Lautréamonta o tym, że poetą może być każdy ${ }^{144}$. Centralną procedurą w Airiańskim uniwersum literackim jest wspomniana „ucieczka do przodu”, zapewniającą ciągłość dzieła, w którym nie liczą się poszczególne elementy („Przeraża mnie, że oceniają mnie za moje książki” ${ }^{145}$ ), lecz sama inwencja i proces twórczy. Z właściwym sobie humorem i swadą autor El llanto (Płaczu) pisze:

Mój sposób życia i pisania stosował się zawsze do niesławnej procedury „ucieczki do przodu”. Z tą przywarą mojego charakteru pogodziłem się dawno temu, a okazało się, że znalazła świetne zastosowanie w powieści. W pisaniu - o ile celem nie jest jedynie produkowanie powieści takich jak inne - chodzi o to, by pis a ć dalej, by to, co mamy do opowiedzenia, nie skończyło się na drugiej lub trzeciej stronie. Odkryłem, że jeśli robi się rzeczy dobrze, wszystko może skończyć się zbyt szybko, przynajmniej ochota na pisanie, wystarczający powód lub bodziec, pozostawiwszy po sobie jedynie mechaniczny bezwład. A więc pisząc nie tak dobrze (lub po prostu: pisząc źle), uzyskuje się doskonały powód, by pisać dalej: usprawiedliwić lub naprawić dzisiaj to, co popsuło się wczoraj. Wymyślić rozdział drugi,

\footnotetext{
142 Ibid., s. 168.

143 Idem, Ars narrativa.

144 La poésie doit être faite par tous. Non par un; Lautréamont, Poésies II, w: idem, Euvres complètes, GLM, Paris 1938, s. 327.

145 César Aira, Ars narrativa.
} 
który byłby racją bytu niedoróbek rozdziału pierwszego, a niedociągnięcia rozdziału drugiego naprawić w trzecim... Mój styl „ucieczki do przodu”, moje lenistwo i prokrastynacja sprawiają, że wolę tę metodę, aniżeli metodę cofania się i poprawiania; udaje mi się nie poprawiać już niczego, zostawić wszystko tak, jak mi wychodzi, całkowicie improwizować ${ }^{146}$.

Konsekwencje tej programowej nadprodukcji twórczej są dwojakie. $\mathrm{Z}$ jednej strony wywołuje ona wspomniane wyżej wrażenie ciągłości dzieła - nie liczą się konkretne książki, lecz relacje, które je łączą. Krótkie i publikowane jedna po drugiej powieści czytać można jako kolejne wpisy w quasi-dzienniku, tym bardziej że często utrzymane są w konwencji autofikcji i w banalnej, czerpiącej z estetyki telewizyjnego show fabule nierzadko kryją się komentarze do własnej ars narrativa. $\mathrm{Z}$ drugiej strony procedura „ucieczki do przodu” unieważnia wszelkie strategie oceny: styl, plan, oryginalność, przesłanie etc. - jeśli metoda twórcza opiera się na przypadkowości, jedynym ideałem możliwym do osiągnięcia jest bezformie (lo informe), czyli właśnie dyskwalifikacja wszelkiego porządku lub architektury ${ }^{147}$.

Continuum - pisze Graciela Speranza - jest także sposobem na przeorganizowanie argentyńskiej mapy literackiej według zasady pokrewieństwa, i wyniesienie pisarzy niedoskonałych [escribidores] - Gombrowicza, Arlta, Lamborghiniego, Copiego, Pizarnik, Puiga - ponad tych, którzy - pod egidą Borgesa - aspirują do doskonałości ${ }^{148}$.

Tym sposobem Aira wymyka się krytyce, deklarując przewrotnie, że od lat walczy o „złą literaturę”: „złe, zdefiniowane na nowo, oznacza to, co nie stosuje się do ustalonych kanonów dobrego, czyli po prostu do żadnych kanonów; nie ma bowiem kanonów tego, co ułomne [lo fallido]” ${ }^{149}$. Od artystów nie oczekuje się dzieł „porządnie zrobionych" albo "solidnych", ale coraz to nowszych, ciągłej transformacji,

\footnotetext{
146 Ibid.; wyróżnienie w oryginale.

147 Graciela Speranza, Fuera de campo. Literatura y arte argentinos después de Duchamp, Anagrama, Barcelona 2006, s. 295-299.

148 Ibid., s. 305; wyróżnienie w oryginale.

149 César Aira, La innovación, „Boletín del Centro de Estudios de la Teoría y Crítica Literaria" (Rosario) 1995, nr 4, s. 29-30.
} 
która z oczywistych przyczyn nie może być realizacją żadnych istniejących zasad.

Ideał „złej literatury” wprowadza w tym zwartym continuum jedyną, ledwie widoczną cezurę: po opublikowaniu kilku pierwszych powieści, m.in. Ema, la cautiva (1978, Branka Ema), La luz argentina (1980, Argentyńskie światło), El vestido rosa (1982, Różowa sukienka) lub Una novela china (1984, Chińska powieść), Aira - rzecz niezwykła - milknie na około trzy lata, by w jednym tylko 1987 roku wydać cztery krótkie teksty: El Bautismo (Chrzest), Los Fantasmas (Duchy), La Liebre (Zając) oraz Embalse (Sztuczne jezioro). Od tej pory utrzymuje to zawrotne tempo twórcze, publikując od dwóch do pięciu novelitas rocznie. Co więcej, jak zauważa Sandra Contreras, w tekstach datowanych od roku 1987 mamy do czynienia z nową jakością formalną, na którą składają się następujące elementy: wątek katastroficzny w wersji apokaliptycznej (potop, katastrofa nuklearna), humor, ironiczne przedstawienie autora jako jednej z postaci oraz nowa forma rozwiązania akcji opowiadania, które w szybkim tempie zmierza do spektakularnego finału ${ }^{150}$. Książki są krótkie, bo służą jedynie eksperymentowaniu z procedurą: „zwykle wypróbowuję coś nowego i zanim dojdę do stu stron, wiem już jak działa; pisanie dalej byłoby bezużyteczne"151. Powyższe cechy, inspirowane estetyką telewizyjną (krótkim formatem, banalnością tematów, doraźnym i natychmiastowym efektem), czyli tym, co uchodzi za literacko gorsze, za podły materiał (materias bajas) ${ }^{152}$, składają się właśnie na realizację modelu „złej literatury”.

150 Sandra Contreras, Las vueltas de César Aira, Beatriz Viterbo, Rosario 2002, s. 119120.

151 Luis Fernando Afanador, El último vanguardista. Entrevista a César Aira, „El Malpensante", http://goo.gl/JLIFMl, dostęp: 7 IX 2016.

152 „Niewiele jest we współczesnej literaturze latynoamerykańskiej projektów pisarskich (Virgilia Piñery, Juana Rodolfa Wilcocka i może Osvalda Lamborghiniego), w których wytworzenie wartości estetycznej byłoby - jak u Airy - tak ściśle związane $\mathrm{z}$ użyciem podłych materiałów, wykorzystywanych $\mathrm{w}$ formach chwiejnych, kruchych, roztrzaskanych"; Reinaldo Laddaga, Una literatura de la clase media. Notas sobre César Aira, „Hispamérica” 2001, t. 30, nr 88, s. 37. 
Ideał ten, jak wyżej pisałam, funkcjonuje w literaturze argentyńskiej jako rewers borgesowskiej doskonałości, ale także jako rodzaj praktyki literackiej o mocy subwersywnej, stawiającej opór różnym formom władzy - od politycznej do rynkowej. W taki sposób tradycyjna krytyka zwykła czytać np. „złą literaturę” Roberta Arlta ${ }^{153}$ jako podkopującą kanon, w którym upatruje się filaru aktualnie dominującego dyskursu władzy. Otóż chaotyczna nadprodukcja Airy, który programowo publikuje wszystko, także teksty literacko niedoskonałe, mieści się w tejże antysystemowej funkcji literatury, polegającej na oporze przeciwko dyktatom współczesnego rynku ${ }^{154}$. Autor Ema, la cautiva przyswaja sobie wprawdzie serię strategii właściwych kulturze masowej (od seryjnej, krótkiej formy po treść inspirowaną telewizją i kinem klasy B), ale jego twórczość w żadnej mierze nie jest skierowana do odbiorcy masowego, przeciwnie - wymaga, paradoksalnie, czytelnika-profesjonalisty. Ten ironiczny i opozycyjny sposób istnienia na rynku potwierdza jeszcze wydawnicza taktyka Airy, który publikuje swoje novelitas w wydawnictwach niezależnych, dbając o to, by były trudno dostępne $e^{155}$, a sam występuje publicznie niezmiernie rzadko.

Jak ten uwspółcześniony powrót do awangardy zgodzić z programem literackim Gombrowicza? Na poziomie konstrukcyjnym podobieństw - jak zobaczymy - nie brakuje, trudniej jednak przyswoić postulowane przez Airę radykalne usunięcie sfery egzystencjalnej - „całej tej psychologicznej panoplii”, „koszmaru »ja«”156 - która autora

153 V. Ricardo Piglia, Roberto Arlt, una crítica de la economía literaria, „Los Libros” 1973, $\mathrm{nr} 29$, s. 22-27.

154 Jak pisze Anna Zeidler-Janiszewska w odniesieniu do koncepcji Lyotarda, choć jej słowa stosują się doskonale do zasadniczo niechętnemu postmodernizmowi Airy: „Eksperymentowanie prowadzące często do wzniosłości staje się podstawowym składnikiem współczesnej estetyki oporu przeciwko lingwistyczno-medialnemu zn i ewolen i u"; Anna Zeidler-Janiszewska, Pochwała eksperymentowania, w: eadem (red.), Sztuka i estetyka po awangardzie a filozofia postmodernistyczna, Instytut Kultury, Warszawa 1994, s. 74; wyróżnienie w oryginale.

155 Ta wydawnicza niezależność jest wprawdzie ograniczona do rynku argentyńskiego; poza nim Aira jest związany z potężnym wydawnictwem Mondadori.

156 César Aira, Ars narrativa, s. 6. 
Dziennika niewątpliwie frapowała, nawet jeśli była dlań radykalnie nieuchwytna. $Z$ drugiej strony pomimo tych redukcjonistycznych deklaracji dzieło Airy krąży wokół narracji o sobie (ewidentnie fikcyjnej) oraz opowieści o życiu i twórczości innych pisarzy, którzy są dla niego niedoścignionym wzorem, objawieniem twórczego geniuszu. W tekstach krytycznoliterackich - esejach, prologach, monografiach - deklaracjom o obojętności dla dzieła pojętego jako rezultat lub „produkt" towarzyszą wyrazy uwielbienia dla figury artysty: Roussela, Arlta, Copiego, Lamborghiniego, Pizarnik ${ }^{157}$. Kontakt osobisty z dwojgiem tych ostatnich wyniesiony zostaje do rangi doświadczenia granicznego, które umożliwia mu poznanie siebie i zarazem określa jako pisarza: „Dobrze zrobiło mi spotkanie i obcowanie z tymi naprawdę utalentowanymi ludźmi, bo pozbawiło mnie złudzeń: ja nigdy nie mógłbym zostać pisarzem takim, jak oni - posiadacze magicznej różdżki, która wszystko zamienia w złoto; moje pisarstwo musiało być inne"158.

157 Sandra Contreras, César Aira: la novela del artista, „CELEHIS. Revista del Centro de Letras Hispanoamericanas" 1996, t. 2, nr 6-8, s. 205. Aira odżegnuje się wprawdzie od związków z postmodernizmem - także od postmodernistycznych „przeróbek” awangardy - ale jego fascynacja osobą artysty jest symboliczna dla współczesnej kultury. Jak ujmuje to Richard Rorty: „Rzecz w tym, że kapłan, filozof czy uczony zwykli przypisywać sobie wiedzę, będącą w określonej relacji do wszechświata, wiernie go ujmującą. Jeśli natomiast przyjąć za wzór ludzkiego istnienia artystę czy poetę, to nie chodzi już o myślenie o nich w kategoriach słuszności wobec wszechświata. Myśli się o nich jako o mających odwagę i talent tworzenia siebie samych, bycia własnym dziełem. Owo przemieszczenie w stosunku do nowoczesności polega na stwierdzeniu: nie sądź, by wiedza była istotą ludzkiej egzystencji, dla człowieka ważna jest autokreacja, nie zaś wiedza: niechaj to poeta ucieleśnia dla ciebie najlepiej możliwości ludzkie...”; cyt. za: Tadeusz Szkołut, O perspektywach estetyki $w$ dobie kultury postmodernistycznej, w: Anna Zeidler-Janiszewska (red.), op. cit., s. 195-196. Pomimo wspomnianego dystansowania się Airy do teorii postmodernistycznych, krytycy często zwracali uwagę na pokrewność jego estetyki ze sztuką ponowoczesną właśnie; v. Nora Catelli, Los gestos de la postmodernidad, „Punto de Vista” 1984, nr 22, s. 37; Barbara Jaroszuk, Traumy i zabawy. Współczesna proza argentyńska (1983-2013), Muzeum Historii Polskiego Ruchu Ludowego, Warszawa 2013, s. 73-130. 
Wzmianki o zażyłej przyjaźni z Lamborghinim, zawierające ponadto świadectwa ostentacyjnie przeczące legendzie "przeklętego pisarza”, jaką powszechnie cieszy się autor El fiord ${ }^{159}$ (a więc dowodzące, że jego „uczeń” poznał go lepiej niż inni), najlepiej obrazują znaczenie, jakie dla literackiego programu Airy ma mitologizacja figury artysty - awangardowe $\mathrm{w}$ duchu scalenie dzieła i życia - oraz etos bezpośredniego z nią obcowania. To tłumaczy z kolei, dlaczego autora Ema, la cautiva tak zajmowała osobista relacja Gombrowicza z Juanem Carlosem Gómezem ${ }^{160}$, która w oczach innych krytyków pozostaje mało znaczącym dla całości dzieła faktograficznym szczegółem. W artykule Arcydzieło tajemne pisze o Gombrowiczu, że „był przede wszystkim człowiekiem przyjaznym [hombre de amigos]" oraz że jego „tajemnym arcydziełem [...] okazała się gromadka przyjaciół, jakich zebrał wokół siebie"161.

Autorowi Ferdydurke Aira nie poświęcił wprawdzie odrębnego studium, ale jego nazwisko przewija się wielokrotnie wśród grona "geniuszy" - zapytany np. o największych współczesnych pisarzy argentyńskich, wymienia Borgesa, Arlta, Puiga, Lamborghiniego i dodaje: „I trzeba by dorzucić Gombrowicza, którego zaadaptowaliśmy jako Argentyńczyka" ${ }^{162}$. Oprócz dwóch wspomnianych tekstów - prologu

159 V. César Aira, Prólogo, w: Osvaldo Lamborghini, Novelas y cuentos, s. 16.

160 V. idem, Prólogo, w: Juan Carlos Gómez, Gombrowicz, este hombre me causa problemas, Interzona, Buenos Aires 2004, s. 9-15.

161 Idem, Arcydzieło tajemne, przeł. Rajmund Kalicki, „Twórczość” 2003, nr 1, s. 144. Pierwodruk: La obra maestra secreta, „El País” 2001, 26 XI, http://goo.gl/Fj5zcL, dostęp: 7 IX 2016.

162 Luis Fernando Afanador, op. cit. Argentyńska krytyka także wymienia Gombrowicza wśród pisarzy Airze bliskich, ale zwykle nie zagłębia się w naturę tego związku. Cytowana wyżej Graciela Speranza wymienia go wśród pisarzy nieaspirujących do formalnej doskonałości (v. przypis 147). Reinaldo Laddaga odnajduje u obu podobny sposób konstruowania narracji, w której „podejrzeniu groteski towarzyszy uczucie, że wydarzyło się coś poważnego" i w miarę progresu fabuły wydarzenia nie ulegają wewnętrznej konsolidacji, lecz coraz większemu rozproszeniu; Reinaldo Laddaga, Una literatura de clase media, s. 46. Najwięcej o gombrowiczowskiej inspiracji w twórczości Airy pisze Sandra Contreras, do której studium Las vueltas de César Aira będę się dalej odwoływać. 
w książce Gómeza oraz artykułu dla „El País” - Aira poświęca autorowi Dziennika zaledwie jeden krótki artykuł, Nostalgias de un polaco en el exilio $^{163}$ (Tęsknoty Polaka na obczyźnie). Oba artykuły - z wyłączeniem prologu, który ma nieco inny charakter - są typowo popularyzatorskie i dominuje w nich narracja o charakterze recepcyjno-biograficznym: precyzuje się listę „,argentyńskich” dzieł Polaka, odnotowuje kilka zwyczajowych anegdot i oczywiście wspomina o jego „młodych przyjaciołach”. Klucza do interpretacji tych tylko z pozoru banalnych tekstów dostarczają dwa centralne w twórczości Airy koncepty - egzotyka i młodość. Arcydzieło tajemne zaczyna się następująco:

Wszyscy przyznają, że Argentyna - zaludniona przybyszami, okresowo wyludniająca się, ziemia dziwaków i nieobecnych - to kraj, który sam musiał się wymyślić, a literatura, jaką wymyślił, żeby się wymyślić, była podwójnie literacka, to literaturą do kwadratu. [...] Na szczytach tej autoegzotyki najbardziej argentyńskim $\mathrm{z}$ argentyńskich pisarzy stał się również rzekomy polski hrabia, który przypadkowo trafił do Buenos Aires i niespodziewanie tu pozostał ${ }^{164}$.

Tym sposobem rozważania nad „argentyńskim Gombrowiczem” zostają od razu usytuowane w kontekście egzotyki (exotismo), pomijając całkowicie kwestię wygnania (exilio), która dla większości krytyków jest, jak wskazywałam w poprzednim rozdziale, dyżurnym wątkiem interpretacyjnym. Dla Airy ewentualne zasługi autora Trans-Atlanty$k u \mathrm{w}$ redefinicji pojęcia wygnania pozostają bez znaczenia, a Gombrowicz liczy się jako sprawny użytkownik i innowator procedury "egzotyzmu”165.

W artykule pod takim właśnie tytułem - Exotismo - Aira wykłada pokrótce swoją definicję tego narzędzia narracyjnego (nazywając je „narzędziem generującym spojrzenie" ${ }^{166}$ ) i dowodzi, że leży ono u pod-

163 César Aira, Nostalgias de un polaco en el exilio, „Creación” 1986, nr 3, s. 78.

164 Idem, Arcydzieło tajemne, s. 144.

165 Sam Aira także ma na koncie kilka „egzotycznych” powieści, jak Ema, la cautiva, La liebre, Un episodio en la vida del pintor viajero (Epizod z życia wędrownego malarza).

166 César Aira, Exotismo, „Boletín del Centro de Estudios de Teoría y Crítica Literaria” (Rosario) 1993, nr 3. Tekst dostępny on-line: https://goo.gl/VWjxfi, dostęp: $20 \mathrm{x}$ 
staw różnorakich gatunków i tendencji literackich, a także współczesnej nauki ${ }^{167}$. Egzotyzm, jak każda procedura, raz użyty - wyczerpuje się („posiada jedną wspólną cechę z przyrodą, o której ekolodzy mówią alarmistycznie, że jest n i e o d n aw i aln a" ${ }^{168}$ ) i by skutecznie działał dalej, trzeba go wymyślać w coraz to nowych wersjach. Twórcą pierwszej z nich jest Monteskiusz, który w Listach perskich powołuje do życia figurę cudzoziemca, niejako z zewnątrz obserwującego rzeczywistość faktycznie autorowi dobrze znaną - z tego „spojrzenia” ewoluują powieść nowożytna i nauka. Drugi egzotyzm zamienia cudzoziemca i narratora miejscami - ten ostatni staje się podróżnikiem, który zwiedza dalekie kraje i „wraca, by opowiedzieć, co widział na wyspach swojej fantazji, przeznaczenia lub stylu" ${ }^{169}$. Początkowo musi jeszcze w y m yśla ć ten daleki kraj - podobnie jak w narracji o cudzoziemcu trzeba było w y m y śl i ć jego zdziwienie - szybko jednak staje się jasne, że te „obce ziemie” już istnieją, wystarczy je odwiedzić: „Odległy kraj okazuje się fantastyczną scenerią już istniejącą... Un objet trouvé”170. Jako awangardowa procedura ten nowy rodzaj egzotyzmu powinien być zastosowany tylko raz, ale podróże stają się coraz częstsze, komercjalizują się i ostatecznie ten tryb narracyjny ewoluuje ku zwykłej literaturze podróżniczej, science fiction, ku opowieściom o fenomenach paranormalnych etc. Wraz z pojawieniem się książki jako towaru i tym samym czytelnika-konsumenta wymyślony zostaje trzeci rodzaj egzotyzmu:

Pers, który sprzedaje czytelnikom francuskim „perską” Persję, kolorową, odmienną, egzotyczną. Pisarz używający zdziwienia ready-made. Oto podwójne ready-made: jest nim nie tylko materia, ale także podmiot, który ją wyraża. Procedura się domyka. Nie potrzeba ani podróżować, ani importować tubylców. Pers w Paryżu i Francuz w Persji spotkają się

2016. Egzotyzm Airy nie ma jednak nie wspólnego ze „spojrzeniem z zewnątrz” Saera, nie pretenduje bowiem do obalenia kulturowych paradygmatów, tylko je ironicznie wykorzystuje. Ibid.

Idem, Nouvelles impressions du petit Maroc, MEET, Saint Nazaire 1991, s. 64; wyróżnienie w oryginale.

Idem, Exotismo.

Ibid. 
w usłużnym Meksykaninie, któremu nawet nie brak nieszczęsnej świadomości, że sprzedaje swój kraj za trzydzieści srebrników ${ }^{171}$.

Aira drwi oczywiście z realizmu magicznego (w innych miejscach nie szczędzi słów krytyki ani Juanowi Ruflo, ani Gabrielowi Garcíi Márquezowi), ale nie tylko o ten latynoski globalny marketing mu chodzi - trzeci typ egzotyzmu był bowiem motorem dziewiętnastowiecznych narracji narodowościowych, do których Aira odnosi się na początku swojego tekstu o Gombrowiczu. Obecny w nich sztuczny, przerysowany obraz narodowej esencji skrytykował Borges („w Koranie nie ma wielbłądów"172), ale Aira odrzuca jego zarzuty w imię awangardowego ideału wolności sztuki: „[...] wymaga się od artysty autentyczności, zakładając, że jest ona wartością samą w sobie (i z pewnością tak jest). Ale artysta ma właśnie przewartościowywać wartości. A jeśli chce być nieautentyczny? Nikt nie może mu tego zabronić" ${ }^{173}$. Narodowość pozostaje dla niego czystym przypadkiem - tak jak była nim dla siedemnastowiecznych humanistów, którzy odkryli ponadnarodową istotę człowieczeństwa, a także dla Juana José Saera, który pisarzowi zabraniał wszelkiego stadnego przypisania ${ }^{174}$ - tyle że p r z y p a d ki e m zbawiennym, utrzymującym przy życiu literaturę pojętą na sposób awangardowy jako czysta inwencja. W jaki sposób? Sztucznie ubarwiona opowieść o własnym kraju, egzotycznie przerysowana w tej

171 Ibid.

172 Jorge Luis Borges, Pisarz argentyński i tradycja, w: idem, Polemiki, przeł. Joanna Partyka, Prószyński i S-ka, Warszawa 2008, s. 175-188.

173 César Aira, Exotismo.

174 „Być Polakiem. Być Francuzem. Być Argentyńczykiem. Pomijając wybór języka, po cóż wymagać od pisarza podobnych samookreśleń? Być komunistą. Być liberałem. Być indywidualistą. Etykietki tego typu są dla twórcy równie mało istotne, co przynależność do klubu piłkarskiego czy jakiegoś kółka gastronomicznego. Możliwość postrzegania kogoś jako taki czy inny byt, pełniący określoną funkcję w repertuarze społecznych wyobrażeń, jest przywilejem człowieka jako takiego, a nie pisarza, ale człowiek to pierwsza fikcja, wywodząca się z przebrzmiałej estetyki. Przekonanie to jest dlań taką oczywistością, że nie tylko wyznacza kierunek czy przyświeca jego pracy, lecz jawi się jako jedyne jej usprawiedliwienie”; Juan José Saer, Spojrzenie z zewnątrz, przeł. Klementyna Suchanow, Krystian Radny, „Literatura na Świecie” 2001, nr 4, s. 72. 
najgorszej, trzeciej formie, użyta w nowy sposób pozwala, paradoksalnie, w y m yśl i ć własną narodowość. Aira analizuje dla przykładu typowo regionalistyczną powieść Macunaíma Brazylijczyka Mária de Andrade:

Czy Mário nie manipuluje już pewnym ready-made, a w każdym razie pewnym fait accompli, czyli swoją brazylijskością? Nie sądzę [...]. Czyni ze swojego dzieła machinę do stania się Brazylijczykiem. Był nim już wprawdzie wcześniej, ale nowożytność uczyniła z narodowości cechę przypadkową, incydentalną [...]. I nie chodzi tylko o bycie Argentyńczykiem lub Brazylijczykiem, ale o wymyślenie takiego mechanizmu [dispositivo], by warto było nim być ${ }^{175}$.

Celem nie jest autentyczność - ta wartość została już zdyskredytowana - ale afirmacja w sensie nietzscheańskim, potwierdzenie potęgi inwencji twórczej, która korzysta właśnie ze stereotypu i buduje narodowość, manipulując istniejącymi tekstami kultury: w Airiańskim cyklu o pampie Indianie i biali grają swoją szablonową tożsamością, raz ją ostentacyjnie „wypełniając”, a innymi razy równie demonstracyjnie ją negując ${ }^{176}$. „Kraje takie jak nasze, historycznie nowe - i tu Aira zdaje się nawiązywać bezpośrednio do Gombrowicza - oferują lepsze warunki do uruchomienia tego mechanizmu, ponieważ posiadają kwantum niewymyślonego" 177 .

Polska także posiada owo „kwantum niewymyślonego”, które autora Dziennika tak frapuje i pozwala mu „wynaleźć” we Wspomnieniach polskich esencję polskości, „tę dojrzałość niedojrzałości, którą

\footnotetext{
175 César Aira, Exotismo; wyróżnienie w oryginale.

176 V. analizę tego cyklu w oparciu o paradygmat studiów postkolonialnych w książce: Barbara Jaroszuk, op. cit., s. 73-130.

177 Ibid. Choć i w krajach o silnej formie narodowej podobne reinterpretacje tożsamościowe nie są niemożliwe: „Powieść Pani Bovary [jest - E.K.P.] tak podobna do Macunaímy: takie samo poszukiwanie tożsamości na podstawie mitów, identyczne naukowe przerabianie stereotypów... Pozostaje jedna zasadnicza różnica: Flaubert staje się Francuzem z pogardą, tymczasem Mario z miłością zostaje Brazylijczykiem. Straszliwy egzotyzm francuskich prowincjonalnych miasteczek kończy się głupotą i śmiercią"; César Aira, Exotismo.
} 
[...] opracował na podstawie cech narodowych, koniecznych do wytworzenia w sztuce i w myśli”" ${ }^{178}$. Interpretacja Airy ma tę wyższość nad innymi argentyńskimi propozycjami lektury, że nie ignoruje ewidentnego zainteresowania Gombrowicza kwestią przynależności narodowej, z którą wprawdzie pisarz cały czas polemizuje, ale która nieodmiennie pozostaje lejtmotywem jego twórczości. Airze nie chodzi jednak o dekonstrukcję narodowych mitów ani o afirmację ,ja” przeciwko „my” (wszelkie ideologiczne implikacje literatury pozostają poza sferą jego zainteresowania), lecz o wymyślenie narodowej tożsamości, przyjęcie jakiejś fikcji tożsamości - w ostatecznym rozrachunku „wyobrażeniowe potwierdzenie tego, czym już się jest" ${ }^{179}$. W tym sensie Wędrówki po Argentynie czytać można jako przykład egzotyzmu drugiego typu - pisarz wyrusza w podróż, by następnie opowiedzieć o egzotycznej ziemi rodakom - ale także jako tekst przejściowy, prowadzący do Dziennika argentyńskiego, w którym Gombrowicz decyduje się na to, na co nie zdecydował się porównywany z Andrade Francuz Pierre Loti, który swoje opowieści z Japonii snuł zawsze z perspektywy z e w n ę t r z n e g o obserwatora. W Dzienniku argentyńskim bowiem twórcza moc inwencji osiąga swoje apogeum i Gombrowicz staje się Argentyńczykiem: „dokonuje się wymyślone przyjęcie narodowości dotkniętej nieistnieniem"180. Autor Trans-Atlantyku idzie o krok dalej niż Brazylijczyk Mário de Andrade i testuje nową procedurę - wymyśla kolejną tożsamość, rodzaj symulakru tożsamości, który nie dowodzi oczywiście niczego n a p r a w dę (rozważania, czy Gombrowicz był, czy nie pisarzem argentyńskim, są jałowe), a świadczy jedynie o twórczej mocy literatury lub skuteczności nowej procedury, która nie tyle rozpuszcza narodową esencję - jak chcieliby inni interpretatorzy Gombrowicza - ile wymyśla ją na nowo, polemizując z odziedziczonymi po XIX wieku narracjami tożsamościowymi.

Zgodnie z definicją Airy egzotyzm jest „narzędziem generującym spojrzenie” i to właśnie kwestia „spojrzenia” znajduje się w centrum

\footnotetext{
178 Idem, Nostalgias de un polaco en el exilio, s. 78.

179 Sandra Contreras, Las vueltas de César Aira, s. 84.

180 César Aira, Nostalgias de un polaco en el exilio, s. 78.
} 
najdłuższego tekstu poświęconego przezeń Gombrowiczowi, czyli wstępu do książki Juana Carlosa Gómeza Gombrowicz, este hombre me causa problemas (Gombrowicz, ten człowiek sprawia mi kłopoty). Wypracowany przez autora Ferdydurke specyficzny rodzaj „spojrzenia” jest esencją jego procedury narracyjnej, a zarazem naczelną charakterystyką jego sposobu bycia - życie i dzieło nie tylko są nierozdzielnie splątane, lecz po prostu są tym samym: w interpretacji Airy porządki rzeczywisty i fikcyjny są jednym. Chodzi o spojrzenie poseura, nacechowane zasadniczym brakiem naturalności i ostentacyjną sztucznością, a przy tym niepozbawione energii kontestacyjnej: „poza to prawda tymczasowa, która służy, choćby chwilowo, w walce przeciwko jałowemu samozadowoleniu mieszczucha"181, zakłóca ustalony sens i przewidywalny porządek społeczny. Rzec by można, że poza w życiu jest tym, czym stylizacja w narracji - jawnie stosowaną konwencją, która ma odkształcić formę, owo Heideggerowskie „się”. Mechanizm „spojrzenia” - ciągnie Aira - zakłada istnienie interlokutora: w życiu Gombrowicz szuka inteligentnego rozmówcy-adwersarza (Gómeza), a w dziele stwarza detektywa o nieubłaganej jasności umysłu, budzącego jednocześnie uzasadnione podejrzenia o szaleństwo. Przekonanie o byciu wystawionym na spojrzenie Innego zbliża go do egzystencjalizmu, ale od Jeana-Paula Sartre’a różni go odmienne rozumienie tego terminu:

Gombrowicz uważał „spojrzenie wytwarzające” za zastrzeżoną własność intelektualną Sartre’a, ale podczas gdy Sartre reifikował cudze spojrzenie, czyniąc z niego przedmiot analizy filozoficznej, u Gombrowicza pozostaje ono instrumentalne: wytwarza inteligencję, nie jest przedmiotem $[\text { jej analizy - E.K.P. }]^{182}$.

Innymi słowy, Gombrowiczowskie „spojrzenie” jest narzędziem, jest procedurą lub formą opowiadania, poza którą nie da się wyjść. Wymyka się ono interpretacji - ambiwalentnych słów, gestów, min

\footnotetext{
181 Idem, Prólogo, w: Juan Carlos Gómez, Gombrowicz, este hombre me causa problemas, s. 9.

182 Ibid., s. 11.
} 
poseura nie sposób analizować („jedyną [jego] prawdą jest kłamstwo"183), pozostaje tylko podejrzewać ich sens właściwy. Jeśli poseur nieustannie udaje (autentyczność nie jest przecież żadną wartością w sztuce), to nic z tego, co się wydarza - rozmowa, gest, kolacja, zbrodnia etc. - nie wydarza się po prostu i nie przestaje budzić wątpliwości co do swojego znaczenia. Oryginalność Gombrowicza na tym właśnie polega - „na wymyśleniu jedynych w swoim rodzaju opowieści, w których eksponuje się p o d ej r z e n ie [la sospecha]"184. Sens historii nie wynika bezpośrednio z przyczynowo-skutkowego ciągu wydarzeń (np. zdrada - zemsta - zbrodnia - kara), lecz z gry wzajemnych podejrzeń: „Zdrajca, Mściciel, Zbrodniarz i Kat obserwują się wzajemnie z wierzchołków wygiętej i chwiejnej figury geometrycznej"185.

W literaturze Airy na rozbudowaną fabułę domysłu i udawanie kogoś, kim się nie jest nie ma miejsca, a raczej czasu - wszystko dzieje się zbyt szybko, a jego postaci pozbawione są w zasadzie daru introspekcji; i w tym sensie refleksje Argentyńczyka nad Gombrowiczowską procedurą (inaczej niż w przypadku studium o Copim) nie stosują się do jego własnych powieści. Ale ambiwalentna poza nie jest obca przyjętej przez Airę figurze autora i zdarzyło mu się nawet używać terminu poseur w odniesieniu do samego siebie - w artykule zatytułowanym La innovación, po wyłożeniu ideału „złej literatury”, konstatuje: „Moi przyjaciele się dziwią, a ja pozwalam im wierzyć, że jestem pozerem"186. I chociaż dalsze słowa mają przeczyć podejrzeniom o pozerstwo, to humorystyczny styl jego tekstów oraz kłopotliwy dystans do własnych teorii składają się właśnie na obraz błazna, który pragnie wymknąć się jakiemukolwiek ostatecznemu przyporządkowaniu i skutecznie „znokautować” krytykę. W wywiadach często ironicznie kontestuje własne wypowiedzi: „Nie wiem, co chciałam przez to powiedzieć. Nie należy rozliczać mnie ze słów, bo często się

\footnotetext{
183 Ibid., s. 9.

184 Ibid., s. 13; wyróżnienie moje - E.K.P.

185 Ibid., s. 12-13.

186 Idem, La innovación, s. 29.
} 
zapominam. Czasem mówię coś tylko dlatego, że dobrze brzmi, żeby wyglądać na bardziej inteligentnego i bystrzejszego" ${ }^{187}$, lub zapytuje z niedowierzaniem: „Naprawdę to powiedziałem?”"188. Obrona „złej literatury”, z góry neutralizującej każdy możliwy język krytyki, oraz charakteryzujący Airę duch przekory („Kiedy coś zaczyna budzić szacunek, natychmiast piszę na odwrót" ${ }^{\prime 89}$ ) składają się na obraz enfant terrible, pozera, który wzbudza podejrzenia co do tego, czym właściwie są jego hiperintelektualne, a przy tym pełne humoru i świetnie napisane narracje, mogące w każdej chwili „zepsuć się" i w szaleńczym tempie zmierzać do finału ${ }^{190}$. Czy, jak sam pisze w odniesieniu do Gombrowicza, „mętnym konsorcjum szaleństwa i inteligencji, rozumu i obłędu, zmieszanych, zachodzących na siebie i pozbawionych wyraźnych granic, w którym kwitnie pozer"? ${ }^{191}$ W wypadku tego podobieństwa strategii życiowych nie sposób wprawdzie mówić o „związku międzytekstowym”, ale jeśli przyjąć, jak chce Aira, że liczy się tylko całość twórczości, a nie poszczególne jej „składowe” (książki), to okazuje się, że najważniejszym elementem sankcjonującym w a r to ś ć tego dzieła jest podpis autora, jego nazwisko gwarantuje bowiem ciągłość twórczą, scala efemeryczne novelitas w rodzaj dziennika lub - jak wolą inni komentatorzy - encyklopedii. Figura autora, rozumiana jako Aira-pisarz lub Aira-marka, staje się głównym komponentem dzieła, nawet jeśli nie zawsze występuje on w nim jako postać. Dodatkowo jest to figura naznaczona Gombrowiczowską niedojrzałością. „Zawsze uważałem, niezbyt oryginalnie, że dojrzałość jest wynikiem doświadczenia. [...] Liczą się też wrodzone

\footnotetext{
187 Luis Dapelo, Entrevista a César Aira, „Hispamérica” 2007, t. 36, nr 107, s. 44.

188 Luis Fernando Afanador, op. cit.

189 Luis Dapelo, op. cit., s. 53.

190 Elvio Gandolfo w klasycznej już recenzji powieści Los misterios de Rosario (Tajemnice Rosario) stawia w odniesieniu do Airy pytanie: ,jest czy udaje?” (w supozycji: idiotę), które doskonale syntetyzuje nader ambiwalentne uczucia, jakie w czytelnikach wzbudza ekscentryczny styl marki „Aira”; Elvio Gandolfo, El humor no es más fuerte, „Primer Plano” 1994, s. 1.

191 César Aira, Prólogo, w: Juan Carlos Gómez, Gombrowicz, este hombre me causa problemas, s. 10.
} 
predyspozycje: charakter, który prowadzi do doświadczenia. Mnie zaprowadził w przeciwną stronę"192.

Elementem ściśle intertekstualnym na przecięciu estetyk Airy i Gombrowicza jest eksploatacja ideału młodości, który autor Ema, la cautiva, oczywiście po odpowiednich przeróbkach, adaptuje do własnej wizji literatury, ściśle wiążąc go ze wspomnianą wyżej admiracją dla figury artysty. W jego narracjach o mistrzach - Copim, Lamborghinim, Rubénie Darío - powraca odniesienie do mitu młodości jako etapu, w którym formułuje się powołanie twórcze, w którym chce się zostać pisarzem. Zrealizowanie tego pragnienia - zostanie artystą - implikuje wkroczenie w „dojrzałość”, wypełnienie powołania, w języku Airy: odnalezienie Nowego. Ale zważywszy na fakt, że awangardowy ideał Nowości dewaluuje się bardzo szybko, artysta musi nieustannie powracać do „młodości” pojętej jako moment potencji twórczej, jako „formalny element innowacji” ${ }^{193}$. Opozycja młodości i starości jest tutaj rozumiana jako opozycja Nowe-Stare na sposób baudelaireowski: „Baudelaire stworzył »nowe« takie, jakie obecnie znamy, i dokonał tego w paradoksalny sposób. Wymyślił mianowicie - a raczej odkrył - starość, uwiąd cywilizacji, w której się urodził"194. Siła Nowości jest bowiem dostrzegalna (i pożądana) tylko z perspektywy starości i schyłku, podobnie jak złe, niedorobione i nieautentyczne, docenić można tylko z perspektywy ustalonej już hierarchii wartości lub form. Innymi słowy, młodość jest esencją witalizmu, którego Aira broni w sztuce przeciwko wartościom konotowanym przez starość (perfekcja, konsensus, namysł), wszystkie filary jego estetyki - awangardowy imperatyw poszukiwania Nowości, procedura „ucieczki do przodu”, gorączkowy impuls twórczy - są atrybutami tego wieku. „Stary i młody - Gombrowicz już to powiedział: "Człowiek nie chce być Bogiem. Człowiek chce być młody «"195. Fragment, z którego Aira zaczerpnął ten cytat, brzmi następująco:

\footnotetext{
192 Idem, La serpiente, Beatriz Viterbo, Rosario 1997, s. 76-77.

193 Sandra Contreras, Las vueltas de César Aira, s. 247.

194 César Aira, La innovación, s. 28.

195 Idem, Prólogo, w: Juan Carlos Gómez, Gombrowicz, este hombre me causa problemas, s. 14 .
} 
Autentyczność i nieautentyczność życia sa mi równie cenne - moja antynomia to z jednej strony Wartość, a z drugiej Niedo-wartość... Niedostateczność... Niedorozwój... To jest, jak myślę, we mnie najważniejsze, najbardziej osobiste i odrębne. Niepowaga jest dla mnie równie potrzebna człowiekowi, co powaga. Jeśli filozof mówi, że „człowiek chce być Bogiem”, to ja bym to uzupetnit: „człowiek chce być młody”.

I według mnie jednym z narzędzi tej dialektyki Petnia-Niepełnia, Wartość-Niedowartość, są rozmaite okresy wieku ludzkiego. Dlatego tak niezmierną i dramatyczną rolę przyznaję wiekowi wstępnemu - młodości $i^{196}$.

Każdy z nich tę dialektykę przerabia na swój sposób - Gombrowicz w historiach pełnych napięcia, podejrzliwości, ciągłej niepewności co do zamierzeń Innego, skomplikowanych gier „narzucania się”, otwartej konfrontacji Młody-Stary; Aira natomiast, w fabułach o Nowym Początku, czyli w opowieściach o katastrofie, przeżyciu, nowym rozdaniu, cudownym odzyskaniu młodości etc.

Jedną z takich opowieści o odrodzeniu, o „nowym życiu” jest powieść El llanto, której narratorem jest „poeta, pisarz i eseista”"197, autor czternastu opublikowanych własnym sumptem książek, zbliżający się do czterdziestki - wieku, w którym jego kariera znalazła się w krytycznym impasie. Akcja powieści rozpoczyna się opisem przebudzenia:

Wstaję o pierwszym świetle poranka, po bezsennej nocy męczących fantasmagorii... Jestem tak zmęczony, tak zdezorientowany... Nie mogę już, nie mogę dalej. Wszystkie drogi cienia prowadzą mnie ku straszliwej pewności, że wydarzyło się to, czego najbardziej się obawiałem. [...] Nie mogę żyć! Myśl mi nie pomaga, przeciwnie! Tłoczy się we mnie jak wieża, faluje, przyjmuje formę mojego życia... Noc wywleka mnie z rzeczywistości jak odpływ, i oto wydarza się coś niezwykłego... czego tak się obawiałem. Każdy sen oznacza nowy strach, dziurawiący życie byle gdzie, przypadkiem, jest krótkim opowiadaniem bez wymiarów, czystym czasem. Gęstość snu, który mnie dopada i nie daje spać. Gorzej jeszcze: nawet nie wiem, czy jest noc czy dzień; w mieszkaniu światło jest szare, niskie, minimalne, ale dobrze widoczne ${ }^{198}$.

\footnotetext{
196 Witold Gombrowicz, Dziennik 1953-1969; wyróżnienie w oryginale. 
Powracające motywy tego opisu - poranek ujęty jako stan zawieszenia pomiędzy dniem i nocą, mętne światło, senny koszmar powodujący narastające uczucie strachu oraz przeczucie zbliżającej się katastrofy - przywodzą na myśl początek Ferdydurke, przez co powieść zostaje od razu usytuowana w kontekście gombrowiczowskiej problematyki „młodości”, tym bardziej że kilka stron później nawiązuje do autora Dziennika w sposób bardziej eksplicytny. To, czego narrator tak bardzo się obawia, to „nowe życie”, które nieubłaganie rozpoczyna po tym, jak zostawiła go żona (zresztą podobne, niechciane „nowe życie” przytrafia się także Józiowi). Zanim jednak opowie historię rozstania, stanowiącą zasadniczą materię powieści, wspomni swój roczny pobyt w Warszawie na zaproszenie polskiej ambasady, zapewniającej rzekomo wikt i opierunek pisarzowi, który - nieskrępowany materialnymi troskami - miał zajmować się wyłącznie pracą twórczą. Gdy jednak przyjeżdża do polskiej stolicy - opisanej w sposób humorystycznie egzotyczny: „Przybyłem do Warszawy pewnego popołudnia u schyłku lata, piętnaście stopni mrozu"199 - okazuje się, że stypendium jest fikcją i narrator odnajduje się nagle w sytuacji totalnego braku: nie mówi po polsku, nie zna miasta, brak mu doświadczenia w podróżach. Po jakimś czasie dostaje wprawdzie obiecane stypendium, ale w wysokości czysto symbolicznej - „czterdzieści złotych, około dwunastu dolarów"200 - i wówczas koncentruje się na przetrwaniu:

[...] stałem się osobą inną od tej, którą byłem w Buenos Aires. Bardziej niż poetą, wydawałem się dzikim zwierzęciem. Od tego momentu, starałem się tylko przeżyć; moje możliwości umysłowe, grające ze mną w chowanego, na przemian starały się to zadanie wypełnić. [...] Ograniczyłem się do horroru przetrwania. Nie mogę stwierdzić, czy robiłem to dobrze czy źle, czy można było lepiej albo gorzej, reguły gry były bowiem bardzo restrykcyjne: spałem $\mathrm{w}$ ruderach, jedzenia szukałem na śmietnikach, taszczyłem walizki, paliłem koce z gazet, by podgrzać wodę na poranną herbatę $\mathrm{z}$ drugiej ręki ${ }^{201}$.

\footnotetext{
199 Ibid., s. 177.

200 Ibid.

201 Ibid., s. 178.
} 
Aira ironicznie odwraca mit fundujący „argentyńskiego Gombrowicza”, któremu trudne początki w Buenos Aires - naznaczone brakiem tak sugestywnie opisanym przez Piglię w Sztucznym oddychaniu - pozwalają jednocześnie narodzić się na nowo, powrócić do młodości. W El llanto gehenna narratora kończy się wprawdzie po roku, gdy wymęczony powraca do Argentyny, ale koszmar „nowego początku” prześladuje go nadal: jego żona, Claudia, kobieta nadzwyczajnej urody i odwagi ducha (działaczka partii komunistycznej), pragnie - jak sama to ujmuje - „zacząć żyć”, co w jej mężu słusznie wzbudza niepokój połączony z niezrozumieniem: „czyż jest możliwe nowe życie? czyżbyśmy nie mieli tylko jednego?”202. Claudia wkrótce nawiązuje romans z Isso, japońskim terrorystą, porzuca męża i już w Japonii rodzi pięcioraczki, a historia jej nowej miłości służy za kanwę popularnej produkcji filmowej. Inna bohaterka książki, Laura - słynna gwiazda filmowa - nawiązuje współpracę z narratorem, by „spróbować czegoś nowego, czegoś całkiem innego" (ten sugeruje jej adaptację tekstów Roussela, ale kiedy wyjaśnia o co chodzi, aktorka „cofa się z przerażeniem”203). Claudia, która z największą determinacją afirmuje pragnienie „nowego początku”, jest najbardziej zwycięską postacią powieści - oczywiście na tyle, na ile ironiczno-fantasmagoryczna historia pozwala mówić o zwycięstwie. Słowa narratora: „Ostatecznym celem każdego opowiadania jest obudzenie nowego życia" ${ }^{204}$, należy rozumieć przede wszystkim w sensie estetycznym, podobnie jak końcowe odwołanie do postaci dziecka, która opowiadanej historii nagle nadaje nowy bieg: narrator okazuje się mieć dwójkę dzieci i żonę („kobietę mojego życia, pierwszą i ostatnią, i jedyną" ${ }^{205}$ ) - innymi słowy, całkiem nowe lub inne życie ${ }^{206}$.

Opowieść o rozstaniu jest w tej powieści także przyczynkiem do rozważań narratora o relacji z własną ojczyzną: „Argentyna to kraj

\footnotetext{
202 Ibid., s. 199.

203 Ibid., s. 180.

204 Ibid., s. 229.

205 Ibid., s. 231.

206 Stosowany przez Airę zabieg „powrotu do rzeczywistości” poprzez odwołanie do faktycznej sytuacji rodzinnej (żony Liliany i dwójki dzieci) często powtarza się w powieściach utrzymanych w konwencji autofikcyjnej.
} 
neutralny, bez historii, bez kultury - jeden Japończyk wystarczył, by zabarwić jej niebo fosforyzującym niepokojem"207. Sławione przez Gombrowicza argentyńskie nieuformowanie fatalnie sprzyja fantazjom o „nowości” i ułatwia jej dostrzeżenie. Ale „nowe życie” oznacza także nowe zdefiniowanie narodowej tożsamości; w języku Airy: nowe stanie się Argentyńczykiem. Gdy po rozstaniu narrator zapada w letarg, znaczony długotrwałą wstrzemięźliwością seksualną, przekornie nasila się w nim skłonność do „fabuły fallicznej”, wyrażającej tradycyjne mity argentyńskości: machismo, guerrilla, opór wobec dyktatury, lewicowość etc., które jego fantazja neguje:

Nigdy jej [Argentyny] specjalnie nie kochałem. Czułem, że... zostanie poetą było błędem, błędem młodości... w rzeczywistości wszystko we mnie było zbyt młode i niedojrzałe... Moje powołanie było inne. Znacznie bardziej wolałbym na przykład zostać szpiegiem policji albo jeszcze lepiej Sił Wojskowych... infiltrować podejrzane organizacje, jak PCA [Komunistyczną Partię Argentyny - E.K.P.], i dać upust najbardziej nonsensownym i paranoicznym podejrzeniom, przekazywanym moim zwierzchnikom podczas sesji podobnych do egzaminu przed komisją oficerów w mundurach ${ }^{208} \ldots$

Ostentacyjne sprzeniewierzenie się argentyńskiej mitologii oporu (Claudia była wszak działaczką komunistyczną) przywodzi na myśl, po pierwsze, typowo gombrowiczowskie marzenia o tym, by się zbrukać, poniżyć - i w ten sposób pozostać niedojrzałym. Po drugie, oznacza nową, „egzotyczną” konfigurację własnej narodowości, w której ze stereotypów, zbiorowych mitów i symboli wymyśla się nową tożsamość narodową, polemiczną w stosunku do tej oficjalnej. „W tych okolicznościach - konkluduje narrator - Argentyna stała się dla mnie ostatecznie anty-Polską. W pewnym sensie, można powiedzieć że tamtej zimy stałem się Argentyńczykiem"209.

Inną wersją Airiańskiej interpretacji ideału niedojrzałości jest opowieść o młodości odzyskanej, której przykładem jest La serpiente (Wąż).

\footnotetext{
207 César Aira, El llanto, s. 203.

208 Ibid.

209 Ibid., S. 204.
} 
Fabuła tej powieści - jak większości tekstów tego autora - z trudem znosi zabieg streszczenia: narrator, słynny pisarz César Aira, podróżuje do miasteczka Dinosaur City, w którym ma zamiar ukończyć poradnik psychologiczny Jak dobrze wychodzić na zdjęciach. Udaje się przypadkiem do brazylijskiego kościoła ewangelickiego, w którym praktykuje się kult Chrystusa-węża. Uczestniczy w przedziwnej, fantastycznej sesji spirytystycznej - niepozbawionej typowej dla Airy dozy humoru - po czym najwyższa kapłanka kultu zaprasza go na kolację, w której uczestniczą m.in. dwa potężnych rozmiarów mówiące węże oraz pewien staruszek z brodą, który okazuje się „Danielem Moliną, kiedy będzie stary”"10. Narrator natychmiast postanawia go zabić („A dlaczego nie? Dlaczego ja nigdy nie powziąłem żadnej decyzji, dlaczego nie działałem, nie ponosiłem ryzyka?"211), co udaje mu się zrobić w toalecie, przedtem jednak z czułością dotyka jego brody („przeszył mnie dreszcz niezdrowej ekscytacji, jakbym miał po raz pierwszy dotknąć mężczyzny" ${ }^{212}$ ). Jako słynny pisarz zostaje poproszony o przestawienie ostatniej książki kapłanki, na co nie chce się zgodzić, ale także nie potrafi odmówić wprost, i decyduje się dyskretnie opuścić przyjęcie, w czym pomaga mu pewien młodzieniec, Oskar. Oskar od tej pory towarzyszy narratorowi w zawrotnej ucieczce przed goniącymi ich wężami, a dodatkowo muszą chronić się przed trzęsieniem ziemi, kataklizmem nader częstym w Dinosaur City. Ich relacja się zacieśnia po tym, jak okazuje się, że na przyjęciu w kościele narratorowi podano Sodomol, brazylijski narkotyk, który nieodwołalnie zamienia mężczyzn w putos, chyba że w ciągu godziny od spożycia uda im się zbliżyć cieleśnie do młodzieńca. „Co się tyczy Oskara... Pocieszałem się, że nie pierwszy raz wykorzystano nierozważnego i życzliwego młodzieńca jako antidotum na silną truciznę" ${ }^{13}$. W atmosferze narastającej paniki, powtarzających się wstrząsów, deszczu węży strzelających kulkami ze śliny i wybuchu centrali jądrowej

\footnotetext{
210 Idem, La serpiente, s. 43. Daniel Molina jest argentyńskim pisarzem, dziennikarzem i krytykiem sztuki.

211 Ibid., s. 45.

212 Ibid., s. 56.

213 Ibid., s. 106.
} 
bohaterowie kontynuują ucieczkę do Lodowca, który ma im zapewnić schronienie: „Spieszmy się, śpieszmy!”, „do przodu”214 - pogania narrator, nie wiadomo, czy bardziej swojego towarzysza, czy autora, by szybciej zakończył fabułę. W pewnym momencie ślinowa kula dosięga Oskara i ten pada na ziemię, a wówczas okazuje się, że w rzeczywistości był cyborgiem, wytworem najnowocześniejszych technologii. Pochylając się nad nim, narrator dostrzega podobieństwo z samym sobą i odkrywa, że „Oskar to ja, gdy byłem młody. Upewniłem się dzięki pieprzykowi na wewnętrznej części lewego uda (podniosłem mu spodnie, żeby się przekonać). To moje najbardziej szczególne znamię; za młodu używałem go, by rozpoznać samego siebie"215.

Jak zwykle u Airy, nonsensowna i zwariowana fabuła jest komentarzem do jego ars narrativa, a raczej testem procedury; stąd zawrotne tempo wydarzeń i odwołania do pośpiesznego zakończenia, metody improwizacyjnej, potęgi przypadku etc. ${ }^{216}$ Osobnym tematem La serpiente jest młodość i jej miejsce w konglomeracie dzieło-życie Airy, więc nic dziwnego że początek tekstu - tak jak w El llanto - zdradza inspiracje Gombrowiczem. Narrator zaczyna swoje opowiadanie od kłopotliwego wyznania własnego defektu: nie potrafi zrozumieć mimiki, pozostaje niewrażliwy na „gęby” i „miny”. Nieumiejętność ta uczyniła go jednak pisarzem (na drodze analogicznej do Gombrowiczowskiego odkrycia o sprawczej roli spojrzenia i „gęby”, leżącego u genezy jego pisarstwa): „koniec końców, moja koncepcja sztuki zmierza w tym kierunku: przeciwko komunikacji, użyteczności, efekciarstwu"217. Kilka stron dalej narrator przechodzi do opisu Dinosaur City w konwencji typowej dla Gombrowiczowskich opisów Argentyny:

\footnotetext{
214 Ibid., s. 125 i 129.

215 Ibid., s. 145 .

216 „Muszę zrobić coś, czego nie lubię: cofnąć się o krok [...]. Do zakończenia spieszę, i to jak!”; „Jedynym realnym ograniczeniem jest długość życia; reszta to przypadek, okoliczności”; „Improwizacja, innymi słowy Piękno, estetyczna zakrystia. Skrzywienie zawodowe skłaniało mnie do myślenia, że na tym polu wszystkie szczegóły są na miejscu, wzajemnie ustępują sobie, oświetlają się i usprawiedliwiają"; ibid., s. 114, 115 i 106.

217 Ibid., s. 7.
} 
Zapada zmrok nad Dinosaur City. Dzika i niecierpliwa młodość wylega na ulice. Ponownie robię się młody. Albo po raz pierwszy, bo nie wiem, czy kiedykolwiek wcześniej byłem. Zapewne tak, bo jestem Argentyńczykiem, a Argentyna to kraj młodości. Wszystkie napotkane dziewczęta wydają mi się piękne, i są piękne! Mógłbym kochać wszystkie... gdyby istniał Bóg. Co też one o mnie myślą ${ }^{218}$

Argentyna jako miejsce odmłodzenia, sceneria powrotu do niedojrzałości i rozkwitu sił witalnych, zmieszania na ulicy z bezładnym tłumem młodzieży jest lejtmotywem Gombrowiczowskich relacji z przybranej ojczyzny:

Będę musiał to wyznać: pod działaniem wojny, spotęgowania sił „niższych” i sił regresyjnych, nastąpiła we mnie irrupcja jakiejś spóźnionej młodości. Przed klęską uciekłem w młodość i zatrzasnąłem te drzwi. Wyglądałem młodo, miałem twarz świeżą, dwudziestoparoletnią. Świat traktował mnie jak młodzika [...]. Wszystko, i mój wygląd, i moja sytuacja, i to zupełne wytrącenie z kultury, i wibracje tajne mojej duszy, wszystko pchało mnie w lekkomyślność młodzieńczą, w młodą samowystarczalnośćc19.

Odmłodniałem nagle i gwałtownie pod względem psychicznym i fizycznym, na ulicy mówiono mi joven, jakbym nie miał dwudziestu pięciu lat. Nigdy nie byłem bardziej poetą niż wtedy, na przepełnionych, gorących ulicach, zupełnie zagubiony ${ }^{220}$.

Narrator La serpiente, jak tamten joven Gombrowicz, jest niedojrzały i swoją niedojrzałość hołubi, odwołuje się do niej, uważa za najważniejszą cechę dystynktywną ${ }^{221}$. Ona właśnie, zanurzona dodatkowo

218 Ibid., s. 21.

219 Witold Gombrowicz, Dziennik 1953-1969; wyróżnienie w oryginale.

220 Idem, Testament.

221 Przytoczony wyżej cytat o niedojrzałości: „Zawsze uważałem, niezbyt oryginalnie, że dojrzałość jest wynikiem doświadczenia. [...] Liczą się też wrodzone predyspozycje: charakter, który prowadzi do doświadczenia. Mnie zaprowadził w przeciwną stronę”, pochodzi z tej powieści; César Aira, La serpiente, s. 76-77. Narrator wielokrotnie podkreśla własną młodość: „Czasami zapytuję się, co powinienem zrobić, by dojrzeć”; „Z głębi mojej młodości dostrzegłem jej poważny uśmiech"; ibid., s. 81 i 158. 
w otaczającej „Césara Airę” młodości, jest podstawowym impulsem wydarzeń: z przyjęcia ratuje go Oskar (którego cechami dystynktywnymi są młodość i niewinność właśnie), razem rozpoczynają szaleńczą ucieczkę, podczas której chłopak pełni rolę przewodnika po Dinosaur City, sprawiającego wrażenie apokaliptycznego miasta z filmów science fiction. Młodość, jak w Gombrowiczowskich relacjach z pierwszych, bohemicznych lat w Argentynie, konotuje u Airy ideę nowego początku oraz erotyczne napięcie: na tłocznych i gorących ulicach fantastycznego miasta „napada mnie dobrze znana myśl, że miłość jest możliwa, że rozpoczęcie nowego życia jest możliwe... Młodzież w Dinosaur City rozpalała moje przeszłe i przyszłe fantazje erotyczne; wydaje się dosłownie z nich wyjęta"222. Erotyka ta wolna jest od dualizmu płci, bo młodość jest siłą lub wartością samą w sobie, niezależnie od jej jednostkowych wcielen - typowy narrator Airy jest seksualnie niezdeterminowany i to w podwójnym sensie: fascynują go zarówno kobiety, jak i mężczyźni („rzucenie miłości do kobiet nie jest niczym strasznym - po to istnieją mężczyźni”), a dodatkowo - jak w powieści Cómo me hice monja (Jak stałem się zakonnicą) $)^{223}$ - jego własna tożsamość płciowa jest trudna do określenia. Ambiwalencja płci jest bowiem drugorzędna wobec opozycji Stary-Młody lub Dojrzały-Niedojrzały, a wiek pozostaje jedyną cechą naprawdę determinującą postaci. Nie jest jednak rozumiany tak fatalistycznie jak u Gombrowicza, któremu Argentyna młodość przedłużyła, ale tylko po to, by świadomość nieuchronnie zbliżającej się „smugi cienia” stała się jeszcze bardziej dotkliwa. U Airy wiek jest kwestią relatywną, odwracalną - postacie są konfrontowane z własnym młodym „ja” (Oskar jako wcielenie młodego Césara) lub cudzym obrazem starości (stary Daniel Molina), narrator wprawdzie podkreśla swoją młodość - zresztą

\footnotetext{
222 Ibid., s. 87.

223 Idem, Cómo me hice monja, w: idem, Cómo me hice monja, s. 9-98. Tytuł tej powieści bazuje na trudnej do przetłumaczenia na polski grze słów, stąd jego tłumaczenie mogłoby brzmieć zarówno „Jak stałem się zakonnicą” oraz „Jak zostałem zabity”. V. Patricio Pron, De qué hablamos cuando hablamos de autor: la autoficción de César Aira, w: Vera Toro, Sabine Schlickers, Ana Luengo (red.), La obsesión del yo. La auto(r)ficción en la literatura española y latinoamericana, Iberoamericana, Madrid 2010, s. 117.
} 
nie obiektywną, tylko odczuwaną - ale początkowo w nią powątpiewa ${ }^{224}$. Fizyczne starzenie się nie jest dla Airy zmianą definitywną ${ }^{225}$, a to dlatego, że opozycja Młody-Stary ma charakter czysto estetyczny i fabuły jego powieści są transpozycją napięcia między dojrzałością rozumianą jako konwencja, znudzenie, powtarzalność i niedojrzałością - innowacją, nowością, „ucieczką do przodu”.

Z drugiej strony - i to także konsekwencja estetycznego postrzegania wieku - młodość u Airy konotuje destrukcję i przemoc w sposób znacznie bardziej eksplicytny niż u Gombrowicza ${ }^{226}$. W La serpiente jest ona wystarczającym warunkiem i usprawiedliwieniem agresji: „[...] my, młodzi, tacy właśnie jesteśmy. Zabijamy, by rozwiązać mały problem, zabijamy nawet to, co najbardziej kochamy"227. Narrator zabija „starego Daniela Molinę", by spróbować smaku l’acte gratuit, Oskar zabija kolegę, by ułatwić sobie ucieczkę ze świątyni, a tężyzna fizyczna - podstawowy atrybut młodzieńczej witalności - jest wielokrotnie fetowana, np. w ekscentrycznej sesji ćwiczeniowej narratora, groteskowo wykonywanej w przerwie w gorączkowej ucieczce do Lodowca. Znacznie gorzej jest w powieści La prueba (Próba), której młode bohaterki o wdzięcznych pseudonimach Mao i Lenin dokonują prawdziwej (i racjonalnie niczym nieuzasadnionej) masakry w lokalnym supermarkecie w imię miłości do innej dziewczyny, Marcii ${ }^{228}$. U Airy taki obraz młodości nie

224 „[N]ie wiem, czy kiedykolwiek wcześniej byłem młody”; César Aira, La serpiente, S. 21.

225 Kontemplacja własnego młodego „ja” w „osobie” Oskara skłania go do następującej refleksji: „Gdy rozmyślam o różnicach między moim ciałem dziewiętnastoletnim i obecnym, wydaje mi się, że wówczas byłem bardziej giętki, że z czasem zastałem się. Ale nie jest to zmiana nieodwracalna, bo ciało może zaskakująco zmienić się dzięki gimnastyce"; ibid., s. 147.

226 „A tu, na Retiro, widziałem, aby tak się wyrazić, młodość samą w sobie, niezależną od płci, i doznawałem kwitnienia rodzaju ludzkiego w formie najostrzejszej, najbardziej radykalnej i - wobec tego, że była napiętnowana beznadziejnością - demonicznej"; Witold Gombrowicz, Dziennik 1953-1969. Wspomnienia polskie kończy opis witalnej i destrukcyjnej faszystowskiej młodzieży włoskiej i jej tryumfalnych nastrojów w obliczu nadchodzącego zniszczenia. César Aira, La serpiente, s. 100. Idem, La prueba, w: idem, Cómo me hice monja, s. 99-168. 
wynika, znowu, z diagnozy współczesnego społeczeństwa, nie jest także konstatacją historyczną - jaką po części przynajmniej był dla Gombrowicza - a pozostaje w sferze estetyki, reprezentując żywiołowość, (coraz to) nowy początek, także specyficznie pojętą bezczelność (irreverencia), która charakteryzuje Airiańską koncepcję sztuki.

Airę i Gombrowicza łączy wreszcie coś jeszcze - i mowa o właściwości, której na próżno szukać u innych argentyńskich interpretatorów Polaka: zabarwiony groteską humor, powodujący, że czytelnik Ferdydurke lub Trans-Atlantyku, podobnie jak większości powieści Airy, śmiej e się, co samo w sobie jest zresztą oznaką młodzieńczego nieskrępowania ${ }^{229}$. Pozycja outsidera, niechęć do angażowania sztuki w doraźnych, pozaartystycznych celach, obojętność dla ideologii z prawa i z lewa sceny politycznej, połączona $z$ ironicznym zdystansowaniem do narodowych świętości (mit Polski walczącej oraz argentyńskich „znikniętych”) zapewnia im nieskrępowaną możliwość wykpiwania obowiązujących i modnych dyskursów (okazji tej nie będzie miał już np. politycznie zaangażowany Piglia). Ironiczna konwencja obowiązuje także w przedstawieniu powieściowego „ja”, zwykle „Witolda” lub „Césara”, którzy - etycznie ambiwalentni, nierzadko tchórzliwi lub okrutni, często wewnętrznie niespójni - działają zwykle pod wpływem chwili, gubiąc się w domysłach lub, przeciwnie, nie podejmując choćby najmniejszej próby introspekcji.

Na koniec odnotować wypada jeszcze, że Aira kilkakrotnie ucieka się w swoich powieściach do konwencji diarystycznej ${ }^{230}$, zapewne w reakcji na rosnącą popularność tego gatunku w literaturze argentyńskiej końca xx i początków xxi wieku. Sam fakt „wypróbowania” formy dziennika nie jest jeszcze wystarczającym uzasadnieniem związku intertekstualnego, ale kilka innych elementów wskazuje na inspiracje

\footnotetext{
229 W odpowiedzi na reakcje swoich czytelników, którzy deklarowali przede wszystkim podziw dla jego nerwu komediowego, Aira - nieco na przekór - publikuje w 2005 roku melancholijną w tonie powieść Cómo me reí (Ależ się uśmiałem).

230 V. jego powieści Fragmentos de un diario en los Alpes (1993, Fragmenty dziennika z Alp) lub Diario de la hepatitis (1993, Dziennik żółtaczki). Także w powieści Cumpleaños (Urodziny) z roku 2000 Aira testuje formę zbliżoną do dziennika, rodzaj autobiograficznego eseju.
} 
Diario argentino. Po pierwsze, dzienniki Airy mają w rzeczywistości znikomy wymiar autobiograficzny, z całą pewnością nie większy niż inne jego powieści - świadczy o tym chociażby całkowicie umowne „datowanie” wydarzeń, ograniczone, jak u Gombrowicza, do podania dnia tygodnia. Po drugie, podstawowym tematem tych dzienników jest fragmentaryczny wykład koncepcji artystycznej autora - kwestii reprezentacji w sztuce, procedur narracyjnych, „złej literatury” etc. - dla których opisane wydarzenia stanowią jedynie pretekst. Znamienny jest także początek Diario de la hepatitis w formie wielokrotnie złożonego zdania warunkowego, w którego pierwszym członie wylicza się serię najbardziej wymyślnych przeciwności losu: „Gdybym został nagle przygnieciony nieszczęściem, zdruzgotany, bezsilny, w najgorszej nędzy fizycznej lub umysłowej”231 ${ }^{2}$ np. spadłszy z wielkiej góry prosto w śnieg, zamarznięty, z wyrwanymi nogami etc., a drugi zamyka tę groteskową wyliczankę podsumowaniem: nawet wówczas, „mając w ręce kartkę i ołówek, n i e pis ałb y m. Nic, ani jednej linijki, ani jednego słowa [...] z tego samego powodu, dla którego nie piszę teraz: nie chce mi się, jestem zmęczony, znudzony, mam dość; nie wiem, czemu miałoby to służyć"232. Takie otwarcie przywodzi na myśl wyżej cytowany początek Dziennika argentyńskiego, w którym seria niepowodzeń życiowych (symbolicznie skondensowanych w figurze „urzędniczka zarżniętego siedmioma godzinami urzędolenia"233) przekreśla Gombrowicza jako pisarza: zdławiony „we wszystkich przedsięwzięciach pisarskich [...] »Pisarz«? Skąd! Na papierze! W życiu - zero, istota podrzędna"234. Zanegowanie własnej kondycji twórczej na początku tekstu, który bez przeszkód rozwija się dalej - w konwencji dziennika, rozwija się niejako w czasie teraźniejszym, na oczach odbiorcy - oto co Aira powtarza w Diario de la hepatitis, zaprzeczając, że pisze dokładnie w momencie pisania ${ }^{235}$.

\footnotetext{
231 César Aira, Diario de la hepatitis, Bajo la Luna, Buenos Aires 2007, s. 7.

232 Ibid., s. 8; wyróżnienie w oryginale.

233 Witold Gombrowicz, Dziennik 1953-1969.

234 Ibid.

235 I w datowanym na 23 stycznia 1992 wstępie do właściwego dziennika, którego redakcja rozpoczyna się zaledwie tydzień później, w lutym tego samego roku.
} 
Innym „momentem gombrowiczowskim” w Diario de la hepatitis jest jeden z zapisków opatrzonych nic nieznaczącą datą „sobota”:

Straszne doświadczenie końca świata. A przy tym niewinne, przeżyte prawie $\mathrm{w}$ formie estetycznej.

$\mathrm{Na}$ Placu Flores. Trzymałem w ręce, między palcem wskazującym i kciukiem, kostkę cukru. Nagle rozpłynęła mi się w palcach. Jeśli przez chwilę myślałem, że powodem mogła być wilgotność, szybko zorientowałem się, że nie. Powietrze nabrało zielonego i żółtego blasku, wszystko westchnęło i zmarło. Wszyscy, cały świat, umarł w tamtej chwili.

A jednak, był jakiś rodzaj życia-po-życiu (zawsze jest), by zastanowić się nad rzeczą następującą: rozłożyła się chemia atmosfery, szybkie atomy rozpraszały katastrofę we wszystkich kierunkach, w tamtym momencie zatrzymało się życie na planecie. Świetnie. Ale któż o tym wiedział? Naukowcy także umierali. Nie zostawał nikt, kto mógłby dalej zajmować się nauką i zbadać ten fenomen.

Chyba że... w jakiś sposób przebadano go w c z éśn i ej. Na przykład, co ja robiłem na Placu Flores z kostką cukru w ręku? ${ }^{236}$

To apokaliptyczne doświadczenie z kawiarni na Placu Flores jest analogiczne do pamiętnej „ręki kelnera” z Café Querandí, gdzie Gombrowicz pewnej, nota bene, soboty, pił kawę i jadł rogaliki. Oprawa obu zdarzeń jest podobna: „najzwyklejsza zwykłość”237 zostaje przerwana obserwacją z pozoru banalną, która rozpętuje metafizyczny (a u Airy także fizyczny) horror. W trywialne, powszednie życie wkrada się świadomość Zła - cierpienia, śmierci, nicości - która ten błogostan przerywa, zacinają się tryby codzienności, kończy świat, jaki znamy. Sugestia, że ktoś „przebadał wcześn i j” ten fenomen może odnosić się właśnie do Gombrowicza, choć co dla niego miało wymiar ludzki, metafizyczny - stąd jest także bardziej subtelne w opisie i doświadczeniu - dla Airy pozostaje

236 César Aira, Diario de la hepatitis, s. 42-43; wyróżnienie w oryginale. Na marginesie można odnotować, że geograficznym zbiegiem okoliczności w dzielnicy Flores, w której rozgrywa się większość powieści Airy, leży ulica Bacacay. 
„estetycznym” końcem świata, dobrze znaną z jego powieści katastrofą, która rozpocznie „nowy początek”.

Podsumowując, na Gombrowicza Airy składają się nie tyle teksty teoretyczne - ich skromna liczba kontrastuje z krytycznymi monografiami, jakie autor El llanto poświęcił pisarzom takim jak Copi, Alejandra Pizarnik lub Edward Lear, „odzyskiwanym” przez niego w sposób systematyczny - ile literacki temperament. Obaj uciekają się do humoru i groteski nieuznających żadnych tabu, do autofikcji zbudowanej wokół „ja”, które prowokacyjnie podważa powierzone mu zaufanie. Aira odwołuje się często do idei typowo Gombrowiczowskich, przede wszystkim do waloryzacji młodości i niedojrzałości, choć „przerabia” je na własną modłę, odbierając im sens egzystencjalny, a pozostawiając czysto estetyczny. W argentyńską interpretację autora Trans-Atlantyku Aira wnosi nowy sposób rozumienia „formy narodowej” jako konstruktu, który się przybiera lub nakłada jak maskę, a nie dostaje z zewnątrz; zamiast wykazywać „argentyńskość” Gombrowicza, docenia chęć przedstawienia się jako Argentyńczyk, w y myślenia własnej „argentyńskości” (lub „polskości”) w oparciu o polemiczne przerobienie stereotypów i istniejących tekstów kultury. W końcu Aira przyswaja sobie Gombrowiczowski sposób funkcjonowania w polu literackim, określany najczęściej słowem irreverencia (bezczelność, arogancja, brak szacunku dla ustalonej hierarchii i norm) i unikający wszelkiego zaangażowania w kwestie inne niż własna sztuka. Wszystkie składowe tej charakterystyki - podobieństwo stylu, swoiście pojęta przynależność narodowa, eksponowane cechy figury autora - różnią Airę od kolejnego, prawdopodobnie najsłynniejszego argentyńskiego interpretatora Gombrowicza, Ricarda Piglii.

\section{Ricardo Piglia}

„Studiowanie Piglii zakłada trudne do uniknięcia ryzyko. Jego poglądy są mianowicie na tyle spójne i przekonujące, że trudno ich nie przyjąć $\mathrm{i}$ - popadając w tautologię - tłumaczyć jego teksty w oparciu 
o wypracowane przez niego samego koncepcje" - wyznaje Jorge Fornet we wstępie do swojego studium nad prozą Argentyńczyka ${ }^{238}$. To na pozór zaskakujące zastrzeżenie („koncepcje własne” autora bywają zazwyczaj przydatne w krytycznym komentarzu do dzieła), stosuje się w gruncie rzeczy do wszystkich pisarzy, którzy - jak Piglia, a także jak Gombrowicz - w drobiazgowy sposób zaprojektowali scenę odbioru własnych tekstów, wyznaczając czytelnikowi na tyle przekonujące drogi lektury „prawomocnej”, że bardzo trudno je porzucić. Jeśli dodatkowo lektura ta jest atrakcyjna i domyka się w foremną całość, której wszystkie elementy doskonale do siebie pasują - a tak niewątpliwie jest w przypadku autora Sztucznego oddychania, który angażuje kategorie z pozoru literaturze odległe, takie jak spisek, plagiat, własność - jej sugestywność jeszcze wzrasta.

Przestrzenią, w której Ricardo Piglia (1941-2017) szkicuje lekturę własnego dzieła, są teksty fikcyjne oraz krytyczne, przy czym oba te porządki są w jego twórczości pomieszane - w powieściach i opowiadaniach postaci wykładają krytycznoliterackie interpretacje autora, a w esejach i wywiadach (często zresztą całkowicie fikcyjnych ${ }^{239}$ ) pisarz przywołuje osoby i fakty, nie informując o ich zmyślonym charakterze. Krytyczna twórczość Piglii - niewątpliwie dominująca i z powodzeniem „infekująca” fikcję literacką - pozostaje fragmentaryczna: wyraża się przede wszystkim w krótkiej formie (esejach, rozmowach i wywiadach), nigdy w monografiach. Jest tak dlatego, że interpretacyjna praca Piglii ma z gruntu charakter dynamiczny, zmienny - kluczowa dla niego kategoria tradycji literackiej oznacza ruchomy kontekst, przestrzeń funkcjonowania kultury, w której pisarz raz po raz sytuuje samego siebie; jej przeciwieństwem jest kanon, czyli martwa litera, teksty obowiązkowe, szkolna lektura lub

238 Jorge Fornet, El escritor y la tradición. Ricardo Piglia y la literatura argentina, FCE, Buenos Aires 2007, s. 26.

239 Wiele z wywiadów zamieszczonych w zbiorze Críitica y ficción (Krytyka i fikcja) ma taki właśnie, fikcyjny charakter. Za poprzednika tej strategii uznać należy raczej pseudoeseje (pseudoensayos) Borgesa aniżeli fikcyjne rozmowy Gombrowicza z Dominique de Roux. 
zbiór autorów (nie tekstów) konsekrowanych przez mass media ${ }^{240}$. Tradycję tworzą natomiast sami pisarze, od nowa odczytując teksty zawłaszczone przez kanon, często jedne przeciwko innym; odnawianie tradycji dokonuje się bowiem poprzez walkę poetyk i „praktykę polityczną" (o czym za chwilę). W historycznie krótkim kanonie argentyńskim niezwykle trudno znaleźć pisarzy faktycznie marginalnych, których odkrycie przewartościowałoby zasadniczo scenę literacką; pozostaje czytać na nowo, z innego m iejsca teksty już znane - dlatego w uniwersum literackim autora Crítica y ficción miejsce lektury autorów istotnych (Borgesa, Macedonia, Puiga, Walsha) podlega nieustannym przesunięciom. Drugą strategią odnowienia tradycji narodowej jest włączenie tekstów obcych na zasadzie obustronnego warunkowania - determinują one wprawdzie lekturę literatury krajowej, która z kolei wchłania je na własnych warunkach. Status tych tekstów zagranicznych może być dwojaki: funkcjonują albo na zasadzie punktu odniesienia (jakim jest dla Piglii literatura północnoamerykańska), albo zyskują - jak Gombrowicz - pozycję pełnoprawnych, zasymilowanych członków tradycji, tych trudnych do odkrycia „autorów marginalnych" ${ }^{241}$.

W przeciwieństwie do pisarzy omawianych powyżej - przede wszystkim Copiego i Airy - intertekstualny związek łączący dzieła Piglii i Gombrowicza nie obejmuje podobieństwa poetyk; na poziomie stylu, języka i rozwiązań formalnych pozostają sobie całkowicie

\footnotetext{
240 V. Ricardo Piglia, El lugar de Saer, w: Jorge Carrión (red.), El lugar de Piglia. Crítica sin ficción, Candaya, Barcelona 2008, s. 162-163.

241 Dlatego Piglia celebruje w swoim dzienniku wszystkich tych, którzy przyczynili się do odkrycia Gombrowicza dla literatury argentyńskiej. Przy okazji spotkania z Virgiliem Piñerą pisze: „Był przyjacielem Gombrowicza i pomógł mu przetłumaczyć Ferdydurke, dlatego go podziwialiśmy, a w jego znakomitych opowiadaniach słuchać gombrowiczowski ton"; idem, Los diarios de Emilio Renzi. Los años felices, Anagrama, Barcelona 2016, s. 17. W innym miejscu odnotowuje: „Dziś za czterdzieści peso kupiłem numer »Eco Contemporáneo«, modne czasopismo mufados: »liryczny« smutek, depolityzacja i "poezja" doświadczenia. Ich największą zasługą było poświęcenie jednego numeru staremu Gombrowiczowi”; ibid., s. 246.
} 
obcy. Pytany o własnych prekursorów, autor Sztucznego oddychania ostrożnie odpowiada: „Należy odróżnić teksty, które się podziwia, od tekstów, których się używa [...]. Ja na przykład bardzo podziwiam dzieło Gombrowicza, lecz nie czuję, by było ono związane z moją własną twórczością. Choć oczywiście bliskie jest mojemu rozumieniu literatury oraz moim interpretacjom innych tekstów”242. Jego „bliskość” $\mathrm{z}$ autorem Ferdydurke bierze się więc ze sposobu, w jaki ten rozumiał i komentował fenomen literatury - z przenikliwości i nieprzejednania, jakie wykazywał w ocenie zjawisk i mód literackich, z wyczulenia na grzech epigonizmu, a także z utrzymywanej bez względu na nieprzyjazne warunki zewnętrzne dyspozycji do otwartej konfrontacji. „Obecność Gombrowicza wywołała silny oddźwięk w Argentynie, ponieważ natychmiast pojął, kim był Borges, i przeciwstawił mu

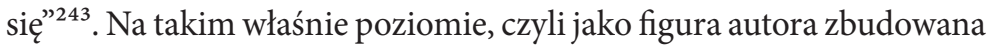
przede wszystkim na odrzuceniu konsensusu, Gombrowicz funkcjonuje w twórczości Piglii, w szczególności w następujących tekstach: powieści Sztuczne oddychanie z 1980 roku, wykładzie pt. La novela polaca (Polska powieść) ${ }^{244}$ wygłoszonym w 1986 na konferencji w Narodowym Uniwersytecie w El Litoral, w artykule Novela y complot (Powieść i spisek), opublikowanym w barcelońskim czasopiśmie „Quimera” $\mathrm{w} 2007^{245}$, oraz w artykule La lengua de los desposeídos (Język

242 Jorge Fornet, Conversación con Ricardo Piglia, w: idem (red.), Ricardo Piglia, Casa de las Américas, Bogotá 2000, s. 21.

243 Marcelo Pellegrini, Samuel Monder, Andrea Jeftanovic, Conversación con Ricardo Piglia, http://letras.s5.com/mpo10810.html, dostęp: 16 III 2016.

244 Wykład ten został rok później przedrukowany w czasopiśmie „Espacios de Crítica y Producción” pod tytułem ¿Existe la novela argentina? Borges y Gombrowicz (Klementyna Suchanow i Krystian Radny w „Literaturze na Świecie” tłumaczą go: Czy istnieje powieść argentyńska? Borges a Gombrowicz), a następnie w roku 2000 w zbiorze Formas breves (s. 69-80), już pod pierwotnym tytułem La novela polaca (Polska powieść).

245 Ricardo Piglia, Novela y complot, „Quimera” 2007, III, s. 45-54. Tekst ukazał się następnie w 2015 roku w zbiorze Antología personal (s. 99-118). Wcześniejsza wersja tego artykułu, zatytułowana Teoría del complot (Teoria spisku), ukazała się w 2002 roku w czasopiśmie „Ramona. Revista de Artes Visuales” (nr 23, s. 4-14) i dostępna jest on-line (https://goo.gl/Y33Dnp5, dostęp: 22 XI 2016). Jego 
wykluczonych), który ukazał się rok później na łamach argentyńskiego dziennika „La Nación”246, a następnie został przedrukowany w rozszerzonej wersji w zbiorze Antología personal (Antologia osobista) ${ }^{247}$ pod tytułem Escritor como lector. Większość studiów na temat Gombrowicza w interpretacji Piglii koncentruje się na analizie powieści Sztuczne oddychanie i pomija te bardziej fragmentaryczne teksty ${ }^{248}$, nie odnotowując tym samym wszystkich momentów, w których twórczość Argentyńczyka czerpie z autora Kosmosu, ani ewolucji, jakiej - zgodnie z wyżej wspomnianym imperatywem ciągłej reinterpretacji tradycji - ten międzytekstowy związek podlega. Całościowa lektura Gombrowicza według Piglii, poparta dodatkowo wzmiankami na temat autora Ferdydurke w dziennikach Emilia Renziego, pozwala wyróżnić kilka etapów lub „odchyleń” interpretacyjnych, które skądinąd odpowiadają przewodnim ideom ars narrativa argentyńskiego pisarza. Od połowy lat 6o. do lat 8o. Piglia czyta Polaka przede wszystkim przez pryzmat

rozszerzona wersja ukazała się z kolei w roku 2007 pod tym samym tytułem (Teoría del complot) nakładem wydawnictwa Mate w Buenos Aires.

246 Idem, La lengua de los desposeídos, „La Nación” 2008, 19 Iv, https://goo.gl/Kv7XGb, dostęp: 16 I 2012.

247 Idem, Escritor como lector, w: idem, Antología personal, s. 83-98. Polska wersja tego tekstu ukazała się pod tytułem Pisarz jako czytelnik (przeł. Ewa Kobyłecka-Piwońska, „Czytanie Literatury” 2014, nr 3, s. 399-404; 2015, nr 4, s. $253-260$ ).

248 Studia Pau Freixy Terradesa (op. cit.) oraz Rodriga Blanco Calderóna ( $P i$ glia y Gombrowicz: sobre el fracaso y otras estrategias de la escritura, w: Jorge Carrión [red.], op. cit.) uwzględniają jeszcze artykuł La novela polaca. Silvana Mandolessi (Una literatura abyecta. Gombrowicz en la tradición argentina, Rodopi, Amsterdam-New York 2012) odnotowuje ponadto Teoría del complot, ale raczej zdawkowo, koncentrując swoje analizy na Sztucznym oddychaniu. Pablo Gasparini (El exilio procaz) raczej pobieżnie analizuje interpretacje Piglii, oceniając je zresztą bardzo krytycznie jako wypaczające przesłanie Gombrowiczowskiego dzieła. Marzena Grzegorczyk (Kształt życia i bezkształt tradycji. Argentyńska spuścizna Witolda Gombrowicza, w: Ewa Płonowska-Ziarek [red.], Grymasy Gombrowicza. W kręgu problemów modernizmu, społeczno-kulturowej roli płci i tożsamości narodowej, przeł. Janusz Margański, Universitas, Kraków 2001, s. 159-182) ogranicza się do - skądinąd bardzo ciekawej - analizy powieści Piglii. 
formy narodowej, tradycji literackiej, wygnania, języka i stylu, które to kwestie zostaną rozwinięte w powieści Sztuczne oddychanie oraz artykule La novela polaca. Ten pierwszy etap jest naznaczony lekturą Trans-Atlantyku - w dzienniku pod rokiem 1965, a więc na kilka lat przed rozpoczęciem pracy nad pierwszą powieścią, Piglia notuje:

Zanalizować powieści napisane w tych samych latach przez Nabokova (Sebastian Knight), Gombrowicza (Trans-Atlantyk) oraz Becketta (Malone umiera). We wszystkich trzech jest podwójna narracja, niska, zdegradowana pierwsza osoba oraz proza zrodzona z zapomnienia ojczystego języka, którym już się nie posługuje (wygnanie i język). [Teksty te - E.K.P.] są ekstremalną realizacją pisania bez ojczyzny, bez powieści ${ }^{249}$.

Następnie, od lat 90., ciężar interpretacyjny w zaproponowanej przez Piglię lekturze Gombrowicza zostaje przesunięty na pytania: Jak konstruowana jest wartość dzieła sztuki? Co decyduje o jego znaczeniu i prestiżu? Tekstem kluczowym staje się wówczas Gombrowiczowski wykład Przeciw poetom. Równolegle, niejako w odpowiedzi na pytania dotyczące wartości, Piglia pracuje nad teorią „fikcji paranoicznej” (ficción paranoica), swoistym rozwinięciem narracji detektywistycznej, zainspirowanym m.in. lekturą Kosmosu. Na każdym z tych etapów krytyczne i literackie teksty Argentyńczyka, którego twórcze credo okrzepło w rozpolitykowanych latach 6o., są odpowiedzią na bieżące wydarzenia - w latach 70. i 8o. Piglia pisze przeciwko dyktaturze wojskowej, a w kolejnych dekadach, by kontestować dyskurs ekonomiczno-społeczny doktryny neoliberalnej. Gombrowicz Piglii jest więc nie tylko Gombrowiczem narodowym, ale także Gombrowiczem politycznym $^{250}$.

249 Ricardo Piglia, Los diarios de Emilio Renzi. Años de formación, Anagrama, Barcelona 2015, s. 198.

250 „Według mnie [polityka - E.K.P.] jest elementem fikcji. Z drugiej strony uważam, że wszystkie wielkie teksty są polityczne. Z polityką mamy do czynienia w zbrodni, w języku, pieniądzach i namiętnościach”; idem, Novela y utopía, w: idem, Crítica y ficción, s. 94. 
Sztuczne oddychanie, powieść opublikowana w tragicznych czasach terroru wojskowego - choć jej redakcja rozpoczęła się dużo wcześniej, bo jeszcze w latach 7o. - jest więc realizacją specyficznie pojętego ideału literatury zaangażowanej, która proponuje narracje konkurencyjne wobec narracji opresyjnego państwa, przerywając tym samym jego monopol na interpretację wydarzeń. Przedstawiona w niej historia ma z oczywistych względów charakter niedopowiedziany, aluzyjny (junta drobiazgowo cenzurowała kulturę), a najważniejsze jej elementy zostają przemilczane - zgodnie zresztą z wyznawanymi przez Piglię zasadami konstrukcyjnymi opowiadania ${ }^{251}$. Sztuczne oddychanie jest więc historią o zaginięciach i poszukiwaniach: Emilio Renzi (powracający w kolejnych powieściach porte-parole autora) próbuje odnaleźć swojego wuja, Marcelego Maggiego, bohatera skandalizujących opowieści rodzinnych; Maggi z kolei usiłuje dociec prawdy o Enrique Ossoriu, współczesnym Sarmienta i rzekomym zdrajcy ojczyzny. Pierwsza część powieści ma charakter „pisemny” - rzadko dochodzi do bezpośredniego spotkania, postaci raczej ślą do siebie listy lub prowadzą dziennik. W drugiej natomiast - interesującej ze względu na gombrowiczowskie echa - przeważa rozmowa: Renzi przyjeżdża do prowincjonalnego miasta Concordia na spotkanie $\mathrm{z}$ wujem, lecz zamiast niego (Maggi nie zjawia się, a jego zniknięcie w czasach terroru dyktatury wojskowej jest oczywiście bardzo wymowne), spotyka jego przyjaciela, Polaka Tardewskiego, z którym toczy całonocny dialog o literaturze i filozofii. Zgodnie z wielokrotnie powtarzanymi deklaracjami samego Piglii, zwykło się uważać tę postać za wcielenie Gombrowicza ze względu na szereg podobieństw natury faktograficznej. Samo nazwisko Tardewski odsyła do przyjaciela Gombrowicza z pierwszych lat jego pobytu w Argentynie, Włodzimierza Taworskiego. Ponadto Tardewski, polski emigrant, pracował kilka lat w Banco Polaco w stolicy, a potem przeniósł się do filii w Concordii, prowadzi dziennik i gustuje w grze w szachy. Jest także obdarzony filozoficznym nastawieniem do życia oraz nieprzejednanym charakterem, który uniemożliwia mu wygodne lądowanie w uniwersyteckich kręgach Buenos Aires:

251 V. idem, Tesis sobre el cuento, w: idem, Formas breves, s. 103-111. 
[...] nie powściągnąłem niewyparzonego języka, przeciwnie, coraz bardziej skłaniałem się ku szczerości, to wśród akademików grzech śmiertelny. Coraz jaśniej wyrażałem swoje prawdziwe opinie. Ja, polski emigrant, nader życzliwie przyjęty przez miejscowe znakomitości, dałem się ponieść własnym poglądom ${ }^{252}$.

Nazwisko samego Gombrowicza pada w powieści kilkakrotnie, zawsze zresztą w kontekście dla niego raczej nieprzychylnym, a mianowicie obok nazwisk osiadłych w Argentynie europejskich intelektualistów, którym ta zawdzięcza „swój najpotężniejszy kompleks niższości" ${ }^{253}$. Autor Ferdydurke wymieniany jest jednym tchem obok Paula Groussaca, Charlesa de Soussensa i Williama Hudsona, „wcieleń uniwersalnej wiedzy" i wzorów do naśladowania, którzy zwykle sami byli ,jedynie dokładną kopią, platońskim cieniem innego modelu” ${ }^{254}$. Osobliwe to towarzystwo, szczególnie mając na uwadze fakt, że Piglia zwykł waloryzować wręcz przeciwne miejsce Polaka w literaturze argentyńskiej, znacznie bardziej peryferyjne i bliższe temu, które zajmował enfant terrible Roberto Arlt. W powieści realny Gombrowicz rozpada się niejako na dwie postaci - kanonicznego pisarza, który wreszcie odnosi światowy sukces i ex post zyskuje uznanie w Argentynie oraz fikcyjnego Tardewskiego, życiowego nieudacznika z wyboru, któremu kariera się nie powiodła (bo nawet o nią specjalnie nie zabiegał) i wiedzie skromne życie na prowincji. Historia przyjazdu Tardewskiego do Argentyny jest całkowicie fikcyjna, jeśli nie liczyć doniosłej roli przypadku, który także odegrał znaczącą rolę w finale zamorskiej wyprawy Gombrowicza ${ }^{255}$. W latach 30. przyszły

\footnotetext{
252 Idem, Sztuczne oddychanie, przeł. Barbara Jaroszuk, Muza, Warszawa 2009, s. 171.

253 Ibid., s. 110.

254 Ibid., s. 110 i 116-117.

255 Gombrowicz pisze w Dzienniku: „Ja do Argentyny wyruszyłem przypadkiem, na dwa tygodnie tylko, gdyby zrządzeniem losu wojna nie wybuchła w ciągu tych dwóch tygodni, wróciłbym do Polski - ale nie ukrywam, że gdy klamka zapadła i zatrzasnęła się nade mną Argentyna, to było, jakbym siebie samego na koniec usłyszał”. Koniec jego argentyńskiej przygody także naznaczony jest przemożnym doświadczeniem przypadkowości: „[...] spojrzałem przypadkiem na wodę portu, przez jedną sekundę ujrzałem kamienne obmurowanie, latarnię na chodniku,
} 
przyjaciel Maggiego przygotowywał pod kierunkiem Ludwiga Wittgensteina doktorat w Cambridge, skąd w sierpniu 1939 roku wybrał się na wakacje do Warszawy, a tam zaskoczyła go - choć to może nie najlepsze słowo, bo w gruncie rzeczy się jej spodziewał - wojna. Zdołał przedostać się do Marsylii i załapać na ostatni statek za ocean, który - jak błędnie sądził - zabierze go do Stanów Zjednoczonych. Wylądował tymczasem w Argentynie, o której nie wiedział absolutnie nic, niewiedzą, którą można by określić „mianem niewiedzy encyklopedycznie wyczerpującej" ${ }^{256}$. I tak, gdy spotyka Renziego, przebywa już w Argentynie ponad czterdzieści lat, ucząc w prowincjonalnej szkole i wiodąc spokojny żywot filozofa.

Drugim pierwowzorem tej postaci - zwykle zresztą pomijanym w opracowaniach krytycznych - jest autor Traktatu logiczno-filozoficznego; sam Tardewski wyznaje: „zostałem [...] n a zn a czony przez Wittgensteina"257. W Sztucznym oddychaniu najsilniejszym wittgensteinowskim piętnem jest ciążące nad bohaterami wszechobecnie milczenie - słynne słowa zamykające Traktat Tardewski przywołuje

obok słup z tabliczką, dalej trochę kołyszące się szalupy i łódki, zieloną murawę brzegu... Oto jak mi się zakończyła Argentyna: jednym nieuważnym, zbędnym spojrzeniem w przypadkowym kierunku, latarnia, tabliczka, woda, to właśnie wessało się we mnie na zawsze"; Witold Gombrowicz, Dziennik 1953-1969. Ricardo Piglia, Sztuczne oddychanie, s. 165. Ibid., s. 161; wyróżnienie w oryginale. O swojej inspiracji Wittgensteinem mówi także sam Piglia w jednym z wywiadów: „Wittgenstein, który dziś jest obiektem wielkiego zainteresowania, był oczywiście ważną figurą, kiedy pisałem Sztuczne oddychanie. Ujęło mnie natężenie jego artystycznej siły, zafascynowały koleje losu i dramatyczny wymiar doświadczenia. Umieszczenie go w centrum powieści wydało mi się przesadne, choć być może myliłem się. Wymyśliłem więc takiego pseudo-Wittgensteina, którym był Tardewski, kombinacja Gombrowicza z Wittgensteinem"; Marcelo Pellegrini, Samuel Monder, Andrea Jeftanovic, op. cit. Fuzja tych dwóch osobowości - filozofa i pisarza - była tym doskonalsza, że chodziło o osobowości na wiele sposobów sobie bliskie: obaj niechętnie przyznawali się do swojego homoseksualizmu, obaj doświadczali swego rodzaju degradacji finansowej (znacznie bardziej spektakularnej w przypadku Wittgensteina, pochodzącego z jednej z najbogatszych austriackich familii), obu wojna zmusiła do wygnania, które nasiliło tylko i tak już w nich obecne skłonności do wybuchowości i mizantropii. 
wprost, lecz bardziej jeszcze wymowne w kontekście narzuconym przez powieść są słowa skierowane przez Wittgensteina do jednego z wydawców jego pierwszego dzieła:

[...] książka ta ma sens etyczny. Chciałem swego czasu dać w przedmowie zdanie, którego teraz faktycznie tam nie ma, ale które tu piszę, bo może będzie dla Pana kluczem. Otóż chciałem napisać, że moja praca składa się z dwu części: z tego, co w niej napisałem, oraz z wszystkiego, czego nie napisałem. I właśnie ta druga część jest ważna. Treść etyczną moja książka wyznacza niejako od wewnątrz; i jestem przekonany, że TYLKO tak da się ją wyznaczyć ściśle ${ }^{258}$.

W przeciwieństwie do tego, co pragnęli wyczytać z dzieła wczesnego Wittgensteina neopozytywiści, milczenie skrywać ma nie kwestie pozbawione sensu, bo niewyrażalne w poprawnym logicznie zdaniu, lecz właśnie problemy o kapitalnym znaczeniu, jedyne naprawdę warte filozofowania. Dialektyka tego, co wypowiedziane, i tego, co przemilczane, bliska jest pisarstwu Ricarda Piglii w warstwie zarówno formalnej („tego, co najważniejsze, nigdy się nie opowiada"259), jak i treściowej, w której Sztuczne oddychanie ma także wymiar etyczny: jest, jak wyżej pisałam, oskarżeniem argentyńskiej dyktatury wojskowej. „Oczywiście rozumie pan doskonale, podejmuje Tardewski, że mówiliśmy to wszystko, mówiliśmy tak długo, tylko po to, aby nie mówić o profesorze. Mówiliśmy o czym innym, bo o nim nie da się nic powiedzieć"260.

Esencją Sztucznego oddychania jest opowiadanie historii: o Historii, literaturze, filozofii, życiu - stąd spiętrzenie czasowników wprowadzających kolejne poziomy mowy zależnej („mówił Marconi, opowiada Tardewski”261). Społeczeństwo - pisze gdzie indziej Piglia - jest siecią

258 Georg Henrik von Wright, Historical Introduction, w: idem, Ludwig Wittgenstein. Prototractatus, Routledge and Kegan Paul, London 1971, cyt. za: Bogusław Wolniewicz, Wstęp. O,Traktacie”, w: Ludwig Wittgenstein, Tractatus logico-philosophicus, przeł. Bogusław Wolniewicz, Wyd. Naukowe PWN, Warszawa 2004, s. viII; wyróżnienie w oryginale.

259 Ricardo Piglia, Tesis sobre el cuento, s. 108.

260 Idem, Sztuczne oddychanie, s. 211.

261 Ibid., s. 158. 
opowiadań, zbiorem historii i fikcji krążących wśród jego członków. Jednym z głównych opowiadaczy, scalającym wielość historii prywatnych i publicznych w jednej spójnej historii, jest Państwo (Estado, pisane przez Piglię wielką literą): „Państwo opowiada. Sprawowanie władzy politycznej oznacza zawsze narzucenie pewnego sposobu opowiadania o rzeczywistości"262. Dyktatura wojskowa posługiwała się narracją medyczną: kraj był zaatakowany przez wirus i tylko drastyczna, natychmiastowa interwencja chirurgiczna odcinająca zarażoną część była w stanie go uratować. Po powrocie do demokracji, państwowa opowieść przybiera formę powieści psychologicznej, upowszechnia się technika monologu wewnętrznego, która po równo rozdzielając winy, „rozpuszczała” odpowiedzialność Państwa za lata terroru ${ }^{263}$. Literatura nie tyle odzwierciedla czy denuncjuje te fikcyjne machinacje, co z nimi konkuruje, próbuje je wyprzedzić - wykorzystuje do tego wypracowane przez władzę narracje, których esencją, przynajmniej w Argentynie, są spisek (complot) i fałszerstwo (falsificación). W powieści „nie chodzi o dostrzeżenie rzeczywistości w fikcji (realizm), a o dostrzeżenie fikcji w rzeczywistości (utopia)"264. Emblematycznymi autorami rywalizującymi z narracją Państwa są dla Piglii Roberto Arlt i Macedonio Fernández: pierwszy z nich przepowiada w swojej „ekonomii literackiej”265 przyszłe opowieści rynków finansowych, drugi odkrywa figurę spisku jako centralną kategorię historii i polityki argentyńskiej, z powodzeniem odtwarzanej przez aparat Państwa w neoliberalnych czasach menemizmu. Szczególnie interesująca jest w tym kontekście lektura, jakiej Piglia poddaje twórczość Macedonia, u polityczniając ją: mistrz Borgesa i „martinfierystów”, autor autoreferencyjnego Museo de la Novela de la Eterna, awangardowej z ducha parodii konwencji literackich, jest dla Piglii pisarzem przenikliwie tropiącym narracyjne sieci historii oficjalnych, wytrawnym graczem, zdolnym formuło-

\footnotetext{
262 Idem, Una trama de relatos, w: idem, Crítica y ficción, s. 35.

263 Idem, Los relatos sociales, w: idem, Crítica y ficción, s. 106-107.

264 Idem, Ficción y política en la literatura argentina, w: idem, Crítica y ficción, s. 123.

265 Idem, Roberto Arlt, una crítica de la economía literaria.
} 
wać utopie wyprzedzające fikcyjne moce przerobowe aparatu bezpieczeństwa. Z podobnym upolitycznieniem - chronologicznie nawet wcześniejszym, bo równoległym do lat dyktatury wojskowej - mamy do czynienia w przypadku proponowanej w Sztucznym oddychaniu lektury Gombrowicza, którego koncepcja sztuki oparta na ideale niedojrzałości posiadała według Piglii potencjał polityczny, sabotujący oficjalną opowieść Państwa ${ }^{266}$. Przemawia za tym fakt, że wzorowana na autorze Ferdydurke postać Tardewskiego pojawia się w momencie, w którym prace nad powieścią były już zaawansowane ${ }^{267}$, przez co wydaje się elementem konstrukcyjnym wymuszonym przez rzeczywistość Procesu Narodowej Reorganizacji (jak nazywała siebie dyktatura lat 1976-1983). Dywersyjny - w języku Piglii: „utopijny” - wymiar postaci Tardewskiego-Gombrowicza realizuje się na trzech poziomach: w dialektyce pomiędzy swoim i obcym, reinterpretacji tradycji literackiej oraz estetyzacji doświadczenia porażki.

Prawie wszyscy główni bohaterowie Sztucznego oddychania są w jakimś sensie obcy: Enrique Ossorio jest paradygmatem banity politycznego w XIX wieku, kiedy konstytuowanie się argentyńskiego narodu zakładało wygnanie jego elity intelektualnej; hrabia Tokraj to uciekinier z Rosji bolszewickiej, typowy imigrant, hołubiący wspomnienia utraconej podwójnie ojczyzny (historycznie traci ją z obaleniem caratu, geograficznie - uciekając do Argentyny); profesor Maggi jest „zniknięty” przez dyktaturę; Tardewski natomiast ucieleśnia obcość jako wartość samą w sobie, jako estetyczny wymiar życia, który umożliwia ostranienie, postrzeganie wytrącone $\mathrm{z}$ automatyzmu przyzwyczajeń, patrzenie z dystansu na rzeczy zupełnie już opatrzone, „spojrzenie turysty, jak i, w ostatecznym rozrachunku, filozofa"268 ${ }^{20}$ Po przyjeździe do Argentyny zostaje idealnie wyzuty ze wszystkiego: „ojczyzny, pieniędzy,

\footnotetext{
266 Piglia jest naturalnie świadom faktycznych pozycji politycznych Gombrowicza; v. idem, Los diarios de Emilio Renzi. Los años felices, s. 308-309.

267 „W pierwszej wersji Sztucznego oddychania rozmowa Renziego z Tardewskim była zaledwie krótką sceną. Postać Tardewskiego pojawiła się późno, kiedy powieść była już zaawansowana"; idem, La Forma inicial. Conversaciones en Princeton, Eterna Cadencia, Buenos Aires 2015, s. 86.

268 Idem, Sztuczne oddychanie, s. 153.
} 
języka, przyszłości, przyjaciół lub choćby ubrania na zmianę"269, przy czym brak ten celebruje w zgodzie z cynicką tradycją jako komfortową sytuację nieuwikłania w więzy narodowe, obyczajowe i społeczne. Brak ten jest w pewnym sensie brakiem doskonałym, bo Tardewski zostaje pozbawiony nawet języka, i w ten sposób okazuje się niezdolny do wypowiadania się: „trudno mówić prawdę w obcym języku”, „jedną z pierwszych rzeczy, jakie się traci przy zmianie języka, jest zdolność opisu”270. Zaraz po przybyciu doświadcza absurdu własnej sytuacji: publikuje w gazecie swój przetłumaczony na hiszpański tekst, którego nie może nawet przeczytać, bo nie zna języka. Tardewski, turysta-filozof, całkowicie ni e u p rawni ony do wypowiadania się o kwestiach literackich, publikuje swoje epokowe odkrycie, dobrze wiedząc, że nie zostanie usłyszany z tego właśnie powodu - bo brak mu autorytetu, jaki posiadali Sarmiento, Borges lub Groussac. Polityczny wymiar tej postaci w okresie dyktatury jest następujący: w odpowiedzi na oficjalną narrację o czystości tradycji (narodowej, literackiej, językowej) Tardewski uosabia tradycję alternatywną, zainfekowaną obcością w dwojakim sensie. Po pierwsze, sam jest wygnańcem (egzotycznym, ekscentrycznym, dziwacznym), który cieszy się swoim wygnaniem, ponieważ wartości narodowe jawią mu się jako ciężar; a po drugie, choć nieuprawniony do wypowiadania się - brak mu autorytetu, nie zna nawet języka - mówi niepytany, prowokacyjnie zabiera głos w sprawach dla narodowej kultury kluczowych i wykpiwa jej mity.

Projekt reinterpretacji tradycji narodowej - formułowany skądinąd przez samego Piglię w rozlicznych wywiadach i tekstach nieliterackich - artykułuje w powieści Emilio Renzi, a jego sednem jest ufundowanie dwudziestowiecznej literatury argentyńskiej nie na modelu Borgesa, lecz Arlta. Tego pierwszego przedstawia się w Sztucznym oddychaniu jako twórcę zamykającego dwie podstawowe tendencje dziewiętnastowiecznej literatury z regionu La Platy. Pierwszą z nich jest wspominany już europeizm, nieznośna i kompromitująca tęsknota za dorównaniem literaturze starego kontynentu, która rozpoczyna

269 Ibid., s. 185.

270 Ibid., s. 105. 
się na pierwszej stronie Facunda. Sarmiento zamieszcza tam słynne motto On ne tue point les idées, nie przypadkiem po francusku: „barbarzyńcy” nie mogą go zrozumieć i tym samym udowadniają swoje nieokrzesanie. Erudycja Sarmienta sama jest jednak podszyta ignorancją: oto okazuje się, że błędnie przypisuje to zdanie niejakiemu Fortoulowi, gdy w rzeczywistości wypowiedział je inny Francuz, Volney ${ }^{271}$. Gdy Sarmiento ostentacyjnie obnosi się ze swoim oczytaniem, na jaw wychodzi jego udawana kultura - a stąd jesteśmy tylko o krok od stylu Borgesa: „[...] teksty będące zlepkiem zmyślonych, apokryficznych cytatów [...], całe to jątrzenie, parodiowanie naszej kultury, kultury z drugiej ręki, kultury przeżartej do cna żałosną pedanterią. Z tego wszystkiego Borges kpi sobie w żywe oczy" ${ }^{272}$. Świadomie manifestując fałszywą erudycję, powołując się na nieistniejące, samodzielnie sfabrykowane źródła, sprowadza do absurdu - i tym samym zamyka - całą tradycję argentyńskiego europeizmu. Ponadto Borges finalizuje także tendencję przeciwną, bazującą na literaturze gauczów (tzw. gauchesca) i pretendującą do wyrażania głosu ludu. Opowiadania takie jak Człowiek z przedmieścia albo Południe, stylizowane na język mówiony historie o odwadze, zdradzie i honorze, są - mówi w powieści Emilio Renzi - parodią najsłynniejszego poematu gauczów, Martína Fierro. Z drugiej strony styl Borgesa pozostał „precyzyjny i jasny, prawie doskonały” i „przeobraził się w szkolną gwarancję językowej poprawności" ${ }^{273}$, jest kontynuacją (choć twórczą i krytyczną) stylu purystów w rodzaju Leopolda Lugonesa i Paula Groussaca, dla których:

271 Co znamienne, Emilio Renzi - porte-parole Piglii, wykładający w Sztucznym oddychaniu wszystkie doniosłe konsekwencje pomyłki Sarmienta - sam popełnia błąd, zmieniając nazwisko Hyppolite’a Fortoula na „Fourtol”.

272 Ricardo Piglia, Sztuczne oddychanie, s. 129. Gombrowicz czyni podobne obserwacje na temat Borgesa, choć, jak się zdaje, nie zauważając jego prześmiewczej intencji. Dominique de Roux mówi o „pseudoerudycji” autora Fikcji i wyjaśnia: „każda erudycja jest i musi być pseudo; Borges-erudyta jest straszliwym ignorantem, ale jest też niezbyt inteligentny, ponieważ erudycja $z$ istoty swojej jest nieinteligentna"; Witold Gombrowicz, Testament.

273 Ricardo Piglia, Czy istnieje powieść argentyńska?, s. 68. 
[...] literatura [...] ma bronić czystości języka narodowego przed wywołanym przez imigrantów rozpadem, pomieszaniem. Do tego sprowadza się teraz jej ideologiczna funkcja: ma wyznaczać wzorce wła ś c i w e go u ży ci a mowy ojczystej. Pisarz staje się w takich warunkach strażnikiem jej czystości [...]. To pisarstwo, którego zadaniem jest zatrzeć najdrobniejszy nawet ślad tego, co stało się z naszym językiem pod wpływem imigrantów ${ }^{274}$.

Użyty w tym fragmencie metaforyczny język opozycji pomiędzy czystością i stosownością a chaosem i rozpadem jest parafrazą narracji dyktatury o zakażonym ciele narodu. Narracją doń konkurencyjną jest literatura Arlta, dla którego „język to obszar współżycia i konfrontacji najróżniejszych idiolektów z ich rejestrami i tonami" ${ }^{275}$, dlatego stroni od poprawności narzuconej przez elitę i instytucję szkoły. „Ten alchemiczny, przewrotny, marginalny styl Arlta, ta mieszanina resztek - to nic innego, jak transpozycja jego tematów" ${ }^{276}$. Teoria ewolucji literatury argentyńskiej pojętej jako zastąpienie tradycji stylistycznej elegancji tradycją tematycznie i językowo „nieczystą” zostaje przez Piglię rozwinięta w artykule Czy istnieje powieść argentyńska? Borges a Gombrowicz, opublikowanym sześć lat po Sztucznym oddychaniu. Centralną postacią jest w tym tekście właśnie autor Ferdydurke, którego teoria kulturowej niższości jednych nacji względem drugich zbliża wprawdzie do Borgesa, ale którego język jest właściwy dla prozy „przyszłości”, czyli dla Arlta i Macedonia. Chodzi bowiem o ,język na wygnaniu” (lengua exiliada), cechujący się „odmiennością"277 - wypracowany w oddaleniu od bezpiecznego kontekstu narodowego, w środowisku kulturowo i materialnie podrzędnym, niemający w zasadzie nic wspólnego z tradycją wielkich stylistów. „Zamiarem Gombrowicza, jak opowiadano, było wymyślić język na nowo nie chodziło o tworzenie neologizmów (chociaż i takie można w tej książce odnaleźć [...]), lecz o wymuszenie na słowach nowych znaczeń, o przeniesienie ich z jednego kontekstu

\footnotetext{
274 Idem, Sztuczne oddychanie, s. 133-134; wyróżnienie w oryginale.

275 Ibid., s. 134.

276 Ibid., s. 135.

277 Idem, Czy istnieje powieść argentyńska?, s. 67.
} 
w drugi”278. „Przeniesienie kontekstu” - tutaj użyte w odniesieniu do języka - jest, jak wykazuję poniżej, kwintesencją spojrzenia Piglii na istotę literatury.

Wyłożona przez Renziego reinterpretacja fundamentów narodowej kultury, której sednem jest rewaloryzacja języków i stylów „nieczystych”, jest następnie uzupełniona przez opowieść Tardewskiego-Gombrowicza o odkryciu dokonanym jeszcze w Europie, a w Argentynie ogłoszonym we wspomnianym już artykule po hiszpańsku. Podczas pobytu w Cambridge, w bibliotece British Museum, za sprawą błędnej sygnatury w katalogu - perturbacji w borgesowskim porządku idealnym - dostaje on zamiast dzieła sofisty Hippiasza Mein Kampf Adolfa Hitlera, egzemplarz opatrzony komentarzem na marginesach. Dokonuje wówczas odkrycia w duchu szkoły frankfurckiej: książka führera jawi mu się jako kontynuacja Rozprawy o metodzie i najdoskonalsza manifestacja europejskiego racjonalizmu. Potem wpada na trop daleko bardziej doniosły: w końcu pierwszej dekady xx wieku doszło w Pradze do serii spotkań Franza Kafki z Hitlerem, które okazały się decydujące dla twórczości pisarza - on pierwszy pojmuje znaczenie szalonego języka Historii, która przemawia ustami przyszłego wodza Rzeszy. Rzekome odkrycie Tardewskiego jest całkowicie zmyślone, ale prawda literatury nie musi się pokrywać z prawdą Historii ${ }^{279}$. Sens tej fikcyjnej narracji - Piglia, jak Macedonio czy Arlt, także snuje opowieści konkurencyjne wobec narracji totalitarnej władzy - jest dwojaki. Po pierwsze, obrazuje sposób, w jaki literatura wyprzedza bełkot Historii, przepowiada

278 Ibid., s. 69.

279 V. José Emilio Pacheco, "El proceso«, "El castillo«, las alambradas, w: Jorge Fornet (red.), op. cit., s. 141-148. Pomysł na tę zaskakującą znajomość wziął się być może z innej, lepiej udokumentowanej: Adolf Hitler i Ludwig Wittgenstein prawdopodobnie poznali się w gimnazjum w Linzu w roku 1904/1905. Powracające w powieści odwołania do Kafki mają także inne, bardziej aktualne znaczenie: okres rządów argentyńskiej junty wojskowej, zwany Procesem Narodowej Reorganizacji, zwykło się ironicznie nazywać w skrócie Procesem. V. Daniel Balderston, El significado latente en Respiración artificial, w: Jorge Fornet (red.), op. cit., s. 171. 
przyszłość tym, którzy umieją czytać między wierszami ${ }^{280}$. „Literatura zawsze jest nieaktualna - pisze Piglia w tekście o związkach między fikcją a polityką - opowiada w innym miejscu i nie w porę prawdziwą historię. W gruncie rzeczy wszystkie powieści wydarzają się w przyszłości”281. Sztuczne oddychanie także wydarza się w przyszłości - „konstruuje nowe z resztek teraźniejszości” ${ }^{282}$ - w tym sensie, że obecne w nim aluzje do spisku doskonale opowiedzą rzeczywistość epoki demokratycznej transformacji w drugiej połowie lat 80. i w latach 9o. Po drugie, opowieść Tardewskiego o własnym odkryciu, świadomie eksponująca jego przygodny charakter - nie jest ono przecież owocem żmudnej pracy, lecz pomyłki w katalogu - rozmontowuje p raw o m o cną drogę odkrycia naukowego. Nauka, czyli język, który pragnie postrzegać się jako obiektywny i obowiązujący (i w tym sensie monopolistyczny jak język władzy), zbliża się w ten sposób do sztuki - przypadek jest wszak metodą twórczą awangardy. Gombrowicz ujmuje to następująco: „A więc cała ta nasza dialektyka - filozoficzna, etyczna - toczy się na tle bezmiaru, któremu na imię niedokształt, który nie jest ani ciemnością, ani jasnością, lecz właśnie mieszaniną wszystkiego, fermentem, nieporządkiem, nieczystością i p r z y p a d ki e m"283. Przypadek jest tu synonimem niedojrzałości, przeciwstawiającej się myśli dojrzałej i uformowanej, która pretenduje do opisu całościowego, a więc z gruntu fałszywego. Więcej nawet - sama forma jest w gruncie rzeczy dziełem splotu okoliczności, dlatego bezwiedny, machinalny gest lub spojrzenie często bywa w Gombrowiczowskich narracjach wydarzeniem o doniosłych konsekwencjach.

Postać Tardewskiego jest w końcu pretekstem do refleksji nad doświadczeniem klęski - w prawie wszystkich tekstach Piglii powraca postać losera, ofiary takiej lub innej (najczęściej jednak literackiej) porażki, która rozpaczliwe szuka kogoś, kto zechce jej wysłuchać ${ }^{284}$.

\footnotetext{
280 Tardewski mówi: „Nikt nie czyta, nikt nie umie czytać. Bo żeby czytać, trzeba umieć kojarzyć”; Ricardo Piglia, Sztuczne oddychanie, s. 202.

281 Idem, Ficción y política en la literatura argentina, s. 123.

282 Idem, La lectura de la ficción, w: idem, Crítica y ficción, s. 14.

283 Witold Gombrowicz, Dziennik 1953-1969; wyróżnienie moje - E.K.P.

284 V. Jorge Fornet, Un deabte de poéticas: las narraciones de Ricardo Piglia, w: Elsa Drucaroff (red.), op. cit., s. 349-350. Dla Rodriga Blanco Calderóna motyw
} 
Tardewski opowiada Renziemu, że jego własna „fascynacja klęską” rozpoczęła się we wczesnej młodości od zainteresowania ludźmi przegranymi, których definiuje następująco: „To ktoś obdarzony licznymi talentami, często liczniejszymi niż ci, którym się powiodło. To ktoś, kto ma te talenty [...] ale z nich nie korzysta. Kto je niszczy. Tak że w gruncie rzeczy [...] niszczy swoje życie"285. Życiowa klęska - kontynuuje bohater - umożliwia i pielęgnuje zarazem pewien specyficzny sposób patrzenia na świat, ponownie określany rosyjskim terminem ostranienie, które udziwnia oswojony skądinąd świat rzeczy znanych. Konsekwentnie kultywowane zdziwienie wobec rzeczywistości, sceptyczne niedowierzanie charakteryzujące „przegranych”, ewoluuje w stronę „obłąkańczej przenikliwości”286, która spycha ich jeszcze głębiej w klęskę. W ten sposób doświadczenie porażki jest punktem wyjścia „fikcji paranoicznej” - innej kluczowej dla Piglii kategorii literackiej, którą zajmę się przy okazji omawiania związków pomiędzy powieścią a spiskiem. W tym miejscu dodam jedynie, że jego rozważania na temat pozytywnej roli doświadczenia porażki zbiegają się z poglądami Pierre’a Bourdieu, dla którego projekt twórczy pisarza konstruuje się w odniesieniu do dwóch - zwykle niezależnych od siebie - determinant: z jednej strony bierze pod uwagę wewnętrzną logikę dzieła, jego estetyczne i autonomiczne założenia, $\mathrm{z}$ drugiej natomiast spodziewane uwarunkowania społeczne (ogólnie rzecz ujmując, oczekiwania publiczności). U pisarzy popularnych, którzy odnieśli sukces, te ostatnie - czyli nastawienie na kontynuację sprawdzonej estetyki, strach przed utratą popularności - przyćmiewają zwykle wewnętrzną logikę dzieła i w rezultacie doprowadzają do uzależnienia „projektu twórczego” jedynie od uwarunkowań wobec dzieła zewnętrznych: „możliwe, że twórcy są bardziej wrażliwi na sukces niż

przegranej jest także kluczem do zrozumienia stosunku Piglii do pisarstwa Gombrowicza; v. jego artykuł pt. Piglia y Gombrowicz: sobre el fracaso y otras estratgias de escritura, w: Jorge Carrión (red.), op. cit., s. 27-43.

285 Ricardo Piglia, Sztuczne oddychanie, s. 152.

286 Ibid., s. 153. 
porażkę i zdarza się, że - nie wiedząc, jak zapanować nad własnym triumfem - podporządkowują się restrykcjom narzuconym przez społeczną definicję dzieła uświęconego sukcesem" ${ }^{287}$.

Przedstawione w drugim rozdziale analizy kompozycji Dziennika argentyńskiego tłumaczą, dlaczego proponowane za oceanem interpretacje Gombrowicza ciążą ku postrzeganiu jego osoby i twórczości przez pryzmat doświadczenia klęski. W koncepcji Piglii klęsce nie przypisuje się swoistej funkcji sublimacyjnej, którą odgrywa ona w wyobraźni popularnej: porażka pisarza jest przez nią zwykle postrzegana jako warunek „głębokiego” znaczenia dzieła - cierpienie osoby przekłada się jakoby na wartość tekstu. Zgodnie z tą logiką pisarz miałby „odkryć użyteczność cierpienia w gospodarce słowem [economía de la expresión] tak jak święci odkryli użyteczność bólu w ekonomii religijnej" ${ }^{288}$. Dla autora Sztucznego oddychania doświadczenie porażki jest jednocześnie destrukcyjne - jak w przypadku Cesare Pavesego, którego ostatecznie doprowadza do samobójstwa - oraz twórcze, ponieważ zmusza do nowego zdefiniowania fundamentów sztuki, w szczególności reinterpretacji problemu wartości (valor): kto o niej decyduje? jak się tworzy? Jeden z częściej analizowanych przez argentyńskiego pisarza i krytyka Gombrowiczowskich tekstów, czyli wygłoszony w 1947 roku wykład Przeciw poetom, jest próbą takiego właśnie przewartościowania wartości literackich. Zważywszy na postulowaną przez Piglię bliskość estetyk Gombrowicza i Arlta, wykład ten można czytać jako rozwinięcie opowiadania Argentyńczyka Escritor fracasado (Niespełniony pisarz) z 1933 roku - oba teksty stylizowane są na antyczną diatrybę i drwią z rutyny i konwencji w konstruowaniu wypowiedzi literackiej, przy czym pierwszy sytuuje się po stronie czytelnika, a drugi autora. W opowiadaniu Arlta tytułowy niespełniony pisarz, za młodu obwołany (nieco na wyrost) geniuszem, opowiada historię swojej niemocy twórczej, której sednem jest podejrzenie własnej wtórności wobec form skonsolidowanych.

\footnotetext{
287 Pierre Bourdieu, Campo intelectual y proyecto creador, przeł. Jorge Dotti, w: idem, Campo de poder, campo intelectual, Montessor, Buenos Aires 2002, s. 9-50.

288 Ricardo Piglia, Los diarios de Emilio Renzi. Años de formación, s. 143.
} 
Moim towarzyszom oznajmiłem, że przygotowuję Estetykę dla Wymagających, na bazie „koktajlu” z kubizmu, faszyzmu, marksizmu i teologii [...]. W kilka tygodni rozpropagowaliśmy nasze zasady, rozrzucając je między kawiarnianymi stolikami i rozsiewając w kręgach artystycznych, a po roku odkryliśmy, w zgodzie z prawami naszej estetyki, kilku anonimowych geniuszy. Namydliwszy ich nieco modernizmem i ogoliwszy z resztek jasności i logiki, wystawiliśmy na pokaz, ku ekstazie tłumu. Tłum, trzeba to powiedzieć jasno i bez ogródek, nigdy nas nie interesował. Z dumą oświadczam, że zawsze pogardzałem szeroką publicznością: zważywszy jednak na fakt, że gawiedź należy cywilizować, a i my, bogowie, nie możemy bez przerwy przebywać na wysokościach z obawy przed sflaczeniem, raczyliśmy zainteresować się pospólstwem i zawiadomić je o naszych odkryciach w dziedzinie piękna ${ }^{289}$.

Następnie, odkrywszy w sobie skłonności inkwizytorskie, bohater staje się przedstawicielem profesji szczerze przez Arlta znienawidzonej, krytykiem literackim, a później na próżno próbuje sojuszu z klasą robotniczą w nadziei, że - parafrazując Gombrowicza - jego wymyślne szarady stanowić będą pokarm duchowy prostaczków ${ }^{290}$. Ostatecznie tytułowy pisarz uznaje swoją klęskę i wyzbywa się wszelkich oczekiwań wobec samego siebie i sztuki: „[...] zastąpiłem nienawiść antypatią, a antypatię obojętnością. Następnie wymieniłem obojętność wynikającą z niewiedzy bardziej subtelną obojętnością, przejawiającą się w wychwalaniu wszystkiego. Dobrego i złego"291. To zdystansowanie „niespełnionego pisarza” oraz jego przekonanie o umowności „wielkich narracji” prowadzi do kluczowego - zdaniem Piglii - zagadnienia Przeciw poetom, czyli zagadnienia wartości w sztuce.

Problem ten zostaje rozwinięty w późniejszym eseju Pisarz jako czytelnik, w którym Piglia wychodzi właśnie od analizy treści i okoliczności wykładu Gombrowicza z 1947 roku. Najpierw poświęca sporo uwagi czynnikom pozatekstowym, takim jak wybór języka oraz miejsca odczytu, które z kolei w dużej mierze określają dobór

289 Roberto Arlt, Escritor fracasado, w: idem, Narrativa corta completa, t. 1, Universidad de la Laguna, La Laguna 1995, s. 31-32.

290 Witold Gombrowicz, Przeciw poetom, w: idem, Dziennik 1953-1956.

291 Roberto Arlt, Escritor fracasado, s. 37. 
słuchaczy. Autor Trans-Atlantyku, ogólnie rzecz ujmując, postanawia przemawiać z pozycji niedojrzałości - wybiera księgarnię Fray Mocho, daleką „od prestiżowych kręgów konferencyjnych tamtych lat, takich jak Wolne Kolegium Studiów Wyższych, gdzie od 1946 wykładał Borges, lub Centrum Przyjaciół Sztuki, w którym zbierał tłumy Ortega y Gasset" ${ }^{292}$. Co bardziej doniosłe, decyduje się mówić po hiszpańsku, choć uzus konferencyjny tamtych lat sugerował znacznie lepiej mu znany francuski - w tym języku mówili Victoria Ocampo i Roger Caillois. Wybór hiszpańskiego Piglia uważa za manifestację niższości - po pierwsze dlatego, że w Argentynie pierwszej połowy xx wieku był on postrzegany jako język kulturowo drugorzędny, o wątłym kręgu oddziaływania $^{293}$, po drugie dlatego, że Gombrowicz włada nim nie tylko słabo, ale także w specyficznej, argotycznej wersji:

Hiszpański Gombrowicza jest językiem wykluczenia. Nie ma nic wspólnego $\mathrm{z}$ angielskim Nabokova, wyuczonym w dzieciństwie w towarzystwie angielskich guwernantek. Gombrowicz poznaje hiszpański w Retiro, w portowych barach, uczy się od chłopców, robotników i marynarzy; to język powiązany z obiegiem seksualnym i wymianą z nieznajomymi. Retiro - nazwa jakże znacząca - to część El Bajo, położona w pobliżu tak zwanego Paseo de Julio ${ }^{294}$, okolice, po których błąkać się będzie Emma Zunz - targowisko, szemrane knajpy i burdele. Ów hiszpański to język miejsc pokątnych, związany z poślednimi odmianami życia społecznego ${ }^{295}$.

Gombrowicz przekuwa ten szemrany i chwiejny hiszpański na swoją korzyść, bo dzięki niemu uwalnia się od fałszywie brzmiącego języka

292 Ricardo Piglia, Pisarz jako czytelnik (2014, nr 3), s. 400.

293 Victoria Ocampo pisała: „Moja łatwość wyrażania się w wielu językach oraz trudności z odnalezieniem, odkryciem własnego, czyżby były tylko moim udziałem? Nie sądzę. Muszą istnieć w nas jako narodowa dyspozycja. [...] Ogromna praca przekładowa, która przemiela języki i, jak mówi Drieu, zdobywa świat, urzeczywistniła się wśród nas. Słowa francuskie, włoskie, angielskie i niemieckie ciągle przychodzą mi do głowy, by ukryć luki mojego zubożałego hiszpańskiego"; cyt. za: Jorge Fornet, El escritor y la tradición, s. 194. 
kultury, zyskuje doskonałe tworzywo lub formę do wyrażenia treści, których sednem jest rewaloryzacja narodowej i indywidualnej niższości - znajdująca także swoje odzwierciedlenie w temacie wykładu. Możliwości tej nie dawał mu, ze zrozumiałych względów, język ojczysty, dlatego w polskiej wersji Przeciw poetom znika odniesienie do językowej niezręczności, która wszakże okazuje się dobrą dla zdrowia „przymuszoną dietą”, bo faktycznie u m o żl i w i a sformułowanie głównej tezy wykładu: kiedy nie włada się językiem wystarczająco dobrze, by naukowo rozprawiać o współczesnej poezji, stawia się pytania daleko bardziej podstawowe. Piglia ujmuje to następująco: „W Buenos Aires [Gombrowicz - E.K.P.] odnalazł język, będący także wyrazem pewnego sposobu życia: ubóstwo mowy powiela niedostatek pieniędzy i niepewność życia. Hrabia podobny żebrakowi jest odpowiednikiem wielkiego stylisty, który nie umie mówić" ${ }^{296}$.

Główna teza Przeciw poetom jest, zdaniem Piglii, następująca: nie istnieje żaden element językowy, który decydowałby o tym, że dany tekst jest poetycki (a tym samym Gombrowicz przeciwstawia się formalistom rosyjskim i ich poszukiwaniom „literackości”). Jeśli poezja jest jedynie g o to wo ści ą czytania tekstu jako poetyckiego, specyficznym nastawieniem, tym „międzyludzkim”, to obowiązkiem artysty jest przede wszystkim wpływać na te sposoby postrzegania, przygotowywać własną recepcję - co zresztą Piglia i Gombrowicz robili bardzo skutecznie. Tworzenie „poetyckiego podejścia” jest w gruncie rzeczy równoznaczne z tworzeniem poezji, bo to "społeczne sieci”, a nie dzieło samo, decydują o wartości: „wybitność”, „wielkość” tych utworów jest pochodną odbioru. Dlatego postulat rozluźnienia formy w sztuce stosuje się właśnie do form postrzegania i doświadczenia dzieła, nie zaś do jego kategorii wewnętrznych.

Próbą takiej właśnie zmiany w sposobach postrzegania, próbą rozluźnienia formy odbioru jest teoria „ekonomii literackiej”, sformułowana przez Piglię jeszcze w latach 70. w odniesieniu do twórczości Roberta Arlta ${ }^{297}$. Zainspirowana lekturami Waltera Benjamina,

\footnotetext{
296 Ibid., s. 402.

297 Idem, Roberto Arlt, una crítica de la economía literaria.
} 
Bertolta Brechta i szkoły frankfurckiej, teoria ta łączy kwestię wartości w sztuce $z$ logiką i obiegiem pieniądza, a jej sednem jest lektura dzieła literackiego jako tekstu przekładającego uwarunkowania ekonomiczne na język symboliczny, co z kolei pozwala ustanowić analogie pomiędzy produkcją dóbr materialnych oraz tworzeniem dóbr artystycznych. Stąd centralną kategorią tej interpretacji jest własność (propiedad) - rozumiana bądź w sensie dosłownym, jako posiadanie książki „na własność”, bądź metaforycznym, jako prawo autorskie - oraz jej rewers, kradzież, która odpowiednio przybiera formę zwykłego przywłaszczenia lub plagiatu. Obie kategorie powracają w krytycznej i literackiej twórczości Piglii: jego analiza El juguete rabioso (Wściekłej zabawki) Arlta oparta jest w dużej mierze na symbolice nieuprawnionego, nielegalnego dostępu do dóbr kultury, a w opowiadaniu Homenaje a Roberto Arlt (W hołdzie Robertowi Arltowi), którego głównym tematem jest plagiat, Piglia przytacza - nie podając źródła, ale pozostawiając szereg wskazówek - obszerny fragment innego tekstu ${ }^{298}$. Ponadto główny bohater tego utworu, krytyk „Ricardo Piglia”, dokonuje naukowego odkrycia, które na próżno próbuje posiąść na własność; podobne rozczarowanie spotyka Tardewskiego ze Sztucznego oddychania, kiedy pod swoim artykułem, relacjonującym odkrycie na temat spotkania Kafki z Hiltlerem, zobaczy własne nazwisko wydrukowane z błędem: Tardowski: „Czyż to nie wspaniała nauczka? Zachowałem się jak akademicki idiota. [...] A le trudno pozbyć się instynktu własności”299. Pragnienie "posiadania tekstu” jest w obu przypadkach skompromitowane jako wyraz filisterskiej ambicji, pogoni za uznaniem w oczach wąskiej grupy sobie podobnych wyrobników literatury. Dla Gabrieli Speranzy stosowane przez Piglię zabiegi ukrytych cytatów albo, przeciwnie, cytatów apokryficznych są realizacją awangardowej procedury twórczej détournement, praktykowanej przez sytuacjonistów w latach 50. xx wieku (a wcześniej przez Duchampa w ready-mades). Détournement, czyli „przemieszczenie”,

\footnotetext{
298 Idem, Homenaje a Roberto Arlt, w: idem, Nombre falso, Anagrama, Barcelona 2002, s. 97-157. Chodzi o opowiadanie Leonida Adriejewa Ciemność z 1907 roku.

299 Idem, Sztuczne oddychanie, s. 186; wyróżnienie w oryginale.
} 
ale także „malwersacja”, „nadużycie”, zakłada przesunięcie elementu z właściwego mu „środowiska” do innego, w którym zyskuje nowe, zwykle także krytyczne wobec kanonicznych wartości estetycznych znaczenie. „Détournement - pisze Speranza - dąży do przezwyciężenia drobnomieszczańskiego kultu oryginalności i prywatnej własności”300.

W eseju Pisarz jako czytelnik Piglia wykorzystuje dwuznaczność hiszpańskiego słowa valor (które przełożyć można zarówno jako „wartość”, jak i „papiery wartościowe”), by wydobyć paralele pomiędzy funkcjonowaniem sztuki („poezji”) a przepływem pieniądza:

Bank jest [...] sceną dla poetów. Obieg, wymiana, pożyczki, kredyty, procenty, względna wartość pieniądza, który - powiedziałby Gombrowicz - jest konwencją tak samo jak poezja. Pieniądz jako odpowiednik wszystkiego; pieniądz jako metaforyczna maszyna, która zmienia się zawsze w coś innego [...]. Pieniądz działa jak poezja, to znaczy ustala ekwiwalenty, jest metaforycznym systemem świadczeń i wymiany. Tak definiuje poezję Gombrowicz, jako konwencję i sieć społeczną; system kredytów i system przekonań ${ }^{301}$. Ekonomia poetycka, czyli zbiór wartości, w którym głębia ${ }^{302}$ jest gwarantem formy, także opiera się na konwencji. Poezja krąży, dewaluuje się, gromadzi, jest walutą [valor], dotyka jej inflacja i niedobór ${ }^{303}$.

Wartość pieniądza (jak wartość poezji) nie jest mu immanentna, bo nie zawiera kruszcu - podlega wyłącznie kwestii ustalenia, umowy społecznej. Kurs poezji, jak kurs papierów wartościowych oraz cena dóbr materialnych, jest zmienny i zależy od popytu (odbioru), o który współczesny rynek dba bardziej niż o produkcję, czyli w y t w a r z a n i e towarów. W interpretacji Piglii specjalnego znaczenia nabiera fakt, że na odczycie Przeciw poetom obecny był prezes Banco Polaco, który zaraz potem zatrudnił Gombrowicza w swojej instytucji. Cytowany

\footnotetext{
300 Graciela Speranza, op. cit., s. 249.

301 Niemożliwa do oddania po polsku gra słów crédito (kredyt) i creencias (przekonanie).

302 Piglia używa tutaj wieloznacznego słowa fondo, które po polsku oznacza tak głębię i sedno, jak fundusz.

303 Ricardo Piglia, Pisarz jako czytelnik (2015, nr 4), s. 256.
} 
w tekście Juan Carlos Gómez mawiał, że pisarz rozegrał wówczas gambit doskonały: pozbył się poetów, a zyskał bankiera (to podczas pracy w banku napisał Trans-Atlantyk). Symbolicznym zbiegiem okoliczności Przeciw poetom inauguruje pracę Gombrowicza w banku i ustawia go w rzędzie z innymi pisarzami-bankierami: T.S. Eliotem, Joycem, także z Kafką - inspektorem w zakładzie ubezpieczeniowym. „Zbadanie stosunku Gombrowicza do pieniędzy pomogłoby lepiej zrozumieć jego twórczość", konkluduje Piglia ${ }^{304}$.

Takie rozumienie literatury, które wiąże ją z logiką ekonomiczną z jednej strony, a z drugiej osadza na konwencji, na umowie społecznej, zbliża nas do kolejnego lejtmotywu w krytyce Piglii - stosowanego także w odniesieniu do Gombrowicza - a mianowicie do praktyki spisku. Awangarda (Gombrowicz, Macedonio Fernández, Roberto Arlt) - pisze w Teoría de complot - świadoma tego, że nie istnieje żadna obiektywna wartość poetycka, proponuje inne systemy wartości, podważa hierarchie już ustalone - jako przykład niechaj posłuży obrazoburczy tekst Polaka o Dantem. W ten sposób spiskuje: przeciwstawia się konsensusowi społecznemu, który jest także gwarantem kanonu takiego, jak rozumie go Piglia, czyli utrwalonej hierarchii tekstów opartej na wierze w ich obiektywną wartość. Idealnym środowiskiem dla funkcjonowania sztuki nie jest kompromis, lecz walka - dlatego Gombrowicz w Przeciw poetom pisze:

Człowiek, który uformował się jedynie w styczności z ludźmi podobnymi sobie, który jest produktem wyłącznie swego środowiska, ciaśniejszy, gorszy będzie miał styl od tego, który doznał rozmaitych środowisk i ludzi [...]. I sztuka moja wykształciła się nie w zetknięciu z grupą ludzi mnie pokrewnych, lecz właśnie w odniesieniu do wroga i w zetknięciu z wrogiem ${ }^{305}$.

Literatura wykluwa się tylko w miejscach mało przyjaznych, bo konfrontacja - $\mathrm{z}$ innym językiem, $\mathrm{z}$ innym kontekstem społecznym, z „niepoetycko” nastrojonym czytelnikiem - zapewnia jej siłę

\footnotetext{
304 Ibid.

305 Witold Gombrowicz, Przeciw poetom.
} 
przetrwania. Co więcej, sieć literackich powiązań nie jest tutaj pojmowana jako łagodna wymiana myśli czy wzajemna inspiracja: jeśli brakuje instancji, która ex cathedra wyrokowałaby o wartości dzieła i ustalała obowiązujące hierarchie, to każdy nowy gest literacki, pragnąc narzucić się innym, potencjalnie podważa istniejące już systemy wartości, wsysa je i przezwycięża. „Pisarz zawsze ma wrogów, bo jego dzieło anuluje i kwestionuje inne poetyki" ${ }^{306}$ - pisze autor Crítica y ficción.

Zważywszy na fakt, że dla Piglii sfera literatury i sfera polityki przenikają się, wywrotowe działania awangardy muszą mieć zasięg szerszy od stricte literackiego: $\mathrm{w}$ wymiarze politycznym awangarda jest „odpowiedzią na idee konsensusu i paktu jako gwarancji funkcjonowania społeczeństwa, na ideał przejrzystości przestrzeni publicznej oraz pojęcia reprezentacji i większości jako form legitymizacji władzy"307. W Argentynie w pierwszych dekadach xx wieku literatura była reakcją na kryzys, któremu uległ liberalizm: idealny model społeczny wypracowany przez Sarmienta i pokolenie 1837 zostaje zdmuchnięty przez masową imigrację. W latach dyktatury proponuje narracje konkurencyjne wobec opowieści Państwa, a w kolejnych dekadach (do czasów obecnych) obszar konfliktu, w którym interweniuje pisarz, sytuuje się w obrębie działań rynku, „jednego z wielkich współczesnych dyskursów społecznych"308. Istotą jego funkcjonowania jest tajemnica - dostęp do tajnych informacji jest gwarantem sukcesu - chroniona specjalnym żargonem językowym, który fałszuje rzeczywistość. „Ucieczka kapitału jest doskonałą metaforą dzisiejszego terroru”309, pisze Piglia. Wywrotowe działania literatury polegają na obnażeniu konwencjonalnego, umownego charakteru tego dyskursu oraz propo-

\footnotetext{
306 Jorge Fornet, Conversación con Ricardo Piglia, s. 27.

307 Ricardo Piglia, Teoría del complot, s. 108.

308 Idem, La forma inicial, s. 233. O nowym paradygmacie literatury argentyńskiej, wymuszonym przez neoliberalną ekonomię w latach 9o. ubiegłego wieku i charakteryzującym się m.in. zanikiem dążenia do intelektualnej konfrontacji i pragnieniem powszechnego konsensusu, pisze wyczerpująco Daniel Link w artykule Literatura y mercado, w: Jorge Carrión (red.), op. cit., s. 145-157. 
zycji konkurencyjnych systemów organizacji społecznej: jeśli w poezji obowiązują zmienne hierarchie wartości i różnorodne formy wymiany (zapożyczeń), to możliwe są także alternatywne systemy wymiany pieniądza, konkurencyjne wobec dominującego modele gospodarcze. Wspomnieć wypada, że w pierwotnej wersji Teoría del complot była także (jak Przeciw poetom) odczytem, który Piglia wygłosił w ramach spotkań zaaranżowanych przez Projekt Venus, organizację non-profit stworzoną przez Jacques'a Fresco, promującą gospodarkę opartą na zasobach i krytykującą system monetarny jako przestarzały. Zgodnie $\mathrm{z}$ tezą Fresco obecny model gospodarczy, nastawiony na konsumpcjonizm i zysk, ma być zastąpiony przez gospodarkę opartą na współpracy ludzi między sobą, a więc promującą inny kodeks wartości - metaforyczny system wzajemnych świadczeń i wymiany. Literatura proponuje więc opowieść konkurencyjną wobec narracji wolnego rynku: jej podmiotem jest artysta, rozumiany tak, jak rozumie go Gombrowicz w Przeciw poetom - patrzący z dystansu, histrion i prześmiewca.

Kategoria spisku pomaga także zdefiniować pojęcie „fikcji paranoicznej", którym Piglia posługuje się w odniesieniu do specyficznego rozwinięcia narracji detektywistycznej, dokonanego pod wpływem rosnącej roli zależności rynkowych w organizacji współczesnego społeczeństwa. Genetyczne cechy tego gatunku literackiego, z góry wiążące go z logiką kapitalizmu - rodzi się wraz z wolnym rynkiem, pomyślany zostaje jako towar do sprzedania, operuje powtarzalnym schematem - ulegają obecnie spotęgowaniu w fikcji paranoicznej. Jej pierwszą cechą konstytutywną jest towarzyszące bohaterom poczucie zagrożenia, przeczucie spisku zawiązanego przez mniej lub bardziej skonkretyzowanego wroga. Drugą - „interpretacyjne delirium, czyli taka analiza, która stara się wymazać przypadek, udowadniając, że nie istnieje, że wszystko posiada jakąś - często nieznaną - przyczynę, że wydarzenia kryją zaszyfrowaną wiadomość o tym, że »[wszystko] mnie dotyczy « ${ }^{310 ”}$. Tak zdefiniowana fikcja paranoiczna obowiązuje w większości tekstów Gombrowicza, w których narrator przyjmuje zwykle jedną z dwóch ról przypisanych do powieści detektywistycznej - jest

310 Idem, La ficción paranoica, „Clarín. Revista Ñ” 1991, 10 X, s. 4-5. 
śledzącym (detektywem i ofiarą zarazem) lub sprawcą ${ }^{311}$ - a najlepiej urzeczywistnia się w Kosmosie, do którego zresztą Piglia odnosi się wprost w kilku przynajmniej tekstach poświęconych powieści detektywistycznej ${ }^{312}$. Sam stosuje taki rodzaj „delirycznej interpretacji” w pierwszej części Sztucznego oddychania, w której cenzor Arocena drobiazgowo analizuje cudze listy, szukając w nich ukrytych znaków, tajemnych szyfrów mających obnażyć nieznane, niedokonane nawet zbrodnie $^{313}$. Samo podejrzenie przestępstwa - przemożna potrzeba interpretacji - znajduje następnie swoiste uzupełnienie lub domknięcie ex post $\mathrm{w}$ figurze mordercy, który faktycznie dokonuje zbrodni (jak w Kosmosie) lub przyznaje się do niej (jak w Zbrodni z premedytacją, ale także w katowniach wojskowych urzędów bezpieczeństwa, którym służy Arocena).

Przedstawienie Gombrowicza Piglii zakończyć wypada krótkim komentarzem na temat formy dziennika, w szczególności wielokrotnie wyżej cytowanych Los diarios de Emilio Renzi, bo pod takim tytułem ukazują się kolejne tomy diarystyki samego Piglii ${ }^{314}$. Gombrowicz nie jest z pewnością ich najważniejszym modelem - ginie w natłoku innych diarystów, których lektura zostaje odnotowana przez Renziego: Kafka, Gide, Robert Musil, Lew Tołstoj, Pavese... Brak w tej serii Polaka jest zaskakujący - Piglia wielokrotnie wspomina o Ferdydurke,

311 V. Andrzej Falkiewicz, Spór śledzącego i sprawcy, w: Zdzisław Łapiński (red.), op. cit., s. 561-572.

312 Ricardo Piglia, La ficción paranoica, s. 5; v. też idem, La forma inicial, s. 174. W dzienniku Piglia notuje z kolei: „Odkrywam hiszpańskie wydanie Pornografii [La seducción - E.K.P.] Gombrowicza, którą wcześniej czytałem po włosku jako Pornografię. Ptaszek powieszony na drucie, czyżby wróbel?”; idem, Los diarios de Emilio Renzi. Los años felices, s. 41. Odniesienie do Kosmosu funkcjonuje tu jako ironiczna supozycja tajemnego znaczenia, jakie kryje „podwójny” tytuł Pornografii.

313 V. Sonia Mattalia, La ley y el crimen. Usos del relato policial en la narrativa argentina (1880-200o), Iberoamericana, Madrid 2008, s. 192-197.

314 Dotychczas ukazały się dwa tomy: pierwszy z podtytułem Años de formación (Czas dorastania), obejmuje okres od 1957 do 1967; drugi, Los días felices (Szczęśliwe dni), kończy się w 1975 roku. Na rok 2017 planowane jest wydanie ostatniej części dzienników, zatytułowanej Un día en la vida (Dzień z życia). 
parafrazuje Kosmos, Trans-Atlantyk to dla niego narracja par excellence o Argentynie, Pornografię czyta po włosku i potem odkrywa po hiszpańsku, a o Dzienniku nie ma w Dziennikach ani słowa ${ }^{315}$. Jego treść jest Piglii bez wątpienia znana - wspomina o nim w Pisarzu jako czytelniku, wpisując go w obowiązującą tam retorykę ekonomiczno-literackich zależności: „Dziennik Gombrowicza jest złączony $\mathrm{z}$ wygnaniem i z niedostatkiem. Jest nawet jego wynikiem: anty-Gide, anty-Bioy Casares. Żadnego dochodu, żadnej własności ziemskiej”316. Zwyczajowa treść „dziennika pisarza”, czyli materia literacka - notowane ad hoc impresje z lektury, systematyczne komentarze do tekstów, cytaty, stanowiące zresztą gros diarystyki Piglii - są Gombrowiczowi niedostępne („Jestem skazany na czytanie tych tylko książek, które mi wpadną w ręce, ponieważ nie stać mnie na kupowanie" ${ }^{317}$ ). Tak jak brak językowy pchnął go ku pytaniom bardziej podstawowym o istotę poezji, tak brak dostępu do dóbr symbolicznych (książek) ucina w zasadzie możliwość namysłu na tematy bieżącej kultury i skłania ku systematycznej refleksji nad własnym „ja”. Piglia przytacza w tym kontekście historię argentyńskiego (nie)wydania Dziennika - Gombrowicz odmówił mianowicie zgody na wznowienie Ferdydurke przez prestiżowe wydawnictwo Fabril Editora, ponieważ jego dyrektor nie zgodził się na jednoczesne wydanie Dziennika:

Ten tekst [dwie strony maszynopisu Dziennika - E.K.P.], opowiada wydawca, porwał mnie od pierwszego wiersza i gdy doczytałem do końca, powiedziałem: tak, niewątpliwie jest to próbka dość wymowna, ale nie podejmę się opublikować go bez znajomości całości. Gombrowicz nie odpowiedział. Wstał. Ponad biurkiem zabrał mi z rąk swoje dwie strony, mruknął coś, co jeżeli nie było obelgą, mogło być pożegnaniem i, nie czekając, obrócił się na pięcie i wyszedł ${ }^{318}$.

\footnotetext{
315 Przynajmniej w dwóch pierwszych tomach, które ukazały się dotychczas.

316 Witold Gombrowicz, Dziennik 1953-1969. Fragment ten cytuje także Piglia w artykule Pisarz jako czytelnik.

317 Witold Gombrowicz, Dziennik 1953-1969.

318 Ricardo Piglia, Pisarz jako czytelnik (2015, nr 4), s. 259. Cf. relacja Jacobo Muchnika, w: Rita Gombrowicz, Gombrowicz w Argentynie. Świadectwa i dokumenty
} 
Odmowa ta jest dla Piglii gestem symbolicznym - przypieczętowuje bowiem porażkę, którą autor Pornografii wybiera dla siebie w Argentynie, na własne życzenie stając się tam na kolejne lata „pisarzem przegranym”. Dla tej opowieści biograficzne dowody na „walkę o sławę", którą Gombrowicz metodycznie prowadził tak w Argentynie, jak w Europie, są zgoła nieistotne - chodzi bowiem o opowieść właśnie, o fikcję, w której postać Polaka zostaje wykorzystana jako symbol, a raczej rewers innej paradygmatycznej dla Piglii postaci - naukowca, który pragnie posiąść na własność przedmiot swojego odkrycia, zagwarantować sobie do niego prawo.

Dzienniki Emilia Renziego w niewielkim stopniu przypominają Dziennik, podobnie jak w powieściach Piglii trudno doszukać się Gombrowiczowskiego tonu. Analogie dotyczą za to sfery bardziej ogólnej, czyli traktowania zapisków diarystycznych jako „laboratorium fikcji”, w którym dojrzewają i konkretyzują się literackie projekty. Zapiski te mają niewiele wspólnego z linearnym zapisem faktów z życia, przybierają raczej formę hybrydyczną, w której mieszają się notatki z lektur, opowiadania, polemiki, pomysły na powieści, historie własne z historiami cudzymi. Zaskakujące - choć z pewnością przypadkowe, bo Piglia nie mógł znać Kronosu - są obecne w obu tekstach potrzeba grupowania opisanych wydarzeń w serie, poszukiwanie ukrytych analogii, nadawanie kształtu chaotycznemu biegowi wydarzeń. W przypadkach obu pisarzy dziennik jest osią twórczości, ale porządek jego publikowania jest odmienny - dla Piglii diarystyka jest zwieńczeniem twórczości: „zawsze powtarzam, że wydam jeszcze dwie, trzy powieści, żeby umożliwić publikację mojego dziennika"319. Argentyńczyk potrzebuje wprzódy udowodnić atrakcyjność własnego „ja”, która uzasadniałaby wydanie dziennika - wykwitu komicznej skądinąd potrzeby rejestrowania dzień po dniu własnego życia; Gombrowiczowi, jak wiadomo, nie przeszkadza pisanie „znikąd”, po to, by swoje sugestywne i narzucające się „ja” skonstruować dopiero w tekście. Obaj pisarze $\mathrm{z}$ góry rezygnują $\mathrm{z}$ zawarcia autobiograficznego paktu, ich diarystyczne

1939-1963, przeł. Zofia Chądzyńska, Anna Husarska, Wydawnictwo Literackie, Kraków 2005, s. 212-217.

319 Ricardo Piglia, Novela y utopía, w: idem, Crítica y ficción, s. 92. 
zapiski są wyselekcjonowanymi fragmentami fikcji inspirowanej życiem, przy czym Piglia idzie o krok dalej w sygnalizowaniu tej fikcyjności, umieszczając w tytule nazwisko Emilia Renziego i redagując wstęp w trzeciej osobie: „[...] zaczął pisać dziennik pod koniec 1957, i nadal go pisze. Wiele rzeczy od tamtej pory się zmieniło, ale tej manii pozostał wierny”320. Gombrowicz doświadczał uczuć „nie inaczej jak w cudzysłowie"321, Piglia zaś opatruje cudzysłowem samo „ja”, pisząc de facto o in ny m. Odwraca tym samym zwyczajowy sens autofikcyjnego protokołu, przenosząc postać fikcyjną - bohatera Sztucznego oddychania, Blanco nocturno - na karty własnego dziennika.

\section{Ryzykowne związki: Julio Cortázar i Juan José Saer}

Gombrowicz, co starałam się wykazać powyżej, jest autorem znaczącym lub przynajmniej bliskim dla twórczości centralnych postaci literatury argentyńskiej, choć reprezentujących bardzo odmienne estetyki (Ricarda Piglii i Césara Airy). Ta swoista „interpretacyjna pojemność”, pozwalająca „skojarzyć” Gombrowicza z autorami, którzy w Argentynie uchodzą za antagonistycznych, może skłaniać do ustanawiania międzytekstowych związków na terenach grząskich - w połączeniu z twórczością innych znaczących pisarzy, którzy wprawdzie autora Ferdydurke czytają i, jak deklarują, podziwiają, ale faktycznie w nikłym stopniu w y k o r z y s t uj ą w swoich tekstach jego idee, koncepcje czy legendę.

Jednym $\mathrm{z}$ takich grząskich terenów interpretacyjnych jest twórczość Julia Cortázara (1914-1984). Do ustanawiania paraleli między tymi dwoma pisarzami zachęca powinowactwo biograficzne: obaj spędzili większą część życia poza krajem, co przyczyniło się do poczucia, że funkcjonują na marginesie narodowej wspólnoty, choć jednocześnie żaden nie zrezygnował z pisania w ojczystym języku książek

\footnotetext{
320 Idem, Nota del autor, w: idem, Los diarios de Emilio Renzi. Años de formación, S. 11.

321 Witold Gombrowicz, Dziennik 1953-1969.
} 
skierowanych przede wszystkim do publiczności rodzimej - Polaków i Argentyńczyków ${ }^{322}$. Na tym jednak symetria ich życiorysów się kończy (czy nawet odwraca z chwilą, gdy w 1963 roku Cortázar czynnie zaangażował się w walkę na rzecz rewolucji kubańskiej), a ich literackie światy pozostają od siebie niezależne. Jedynym mostem, który można by między nimi przerzucić, jest Gra w klasy (1963), a konkretnie zamieszczony w niej półstronicowy cytat z Przedmowy do Filidora dzieckiem podszytego (o „zbudowaniu dzieła na fundamencie poszczególnych części", nie zważając na krytyki literackiego establishmentu) ${ }^{323}$. Najsłynniejsza antypowieść Cortázara jest jednak z założenia collage’em głosów, w którym Gombrowiczowski fragment funkcjonuje jako jeden $\mathrm{z}$ wielu ready-mades, połączonych w całość na zasadzie surrealistycznej przypadkowości, i nie stanowi w tym almanachu głosu dominującego. Awangardowa Gra w klasy jest w dużej mierze dziełem epoki i jako taka była czytana w świetle teorii strukturalistycznych, poststrukturalistycznych i egzystencjalnych, co oczywiście pozwoliłoby ustalić jakieś analogie z Gombrowiczem, „pierwszym strukturalistą", ale te byłyby raczej konsekwencją zaaplikowanej teorii literackiej aniżeli samego tekstu.

Innym pisarzem, którego krytycy czasami umieszczają w obrębie oddziaływania autora Dziennika, jest Juan José Saer (1937-2005). Polak był dla niego bez wątpienia pisarzem ważnym, o czym najlepiej świadczy wielokrotnie wyżej cytowany esej Spojrzenie z zewnątrz, wydobywający argentyński wymiar jego twórczości. W przeciwieństwie jednak do Ricarda Piglii, który pisząc o autorze Ferdydurke (a także o innych bliskich sobie twórcach), pisał w gruncie rzeczy o sobie, używał Gombrowicza do umocnienia własnej koncepcji literatury, Saer uprawia klasyczną krytykę literacką, której celem jest komentowanie cudzego dzieła. Innymi słowy, esej Spojrzenie z zewnątrz sporo

\footnotetext{
322 V. Marta Jordan, Gombrowicz i Cortázar - nasi współcześni, w: Jerzy Jarzębski (red.), op. cit., s. 626-636; Carlos Brück, Ferdydurke, campeón de Rayuela, „Página/12" 2004, 28 IX, https://goo.gl/xF7RC2, dostęp: 18 I 2017.

323 Julio Cortázar, Gra w klasy, przeł. Zofia Chądzyńska, Muza, Warszawa 20oo, s. 639 .
} 
mówi o Gombrowiczu, a niewiele o samym Saerze (z wyjątkiem może wyłożonej na początku niechęci do bycia klasyfikowanym według narodowości lub politycznej orientacji, czyli postrzegania pisarza jako „taki czy inny byt, pełniący określoną rolę w repertuarze społecznych wyobrażeń" ${ }^{324}$, która bez wątpienia charakteryzuje także literaturę Argentyńczyka). Wspólnota doświadczenia wygnania - Saer mieszkał we Francji od 1968 roku aż do śmierci - byłaby, ponownie, jedyną łączącą ich cechą, mającą wprawdzie wpływ na ich estetyczne koncepcje, ale mało dystynktywną, zważywszy na powszechność jej występowania w literaturze argentyńskiej.

\section{„Uczniowie" Gombrowicza}

O ile w odniesieniu do pisarzy i intelektualistów zaangażowanych w prace komitetu tłumaczy Ferdydurke używa się zwykle terminu „przyjaciele [amigos] Gombrowicza”, o tyle w stosunku do „przyjaciół” poznanych mniej więcej dekadę później w Tandilu i Buenos Aires, termin ten opatruje się zwykle przymiotnikiem „młody” (bo faktycznie tacy byli) lub zastępuje dość wieloznacznym discípulo. Słowo to oznacza ucznia albo adepta szkoły bądź doktryny, której tajniki poznaje pod przewodnictwem mistrza, a następnie kontynuuje ją i krzewi po jego śmierci. Gęba „adepta gombrowiczologii” przywarła więc do tych „młodych przyjaciół” niezależnie od pewnej zasadniczej nieprzystawalności terminu „uczeń” do Gombrowiczowskiej filozofii życiowej, przy czym o ile w przypadku Juana Carlosa Gómeza wydaje się trafnie określać jego stosunek do „mistrza” i w miarę celnie określa postawę Néstora Tirriego, o tyle dla Jorgego Di Paoli jest zdecydowanie krzywdząca. Poniżej zajmę się omówieniem twórczości literackiej i komentatorskiej tych „adeptów”, którzy pozostawili po sobie teksty w różnym stopniu naznaczone Gombrowiczem, zaczynając od Juana Carlosa Goméza (1934-2012), u którego mamy do czynienia

\footnotetext{
324 Juan José Saer, Spojrzenie z zewnątrz, s. 72.
} 
z prawdziwym piętnem odciśniętym na równi przez przyjaźń z autorem Dziennika oraz przez jego teksty.

Symboliczną raison dêtre twórczości komentatorskiej Gómeza jest humorystyczne zaświadczenie, wystawione mu przez Gombrowicza w jednym z listów napisanych z Europy w 1963 roku: „Juan Carlos Gómez, alias Goma, jest Argentyńczykiem najbardziej wprowadzonym w mój świat i zna wiele moich sekretów"325. O tym żartobliwym certyfikacie - przywoływanym zresztą przez samego zainteresowanego z częstotliwością, która szybko pozbawiła „dokument” pierwotnej gracji - Rajmud Kalicki pisze następująco:

Ten dokument Gómez miał okazać pewnej zdolnej, młodej autorce, kto wie, może jeszcze pannie, która usłyszała o genialnym polskim pisarzu i chciała go poznać, a to pech, Polak właśnie wyjechał. Gómez ma bidulę pocieszyć, bo jest ciekawa szczegółów, a żeby mógł dobrze wykonać zadanie, Gombro mianuje go swoim pełnomocnikiem ${ }^{326} \ldots$

Trudno oprzeć się wrażeniu, że taką biedną, „młodą autorką", poszukującą kontaktu z Gombrowiczem (nawiasem mówiąc, Marta Lynch, o której tu mowa, była sporo starsza od „wtajemniczonego”), jest polski czytelnik, dla którego Juan Carlos Gómez pozostaje głównym przewodnikiem po argentyńskim wymiarze dzieła Polaka. Przyczyniła się do tego przede wszystkim seria artykułów jego autorstwa opublikowana w „Twórczości” w latach 1999-2008 oraz entuzjastyczne komentarze Henryka Berezy, który w odniesieniu do „młodego adepta” szafuje najpierw określeniami takim jak „duchowy wybraniec”, „Syn z Ducha” ${ }^{327}$, a następnie stwierdza, że „między tymi dwoma twórcami, jednym spełnionym i drugim potencjalnym, zdarzyło się coś najdonioślejszego w ich życiu i to po równi dla obydwóch", a ich dzieła są jednakowo zdumiewające ${ }^{328}$. Bardziej chłodne oceny egzegetycznej

325 Chodzi o list z 5 sierpnia 1963 roku; v. Witold Gombrowicz, Cartas a un amigo argentino, Emecé, Buenos Aires 1999, s. 47. Polski przekład za: Rajmund Kalicki, Twój list jest jak tango, „Twórczość” 1999, nr 7, s. 107.

326 Rajmund Kalicki, op. cit., s. 107.

327 Henryk Bereza, Goma, „Twórczość” 200o, nr 7, s. 85-86.

328 Idem, Goma (2), „Twórczość” 2004, nr 7/8, s. 150. 
działalności Gómeza każą rzeczywiście widzieć w nim sprawnego obrońcę Gombrowiczowskiej ortodoksji - był wnikliwym czytelnikiem c ałe go dzieła Polaka (co odróżnia go od typowych w Argentynie fragmentarycznych interpretacji) i zażartym wprost analitykiem jego epistolografii, a niektóre jego teksty (jak Gombrowicz jest w nas ${ }^{329}$ ) są rzeczywiście przenikliwe i świeże.

Na Gómeza opus o Polaku składają się następujące teksty: wspomniany wyżej Gombrowicz jest w nas, napisany w 1964 roku jako odpowiedź na wstęp Ernesta Sábato do nowego wydania Ferdydurke (i rzeczywiście dużo od niego lepszy); zainspirowana Dziennikiem książka Gombrowicz, este hombre me causa problemas z 2004, po polsku opublikowana pod tytułem Milonga dla Gombrowicza ${ }^{330}$; Uwaga gombrowiczanie! $!^{331}$, wykład wygłoszony przy okazji prezentacji wymienionej powyżej książki w Ambasadzie Polskiej w Buenos Aires; Zobaczymy się w Bueno Saires ${ }^{32}$, wybór z listów Gómeza do Gombrowicza, opatrzony komentarzem Argentyńczyka; Nowy przewodnik po Gombrowiczu ${ }^{333}$, czyli fragmenty korespondencji Gombrowicza ze swoimi „uczniami”, także wybrane i objaśnione przez Gómeza, oraz heterogeniczne Zapiski gombrowiczowskie ${ }^{334} \mathrm{z}$ roku 2008. Do tego korpusu wliczyć można pośrednio Cartas a un amigo argentino (Listy

329 Juan Carlos Gómez, Gombrowicz está en nosotros, w: Witold Gombrowicz, Cartas a un amigo argentino, s. 145-152. Polska wersja: idem, Gombrowicz jest w nas, przeł. Rajmund Kalicki, „Literatura na Świecie” 2001, nr 4, s. 57-61.

330 Idem, Milonga dla Gombrowicza, przeł. Rajmund Kalicki, „Twórczość” 2004, nr $7 / 8$, s. 79-134.

331 Idem, Uwaga gombrowiczanie!, przeł. Ewa Zaleska, „Twórczość” 2005, nr 9, s. $110-117$.

332 Idem, Zobaczymy się w Bueno Saires, przeł. Rajmund Kalicki, „Twórczość” 2004, nr 4, s. 46-92.

333 Idem, Nowy przewodnik po Gombrowiczu, przeł. Rajmund Kalicki, „Twórczośc” 2004, nr 5, s. 48-134. Jest to ciąg dalszy fragmentów listów Gombrowicza do „młodych przyjaciół”, ogłoszonych wcześniej w „Twórczości”: Wyimki z listów Witolda Gombrowicza do argentyńskich przyjaciół, wyb. Juan Carlos Gómez, przeł. Rajmund Kalicki, „Twórczość” 1999, nr 7, s. 73-84.

334 Idem, Zapiski gombrowiczowskie, przeł. Ewa Zaleska, „Twórczość” 2008, nr 11, s. $77-101$. 
do argentyńskiego przyjaciela) ${ }^{335}$, czyli listy Gombrowicza do Gómeza („opowiadające sagę o niespełnionym powrocie [Polaka - E.K.P.] do Argentyny"336), przede wszystkim ze względu na fakt, że stanowią one stały punkt odniesienia $\mathrm{w}$ analizach proponowanych przez Argentyńczyka. Wszystkie powyższe teksty - jak te napisane przez Pierre’a Ménarda z opowiadania Borgesa - mają charakter w jakimś sensie wtórny lub odtwórczy, ich podstawą jest bowiem tekst obcy (tekst Gombrowicza), który zostaje obficie zacytowany lub opatrzony komentarzem. Z gruntu krytyczna twórczość argentyńskiego egzegety została jednak włączona do rozdziału, w którym omawiam dzieła literackie dlatego, że - jak ujmuje to Bereza - „słowo Gómeza jest z Gombrowicza, ale przez metaliteracki użytek staje się ono własnością Gómeza" ${ }^{337}$. Jorge Di Paola nazywa z kolei twórczość Gómeza „literaturą zbudowaną ze strzępów, jakiej stajemy się współtwórcami. Literaturą podobną do sztuki konceptualnej, prawdziwego ready-made złożonego z gotowych fragmentów" ${ }^{338}$.

Elementem scalającym przedstawiony wyżej korpus tekstów jest specyficzna metoda badawcza, której znakiem szczególnym jest ciągłe napięcie pomiędzy wspomnieniami o „mistrzu” a imperatywem chłodnej, wyważonej analizy tekstu. Gómez próbuje utrzymać obiektywizm - nie chce li tylko serwować anegdot, pragnie cz y t a ć, ko m entow á - ale równowaga pomiędzy zdystansowanym krytykiem a targanym sprzecznymi emocjami przyjacielem jest chwiejna, czego zresztą sam autor jest świadom: „moja książka [Gombrowicz, este hombre me causa problemas - E.K.P.] ma trudny do ukrycia rys osobisty, ponieważ w każdym rozdziale mówię o naszej wzajemnej relacji, nadal żywej po pół wieku”339 ${ }^{3}$ Etos przyjaźni, szczególnego

335 V. polski przekład fragmentów tej korespondencji: Witold Gombrowicz, Listy do Juana Carlosa Gómeza, przeł. Ewa Zaleska, „Literatura na Świecie” 2001, nr 4, S. 5-29.

336 Jorge Di Paola, Epilog gumowaty, przeł. Rajmund Kalicki, „Twórczość” 2001, nr 4, s. 152.

337 Henryk Bereza, Goma (2), s. 147.

338 Jorge Di Paola, Epilog gumowaty, s. 152.

339 Juan Carlos Gómez, Uwaga gombrowiczianie!, s. 113. 
rodzaju łączącej ich więzi - zresztą jeden z toposów argentyńskiej literatury $^{340}$ - wydaje się podstawowym narzędziem legitymizującym rozważania „wiernego Gomy”, a odwołanie do wspólnej przeszłości (anegdot i listów) ma nie tylko charakter ludyczny, ale także rozstrzygający, niczym odwołanie do empirii. Rozumowanie interpretacyjne domaga się wsparcia, ufundowania na opowieści ze wspólnego życia. Samemu Gómezowi pozwala przy okazji zbudować własną legendę jako jedynego „właściwego adresata” całej Gombrowiczowskiej epistolografii do Argentyńczyków ${ }^{341}$, modelowego czytelnika oraz „przedstawiciela Gombrowicza na ziemi” ${ }^{342}$, jak siebie (nie do końca) ironicznie nazywa. Pierwszą stałą jego tekstów jest więc oscylacja pomiędzy poszukiwaniem człowieka a poszukiwaniem dzieła - co zresztą nie deprecjonuje jego rozważań, przeciwnie, wydaje się doskonale pasować do pisarza, który w życiu teatralnie o d g r y w ał samego siebie i pogrążał pojęcia abstrakcyjne w ciałach swoich bohaterów ${ }^{343}$. Drugim wyróżnikiem tej metody, na który zwraca uwagę Bereza, jest specyficzne, samotne miejsce, z jakiego Gómez pisze: nie korzysta bowiem „ze zdobyczy konwencjonalnej gombrowiczologii ani nie wdaje się w żadną z nią wojnę" ${ }^{344}$. Polska krytyka jest mu niedostępna ze względów językowych, a o argentyńskich próbkach interpretacyjnych wypowiada się lekceważąco. W końcu wszystkie jego teksty mają charakter urywkowy - bazują wprawdzie na znajomości całego Gombrowiczowskiego dzieła, ale zdolne są je uchwycić nie w narracji ciągłej, lecz we fragmentach tematycznych: „nuda”, „Argentyna”, „ból”, „historia”, „ręce”, „Bóg, Ojczyzna i Rodzina”, „Gombrowicz i strukturalizm" etc.

Gómeza opowieść o Gombrowiczu nieustannie rwie się, ponieważ inaczej nie sposób komentować myśli, której naczelną zasadą

\footnotetext{
340 O argentyńskim kulcie przyjaźni, wywodzącym się z romantycznej epopei Martín Fierro José Hernándeza pisze Carlos Gamerro w Facundo o Martín Fierro. Los libros que inventaron la Argentina (Sudamericana, Buenos Aires 2015).

341 Henryk Bereza, Goma (2), s. 150.

342 Juan Carlos Gómez, Uwaga gombrowiczianie!, s. 11.

343 V. idem, Gombrowicz jest w nas, s. 59.

344 Henryk Bereza, Goma (2), s. 147.
} 
jest sprzeczność, negacja samej siebie w obawie przed zastygnięciem formy. Antynomia ta wyraża się, po pierwsze, w dialektycznym oscylowaniu pomiędzy dwoma ekstremami: forma-chaos, ból-zachwyt, brzydota-piękno, stary-młody, dojrzałość-niedojrzałość, wyższy-niższy. Sprzeczność jest nie tylko witalną zasadą dzieła, jest także zasadą życia - funkcjonowania w społeczeństwie i kulturze jako zaprzeczenie tego, co głosi rozmówca ${ }^{345}$. Imperatyw zanegowania dotyka w końcu także jego samego:

[...] za najelegantszą formę osłabiania [...] zwalczanych idei uważał zamazywanie ich konturów. Jego własne przemyślenia uległy rozproszeniu, jego poglądy na temat formy i niedojrzałości są niczym wymykające się z ręki piskorze. Trzeba zatem zadać sobie pytanie, czy rzeczywiście pragnął być zrozumiany, czy też chciał być jedynie tajemnicąa ${ }^{346}$.

Pytanie to Gómez faktycznie sobie stawia - „jest piskorzem czy nie jest piskorzem?"347 - ale odpowiedź wydaje się niemożliwa tym bardziej dlatego, że „wierny Goma” szuka nie ja ki e g o ś Gombrowicza - nawet nie „własnego Gombrowicza”, nie mówiąc już o tym sztucznym, fabrykowanym przez gombrowiczologów - lecz Gombrowicza prawdziwego.

Oryginalnym aspektem jego interpretacji jest zwrócenie uwagi na fakt, że Gombrowiczowskie wprowadzenie ciała do filozofii oznacza nie tylko otwarcie na erotykę, ale także dostrzeżenie transcendentalnej roli fizycznego cierpienia w tym, co nazywamy istnieniem. Zmysłowość to także ból, jak zauważa Gómez w tekście z 1964 roku. Ból pozostaje jedną z kategorii interpretacyjnych w Milondze dla Gombrowicza, gdzie jednak - z zasady jednoczącej cały świat zwierzęcy, a więc

345 Nawiasem mówiąc, Gombrowicz ponownie okazuje się bliski Bourdieu, który pisze: „zasadnym jest pytanie, czy intelektualny projekt każdego z oponentów nie jest w treści jedynie zaprzeczeniem projektu adwersarza”; Pierre Bourdieu, op. cit., s. 30. Wykładana przez francuskiego socjologa logika działania pola intelektualnego, oparta na dialektyce wzajemnych obrazów i oczekiwań, przypomina Gombrowiczowskie „narzucanie się”.

346 Juan Carlos Gómez, Uwaga gombrowiczanie!, s. 112.

347 Ibid., s. 115. 
czujący - ewoluuje ku erotyzmowi i wkrótce gubi się w meandrycznych rozważaniach na temat homoseksualizmu pisarza i jego bezwzględnej odrazy dla fizycznej brzydoty. Podobnie podrozdział poświęcony Argentynie jest w rzeczywistości przyczynkiem do rozważań na temat utajonych skłonności Gombrowicza, jak gdyby Retiro było synekdochą całego kraju. Gómeza konsekwentne roztrząsanie tego problemu jest z pewnością uzasadnione wyżej referowanym scaleniem analizy literacko-filozoficznej z życiem, w tym wypadku chodziłoby na równi o życie mistrza, jak adepta, który do tej sfery dzieła nie został dopuszczony. Innymi słowy, Gómez błądzi po Retiro zawzięcie, lecz po omacku, bo brak mu rozstrzygających instancji - anegdoty lub wspomnienia.

Jako Gombrowiczowski krytyk Gómez jest znacznie bardziej doceniany w Polsce niźli w rodzimej Argentynie, co zawdzięcza w dużej mierze nieistnieniu polskiej wersji cyklu gombrowiczidas, które on sam chętnie propagował, wykorzystując narzędzia dostarczane przez nowe technologie ${ }^{348}$. Neologizm gombrowiczida, bazujący na hiszpańskim sufiksie cida, oznaczającym „zabójcę”, miał w zamyśle autora oznaczać próby twórczej kontestacji relacji mistrz-uczeń oraz zapewnić przestrzeń do kultywowania pamięci o Gombrowiczu w Argentynie. Goma opisuje w nich swoje spotkania oraz publikuje korespondencje z pisarzami, krytykami, wydawcami, animatorami kultury - wszystkimi tymi, których w mniej lub bardziej luźny sposób mógł powiązać z Gombrowiczem - nadając im w większości dość obraźliwe pseudonimy i nie szczędząc pozbawionych wdzięku złośliwości. Ostatecznie więc setka gombrowiczidas posłużyć może raczej jako materiał do studium przypadku obsesji, którą ich autor rozwinął na punkcie swojego mistrza, aniżeli jako platforma gromadząca miłośników pisarza w jego przybranej ojczyźnie ${ }^{349}$.

\footnotetext{
348 Sieć mailowych kontaktów osobistych oraz strony internetowe, takie jak www. elortiba.org.

349 „Wybrał siedmiu »wspaniałych«, z których potem zrobiło się dziewięciu, jedenastu, trzynastu i ich liczba dalej rosła, aż osiągnęła bliżej niesprecyzowany wynik, po czym zaczął wysyłać im codziennie mailem fragment swojej nowej książki, która też rosła w sposób niekontrolowany. Wyłącznym tematem korespondencji był Gombrowicz: każda jego książka, każde wypowiedziane przez niego lub na
} 
W tym kontekście warto przemyśleć hipotezy na temat „niezwykłości tego fenomenu społecznego, jakim stała się argentyńska szkoła duchowa Gombrowicza" ${ }^{\text {350 }}$, a której najznamienitszym reprezentantem byłby „wierny Goma”. Egzaltacja Berezy wydaje się wpisana w jego interpretację, ale zastanawiać może podobnie entuzjastyczny w tonie głos Airy, dla którego „gromadka przyjaciół, garstka istnień, które rozjaśnił", była sekretnym arcydziełem Gombrowicza. Dla autora Ferdydurke - utrzymuje Aira - przyjaźń ta była grą, rodzajem intrygi, w której „odmłodzenie” nie było wcale najważniejszą stawką: „Jego przyjaciele byli za młodzi, niedojrzali, za głupi. I była to konwencja niezbędna w tym wewnętrznym teatrze, jaki założył, gdzie chór drobnomieszczańskich szczeniaków z Trzeciego Świata był w nieubłagany sposób rozgniatany przez dialektykę oraz złote myśli Geniusza" ${ }^{\text {351 }}$. Autor La serpiente deklaruje wprawdzie, że mistrz się pomylił: „W rzeczywistości nie byli tacy głupi, świadectwem jest, że przyjęli swoją rolę”, i dzięki nim odniósł „tajemne zwycięstwo nad nieobecnością"352. Jak już wyżej pisałam, zaangażowanie Airy w obronę legendy tej przyjaźni znajduje swoje uzasadnienie w jego własnym programie literackim, którego ważną częścią jest młodzieńcze doświadczenie obcowania z Geniuszem, decydujące dla symbolicznego samookreślenia się jako pisarza. Z drugiej

jego temat słowo, każda osoba, którą poznał (w Polsce, Argentynie, Niemczech, potem we Francji); ale przede wszystkim Gómez praktykował radykalny gombrowiczyzm - permanentne, jadowite wyzwanie rzucone światu i adresatom. Przez przynajmniej siedem lat otrzymywałem codziennie, także w niedziele, mail (często więcej niż jeden) od Gómeza. Dosłownie każdego dnia przez siedem lat. Zawsze były niepohamowane, czasami dość wyczerpujące w swoim jadzie i obsesji, ale przynajmniej raz w tygodniu przychodził jeden niezwykły. Gómez używał Gombrowicza do wytłumaczenia sobie świata i jego bezsensu: był jego Alefem i Yijing, pokutą i czarną dziurą. Gómez był jak Gombrowicz: swoimi diatrybami obraził lub zmęczył połowę swoich znajomych, w pewnym momencie nie uniknął powtarzania się, ale trzeba było go czytać, bo w najmniej spodziewanym momencie nadchodził przebłysk”; Juan Forn, El fiel Goma, „Pagina/12” 2012, 14 XII, https://goo.gl/zGVIYL, dostęp: 4 I 2017.

350 Henryk Bereza, Goma (2), s. 148.

351 César Aira, Arcydzieło tajemne, s. 145.

352 Ibid. 
strony trudno nie dostrzec ironii lub co najmniej dwuznaczności w nazywaniu Gomy „najwyższym kapłanem gombrowiczowskiego kultu”353. Wydaje się, że najlepszym reprezentantem „duchowej szkoły Gombrowicza w Argentynie”, o ile takowa istnieje, byłby inny jej członek, skądinąd pisarz bardzo doceniany przez Airę - Jorge Di Paola, którego sukces polegał m.in. na umiejętności zdystansowania się do figury mistrza, odrzucenia jej niczym drabiny, po której się wcześniej wspięło.

Gombrowicz nie bywa bowiem postacią w książkach Jorgego Di Paoli (1940-2007), który nie zwykł także pisać o „mistrzu” tekstów wspominkowych ${ }^{354}$. Mimo tego nieśmiertelna anegdota o tym, jak pewnego popołudnia w Tandilu „mistrz” przedstawia się swoim „uczniom”, a jeden z nich - Dipi właśnie - rozpoznaje w nim autora przeczytanej wcześniej Ferdydurke, po czym Gombrowicz wykrzykuje zaskoczony i mile połechtany: „Czytelnik na dzikiej pampie!”, urosła do mitu inicjacyjnego Di Paoli. W przytłaczającej większości studiów krytycznych o Argentyńczyku wcześniej czy później pada nazwisko polskiego pisarza, skazując Dipiego na funkcjonowanie w obrębie lub przynajmniej w odniesieniu do literackiego systemu „mistrza”. Dzieje się tak nawet wtedy, gdy zamiarem krytyka jest właśnie umniejszenie znaczenia lub wręcz odwrócenie tej relacji mistrz-uczeń. Sergio Bizzio pisze:

Zawsze podejrzewałem, że Dipi świadomie oszczędził mi błędu, jaki sam popełnił z Gombrowiczem, a który polegał na tym, że go słuchał. Może to brzmieć jak herezja w uszach tego, kto nigdy nie wpadł w jego pazury. Ekstrawagancja mistrza mojego mistrza wydawała mi się bardziej uciążliwa niż interesująca ${ }^{355}$.

Wtóruje mu Daniel Guebel:

[...] mówi się o nim, że był uczniem Gombrowicza. Być może on sam nadal tak twierdzi [...]. Ja chciałbym podkreślić, że to, czego dokonał Dipi,

\footnotetext{
353 Ibid., s. 144.

354 Wyjątkiem byłby apendyks Witoldo, el escritor tábano (w: Elsa Drucaroff [red.], op. cit., s. 373-375).

355 Sergio Bizzio, Notas Para Un Homenaje a Dipi Di Paola, „Ramona”, https://goo. gl/DBOuD6, dostęp: 9 XII 2016.
} 
było znacznie trudniejsze niż gombrowiczowskie gesta. Gombrowicz stworzył własny krąg [przyjaciół] i użył swojego dzieła do zbudowania sławy, co zresztą nie było skomplikowane, biorąc pod uwagę to, że jego figura posiadała bardzo wyraźne cechy promocyjne. Niemożliwością było, żeby w dłuższej perspektywie inteligencja argentyńska nie padła do jego stóp, niezależnie od tego, co mogła sądzić o jego książkach. Sądzę, że Dipi, hipotetyczny uczeń, obrał drogę przeciwną: w miarę upływu czasu odcinał się od bezpiecznego blasku jego [„mistrza” - E.K.P.] postaci, przebywając drogę na wygnanie, które kiedyś zwykło się nazywać „wygnaniem wewnętrznym”356.

Nie bez znaczenia pozostaje fakt, że w obu przypadkach - Bizzia i Guebela - mamy do czynienia z uznanymi w Argentynie „młodymi” pisarzami, dla których to sam Di Paola jest literackim „mistrzem”. Większość krytyków jest bowiem skłonna bardziej przychylnie interpretować znaczenie, jakie dla „niedojrzałego” pisarza miało spotkanie z Polakiem. César Aira akcentuje fakt, że Dipi „dziedziczy” po Polaku kondycję obcego, pisarza z zewnątrz, co skutkuje porzuceniem typowego dla literatury argentyńskiej statycznego przywiązania do miejsca i bezruchu na rzecz eksponowania w powieści dynamicznej zmiany, szybkiego tempa wydarzeń ${ }^{357}$. Z kolei Piglia nawiązuje do mitycznego spotkania w Tandilu:

[...] oto młody odkrywa i legitymizuje nieznanego pisarza. Gdyby nie to przypadkowe spotkanie, inny byłby los Gombrowicza, który znalazł tam [w Tandilu - E.K.P.] grupę przyjaciół, zdolnych rozsławić go wśród kolejnych pokoleń, i oczywiście inne byłoby literackie przeznaczenie Di Paoli, gdyby nie rozmowy i listy wymieniane przez lata $\mathrm{z}$ autorem Kosmosu ${ }^{358}$.

Jakkolwiek nie interpretować owego spotkania w 1956 roku oraz jego skutków, pozostaje faktem, iż Di Paola jest jedynym członkiem

\footnotetext{
356 Daniel Guebel, Jorge Di Paola (1940-2007), „Ramona”, https://goo.gl/hB2ifW, dostęp: 9 XII 2016.

357 César Aira, El deseo de viajar, „Ramona”, https://goo.gl/EUSTTy, dostęp: 9 XII 2016.

358 Ricardo Piglia, Prólogo, w: Jorge Di Paola, Minga!, FCE, Buenos Aires 2012, s. 9.
} 
grupy „młodych przyjaciół” Gombrowicza, który zostaje pisarzem, i to pisarzem w Argentynie rozpoznawalnym i wznawianym ${ }^{359}$. W roku 2012 ukazało się drugie wydanie jego powieści Minga!, w redagowanej przez Ricarda Piglię prestiżowej „Serie del Recienvenido”, prezentującej książki napisane w ostatnich dekadach $\mathrm{xx}$ wieku, lecz pozostające $\mathrm{w}$ dialogu $\mathrm{z}$ aktualnymi tendencjami literackimi, które niejednokrotnie antycypują. Opublikowana pierwotnie w 1984 - a więc rok po zakończeniu dyktatury - Minga! zapowiadała charakterystyczny dla tamtych lat odwrót od literatury zaangażowanej, spowodowany bankructwem imperatywów literackich wcześniejszych dekad, a skutkujący wystrzeganiem się lokalnej problematyki społeczno-politycznej na rzecz tematów uniwersalnych - estetyki, natury rzeczywistości, kwestionowania wszelkich form władzy. Powieść ta, jak wcześniejsze o kilka lat Sztuczne oddychanie Piglii, jest złożona z cytatów; głos Gombrowicza współbrzmi w niej i nakłada się na inne głosy: na literacki idiolekt Macedonia, słyszalny przede wszystkim w ironicznym tonie, grach formalnych i rozlicznych coups d'oil do czytelnika, na la gauchesca Hernándeza oraz jej późniejsze przeróbki w wykonaniu Borgesa i Lamborghiniego. W odróżnieniu jednak od powieści Piglii, Gombrowicz w Minga! jest słyszalny także na poziomie stylu (przede wszystkim w przesyconym humorem zdaniu), nie tylko w warstwie charakterystycznej dlań problematyki - co piszę świadoma faktu, iż sam Dipi odżegnywał się od estetycznej zależności od polskiego „mistrza” ${ }^{360}$.

359 Oprócz znanego w Polsce dramatu Hernán (1963) z prologiem Gombrowicza Di Paola opublikował jeszcze dwa zbiory opowiadań La virginidad es un tigre de papel (1974, Dziewictwo to papierowy tygrys) i El arte del espectáculo (2001, Sztuka spektaklu), powieść szpiegowską Moncada (2003), napisaną wspólnie z Robertem Jacobym, oraz powieść Minga! (1987). Niesprawiedliwy jest więc osąd Justyny Myszkowskiej, która w krótkim artykule poświęconym zresztą związkom polskiego pisarza z Juanem Carlosem Gómezem pisze o Dipim, że „po wyjeździe Gombrowicza z Argentyny napisał niewiele”; Justyna Myszkowska, Mistrz, „Twórczość” 2004, nr 4, s. 128.

360 W wywiadzie udzielonym Jorgemu Hardmeierowi Di Paola utrzymywał, że „estetyka Gombrowicza ma dla mnie mniejsze znaczenie niż jego etyka, a częste proroctwa Dziennika zawsze mnie olśniewały"; Jorge Hardmeier, Sostiene Dipi, „Ramona”, https://goo.gl/tZSAod, dostęp: 12 XII 2016. 
Akcja powieści rozpoczyna się, gdy główny bohater, Pablo von Paulus, matematyk, otrzymuje telegram $\mathrm{z}$ informacją o śmierci przyjaciela, któremu fatalnym zbiegiem okoliczności ścina głowę zerwana przez wiatr dachówka na plaży w Ipanemie. Zdruzgotany tak okrutnym zrządzeniem ślepego losu, von Paulus porzuca na kilka dni swoją codzienność w mieście o symptomatycznej nazwie Huyamos-de-aquí (Uciekajmy-stąd) i rozpoczyna przypadkową wędrówkę po argentyńskiej pampie, wyruszając z nadmorskiego Portu Amnezja w głąb par excellence argentyńskiego krajobrazu. Po drodze spotyka - jak Józio z Ferdydurke - serię archetypicznych postaci: wystraszoną kobietą o imieniu Malena (przywodzącym na myśl słynne argentyńskie tango o takim właśnie tytule), z którą nawiązuje romans, starego Poetę mówiącego językiem gauczowskich poematów, chłopów grających w bilard w barze jakiejś zapadłej na pampie wsi, gdzie pod naporem prostoty wiejskiego życia ze wstydem ukrywa swoje intelektualne pochodzenie i podziwia tężyznę fizyczną tubylców. Narracja o jego wędrówce jest raz po raz przerywana zdecydowanym cięciem, by skupić się na perypetiach Nataszy Filipownej (sic!), ukochanej, do której von Paulus ostatecznie powraca, ale gdy już biegnie ku niej gotów wyznać skrywane długo uczucia, jego także dopada okrutny los - zostaje (prawdopodobnie, bo autor oszczędza czytelnikowi tragicznego finału, urywając narrację w środku szalonego biegu ku ukochanej) zagryziony przez zdziczałe psy.

Co w tej groteskowej, utrzymanej w zawrotnym tempie i rozbitej na dwie przestrzenie powieści jest z Gombrowicza? Jego obecność jest wielokrotnie anonsowana pseudocytatami, aluzjami, porozumiewawczymi mrugnięciami oka do wtajemniczonego czytelnika. Autor pisze o Argentynie, że „w tym kraju na wywrót jedynie parobcy umieli się zachować, spokojni i pewni siebie"361, parafrazując słynne zdanie z Gombrowiczowskiego Dziennika, że Argentyna „to kraj na wywrót, w którym szczeniak, sprzedawca literackiej revisty, ma więcej stylu od wszystkich jej współpracowników" ${ }^{362}$. Naga, wystawiona na

\footnotetext{
361 Jorge Di Paola, Minga!, s. 85.

362 Witold Gombrowicz, Dziennik 1953-1969.
} 
cudze spojrzenia stopa, która konfunduje jedną z bohaterek (służącą!), ma także swój odpowiednik w Gombrowiczowskim uniwersum ${ }^{363}$, a zagmatwana tożsamość Nataszy Filipownej - „była córką białego Rosjanina, który uciekł przez Persję i ożenił z prawie czystej krwi Indianką mapucze, w Patagonii, gdzie kupował czarne owce, by potem sprzedawać je jako karakuły"364 - przywodzi na myśl komiczną hybrydę pochodzenia Goznala z Trans-Atlantyku. Ukochana głównego bohatera daje ich wspólnemu przyjacielowi iście gombrowiczowską radę: „Możesz nadać sobie psuedopodium [seudopodio], pseudonim. W końcu to nie człowiek się nazywa, ale jego nazywają", po czym narrator dodaje od siebie: „Nie ma nic trudniejszego niż wytłumaczyć ten problem" ${ }^{365}$. Umieszczony w środku powieści Prolog epilogu jest przez argentyńskich krytyków interpretowany jako spadek po prologach z Museo de la Novela de la Eterna Macedonia, ale można w nim także widzieć analogię do dwóch przedmów z Ferdydurke. Podobnych rozsianych w tekście aluzji jest więcej, jednak głównym Gombrowiczowskim akcentem, scalającym chaotyczne wydarzenia powieściowe jest pochwała przypadku: von Paulus zajmuje się kombinatoryką, rachuje prawdopodobieństwo wydarzeń aż do czasu, gdy nieszczęsna dachówka (nawiązująca, zdaniem Airy, do demonicznego ręcznika z Opętanych ${ }^{366}$ ) burzy misternie sformalizowany porządek. Wprawdzie „[n]aukowcy to wielcy poeci naszych czasów”367, ale Minga! rozpoczyna się właśnie w momencie, w którym pełnia się wali: „Dachówka [La Teja] sprawiła, że relacja Pabla do Czasu [Tiempo] stała się nienormalna. Nazwijmy tę niewiadomą relację $\mathrm{T} / \mathrm{t}^{-1}$ "368 . Jego chaotyczna, niepowodowana żadnym choćby mgliście określonym celem włóczęga po pampie jest alegorią podróży po świecie, w którym matematyka raz po raz groteskowo zawodzi („Miłość jest asymetryczna - skwapliwie

\footnotetext{
363 V. Jorge Di Paola, Minga!, s. 172.

364 Ibid., s. 33.

365 Ibid., s. 98.

366 V. César Aira, El deseo de viajar.

367 Jorge Di Paola, Minga!, s. 22.

368 Ibid., s. 52.
} 
wyjaśnia w przypisie narrator $-\mathrm{A}+\mathrm{B} \neq \mathrm{B}+\mathrm{A}^{\text {”369 }}$ ). W innym miejscu Di Paola mówi à propos swojej powieści: „Czymże jest związek przyczynowo-skutkowy, jeśli nie wiem, czy król jest królem, bo siada na tronie, czy też siada na tronie, bo jest królem?"370. Królewski majestat, jego źródło, natura i egzekwowanie, przenosi nas w rewiry Gombrowiczowskiej formy i jej nieodłącznego korelatu - bezformia, którego przypadek byłby jedną z realizacji. Fakty wydarzają się w przypadkowym zetknięciu, są w gruncie rzeczy zbiegiem okoliczności, „fuksem”; albo są wywoływane, potęgowane bezzasadnie - jak „ręka kelnera” z Dziennika. Chaos jest innym wcieleniem niedojrzałości, dlatego von Paulus śni, że opracowuje Teorię Dojrzałości (Teoría de la madurez): „Nazwijmy te obserwacje tym, co znane. Nazwijmy znanym to, co postrzegamy ze zdziwieniem. Nazwijmy Pablem tę zaniepokojoną twarz w lustrze" ${ }^{\text {371 }}$. Niestety, bohater swoją Teorię gubi, przez co on sam pozostanie nieuleczalnie niedojrzały - „nazwijmy paniką bieżącą utratę wymiętoszonego rękopisu" "372 - a świat, w którym żyje, chaotyczny. Von Paulusowi, tak jak Witoldowi z Kosmosu, nie udaje się dopatrzyć konieczności lub choćby sensu w natłoku faktów, które nie dają się uporządkować w logicznych, wynikowych ciągach.

Minga! - tytuł można przełożyć jako „Figa z makiem!” - jest także powieścią, w której wiele wydarza się na poziomie języka, dlatego pewne jej niuanse nieuchronnie zgubiłyby się w tłumaczeniu. „Gdy ją czytam w całości, jest powieścią, gdy czytam tylko jedną stronę - jest poezją, pisał Sergio Bizzio ${ }^{373}$, bo Di Paola ma genialne wyczucie języka, miesza rejestry, odtwarza cudze głosy, gra brzmieniem i znaczeniem słów (cała powieść jest np. zbudowana wokół aliteracji głoski „t” - od

\footnotetext{
369 Ibid., s. 63.

370 Jorge Hardmeier, op. cit.

371 Jorge Di Paola, Minga!, s. 216.

372 Ibid. W scenie tej odnaleźć można co najmniej kilka Gombrowiczowskich detali - owinięty w ręc z n i k Pablo próbuje odtworzyć swoją teorię, zapisując ją na ścianie pogryzionym ołówkiem. Na koniec budzi go mól (una polilla), zdychający mu na czole. W argentyńskim tłumaczeniu Ferdydurke Miętusa przełożono jako Polilla.

373 Sergio Bizzio, op. cit.
} 
Teoría, Tiempo, Teja). Humor jest przy tym - Gombrowiczowskim wzorem - naczelną zasadą twórczą, bo śmiech to wprawdzie stygmat szaleństwa, ale także metoda zdystansowania się do rzeczywistości, która płata figle swoim bezładem. Język interesuje Di Paolę jako przestrzeń, w której rozgrywa się to, co międzyludzkie (Gombrowiczowski teatr spojrzeń jest tu praktycznie nieobecny), dlatego jest tak wrażliwy na językowe konwenanse, na rzeczy, które mówią się same. Idiolekty - szczególnie te, które są mocno osadzone w tradycji kulturowej - rozsiewają się, „przyklejają się” rozmówcy jak wtedy, gdy Pablo śni o spotkaniu z gauczowskim poetą i w konsekwencji sam zaczyna mówić ( $w$ formie i treści) kodem gauczowskich poematów. W tym sensie Minga! jest także gombrowiczowską nadliteraturą, tekstem zbudowanym „nad” i „z" innych tekstów, przede wszystkim z narracji la gauchesca, wciąż na nowo przepisywanej w literaturze argentyńskiej.

Język jest także problemem tej powieści na podstawowym poziomie twórczym: Jak opowiadać? Jak przełożyć treści wyobraźni na sferę intersubiektywną? Jak słowa stosują się do rzeczy? „Czemuż w umyśle Autora scena ta [snu jednego z bohaterów - E.K.P.] przedstawia się w idealnym obrazie zapłodnionego jaja, i tak trudno mu ją przenieść na poziom ludzki, słowny, wydrzeć ją postrzeganiu w tej formie? Jakże ciężkim zadaniem jest kontynuowanie tradycji opowiadania!" 374 . Problem języka pozostaje nierozstrzygalny - wszystkie rozwiązania narracyjne są tymczasowe i bezustannie domagają się wyjaśnień, komentarzy, dopisków, przez co wtrącający się co rusz Autor staje się jedną z pierwszoplanowych postaci: „Czytelniku, czyżbyś uważał, że ten esej Telefon i pasjanse jest nie na miejscu, wśród tylu niedokończonych jeszcze przygód? Przykro mi, ale zapewne rozumiesz, że żadna ludzka relacja z rzeczą nie jest prosta, i dlatego warta jest opowiadania" ${ }^{375}$. Tego rodzaju parateksty odpowiadają rozlicznym autokomentarzom, jakie Gombrowicz rozsiewał w swoim dziele (przede wszystkim w Dzienniku i Testamencie, ale także w powieściach) w celu eksplikacji własnej estetyki. Różnica polega na tym, że wykłada

374 Jorge Di Paola, Minga!, s. 130.

375 Ibid., s. 60. 
on ex cathedra, pewien swoich racji, natomiast Autor Di Paoli jest bardziej emocjonalny - śmieje się, martwi, zdumiewa - oraz mniej apodyktyczny. Sam Dipi w powieści nie występuje, ale typowe dla Gombrowicza utożsamienie z głównym bohaterem zachodzi właśnie poprzez postać Autora, który ucieleśnia wahania, obawy, ironiczną rezerwę i rozterki twórcze autora.

Kolejnym reprezentantem „szkoły duchowej” Gombrowicza jest inny „młody przyjaciel” z Tandilu, Néstor Tirri. W 1985 roku opublikował on powieść La piedra madre (Skała matka), w której „mistrz” pojawia się wprawdzie nie z nazwiska, ale z imienia (Witoldo), a dodatkowo kilka dość dobrze znanych anegdot rozwiewa całkowicie ewentualne wątpliwości co do pierwowzoru tej postaci. Powieść osadzona jest w Tandilu i opowiada historię osobliwego przedsięwzięcia: grupa sąsiadów organizuje się, by odtworzyć słynny ruchomy Kamień, cud natury, który w XIX wieku przyciągał do miasteczka turystów, a jego rekonstrukcja ma być lekarstwem na panujące tam marazm i zaściankowość. La piedra madre jest więc przede wszystkim fikcyjną kroniką Tandilu, utrzymaną $\mathrm{w}$ groteskowym tonie i atmosferze bliskiej realizmowi magicznemu, a pobyt Gombrowicza jest tu raczej wątkiem pobocznym i wyczerpuje się w jednym rozdziale. Opowiada on historię przyjazdu tajemniczego cudzoziemca, który zaprzyjaźnia się z „młodymi” - m.in. Marianem (Betelú), Pipim (Di Paolą) oraz narratorem (Tirrim) - którzy uznają „prestiż i sławę tego prawie nieznanego pisarza” ${ }^{376}$, a następnie wspierają go w zabawnym skądinąd zatargu z lokalną „elitą kulturalną”. Jak słusznie zauważa Pau Freixa Terradas, wraz z postacią Gombrowicza przenikają do powieści pewne charakterystyczne dla jego estetyki cechy i motywy: groteskowy ton ulega nasileniu, postać mistrza rozdwaja się, po czym w wyniku groteskowego pojedynku zostaje wyłoniony „ten prawdziwy"377. Wygłasza on diatryby przeciw poetom, nadaje swoim przyjaciołom pseudonimy, a ostatecznie - jak bohater opowiadania Przygody z tomu Bakakaj - odlatuje balonem. Tirri sprawnie wykorzystuje odgrywaną przez realnego Gombrowicza pozę, przerysowując ją

\footnotetext{
376 Néstor Tirri, La piedra madre, Galerna, Buenos Aires 2007, s. 96.

377 Pau Freixa Terradas, op. cit., s. 140 i 246.
} 
jeszcze w powieści - Witoldo jest tu ostentacyjnie teatralny, sztuczny i hrabiowski. Te walory La piedra madre mają jednak przede wszystkim wymiar wspomnieniowy i biograficzny - są zabawną wariacją na temat postaci „mistrza”, zręcznie wykorzystującą charakterystyczne dlań tendencje do zacierania granic pomiędzy życiem i dziełem. Trudno jednak dopatrzeć się w tej powieści jakichś nowatorskich reinterpretacji Gombrowiczowskiej estetyki, które dodatkowo byłyby znaczące dla powieści argentyńskiej ostatnich dekad xx wieku.

Powyższa ocena stosuje się także do powieści innego „ucznia” z Tandilu, Jorgego Vileli (1934-2014). La mañana del 10 de enero (Poranek 10 stycznia) ukazała się już po śmierci autora nakładem wydawnictwa argentyńskiej Biblioteki Narodowej w serii „Los Raros” (Osobliwi), której celem jest włączanie do obiegu wydawniczego książek z różnych powodów zapomnianych, a - zdaniem autorów serii - istotnych dla argentyńskiego kanonu ${ }^{378}$. Jak w przypadku Dipiego, symbolicznym początkiem interpretacji dzieła Vileli, punktem zaczepienia analizy, którą proponują we wstępie do powieści jej redaktorzy, pozostaje spotkanie z Gombrowiczem:

Vilela nawiązuje ze Starym [Gombrowiczem] związek miłosny właściwy uczniom i admiratorom, aż otrzymuje od niego nowe imię, w którym się rozpoznaje: nadanie imienia, w przypadku Marlona, określa cały jego los, czyli koncepcję życia, pomysł na literaturę, związek z pisaniem. Właśnie tam, w spotkaniu z Gombrowiczem, należałoby szukać [wytłumaczenia - E.K.P.] dla jego własnego pisarstwa i jego powieści, La mañana del 10 de enero ${ }^{379}$.

378 Trudno ocenić, na ile ten szczytny cel - włączenie autorów marginalnych, „osobliwych” do literackiego kanonu - udało się zrealizować. Od 2005 roku ukazało się w tej serii około pięćdziesięciu tytułów, przy czym szerzej rozpoznawalni pozostają pisarze skądinąd już uznani, jak Ezequiel Martínez Estrada lub Eduardo Wilde. W przypadku reszty autorów, w tym Jorgego Vileli, argentyńskiej Bibliotece Narodowej udało się nie tyle przedsięwzięcie „kanonizacyjne”, co skromniejsze zadanie „uchronienia przed zapomnieniem”.

379 Marcela Dimine, Emilio Bernini, Estudio preliminar. Literatura es lo que duele. Vilela, Gombrowicz y la escritura, w: Jorge Vilela, La mañana del 10 de enero, Biblioteca Nacional, Buenos Aires 2014, s. 11. 
Nowe imię, Marlon (od Marlona Brando), miało uwypuklać jego młodzieńcze rysy, ale także charakterystyczny dlań dystans do ludzi i skłonność do pozostawania z boku, obserwowania z ukosa głównego nurtu wydarzeń. Pierwsze spotkanie z „mistrzem” - akt inicjacji podobny do tego, który funduje przyjaźń z Dipim - urasta do rangi indywidualnej legendy, posiadającej różnorakie, mniej lub bardziej romantyczne wersje $\mathrm{e}^{380}$. Do tego mitu inicjacyjnego dochodzi późniejsze „wykluczenie” - Vilela miał stanowić, obok Dipego i Flora (Mariana Betelú), trzon paczki „młodych przyjaciół” z Tandilu, a w Dzienniku Gombrowicz prawie go pomija, brak jego świadectw w książce Rity Gombrowicz ${ }^{381}$, nie występuje również w słynnym filmie Alberta Fischermana Gombrowicz o La seducción.

Cień Gombrowicza faktycznie ciąży nad La mañana del 10 de enero, ale nie tyle we wspomnieniach jego osoby - wzmianek jest zaledwie kilka - co w następstwach nawiązanej wówczas przyjaźni, przede wszystkim w spotkaniach z Marianem i Dipim, które odliczają upływ czasu w mrowiu codziennych, powtarzalnych wydarzeń, stanowiących sedno tej powieści. Czas krąży w niej zresztą jak w spirali - teraźniejszość odsyła do przeszłości, lato 1971 do lata 1967 roku i poprzednich. Nie ma tutaj typowo Gombrowiczowskich fleksji, ani $\mathrm{w}$ warstwie tematycznej, ani formalnej, jednak autorzy wstępu powołują się na wpływ Polaka w sposobie pojmowania literatury i postrzegania własnego pisarstwa przez Vilelę, odwołując się nie wprost do mitu „pisarza przegranego", jaki krytyka argentyńska ukuła dla autora Ferdydurke. Vilela jest bowiem twórcą par excellence niespełnionym:

380 Vilela utrzymywał, że poznał Gombrowicza w noc wigilijną w 1957 roku, kiedy to spóźnił się na autobus, który miał go zawieść na rodzinną kolację. Miał wówczas spędzić noc na ławce w parku w towarzystwie Polaka; v. Marcela Dimine, Emilio Bernini, op. cit., s. 10. Gombrowicz nie wspomina o tym w Dzienniku, a Vilelę (Marlona) wymienia z imienia tylko raz, w 1960 roku. W Tandilu w 1957 odnotowuje spotkanie z „młodymi przyjaciółmi” (w tym być może z Vilelą): „O 5-tej stawili się, trzech chłopaczków, nie mających o mnie pojęcia i wypytujących, skąd się wziąłem w Argentynie”; Witold Gombrowicz, Dziennik 1953-1969.

381 Rita Gombrowicz, op. cit. 
jedyna opublikowana powieść ukazała się już po jego śmierci, a na dodatek opowiada o niemożności pisania („Dlaczego nie pisałem? Całe opowieści były niedokończone, a inne nawet nie zaczęte"382) i o serii tekstów zagubionych lub spalonych przez samego autora. Gombrowicz cieszy się w Argentynie sławą pisarza odrzuconego przez elitę, ale nieustępliwego w obronie własnych przekonań nawet za cenę wieloletniej nędzy - i ten sam mit kogoś, kto d obrow ol n i e (przede wszystkim poprzez destrukcję własnej twórczości) funkcjonuje na marginesie literackiego świata, stosuje się do Vileli. Z drugiej strony tym gestom autodestrukcji towarzyszy pragnienie odwrotne - zdobycia wydawcy: kolejne układy i umowy (zawsze niedoszłe do skutku) są w powieści szczegółowo odnotowywane. Naznaczona brakiem narracja literacka (na zmianę o poszukiwaniu wydawcy i zniszczeniu tekstu) przeplata się z narracją o braku bardziej fundamentalnym - środków do życia: Vilela opisuje drobiazgowo co udaje mu się zjeść, gdzie spać etc. W tym sensie bliski jest Gombrowiczowi z Kronosu, beznamiętnie rejestrującemu swoje literackie osiągnięcia na równi z kolacjami we Fragacie czy Sorrento.

Vilela poświęca autorowi Dziennika jeden tylko dłuży passus i to nie o „legendarnym” spotkaniu w Tandilu w 1957 roku, ale o ostatecznym rozstaniu, opowiedzianym w tonie sarkastycznej kpiny:

Stary [Gombrowicz] zrobił się wściekle (jak to w Buenos Aires bywa) modny dzięki wspaniałemu - dla rozkręcenia promocji i zwiększenia sprzedaży w Królowej La Platy [Buenos Aires - E.K.P.] - pomysłowi na to, by umrzeć [...] i to w miejscu dla nas bardzo wyrafinowanym, jakim są Alpy Nadmorskie na Lazurowym Wybrzeżu ${ }^{383}$.

Wiadomość o jego śmierci przynoszą gazety - Vilela dzwoni wówczas do Dipiego: „Rozmowa nie była długa - najniższa taryfa, trzy minuty, zmarnowaliśmy dwie" ${ }^{384}$. Cyniczna modulacja, z jaką Vilela opowiada o śmierci „mistrza”, jest z pewnością zapożyczona od niego samego

\footnotetext{
382 Jorge Vilela, La mañana del 10 de enero, s. 30.

383 Ibid., s. 169.

384 Ibid., s. 170.
} 
(znanego z „ekscentrycznego mówienia o tych i owych”385), ale sama anegdota wpasowuje się doskonale do powieściowej logiki porażki: rozgłos po śmierci Gombrowicza spływa po trosze na jego „uczniów”, pewien wydawca zainteresowany jest książką ze wspomnieniami o „Starym”, ale najpierw, „bo była już napisana i gotowa, miał wydać Nohaytutía [powieść Vileli - E.K.P.]" ${ }^{386}$. Z publikacji oczywiście nic nie wychodzi i Vilela kontynuuje odyseję swojej klęski.

Część interpretacyjną poświęconą „uczniom” Gombrowicza zamknąć wypada krótkim komentarzem na temat filmu w reżyserii Alberta Fischermana Gombrowicz o La seducción (representado por sus discípulos) z 1986 roku. Jego tytuł przetłumaczony został na polski jako Gombrowicz, czyli kuszenie ${ }^{387}$ lub Gombrowicz, czyli Pornografia ${ }^{388}$ (ten drugi przekład, choć mniej zgrabny, oddaje występujący w oryginale związek z Gombrowiczowską powieścią, która w pierwszym przekładzie na hiszpański otrzymała dość eufemistyczny tytuł La seducción, czyli „uwiedzenie”). Ten eksperymentalny film, rodzaj pseudodokumentu, w którym trudno rozdzielić fikcję od prawdy historycznej, został świetnie przyjęty przez krytykę i okrzyknięty jednym z najlepszych filmów argentyńskich lat 8o. Pierwszoplanowe role przypadły „uczniom” Gombrowicza (Alejandro Rússovichowi, Juanowi Carlosowi Gómezowi, Marianowi Betelú oraz Jorgemu Di Paoli), przy czym ich "gra” jest metaforyczna, ponieważ o d g r y w aj ą samych siebie wedle scenariusza Rodolfa Rabanala, który zakładał pewien wąski margines improwizacji ${ }^{389}$. Film został podzielony na kilku- i kilkunastominutowe sekwencje (o tytułach takich jak „Zagadka”, „Egzaminy”, „Choroby”,

385 Ibid., s. 169.

386 Ibid., s. 170.

387 V. Juan Carlos Gómez, Gombrowicz, czyli kuszenie, przeł. Rajmund Kalicki, „Twórczość" 2004, nr 4, s. 142.

388 V. idem, Kochani gombrowiczanie, przeł. Justyna Myszkowska, „Twórczość” 200o, nr 4, s. 151.

389 Jak notuje Rabanal w swoim dzienniku, ostateczny scenariusz był tworzony na podstawie rozmów z poszczególnymi „uczniami”: „[...] wszystkie te historie złożyły się w jedną. Kim był Gombrowicz dla Rússovicha? A kim dla Mariana i Dipiego?"; Rodolfo Rabanal, La vida escrita, Seix Barral, Buenos Aires 2014, s. 201. 
„Sława”, „Nietykalny król” lub „Kogo lubił bardziej?”), w których stopniowo powstają kolejne, sprzeczne ze sobą obrazy „mistrza” (wymagający, sztuczny, szyderczy, czuły, serdeczny etc.). Ich budulcem są przede wszystkim wspomnienia „uczniów” oraz dalszych przyjaciół ${ }^{390}$, czytane przez Rússovicha fragmenty Dziennika i listy Gombrowicza z Europy, przywoływane przez adresatów (przede wszystkim Gómeza i Betelú).

Osią filmu jest rozmowa czwórki „uczniów” przy kawiarnianym stoliku, przypominająca seans spirytystyczny, podczas którego przywołuje się ducha „mistrza” - po to, by w rezultacie ostatecznie go pożegnać i uwolnić się od niego. Kawiarniana sala przypomina scenę teatralną, a toczona przy stoliku rozmowa sztukę, której reżyserem byłby, koniec końców, sam „mistrz”. W jednej z końcowych scen Dipi, rozczarowany rezultatem spotkania, stwierdza gorzko: „Przyszedłem tu, by pochować Gombrowicza”, ale próba była, jak się domyślamy, nieskuteczna. Głównym problemem filmu nie jest bowiem twórczość Gombrowicza (choć autorzy niewątpliwie świetnie się w niej orientują, o czym świadczą liczne odniesienia do Pornografii, Ferdydurke i Dziennika, utrzymana w stylu gombrowiczowskiej groteski narracja, pojedynki słowne, natarczywe spojrzenia etc.), nie są nim w gruncie rzeczy także życie Polaka i jego argentyńskie przygody (mimo że anegdoty stanowią istotną część opowieści), jest nim natomiast ślad, jaki pozostawił po sobie w psychice swoich najbliższych przyjaciół: „[...] zaburzona tożsamość uczniów, nazbyt gorliwie i bezwarunkowo adorujących mistrza. Intuicja podpowiada nam (Albertowi i mnie), że mamy do czynienia z reinterpretacją Uczty" ${ }^{391}$. Film ma niewątpliwie cechy sokratejskie - „uczniowie” wspominają swoją młodość przy Gombrowiczu, dialogi i nauki, jakich im udzielił, raz po raz

\footnotetext{
390 W filmie występują także Adolfo de Obieta (syn Macedonia Fernándeza), Jorge Calvetti, Alicia Giangrande, Halina Grodzicka, Maria Świerczewska, Néstor Tirri i Miguel Grinberg.

391 Rodolfo Rabanal, op. cit., s. 213. We fragmentach swojego dziennika poświęconych pracy nad filmem Rabanal wielokrotnie wspomina o napięciach na planie filmowym i trudach współpracy z czwórką „Gombrowiczowskich egzegetów”; ibid., s. 212.
} 
powraca także motyw miłości homoseksualnej - ale na tym koniec: autor Ferdydurke nie był bowiem skłonny majeutycznie towarzyszyć swoim „uczniom” na drodze ku prawdzie, wolał inne, bardziej eksperymentalne metody. Dlatego spod typowo kawiarnianej atmosfery spotkania, śmiechów i kolejnych anegdot ze wspólnej przeszłości, wyziera najpierw coraz to bardziej kąśliwa ironia, a następnie jawny konflikt pomiędzy Rússovichem a Gómezem, zakończony słownym pojedynkiem, po którym ten pierwszy, ostentacyjnie i po gombrowiczowsku opuszcza kawiarnię.

Atutem Fischermana opowieści o Gombrowiczu jest zręcznie budowana atmosfera napięcia, specyficznego suspensu właściwego thrillerom (choć obecnemu także w Kosmosie i Pornografii), akcentowanego przez niepokojącą muzykę wrażenia, że za chwilę coś się w ydar zy. Efekt ten zostaje uzyskany dzięki nieustannym wahaniom pomiędzy dwoma przeciwstawnymi klimatami opowieści wspomnieniowej: z jednej strony mamy uczniów, apostołów mistrza, powołanych do głoszenia jego nauk oraz pogodne wspomnienia Polonii (Marii Świerczewskiej, Haliny Grodzickiej) o z gruntu serdecznym, choć ekscentrycznym pisarzu, a z drugiej - iście demoniczne imitacje „mistrza”, których po kolei próbują wszyscy kawiarniani rozmówcy, z wyjątkiem Dipiego. To on konstatuje, że w tym symbolicznym, teatralnym pow ta r zan i u Gombrowicza jest coś złowieszczego i chorobliwego, i wrażenie to pozostaje pomimo jednej z końcowych scen, w której wszyscy z jednej miski radośnie siorbią kompot. W filmie Fischermana nic nie jest bowiem rozstrzygnięte ani wyjaśnione - zagadka „tajemnego dzieła” Gombrowicza, jego „duchowej szkoły” pozostaje. „Kompot wyjaśnił mi wszystko. Tak samo, jak zbabrałem kompot zamieniając go w rozwiązłą papkę, tak też mogłem zniszczyć nowoczesność pensjonarki, doprowadzając do niej pierwiastki obce, heterogeniczne, mieszając, co wlezie"392.

392 Witold Gombrowicz, Ferdydurke, s. 129. Sukces filmu Fischermana przyczynił się do powstania kolejnych obrazów poświęconych „argentyńskiemu Gombrowiczowi”: dokumentu Gombrowicz, l’Argentine et moi (1998) w reżyserii Alberto Yacceliniego (film składa się z serii wywiadów, m.in. z Rússovichem, Di Paolą, Grinbergiem i Saerem), El ojo Witoldo (1999) w reżyserii Pauli Kleinman oraz, pośrednio, polskiego Listu z Argentyny (1997) Grzegorza Packa. 


\section{Koło Gombrowicza}

Występujący w filmie Rússovich nie należy, ściśle rzecz ujmując, do grona „młodych przyjaciół” - jego przyjaźń z Gombrowiczem jest wcześniejsza (datuje się na lata 40. i epokę przekładu Ferdydurke), a ponadto jest dużo straszy od pozostałej trójki. To starszeństwo widać zresztą w filmie - to on najczęściej (i najlepiej ${ }^{393}$ ) odgrywa Gombrowicza, parodiuje jego gesty oraz charakterystyczny, sztuczny tembr głosu i polski akcent. Rússovich stanowi za to punkt styczny z kolejnym ośrodkiem powołanym do interpretacji i popularyzacji twórczości Polaka, a mianowicie z Círculo Gombrowicz (Kołem Gombrowicza), powstałym w początku lat 9o. przez Gérmana Garcíę. Jego aktywność nie była specjalnie prężna, ale niewątpliwie Koło zdołało skupić kilkoro intelektualistów, którzy podjęli się lektury i komentarza (w formie krytycznej, eseistycznej lub powieściowej) Gombrowiczowskiego dzieła i legendy. Linia interpretacyjna rozwijana przez Rússovicha - stosująca pryzmat wielkich pojęć filozoficznych - została już przeze mnie omówiona wyżej, przy okazji komentowania instytucjonalnego (podręcznikowego) umocowania Gombrowicza jako pisarza argentyńskiego. Rússovich rozwija ją także w innych tekstach, np. w ¿Quién es Witold Gombrowicz? ${ }^{394}$ (Kim jest Witold Gombrowicz?), w którym umieszcza go w kontekście wielkich nazwisk filozofii od starożytności po współczesność (m.in. Platona, Arystotelesa, Hegla, Wittgensteina i Heideggera), cytuje obszerne fragmenty tekstu „Aurory” („Aurora. Revista de la Resistencia”) oraz definiuje pojęcie formy jako nieusuwalnego wymiaru istnienia: „Być byciem to być formą. Nie ma wyjścia, nie ma sposobu na zażeganie tego konfliktu, bo to on nas stwarza"395.

Innym członkiem Círculo Gombrowicz był Tomás Abraham, profesor filozofii na Uniwersytecie w Buenos Aires, który pisze o autorze

\footnotetext{
393 Rabanal konstatuje parodystyczny talent Rússovicha, porównując jego imitacje z oryginalnym głosem Gombrowicza nagranym na taśmie, udostępnionej mu przez Ritę Gombrowicz; v. Rodolfo Rabanal, op. cit., s. 212.

394 V. Alejandro Rússovich, ¿Quién es Witold Gombrowicz?, w: Tomás Abraham (red.), Vidas filosóficas, Eudeba, Buenos Aires 1999, s. 313-326.

395 Ibid., s. 320.
} 
Ferdydurke w obszernym eseju Los polacos (Polacy), opublikowanym w dość heterogenicznym tomie Fricciones (Tarcia) ${ }^{396}$. Gombrowicz jest tu punktem wyjścia do refleksji o przedwojennej Polsce, jej związkach z kulturą żydowską oraz wschodnioeuropejską imigracją do Argentyny. Na poziomie studiów z zakresu gombrowiczologii (które stanowią tylko jeden $\mathrm{z}$ wielu poruszanych przez Abrahama wątków), tekstem tym rządzą dwie sprzeczne intencje: $z$ jednej strony autor dąży do odzyskania czy zadośćuczynienia „argentyńskości” tego pisarza ${ }^{397}$, czemu służy np. periodyzacja jego pobytu w Buenos Aires i wskazywanie analogii pomiędzy Polską i Argentyną, z drugiej natomiast osadza jego legendę i dzieło w polskiej przedwojennej tradycji kulturowej i literackiej, w klimacie zdominowanym przez twórczość autorów tworzących "postnietzcheańskie trio" ${ }^{398}$, w skład którego, prócz autora Trans-Atlantyku, wchodzili Bruno Schulz oraz Witkacy. Jego wywód dodatkowo komplikuje fakt, że losy tych trzech pisarzy stają się pretekstem dla narracji historycznej poświęconej życiu wspólnoty polskich Żydów przed i po Auschwitz, przez co w długich pasażach wątek Gombrowiczowski zatraca się całkowicie. W dziedzinie badań nad obecnością polskiego pisarza w Argentynie niewątpliwą zaletą tego skądinąd dość chaotycznego studium jest kilka celnych uwag na temat estetyki i filozofii Polaka, w szczególności nacisk na pojęcie pozy, którą w tym samym czasie także César Aira uczynił jedną z centralnych kategorii Gombrowiczowskiego uniwersum ${ }^{399}$. Poza, teatralne odgrywanie siebie - jakże charakterystyczne dla argentyńskiego ducha - jest według Abrahama podstawową regułą społecznego funkcjonowania oraz jedyną metodą utrzymania wewnętrznej spójności „ja”.

\footnotetext{
396 V. idem, Los polacos, w: idem, Fricciones, Sudamericana, Buenos Aires 2004, S. $11-105$.

397 „Gombrowicza uratowała Argentyna. Komentatorzy i wydawcy z całego świata, w szczególności polscy i francuscy, uznają ten fakt bardzo niechętnie. A jeśli w końcu to robią, to tylko dlatego, że sam Gombrowicz nie przestawał o tym mówić"; ibid., s. 18.

398 Ibid., s. 95.

399 V. César Aira, Prólogo, w: Juan Carlos Gómez, Gombrowicz, este hombre me causa problemas.
} 
Działalność Círculo Gombrowicz zaowocowała powstaniem dwóch powieści, w których argentyńska legenda polskiego pisarza (świadomie przerobiona i zniekształcona) posłużyła za kanwę opowiadanej historii. Pierwszą z nich jest Witoldo o la mirada extranjera (Witoldo lub spojrzenie cudzoziemca) Guillerma Davida z 1998 roku, wydana, co znamienne, w serii esejów argentyńskiego wydawnictwa Colihue. Ta „protopowieść nadeseistyczna” (protonovela supraensayística), jak nazywa ją sam autor, jest bowiem przyczynkiem do rozważań na temat literatury, tożsamości narodowej, psychoanalizy i filozofii utrzymanym w tradycji właściwej Piglii (jego słowa: „Krytyk jest awanturnikiem, który przemieszcza się wśród tekstów, poszukując sekretu, który czasem nie istnieje”, są mottem tej powieści), przy czym ciężki i przeładowany styl Davida kontrastuje z przejrzystą frazą autora Sztucznego oddychania ${ }^{400}$. Gros akcji stanowi rozmowa pomiędzy dwoma pisarzami, przerywana dodatkowo długimi refleksjami autora, które z jednej strony wiernie odtwarzają historyczno-społeczne realia (pobyt Gombrowicza w Argentynie, jego konflikt z „Sur”, analizy jego powieści, literacką trajektorię José Bianco), z drugiej natomiast mnożą nazwiska i koncepty, nazbyt ostentacyjnie dowodząc erudycji samego Davida.

Akcja Witoldo o la mirada extranjera rozgrywa się na krótko przed powrotem Gombrowicza do Europy, a więc w końcu jego argentyńskiej tułaczki i w przededniu światowej sławy. Powieść ta jest wariacją na temat Pornografii: dwóch dojrzałych mężczyzn (w powieści podkreśla się ich powolną degradację fizyczną), Witold Gombrowicz i José Bianco, przybywają do domu na prowincji, gdzie po jakimś czasie dociera także młoda dziewczyna Lila, której niedojrzałość wprowadza rodzaj erotycznego napięcia i burzy pokojową, opartą na intelektualnej rozmowie koegzystencję mężczyzn. Dialektyka starość-młodość jest więc tutaj jasno zarysowana, odbywa się „[ś]ciąganie w dół dwóch starszych panów... w ciało, zmysły,

\footnotetext{
400 Podzielam w tym względzie osąd Pau Freixy, który krytykuje Davida m.in. za pretensjonalny, nazbyt kwiecisty styl; v. Pau Freixa Terradas, op. cit., s. 173-176 i 257 .
} 
nieletniość..." ${ }^{401}$ (gdy np. Lila, wzorowana skądinąd także na Zucie Młodziakównie, pozwala podejrzeć się nago pod prysznicem).

Zanim jednak pojawia się Lila, obaj panowie toczą długie rozmowy o literaturze, podczas których Bianco - przyszły tłumacz Opętanych na hiszpański - wykłada Gombrowiczowi swój wieloletni literacki projekt, związany z historią Enocha Soamesa, tytułowego bohatera opowiadania Maxa Beerbohma. W ostatniej dekadzie XIX wieku narrator tego tekstu, czyli sam Beerbohm, spotyka niezbyt uzdolnionego poetę Soamesa, tak obsesyjnie pragnącego upewnić się o ważkości własnego dzieła, że gotowego zawrzeć pakt z diabłem: ten pozwala mu przenieść się o sto lat w przyszłość, by w czytelni Brytyjskiego Muzeum mógł ocenić rozmiary swojej pośmiertnej sławy, a w zamian zabiera jego duszę do piekła. Soamesowi faktycznie dane jest spędzić jedno czerwcowe popołudnie 1997 roku w tym szacownym przybytku, ale odkrywa tam rzecz dla siebie tragiczną: dla potomności istnieć będzie jedynie jako fikcyjny bohater satyrycznego opowiadania niejakiego Maxa Beerbohma - mierny poeta, przekonany o własnym talencie ${ }^{402}$. Powieściowy Bianco dopowiada do tego własną historię spotkania z Ezrą Poudem, zamkniętym pod koniec życia w przytułku we włoskim Rapallo. Wiele lat po tym spotkaniu przyszły tłumacz Opętanych dowiaduje się przypadkiem, że w tym samym czasie słynnego poetę odwiedził jeszcze inny, tajemniczy mężczyzna, opisem przypominający Enocha Soamesa, którego Poud po krótkiej rozmowie wyrzuca, obrzucając obelgami. Bianco wyobraża sobie, że faktyczne chodziło o niespełnionego poetę, który bezskutecznie przyszedł prosić wielkiego Pouda o wstawiennictwo i uratowanie od istnienia li tylko na kartach opowiadania Beerbohma. W typowo argentyńskim (borgesowskim) geście Bianco razem z Virgiliem

\footnotetext{
401 Witold Gombrowicz, Dziennik 1953-1969. David cytuje wiele ustępów z Dziennika poświęconych interpretacji Pornografii. Drugim Gombrowiczowskim dziełem silnie obecnym w tej powieści jest Ferdydurke.

402 Max Beerbohm, Enoch Soames, przeł. Rodolfo Walsh, https://goo.gl/7K5q3y, dostęp: 3 I 2017.
} 
Piñerą, Héctorem Mureną, Rodolfo Walshem i Martínezem Estradą postanawiają uratować Soamesa, „wymyślić mu biografię, dzieło i bogaty komentarz krytyczny, by buńczucznie sprzeciwić się potomności” ${ }^{403}$, choć pomysłu tego nie udaje im się zrealizować, „co wzmacnia tylko tezę opowiadania" ${ }^{404}$ - Soames pozostaje postacią fikcyjną. W jego emblematycznej figurze Bianco dostrzega „staranną konstrukcję własnej klęski”405, która nawiedzała wielu argentyńskich pisarzy, zdławionych przeczuciem niespełnienia lub sparaliżowanych myśleniem o przemijaniu i o losie własnego dziedzictwa. Historia Soamesa jest także paralelą argentyńskiego losu Gombrowicza, dlatego Bianco niechętnie przyjmuje jego propozycję zaangażowania w intrygę fałszywej biografii: „dostrzegał w nim [...] charakter zbyt podobny do tego, który posiadał duch Soamesa: niewystarczający dystans krytyczny wykluczał go jako autora [intrygi - E.K.P.]" ${ }^{406}$.

Problematyka Witoldo o la mirada extranjera bazuje na odmiennych sensach, jakie obaj pisarze nadają historii Enocha Soamesa, przykładając ją do własnej biografii niczym jej niepokojącą, fatalną matrycę. Niestety czytelnik tej powieści gubi się ostatecznie w mnogości sugestii, metafikcyjnych aluzji i interpretacyjnych możliwości podsuwanych przez narratora oraz postaci, a niezmierzających, jak się wydaje, w kierunku jakichś konkretnych wniosków lub choćby supozycji. Wydaje się, że słynący ze swojej skromności Bianco - przez lata znany bardziej jako sekretarz „Sur” i świetny tłumacz aniżeli autor własnych tekstów - nie unika ostatecznie „syndromu Soamesa”, pragnienia uznania w oczach potomnych. Z kolei w decyzji Gombrowicza o zaangażowaniu w ten „literacki spisek” można widzieć kpiny z instytucji literatury i niektórych jej imperatywów (jak w Przeciw poetom), prztyczek dla autora Alefa (powieściowy Gombrowicz sugeruje, że historia Soamesa jest w rzeczywistości wymysłem

\footnotetext{
403 Guillermo David, Witoldo o la mirada extranjera, Colihue, Buenos Aires 1998, s. 103.

404 Ibid.

405 Ibid., s. 100.

406 Ibid., s. 164.
} 
Borgesa i Bioya, pierwszych tłumaczy opowiadania Beerbohma na hiszpański), ostatecznie można się w niej także dopatrywać perwersyjnej gry z młodością, do której należy tak pożądana przez Soamesa przyszłość. Z tej perspektywy wizytę Gombrowicza w domu na prowincji w przededniu powrotu do Europy można także rozumieć jako próbę naprawienia błędu, który polegał na nieumiejętności znalezienia w Argentynie współczesnych sobie rozmówców i odkładaniu „Zrozumienia” własnego dzieła na przyszłość:

Była to ostatnia okazja [...], by [Bianco - E.K.P.] odpowiedział na pretensje tego głosu, który z pychą domagał się usłyszenia, pozostawienia śladu w pamięci innych - jedynego dopuszczalnego dla ludzkiego plemienia rodzaju trwania. Tak jak Soames, który udał się z prośbą do Pounda [...], tak Gombrowicz - dopiero teraz to zrozumiał! - przychodził do niego, do José Bianco, w tajemnicy [...], by potwierdzić swoje imię, poczuć jak rezonuje w legitymizujących słowach, które tworzą pamięć ludzi ${ }^{407}$.

Drugą powieścią powstałą przy Kole Gombrowicza jest opublikowana w 2004 roku La fortuna (Los) Gérmana Garcíi - założyciela i koordynatora tej filozoficzno-literackiej tertulii, a także autora związanego z wyżej omawianą grupą „Literal”. Odmienna w stylu od wcześniejszych powieści tego autora La fortuna - o bardziej klasycznej narracji i mniej prowokacyjna w warstwie obyczajowej - jest opowieścią inspirowaną przede wszystkim życiem autora, a w mniejszym stopniu jego lekturami Gombrowicza. Ten autofikcjonalny chwyt jest obecny w twórczości Garcií już od pierwszej powieści Nanina, która opowiada o dzieciństwie w prowincjonalnym Junín, a w La fortuna służy do fikcjonalizacji doświadczenia wygnania z lat 70. i 80. Główny bohater, Federico Braun Fernández, alter ego autora, jest zmuszony opuścić Argentynę z obawy przed represjami za zaangażowanie (zresztą podejmowane przezeń bez większego przekonania) w działalność lewicowych organizacji politycznych. W samolocie do Europy spotyka Cadlera, który skłania go, by udał się do Barcelony, którą on sam

407 Ibid., s. 167. 
wybrał na miejsce swojego wygnania. Cadler jest Polakiem, który ojczyznę opuścił wiele lat temu, mieszkał m.in. w Argentynie, gdzie poznał autora Ferdydurke:

Razem z Witoldem Gombrowiczem, przez blisko rok utrzymywali się w Buenos Aires bardzo prostym sposobem: co noc uczestniczyli w stypach, o których dowiadywali się z gazet. Przyglądali się zmarłemu, ściskali dłonie tych, którzy wyglądali na krewnych i przechodzili do kuchni. Tam jedli, pili, a potem - na szachy, z dala od Rexa, do którego Gombrowicz chodził z innymi osobami, których Cadler nie znosi ${ }^{408}$.

Z Gombrowiczem łączy go, bardziej niż te faktograficzne szczegóły, skrzyżowanie losów w dalekiej Argentynie - specyficzna konceptualizacja wygnania i narodowego wykorzenienia (Cadler odcina się nawet od polskiego nazwiska), które przestają być fatalnym zrządzeniem losu, by stać się życiowym wyborem, pożądaną kondycją ludzką. Pseudonim "Cadler” odsyła zresztą do twórcy mobilów - rzeźb istniejących w ruchu, zmiennych, pozbawionych statycznej formy, która by je określała jako „wyjściowa” lub „naturalna”. Ten ambiwalentny stosunek do ojczyzny - dość wyjątkowy w latach dramatycznego rozrostu argentyńskiej diaspory - adaptuje także Braun, któremu przy p a d ki e m wybrana Barcelona bez trudu zastępuje ojczyste miasto, tak jak pr zy p a d kow a podróż do Buenos Aires uratowała Gombrowicza od pancerza narodowej formy.

Sam polski pisarz nie jest sensu stricto postacią w La fortuna, choć jej narrator raz po raz natrafia na jego ślady w swojej autobiograficznej opowieści: Braun rozmawia o nim z Cadlerem, kiedy poznają się w samolocie, po powrocie do Argentyny zaprzyjaźnia się z Alicją Giangrande ${ }^{409}$, poznaje także Juana Carlosa Gómeza, którego nie darzy specjalną estymą, wspomina o wizycie polskiego profesora, autora Gry w Gombrowicza, o obrazie Fischermana i o polskich filmowcach

408 Germán García, La fortuna, Ediciones de la Flor, Buenos Aires 2004, s. 125. Historia o stołowaniu się na stypach jest prawdziwa; v. Witold Gombrowicz, Testament.

409 Malarka Alicja Giangrande była przyjaciółką Gombrowicza w Argentynie. 
kręcących żartobliwy List $z$ Argentyny ${ }^{410}$. Gombrowicz jako postać historyczna jest w tej powieści, skupionej na opowiadaniu doświadczenia migracji, wątkiem marginalnym, ale uporczywie obecnym jako luźne skojarzenie (np. wzmianka o Tandilu natychmiast uruchamia asocjacje $\mathrm{z}$ autorem Pornografii ${ }^{411}$ ) lub pretekst do gawędy o sobie, utrzymanej w rytmie kawiarnianej rozmowy, spotkań, przyjaźni i konfliktów. Warto na marginesie odnotować, że w tradycyjnym dla argentyńskiej perspektywy lekturowej stylu narrator podejmuje kwestię literackiej porażki Gombrowicza jako zamierzonego projektu, planowanej i pożądanej strategii, której celem miałaby być niezależność, uniknięcie wessania na równi z innymi literackimi nowinkami, tak entuzjastycznie przyjmowanymi w intelektualnie zacofanym Buenos Aires. „Braun był pewien: Gombrowicz umiał sprawić, by Argentyńczycy go odrzucili, bo ich akceptacja byłaby końcem jego literatury”412. Tezę o tej „skonstruowanej klęsce" Braun powierza Adolfowi Obiecie i Ricardowi Piglii, którzy oczywiście ją podzielają.

Luis Gusmán (ur. 1944) nie należał wprawdzie do Koła Gombrowicza, ale - zważywszy na jego powiązania z Germánem Garcíą z czasów „Literal” - do jego ostatnich tekstów o Gombrowiczu nawiążę przy tej okazji. W 2015 ukazała się jego La ficción calculada 2 (Fikcja skalkulowana 2), przeredagowana i uzupełniona - m.in. o komentarze poświęcone autorowi Ferdydurke - wersja zbioru esejów opublikowanego po raz pierwszy w 1998 roku. Gombrowicz jest głównym bohaterem dwóch tekstów, ale jego nazwisko przewija się często w kontekście innych autorów, a całość opatrzona jest mottem z Dziennika: „Nie w tym rzecz, aby nie było błędów językowych - ale w tym, aby błąd nie hańbił”. Esej zatytułowany El artista polaco. Las moscas ${ }^{413}$ (Polski artysta. Muchy) składa się z krótkich fragmentów, w których obficie cytuje się autobiograficzne utwory Polaka - Testament i Diario argentino - by

\footnotetext{
410 V. Germán García, La fortuna, s. 245-255.

411 Ibid., s. 276.

412 Ibid., s. 254.

413 Luis Gusmán, El artista polaco. Las moscas, w: idem, La ficción calculada 2, Ediciones Godot, Buenos Aires 2015, s. 79-100.
} 
odtworzyć Gombrowiczowskie miejsca wspólne, sposoby istnienia w przestrzeni publicznej (autoprezentacje) i metody twórcze. Tytułowe muchy (pojawiające się już w manifeście „Literal”414) są najpierw przywołane jako symbol przytłaczającego swą przyziemnością życia, które wiedzie artysta, podczas gdy „zamieniony w kulturę utwór bujał na wysokościach" ${ }^{115}$. Następnie, za sprawą innego cytatu, mucha - denerwujący atrybut egzystencji do bólu trywialnej - zaczyna konotować sam b ó l, moment, w którym tak hołubiona cielesność wynaturza się: Gombrowicz zabija muchy drucianą packą. „Naturalnie nie wszystkie uśmiercam od razu - niektóre, silnie pokiereszowane, upadają na podłogę i co pewien czas odkrywam taką muchę, pozostawioną sam na sam $\mathrm{z}$ konaniem" ${ }^{\text {416. }}$.

Następnie luźno ze sobą powiązane sceny lub obrazy literackie przedstawiają odsłony kolejnych „Gombrowiczów”, których Gombrowicz wystawia na scenie swojego Dziennika. Najciekawszym jest „artysta infiltrowany” (artista infiltrado), przeciwieństwo „artysty wygnanego" (artista exiliado), bo zamiast wydobywać typowe dla tego ostatniego skojarzenia, takie jak obcość lub egzotyka, wynosi pisarza, który wnika wewnątrz istniejących, okrzepłych grup literackich interesów, by ironią i błazenadą rozsadzić je od wewnątrz: najpierw establishment „Sur”, potem, w latach 6o. i 70., środowisko domagające się społecznego zaangażowania sztuki. Infiltracja jako główny rys Gombrowiczowskiego sposobu istnienia w literackim świecie Buenos Aires przywodzi na myśl artystę-spiskowca, którego w autorze Pornografii dostrzegał Ricado Piglia. Dla Gusmána Gombrowicz pozostaje nade wszystko pisarzem w ciągłym ruchu przeciwko - zarówno temu, co narzucane z zewnątrz („dlatego pozostaje w stanie ciągłej dialektycznej sprzeczności z teraźniejszością swojej epoki”417), jak i temu,

\footnotetext{
414 „W kluczowym momencie powieści (jak mówi nam Gombrowicz) przeszkadza braciszek, mucha zaczyna bzyczeć właśnie wtedy, gdy czytelnik dociera do punktu kulminacyjnego: i efekt stracony"; No matar la palabra y no dejarse matar por ella, s. 8.

415 Witold Gombrowicz, Testament.

416 Idem, Dziennik 1953-1969.

417 Luis Gusmán, El artista polaco, s. 89.
} 
co podsuwa mu własna forma. Aktor, prowokator, nigdy nie opuszcza gardy, „zawsze ma w zanadrzu jakąś wybuchową metaforę" ${ }^{18}$, by podgryźć u for mow an e, porządkujące narracje.

W drugim, krótszym tekście z La ficción calculada 2, zatytułowanym Escrito con vergüenza (Napisane ze wstydem), Gusmán - z zawodu psychoanalityk - nawiązuje do odnotowanej w Dzienniku anegdoty o tym, jak Gombrowicz poślinionym ołówkiem bazgrze po ścianie ustępu przy ulicy Callao ${ }^{419}$. Drobne atrybuty tej sceny, takie jak kolor ołówka, sama ściana, atmosfera wstydliwego podniecenia przywodzą Gusmánowi na myśl inne obrazy: portret Sigmunda Freuda, opowiadanie Grahama Greena, własne wspomnienie z młodości, które od tej pory rezonują z historią nieprzyzwoitego graffiti. „Tyle lat zmarnowałem, nie znając rozkoszy równie taniej i pozbawionej wszelkiego ryzyka", pisze Gombrowicz, a Gusmán dodaje, że podniecające ryzyko nie brało się wcale z niebezpieczeństwa wykrycia sprawcy, lecz właśnie z możliwości samotnego, anonimowego przeżywania tej nieznanej wcześniej rozkoszy, „nieprzytomnej zachcianki”420. Zawstydzony Gombrowicz, oscylujący między wyznaniem i zatajeniem, wstydem i ostentacją jest dopełnieniem Gombrowicza-prowokatora, który towarzyszy Gusmánowi od czasów „Literal”.

\section{„Prowincjonalne kręćki”}

Najnowsza literatura argentyńska „pisze Gombrowiczem” także teksty o całkowicie odmiennej poetyce, wprawdzie również ufundowane na toposie „spojrzenia z zewnątrz”, ale w tym wypadku spojrzenie to nie jest skierowane w stronę buenosariańskiej elity, lecz prowincji. Jego podróże po kraju, dyktowane raczej zdrowiem niż ciekawością egzotyki, pozwoliły mu - jak wyżej pisałam - poszerzyć pojęcie argentyńskości, przez samych Argentyńczyków definiowane wyłącznie w odniesieniu

\footnotetext{
418 Ibid., s. 91.

419 Idem, Escrito con vergüenza, w: idem, La ficción calculada 2, s. 119-123.

420 Witold Gombrowicz, Dziennik 1953-1969.
} 
do rozrastającego się obwodu stolicy oraz do literackich wyobrażeń pampy, o miejsca kulturowo odległe, wypchnięte z wyobrażeniowego obrazu „siebie”, bo jawnie z nim sprzeczne. W Santiago del Estero, Tandilu, Córdobie lub Mar del Plata Gombrowicz, sam będący wcieleniem „inności”, spotyka innych „innych”: prowincjonalnych intelektualistów, lewicowych guerrilleros i obrońców ludności tubylczej, których poglądy i działalność nie mieszczą się w argentyńskości oficjalnej, definiowanej z centrum tej kultury. „Przyglądałem się wówczas - pisze w Dzienni$k u$ - wszystkim kręćkom, zadrażnieniom i zahamowaniom tej zabitej prowincji, duszonej we własnym sosie"421. W każdej miejscowości, w której zatrzymuje się na dłużej, powtarza ten sam rytuał prezentacji: „domaga się kontaktu z lokalną klasą kulturalną - jak to czyni w Buenos Aires - czym otwiera zaskakujący rozdział uszczypliwych uwag o tej odległej faunie intelektualnej, naznaczonej przeżutą postępowością, głuchym prowincjonalizmem, egzaltacją, skrywającą nieodkryte skarby" ${ }^{\prime 22}$. Nawiasem mówiąc, na prowincję także przybywa niezaproszony - jak w 1939 roku do Buenos Aires - choć, rzecz jasna, zostaje cieplej przyjęty niż w stolicy ${ }^{423}$, a taki nieoficjalny tryb pobytu sprzyja nawiązywaniu i kultywowaniu znajomości nieoczywistych, niewymuszonych rachunkiem zysków i strat w symbolicznym kapitale „kontaktów”.

Jednym z takich przypadkowych i niezwykłych spotkań, w których los zdaje się działać według nieprawdopodobnej, fantastycznej logiki właściwej bardziej powieściom niż życiu, było spotkanie z Robertem Santuchem, wówczas młodym chłopakiem, ale zaledwie dekadę później przywódcą lewicowej guerrilli Ejército Revolucionario del Pueblo (Rewolucyjne Wojsko Ludowe). W Dzienniku i Podróżach po Argentynie pisarz kilkakrotnie wspomina o licznej rodzinie Santucho,

421 Ibid.

422 Horacio González, Restos pampeanos. Ciencia, ensayo y política en la cultura argentina del siglo XX, Colihue, Buenos Aires 1999, s. 400; wyróżnienie w oryginale.

423 Borges, dla przykładu, dwukrotnie odwiedził Santiago del Estero, ale zawsze oczekiwany przez tamtejszą elitę: w 1949 roku na zaproszenie Canala Feijóo wygłasza serię trzech wykładów na lokalnych salonach; powraca, także z wykładami, w roku 1969. 
w szczególności o bracie Roberta, Francisco Rene, który pewnego popołudnia prawi mu w santiageńskim barze o indiańskim dziedzictwie lokalnej kultury, podczas gdy Gombrowicza ponosi „natężenie piękności tutejszej" ERP wspomina w Dzienniku dwa lata później, gdy ten pisze do niego z prośbą o przesłanie egzemplarza Ferdydurke i poucza przy okazji, co powinien zmienić w swojej koncepcji niedojrzałości i podrzędności („Nie możesz zrozumieć, że najważniejsza »obecnie« jest sytuacja krajów niedorozwiniętych"425). Podirytowany tą bezczelnością Gombrowicz, z niezwykłą przenikliwością pisze o Robym, że to „żołnierz urodzony, nadający się do karabina, okopów, konia”, i niezwykle trafnie przewiduje jego dalsze losy:

Ręka gotowa zabić w imię dzieciństwa. Przedłużeniem bzdury, przez niego rojonej, był skrwawiony bagnet... Dziwna istota - o głowie zamroczonej i błahej, o ręce groźnej. Nasunęła mi się myśl, niezbyt wyraźna i nie domyślana, którą jednak pragnę tutaj zanotować... To brzmiałoby mniej więcej tak: jego głowa jest wypełniona chimerami, więc godna politowania; ale jego ręka ma dar przetwarzania chimer w rzeczywistość, jest zdolna do stwarzania faktów. Nierzeczywistość zatem od strony głowy, rzeczywistość od strony ręki... i powaga od jednego końca ${ }^{426} \ldots$

W połowie lat 70. dowodzona przez Roby'ego marksistowsko-leninowskia ERP dokona szeregu porwań dla okupu i krwawych zamachów w różnych częściach kraju, a sam Santucho zginie w zamachu w 1976 roku. Jego „zbrodnicza ręka” nawiedzać będzie Gombrowicza jeszcze w Berlinie, gdzie skonstatuje, zgodnie z ideą wiecznego powrotu tego samego, istnienie powojennych, niepokojących blizn po aberracjach cywilizowanego rozumu ${ }^{427}$.

Opisana w Dzienniku znajomość z Robym Santuchem i krótka wymiana telegramów stała się inspiracją dla powieści epistolarnej

\footnotetext{
424 Witold Gombrowicz, Dziennik 1953-1969.

425 Ibid.

426 Ibid.; wyróżnienie w oryginale.

427 V. ibid.
} 
Luisa Mattiniego Cartas profanas (Bluźniercze listy) z 2008 roku. Sam Mattini (właśc. Juan Arnol Kremer, ur. 1941), argentyński intelektualista i guerrillero, był bezpośrednim następcą Santucha na stanowisku szefa ERP. Powieść ta, powstała po upływie ponad trzech dekad od opisanych wydarzeń, jest dla niego platformą do rewizji przeszłości, w szczególności ideałów argentyńskiej lewicy lat 60. i 70., dokonanej z samego jej wnętrza - Mattini dystansuje się do ideologii wyznawanej przezeń w tamtej epoce, co jest zresztą godne odnotowania, bo hekatomba dyktatury zwykle ucina wszelkie próby krytycznego przemyślenia dogmatów argentyńskiej lewicy. Cartas profanas nawiązują do popularnej w latach 7o. literatury świadectwa, której celem było sabotowanie oficjalnej wersji wydarzeń, uznanej za zmanipulowaną lub po prostu fałszywą. Specyficzny charakter narracji-świadectwa, prowadzonej przez doświadczoną przez los i Historię jednostkę, opowiadającą prawdziwą, traumatyczną historię, której ona sama jest bohaterem i ofiarą, sytuował ten tryb opowiadania poza zasięgiem krytycznego osądu: jak piętnować estetyczne niedociągnięcia wobec bezmiaru opisanej tragedii, jak wytykać drobne nieścisłości faktograficzne wobec autorytetu pierwszej osoby - świadka lub bohatera wydarzeń ${ }^{428}$ Mattini unika wprawdzie tradycyjnej retoryki pamięci, nie opowiada własnej historii (a przynajmniej nie czyni tego wprost) i ucieka się do fikcji ${ }^{429}$, pozostaje jednak echo autorytetu - dobrze znał Santucha i w powieści pragnie dopowiedzieć lub przynajmniej zasugerować nieznane fakty $\mathrm{z}$ jego życia.

Zasadniczą materią Cartas profanas są listy, jakie Witoldo i Roby mieli do siebie pisać w latach 1960-1968, rzekomo zachowane w posiadaniu pewnego argentyńskiego adwokata, byłego lewicowego bojownika, który w 2002 roku pokazuje je narratorowi powieści. Ich rozmowy, także przytoczone w tekście, pełnią funkcję objaśniającą lub dopowiadającą historyczne dane (na temat pobytu Gombrowicza

428 V. Beatriz Sarlo, Tiempo pasado. Cultura de la memoria y giro subjetivo. Una discusión, Siglo Veintiuno, Buenos Aires 2005.

429 Potomkowie Maria Roberta Santucha, jak udało mi się ustalić, nie są w posiadaniu żadnej jego korespondencji z Gombrowiczem. 
w Argentynie, działalności ERP etc.), które mają niezbyt obeznanemu czytelnikowi ułatwić zrozumienie „przedrukowanej” korespondencji. Stawką w tej grze jest niewątpliwie postać Santucha, dla którego Gombrowicz, choć objętościowo obecny w powieści w równym stopniu, jest tylko kontrapunktem, rodzajem ściany, od której odbija się rewolucyjna nowomowa Argentyńczyka. Comandante jest bez wątpienia lepiej znany potencjalnym czytelnikom Mattiniego i zapewne jest dlań także bardziej interesujący, a polskiego pisarza trzeba dopiero dopowiedzieć i wyjaśnić. Stąd ambicją Mattiniego nie jest komentarz do dzieła Polaka, ale glosa do wyznawanej przez Santucha (a także niego samego) koncepcji historii, której słabości i fanatyzmy stają się z czasem coraz bardziej widoczne, oraz, w dalszej kolejności, pragnienie zgłębienia zagadki jego śmierci (stąd obecny w powieści element detektywistyczny). Pomysł na przeprowadzenie swoistego rozrachunku z przeszłością w oparciu o dialektyczne zestawienie postaci Santucha i Gombrowicza staje się lepiej zrozumiały, jeśli wziąć pod uwagę dwie cechy charakterystyczne dla lewicowych frakcji populistycznych w Argentynie lat 6o. i 70.: utożsamienie z charyzmatycznym liderem oraz niechęć do wykształconej elity, która jest symbolem konserwatywnego porządku (co zresztą nie przeszkadzało młodym rewolucjonistom okopanym na pozycjach antyintelektualistycznych toczyć zażartych dyskusji o ideologii ${ }^{430}$ ). Struktura Cartas profanas - rozciągnięta w czasie dyskusja między młodym Santuchem, który stopniowo się radykalizuje, by ostatecznie, wzorem Che Guevary, stać się charyzmatycznym comandante, a starym, cynicznym Gombrowiczem - bazuje na tej właśnie, wyjściowej opozycji.

Z literackiego punktu widzenia powieść Mattiniego nie zachwyca. Uzasadnienie podtrzymywania tej wieloletniej korespondencji - Santucho, „wyrafinowany barbarzyńca”, miałby uwodzić polskiego pisarza swoją autentyczności, którą ten pragnąłby zdyskredytować, poniżyć, wykazując jej, że służy jedynie wyzwoleniu „wysublimowanych instynktów"431 - jest nader wątpliwe. Co gorsza, konwencja powieści

\footnotetext{
430 Beatriz Sarlo, op. cit., s. 89.

431 Luis Mattini, Cartas profanas. Novela de correspondencia entre Santucho y Gombrowicz, Peña Lili/Continente, Buenos Aires 2008, s. 177.
} 
epistolarnej wymaga sprawnego imitowania obu idiolektów i o ile język comandante brzmi stosunkowo wiarygodnie (Mattini jest z nim obeznany, a do tego obszernie korzysta z krótkiego tekstu Santucha Poder burgués y poder revolucionario [Władza burżuazyjna i władza rewolucyjna], utrzymanego w stylu rewolucyjnej nowomowy), o tyle styl Gombrowicza wypada oczywiście sztucznie pomimo licznych parafraz fragmentów Dziennika i inspiracji Cartas a un amigo argentino.

Prowincjonalny wymiar Gombrowiczowskiego doświadczenia Argentyny jest znacznie lepiej uchwycony w powieści Lucasa Daniela Cosciego (ur. 1966), 1958, estación Gombrowicz (1958, przystanek Gombrowicz), w której przekonująco przedstawia się zderzenie cynizmu pisarza z naiwnym dyskursem o etnicznej determinacji w wykonaniu lokalnych elit i w sposób dalece mniej nachalny ukazuje jego polityczno-społeczne uwikłanie. Powieść opowiada historię Daniela, który prowadzi prywatne śledztwo na temat relacji, jaka łączyła jego zmarłego przed laty ojca Macaria Fuentesa z Witoldem Gombrowiczem. Poznali się zimą 1958 roku, kiedy pisarz przybył do Santiago del Estero podreperować nadwerężone powietrzem stolicy zdrowie i „uległ - jak notuje w Dzienniku - fali spóźnionego erotyzmu"432. Stosunkowo krótka przyjaźń z wielkim pisarzem była, jak w przypadku innych „młodych przyjaciół”, doświadczeniem formacyjnym dla młodego Macaria, którego Gombrowicz z właściwą sobie manierą przezwał El Escriba (Skryba), przewidując jego niezbyt udaną karierę literacką. Zagadka tej znajomości tkwi w całkowitym przemilczeniu Macaria w Dzienniku, Wędrówkach po Argentynie i Kronosie, które Daniel na próżno wertuje w poszukiwaniu wzmianek o ojcu. „Co ma oznaczać obsesyjne poszukiwanie imienia ojca w tekście nieżyczliwego języka?"433 Ostateczne odpowiedzi nie padają nigdy, pojawiają się jedynie sugestie homoseksualnego związku, które skądinąd nie przybliżają narratora do rekonstrukcji figury ojca i w ten sposób historia, zapowiadająca się jako klasyczna narracja o poszukiwaniu korzeni i tożsamości, staje się opowieścią o pułapkach pamięci i niemożliwości uchwycenia

\footnotetext{
432 Witold Gombrowicz, Dziennik 1953-1969; wyróżnienie w oryginale.

433 Lucas D. Cosci, 1958, estación Gombrowicz, EDUNSE, Santiago del Estero 2015, s. 23.
} 
przeszłości w jednolitym, koherentnym obrazie. Powieść Cosciego podejmuje więc - choć to zbieżność przypadkowa, a nie zamierzona inspiracja - główny temat Kronosu, jakim jest mozolna rekonstrukcja przeszłości ze strzępków wspomnień. Ta przeszłość w postaci suchego repertorium faktów okazuje się, co więcej, bardzo kłopotliwa dla tych, którzy muszą się z nią zmierzyć: Rita Gombrowicz wyznała, że tekst Kronosu przez lata ukrywała pod łóżkiem, bojąc się jego ujawnienia ${ }^{434}$; zebrane w zakurzonym pudle świadectwa przyjaźni Macaria z Gombrowiczem rodzina przekazuje Danielowi ze wstydem i obrzydzeniem.

Początkowe zdania powieści Cosciego są parafrazą pierwszego akapitu argentyńskiego traktatu narodowego, Facunda Dominga Faustina Sarmienta, w którym autor przywołuje ducha zmarłego kacyka, by ten wytłumaczył „wewnętrzne konwulsje targające trzewiami tej szlachetnej nacji” ${ }^{435}$, której on sam jest uosobieniem, zgodnie z romantyczną ideą utożsamiającą naród z wybitną jednostką. W 1958 duch Gombrowicza powraca wprawdzie sam, nieproszony - „po co wracasz, kiedy nikt już cię nie woła?”436 - ale idea pozostaje podobna: w Gombrowiczu ma ogniskować się argentyńska dusza, z całym wachlarzem jej sprzeczności, obsesji i defektów. Jedną z tych idée fixe jest relacja centrum-peryferie, w szczególności intelektualna zaściankowość prowincji, którą powieściowy Gombrowicz obnaża w swoich kawiarnianych dyskusjach z lokalnymi ludźmi pióra. Z drugiej strony zdaje się nawiązywać z kulturą tubylczą związek znacznie bardziej intymny od tego, który proponują propagatorzy teluryzmu - śni w indiańskim języku keczua sny, których nie może zrozumieć. I choć nigdy nie dowiemy się, czy to nie jedna z Gombrowiczowskich błazenad, to problem kulturowego przekładu - z polskiego na hiszpański, z keczua na hiszpański - oraz kwestia podrzędności jednych języków względem drugich, pozostaje centralnym tematem powieści. Co więcej, w osobie

\footnotetext{
434 V. Maciej Nowicki, Witold Gombrowicz oczami żony: Zostawiłam mu wolność, „Newsweek” 2013, 9 v, https://goo.gl/VSLvqw, dostęp: 12 I 2017.

435 Domingo Faustino Sarmiento, Facundo, Biblioteca Virtual Universal, https://goo. gl/IqLe3f, dostęp: 12 I 2017.

436 Lucas D. Cosci, op. cit., s. 17.
} 
polskiego pisarza binarna opozycja centrum-peryferie ulega zasadniczej komplikacji: centralne i dominujące Buenos Aires okazuje się zaściankiem Europy, a jego elita zależna od nowinek zza oceanu.

Podobnie jak Cartas profanas były krytycznym rozliczeniem z ideologią rewolucyjnego populizmu, tak 1958 jest bez wątpienia rozrachunkiem z „santiageńskością" (santiagueñidad) autora i całym konglomeratem teorii, które próbują ją zdefiniować i opisać. Bilans tego rozrachunku nie jest jednak wyłącznie ujemny, przeciwnie - refleksje o kulturze „skazanej na wieczną prowincjonalną sjestę ${ }^{\text {"37 }}$ przybierają czasem tak żarliwy ton rewindykacyjny, że trącą dydaktyzmem, ale warto przy tym pamiętać, że - w przeciwieństwie do większości argentyńskich powieści z Gombrowiczem w tle - stoi za nimi narrator, który nie jest alter ego autora. Daniel, sam uwikłany w prowincjonalny światopogląd i moralność, jest skłonny do podtrzymywania dyskursu o krzywdzie i niedocenieniu, charakterystycznego dla kulturowych i politycznych peryferii. Ten całkowicie fikcyjny punkt widzenia pozwala zresztą uniknąć dość już zużytej perspektywy narracyjnej, w której Gombrowicz jest przedstawiony jako genialny, choć ekscentryczny intelektualista, niesłusznie niedoceniony w Buenos Aires. Daniel widzi w nim nade wszystko przybysza z zewnątrz, który uwiódł jego ojca duchowo i cieleśnie (a na prowincji musiało być to bardziej ryzykowne niż w permisywnej, wielkomiejskiej przestrzeni), a następnie porzucił i skazał na nieistnienie w historii literatury, tworzonej przez jego teksty.

Podobnie jak Mattini, Cosci także decyduje się na ryzykowne posunięcie „pisania Gombrowiczem”: przedostatni rozdział książki to transkrypcja apokryficznego fragmentu Dziennika z pobytu w Santiago del Estero. Autorowi 1958 udaje się jednak lepiej wybrnąć z tej specyficznej „podróbki” przede wszystkim dlatego, że nie sili się na naśladowanie Gombrowiczowskiego stylu - powtarza kilka motywów i miejsc wspomnianych w Dzienniku, ale unika charakterystycznego dlań frazowania, nie stara się oddać sarkastycznych komentarzy etc. Wydaje się, że pomysł na tę rekonstrukcję jest chwytem służącym do sfokalizowania narracji na Gombrowiczu; reszta jego pobytu

437 Ibid., s. 71. 
w Santiago del Estero jest w widoczny sposób odtworzona z deklaracji świadków oraz supozycji narratora, apokryficzny dziennik (rodzaj fuzji Dziennika i Kronosu) pozwala uwzględnić jego „spojrzenie z zewnątrz”.

Temat „Gombrowicz na argentyńskiej prowincji” zamknąć wypada komentarzem do powieści Hernána Ronsino (ur. 1975) La descomposición (Rozkład) z 2007 roku, rozgrywającej się na przedmieściach prowincjonalnego miasteczka Chivilcoy w prowincji Buenos Aires. Tytuł nawiązuje do procesu powolnego zepsucia, jakiemu w latach 90. ulegały po kolei polityczne, ekonomiczne i etyczne stałe argentyńskiej tożsamości - rodzina, sielanka konserwatywnej prowincji, nawet zaprowadzony jeszcze w czasie dyktatury neoliberalny projekt gospodarczy, który z hukiem upada w roku 2001. W Chivilcoy - rodzinnym miasteczku Ronsina - rozkład ten widać doskonale, zanim jeszcze dotrze do wielkich metropolii, prowincja jest bowiem barometrem kryzysu, który wkrótce ogarnia cały kraj. Umiejscowienie akcji akurat w Chivilcoy jest tym bardziej znaczące, że było ono cywilizacyjnym wzorem Sarmienta, wcieleniem liberalnej utopii, która polegała na transplantacji północnoamerykańskiego modelu farmerskiego: na równo wydzielonych parcelach ziemi mieli w zgodzie żyć i pracować gauczowie i imigranci. Powolna degrengolada tego miasteczka przypieczętowuje więc symboliczny upadek Argentyny jako kraju, który na tle swoich latynoskich sąsiadów przez lata faktycznie wyróżniał się racjonalnymi rządami, realizującymi projekt nowoczesnego państwa.

Narrator powieści Abelardo Kieffer, dziennikarz lokalnej gazety „La Verdad” (Prawda), obchodzi sześćdziesiąte urodziny i z tej okazji zaprasza na tradycyjne argentyńskie asado jedyną bliską osobę, która mu pozostała, Bicha Souzę, muzyka i nauczyciela matematyki. Ich rozmowa tworzy oś konstrukcyjną tej powieści i jest puntem wyjścia dla fragmentarycznych wycieczek w przeszłość, z których czytelnik na końcu wyłowi tę najważniejszą - historię tragicznej śmierci żony narratora. Wycinki z pamięci obu rozmówców sięgają bliżej lub dalej: w czasie polowania ośmioletni Abelardo przypadkowo zabija człowieka; trochę starszy, pamięta jak jego ojciec, członek nazistowskiej loży, pieczołowicie pielęgnuje aryjskie tradycje; później, w latach dyktatury wojskowej, która Argentynie trawionej rewolucyjną chorobą zgotuje 
terapię szokową, odwiedza w szpitalu psychiatrycznym przyjaciela Pajarita Lernú. Inny moment, w którym Historia zawitała do uśpionego Chivilcoy, wspomina Bicho Souza: w końcu lat 50. przybył tu kilkakrotnie polski hrabia, który po powrocie do Europy wydał dziennik. Zatrzymywał się w tutejszym hotelu i około północy zachodził do pobliskiego baru, gdzie ,jego dziwna, jasna, perwersyjna twarz” od wejścia przykuwała uwagę miejscowych:

Stanął w drzwiach i patrzył każdemu z osobna w oczy, starając się ich onieśmielić, zimnym spojrzeniem, które przenikało do kości; i choć doskonale wiedział, że to miasteczko nie nazywało się Tandil, powiedział cokolwiek, byle tylko sprowokować kpinę tych typów, czystych tylko od zewnątrz: Czy to Tandil? - spytał Polak, wysilając się, by jego hiszpański brzmiał bardziej jeszcze obco. Wszyscy zarechotali prostacko, nawet Efraín Bunges, wówczas młody chłopak. Polak wyszedł ${ }^{438}$.

Podobna scena rozgrywała się przez kolejne dwa lata - Polak wchodził do baru i pytał, czy to Tandil - aż ostatnim razem wyszedł za nim młody Efraín Bunges, dogonił samochodem i zaprosił do środka, a potem zaparkował w odludnym miejscu na jakieś dwie godziny. $\mathrm{Na}$ tym historia Polaka w La descomposición się kończy, ale inną jej wersję znajdujemy w nieopublikowanym opowiadaniu Ronsina Gombrowicz, el viejo inmaduro (Gombrowicz, niedojrzały starzec). Znani z powieści Pajarito Lernú i Bicho Souza w miejscowym barze o poranku sączą piwo, obserwując młodą dziewczynę, która uciekła ze szkoły. „Oto jest Gombrowiczowska niedojrzałość" - mówi Pajarito i wykłada przyjacielowi o formie i bezformiu, przeplatając prawdziwe wydarzenia $\mathrm{z}$ argentyńskiego życia pisarza (jak tłumaczenie Ferdydurke) z fikcyjnymi - odwiedzinami w Chivilcoy, które równie dobrze mogłoby być położonym o ponad trzysta kilometrów na południe Tandilem. Wiele lat po rzekomym przyjeździe Gombrowicza Pajarito opowiada o tych odwiedzinach młodemu dziennikarzowi „La Verdad”, wspominając także o przygodzie pisarza z młodym chłopcem, obecnie „słynnym przedsiębiorcą". Żurnalista jest zwolniony zaraz po opublikowaniu

\footnotetext{
438 Hernán Ronsino, La descomposición, Eterna Cadencia, Buenos Aires 2014, s. 74-75.
} 
swojego odkrycia, bo okazuje się, że to Efraín Bunge jest właścicielem gazety. „Ta dziennikarska nota, jeśli dodatkowo zna się jej konsekwencje, pozwala odkryć mechanizmy Formy i ich funkcjonowanie”, mówi Pajarito $^{439}$. Młodzieńcza przygoda przyszłego przedsiębiorcy była chwilowym wyzwoleniem z formy - prowincjonalnej, tradycyjnej, seksualnej - by z czasem stać się źródłem skrywanego głęboko wstydu. W analogiczny sposób Forma, którą Gombrowicz analizuje w swoich tekstach, obraca w rękach, rozkłada na czynniki pierwsze i rozluźnia, staje się w konsekwencji jego najtrwalszą definicją i najsurowszym więzieniem: „Forma cię przygniata, wygina, robi z tobą, co tylko chce; myślisz, że daje ci wolność, sprawia, że czujesz się wolny, nawet zostawia ci miejsce, żebyś się zabawił i wymyślił pojęcie n i e d o j r z a ło ści, a potem wybucha ci śmiechem w twarz" ${ }^{440}$.

Dla Ronsina i Cosciego peryferyjne umiejscowienie narracji jest podstawową składową ich literackiego credo: konsekwencją ich życiorysów (dorastali na prowincji lub nadal tam mieszkają), ale także wyborem, którego konsekwencje wykraczają daleko poza literaturę. Jak ujmuje to autor La descomposición (z trzech omawianych tu pisarzy niewątpliwie najbardziej ceniony i komentowany przez krytykę), „opowiadanie z perspektywy Buenos Aires oznaczałoby wyrzeczenie się mojego prowincjonalnego pochodzenia, rezygnację z doświadczenia, które skłania do określonego spojrzenia na kraj i świat"441. To spojrzenie spoza centrum, a więc $\mathrm{z}$ zewnątrz - realizowane w obu powieściach m.in. poprzez figurę Gombrowicza - ma również swój wymiar polityczny, który polega na rezygnacji z perspektywy najbliższej i najwygodniejszej dla argentyńskiej literatury (ale także kultury, polityki i gospodarki), czyli z perspektywy Buenos Aires. Takie poszerzenie literackiego horyzontu o prowincjonalną optykę ${ }^{442} \mathrm{z}$ jej dyżurnymi tematami, takimi jak zaściankowość,

\footnotetext{
439 Idem, Gombrowicz: el viejo inmaduro, „Enfocarte.com - Revista Digital de Arte y Cultura" [s.a.], nr 14, https://goo.gl/9YXDCo, dostęp: 13 I 2017.

440 Ibid.; wyróżnienie w oryginale.

441 V.Silvina Friera, Me interesan las pequeñas historias de los pueblos, „Página/12” 2007, 10 XII, https://goo.gl/g8SRs3, dostęp: 16 I 2017.

442 Mające w literaturze argentyńskiej swoją długą tradycję, reprezentowaną m.in. przez Juana José Saera, Ricarda Zelarayána, Néstora Sáncheza. V. Laura Estrin,
} 
obskurantyzm i kompleksy wobec centrum, pozostaje w duchu Gombrowiczowskiej koncepcji kultury i głoszonego przez nią napięcia między jej wyższymi i niższymi reprezentantami. Współcześnie Argentyna, niegdyś kraj formy luźnej, okazuje się stopniowo formę tę zacieśniać, spychając „niedojrzałość” i „niższość” na swoje kulturowe, prowincjonalne obrzeża.

\section{Inne lektury}

Zarówno w La descomposición, jak i 1958, estación Gombrowicz istotnym elementem intrygi jest homoseksualizm pisarza, będący bez wątpienia atrybutem znacznie bardziej skandalicznym (i tym samym sprawniej generującym powieściowe wydarzenia) na prowincji aniżeli w samej stolicy. W Buenos Aires - mimo że zakazany przez prawo i, w zależności od politycznej koniunktury, mniej lub bardziej surowo tępiony przez policję - nie był jednak, przynajmniej w kręgach artystycznej bohemy, niczym niezwykłym, co zostaje zresztą niejednokrotnie odnotowane w Dzienniku ${ }^{443}$. Ta permisywna atmosfera, w której puto jest pierwiastkiem oswojonym i tolerowanym, tłumaczy fakt, że w powieściach pisanych z perspektywy stolicy (zaliczam do nich również te, które osadzone są na prowincji, ale których problematyka pozostaje problematyką centrum) kwestia seksualnej tożsamości Gombrowicza jest pomijalna jako znaczeniowo mało

Nuevas lecturas del viaje del provinciano, w: Miguel Vitagliano (red.), Boedo. Políticas del realismo, Título, Buenos Aires 2012, s. 265-302.

443 „[Z]a pośrednictwem pewnych moich przyjaciół z baletu, który przybył do Argentyny na gościnne występy, wszedłem w środowisko krańcowego, szalonego homoseksualizmu. Mówię »krańcowego«, gdyż o homoseksualizm »normalny« ocierałem się od dawna, światek artystyczny pod wszystkimi równoleżnikami przepojony jest tą miłością - ale tu objawiło mi się jej oblicze już do szaleństwa frenetyczne [...] grono, z którym teraz się spotkałem, było złożone z mężczyzn zakochanych w mężczyźnie bardziej niż jakakolwiek kobieta, byli to putos w stanie wrzenia, nie znający chwili odpoczynku, w ciągłej pogoni, »rozrywani przez chłopców jak przez psy«, podobnie jak mój Gonzalo w Trans-Atlantyku”; Witold Gombrowicz, Dziennik 1953-1969. 
inspirująca. Wyjątkiem jest opowiadanie Edgarda Cozarinsky'ego (ur. 1939) Navidad del 54 (Boże Narodzenie '54), którego bohaterem jest profesor, literat pochodzący wprawdzie z Wiednia, ale zdradzający szereg cech wspólnych z Gombrowiczem (w szczególności fascynację młodością). Profesor udaje się na zwyczajowy spacer w okolice dworca kolejowego Retiro, gdzie

odkrył (poza okazjonalną usługą erotyczną, na którą jego ograniczone środki finansowe rzadko mu pozwalały), serdeczność znacznie bogatszą w niuanse i niespodzianki aniżeli przyjaźń, jaką oferowali mu pogrążeni w nostalgii rodacy, więźniowie Europy bardziej utęsknionej niż pamiętanej, oraz grzeczną obojętność kilku tutejszych intelektualistów, którzy w ogóle dostrzegli jego obecność w kraju ${ }^{44}$.

Tej gorącej, grudniowej nocy zostaje jednak ostrzeżony przez byłego kochanka - młodego żołnierza, którego historię przedstawia dalsza część opowiadania - przed obławą policji.

Celem opowiadania Cozarinsky'ego jest uchwycenie atmosfery epoki: w pierwszym akapicie wspomina się o „prezydencie i jego zmarłej żonie", bo opisane wydarzenia są bezpośrednią konsekwencją politycznego sojuszu peronizmu z Kościołem, który przypieczętował represje wobec homoseksualistów. Przedstawieni w opowiadaniu młodzi chłopcy to należący do społecznych nizin cabecitas negras, dla których Perón był symbolem sprawiedliwości i wolności, ale - co pragnie wykazać Cozarinsky - zrealizowana przezeń społeczna zmiana nie obejmowała homoseksualistów, którzy niezależnie od swojego pochodzenia, pozostali obywatelami drugiej kategorii ${ }^{445}$. O paradoksalnej zbieżności pomiędzy postulatami peronizmu a Gombrowiczowskim uwielbieniem dla niższości pisałam wyżej, ale Cozarinsky idzie o krok dalej - używa figury polskiego pisarza do sentymentalnej (jak słusznie ujmuje to Pau

444 Edgardo Cozarinsky, Navidad del 54, https://goo.gl/WlJQMM, dostęp: 16 I 2017. Tekst opublikowany w: idem, La novia de Odessa, Emecé, Buenos Aires 2001. Na temat sytuacji homoseksualistów w peronistowskiej Argentynie v. Juan José Sebreli, Historia secreta de los homosexuales en Buenos Aires, w: idem, Escritos sobre escritos, ciudades bajo ciudades. 1950-1997, Sudamericana, Buenos Aires 2015, s. 313-322. 
Freixa ${ }^{446}$ ) opowieści o braterstwie i miłości homoerotycznej, która jest głosem w toczonej wówczas debacie publicznej na temat praw mniejszości seksualnych. Ta maska politycznej poprawności pasowałaby doskonale np. Manuelowi Puigowi, który był jednym z założycieli argentyńskiego Frente de Liberación Homosexual (Front Wyzwolenia Homoseksualistów), ale Gombrowiczowi nie przystaje zupełnie. $\mathrm{O}$ tym, że zestawiona $\mathrm{z}$ autorem Trans-Atlantyku teza opowiadania zgrzyta, świadczą dwukrotnie powtórzone w opowiadaniu Cozarinsky’ego słowa ostrzeżenia, jakie młody kochanek kieruje do swojego europejskiego przyjaciela: „Przepraszam, profesorze, lepiej niech pan stąd natychmiast idzie. Policja jest na dole i ma rozkazane zabrać co najmniej stu...”, i nie kończy, bo „żadne ze słów, które znał, nie nadawało się do uszu człowieka tak kulturalnego" ${ }^{47}$. Tymczasem to właśnie Gombrowicz pierwszy uległ „semantycznej i fonicznej fascynacji”"448 słowem puto, tak trudno przekładalnym na inne języki w całym swym znaczeniowym bogactwie - słowem, którego szeroki wachlarz pejoratywnych i aprobatywnych konotacji oddaje jego złożony stosunek do własnej tożsamości seksualnej.

Opowiadanie Edgarda Cozarinsky’ego zamyka listę dzieł, które współczesna literatura argentyńska napisała w związku z Gombrowiczem, a których interpretacja domaga się wydobycia tej filiacji, bo "rezonowanie” z twórczością autora Ferdydurke jest w te teksty wpisane. Intertekstualne związki - przy czym za tekst uznaję także tekst biografii - można by z pewnością ustanawiać dalej, poszerzając listę o takie dzieła, dla których Gombrowicz był bez wątpienia inspiracją, choć jego „obecność” jest zarówno na poziomie treści, jak i formy mniej eksplicytna. Ciało - nie jako przedmiot erotycznego pożądania, ale ciało zdeformowane i odrażające w swojej fizjologicznej dosłowności - jest tematem powieści Fernandy Garcíi Lao (ur. 1966) o przewrotnym tytule Muerta de hambre (Zmarła z głodu) z 2005 roku.

\footnotetext{
446 Pau Freixa Terradas, op. cit., s. 258-259.

447 Edgardo Cozarinsky, op. cit.

448 Carlos Gamerro, El puto en la literatura argentina, w: idem, Facundo o Martín Fierro.
} 
Ta argentyńska poetka, powieścio- i dramatopisarka, debiutowała jako reżyserka teatralna, wystawiając Iwonę, księżniczkę Burgunda na deskach Sportivo Teatral, i o swojej fascynacji Gombrowiczem wspomina często w wywiadach. Muerta de hambre, której pierwszy rozdział został opatrzony cytatem zaczerpniętym z Testamentu: „Byłem niczym, więc mogłem pozwolić sobie na wszystko" ${ }^{49}$, opowiada historię kobiety, której monstrualna otyłość, pielęgnowana przez nią z żelazną konsekwencją jest metaforą jej nieprzystosowania do świata, który z kolei sam jest groteskowo wynaturzony (rodzina, przyjaźń, miłość są swoim cynicznym rewersem). Zwykło się przyjmować, że zainteresowanie ciałem w zachodniej kulturze jest konsekwencją kryzysu wiary w język jako transparentny, bezpośredni środek komunikacji; w przeciwieństwie do ciała, które samo należy do świata fizycznego, język miałby nas właśnie odcinać, oddalać od rzeczywistości, niemającej przecież charakteru słownego. „Moje ciało jest moją mową. Mam nadzieję, że ktoś mnie zrozumie” ${ }^{450}$, konstatuje bohaterka, usiłując „nażreć się na śmierć”. Ale u Gombrowicza i Garcíi Lao ciało jest właśnie problematyczne - rozpada się na części, jest wynaturzone starością bądź tuszą, postrzegane jako obce, co tłumaczy powracający motyw wstrętu. Nieumiarkowane jedzenie (a także jego konsekwencja - wymioty) byłoby właśnie specyficzną mową ciała, które nie chce lub nie potrafi zbliżyć się do Innego, bo on także jest odrażający ${ }^{451}$. Z drugiej strony kwestia języka - nie jako zdyskredytowanego narzędzia komunikacji, ale Gombrowiczowskiej „fabuły językowej”, o której pisałam wyżej - także jest istotna u Garcíi Lao. Słowa same - ich dwuznaczności i opozycje, jak ta między carne (mięso) i cuerpo (ciało) - fatalistycznie prowokują

\footnotetext{
449 Witold Gombrowicz, Testament.

450 Fernanda García Lao, Muerta de hambre, El Cuenco de Plata, Buenos Aires 2005, s. 21.

451 „Słońce. Mdło. Tutaj stoimy w kolejce, a tam, na przeciwległym chodniku, idą i idą, mijają i mijają, bez przerwy lizą i lizą, skąd tyle tego, przecież już jestem o dwadzieścia kilometrów od centrum Buenos Aires! A jednak mijają i mijają, wciąż wyłażą zza rogu i przechodzą i wyłażą i przechodzą i wyłażą i przechodzą i wyłażą aż zwymiotowałem. Zwymiotowałem, a ten co przede mną stał spojrzał i nic, bo i cóż! Tłok. Ja znowu zwymiotowałem i - nie wiem, czy nie przesadzam - jeszcze raz zwymiotowałem"; Witold Gombrowicz, Dziennik 1953-1969.
} 
wydarzenia: „Zamówiłam mięso. Boję się zamawiać mięso... bo wiem, że zaraz potem powiem »krwiste " $"$ "52. Last but not least, pomysłowy język tej powieści - sprawnie grający na dwuznacznościach, homonimii i zbitkach słownych - jest pełen cynicznego humoru i ironii, które pozwalają bez sentymentalizmu i moralizatorstwa opowiedzieć historię z gruntu tragiczną - o rozczarowaniu, bólu i samotności.

Z kolei Damián Tabarovsky (ur. 1967) - pisarz, tłumacz (m.in. Copiego i Raymonda Roussela), krytyk i wydawca - wykorzystuje w Coney Island (1996) schemat powieści detektywistycznej zaczerpnięty z Kosmosu. Główny bohater, detektyw Dupont, prowadzi dochodzenie przeciwko tajemniczej organizacji EEAAPP, która zamierza zawładnąć światem. Zdaje się podążać za wskazówkami, śledzić podejrzanych, zżelazną logiką demaskować ukryte powiązania, by wniknąć w prawdziwą naturę rzeczy. Podobnie jak w ostatniej powieści Gombrowicza, w Coney Island - choć tutaj z większym humorystycznym dystansem - wszystko odnosi się do wszystkiego, żadne wydarzenie ani jego okoliczności nie są przypadkowe, bo Dupont potrafi wpleść je w ciąg logicznego wynikania: „wie, że jego misją jest rozszyfrowanie tego labiryntu, zbudowanie chronologii, spójnej fabuły" ${ }^{453}$. Tajemne związki między rzeczami czy faktami są tak stłoczone lub nawarstwione, że przestają cokolwiek znaczyć, jak wtedy, gdy Dupont śledzi przypadkową kobietę: wchodzi za nią do księgarni i na chybił trafił ogląda książki, z których każda wydaje mu się odnosić do podejrzanej. Aluzji do Gombrowicza jest w powieści Tabarovsky’ego więcej - kiedy np. Dupont obserwuje okruszynę chleba, a ta zaczyna „zachowywać się” jak „ręka kelnera” z Querandí lub popielniczka na stole, wyłowiona „z bezmiaru dziejących się zjawisk”454:

Była straszna, Dupont odwrócił wzrok. Jakikolwiek przedmiot, najbanalniejszy i najnormalniejszy, jakakolwiek osoba, sytuacja lub okoliczność, jeśli zatrzymamy się popatrzeć na nie przez dłuższą chwilę, jeśli zrobimy to skrupulatnie i z uwagą, dogłębnie i z obsesją, to zmienią się w coś odrażającego ${ }^{455}$.

\footnotetext{
452 Fernanda García Lao, op. cit., s. 23.

453 Damián Tabarovsky, Coney Island, Sudamericana, Buenos Aires 1996, s. 23.

454 Witold Gombrowicz, Dziennik 1953-1969.

455 Damián Tabarovsky, op. cit., s. 39.
} 
Do „orędowników” Gombrowicza na argentyńskiej scenie literackiej należy bez wątpienia Guillermo Martínez, poczytny autor m.in. przełożonej na polski bestsellerowej Oxfordzkiej serii. Jego styl literacki nie ma wprawdzie wiele wspólnego z autorem Pornografii, ale Martínez o Gombrowiczu pisuje sporo tak w popularnej prasie, jak w esejach krytycznych. Szczególnie ceni sobie Kosmos za jego wymiar filozoficzny - absurdalne śledztwo „poprzez natężenie poszukiwań i rozdrażnienie tego, co racjonalne, stwarza sieć przyczynowo-skutkową, perwersyjny kosmos, który prowadzi do najstraszniejszego uczynku, zbrodni" ${ }^{356}$. Z wykształcenia logik i matematyk, Martínez czyta także Gombrowicza z perspektywy jego potencjału dialektycznego. Na podstawie bogatego repertorium cytatów (przede wszystkim z Dziennika, w mniejszym stopniu Ferdydurke, Trans-Atlantyku i Bakakaju) odnajduje rozmaite realizacje dialektycznej zasady - powracające opozycje (młodość-dojrzałość, wartość-niedowartość etc.), transformacje jednego pojęcia w drugie, (tego, co nieważne, w to, co ważne, przypadkowości w konieczność etc.), antynomie, które ujawniają się po uważnym badaniu (zmienna natura rzeczy), sprzeczność w samym sobie, transformację jakości w ilość i degradację jakości w ilości, dążenie do zaprzeczenia każdemu sądowi i następnie odnowienia dialektycznej opozycji ${ }^{457}$. Szkoda tylko, że na tym bogatym korpusie cytatów Martínez nie rozwija jakiejś szerszej refleksji metaliterackiej.

Wśród popularyzatorów twórczości Gombrowicza wymienić warto także Eduarda Bertiego (ur. 1964), mieszkającego w Buenos Aires, Paryżu i Madrycie pisarza, tłumacza i scenarzystę, który na temat autora Ferdydurke publikuje krótkie, popularnonaukowe teksty na

\footnotetext{
456 Guillermo Martínez, Clásicos contemporáneos: "Cosmos” de Gombrowicz, https:// goo.gl/94gjda, dostęp: 18 I 2017. Tekst ukazał się w czasopiśmie „7 Dias” w numerze ze stycznia 2013 roku.

457 V. idem, Gombrowicz, escritor de la dialéctica, w: Nicolás Hochman (red.), El fantasma de Gombrowicz recorre la Argentina, Heteronimos, Buenos Aires 2015, s. 37-50. Tekst ten został, z niewielkimi skrótami, przedrukowany w: idem, $L a$ razón literaria. Ensayos y polémicas, Seix Barral, Buenos Aires 2016, s. 193-217.
} 
swoim blogu ${ }^{458}$. Ciekawym przypadkiem inspiracji, a raczej hołdu złożonego Gombrowiczowi jest postać Witolda Borcicha, stworzona przez urugwajskiego pisarza, poetę i artystę plastyka polskiego pochodzenia Gustava Wojciechowskiego (ur. 1956). Borcich - polski pisarz, autor książki rzekomo przełożonej na hiszpański przez Wojciechowskiego Abisinia: entre algunas cosas que pude haber escrito y hoy no recuerdo ${ }^{459}$ (Abisynia: wśród rzeczy, które mogłam napisać, ale dziś już nie pamiętam) - jest bardzo luźno wzorowany na Gombrowiczu. Abisinia, której tytuł jest grą ze słowem abismo (przepaść), jest rodzajem dziennika Borcicha zmarłego tragicznie w 1969 roku, a niektóre jego wpisy - polemiczny stosunek do ojczyzny, problematyka ,ja”, rozczarowanie tak pożądaną wcześniej sławą - można uznać za Gombrowiczowskie toposy.

W Argentynie Gombrowicz pozostaje póki co „pisarzem dla pisarzy”, mało znanym szerokiej publiczności, choć można podejrzewać, że sytuacja ta będzie się dynamicznie zmieniać z jednej strony dzięki wznowieniu jego dzieł przez wydawnictwo El Cuenco de Plata, z drugiej zaś dzięki aktywności Congreso Gombrowicz, prężnie działającej grupy młodych sympatyków pisarza, którzy - pod przewodnictwem Nicolása Hochmana (ur. 1982), pisarza, krytyka i badacza dzieła Polaka - organizują w Buenos Aires wydarzenia popularyzujące jego twórczość. W 2014 roku z ich inicjatywy odbyła się w argentyńskiej Bibliotece Narodowej konferencja o Gombrowiczu, rok później - w ramach cyklu „Echemos a Gombrowicz a la calle” (Wyrzućmy Gombrowicza na ulicę) w jednej z kawiarni w San Telmo (niedaleko ulicy Venezuela, przy której pisarz wiele lat mieszkał) zorganizowali rodzaj literackiego performace'u: Gombrowicz en un minuto (Gombrowicz w jedną minutę), podczas którego znani argentyńscy literaci czytali krótkie fragmenty książek Polaka. Kolejnym wydarzeniem przygotowanym przez grupę Congreso Gombrowicz było zorganizowane w Teatro

\footnotetext{
458 V. La filosofía de Gombrowicz, https://goo.gl/bQgulk oraz Gombrowicz en Argentina, https://goo.gl/VXyY4E, dostęp: 18 I 2017.

459 Witold Borcich [właśc. Gustavo Wojciechowski], Abisinia: entre algunas cosas que pude haber escrito y hoy no recuerdo, wyb. i przeł. Gustavo Maca Wojciechowski, Yaugurú, Montevideo 2009.
} 
Globo w Buenos Aires Contra los escritores (Przeciw pisarzom) - widowisko stworzone na wzór telewizyjnego show, w trakcie którego argentyńscy celebryci (dziennikarze, piosenkarze, sportowcy) czytali fragmenty książek i rozprawiali, oczywiście w rozrywkowym tonie, o autorze Ferdydurke. W październiku 2017 roku miał swoją premierę pierwszy (i zapewne ostatni) numer czasopisma „Witolda. Revista de la Persistencia” (Witolda. Czasopismo Niezłomności), wzorowanego na wydanym przez Gombrowicza w 1947 roku „Aurora. Revista de la Resistencia” (Aurora. Czasopismo Oporu). Ma ono charakter popularyzatorski, a o swojej przygodzie z lekturą Gombrowicza piszą w nim akademicy, tłumacze, a także słynni współcześni pisarze latynoscy (m.in. César Aira, Juan Villoro, Martín Kohan, Hernán Ronsino). 


\section{Zakończenie}

„Argentyński Gombrowicz” jest szczególnym przypadkiem recepcji pisarza obcego w kulturze narodowej. Szczególność ta jest, paradoksalnie, konsekwencją tego właśnie procesu recepcji, który udaje się do tego stopnia, że polskość pisarza zostaje zakwestionowana lub zignorowana, a autor Ferdydurke zostaje „wprzęgnięty” w narodowe tryby interpretacyjne. „Nie byłem członkiem ich drużyny literackiej w międzynarodowym meczu", konstatuje Gombrowicz w Testamencie ${ }^{1}$, ale po upływie prawie pięćdziesięciu lat - w innej geografii literackich zależności i priorytetów - jego sarkastyczna obserwacja ulega dezaktualizacji. Piglia napisze o nim, że był „największym współczesnym pisarzem argentyńskim"2, kierując tę boutade przeciwko wszystkim tym, którzy bronią czystości narodowej kultury, ale jego słowa trafnie (choć hiperbolicznie) opisują także wysiłki krytyki na drodze ku „argentynizacji” pisarza. Proces ten - ułatwiony charakterystycznym dla inkluzywnych kultur pogranicza otwarciem na to, co inne, i skutkujący sprawnym adoptowaniem pisarzy w różnym stopniu obcych - powoduje, że autor Trans-Atlantyku uzyskuje specyficzny status pisarza, który z obrzeży narodowej kultury potrafi mówić o niej przenikliwie i odkrywczo. Ta

$1 \quad$ Witold Gombrowicz, Testament. Rozmowy z Dominique de Roux, przeł. Ireneusz Kania, Wydawnictwo Literackie, Kraków 2012, e-wydanie.

2 Juan José Saer, Spojrzenie z zewnątrz, przeł. Klementyna Suchanow, Krystian Radny, „Literatura na Świecie” 2001, nr 4, s. 74. 
wtórnie nabyta tożsamość powoduje, że przypadek „argentyńskiego Gombrowicza" nie mieści się w modelach metodologicznych przeznaczonych do badania dzieł literackich poza ich rodzimym kontekstem. Nie dochodzi tutaj do zaistnienia literatury światowej w akcie lektury, jak chciałby David Damrosch, właśnie ze względu na to, że Argentyńczycy nie są skłonni czytać tego pisarza w oderwaniu od ich własnej kultury. Także prawa kierujące funkcjonowaniem „światowej republiki literatury" nie znajdują tu zastosowania, bo kulturowa wymiana następuje na jej peryferiach, a illusio tej "gry w Gombrowicza” jest zaakcentowanie związków z przybraną ojczyzną, a nie miejsca w kanonie uniwersalnym.

„Argentyński Gombrowicz” istnieje z jednej strony dzięki swojej argentyńskiej legendzie, z drugiej - poprzez „argentyńskie” teksty. Najnowsze studia przekładoznawcze, skłonne raczej koncentrować się na procesie przepisywania (rewriting) tekstu w tłumaczeniu, aniżeli na piętnowaniu ewentualnych odstępstw od oryginału, pozwalają wydobyć z hiszpańskojęzycznych dzieł Gombrowicza (w szczególności z tłumaczeń odautorskich) pewne narodowe dopasowania. W przypadku Ferdydurke będzie to przede wszystkim nowy, sztuczny i udziwniony język, wymierzony przeciwko panującemu wówczas w Argentynie kultowi stylistycznej elegancji. W Ślubie „refrakcja” przekładu jest bardziej subtelna: co w polskiej wersji było przede wszystkim wewnętrznym dramatem Henryka, konsekwencją sprawczej mocy jego ducha, w kulturze docelowej rozgrywa się bardziej pod naporem tego, co międzyludzkie. W Dzienniku argentyńskim interpretacyjne odchylenia są wynikiem odmiennej architektury tekstu - nowe ułożenie wybranych z pełnej wersji tekstu fragmentów skutkuje innym rozłożeniem akcentów i polski Gombrowicz-manipulator, skłonny raczej bezpardonowo walczyć o sławę, ustępuje miejsca Gombrowiczowi-pisarzowi niedocenionemu, skazanemu na porażkę.

Dotychczasowa krytyka zajmująca się odbiorem polskiego pisarza w Argentynie stała na stanowisku, że jedynym materiałem badawczym mogą być nie tyle związki intertekstualne (te bowiem nie istnieją), ile portret wyobrażeniowy Gombrowicza, jego image, którego nośność była odwrotnie proporcjonalna do znajomości dzieła. Teksty 
polskiego pisarza były faktycznie do niedawna trudno dostępne szerokiemu gronu czytelników, jednak to praktyczne ograniczenie nie dotyczyło wąskiego kręgu profesjonalistów - pisarzy i krytyków, którzy Gombrowicza jednak czytali (bywało, że w przekładach) i stopniowo wprowadzali do obiegu jako pożądany punkt odniesienia. Fakt, że autor Trans-Atlantyku figuruje stosunkowo często jako postać w argentyńskiej fikcji literackiej, może stanowić co najwyżej argument za znajomością jego tekstów, w większości zainfekowanych przecież przez autofikcjonalne chwyty, a nie przeciwko niej. Ciąg życia i ciąg literatury - oba jednako „zmontowane” - składają się na konstrukcję „ja”, które istnieje poprzez opowiadanie (historii fikcyjnych i autobiograficznych, anegdot).

Obszar „intertekstualności aprobowanej i pożądanej”3 dla Gombrowicza zakreślam wokół pięciu wątków interpretacyjnych, z których pierwszy koncentruje się na sposobach doświadczania i opisywania indywidualnego przyporządkowania przestrzennego. W tradycji argentyńskiej autor Dziennika jest podróżnikiem, wędrowcem, który - wzorem europejskich intelektualistów - przemierza kraj, z tą jednak różnicą, że zajmują go regiony drugorzędne, mało znaczące z historycznego i kulturowego punktu widzenia. Gombrowicz (jako narrator powieści i podmiot Dziennika) jest także wygnańcem, który swoje wygnanie kwestionuje: nie godząc się na bycie obcym, w opozycji do którego narodowa wspólnota określa swoją tożsamość, nie chce być także swój i w konsekwencji zajmuje pozycję p o m i ę d zy. Gonzalo-Gombrowicz jest hybrydą niemożliwą do sklasyfikowania w konstytutywnej dla narodowej tożsamości siatce opozycji (swojski-inny, cywilizowanybarbarzyński, męskie-żeńskie). Z czasem ta kulturowa ambiwalentność - ani tu, ani tam - staje się charakterystyczna dla współczesnego doświadczenia migracji, czyli wyzbytej z narodowych sentymentów podróży, podważającej tradycyjne, esencjalistyczne związki łączące człowieka z miejscem w przestrzeni. Trans-Atlantyk anonsuje także i ten aspekt przestrzennego przemieszczenia, tzw. literaturę bez

3 Michał Głowiński, O intertekstualności, w: idem, Prace wybrane, t. 5: Intertekstualność, groteska, parabola. Szkice ogólne i interpretacje, Universitas, Kraków 200o, s. 31. 
terytorium, rozgrywającą się z dala od przypisanego danemu narodowi obszaru lub miejsca, w diasporycznym rozproszeniu. Drugi aspekt Gombrowiczowskiego dzieła, który krytyka argentyńska chętnie podnosi, ma związek z cielesnością, uwikłaniem w homoseksualność i erotycznym zachwytem nad młodością - w tym kontekście czyta się przede wszystkim Trans-Atlantyk oraz Dziennik. Akcentowane są przy tym rodzime uwarunkowania tych fascynacji: moment historyczny, czyli sukces peronizmu, siły politycznej wyniesionej do władzy przez młode, imigranckie masy, oraz miejsce - atmosfera wielokulturowego Buenos Aires, którego Gombrowicz doświadcza przede wszystkim w kręgach kulturowo podrzędnych (jak Retiro lub kawiarnia Fray Mocho, gdzie wygłasza Przeciw poetom). Opisane w Dzienniku miasto jest antytezą romantycznego urbe, w którym realizowany był liberalny projekt cywilizacyjny - przestrzeni per se pedagogicznej, zdolnej samoistnie edukować nieokrzesany plebs. Korelatem Gombrowiczowskiego przywiązania do miejsc peryferyjnych i kulturalnie niskich jest jego relacja $\mathrm{z}$ hiszpańskim, przede wszystkim akcentowany po wielokroć językowy brak, ułomna znajomość, która wymusza specyficzny tryb przekładowy w przypadku Ferdydurke - kawiarniane tłumaczenie ostentacyjnie godzi bowiem w rodzące się w latach 40. standardy określające prawomocne, kanoniczne przekłady. Kolejnym tematem, który krytyka argentyńska skwapliwie podejmuje, jest rozwinięta w Dzienniku autofikcja, pojmowana jako otwarty (nieukończony) proces tworzenia własnego „ja” w tekście literackim. W przypadku Gombrowicza dramaturgia tego procesu bazuje na ostentacyjnych sprzecznościach w konstrukcji podmiotu oraz cynicznym zdystansowaniu do wszelkich ideologii, postrzeganych jako dyskursy stadne; jest rodzajem sceny, na której autor wystawia siebie - narcystycznie usposobiony podmiot - na widok publiczny, mieszając fikcję z założoną w diarystyce prawdą, „Gombrowicza” tekstowego z Gombrowiczem realnym. Rejestr interpretacyjnych soczewek, które argentyńska krytyka przykłada do twórczości Polaka, podsumowuję krótkimi rozważaniami na temat jego miejsca w literackim kanonie przybranej ojczyzny, a konkretnie ewentualnych związków z twórczością Borgesa, która stanowi bezsprzeczne centrum tej literatury, obligatoryjny punkt odniesienia 
poprzez utożsamienie lub odrzucenie. Spektrum stanowisk w kwestii intertekstualnych paraleli między oboma autorami jest szerokie: od tych, którzy (jak Saer i Piglia) skłonni są akcentować podobieństwa, poprzez problematyzowanie tych podobieństw (Mandolessi), aż do ich negacji (Gasparini). Przyjęte w tej kwestii stanowisko pośrednio determinuje z kolei określenie ewentualnych argentyńskich „spadkobierców” Gombrowicza, z których większość to pisarze kontynuujący tradycyjne, borgesowskie polemiki, zorientowane wokół szeroko pojętej problematyki narodowej, a mniejszość - pisarze indywidualnego głosu, świadomie rezygnujący z prawa do dopisywania dalszych ciągów klasycznych debat literackich.

Rozpatrywany w poprzednim rozdziale „Gombrowicz pisarzy argentyńskich” - a właściwsza byłaby tu liczba mnoga "Gombrowicze” - zostaje każdorazowo stworzony na prekursora, „jego dzieło modyfikuje [ich - E.K.P.] postrzeganie przeszłości tak samo, jak będzie musiało zmodyfikować przyszłość" ${ }^{4}$. Pierwsza argentyńska lektura Gombrowicza niezależna od odautorskich dyrektyw interpretacyjnych innych niż te zawarte w samym tekście została zaproponowana przez grupę związaną z czasopismem „Literal”, na którego łamach autor Ferdydurke pojawia się przelotnie jako pisarz komplementarny wobec Macedonia Fernándeza. „Literal” odcina się od legendy Polaka, waloryzuje lekturę dzieł, której sam dokonuje w hermetycznym żargonie modnej wówczas psychoanalizy lacanowskiej. W powieściach założyciela tej grupy literackiej, Germána Garcíi, odniesienia do Gombrowiczowskiej estetyki funkcjonują dodatkowo jako kontrapunkt dla obowiązującego w latach 6o. paradygmatu literatury zaangażowanej. Inny członek „Literal”, Osvaldo Lamborghini, będzie „pisał Gombrowiczem” jeszcze w latach 8o., budując fabuły złożone z wydarzeń językowych - użyć metaforycznych wziętych dosłownie, gier i brzmień słów, komicznych zlepków socjolektów en vogue. Podobne pomieszanie między porządkiem znaczącego i znaczonego występuje u innego Argentyńczyka zadłużonego u Gombrowicza, Copiego, który dodatkowo adaptuje

4 Jorge Luis Borges, Kafka i jego prekursorzy, w: idem, Dalsze dociekania, przeł. Andrzej Sobol-Jurczykowski, Prószyński i S-ka, Warszawa 1999, s. 160. 
kilka chwytów z Bakakaju - konfundującą relację z „panem”, narrację o cudownych przygodach, absurdalne zwroty akcji.

Z kolei Ricardo Piglia przedstawi zupełnie inną lekturę dzieła Polaka - najbardziej nośną, bo jej popularność jest pochodną literackiej marki autora - która wpisuje się w szerszy projekt krytyczny, a mianowicie zaproponowaną przezeń reinterpretację argentyńskiego kanonu. Z punktu widzenia obfitości metatekstów lektura Piglii jest najbardziej płodna - zostaje rozwinięta w kilku artykułach eseistycznych oraz powieści Sztuczne oddychanie z 1980 roku, będącej jedną z najbardziej wyrafinowanych realizacji ideału literatury zaangażowanej w Argentynie. Piglia, pisarz uformowany w latach 60. i 7o., będzie później - na przekór nowym trendom - kontynuował ten model pisania i czytania tekstów literackich (także Gombrowiczowskich), w którym na horyzoncie zawsze pojawia się przeciwnik w postaci opresyjnego Państwa lub jego odpowiednika, produkującego i narzucającego własne narracje, porządkujące historię i dyscyplinujące społeczeństwo. Polityczna funkcja pisarza polega na wytwarzaniu kontrnarracji, wyprzedzaniu i demaskowaniu aktywności Państwa na polu fikcji, a Gombrowiczowski model takiej narracji wywrotowej polega - zdaniem Piglii - na kwestionowaniu czystości tradycji kulturowej i negowaniu istnienia obiektywnych wartości w sztuce.

W drugiej połowie lat 8o., po czasie nieuchronnych rozliczeń z dyktaturą i poprzedzającą ją rewolucyjną gorączką, wyczerpuje się wśród młodszych twórców kulturowy paradygmat oparty na bliskich związkach pomiędzy literaturą a polityczną praxis i pojawiają się nowe głosy, które stanowczo zastrzegają, że mówią wyłącznie we własnym imieniu, bo dyskursy zbiorowe z lewa i prawa sceny politycznej albo się skompromitowały, albo odniosły porażkę ${ }^{5}$. W tej nowej estetyce, której najsłynniejszym orędownikiem będzie César Aira, Gombrowicz odnajduje swoje miejsce jako pisarz awangardowy, twórca „procedur” opowiadania, „narzędzi generujących spojrzenie”, które u autora

5 V. Verónica Delgado, Las poéticas antirrepresentativas en la narrativa argentina de las dos últimas décadas: César Aira, Alberto Laiseca y Daniel Guebel, „CELEHIS. Revista del Centro de Letras Hispanoamericanas” 1996, t. 2, nr 6-8, s. 255-268. 
Zbrodni z premedytacją (Airze najbliżej do Bakakaju) przybiera formę nieustannej podejrzliwości co do interpretacji gestów, czynów lub słów. Argentyńczyk odwołuje się także do ideału młodości rozumianej $\mathrm{w}$ sensie estetycznym jako inwencja twórcza i impuls opowiadania (w opozycji do metaliterackiej dygresji), a zbudowana przezeń figura autora - kontrowersyjna, wewnętrznie sprzeczna, skandalizująca - wykazuje szereg podobieństw do „ja” zamkniętego w Dzienniku.

Im bliżej teraźniejszości, tym trudniej wyznaczać dominanty interpretacyjne: w końcu xx i początkach xxI wieku piszą nadal „uczniowie" Gombrowicza, pielęgnujący wspomnienie więzów łączących ich z „mistrzem” (jak Juan Carlos Gómez i w mniejszym stopniu Néstor Tirri) lub dystansujący się od przytłaczającego ciężaru tej postaci (Jorge Di Paola, Jorge Vilela). Legenda Gombrowicza wciąż pracuje, przy czym nie chodzi już o dochodzenie prawdy o pisarzu, a - jak to czyni Alberto Fischerman w filmie Gombrowicz o La seducción - o rekonstrukcję wielości sprzecznych wspomnień, emocji i impresji, które same w sobie są już kolejną Gombrowiczowską fikcją. Pisarze i intelektualiści zgromadzeni wokół działającego od lat 9o. Koła Gombrowicza (Tomás Abraham, Alejandro Rússovich) kontynuują tradycyjną interpretację opartą na eksploracji związków z klasycznymi pytaniami filozofii nowożytnej, próbując jednocześnie zadośćuczynić argentyńskim uwarunkowaniom tego dzieła. Zapoczątkowaną przez Piglię tradycję krytyka-detektywa kontynuuje Guillermo David, podnosząc charakterystyczny dla tej lektury temat klęski twórczej. W ostatnich latach autor Trans-Atlantyku nadal służy argentyńskim pisarzom do opowiadania o własnym kraju, w szczególności do dokonywania historycznych i geograficznych rozliczeń. Gombrowiczowski cynizm w zestawieniu $\mathrm{z}$ fanatyzmem lewicowego comandante (Luis Mattini) oraz marazmem zapomnianej prowincji (Hernán Ronsino, Lucas Cosci) ujawnia - mniej lub bardziej zręcznie balansując na chwiejnej w tym wypadku opozycji swój-obcy - napięcia właściwe dla argentyńskiej kultury w pierwszych dekadach XxI wieku. 



\section{Miradas desde el afuera. Witold Gombrowicz en la literatura argentina (1970-2017) (resumen)}

El objetivo de la monografía es determinar el legado de la obra de Witold Gombrowicz en la literatura argentina de los últimos 50 años, enfocándose en cómo los textos y la leyenda del autor polaco funcionan o actúan dentro del universo de las letras argentinas. Pese a que el autor de Ferdydurke pasó en su patria adoptiva más de 20 años y escribió allí la mayor parte de su obra, la crítica polaca suele obviar el contexto argentino de su quehacer artístico, limitándose a considerar como relevantes solo sus vínculos con la cultura e historia polacas. El interés por la reconstrucción de los detalles biográficos de su vida argentina no ha remediado, en realidad, estas restricciones de una perspectiva meramente nacional, en la que Gombrowicz sigue siendo un autor difícilmente interpretable sin tener en cuenta su polonidad. En la presente monografía, estos imperativos de lectura elaborados por la crítica polaca quedan suspendidos para poder leer y reconstruir al "Gombrowicz argentino", es decir, a un escritor cuya obra se inscribe e interviene dentro del canon literario argentino. El hecho de adoptar la perspectiva de la cultura de acogida (y eludir la de origen) presupone una serie de concesiones con respecto a esta cultura, a la que se concede el derecho de una interpretación independiente, es decir, llevada a cabo con indiferencia hacia los orígenes polacos del autor. En otras palabras, el Gombrowicz leído y comentado en estas páginas es un autor cuya obra deja de estar protegida por el canon nacional polaco - en el que ocupa el lugar privilegiado de clásico - para tener 
que defenderse y persistir en un campo literario que le asigna el rol de escritor por excelencia marginal.

Se establece el año 1970 como principio de la época que se investiga en la presente monografía, para centrarse en las interpretaciones no intermediadas por el autocomentario del autor. El mismo abandona Argentina en 1963 y, a partir de ese momento, su obra se va liberando gradualmente del peso de la leyenda de Gombrowicz-provocador o Gombrowicz-amigo-de-jóvenes y empieza a ser leída por los que no lo conocieron en persona.

En el primer capítulo se elabora el método de investigación aplicado para el caso del "Gombrowicz argentino". Con tal objetivo, se repasan primero las nuevas tendencias dentro de la literatura comparada, que - en las últimas décadas - ha propuesto una serie de acercamientos competitivos para con las filologías nacionales. Se atiende, en primer lugar, la cuestión de la traducibilidad de una cultura - especialmente la considerada como periférica o "débil" - a los códigos propios de una cultura diferente. Luego, se debaten las clásicas teorías de recepción (sobre todo, la de Hans Robert Jauss), que, sin embargo, solo podrán aplicarse con una notable restricción: en Buenos Aires, Gombrowicz no será recibido como un autor realmente extranjero, sino como un autor argentino, aunque situado en los márgenes de la tradición literaria nacional. De igual manera, este Gombrowicz se escapa a los mecanismos de la llamada "literatura nacional". El modelo de Pascale Casanova solo atiende la dinámica de relaciones entre centro (hasta hace poco, París) y periferias, mientras que el intercambio aquí tratado se da entre dos espacios periféricos, de los cuales ninguno parece mejor cotizado en la bolsa de la literatura universal. En cambio, la teoría de David Damrosch, a primera vista más flexible y mejor adaptable al caso en cuestión, tiene el importante defecto de exigir al lector una disposición a comprometerse con el mundo ajeno, una especie de apertura a la otra cultura que los lectores argentinos no se plantean, pretendiendo precisamente lo contrario: nacionalizar a Gombrowicz. A continuación, se comentan brevemente las fronteras de las relaciones intertextuales, que - si bien pueden no ser proyectadas conscientemente por el autor - necesitan fijarse en o explicarse por los textos mismos. En otras palabras, para 
medir el "efecto Gombrowicz" en las letras argentinas, las relaciones intertextuales propuestas requieren una legitimización concreta más allá de la imaginación o voluntad del crítico.

En el segundo capítulo se reflexiona sobre las traducciones de las obras del escritor polaco al español, siendo estas reflexiones precedidas, otra vez, por los comentarios de orden metodológico, concentrados en el papel que se asigna a los textos extranjeros en las literaturas nacionales. Se estudian con más detenimiento tres obras gombrowiczianas en las que la intervención del autor en la preparación del texto castellano fue especialmente relevante (autotraducciones o libros ampliamente revisados): Ferdydurke, Casamiento y Diario argentino. En el caso de la primera de ellas - cuyo proceso de traducción sigue siendo uno de los más comentados en la historia literaria argentina - nos distanciamos de los dictámenes críticos desarrollados por los investigadores polacos, que se enfocan en demostrar las pérdidas impuestas por la traducción (deslices, omisiones, simplificaciones, etc.), ignorando los beneficios: ante todo, el ensanchamiento del horizonte interpretativo. Siguiendo las reflexiones de Bozena Zaboklicka, se demuestra el mismo potencial de nuevas lecturas en la versión castellana de Casamiento, cuya traducción fue llevada a cabo por Gombrowicz y Alejandro Rússovich. Diario argentino es, desde la perspectiva meramente traductológica, un caso particular, puesto que no se trata de una autotraducción, sino de un texto reconstruido a posteriori por el autor: Gombrowicz seleccionó fragmentos de su Diario y los dispuso en un orden nuevo, dotándolos así de un significado diferente al que tuvieron en la versión original. $\mathrm{El}$ análisis de las traducciones, concentrado en su aspecto pragmático (¿cómo funcionan en la cultura de acogida?, ¿cómo moldea esta la recepción?, ¿qué matices textuales resultan allí especialmente relevantes?), nos lleva a la conclusión de que, en Argentina, se lee a un Gombrowicz en cierta medida distinto al Gombrowicz polaco, lo cual, a su vez, justifica una serie de divergencias interpretativas en ambos países. Por ejemplo, el rótulo de "escritor fracasado" que se le atribuye en su patria adoptiva - de acuerdo con su autopresentación plasmada en las versiones argentinas de sus textos - resulta completamente inoperante (o incluso falso) para la crítica polaca. 
El capítulo siguiente se dedica al estudio de la producción crítica argentina sobre el autor de Ferdydurke. Para desbrozar el camino hacia un mejor entendimiento de sus postulados, se propone primero un largo apartado introductorio en el que se discute la formación de la identidad nacional argentina para después referir el proceso de la nacionalización ex post de Gombrowicz, es decir, su paulatina inclusión dentro de la tradición literaria argentina.

El corpus de los textos críticos queda dividido en cuatro grupos en función de lo que se destaca como lo esencial para su obra (lo gombrowicziano) o lo más productivo dentro del canon literario argentino. Así, el primer grupo es fomado por los acercamientos que gravitan alrededor de la problemática del exilio y la desterritorialización. Nuestros análisis se enfocan, por un lado, en los travel writing de Gombrowicz (Diario argentino, Peregrinaciones argentinas) y, por otro, en su propia condición vital de exiliado, cuyo papel en la formación de la identidad nacional fue clave hasta los años 80 del siglo pasado. Se analiza asimismo el fenómeno de la migración actual (desplazamientos, dislocaciones, etc.) para determinar la vigencia de la obra gombrowicziana en este campo conceptual. El segundo grupo de textos críticos se centra en la problemática vinculada con lo corporal. Se reflexiona ante todo sobre las relaciones entre la estetización de la juventud plebeya, esencial en el proyecto literario de Gombrowicz, y la realidad sociopolítica de la Argentina de los años 40 y 50 . El siguiente tema hacia el que la crítica argentina suele orientar su interés concierne el tema del lenguaje: la posible adscripción del autor de Trans-Atlántico a la literatura llamada por Steiner "extraritorial", y el papel que ocupa la traducción de Ferdydurke en la ideología reinante en el campo literario argentino a partir de los años 40. Finalmente, se atienden las maneras en que la crítica argentina se acerca a la prosa autoficcional de Gombrowicz: se estudia el yo plasmado en los textos narrativos pero, sobre todo, se destaca la productividad de la construcción del yo expuesta en el Diario. Su ostensible "figura de autor", caracterizada por la irreverencia y el cinismo, interiormente contradictoria y nunca cerrada en una imagen definitiva, será modelo para una serie de autores argentinos (Aira, Lamborghini, Fogwill). El capítulo dedicado a la 
crítica argentina sobre Gombrowicz se cierra con algunas reflexiones acerca del lugar que ocupa este escritor en el canon literario de su patria adoptiva. Se analiza sobre todo la amplitud de juicios críticos acerca de las relaciones entre la obra de Gombrowicz y la de Jorge Luis Borges, sobre las que se opina, ora destacando las semejanzas, ora insistiendo en las diferencias fundamentales.

En el último capítulo de la monografía, y también el más extenso, se reconstruyen y comentan las lecturas que hacen de la obra gombrowicziana los principales agentes en el campo literario argentino a partir de los años 70. Conforme a las estipulaciones metodológicas del primer capítulo, se evita la noción de "influencia" (por cargada con significados confusos), prefiriendo la de "uso": se presupone que cada escritor lee los textos gombrowiczianos de acuerdo con la dinámica de su propia obra, haciéndola actuar a favor de sus convicciones literarias individuales. Así, el primer "proyecto de lectura" analizado es el propuesto por el grupo Literal y su principal espíritu impulsor, Germán García, que en la primera mitad de los 70 usan la estética gombrowicziana para combatir las ideologías reinantes en la cultura argentina por aquel entonces, es decir, el realismo, el populismo y el imperativo del compromiso social. Luego, nos enfocamos en las relaciones intertextuales existentes entre Gombrowicz y Osvaldo Lamborghini, optando por buscarlas en el cuento La causa justa, de 1983. Los universos literarios de ambos autores convergen, entre otros aspectos, en elaborar las "fábulas lingüísticas", es decir, narraciones en las que los "hechos lingüísticos" (palabras, maneras de hablar, polisemia, etc.) tienen el peso de acontecimientos reales que impulsan la acción.

Otro autor en cuya estética detectamos relaciones intertextuales con lo gombrowicziano es Copi, escritor igualmente situado al margen del canon argentino, puesto que su obra se compuso casi exclusivamente en francés. Trazamos una serie de paralelismos entre el cuento "L'Uruguayen", de Copi, y dos cuentos del volumen Bacacay ("Aventuras" y "Acerca de lo que ocurrió a bordo de la goleta Banbury"). Así, en los tres constatamos la construcción narrativa basada en el principio de pura invención, la fábula conducida a un ritmo veloz y liberada de la lógica de las relaciones causales, así como el uso 
especial del lenguaje, en el que las relaciones metafóricas son tratadas literalmente. Además de similitudes formales, encontramos una serie de convergencias a nivel de contenido, como referencias irónicas a la dialéctica del amo y el esclavo, relatos de supervivencia y un retrato burlesco de la comunidad exiliada polaca y argentina.

Este espacio de afinidades constituye un excelente punto de partida para estudiar la obra de César Aira desde la perspectiva de sus deudas para con lo gombrowicziano, teniendo en cuenta que Aira profesa asimismo una explícita admiración por la obra y figura de Copi. Para tal propósito, se describe primero el original proyecto novelesco del autor de La liebre, haciendo hincapié en los conceptos de "procedimiento", "huida hacia adelante", "mala literatura" o "exotismo", que se originan en su deseo artístico de volver a la estética de las vanguardias. Para Aira, Gombrowicz practica en el Diario argentino una especie de exotismo à rebours, que consiste en "la adopción imaginaria de una nacionalidad afectada de inexistencia”. Además de las analogías a nivel formal, a las que ya nos hemos referido hablando de Copi y que bien pueden establecerse también con respecto a la novelística de Aira, el más importante punto en común con la literatura del polaco consiste en la exploración del ideal de la juventud, aunque para el autor de La serpiente este tenga un valor meramente estético. Finalmente, Aira abraza también la figura del autor que se autoconfiguró Gombrowicz, una figura basada en la irreverencia, propensión a la polémica y firmeza de juicios.

Esta característica, en cambio, no se aplica en ningún aspecto al más conocido interpretador argentino de Gombrowicz, Ricardo Piglia, cuyos parentescos con el escritor polaco pueden trazarse en el ámbito meramente teórico, estando por completo ausentes en su figura autorial y estilo literario. De entre todos los "herederos" argentinos de Gombrowicz, el autor de Respiración artificial lo usa de una forma más radical, leyéndolo conforme a la dinámica de su propia obra. Así, primero, el autor de Trans-Atlántico le sirve en su proyecto de reorganización del canon literario argentino, como un escritor que, desde ocupar las posiciones marginales, pasa a formar su núcleo más sólido, junto con Roberto Arlt y Macedonio Fernández. Más adelante, el Gombrowicz pigliano llega a ser el que, en su conferencia "Contra los 
poetas", cuestiona tajantemente las maneras tradicionales de asignar el valor a una obra de arte. Finalmente, la novela gombrowicziana Cosmos le ayuda a Piglia a elaborar la teoría de "ficción paranoica", en la que el relato detectivesco clásico se desvía a contar un complot tramado para socavar jerarquías (sociales, estéticas, éticas) establecidas. En cada momento, la narrativa del argentino busca intervenir en la realidad extraliteraria y responder a problemas sociopolíticos actuales, por lo cual, de rebote, la obra gombrowicziana también adquiere el valor de compromiso ideológico.

A continuación, indagamos las maneras en que los antiguos “jóvenes amigos" del autor de Ferdydurke procesan su obra desde la distancia temporal, cómo la releen ya de adultos. Estudiamos, pues, una serie de textos de Juan Carlos Gómez, reparando en su peculiar metodología, caracterizada por la tensión entre un tono meramente rememorativo y un análisis crítico riguroso y seco. Más adelante, examinamos la novela Minga!, de Jorge di Paola -que consideramos la más lograda de todas las traídas a colación en este apartado-, así como las novelas de Néstor Tirri y Jorge Videla, cerrando estas reflexiones con un breve comentario acerca de la película de Alberto Fischerman, Gombrowicz o La seducción.

Otro centro de lectura de la obra del polaco se constituyó en los años 90 bajo el nombre de "Círculo Gombrowicz", dirigido por Germán García y formado, entre otros, por el filósofo Tomás Abraham, cuyo ensayo Fricciones se ocupa de Gombrowicz como escritor polaco-argentino. En el marco de la actividad de esta tertulia filosófico-literaria, se escribieron dos novelas en las que Gombrowicz interviene como personaje. En la primera, Witoldo o la mirada extranjera, de Guillermo David, se siguen explorando los tópicos de la lectura pigliana, de ahí el interés por la figura del escritor fracasado y la tendencia a la mezcla de géneros literarios (crítica y ficción). En la segunda, La fortuna, de Germán García, una novela de fuerte impronta autobiográfica, Gombrowicz sirve como modelo a uno de los personajes principales. Al "Círculo" no perteneció el amigo de García de la época de Literal, Luis Gusmán, pero su texto "El artista polaco", a caballo entre literatura y filosofía, bien se podría incluir en el mismo acercamiento crítico. 
En el apartado siguiente, hemos agrupado las novelas publicadas ya en el siglo XxI, que tienen en común el hecho de ficcionalizar las relaciones que Gombrowicz cultivó con la provincia argentina como un espacio "bajo" o culturalmente atrasado. Cartas profanas, de Luis Mattini, se basa en la historia del encuentro entre el polaco y el futuro jefe de una guerrilla izquierdista argentina, Roberto Santucho. 1958, Estación Gombrowicz, de Lucas Cosci, cuenta aventuras imaginarias del autor del Diario en Santiago del Estero, mientras que en La descomposición, de Hernán Ronsino, ambientada en un pueblo de la provincia de Buenos Aires, el escritor polaco protagoniza uno de los episodios secundarios. La monografía se cierra con una serie de referencias a los autores que siguen explotando el procedimiento de hacer intervenir a Gombrowicz como personaje de sus ficciones (Edgardo Cozarinsky o el uruguayo Gustavo Wojciechowski) o aquellos cuya deuda con el autor de Ferdydure se contrae a niveles menos directos (por ejemplo, mediante el empleo de lo grotesco o de una narración absurda que tuerce hasta lo imposible la lógica de las relaciones causales), como sería el caso de Fernanda García Lao o Damián Tabarovsky. 


\section{Bibliografia}

\section{Dzieła Witolda Gombrowicza}

\section{Przekłady na język hiszpański}

Ferdydurke [1947], przeł. autor i komitet tłumaczy, Seix Barral, Barcelona 2011. El casamiento [1948], przeł. Alejandro Rússovich, Witold Gombrowicz, El Cuenco de Plata, Buenos Aires 2010.

Pornografía [La seducción, 1965], przeł. Gabriel Ferrater, Seix Barral 2011.

Diario argentino [1968], przeł. Sergio Pitol, Adriana Hidalgo, Buenos Aires 2006. Yvonne, princesa de Borgoña [1968], przeł. Jorge Lavelli, Roberto D. Scheuer, w: Ludwik Margules (oprac.), Teatro polaco contemporáneo, Ediciones El Milagro, México 1996.

Cosmos [1969], przeł. Sergio Pitol, Seix Barral, Barcelona 2010.

La virginidad, przeł. Sergio Pitol, Tusquets, Barcelona 1970.

Testamento. Conversaciones con Dominique de Roux [Lo humano en busca de lo humano. Witold Gombrowicz conversa con Dominique de Roux, 1970], przeł. Rosa Alapont, Anagrama, Barcelona 2006.

Trans-Atlántico [1971], przeł. Sergio Pitol, Kazimierz Piekarec, Seix Barral, Barcelona 2003.

El Matrimonio/Opereta, przeł. Javier Fernández de Castro, Barral Editores, Barcelona 1973 .

Bacacay [1974], przeł. Sergio Pitol, Bożena Zaboklicka, Pau Freixa Terradas, El Cuenco de Plata, Buenos Aires 2015.

Los hechizados [1982], przeł. José Bianco, Seix Barral, Barcelona 2005.

Recuerdos de Polonia, przeł. Bożena Zaboklicka, Juan Carlso Vidal, Versal, Barcelona 1985.

Peregrinaciones argentinas, przeł. Bożena Zaboklicka, Francesc Miravitlles, Alianza, Madrid 1987. 
Yo y mi doble, przeł. z fr. Mónica Mansour, „Pagina/12” 1996, 11 viII, s. 4-5.

Curso de filosofía en seis horas y cuarto, przeł. José María Ventosa, Tusquets, Barcelona 1997.

Cartas a un amigo argentino, Emecé, Buenos Aires 1999.

Diario 1953-1969 [Diario I, 1988; Diario II, 1989], przeł. Bożena Zaboklicka, Francesc Miravitlles, Seix Barral, Barcelona 2005.

Ferdydurke, przeł. Jerzy Sławomirski, Anna Rubió, Biblioteca Universal del Circulo de Lectores, Barcelona 2005.

Contra los poetas, przeł. Francisco Ochoa de Michelena, Sequitur, Madrid 2009. Autobiografía sucinta. Correspondencia, Página/12, Buenos Aires 2010.

\section{Wybrane teksty polskojęzyczne}

Autobiografia pośmiertna, oprac. Włodzimierz Bolecki, Wydawnictwo Literackie, Kraków 2002.

Bakakaj i inne opowiadania, oprac. Zdzisław Łapiński, Wydawnictwo Literackie, Kraków 2002.

Dramaty, Wydawnictwo Literackie, Kraków 1986.

Dziennik 1953-1969, Wydawnictwo Literackie, Kraków 2013, e-wydanie.

Ferdydurke, oprac. Włodzimierz Bolecki, Wydawnictwo Literackie, Kraków 2004. Giedroyc Jerzy, Gombrowicz Witold, Listy 1950-1969, wyb., wstęp i przypisy Andrzej Stanisław Kowalczyk, Czytelnik, Warszawa 1993.

Kosmos, Wydawnictwo Literackie, Kraków 1986.

Kronos, wstęp Rita Gombrowicz, posł. Jerzy Jarzębski, przypisy Rita Gombrowicz,

Jerzy Jarzębski, Klementyna Suchanow, Wydawnictwo Literackie, Kraków 2013 .

Listy do Juana Carlosa Gómeza, przeł. Ewa Zaleska, „Literatura na Świecie” 2001, nr 4, s. 5-29.

Pornografia, posł. Jerzy Franczak, Wydawnictwo Literackie, Kraków 2011.

Testament. Rozmowy z Dominique de Roux, przeł. Ireneusz Kania, Wydawnictwo Literackie, Kraków 2012, e-wydanie.

Trans-Atlantyk, Wydawnictwo Literackie, Kraków 1986.

Varia 1. Czytelnicy i krytycy, Wydawnictwo Literackie, Kraków 2004.

Varia 2. Polemiki i dyskusje, Wydawnictwo Literackie, Kraków 2004.

Wspomnienia polskie. Wędrówki po Argentynie, koment. Jan Kott, Zofia Chądzyńska, Wydawnictwo Literackie, Kraków 1999.

Wyimki z listów Witolda Gombrowicza do argentyńskich przyjaciół, wyb. Juan Carlos Gómez, przeł. Rajmund Kalicki, „Twórczość” 1999, nr 7, s. 73-84. 


\section{Teksty pisarzy argentyńskich}

Aira César, Arcydzieło tajemne, przeł. Rajmund Kalicki, „Twórczość” 2003, nr 1, s. 143-145. Pierwodruk: La obra maestra secreta, „El País” 2001, 26 XI, http:// goo.gl/Fj5ZcL, dostęp: 7 IX 2016.

—, Ars narrativa, „Criterion” 1994, nr 8, http://goo.gl/Gokfn6, dostęp: 31 viII 2016.

—, Cómo me hice monja, w: idem, Cómo me hice monja, Mondadori, Barcelona 1998, s. 9-98.

—, Copi, Beatriz Viterbo, Rosario 1991.

—, Diario de la hepatitis, Bajo la Luna, Buenos Aires 2007.

—, El deseo de viajar, „Ramona”, https://goo.gl/EUSTTy, dostęp: 9 XII 2016.

—, El llanto, w: idem, Cómo me hice monja, Mondadori, Barcelona 1998, s. 167-231.

—, Exotismo, „Boletín del Centro de Estudios de Teoría y Crítica Literaria” (Rosario) 1993, nr 3, https://goo.gl/VWjxfi, dostęp: 20 x 2016.

—, La innovación, „Boletín del Centro de Estudios de la Teoría y Crítica Literaria” (Rosario) 1995, nr 4, s. 29-30.

—, La nueva escritura, „Boletín del Centro de Estudios de Teoría y Crítica Literaria" (Rosario) 2000, $\mathrm{nr} 8$, s. 165-170.

—, La prueba, w: idem, Cómo me hice monja, Mondadori, Barcelona 1998, s. 99-168.

—, La serpiente, Beatriz Viterbo, Rosario 1997.

—, Nostalgias de un polaco en el exilio, „Creación” 1986, nr 3, s. 78.

—, Nouvelles impressions du Petit Maroc, MEET, Saint Nazaire 1991.

-, Novela argentina: nada más que una idea, „Vigencia” 1981, nr 51, s. 55-58.

—, Prólogo, w: Juan Carlos Gómez, Gombrowicz, este hombre me causa problemas, Interzona, Buenos Aires 2004, s. 9-15.

—, Prólogo, w: Osvaldo Lamborghini, Novelas y cuentos, Ediciones del Serbal, Barcelona 1988, s. 7-16.

Arlt Roberto, Escritor fracasado, w: idem, Narrativa corta completa, t. 1, Universidad de la Laguna, La Laguna 1995, s. 31-48.

Berti Eduardo, Gombrowicz en Argentina, https://goo.gl/VXyY4E, dostęp: 18 I 2017.

—, La filosofía de Gombrowicz, https://goo.gl/bQgulk, dostęp: 18 I 2017.

Borcich Witold [właśc. Gustavo Wojciechowski], Abisinia: entre algunas cosas que pude haber escrito y hoy no recuerdo, wyb. i przeł. Gustavo Maca Wojciechowski, Yaugurú, Montevideo 2009.

Borges Jorge Luis, Kafka i jego prekursorzy, w: idem, Dalsze dociekania, przeł. Andrzej Sobol-Jurczykowski, Prószyński i S-ka, Warszawa 1999, s. 156-16o.

—, Pisarz argentyński i tradycja, w: idem, Polemiki, przeł. Joanna Partyka, Prószyński i S-ka, Warszawa 2008, s. 175-188. 
—, Tamten, w: idem, Księga piasku, przeł. Zofia Chądzyńska, Prószyński i S-ka, Warszawa 1998, s. 5-16.

Copi, El uruguayo, przeł. Enrique Vila-Matas, http://goo.gl/krmEHK, dostęp: 16 vi 2016. Tekst opublikowany w: Héctor Libertella (red.), Copi, Lamborghini, Wilcock y otros: 11 Relatos Argentinos del siglo xx (Antología Alternativa), Perfil, Buenos Aires 1997.

—, La Internacional Argentina, przeł. Alberto Cardín, Anagrama, Barcelona 1989. Cortázar Julio, Gra w klasy, przeł. Zofia Chądzyńska, Muza, Warszawa 2000.

Cosci Lucas D., 1958, estación Gombrowicz, EDUNSE, Santiago del Estero 2015. Cozarinsky Edgardo, Navidad del 54, https://goo.gl/WlJQMM, dostęp: 16 I 2017. Tekst opublikowany w: idem, La novia de Odessa, Emecé, Buenos Aires 2001. David Guillermo, Witoldo o la mirada extranjera, Colihue, Buenos Aires 1998. Di Paola Jorge, Apéndice: Witold, el escritor tábano, w: Elsa Drucaroff (red.), Historia crítica de la literatura argentina, t. 11, Emecé, Buenos Aires 2000, s. 373-375. —, Epilog gumowaty, przeł. Rajmund Kalicki, „Twórczość” 2001, nr 4, s. 152.

—, Las jornadas de Sebregondi, „Panorama” 1973, 14 VI, s. 66.

-, Minga!, FCE, Buenos Aires 2012.

—, Osvaldo Lamborghini: un museo literal, „Panorama” 1973, 2 II, s. 62-63.

Fernández Macedonio, Museo de la Novela de la Eterna, oprac. Ana Camblong, Adolfo de Obieta, ALLCA xx, Madrid 1997.

García Lao Fernanda, Muerta de hambre, El Cuenco de Plata, Buenos Aires 2005. García Germán, Cancha Rayada, Otium Narrativa, Buenos Aires 2014.

—, Gombrowicz textual, „Los Libros” 1972, nr 26, s. 26-28.

—, Gombrowicz, citado, „Pluma y Pincel” 1976, nr 15, s. 3.

—, Gombrowicz. El estilo y la heráldica, Atuel, Buenos Aires 1992.

-, La fortuna, Ediciones de la Flor, Buenos Aires 2004.

—, Leer a Gombrowicz, „Los Libros” 1969, nr 2, s. 12.

Gómez Juan Carlos, Gombrowicz, czyli kuszenie, przeł. Rajmund Kalicki, „Twórczość" 2004, nr 4, s. 142.

—, Gombrowicz jest w nas, przeł. Rajmund Kalicki, „Literatura na Świecie” 2001, nr 4, s. 57-61. Pierwodruk: Gombrowicz está en nosotros, w: Witold Gombrowicz, Cartas a un amigo argentino, Emecé, Buenos Aires 1999, s. 145-152.

—, Kochani gombrowiczanie, przeł. Justyna Myszkowska, „Twórczość” 200o, nr 4, s. 150-151.

—, Listy Juana Carlosa Gómeza do Witolda Gombrowicza, przeł. Rajmund Kalicki, „Twórczość” 1999, nr 7, s. 85-104.

—, Milonga dla Gombrowicza, przeł. Rajmund Kalicki, „Twórczość” 2004, nr 7/8, s. 79-134. Pierwodruk: Gombrowicz, este hombre me causa problemas, Interzona, Buenos Aires 2004. 
-, Nowy przewodnik po Gombrowiczu, przeł. Rajmund Kalicki, „Twórczość” 2004, nr 5, s. 48-134.

—, Uwaga gombrowiczanie!, przeł. Ewa Zaleska, „Twórczość” 2005, nr 9, s. 110117.

-, Zapiski gombrowiczowskie, przeł. Ewa Zaleska, „Twórczość” 2008, nr 11, s. 77-100.

—, Zobaczymy się w Bueno Saires, przeł. Rajmund Kalicki, „Twórczość” 2004, nr 4, s. 46-92.

Gusmán Luis, El frasquito, Ediciones Noé, Buenos Aires 1973.

—, La ficción calculada 2, Ediciones Godot, Buenos Aires 2015.

Lamborghini Osvaldo, Novelas y cuentos, Ediciones del Serbal, Barcelona 1988.

-, Las hijas de Hegel, w: idem, Novelas y cuentos I, Sudamericana, Buenos Aires 2013, s. 185-238.

Martínez Guillermo, Clásicos contemporáneos: "Cosmos" de Gombrowicz, https:// goo.gl/94gjda, dostęp: 18 I 2017.

-, Gombrowicz, escritor de la dialéctica, w: Nicolás Hochman (red.), El fantasma de Gombrowicz recorre la Argentina, Heteronimos, Buenos Aires 2015, s. 37-50. Przedruk w: idem, La razón literaria. Ensayos y polémicas, Seix Barral, Buenos Aires 2016, s. 193-217.

Mattini Luis, Cartas profanas. Novela de correspondencia entre Santucho y Gombrowicz, Peña Lili/Continente, Buenos Aires 2008.

Piglia Ricardo, Antología personal, Anagrama, Barcelona 2015.

-, Crítica y ficción, Anagrama, Barcelona 2006.

-, Czy istnieje powieść argentyńska? Borges a Gombrowicz, przeł. Klementyna Suchanow, Krystian Radny, „Literatura na Świecie” 2001, nr 4, s. 65-71.

-, El lugar de Saer, w: Jorge Carrión (red.), El lugar de Piglia. Crítica sin ficción, Candaya, Barcelona 2008, s. 162-163.

-, El relato fuera de la ley, w: Luis Gusmán, El frasquito, Ediciones Noé, Buenos Aires 1973, s. 7-23.

-, Formas breves, Anagrama, Barcelona 2000.

-, Homenaje a Roberto Arlt, w: idem, Nombre falso, Anagrama, Barcelona 2002, s. 97-157.

—, La ficción paranoica, „Clarín. Revista N” 1991, 10 X, s. 4-5.

-, La forma inicial. Conversaciones en Princeton, Eterna Cadencia, Buenos Aires 2015.

—, La lengua de los desposeídos, „La Nación” 2008, 19 Iv, https://goo.gl/Kv7XGb, dostęp: 16 I 2012.

-, Los diarios de Emilio Renzi. Años de formación, Anagrama, Barcelona 2015.

-, Los diarios de Emilio Renzi. Los años felices, Anagrama, Barcelona 2016. 
—, Pisarz jako czytelnik, przeł. Ewa Kobyłecka-Piwońska, „Czytanie Literatury” 2014, nr 3, s. 399-404; 2015, nr 4, s. 253-26o.

—, Prólogo, w: Jorge Di Paola, Minga!, FCE, Buenos Aires 2012, s. 9-11.

—, Roberto Arlt, una crítica de la economía literaria, „Los Libros” 1973, nr 29, s. 22-27.

—, Sztuczne oddychanie, przeł. Barbara Jaroszuk, Muza, Warszawa 2009.

Ronsino Hernán, Gombrowicz: el viejo inmaduro, „Enfocarte.com - Revista

Digital de Arte y Cultura" [s.a.], nr 14, https:/goo.gl/9YXDCo, dostęp: 13 I 2017.

—, La descomposición, Eterna Cadencia, Buenos Aires 2014.

Saer Juan José, El escritor argentino en su tradición, „La Nación” 2002, 21 VII, http://goo.gl/tofulW, dostęp: 14 XI 2016.

-, Spojrzenie z zewnątrz, przeł. Klementyna Suchanow, Krystian Radny, „Literatura na Świecie” 2001, nr 4, s. 72-82. Pierwodruk: idem, La perspectiva exterior: Gombrowicz en la Argentina, „Punto de Vista” 1989, nr 35, s. 11-15; przedruk w: idem, El concepto de ficción, Seix Barral, Barcelona 2004, s. 20-32.

Tabarovsky Damián, Coney Island, Sudamericana, Buenos Aires 1996.

—, El heredero de Gombrowicz, „Clarín. Revista N” 2013, 13 III, http://goo.gl/ 7JZuVa, dostęp: 15 XII 2014.

-, Literatura de Izquierda, Beatriz Viterbo, Rosario 2004.

Tirri Néstor, La piedra madre, Galerna, Buenos Aires 2007.

Vilela Jorge, La mañana del 10 de enero, Biblioteca Nacional, Buenos Aires 2014.

\section{Krytyka argentyńska o Witoldzie Gombrowiczu}

Abraham Tomás, Los polacos, w: idem, Fricciones, Sudamericana, Buenos Aires 2004, s. 11-105.

—, (red.), Vidas filosóficas, Eudeba, Buenos Aires 1999.

Abós Álvaro, Kwartet $z$ Buenos Aires, przeł. Justyna Ziarkowska, „Odra” 1995, nr 2, s. 35-43.

Amícola José, Autoficción, una polémica literaria vista desde los márgenes (Borges, Gombrowicz, Copi, Aira), „Olivar” 2009, nr 12, s. 181-196.

—, El diario trans-atlántico de Witold Gombrowicz, „Zama” 2012, nr 4, s. 137-146.

—, Estéticas bastardas, Biblos, Buenos Aires 2012.

Blanco Calderón Rodrigo, Piglia y Gombrowicz: sobre el fracaso y otras estrategias de escritura, w: Jorge Carrión (red.), El lugar de Piglia. Crítica sin ficción, Candaya, Barcelona 2008, s. 27-43.

Brück Carlos, Ferdydurke, campeón de Rayuela, „Página/12” 2004, 28 Ix, https:// goo.gl/xF7RC2, dostęp: 18 I 2017. 
Cang Adrián, Estampas de la decepción, „Revista La Biblioteca” 2008, nr 7, s. $72-87$.

Cardozo Cristian, Agente social y estrategias discursivas: La seducción de Witold Gombrowicz como caso, V Jornadas de Sociología de la Universidad Nacional de La Plata, 2008, http://goo.gl/B32iuQ, dostęp: 1 x 2016.

-, Gombrowicz y la irreverencia de la forma: estrategias discursivas para ingresar al campo literario argentino del periodo 1939-1963, viII Congreso Internacional de Teoría y Crítica Literaria Orbis Tertius, Universidad Nacional de La Plata, 2012, http://goo.gl/B32iuQ, dostęp: 1 x 2016.

-, Sobre la construcción del yo en Diario (1953-1969) y Diario Argentino de Witold Gombrwoicz, Actas del II Coloquio Internacional "Escrituras del Yo", Universidad de Rosario, 2010, http://goo.gl/2btcqP, dostęp: 1 x 2016.

Chejfec Sergio, Gombrowicz, mito nativo, „El Ciudadano” wiosna 1999, s. nlb.

—, La música de las anomalías, w: Gisela Heffes (red.), Poéticas de los (dis)locamientos, Literal Publishing, Texas 2012, s. 45-62.

-, La tradición de la angustia, „El Ojo Mocho” (Buenos Aires) wiosna/lato 2004, nr 18/19, s. 62.

Chitarroni Luis, Un maestro indiscutible de la forma, „Clarín. Revista Ñ 2015, 3 XII, http://goo.gl/cxiKQ5, dostęp: 10 x 2016.

Gamerro Carlos, El puto en la literatura argentina, w: idem, Facundo o Martín Fierro. Los libros que inventaron la Argentina, Sudamericana, Buenos Aires 2015, e-wydanie.

Gasparini Pablo, El exilio procaz. Gombrowicz por la Argentina, Beatriz Viterbo, Rosario 2006.

García Germán, Arnaldo Rascovsky, una controversia silenciada, w: idem, El psicoanálisis y los debates culturales. Ejemplos argentinos, Paidós, Buenos Aires 2005, s. 183-185.

-, Gombrowicz y la ciudad: las oscuridades de Retiro, w: Daniel Balderston et al., Literatura y otras artes en America latina. Actas del XXXIV Congreso del Instituto Internacional de Literatura Iberoamericana, Iowa City, 2 al 6 de julio de 2002, t. 1, University of Iowa, Iowa 2004, s. 177-180.

-, La extraterritorialidad del pobre, w: Nicolás Hochman (red.), Pensar el afuera, Kazak Ediciones, Mar del Plata 2010, s. 103-121.

-, Patria y "filiatrías" (exilio y transnacionalidad en Gombrowicz, Copi y Perlongher), „Hispamérica” 2006, t. 30, nr 105, s. 45-58.

González Horacio, Restos pampeanos. Ciencia, ensayo y política en la cultura argentina del siglo XX, Colihue, Buenos Aires 1999.

Gusmán Luis, Ideales y rodeos del esclavo de sus diarios, „Clarín. Revista Ñ” 2014, $30 \mathrm{x}$, http://goo.gl/mSrjGu, dostęp: 5 III 2015. 
—, Qué significó Gombrowicz en los 6o, „Clarín. Revista Ñ” 2006, 11 II, http://goo. gl/5A8Z9r, dostęp: 5 v 2016.

Hochman Nicolás, Exilio y paralaje, „Letras Históricas” 2011, nr 4, s. 121-138.

Ísola Laura, Escrituras del exilio: Gombrowicz en Buenos Aires, w: Alvaro Fernández Bravo, Florencia Garramuño, Saúl Sosnowski (red.), Sujetos en tránsito: (in)migración, exilio y diáspora en la cultura latinoamericana, Alianza, Madrid-Buenos Aires 2003, s. 175-184.

—, "Ferdydurke" de Witold Gombrowicz. Diario de una traducción, w: Jorge Monteleone, Sylvia Iparraguirre (red.), Nuevos territorios de la literatura latinoamericana, Instituto de Literatura Hispanoamericana, Buenos Aires 1997, s. 393-397.

Mandolessi Silvana, Cultural Hierarchies, Secondary Nations. The Tension between Europe and "Minor" Cultures in Witold Gombrowicz and Jorge Luis Borges, w: Nele Bemong, Mirjam Truwant, Pieter Vermeulen (red.), Re-thinking Europe. Literature and (Trans)national Identity, Rodopi, Amsterdam-New York 2008, s. 151-162.

—, „Heterotopia” i literatura narodowa $w$ „Dzienniku argentyńskim” Witold Gombrowicza, przeł. Natalia Gendaj, „Rocznik Komparatystyczny” 2010, t. 2, s. 245-260. Pierwodruk: Heterotopía y literatura nacional en "Diario argentino” de Witold Gombrowicz, „Ciberletras: Revista de Crítica Literaria y de Cultura" 2007, nr 18.

-, Sobre exiliados, migrantes y extranjeros: hacia una definición terminológica, „Cahiers du CRICCAL” 2010, t. 39, nr 1, s. 71-78.

-, Una literatura abyecta. Gombrowicz en la tradición argentina, Rodopi, Amsterdam-New York 2012.

Matamoro Blas, La Argentina de Gombrowicz, „Cuadernos Hispanoamericanos” 1989, nr 469/470, s. 271-279.

Mozejko Danuta Teresa, Condiciones de aceptabilidad del discurso de un migrante. El caso Gombrowicz en la Argentina, „Amerika. Mémoires, Identités, Territoires” 2011, nr 5, http://amerika.revues.org/2537, dostęp: 1 X 2016.

Pauls Alan, Cómo se escribe el diario íntimo, El Ateneo, Buenos Aires 1996.

Riccio Alessandra, Gombrowicz o de la ingratitud, „Inti. Revista de Literatura Hispánica” 1998, nr 48, s. 19-32.

Rússovich Alejandro, El otro idioma de Witoldo, „Clarín. Revista Ñ” 1999, 25 VII, https://goo.gl/KTTqB7, dostęp: 10 XI 2015.

-, Gombrowicz en el relato argentino, w: Elsa Drucaroff (red.), Historia crítica de la literatura argentina, t. 11, Emecé, Buenos Aires 2000, s. 361-377.

-, Gombrowiczowska wizja świata wedle dzieł napisanych w Argentynie, z fr. przeł. E. Jogałła, w: Jerzy Jarzębski (red.), Witold Gombrowicz nasz współczesny. 
Materialy międzynarodowej konferencji naukowej w stulecie urodzin pisarza. Uniwersytet Jagielloński - Kraków, 22-27 marca 2004, Universitas, Kraków 2010, s. 17-21.

-, Sobre esta traducción, w: Witold Gombrowicz, El casamiento, przeł. Alejandro Rússovich, Witold Gombrowicz, El Cuenco de Plata, Buenos Aires 2010, s. 5-6.

-, ¿Quién es Witold Gombrowicz?, w: Tomás Abraham (red.), Vidas filosóficas, Eudeba, Buenos Aires 1999, s. 313-326.

Sierra Marta, Las "Tierras de la memoria": las estéticas sin territorio de Witold Gombrowicz y Felisberto Hernández, „Hispanic Review” 2006, t. 74, nr 1, s. 59-82.

Tcherkaski José, Las cartas de Gombrowicz (Jorge Lavelli lo recuerda en una conversación entrañable), Siglo XxI, Buenos Aires 2004.

\section{Krytyka na temat literatury argentyńskiej}

Afanador Luis Fernando, El último vanguardista. Entrevista a César Aira, „El Malpensante", http://goo.gl/JLIFMl, dostęp: 7 IX 2016.

Amícola José, "L'Uruguayen" de Copi como espejo del triple estereotipo, w: Florent Kohler (red.), Stéréotypes culturels et constructions identitaires, Presses universitaires François-Rabelais, Tours 2007, s. 145-151.

Balderston Daniel, El significado latente en Respiración artificial, w: Jorge Fornet (red.), Ricardo Piglia, Casa de las Américas, Bogotá 2000, s. 171-178.

Bizzio Sergio, Notas Para Un Homenaje a Dipi Di Paola, „Ramona”, https://goo. gl/DBOuD6, dostęp: 9 XII 2016.

Carbone Alberto, Julio Cortázar: mi ametralladora es la literatura, „Crisis” 1973, nr 2, s. 10.

Catelli Nora, Los gestos de la postmodernidad, „Punto de Vista” 1984, nr 22, s. 37.

-, Rastros de la lucha: traducciones, versiones y menciones en la cultura argentina, „Punto de Vista” 1999, nr 64, s. 1-5.

Cella Susana (red.), Dominios de la literatura. Acerca del canon, Losada, Buenos Aires 1998.

Chitarroni Luis, Continuidad de las partes, relato de los límites, w: Elsa Drucaroff (red.), Historia crítica de la literatura argentina, t. 11, Emecé, Buenos Aires 200o, s. 161-182.

Contreras Sandra, César Aira: la novela del artista, „CELEHIS. Revista del Centro de Letras Hispanoamericanas” 1996, t. 2, nr 6-8, s. 205-215.

—, Las vueltas de César Aira, Beatriz Viterbo, Rosario 2002.

García Tomeu José, Una polémica actual: la reconstrucción del sistema literario argentino, „Anales de Literatura Hispanoamericana” 2007, t. 36, s. 199-219. 
Gregorich Luis, La literatura dividida, w: Saúl Sosnowski (red.), Represión y reconstrucción de una cultura: el caso argentino, Eudeba, Buenos Aires 1988, S. $121-124$

Dapelo Luis, Entrevista a César Aira, „Hispamérica” 2007, t. 36, nr 107, s. 41-54. Delgado Verónica, Las poéticas antirrepresentativas en la narrativa argentina de las dos últimas décadas: César Aira, Alberto Laiseca y Daniel Guebel, „CELEHIS. Revista del Centro de Letras Hispanoamericanas” 1996, t. 2, nr 6-8, s. 255-268.

Di Paola Jorge, Gusmán: el dominio de los mitos informes, „Panorama” 1973, 18 I, s. 30. Dimine Marcela, Bernini Emilio, Estudio preliminar. Literatura es lo que duele. Vilela, Gombrowicz y la escritura, w: Jorge Vilela, La mañana del 10 de enero, Biblioteca Nacional, Buenos Aires 2014, s. 9-28.

Drucaroff Elsa, La narración gana la partida, w: eadem (red.), Historia crítica de la literatura argentina, t. 11, Emecé, Buenos Aires 2000, s. 7-15.

—, Los hijos de Osvaldo Lamborghini, w: Noé Jitrik (red.), Atípicos en la literatura latinoamericana, Universidad de Buenos Aires, Buenos Aires 1997, s. 145-154.

Estrin Laura, Nuevas lecturas del viaje del provinciano, w: Miguel Vitagliano (red.), Boedo. Polítcas del realismo, Título, Buenos Aires 2012, s. 265-302.

Fernández Javier, Carlos Correas: un autorretrato en la ciudad, w: Miguel Vitagliano (red.), Boedo. Políticas del realismo, Título, Buenos Aires 2012, s. 237-263.

Fernández Leopoldo [właśc. Germán García], Los nombres de la negación, w: Osvaldo Lamborghini, El fiord, Chinatown, Buenos Aires 1969. Przedruk w: Germán García, Fuego amigo. Cuando escribí sobre Osvaldo Lamborghini, Grama Ediciones, Buenos Aires 2003, s. 13-29.

Ferro Roberto (red.), Historia crítica de la literatura argentina, t. 8: Macedonio, Emecé, Buenos Aires 2007.

Flisek Agnieszka, Algunas consideraciones sobre el carácter cínico de la escritura de Osvaldo Lamborghini, „Sociocriticism” 2011, t. 26, nr 1/2, s. 305-336.

-, Osvaldo Lamborghini y Copi: caminos de la escritura los por que el yo abandona a sí mismo para salir al encuentro de otro, „Sociocriticism” 2009, t. 24, nr $1 / 2$, s. 337-366.

Forn Juan, El fiel Goma, „Pagina/12” 2012, 14 XII, https://goo.gl/zGVIYL, dostęp: 4 I 2017.

Fornet Jorge, Conversación con Ricardo Piglia, w: idem (red.), Ricardo Piglia, Casa de las Américas, Bogotá 2000.

—, El escritor y la tradición. Ricardo Piglia y la literatura argentina, FCE, Buenos Aires 2007.

—, Un debate de poéticas: las narraciones de Ricardo Piglia, w: Elsa Drucaroff (red.), Historia crítica de la literatura argentina, t. 11, Emecé, Buenos Aires 200o, s. 349-350. 
Friera Silvina, Me interesan las pequeñas historias de los pueblos, „Página/12” 2007, 19 XII, https://goo.gl/g8SRs3, dostęp: 16 I 2017.

Gallego Cuiñas Ana, Literatura argentina y mercado editorial (una mirada estrábica), „Ínsula” 2013, nr 793/794, s. 32-33.

Gandolfo Elvio, El humor no es más fuerte, „Primer Plano” 1994, s. 1.

Giordano Alberto, La contraseña de los solitarios. Diarios de escritores, Beatriz Viterbo, Rosario 2012.

Guebel Daniel, Jorge Di Paola (1940-2007), „Ramona”, https://goo.gl/hB2ifW, dostęp: 9 XII 2016.

Gusmán Luis, Sebregondo no retrocede, w: Juan Pablo Dabove, Natalia Brizuela (red.), Y todo el resto el resto es literatura. Ensayos sobre Osvaldo Lamborghini, Interzona, Buenos Aires 2008, s. 49-54.

Hardmeier Jorge, Sostiene Dipi, „Ramona”, https://goo.gl/tZSAod, dostęp: 12 XII 2016.

Idez Ariel, "Literal". La vanguardia intrigante, Prometeo, Buenos Aires 2010.

Jaroszuk Barbara, Traumy i zabawy. Współczesna proza argentyńska (1983-2013), Muzeum Historii Polskiego Ruchu Ludowego, Warszawa 2013.

Jitrik Noé, Miradas desde el borde: el exilio y la literatura, w: Saúl Sosnowski (red.), Represión y reconstrucción de una cultura: el caso argentino, Eudeba, Buenos Aires 1988, s. 133-147.

La intriga, „Literal” 1973, nr 1, s. 119-122.

Laddaga Reinaldo, Espectáculos de realidad. Ensayo sobre la narrativa latinoamericana de las últimas dos décadas, Beatriz Viterbo, Rosario 2007.

—, Una literatura de la clase media. Notas sobre César Aira, „Hispamérica” 2001, t. 30 , nr 88 , s. $37-48$.

Libertella Héctor (red.), Copi, Lamborghini, Wilcock y otros: 11 Relatos Argentinos del siglo XX (Antología Alternativa), Perfil, Buenos Aires 1997.

—, Prólogo, w: idem, Literal 1973-1977, Santiago Arcos, Buenos Aires 2002.

Link Daniel, Literaura y mercado, w: Jorge Carrión (red.), El lugar de Piglia. Crítica sin ficción, Candaya, Barcelona 2008, s. 145-157.

López Casanova Martina, La narración de los cuerpos, w: Elsa Drucaroff (red.), Historia crítica de la literatura argentina, t. 11, Emecé, Buenos Aires 2000, S. $183-215$.

Manrique Sabogal Winston, El yo asalta la literatura, „El País” [dodatek literacki „Babelia”] 2008, 13 Ix, https://goo.gl/GFFVBC, dostęp: 24 XI 2016.

Martínez Estrada Ezequiel, La literatura y la formación de la conciencia nacional, w: Saúl Sosnowski (red.), Lectura crítica de la literatura armericana. La formación de las culturas nacionales, Buenos Aires Biblioteca Ayacucho, Carcacas 1996, s. 22-53. 
Mattalia Sonia, La ley y el crimen. Usos del relato policial en la narrativa argentina (1880-200o), Iberoamericana, Madrid 2008.

Mazzi Joaquín, 1939 y después: el largo invierno austral de Gombrowicz y Caillois, w: Celina Manzoni (red.), Historia crítica de la literatura argentina, t. 7: Rupturas, Emecé, Buenos Aires 2009, s. 411-436.

Mendoza Juan, El proyecto "Literal", w: "Literal” (1973-1977), Biblioteca Nacional, Buenos Aires 2011, s. 7-19.

—, "Permanecer en la vanguardia". Entrevista a Germán García, Dossier Literal de la Biblioteca Nacional Argentina, http://goo.gl/1jUqLG, dostęp: 5 V 2016.

—, "Una manera de leer provocada por una manera de escribir". Entrevista a Luis Gusmán, Dossier Literal de la Biblioteca Nacional Argentina, http://goo. gl/1jUqLG, dostęp: 5 v 2016.

Mesa Gancedo Daniel, Diarios personales hispanoamericanos en el siglo XXI, „Cuadernos Hispanoamericanos” 2013, nr 751, s. 7-23.

Molloy Silvia, Siskind Mariano (red.), Poéticas de la distancia: adentro y afuera de la literatura argentina, Norma, Buenos Aires 2006.

Montaldo Graciela, De pronto, el campo, „Punto de Vista” 1992, nr 42, s. 21-25.

-, Diez años en democracia: los cambios en el Canon, „Hispamérica” 1995, t. 24, nr 7, s. 39-48.

—, Zonas ciegas. Populismos y experimentos culturales en Argentina, FCE, Buenos Aires 2010.

Murena Héctor A., El pecado original de América, FCE, Buenos Aires 2006.

Negroni María, Un tratado sobre la extranjería de lo propio. "El uruguayo" de Copi, „Orbis Tertius: Revista de Teoría y Crítica Literaria” 2006, nr 12, http://goo. gl/4jQfu9, dostęp: 17 vi 2016.

No matar la palabra y no dejarse matar por ella, „Literal” 1973, nr 1, s. 5-13.

Ortega y Gasset José, Meditación del pueblo joven y otros ensayos sobre América, Alianza Editorial, Madrid 1995.

Pacheco José Emilio, »El proceso«, »El castillo«, las alambradas, w: Jorge Fornet (red.), Ricardo Piglia, Casa de las Américas, Bogotá 200o, s. 141-148.

Pauls Alan, ¡Lengua, sonaste!, „Babel” 1989, nr 9, s. 5.

—, Reyes en el exilio, „Suplemento Radar”, http://goo.gl/W4VeMH, dostęp: 10 I 2017.

Pellegrini Marcelo, Monder Samuel, Jeftanovic Andrea, Conversación con Ricardo Piglia, http://letras.s5.com/mpo10810.html, dostęp: 16 III 2016.

Podlubne Judith, Giordano Alberto, Exilio y extraterritorialidad: Wilcock y Bianciotti, w: Elsa Drucaroff (red.), Historia crítica de la literatura argentina, t. 11, Emecé, Buenos Aires 2000, s. 381-403.

Porrúa Ana, César Aira: imposión y juventud, „Punto de Vista” 2005, nr 81, s. 24-29. 
Premat Julio, Héroes sin atributos. Figuras de autor en la literatura argentina, FCE, Buenos Aires 2009.

Prieto Julio, Sobre ilegibilidad y malas escrituras en Hispanoamérica, „Ínsula” 2011, $\mathrm{nr} 777$, s. 2-4.

Prieto Martín, Breve historia de la literatura argentina, Taurus, Buenos Aires 2011, e-wydanie.

Pron Patricio, Aquí me río de las modas. Procedimientos transgresivos en la narratica de Copi y su importancia para la constitución de una nueva poética en la literatura argentina, niepublikowana rozprawa doktorska, Georg-August-Universität de Göttingen, Alemania, 2007, https://goo.gl/o5OPia, dostęp: 19 VI 2016.

-, De qué hablamos cuando hablamos de autor: la autoficción de César Aira, w: Vera Toro, Sabine Schlickers, Ana Luengo (red.), La obsesión del yo. La auto(r)ficción en la literatura española y latinoamericana, Iberoamericana, Madrid 2010, s. 111-121.

Rabanal Rodolfo, La vida escrita, Seix Barral, Buenos Aires 2014.

Quiroga Jorge, Literal, una irrupción en la literatura argentina, Dossier Literal de la Biblioteca Nacional Argentina, http://goo.gl/1jUqLG, dostęp: 5 V 2016.

Sarlo Beatriz, Borges, un escritor de las orillas, Siglo XXI, Madrid 2007.

-, El campo intelectual: un espacio doblemente fracturado, w: Saúl Sosnowski (red.), Represión y reconstrucción de una cultura: el caso argentino, Eudeba, Buenos Aires 1988, s. 95-107.

-, Escritos sobre literatura argentina, Siglo xxi, Buenos Aires 2007.

-, Oralidad y lenguas extranjeras. El conflicto en la literatura argentina durante el primer tercio del siglo $\mathrm{XX}, \mathrm{w}$ : eadem, Carlos Altamirano, Ensayos argentinos: de Sarmiento a la Vanguardia, Siglo xxI, Buenos Aires 1997, s. 269-288.

-, Si no hubiera existido Borges, „La Nación” 2011, 10 vI, http://goo.gl/RZNrJ, dostęp: 3 V 2016.

-, Tiempo pasado. Cultura de la memoria y giro subjetivo. Una discusión, Siglo Veintiuno, Buenos Aires 2005.

Speranza Graciela, ¿Dónde está el autor? Sobre el fantasmático regreso del autor a la ficción, „Quimera” 2008, nr 301, s. 24-29.

-, Fuera de campo. Literatura y arte argentinos después de Duchamp, Barcelona 2006.

Tobeña Verónica, La cuestión del canon en la literatura argentina. Un campo cultural abierto en dos, „A Contracorriente” 2002, t. 9, nr 2, s. 282-318.

Walker Carlos, Jorge Luis Borges: de "Martín Fierro" a "Sur” (1924-1935), „Iberoamericana" 2011, t. 11, $\mathrm{nr}$ 41, s. 25-42.

Wilson Patricia, Página impar: el lugar del traductor en el auge de la industria editorial, w: Sylvia Saítta (red.), Historia critica de la literatura argentina, t. 9, Emecé, Buenos Aires 2004, s. 123-142. 


\section{Polska i zagraniczna krytyka o Witoldzie Gombrowiczu}

Bereza Henryk, Goma, „Twórczość” 200o, nr 7, s. 85-86.

—, Goma (2), „Twórczość” 2004, nr 7/8, s. 146-150.

Berressem Hanjo, Reguly dewiacji. Fizyczne i psychiczne aberracje w powieściach Witolda Gombrowicza, w: Ewa Płonowska-Ziarek (red.), Grymasy Gombrowicza. W kręgu problemów modernizmu, społeczno-kulturowej roli płci i tożsamości narodowej, przeł. Janusz Margański, Universitas, Kraków 2001, s. 135-141.

Błoński Jan, „Dziennik”, czyli Gombrowicz dobrze utemperowany, w: idem, Forma, śmiech i rzeczy ostateczne. Studia o Gombrowiczu, Universitas, Kraków 2003, s. 139-178.

Bolecki Włodzimierz, Czego wyparł się Witold Gombrowicz?, w: Olaf Kühl, Gęba Erosa. Tajemnice stylu Witolda Gombrowicza, przeł. Krzysztof Niewrzęda, Maria Tarnogórska, wstęp Włodzimierz Bolecki, Universitas, Kraków 2005, s. V-XII.

—, Dodatek krytyczny, w: Witold Gombrowicz, Ferdydurke, oprac. Włodzimierz Bolecki, Wydawnictwo Literackie, Kraków 2004, s. 243-832.

Brzozowski Jerzy, Fabuła czy poezja? Bakakaj po portugalsku, w: Elżbieta Skibińska (red.), Gombrowicz i tłumacze, Leksem, Łask 2004, s. 213-224.

Cieński Marcin, O sarmackiej swojskości - czy Gombrowicza można tłumaczyć, nie znając literatury i kultury staropolskiej?, w: Elżbieta Skibińska (red.), Gombrowicz i tłumacze, Leksem, Łask 2004, s. 165-176.

Czermińska Małgorzata, Do kawiarni i za ocean. Paradoksy Gombrowiczowskiej filozofii podróży, w: Bernadetta Żynis (red.), Gombrowicze, Wyd. Pomorskiej Akademii Pedagogicznej, Słupsk 2006, s. 131-148.

Czernicka-Suchanow Klementyna, Proces „ferdydurkizacji” Argentyny, „Teksty Drugie" 2008, nr 3, s. 206-229.

Falkiewicz Andrzej, Spór śledzącego i sprawcy, w: Zdzisław Łapiński (red.), Gombrowicz i krytycy, Wydawnictwo Literackie, Kraków 1984, s. 561-572.

Ferrater Gabriel, Witold Gombrowicz, „Presencia” 1966, nr 9, s. 15.

Fiut Aleksander, Zwiedzanie „Kontynentu z Trzeciego Dnia Stworzenia”: Gombrowicz i Keyserling, w: Jerzy Jarzębski (red.), Witold Gombrowicz nasz wspótczesny. Materiały międzynarodowej konferencji naukowej w stulecie urodzin pisarza. Uniwersytet Jagielloński - Kraków, 22-27 marca 2004, Universitas, Kraków 2010, s. 567-578.

Freixa Terradas Pau, Argentyński portret wyobrażeniowy Gombrowicza, w: Ryszard Nycz, Władysław Miodunka, Tomasz Kunz (red.), Polonistyka bez granic. IV Kongres Polonistyki Zagranicznej, Uniwersytet Jagielloński, 9-11 października 2008, t. 1: Wiedza o literaturze i kulturze, Universitas, Kraków 2011, s. 537-546. 
—, Recepción de la obra de Witold Gombrowicz en la Argentina y configuración de su imagen en el imaginario cultural argentino, niepublikowana rozprawa doktorska, Universidad de Barcelona, 2008, http://goo.gl/A3avU1, dostęp: 6 II 2017.

-, Trans-Atlantyk de Witold Gombrowicz, guia de lectura per a no-polonesos, „Anuari de Filologia. Llengües i Literatures Modernes” 2012, nr 2, s. 1-27.

-, Zaboklicka Bożena, Gombrowicz jako postać fikcyjna w literaturze argentyńskiej, „Teksty Drugie” 2016, nr 1, s. 303-316.

Głowiński Michał, Gombrowiczowska nadliteratura, w: idem, Gombrowicz i nadliteratura, Wydawnictwo Literackie, Kraków 2002, s. 5-15.

-, Straszny piątek $w$ domu u hrabiny (O „Biesiadzie u hrabiny Kottubaj”), w: idem, Gombrowicz i nadliteratura, Wydawnictwo Literackie, Kraków 2002, s. 16-43.

Goldmann Lucien, Krytyka nic nie zrozumiała, przeł. Ireneusz Kania, w: Witold Gombrowicz, Varia 2. Polemiki i dyskusje, Wydawnictwo Literackie, Kraków 2004, s. 132-139.

Gombrowicz Rita, Gombrowicz w Argentynie. Świadectwa i dokumenty 1939-1963, przeł. Zofia Chądzyńska, Anna Husarska, Wydawnictwo Literackie, Kraków 2004.

Grabowska Monika, „Kujmy się, kujmy, bo cwaje dostaniemy” - szkoła w „Ferdydurke" i w jej przekładzie na francuski, w: Elżbieta Skibińska (red.), Gombrowicz i ttumacze, Leksem, Łask 2004, s. 37-52.

Grzegorczyk Marzena, Kształt życia i bezkształt tradycji. Argentyńska spuścizna Witolda Gombrowicza, w: Ewa Płonowska-Ziarek (red.), Grymasy Gombrowicza. W kregu problemów modernizmu, społeczno-kulturowej roli płci i tożsamości narodowej, przeł. Janusz Margański, Universitas, Kraków 2001, s. 159-182. Heydel Magdalena, Angielskie wersje „Ferdydurke” - strategie przekładania nieprzekładalnego, w: Elżbieta Skibińska (red.), Gombrowicz i tłumacze, Leksem, Łask 2004, s. 103-116.

Jarniewicz Jerzy, Frazes i frazeologia w angielskim przekładzie „Trans-Atlantyku”, czyli „tu właśnie cisna mnie buty”, w: Elżbieta Skibińska (red.), Gombrowicz i tłumacze, Leksem, Łask 2004, s. 191-200.

Jarzębski Jerzy, Gombrowicz - pisarz prowincji, w: Dominika Świtkowska, Tomasz Tyczyński (red.), Gombrowicz i okolice, Muzeum Literatury im. A. Mickiewicza, Warszawa 2013, s. 11-18.

-, Między chaosem a forma, w: Bolesław Faron (red.), Prozaicy dwudziestolecia międzywojennego, Wiedza Powszechna, Warszawa 1974, s. 181-217.

—, Natura i teatr. 16 tekstów o Gombrowiczu, Wydawnictwo Literackie, Kraków 2007.

-, W Buenos Aires - po trzydziestu pięciu latach, w: idem, Podglądanie Gombrowicza, Wydawnictwo Literackie, Kraków 2001, s. 221-235. 
Jordan Marta, Gombrowicz i Cortázar - nasi współcześni, w: Jerzy Jarzębski (red.), Witold Gombrowicz, nasz współczesny. Materiały międzynarodowej konferencji naukowej w stulecie urodzin pisarza. Uniwersytet Jagielloński-Kraków, 22-27 marca 2004, Universitas, Kraków 2010, s. 626-636.

Kalicki Rajmund (oprac.), Tango Gombrowicz, Wydawnictwo Literackie, Kraków 1984.

—, Twój list jest jak tango, „Twórczość” 1999, nr 7, s. 105-108.

Kobyłecka-Piwońska Ewa, "Este ecczema de cinco millones". La Buenos Aires de Witold Gombrowicz, w: Nicolás Hochman (red.), El fantasma de Gombrowicz recorre la Argentina, Heteronimos, Buenos Aires 2015, s. 284-295.

Kowalczyk Andrzej Stanisław, „Za niedyskrecję matka biła mnie po łapach”, w: Jerzy Giedroyc, Witold Gombrowicz, Listy 1950-1969, wyb., wstęp i przypisy Andrzej Stanisław Kowalczyk, Czytelnik, Warszawa 2006, s. 5-20.

Kühl Olaf, Gęba Erosa. Tajemnice stylu Gombrowicza, przeł. Krzysztof Niewrzęda, Maria Tarnogórska, wstęp Włodzimierz Bolecki, Universitas, Kraków 2005.

Kurek Marcin, „Ferdydurke” po hiszpańsku (kilka uwag o autorskim przekładzie Gombrowicza), w: Elżbieta Skibińska (red.), Gombrowicz i tłumacze, Leksem, Łask 2004, s. 13-20.

Laurent Maryla, Język Gombrowicza, czyli całkowanie wieloznaczności, w: Elżbieta Skibińska (red.), Gombrowicz i tłumacze, Leksem, Łask 2004, s. 21-36.

—, Przyprawianie gęby Gombrowiczowi, „Teksty Drugie” 2005, nr 3, s. 165-173. Margański Janusz, Geografia pragnień. Opowieść o Gombrowiczu, Wydawnictwo Literackie, Kraków 2005.

Markowski Michał Paweł, Czarny nurt. Gombrowicz, świat, literatura, Wydawnictwo Literackie, Kraków 2004.

Miecznicka Magdalena, Aneks I. Autoryzowane przekłady „Ferdydurke”, w: Witold Gombrowicz, Ferdydurke, oprac. Włodzimierz Bolecki, Wydawnictwo Literackie, Kraków 2004, s. 782-803.

Myszkowska Justyna, Mistrz, „Twórczość” 2004, nr 4, s. 126-129.

Nowicki Maciej, Witold Gombrowicz oczami żony: Zostawiłam mu wolność, „Newsweek” 2013, 9 v, https://goo.gl/VSLvqw, dostęp: 12 I 2017.

Pawłowski Janusz, Erotyka Gombrowicza, w: Zdzisław Łapiński (red.), Gombrowicz i krytycy, Wydawnictwo Literackie, Kraków 1984, s. 531-560.

Płonowska-Ziarek Ewa, Blizna cudzoziemca i barokowa fałda. Przynależność narodowa a homoseksualizm w "Trans Atlantyku” Witolda Gombrowicza, w: eadem, Grymasy Gombrowicza. W kręgu problemów modernizmu, społeczno-kulturowej roli płci i tożsamości narodowej, przeł. Janusz Margański, Universitas, Kraków 2001, s. 243-278. 
Reichardt Dieter, Gombrowicz a literatura argentyńska, przeł. Ryszard Wojnakowski, w: Marek Zybura (oprac.), „Patagończyk w Berlinie”. Witold Gombrowicz w oczach krytyki niemieckiej, Universitas, Kraków 2004, s. 269-294.

Rodak Paweł, Między zapisem a literatura. Dziennik polskiego pisarza w xx wieku, Wyd. UW, Warszawa 2011.

Salgas Jean-Pierre, Witold Gombrowicz lub ateizm integralny, przeł. Jan Maria Kłoczowski, Czytelnik, Warszawa 2004.

Skibińska Elżbieta, Czy „Pornografia” jest przekładalna? Rekonesans: młodość w przekładzie francuskim, w: eadem, Gombrowicz i tłumacze, Leksem, Łask 2004, s. 147-164.

Stasiakiewicz Zofia, Entre Catalunya i Polònia: Witold Gombrowicz i Gabriel Ferrater. Correspondència inèdita (1965-1967), http://goo.gl/iszeik, dostęp: 12 XI 2016.

Suchanow Klementyna, Argentyńskie przygody Gombrowicza, Wydawnictwo Literackie, Kraków 2005.

—, El caso Gombrowicz: La traducción de "Ferdydurke” de 1947, „Hispamérica” 2007, nr 107, s. 3-13.

Surma-Gawłowska Monika, „Ferdydurke” po włosku, czyli Gombrowicz okiełznany, w: Elżbieta Skibińska (red.), Gombrowicz i tłumacze, Leksem, Łask 2004, s. 61-68.

Szczuka Kazimiera et al., Debata „Używanie Gombrowicza, czyli co robimy z klasykami”, w: Dominika Świtkowska, Tomasz Tyczyński (red.), Gombrowicz i okolice, Muzeum Literatury im. A. Mickiewicza, Warszawa 2013, s. 40-68.

Tomaszewski Marek, „Trans-Atlantyk” Witolda Gombrowicza po francusku, w: Elżbieta Skibińska (red.), Gombrowicz i tłumacze, Leksem, Łask 2004, s. 177-19o. Zaboklicka Bożena, Gombrowicz po hiszpańsku, czyli rywalizacja z przekładem autorskim, w: Dominika Świtkowska, Tomasz Tyczyński (red.), Gombrowicz i okolice, Muzeum Literatury im. A. Mickiewicza, Warszawa 2013, s. 83-94.

-, Gombrowicz po hiszpańsku w przekładach Sergio Pitola, tekst niepublikowany.

-, Una nueva interpretación de "El casamiento" de Witold Gombrowicz a la luz de la traducción de la obra al castellano realizada pro el proopio autor, „Eslavística Complutense" 2007, nr 7, s. 31-42.

-, Witold Gombrowicz, ¿escritor argentino?, w: Karolina Kumor, Edyta Waluch de la Torre (red.), Realidades heterogéneas. reflexiones en torno a la literatura, lengua, historia y cultura ibéricas e iberoamericanas, Instituto de Estudios Ibéricos e Iberoamericanos, Warszawa 2012, s. 209-220.

Zieniewicz Andrzej, Osoba między kokieteria, manipulacją i opowieścią, czyli Gombrowicz jako prekursor teorii autoprezentacji, w: Jerzy Jarzębski (red.), 
Gombrowicz nasz współczesny. Materiały międzynarodowej konferencji naukowej w stulecie urodzin pisarza. Uniwersytet Jagielloński - Kraków, 22-27 marca 2004, Universitas, Kraków 2010, s. 233-246.

\section{Studia komparatystyczne i translatologiczne}

Bennett Tony, Habitus Clivé: Aesthetics and Politics in the Work of Pierre Bourdieu, w: Philip Goldstein, James L. Machor (red.), New Directions in American Reception Study, Oxford University Press, Oxford 2008, s. 57-98.

Bernheimer Charles, Wstęp. Lęk przed porównaniem, przeł. Piotr Sobolczyk, w: Tomasz Bilczewski (red.), Niewspółmierność. Perspektywy nowoczesnej komparatystyki, Universitas, Kraków 2010, s. 115-136.

Bolecki Włodzimierz, Kraskowska Ewa (red.), Kultura w stanie przekładu. Translatologia - komparatystyka - transkulturowość, Fundacja Akademia Humanistyczna, Warszawa 2012.

Casanova Pascale, Consécration et accumulation de capitale littéraire. Traduction comme échange inégal, „Actes de la Recherche en Sciences Sociales” 2002, t. 144, nr 1, s. 7-20, https://goo.gl/emHmfi, dostęp: 20 x 2016.

—, La República mundial de las Letras, przeł. Jaime Zulaika, Anagrama, Barcelona 2001. Culler Jonathan, Porównywalność, przeł. Tomasz Bilczewski, w: Tomasz Bilczewski (red.), Niewspółmierność. Perspektywy nowoczesnej komparatystyki, Universitas, Kraków 2010, s. 105-112.

Czapliński Przemysław, Literatura światowa i jej figury, „Teksty Drugie” 2014, nr 4 , s. 13-40.

Dąbrowski Mieczysław (red.), Komparatystyka dla humanistów. Podręcznik akademicki, Wyd. UW, Warszawa 2011.

Damrosch David, Dość czasu i świata, przeł. Adam F. Kola, „Teksty Drugie” 2014, nr 4, s. 100-130.

—, Literatura światowa $w$ dobie postkanonicznej i hiperkanonicznej, przeł. Anna Tenczyńska, w: Tomasz Bilczewski (red.), Niewspótmierność. Perspektywy nowoczesnej komparatystyki, Universitas, Kraków 2010, s. 367-381.

Domíngez César, Saussy Haun, Villanueva Darío, Introducing Comparative Literature. New Trends and Applications, Routledge, New York 2015.

Etiemble René, Porównanie to jeszcze nie dowód, przeł. Wanda Błońska, „Pamiętnik Literacki” 1968, t. 59, z. 3, s. 311-332.

Guillén Claudio, Múltiples moradas. Ensayo de Literatura Comparada, Tusquets, Barcelona 1998.

Głowiński Michał, O intertekstualności, w: idem, Prace wybrane, t. 5: Intertekstualność, groteska, parabola. Szkice ogólne i interpretacje, Universitas, Kraków 2000, s. 5-33. 
Hejmej Andrzej, Komparatystyka. Studia literackie - studia kulturowe, Universitas, Kraków 2013.

Jauss Hans Robert, Historia literatury jako prowokacja, przeł. Małgorzata Łukasiewicz, posł. Kazimierz Bartoszyński, Wyd. IBL, Warszawa 1999.

Kasperski Edward, Kategorie komparatystyki, Wydział Polonistyki UW, Warszawa 2010.

—, Komparatystyka wspótczesna. Zadania i zakres, w: Ewa Szczęsna, Edward Kasperski (red.), Komparatystyka dzisiaj, t. 1: Problemy teoretyczne, Kraków 2010, S. 13-29.

Lefevere André, Ogórki Matki Courage. Tekst, system i refrakcja w teorii literatury, przeł. Agata Sadza, w: Piotr Bukowski, Magda Heydel (red.), Współczesne teorie przekładu. Antologia, Znak, Kraków 2009, s. 223-246.

Markiewicz Henryk, Odbiór i odbiorca w badaniach literackich, „Ruch Literacki” 1979, z. 1, S. 1-15.

Nowicka-Jeżowa Alina, Wierzbicka-Trwoga Krystyna, Wójcik Tomasz (red.), Drogi i rozdroża współczesnej komparatystyki europejskiej, Elipsa, Warszawa 2012. Nycz Ryszard, Możliwa historia literatury, „Teksty Drugie” 2010, nr 5, s. 167-184. —, Intertekstualność i jej zakresy: teksty, gatunki, światy, w: idem, Tekstowy świat. Poststrukturalizm a wiedza o literaturze, Universitas, Kraków 200o, s. 79-110.

—, Poetyka intertekstualna: tradycje i perspektywy, w: Michał Paweł Markowski, Ryszard Nycz (red.), Kulturowa teoria literatury. Główne pojęcia i problemy, Universitas, Kraków 2010, s. 153-180.

Skwara Marta, Polskie serie recepcyjne wierszy Walta Whitmana. Monografia wraz $z$ antologia przekładów, Universitas, Kraków 2014.

—, „Polski Whitman”. O funkcjonowaniu poety obcego w kulturze narodowej, Universitas, Kraków 2010.

—, Stara i nowa komparatystyka literacka, w: Mieczysław Dąbrowski (red.), Komparatystyka dla humanistów. Podręcznik akademicki, Wyd. UW, Warszawa 2011, s. 141-210.

Spivak Gayatri Chakravorty, Death of a Discipline, Columbia University Press, New York 2003.

—, Przekraczanie granic, przeł. Ewa Kraskowska, w: Tomasz Bilczewski (red.), Niewspółmierność. Perspektywy nowoczesnej komparatystyki, Universitas, Kraków 2010, s. 161-184.

Steiner George, Czym jest komparatystyka literacka?, przeł. Agnieszka Matkowska, w: Tomasz Bilczewski (red.), Niewspółmierność. Perspektywy nowoczesnej komparatystyki, Universitas, Kraków 2010, s. 511-530.

Ungar Steven, „Pisanie językami”. Rozważania o dziele tłumaczonym, przeł. Agnieszka Pokojska, w: Tomasz Bilczewski (red.), Niewspółmierność. 
Perspektywy nowoczesnej komparatystyki, Universitas, Kraków 2010, s. $531-546$.

Valdés Mario J., Literatura comparada o literatura mundial en inglés: diálogo internacional o imperialismo cultural, „Ínsula” 2012, nr 787/788, s. 9-12.

Van Tieghem Paul, La littérature comparée, Colin, Paris 1931.

Walas Teresa, Czy jest możliwa inna historia literatury?, Universitas, Kraków 1993.

—, Historia literatury w perspektywie kulturowej-dawniej i dziś, w: Michał Paweł

Markowski, Ryszard Nycz (red.), Kulturowa teoria literatury. Główne pojęcia i problemy, Universitas, Kraków 2010, s. 93-135.

-, Oko innego/cudzoziemca jako możliwa perspektywa poznawcza literatury polskiej, w: Ryszard Nycz, Władysław Miodunka, Tomasz Kunz (red.), Polonistyka bez granic IV Kongres Polonistyki Zagranicznej, Uniwersytet Jagielloński, 9-11 października 20o8, t. 1: Wiedza o literaturze i kulturze, Universitas, Kraków 2011, s. 213-221.

Wellek René, Kryzys literatury porównawczej, przeł. Zdzisław Łapiński, „Pamiętnik Literacki” 1968, t. 59, z. 3, s. 269-279.

Zawadzki Andrzej, Między komparatystyką literacka a kulturowa, w: Teresa Walas, Ryszard Nycz (red.), Kulturowa teoria literatury 2. Poetyki, problematyki, interpretacje, Universitas, Kraków 2012, s. 325-368.

\section{Pozostałe teksty}

Bauman Zygmunt, Globalizacja: i co z tego dla ludzi wynika, przeł. Ewa Klekot, PIW, Warszawa 2004.

Beerbohm Max, Enoch Soames, przeł. Rodolfo Walsh, https://goo.gl/7K5q3y, dostęp: 3 I 2017.

Bielik-Robson Agata, Sześć dni stworzenia. Harolda Blooma mitologia twórczości, w: Harold Bloom, Lęk przed wpływem. Teoria poezji, przeł. Agata Bielik-Robson, Marcin Szuster, Universitas, Kraków 2002, s. 9-44.

Bourdieu Pierre, Campo intelectual y proyecto creador, przeł. Jorge Dotti, w: idem, Campo de poder, campo intelectual, Montessor, Buenos Aires 2002, s. 9-50.

Casas Ana (red.), La autoficción. Reflexiones teóricas, Arco/Libros, Madrid 2012.

Certeau Michel de, Californie, un théâtre des passants, "Autrement” 1981, 31 IV, s. $10-18$.

Doubrovsky Serge, Autobiographie/vérité/psychanalyse, w: idem, Autobiographiques: de Corneille à Sartre, PUF, Paris 1988, s. 61-79.

Fish Stanley, Czy na tych ćwiczeniach jest tekst?, przeł. Andrzej Szahaj, w: idem, Interpretacja, retoryka, polityka, red. i przedm. Andrzej Szahaj, wstęp do pol. wyd. Richard Rorty, Universitas, Kraków 2002, s. 59-80. 
-, Jak rozpoznać wiersz, gdy się go widzi, przeł. Adam Grzeliński, w: idem, Interpretacja, retoryka, polityka, red. i przedm. Andrzej Szahaj, wstęp do pol. wyd. Richard Rorty, Universitas, Kraków 2002, s. 81-98.

-, Profesjonalna poprawność. Badania literackie a polityczna zmiana, przeł. Stanisław Wójtowicz, Wyd. Poznańskiego Towarzystwa Przyjaciół Nauk, Poznań 2012.

García Canclini Néstor, Culturas híbridas. Estrategias para entrar y salir de la modernidad, Paidós, Buenos Aires 2013.

Gaszyńska-Magiera Małgorzata, Recepcja przekładów literatury iberoamerykańskiej w Polsce w latach 1945-2005 z perspektywy komunikacji międzykulturowej, Wyd. UJ, Kraków 2011.

Genette Gérard, Figures III, Seuil, Paris 1972.

_, Palimpsesty. Literatura drugiego stopnia, przeł. Tomasz Stróżyński, Aleksander Milecki, słowo/obraz terytoria, Gdańsk 2014.

Giddens Anthony, Nowoczesność i tożsamość. „Ja” i społeczeństwo w epoce późnej nowoczesności, przeł. Anna Szulżycka, Wyd. Naukowe PWN, Warszawa 2010.

Kristeva Julia, Extranjeros para nosotros mismos, przeł. Xavier Gispert, Plaza \& Janés, Barcelona 1991.

Nycz Ryszard, Kulturowa natura, słaby profesjonalizm. Kilka uwag o przedmiocie poznania literackiego i statusie dyskursu literaturoznawczego, w: Michał Paweł Markowski, Ryszard Nycz (red.), Kulturowa teoria literatury. Główne pojęcia i problemy, Universitas, Kraków 2010, s. 5-38.

Paloff Benjamin, Czy fraza „Polish literature" oznacza "literature polskg̨"? (Problem teorii recepcji i nie tylko...), w: Ryszard Nycz, Władysław Miodunka, Tomasz Kunz (red.), Polonistyka bez granic. IV Kongres Polonistyki Zagranicznej, Uniwersytet Jagielloński, 9-11 października 2008, t. 1: Wiedza o literaturze i kulturze, Universitas, Kraków 2011, s. 81-92.

Poniedziałek Ewelina, Literatura krajów Ameryki Łacińskiej w polskiej recepcji w latach 1945-1989, Wyd. UAM, Poznań-Kalisz-Konin 2009.

Popiel Magdalena, Poetyka autokreacji. Narracje doświadczenia artystycznego, w: Teresa Walas, Ryszard Nycz (red.), Kulturowa teoria literatury 2. Poetyki, problematyki, interpretacje, Universitas, Kraków 2012, s. 63-100.

Prokop-Janiec Eugenia, Etniczność, w: Michał Paweł Markowski, Ryszard Nycz (red.), Kulturowa teoria literatury. Główne pojęcia i problemy, Universitas, Kraków 2010, s. 409-432.

Rama Ángel, La ciudad letrada, Ediciones del Norte, Hanover 1984.

Rodak Paweł, Między zapisem a literatura. Dziennik polskiego pisarza w Xx wieku (Żeromski, Nałkowska, Dąbrowska, Gombrowicz, Herling-Grudziński), Wyd. UW, Warszawa 2011. 
Sebrelli Juan José, Historia secreta de los homosexuales en Buenos Aires, w: idem, Escritos sobre escritos, ciudades bajo ciudades. 1950-1997, Sudamericana, Buenos Aires 2015, s. 275-370.

Sloterdijk Peter, Krytyka cynicznego rozumu, przeł. i wstęp Piotr Dehnel, Dolnośląska Szkoła Wyższa, Wrocław 2008.

Steiner George, Extraterritorial. Ensayos sobre literatura y revolución del lenguaje, przeł. Edgardo Russo, Adriana Hidalgo, Buenos Aires 2000.

Szkołut Tadeusz, O perspektywach estetyki $w$ dobie kultury postmodernistycznej, w: Anna Zeidler-Janiszewska (red.), Sztuka i estetyka po awangardzie a filozofia postmodernistyczna, Instytut Kultury, Warszawa 1994, s. 187-197.

Sarmiento Domingo Faustino, Facundo, Biblioteca Virtual Universal, https://goo. gl/IqLe3f, dostęp: 12 I 2017.

Toro Vera, Schlickers Sabine, Luengo Ana (red.), La obsesión del yo. La auto(r)ficción en la literatura española y latinoamericana, Iberoamericana, Madrid 2010.

Wolniewicz Bogusław, Wstęp. O „Traktacie”, w: Ludwig Wittgenstein, Tractatus logico-philosophicus, przeł. Bogusław Wolniewicz, Wyd. Naukowe PWN, Warszawa 2004, s. VII-XLII.

Zawadzki Andrzej, Autor. Podmiot literacki, w: Michał Paweł Markowski, Ryszard Nycz (red.), Kulturowa teoria literatury. Główne pojęcia i problemy, Universitas, Kraków 2010, s. 217-247.

Zeidler-Janiszewska Anna, Pochwała eksperymentowania, w: eadem (red.), Sztuka i estetyka po awangardzie a filozofia postmodernistyczna, Instytut Kultury, Warszawa 1994, s. 73-82. 


\section{Indeks osobowy}

Abós Álvaro 133

Abraham Tomás 291, 292, 325, 333

Adriejew Leonid 259

Afanador Luis Fernando 212, 214, 215,223

Aira César 42, 97, 109, 123, 150, 151, $155,157,159,160,162,178,181$, 182, 190, 191, 194, 195, 200, 203, 207-225, 227-239, 267, 276-278, 281, 292, 318, 324, 325, 330, 332

Altamirano Carlos 25, 105

Álvarez Jorge 74, 77

Álvarez Turienzo T. 94

Amícola José 71, 98, 99, 118, 132, 137, $147,148,153,156,191,200$

Amo Álvaro del 95

Andrade Mário de 219, 220

Andrzejewski Jerzy 78

Antonioni Michelangelo 108

Apollinaire Guillaume 175

Apter Emily 14

Arlt Roberto 84, 136, 152, 160, 167, 206, 211, 213-215, 244, 247, 249, $251,252,255,256,258,259,261,332$

Aron Raymond 116

Arrabal Fernando 190
Arystoteles 291

Astrada Carlos 136

Augustyn z Hippony, święty 115

Bachtin Michaił 31

Balderston Daniel 136, 252

Balzac Honoré de 208, 209

Baron Supervielle Silvia 113

Barthes Roland 25, 145

Bartoszyński Kazimierz 17

Bassnett Susan 19

Bauman Zygmunt 128

Beckett Samuel 95, 138, 141, 155, 242

Beerbohm Max 294, 296

Bello Andrés 104

Bemong Nele 154

Benedit de Debenedetti Cecilia 79, 85

Benjamin Walter 145, 258

Bennett Tony 19

Bereza Henryk 270, 272, 273, 276

Berman Antoine 51

Bernheimer Charles 13

Bernini Emilio 285, 286

Berressem Hanjo 92

Berti Eduardo 316 
Betelú Mariano 115, 284, 286, 288, 289

Bianco José 88, 95, 141, 293-296

Biancotti Héctor 112, 114

Bielik-Robson Agata 6

Bilczewski Tomasz 11-14, 31, 47, 48

Bioy Casares Adolfo 135, 144, 147, 265,296

Bizzio Sergio 277, 278, 282

Blanco Calderón Rodrigo 83, 241, 253

Bloom Harold 6

Błońska Wanda 10

Błoński Jan 150

Bolecki Włodzimierz 11, 40, 56, 60, 131, 174, 177

Booth Wayne 122

Borchardt Danuta 51

Borcich Witold 317

Borges Jorge Luis 22, 41, 43, 61, 65, $86,95,97,99,104,108,115,119$, $137,141,142,146-156,159,166$, 169, 170, 178, 182, 209, 211, 215, 218, 238-240, 247, 249, 250, 251, 257, 279, 296, 301, 322, 323, 331

Botana Natalio 203

Bourdieu Pierre 19, 21, 25, 110, 152, 254, 255, 274

Brando Marlon 286

Brecht Bertolt 41, 259

Breton André 175

Brizuela Natalia 182

Brück Carlos 268

Brzozowski Jerzy 51

Bukowski Piotr 51

Cage John 208

Caillois Roger 103, 113, 116, 117, 257

Calderón Pedro 115
Calderón Rodrigo Blanco 83, 241, 254

Calvetti Jorge 289

Camblong Ana M. 65, 171

Camus Albert 141

Cangi Adrián 136

Capdevila Arturo 55, 108

Carbone Alberto 109

Cardín Alberto 204

Cardozo Cristian 152

Carrión Jorge 83, 239, 241, 254, 262

Casanova Pascale 10, 21-23, 25-27, $48-50,62,100,328$

Casas Ana 144

Catelli Nora 142, 143

Cella Susana 118

Centurión Luis 54, 60

Certeau Michel de 128

Cervantes Miguel de 115

Chądzyńska Zofia 34, 55, 139, 148, 266, 268

Chejfec Sergio 73, 76, 121

Chitarroni Luis 114, 173, 178

Cieński Marcin 51

Cioran Emil 62

Contreras Sandra 212, 214, 215, 220, 224

Copi (właśc. Raul Damonte) 112, 118, $124,130,147,148,161,179,182$, 189-192, 195-206, 208, 211, 214, 222, 224, 237, 239, 315, 323, 331, 332

Correas Carlos 136

Cortázar Julio 109, 119, 267, 268

Cosci Lucas Daniel 156, 305-307, 310, 325, 334

Cozarinsky Edgardo 312, 313, 334

Culler Jonathan 31

Cunninghame Graham Robert Bontine 112 
Czapliński Przemysław 14, 21, 27

Czermińska Małgorzata 121

Dabove Juan Pablo 182

Damonte Raul, zob. Copi

Damrosch David 12, 21, 26-28, 49$51,57,320,328$

Dapelo Luis 223

David Guillermo 293, 294, 295, 325, 328,333

Dąbrowski Mieczysław 9, 12, 48

Dehnel Piotr 150

Deleuze Gilles 25

Delgado Verónica 324

Di Paola Jorge (Dipi) 43, 115, 116, 157, 173, 178, 269, 272, 277-290, 325,333

Dickens Charles 115

Dimine Marcela 285, 286

Domínguez César 13

Dostojewski Fiodor 23

Dotti Jorge 255

Doubrovsky Serge 144

Drieu la Rochelle Pierre 103, 120, 257

Drucaroff Elsa 105, 114, 116, 171, 173, $182,253,277$

Dubuffet Jean 44

Duchamp Marcel 208, 259

Eliot T.S. 261

Éluard Paul 175

Estrin Laura 310

Etiemble René 10

Falkiewicz Andrzej 264

Faron Bolesław 138

Faulkner William 106, 141

Fernández Bravo Alvaro 62
Fernández de Castro Javier 69, 95, 136

Fernández Leopoldo, zob. Germán García

Fernández Macedonio 65, 84, 115, $155,160,164,168,170,171,206$, $247,261,289,323,332$

Ferrater Gabriel 59-61, 72, 77, 78, 88, $89,94,95,143$

Ferro Roberto 172

Fischerman Alberto 44, 286, 288, 290, 297, 325, 333

Fish Stanley 12, 17-19, 31

Fiut Aleksander 120

Flaubert Gustave 95, 167, 208, 209, 219

Flisek Agnieszka 178, 191

Fogwill Rodolfo 135, 151, 330

Folch i Camarasa Ramón 58

Forn Juan 276

Fornet Jorge 159, 238, 240, 252, 253, 257,262

Foucault Michel 25, 122

Frank Waldo 75, 103

Freixa Terradas Pau 35-40, 44, 84, $88,89,91,94,95,117,180,181,241$, $284,293,312,313$

Fresco Jacques 263

Freud Sigmund 300

Friera Silvina 310

Frost Robert 50

Gaddis William 41

Gallego Cuiñas Ana 72

Gálvez Manuel 108

Gamerro Carlos 131, 132, 273, 313

Gandolfo Elvio 223

García Canclini Néstor 106, 112, 128 
García Germán 75, 76, 108, 135, 162$164,172,173,175,176,291,296-$ 298, 323, 331, 333

García Lao Fernanda 313-315, 334

García Márquez Gabriel 218

García Tomeu José 159

Garramuño Florencia 62

Garzón del Camino Aurelio 95

Gasparini Pablo 98, 116, 117, 120, $122,126,129,130,133,136,139$, 140, 154, 156, 178-180, 191, 241, 323

Gaszyńska-Magiera Małgorzata 18

Gendaj Natalia 30, 121

Genet Jean 106, 141

Genette Gérard 31, 32, 81

Giangrande Alicja 289, 297

Giddens Anthony 146

Gide André 106, 141, 264

Giedroyc Jerzy 40, 6o, 81, 149

Giordano Alberto 105, 144

Girondo Oliverio 115, 169

Gispert Xavier 127

Głowiński Michał 32, 33, 53, 138, 187, 189,321

Godard Jean-Luc 208

Goethe Johann Wolfgang von 21

Goldmann Lucien 69

Goldstein Philip 19

Gombrowicz Rita 7, 34, 35, 55, 62$64,136,139,265,286,291,306$

Gombrowicz Witold 5-9, 14-16, 18, 20, 21, 23-26, 28-30, 33-45, 4995, 97-100, 102, 103, 105, 107-157, 160-184, 187-189, 191, 194-205, 207-211, 213-216, 218-225, 227, 228, 230-245, 248, 250-258, 260, 261, 263-325, 327-334

González Horacio 301
Gómez Juan Carlos 43, 108, 164, 215, $216,221,223,224,261,269-277$, 279, 288-290, 292, 297, 325, 333

Grabowska Monika 51

Green Graham 300

Gregorich Luis 125

Grinberg Miguel 84, 85, 289, 290

Grodzicka Halina 289, 290

Groussac Paul 61, 244, 249, 250

Grzegorczyk Marzena 156, 241

Grzeliński Adam 31

Guebel Daniel 277, 278

Guillén Claudio 13, 140

Gusmán Luis 71, 75, 76, 108, 162, 168, 169, 172, 173, 182, 192, 298-300, 333

Gutiérrez Juan María 24

Hardmeier Jorge 279, 282

Heffes Gisela 73

Hegel Georg Wilhelm Friedrich 291

Heidegger Martin 221, 291

Hejmej Andrzej 9, 12, 47, 48

Herder Johann Gottfried 100

Hernández José 119, 273, 279

Heydel Magda 51, 52

Hidalgo Adriana 79, 138

Hippiasz 252

Hitler Adolf 67-69, 252

Hochman Nicolás 124, 126, 140, 316,317

Hoggart Richard 110

Homer 6

Hudson Guillermo Enrique (William Henry Hudson) 112, 124, 244

Husarska Anna 34, 55, 139, 266

Idez Ariel 167, 169

Iparraguirre Sylvia 55 
Iser Wolfgang 170

Ísola Laura 55, 61, 62

Istrati Panait 62

James Henry 95

Jan III Sobieski, król Polski 23

Jarniewicz Jerzy 90, 91

Jaroszuk Barbara 214, 219, 244

Jarzębski Jerzy 7, 14, 25, 35, 37, 115, 120, 136, 138, 185, 268

Jauss Hans Robert 17-19, 36, 328

Jeftanovic Andrea 240, 245

Jeleński Konstanty (Kot) 49

Jitrik Noé 113, 118, 125, 182

Jogałła Elżbieta 115

Jordan Marta 268

Joyce James 106, 209, 261

Kafka Franz 252, 259, 261, 264

Kalicki Rajmund 55, 108, 215, 270272, 288

Kania Ireneusz 54, 69, 76, 168, 194, 319

Kasperski Edward 10, 11, 29

Keyserling Hermann 75, 103, 120

Kleinman Paula 290

Klekot Ewa 128

Kłoczowski Jan Maria 92

Kobyłecka-Piwońska Ewa 124, 241

Kochanowski Jan 80

Kohan Martín 318

Kohler Florent 200

Kola Adam F. 27, 50

Kopernik Mikołaj 24

Kościuszko Tadeusz 23

Kowalczyk Andrzej Stanisław 40, 149

Kraskowska Ewa 11, 14

Krasov Nina 91
Kristeva Julia 31, 124, 127, 128

Kühl Olaf 131, 177, 180

Kumor Karolina 59

Kunz Tomasz 15, 16, 36

Kurek Marcin 56, 57

Lacan Jacques 177

Laddaga Reinado 150, 151, 178, 212, 215

Lamborghini Osvaldo 76, 109, 115, $124,151,155,157,160,162,172,173$, 178, 189-189, 192, 208, 211, 212, 214, 215, 224, 279, 323, 330, 331

Laurent Maryla 51

Lavelli Jorge 64, 190

Le Corbusier (właśc. Charles-Édouard Jeanneret-Gris) 120

Lear Edward 237

Lefevere André 19, 52, 53, 57, 64

Lévi-Strauss Claude 114

Libertella Héctor 109, 162, 192

Lida Raimund 55, 58

Link Daniel 262

Loti Pierre 220

López Casanova Martina 173

López Llausás Antonio 72, 73, 75, 80

Luengo Ana 144, 232

Lugones Leopoldo 61, 250

Lynch Marta 270

Łapiński Zdzisław 10, 94, 187, 198, 264

Łukasiewicz Małgorzata 17

Machor James L. 19

Malraux André 116

Mandolessi Silvana 30, 44, 71, 92, $98,118,121-124,127,128,132,148$, $153,154,156,241,323$ 
Manrique Sabogal Winston 144

Mansilla Lucio Victorio 146

Mansour Mónica 148

Marechal Leopoldo 169

Margański Janusz 40, 92, 128, 241

Maritain Jacques 116

Markiewicz Henryk 17

Markowski Michał Paweł 5, 29, 31, 111, 145, 165, 177

Martínez Estrada Ezequiel 112, 115, 136, 285, 295

Martínez Guillermo 316

Mastronardi Carlos 75, 107

Matamoro Blas 93, 94

Matkowska Agnieszka 47

Mattalia Sonia 264

Mattini Luis (właśc. Juan Arnol Kremer) 303-305, 307, 325, 334

Mazzi Joaquín 116, 117

Mendoza Juan 162, 168, 174

Menem Carlos 110

Mesa Gancedo Daniel 144

Michaux Henri 116

Mickiewicz Adam 23, 141

Miecznicka Magdalena 56, 59

Milecki Aleksander 31

Miłosz Czesław 16

Miodunka Władysław 15, 16, 36

Miravitlles Frances 57, 70, 78, 93

Molina Daniel 229, 232

Molloy Sylvia 130

Monder Samuel 240, 245

Montaldo Graciela 23, 101, 107, 123, 124

Monteleone Jorge 55

Monteskiusz (właśc. Montesquieu

Charles Louis de Secondat) 217

Mozejko Danuta Teresa 152

Muchnik Jacobo 72, 265
Murena Héctor A. 104, 295

Musil Robert 264

Myszkowska Justyna 279, 288

Nabokov Vladimir 62, 106, 138, 242, 257

Negroni María 195

Nietzsche Friedrich 23

Niewrzęda Krzysztof 131, 177

Norwid Cyprian Kamil 141

Nowicka-Jeżowa Alina 11

Nowicki Maciej 306

Nycz Ryszard 5, 9, 15, 16, 29, 31, 32, $36,111,145$

Obieta Adolfo de 54, 60, 65, 86, 169, 171, 289

Ocampo Silvina 105, 112

Ocampo Victoria 95, 105, 106, 108, $112,114,116,117,141,153,257$

Ochoa de Michelena Francisco 93

Onganía Juan Carlos 108

Ortega y Gasset José 76, 103, 120, 122-124, 257

Pacek Grzegorz 290

Pacheco José Emilio 252

Paloff Benjamin 16

Partyka Joanna 43, 104, 218

Pauls Alan 71, 84, 162, 178

Pavese Cesare 255, 264

Pawłowski Janusz 198

Pellegrini Marcelo 240, 245

Perlongher Néstor 130, 136, 156, 179

Peron Juan Domingo 69, 107-109, 133, 134, 312

Piekarec Kazimierz 88, 89

Piglia Ricardo 26, 37-39, 41, 42, 55, $57,61,83,97,101,110,118,123,141$, 
$143,150,153,154,156,159-161,163$, $167,171,172,176,208,209,213$, $227,234,237-267,278,279,293$, 298, 299, 319, 323-325, 332, 333 Piñera Virgilio 39, 54, 60, 61, 86, 88, $95,133,154,212,239,294,295$

Pitol Sergio 72, 77-80, 87-90, 92, 93 Pizarnik Alejandra 144, 208, 211, 214, 237

Plá Roger 39, 55

Platon 291

Płonowska-Ziarek Ewa 92, 128, 241

Podlubne Judith 105

Pokojska Agnieszka 48

Poniedziałek Ewelina 18

Popiel Magdalena 145, 146

Porchia Antonio 139

Porrúa Ana 208

Premat Julio 149, 150, 172, 178, 182

Prieto Julio 155

Prieto Martín 117, 118, 169

Prokop-Janiec Eugenia 111, 137

Pron Patricio 190, 191, 206, 207, 232

Proust Marcel 190, 209

Puig Manuel 155, 211, 215, 239, 313

Quiroga Jorge 168, 169

Rabanal Rodolf 288, 289, 291

Radny Krystian 8, 26, 30, 55, 71, 99, 143, 171, 218, 240, 319

Rama Ángel 206

Reichardt Dieter 34

Reyes Alfonso 84, 144

Ribeyro Juan Ramón 144

Riccio Alessandra 60

Rodak Paweł 81

Rodríguez Tomeu Humberto 54, 60,86
Ronsino Hernán 156, 308-310, 318, 325, 334

Rorty Richard 18, 146, 214

Rousseau Jean-Jacques 115

Roussel Raymond 208, 214, 227, 315

Roux Dominique de 238, 250

Rubió Anna 51, 58, 88

Ruflo Juan 218

Russo Edgardo 138, 162

Rússovich Alejandro 54, 63, 64, 114-116, 171, 288, 289-291, 325, 329

Sábato Ernesto 55, 58, 72, 75, 271

Sadza Agata 52

Saer Juan José 8, 30, 37, 71, 99, 110, $113,118-120,123,126,127,131,150$, 153, 156, 217, 218, 268, 269, 290, $310,319,323$

Said Edward 48

Saítta Sylvia 141

Salgas Jean-Pierre 89, 92

San Martín José de 174

Sánchez Néstor 310

Santucho Roberto 301-305, 334

Sarlo Beatriz 22, 25, 102, 105, 125, 135, $152,163,303,304$

Sarmiento Domingo Faustino 101, $102,104,115,119,146,172,243$, 249, 250, 262, 306, 308

Sartre Jean-Paul 221

Saussure Ferdinand de 31, 137

Saussy Haun 13

Scheue Robert Daniel 95

Schlickers Sabine 144, 232

Schopenhauer Arthur 115

Schulz Bruno 15, 292

Sebreli Juan José 312

Sierra Marta 91, 129 
Siskind Mariano 130

Skibińska Elżbieta 51, 52, 56, 90, 91

Skwara Marta 18-20, 32, 48

Sloterdijk Peter 150

Sławomirski Jerzy 51, 58, 88

Sobolczyk Piotr 13

Sobol-Jurczykowski Andrzej 159, 323

Sokrates 169

Sosnowski Saúl 62, 112, 125

Soussens Charles de 244

Speranza Graciela 145, 211, 215, 260

Spinoza Baruch 115

Spivak Gayatri Chakravorty 10, 13, 14

Stasiakiewicz Zofia 6o, 94

Steiner George 47, 48, 138, 139, 330

Stendhal (właśc. Marie-Henri Bey-

le) 95

Strawiński Igor 108

Strindberg August 62

Stróżyński Tomasz 31

Suchanow Klementyna 7, 8, 26, 30, $34,35,55,56,66,71,99,136,143$, 171, 218, 240, 319

Surma-Gawłowska Monika 51

Szachowska Zinaida 62

Szahaj Andrzej 18

Szczęsna Ewa 10

Szczuka Kazimiera 89

Szkołut Tadeusz 214

Szulżycka Anna 146

Szuster Marcin 6

Świerczewska Maria 289, 290

Świtkowska Dominika 25, 51, 89

Tabarovsky Damián 162, 173, 315, 334
Tagore Rabindranath 76

Tarnogórska Maria 131, 277

Taworski Włodzimierz 243

Tcherkaski José 64

Tenczyńska Anna 12

Tirri Néstor 38, 269, 284, 289, 325, 333

Tobeña Verónica 152

Tołstoj Lew 264

Tomaszewski Marek 91

Toro Vera 144, 232

Truwant Mirijam 154

Tyczyński Tomasz 25, 51, 89

Ungar Steven 48

Valdés Mario J. 13

Van Tieghem Paul 10

Ventos José María 95

Vermeulen Pieter 154

Vidal Juan Carlos 94

Vila-Matas Enrique 192

Vilela Jorge 285-288, 325

Villanueva Darío 13

Villoro Juan 318

Vitagliano Miguel 136, 311

Walas Teresa 9, 15, 16, 20, 29, 145

Walker Carlos 108

Walsh Rodolfo 152, 239, 294, 295

Waluch de la Torre Edyta 59

Wellek René 10

Whitman Walt 18-20

Wierzbicka-Trwoga Krystyna 11

Wilcock Juan Rodolfo 112, 114, 118, 212

Wilde Eduardo 285

Williams Raymond 110

Wilson Patricia 141 
Witkiewicz Stanisław Ignacy (Witkacy) 15, 80, 292

Wittgenstein Ludwig 245, 246, 252, 291

Wojciechowski Gustav 317, 334

Wojnakowski Ryszard 34

Wolniewicz Bogusław 246

Woolf Virginia 106, 141

Wójcik Tomasz 11

Wójtowicz Stanisław 12

Wright Georg Henrik von 246

Yaccelini Alberto 290
Zaboklicka Bożena 37, 51,57-60, 64, 68-70, 78, 88, 90, 92, 93, 95, 329

Zaleska Ewa 108, 271, 272

Zawadzki Andrzej 9, 145

Zeidler-Janiszewska Anna 213, 214

Zelarayán Ricardo 162, 167, 310

Ziarkowska Justyna 133

Zieniewicz Andrzej 185

Zulaika Jaime 22, 49, 100

Zybura Marek 35

Żynis Bernadetta 121 



\section{Spis treści}

\section{WSTĘP}

O niewdzięcznej praktyce porównywania 5

1.

Komparatystyka, literatura światowa

i „inna” historia literatury 9

Metoda badawcza 9

Co wiadomo o „argentyńskim Gombrowiczu”? 34

Argentyńska stawka w grze o Gombrowicza 41

2.

Jakiego Gombrowicza czytają Argentyńczycy?

Kwestia przekładu 47

Argentyńska Ferdydurke 54

Ślub-przekład na dwie ręce 63

Dziennik argentyński. Rekonstrukcja przeszłości 70

Pozostałe przekłady 87

3.

Krytyka argentyńska o Gombrowiczu 97

O argentyńskiej tożsamości narodowej 100

Gombrowicz jako pisarz argentyński 111

O przestrzeni: podróż, wygnanie, migracja 119

Młodość i cielesność 130

O języku i przekładzie 137

Opowieść o ,ja” 143

Gombrowicz W argentyńskim kanonie literackim 151 
4 .

Miejsca lektury. Gombrowicz czytany

przez argentyńskich pisarzy 159

„Literal”. Germán García 162

Osvaldo Lamborghini 178

Copi 189

César Aira 207

Ricardo Piglia 237

Ryzykowne związki: Julio Cortázar i Juan José Saer 267

„Uczniowie” Gombrowicza 269

Koło Gombrowicza 291

„Prowincjonalne kręćki” 300

Inne lektury 311

ZAKOŃCZENIE 319

MIRADAS DESDE EL AFUERA. WITOLD GOMBROWICZ

EN LA LITERATURA ARGENTINA

(1970-2017) (RESUMEN) 327

BIBLIOGRAFIA 335

INDEKS OSOBOWY 357 
Wydanie I. W.08007.17.0.M

Ark. wyd. 19; ark. druk. 23,125

Wydawnictwo Uniwersytetu tódzkiego

ul. Lindleya 8, 90-131 Łódź

www.wydawnictwo.uni.lodz.pl

e-mail:ksiegarnia@uni.lodz.pl tel. 426655863

Towarzystwo Autorów i Wydawców Prac Naukowych UNIVERSITAS

ul. Sławkowska 17, 31-016 Kraków

www.universitas.com.pl

e-mail: ksiegarnia@universitas.com.pl

tel. 124139136 
